Historic, Archive Document

Do not assume content reflects current scientific knowledge, policies, or practices. 



\section{Free Delivery in the United States}

When cash accompanies your order, we deliver by truck, or we prepay transportation to your post office, express office, or freight station (at our option) on all Flower, Vegetable, and Grass Seeds, also Bulbs and Books. A few exceptions to our Free Delivery Policy are where the value of the merchandise is small compared with transportation cost; they are listed below or are stated on the page of our Catalogue where the variety is offered.

\section{Free Delivery within 50 Miles of New York City}

When cash accompanies your order, we deliver by truck, or we prepay transportation to your post office, express office, or freight station (at our option) on the merchandise listed above, and, in addition, Insecticides, Fertilizers, Garden Supplies and Implements.

\section{Purchaser Pays Transportation on the Following: We do not pay freight, ex- press, or postage on Potatoes, Bents, Plants, and Nursery Stock, or on Insecticides, Fertilizers, Garden Supplies and Implements when shipment is beyond the 50-mile radius. Free Packing. For domestic shipments of seeds, bulbs, fertilizers, and plants we make no packing charge, cost and allow in full when returned, prepaid, with sender's name and address marked on bundle.}

\section{Suggestions to Customers}

SEND MAIL TO NEW YORK. We ask that mail orders and correspondence be sent to 30-32 Barclay St., New York City.

PLEASE USE THE ORDER SHEETS. Also keep a copy of your list, and, above all, do not omit your name and address. Numerous orders reach us every season without these important particulars.

ORDER EARLY. It is difficult for us to serve you as promptly as we wish when we receive a very large number of rush orders just prior to planting-time. Will you not help us by giving us your order early? We will appreciate the favor indeed, and you will gain too: by having the goods on hand you will be able to take advantage of early opportunities for planting.

ERRORS. Ordering early helps to prevent errors. Our orderfilling system calls for complete rechecking by efficient supervisors; customers may be assured of full weight and correct count. We believe we have reduced errors to the minimum, yct should mistakes oceur, our patrons may rely upon us to reetify them promptly.

COMPLAINTS. These will always be adjusted to the purchaser's satisfaction, but we ask that we be notified within 5 days of reccipt of goods. We cannot consider complaints made after this nor can we accept responsibility for crop failures.

ORDERS FOR PLANTS. Kindly use the special order sheet for plants to be found at the end of this book. We ship trees, shrubs, roses, etc., at the correct date for planting, which may be some time after your order reaches us. When the plants arrive, unpack them at once and water them. They should be "heeled in,", that is, be planted temporarily, or should have some soil placed around their roots if you are not ready to use them at once.

IF ANYTHING IS MISSING when you unpack your goods, do not think we have necessarily made an error. Look first for a memorandum, either enclosed with your order or sent by mail, telling you that some items of the order are to follow later; these may be goods which are not ready, or not suitable for using right away. Onion sets, trces, shrubs, roses, and plants genera'ly are not shipped until it is the proper time to plant them. We sometimes enclose small packages in larger bags of seed or fertilizer; please examine these before reporting shortage.

PRICES. Our prices are net, with no discounts, and they are subject to change without notice.

REMITTANCES. These should be made by check, bank draft, post office order, or express money order. Do not send currency unless by registered letter.
C. O. D. We are always glad to supply seeds, bulbs, fertilizers, or insecticides to be paid for on delivery. We do not send shrubs, roots, roses, hedge plants, or other perishable goods C. O. D.

CHARGE ACCOUNTS. We will be pleased to open charge accounts to responsible parties on receipt of the usual trade references; in this case our invoices are payable within 30 days net-no discount.

VISIT OUR BRANCH STORES. Our branch stores are in White Plains, N. Y., Newark, N. J., Hempstead, L. I., and Stamford, Conn. When you shop personally we ask that you patronize our store which is nearest to you, but please send mail orders, inquiries, and correspondence to 30-32 Barclay Street, New York City.

EXPORT DEPARTMENT. Shipments to distant points form an important feature of our business, and we are well equipped to take care of these orders through our Export Department, which is dedicated to serving our clients in foreign lands. Purchasers may rely upon proper packing, prompt delivery to steamers, and correct preparation of the necessary documents. Transportation and special paching will be charged extra at cost.

EMPLO YMENT REGISTER-Superintendents, Gardeners, Greenkeepers, Groundsmen, Poultrymen. We always have on our books the names of men seeking positions, most of whom are known personally to our representatives, and we will be glad to put them in touch with employers seeking help of this kind.

ADVISORY SERVICE. Every mail brings us problems connected with gardening, farming, and lawn-keeping. It is always a pleasure to be of help in solving these, and we take pains to answer these inquiries promptly and fully. In the development of estates or in the seeding of large areas, you may wish to confer with a technical representative on the ground; generally we can arrange this for the cost of transportation to and from New York.

NON-WARRANTY. We, Stumpp \& Walter Co., give no warranty, express or implied, as to description, quality, productiveness or any other matter of any seeds, bulbs, or plants we send out, and will not be responsible for the crop. As bearing on the above, the following remarks, taken from a recent Bulletin of the U.S. Department of Agriculture, are interesting: "Without attempting to discuss the arguments for the seedsman's disclaimer pro and con, the fact remains that reputable seedsmen stand back of their seeds and do not knowingly and willfully sell seeds that are unfit."
GEORGE G. STUMPP, President

JULIAN H. WALTER, Treasurer

THOMAS F. KEARNEY, Asst. Treas.

WILLIAM A. S.PERLING, Secretary

New York Telephones: BA rclay $\left\{\begin{array}{l}7-1110 \\ 7-1113\end{array}\right.$

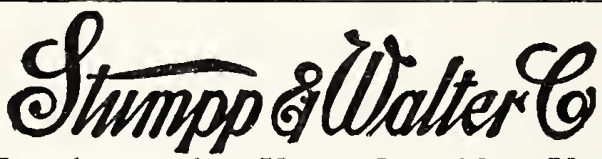

30-32 Barclay and 40 Vesey Sts., New York City 

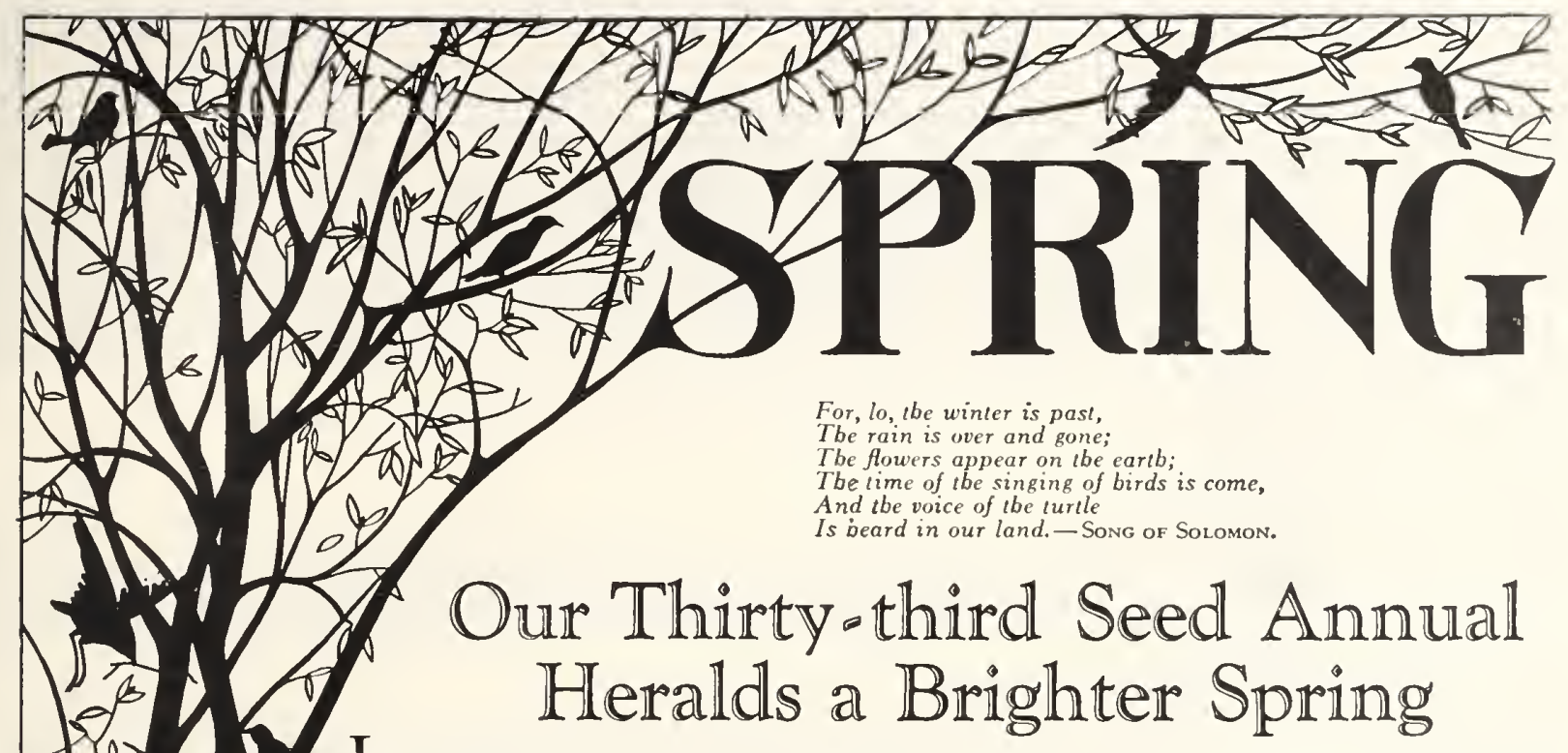

6 Is $-\mathrm{I}_{\mathrm{T}}$ is during winter that we present our Annual Catalogue. But soon tiny frogs will sing their

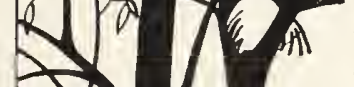

welcome to spring, buds will burst, the first snowdrops will bloom, and the birds will busy them selves with their nests; balmy spring days will arrive, to be followed by sun-drenched summer. Then, in our gardens may be the riot of flowers, the profusion of vegetables, the carpets of emerald lawn that this book suggests.

With the spring of 193 I we seem to enter a new era. Much that was superfluous in American life has given place to things more worth while; we have a clearer vision of real values, and there is a new appeal in the cultivation of the land. The planting of home-grounds always is an investment - never an expense when high-quality materials are used.

More of us find enjoyment in the delights of horticulture than ever before, thanks largely to the efforts of gardening societies and clubs and to the work of landscape architects, professional gardeners, and skilled amateurs.

Good soil and favorable weather conditions are essential for best results in the garden; thought ful planning and health-giving effort are also necessary. But most important of all is reliable quality in the merchandise employed. All our trouble may be wasted and a whole season lost if we fail to use the right quality seeds, bulbs, and plants.

Always important, quality is more important now than ever, and it is with this quality thought always before us that our business, now in its thirty'fourth year, is conducted.

II always before us that our b

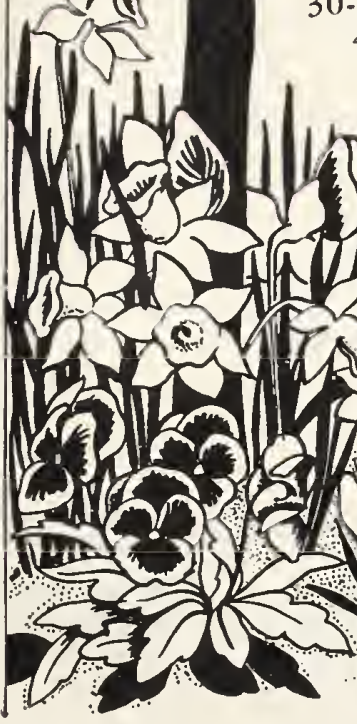

40 Vesey Street, New York

Branch Stores for your convenience at:

STUMPP \& WALTER Co.

WHITE PLAINS, N.Y. NEWARK, N. J. HEMPSTEAD, L. I. STAMFORD, CONN. 


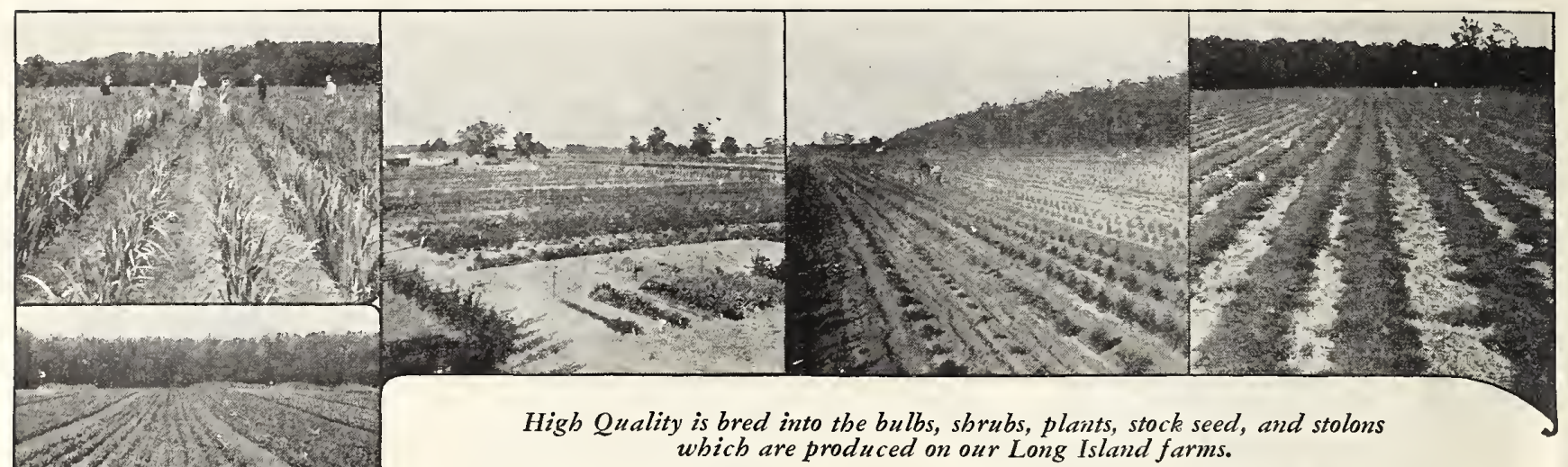

\section{Production and Distribution of the}

\section{OUR FARMS}

On the fertile plains of Long Island we maintain a 64-acre farm at Farmingdale and one of 44 acres at Islip. Seeing these, customers have said, "This is where the Stumpp \& Walter Co. grow their seeds." This is not entirely true, because we ourselves could not hope to grow, on Long Island, any considerable portion of the seeds we offer. We make contracts with men who spend their lives producing one type of seed, each in a part of the world where conditions best suit the particular crop.

\section{FIRST DRIVE FOR QUALITY}

It is in the selcction of the grower, whether he be in the United States, Europe, Asia, or Australia, that we make our first drive for quality. Our next is to visit and inspect, during their growth, as many of our seed-crops as we can. Finally, we obtain our various sceds, clean and grade them, and after assuring ourselves, by a number of tests, that they grow strongly, we offer them for sale.

\section{TESTING FOR QUALITY}

At the same time seeds are being sown by our customers, some of every kind offered by us are also sown at our Long Island farms, there to be grown along until the vegetables are mature or the flower seeds have produced their blooms, as the case may be. The plants are closely watched, so that we assure ourselves that our seeds produce results which are up to our high standards. The testing of our seeds for the purpose of obtaining information about them is the first, and most important, use to which we put our Long Island farms.

\section{STOCK SEEDS}

Then, when an entirely new variety is created, all that we may have at first is a pinch of seeds-perhaps only one seed. It may be years before enough can be produced to have the sort grown in commercial quantities. This nursing period, during which the pinch of seed is multiplied into a few ounces, may take several years. The cultivation of new sorts in this way-we term it the production of stock sced-is the second use to which we put our Long Island farms.

\section{HARDY PERENNIALS}

Again, the hardy perennial plants, peonies, phlox, iris, delphiniums, and hundreds of other sorts, which we offer in our special Catalogue, together with Creeping Bent stolons, are produced by our own experts-a third use for our Long Island farms.

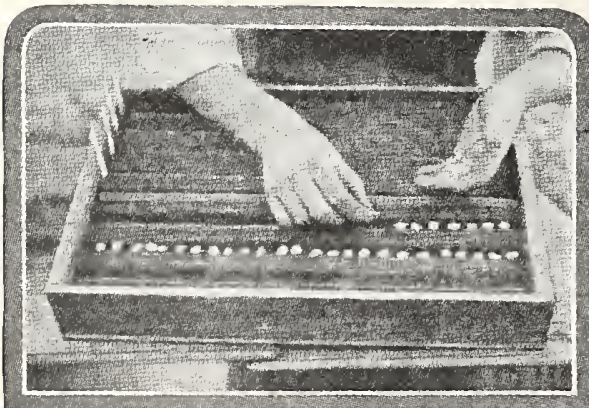

All our seeds are carefully tested for germination before they are made ready for sale, thus assuring their High Quality.

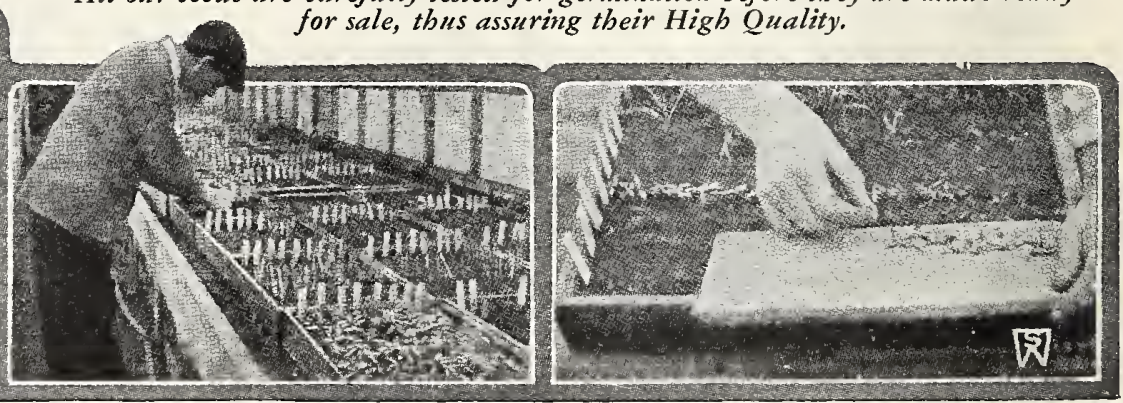




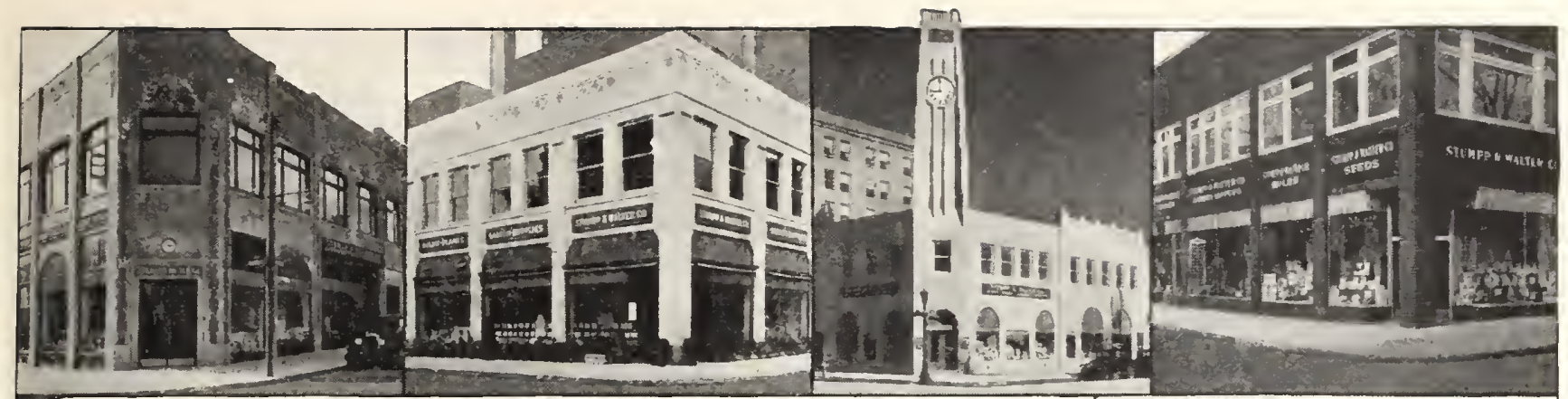

Branches at White Plains, Newark, Hempstead, and Stamford are shown above; these are equipped to give efficient service.

\section{Stumpp \&WalterMerchandise}

\section{NURSERY}

Most of the shrubs, evergrcens, climbers, and hedge plants listed on pages 154 and 157 of this Secd Annual are also our own growing - a fourth rcason for our Long Island farms.

\section{WE GROW OUR OWN BULBS}

Bulbs and corms of daffodils and gladiolus werc produced in Europe and shipped to this country by the million every autumn and spring up to a few ycars ago, but FedcraI

\section{Headquarters: \\ 30-32 Barclay Street, New York \\ 40 Vesey Street, New York \\ One Block from Broadway \\ Phones: \\ BA rclay $\left\{\begin{array}{lll}7.1110 & 7-1111 & 7-1112\end{array}\right.$ \\ White Plains, N. Y., Branch \\ 148.150 Mamaroneck Ave." (at Post Road) \\ Phone: White Plains 9260 \& 9261 Newark, N. J., Branch \\ 29-3 I Central Ave. (at Halsey St.) \\ Phone: Mulberry 4-5595 \\ Hempstead, L. I. Branch \\ 236-238 Fulton Ave. (at Franklin St.) \\ Phone: Hempstead 6420 \\ Stamford, Conn., Branch \\ 674-676 Main St. (at Grove St.) Phone: Stamford 4-0125 \\ GEORGE G. STUMPP, President \\ JULIAN H. WALTER, Treasurer \\ THOMAS F. KEARNEY, Assistant Treasurer \\ WILLIAM A. SPERLING, Secretary}

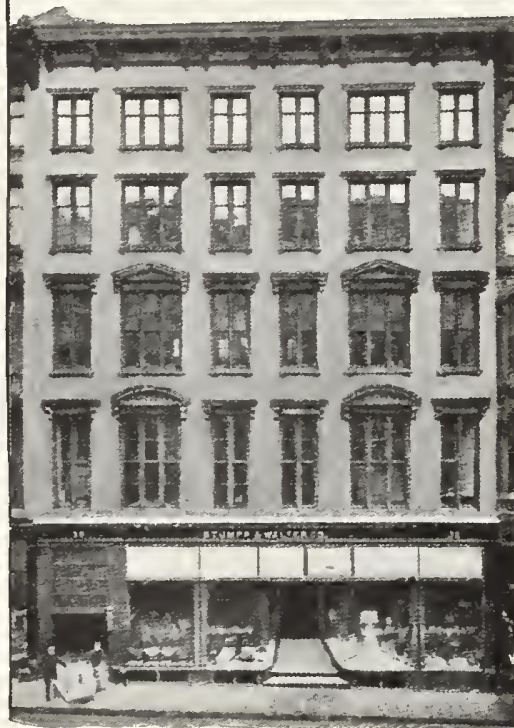
rulings now prohibit their importation. Practically all the daffodil bulbs and gladiolus corms sold by us we produce on our Long Island farms - a fifth reason for their existence. Frost-sensitive narcissi of the Paper-White type are produced in South Carolina.

Headquarters at 30-32 Barclay St., New York. Here is one of the largest seed stores in the country, measuring 200 feet

\section{CARE EXERCISED AT EVERY STEP}

With so much merchandise produced under our own supervision, it is possible for us to exercise, at every step, that meticulous care which is obviously so requisite. In the handling, cleaning, storing, and shipping, care is equally important, for in this Seed Annual alone we list over 2,500 varietics, all living things and many of them identical in appearance with cach other as secds or roots; to kcep these distinct and separate requires painstaking vigilance.

\section{NEW YORK STORES AND BRANCHES}

Our mcrchandise is distributed from our main store and warehouses, at 30-32 Barclay Street and 40 Vesey Street, New York, and from our four branches in the Greater New York area, in Westchester County at White Plains, in New Jersey at Newark, on Long Island at Hempstead, and in Connecticut at Stamford. When you shop personally, we invite you to the Stumpp \& Walter store which is most convenient to you, but we ask that mail orders, inquiries, and correspondence be sent to our Barclay Street, New York, address.

Thousands of test-rows and plots of vegetables, flowers, field crops, and grasses are planted every season on our Long Island farms. This is one method by uhich we maintain our High Quality standards.
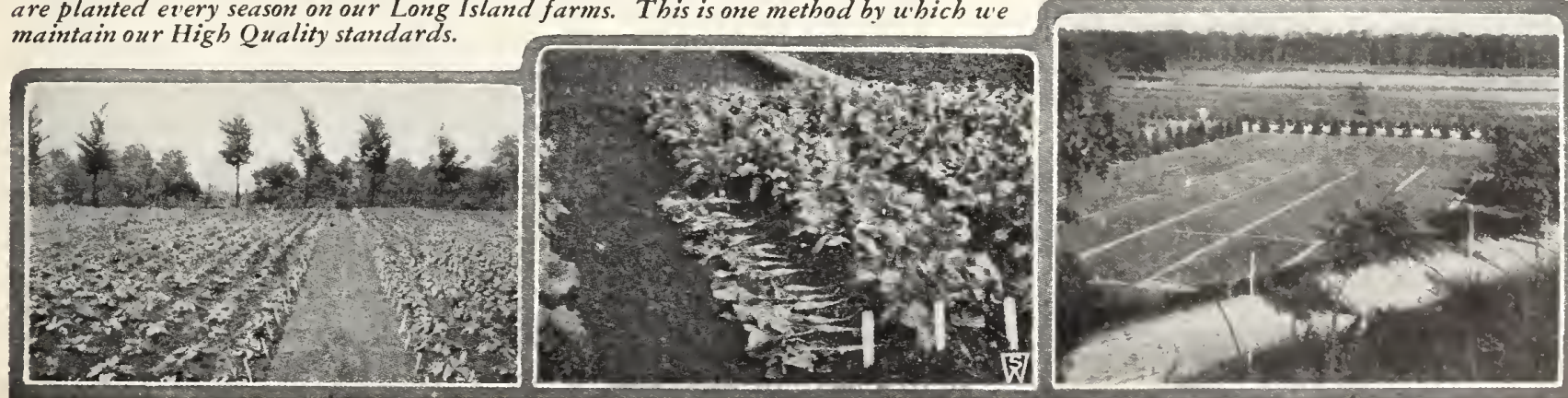


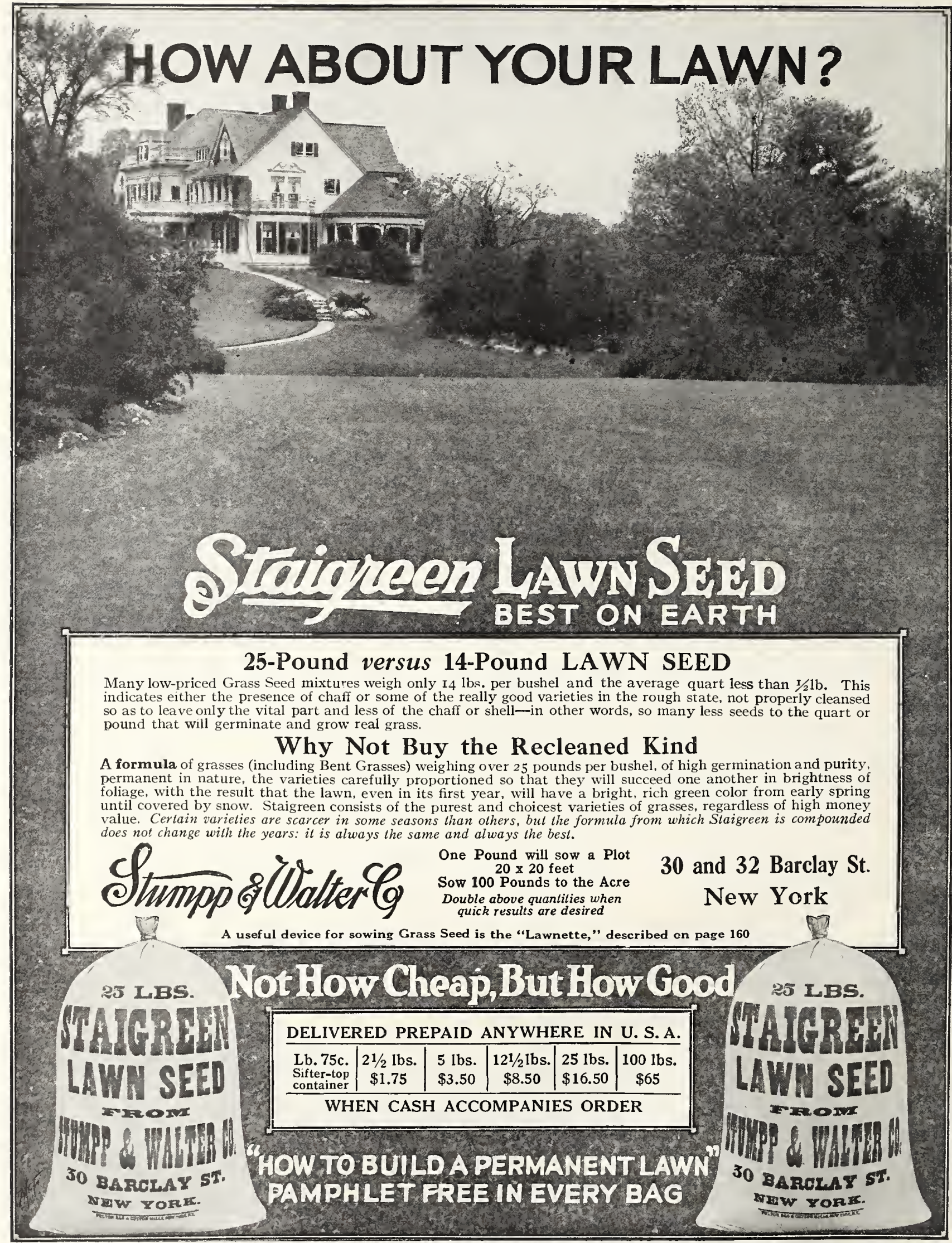




\section{Bent Zurf is}

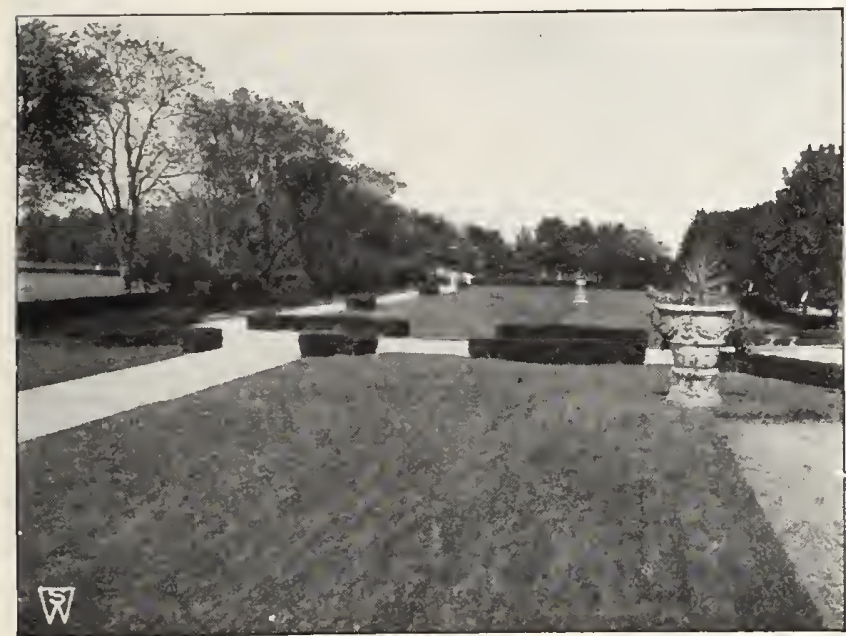

An All-Bent lawn

\section{All Bent Laun Grasseleed}

This is composed of Agrosiis vatieties only, a mixture of the wonderful Bent Grasses with a proportion of high-quality Red Top. In rich soil it will produce a turf much finer in texture than a lawn of the ordinary type, and the creeping character of these grasses causes them to mat together and produce the soft, luxuriant feel of an expensive rug. The turf is a deep, rich green color. All Bent will produce a sod equal in texture to the putting-greens of the more exclusive golf clubs, but the soil should be inherently good and should have additional rotted manure worked into it. Several times during the growing season, Urea or sulphate of ammonia, at the rate of $1 / 2$ ounce to the square yard, should be applied to the turf, first mixing the fertilizer with ten times its bulk of fine sifted soil. Every spring and autumn, also, I $1 / 2$ ounces to the square yard of S. \& W. Co.'s Emerald Grass Fertilizer should be applied, mixed with six times its bulk of soil. Sow the seed at the rate of I pound per 250 square feet or I 75 pounds per acre. Lb. $\$ 1.25$, $21 / 2$ lbs. $\$ 3,5$ lbs. $\$ 5.75,121 / 2$ lbs. $\$ 13.50$, 25 lbs. $\$ 26,100$ lbs. $\$ 100$. Charges prepaid when cash accompanies order.
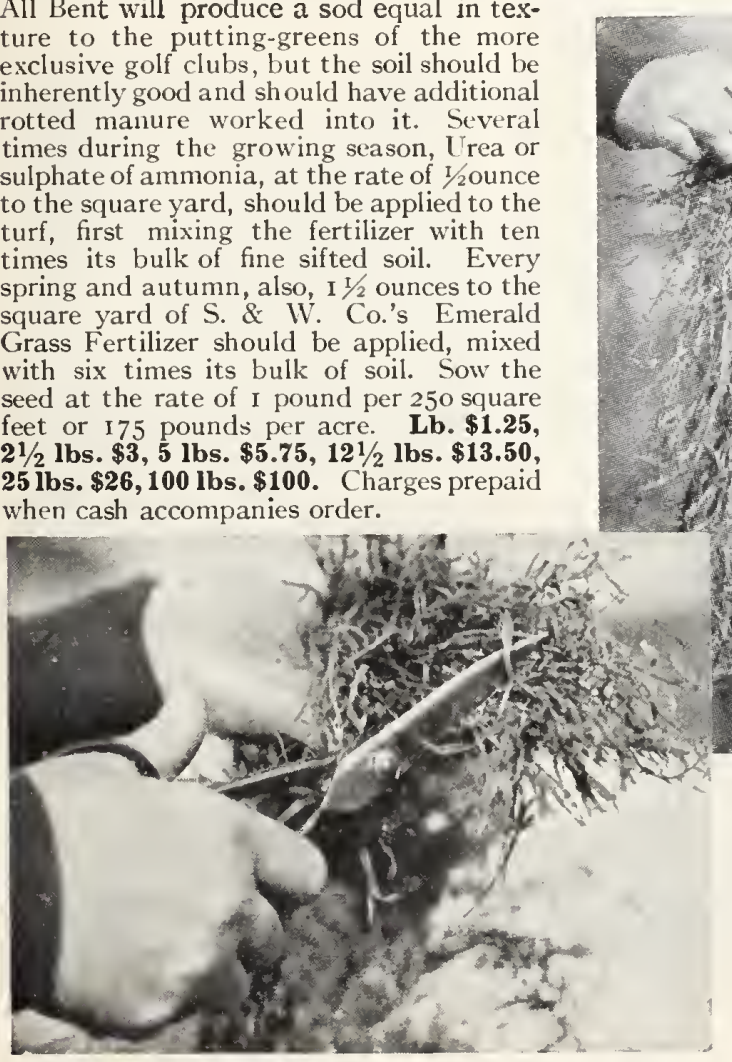

Stolons of Creeping Bent, are shown above. They are cut into short lengths as shown on the left, and planted to form a Bent turf.
SOW SEED of Our All-Bent Lawn Formula or

PLANT STOLONS of Creeping Bent

WHAT ARE BENTS? They are varieties of Agrostis, the dwarfest Grasses in cultivation; they are creeping in habit and they produce a dense mat of the finest silky leaves. They are used chiefly for producing the fine turf on putting-greens of leading clubs.

BENT LAWNS REQUIRE good soil adequately fertilized, sunlight, moisture, average care.

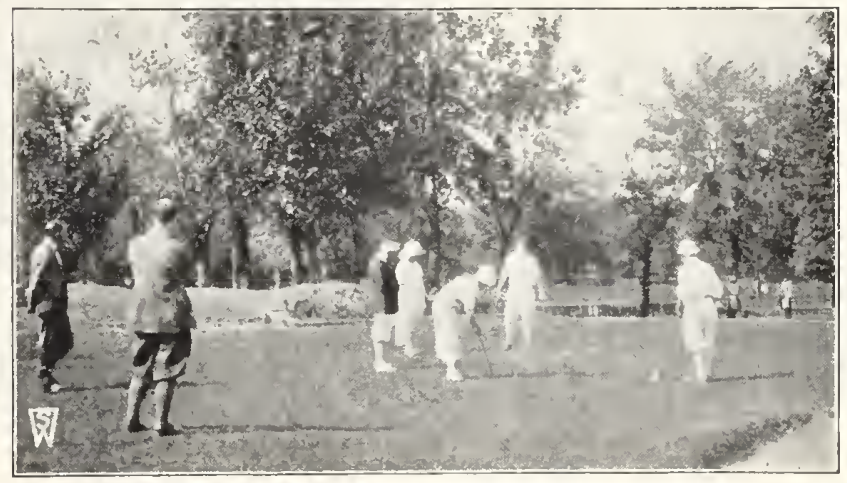

Bent makes a smooth turf for the home putting green

\section{Creeping Benteltolons}

\section{Stolons are creeping stems of the} living grass

\section{HOW TO USE STOLONS}

Growing in the Nurseries of the Stumpp \& Walter Co. are rows of Creeping Bent stolons, known to botanists as Agrostis stolonifera.

To make a Creeping Bent lawn, first estimate the size it will be in square feet and then purchase oneeighth the area in Creeping Bent stolons. For instance, if your lawn is to be 800 square feet in area, order Ioo square feet of the stolons; they cost $\$ 25$ per Ioo square feet. On receipt of your order the required quantity is stripped and sent to you by express.

Immediately the stolons reach you, unpack them, and then shake the earth from them. They will be found to consist mainly of tangled stems, like string. These are the stolons or runners. A stolon or runner of Creeping Bent is able to produce new plants at intervals throughout its length.

The stolons are clipped into pieces about $11 / 2$ inches long. Shears are satisfactory for small quantities, but a chaff-cutter is used for large areas.

Spread the clippings evenly on well-manured fine, smooth earth, and immediately cover them with $1 / 2$ inch of sifted soil.

Water the newly planted lawn daily for two weeks, by which time the young grass should be well through. Many golf greens are planted with stolons of Creeping Bent.

\section{STOLONS Or RUNNERS OF CREEPING BENT GRASS}

5 square feet $\$ 1.75,100$ square feet $\$ 25,1,000$ square feet $\$ 225$

Purchaser pays transportation from our Nurseries. Five square feet will plant a lawn 40 square feet in area; Ioo square feet will plant a lawn 800 square feet in area. Weight of one square foot about one pound. 


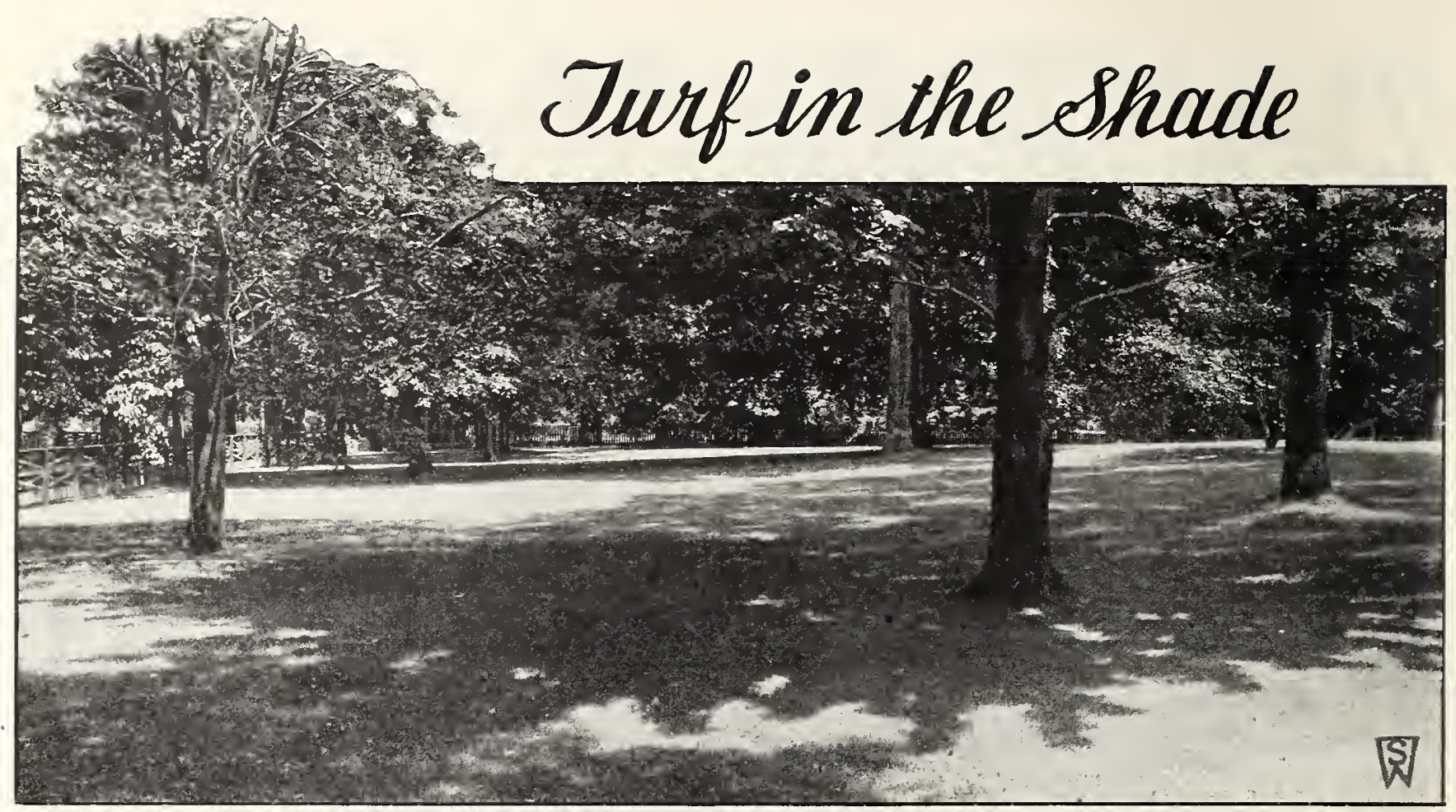

The most beautiful of lawns is the one o'ershadowed by trees

Shady Place Formula Lawn Seed. Consists of shade-tolerant grass varieties, properly proportioned, together with sorts which do well in sunny situations. So the formula may be used for dense shade as well as for those portions of the lawn which reach out into full light. Use as a minimum allowance, I quart for each I 5 by I5 feet, or 5 bushels per acre; sow half these quantities when renovating a lawn, and use double this quantity for quick results. Usually it is easy to obtain turf under trees when our Shady Place Formula is used, but in very stubborn cases it may be necessary to remake the lawn every season for several years, proceeding thus: Add lime every autumn at the rate of I pound per 20 square feet; fork the land lightly in the spring, and apply Pulverized Sheep Manure, I pound per 20 square feet; rake smooth and sow Shady Place Formula Lawn Seed; rake again to cover the seed and either use a roller or flatten with the back of a spade; sow some further seeds to renovate the lawn at the end of summer. Qt. 60 cts., 4 qts. $\$ 2$, 8 qts. $\$ 3.75,1 / 2$ bus. $\$ 7.25$, bus. (20 lbs.) $\$ 14,5$ bus. $\$ 67.50$. Charges prepaid when cash accompanies order.

\section{Turf for Lawn Jennis}

West Side Tennis Formula. The turf required for and vet elastic, fine, and composed of grasses which may be mown closely. Also, it must be one which will stand up well under the localized wear of lawn tennis. This formula is made up of suitable grasses, properly proportioned so as to give an even playing surface throughout the year. It is advisable to sow more seed than the quantity ordinarily used for lawn purposes in order to obtain a playing turf quickly and to crowd out weeds as much as possible; at least one pound for each I50 square feet is advisable on new seeding. Use seed at one-half this rate when renovating an existing tennis court or croquet lawn. Lb. 80 ets., $21 / 2$ lbs. $\$ 1.90,5$ lbs. $\$ 3.75,121 / 2$ lbs. $\$ 9,25$ lbs. $\$ 17.50,100$ lbs. $\$ 67.50$. Charges prepaid when cash accompanies order.

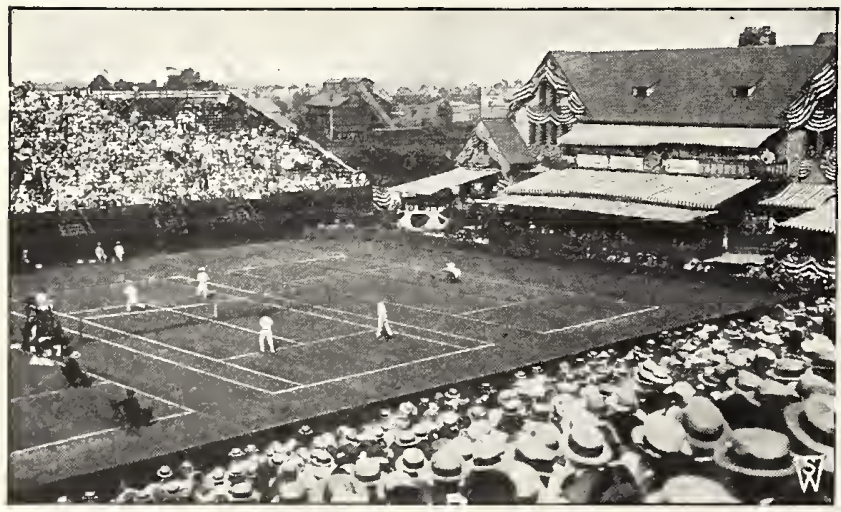

For Lawn Tennis and Croquet

\section{Jurf in the Tarks}

"High-Grade" Lawn Seed. Composed of fine, recleaned Dutch Clover, care being taken to include varieties of high purity and vitality. They are carefully proportioned so that they will succeed one another and give the lawn that much-desired green, velvety appearance through the summer. One quart will sow 15 by I5 feet; five bushels to the acre; use one-half these quantities for renovating old lawns; double quantities for quick results. Qt. 50c., 4 qts. $\$ 1.65,8$ qts. $\$ 3,1 / 2$ bus. $\$ 5.50$, bus. (22 lbs.) $\$ 10,5$ bus. $\$ 47.50$.

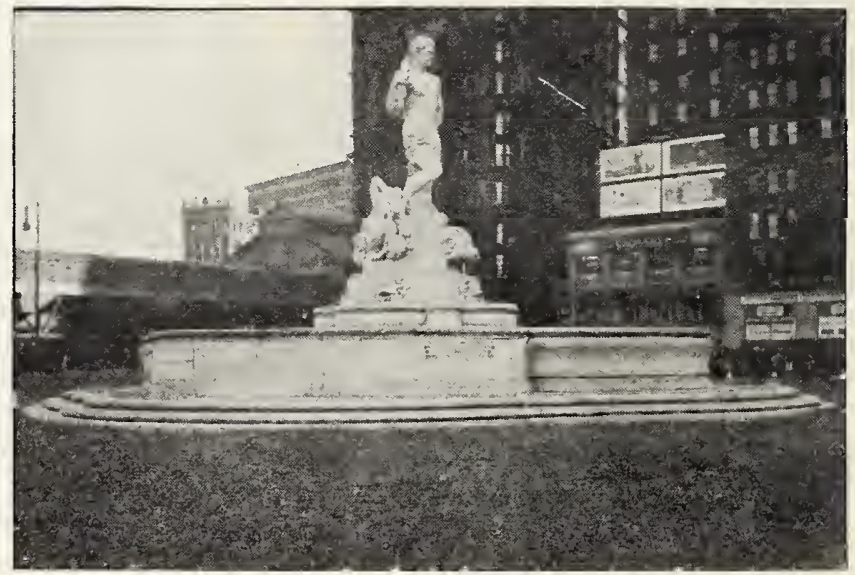

For Parks, College Grounds, and Other Large Areas

We advise the use of "High-Grade" Lawn Seed on large areas or on lawns where low cost of materials is more important than extreme fineness of turf. 


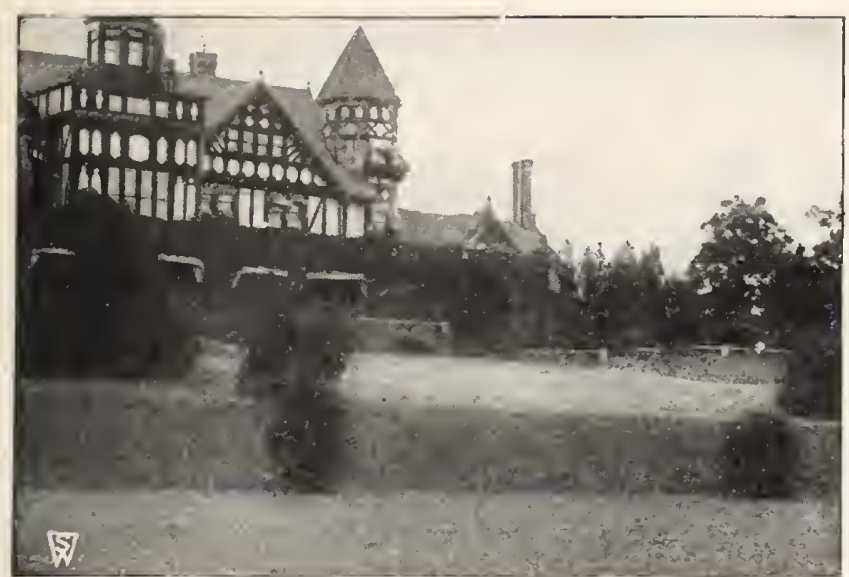

For Terraces, Hill sides and Embankments

\section{Turf on slopes}

Terrace Sod Formula Grass Seed. A mixture of produce strong, spreading roots, will withstand drought and sun, and will thrive on shallow soils. If the slope is gentle, add I inch of topsoil and then broadcast Emerald Grass Fertilizer at the rate of 5 pounds to each Ioo square feet. Rake, and sow Terrace Sod Formula, I quart to each Ioo square feet. Rake again lightly to cover the seed and make firm with a roller or back of a spade. If the slope is severe, proceed as above, except to sow along with the grass seeds some ordinary seed oats-I quart of seeds and I quart of oats to each Ioo square feet. Mow the oats as soon as they are long enough for a mower to cut them, and keep them cut. If the slope is very steep, mix I quart of Terrace Sod Formula with two pailfuls of earth. Make notches with a hoe about 9 inches apart, and fill the notches with the mixture. Qt. 60 cts., 4 qts. $\$ 2,8$ qts. $\$ 3.75,1 / 2$ bus. $\$ 7.25$, bus. (20 lbs.) $\$ 14,5$ bus. $\$ 67.50$. Charges prepaid when cash accompanies order.

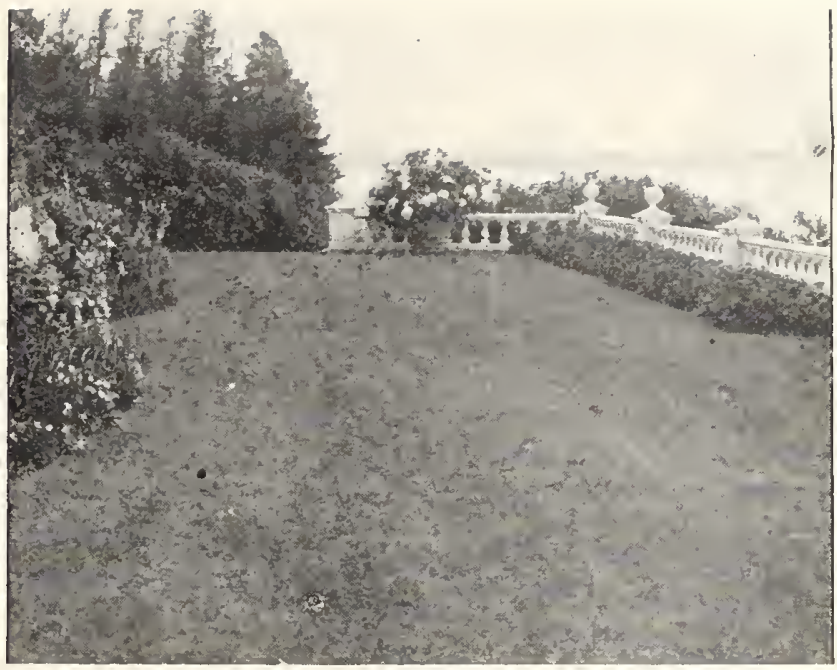

For Areas Subject to the Influence of Salt Spray

\section{Jurf by the sea}

Seashore Lawn Formula Grass Seed. The varieties which this qualities and resistance to salt spray and high winds. The soil in the neighborhood of the sea is frequently very poor, and a very good preparation for seed is to apply Pulverized Sheep Manure at the rate of I pound to each Io square feet; rake after applying this manure and then sow seed. One quart of this seed should be sown on an area I5 by I5 feet, or five bushels to the acre. Use one-half of these quantities for renovating; double quantity of seed for quick results. Qt. 50 ets., 4 qts. $\$ 1.65,8$ q ts. $\$ 3,1 / 2$ bus. $\$ 5.50$, bus. (22 lbs.) $\$ 10,5$ bus. $\$ 47.50$. Charges prepaid when cash accompanies order.

\section{Jurf in the South}

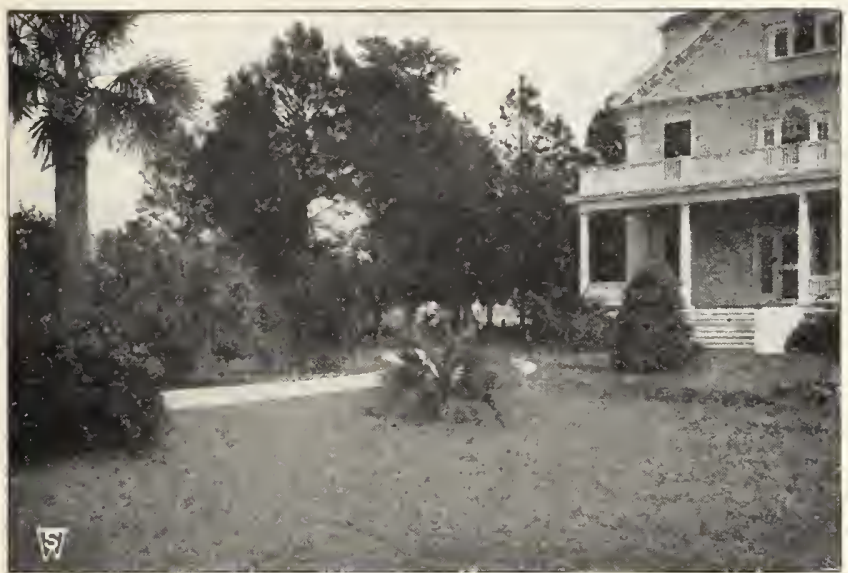

For Lawns in the Southern States

Southern Lawn Formula Grass Seed. From central south, the ordinary northern grasses will not thrive permanently, and good results are not likely to follow the use of the customary mixtures. As a result of an intimate knowledge of southern conditions we offer a special formula of grass seeds which we find is highly satisfactory. We advise that two seedings be made, one in spring and one in fall, allowing at each, I quart to every I 5 by 15 feet or 5 bushels to the acre. Qt. 50 ets., 4 qts. $\$ 1.85,8$ qts. $\$ 3,1 / 2$ bus. $\$ 5.50$, bus. (20 1bs.) $\$ 10,5$ bus. $\$ 47.50$. Charges prepaid when cash accompanies order.

Bermuda Grass Seed. A superior strain for fine lawns and pastures. Lb. 70 cts., 10 lbs. $\$ 6.50,100$ lbs. $\$ 55$.

Carpet Grass Seed. Recommended specially for lawns or pasture in moist soil. Lb. 65 cts., 10 lbs. $\$ 6,100$ lbs, $\$ 50$.

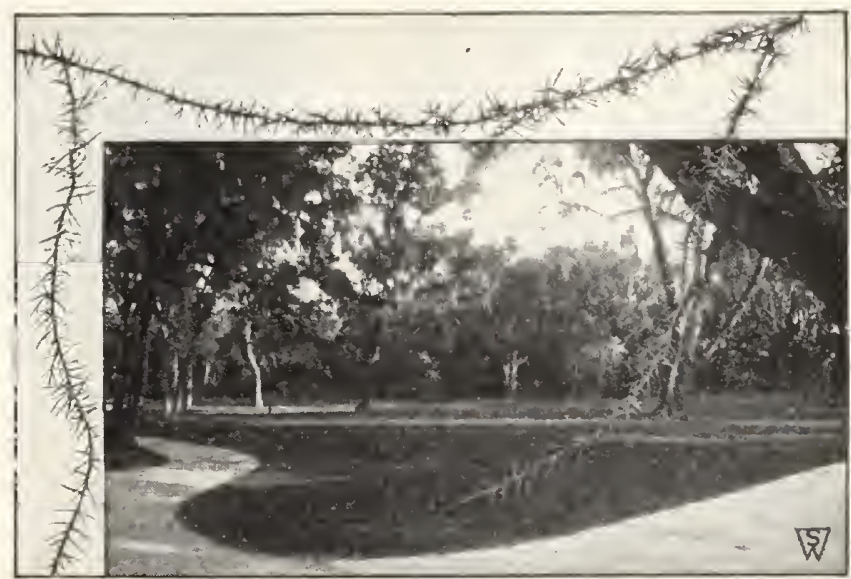

A Lawn in Florida produced from stolons of Centipede Grass. Above, the remarkable creeping growth of Centipede

Centipede Grass Stolons. A remarkable grass for the anth, introduced several years ago. For lawns, polo fields, fairways, airports and athletic fields you will find it the best grass for Florida, as well as other locations south of Virginia and those west to California, under similar climatic conditions. Centipede is a dwarf-growing grass that spreads rapidly, giving a luxurious turf. Centipede is not attacked by insects, withstands cold weather better than other southern grasses and is suitable for all soils. Plant in 8-inch furrows; 35,000 cuttings are sufficient for one acre. Cuttings are 14 to 22 inches in length, 250 to the bundle. $\$ 4.50$ per 1,000 cuttings, $\$ 40$ per 10,000 cuttings. Write for prices on larger quantities. 


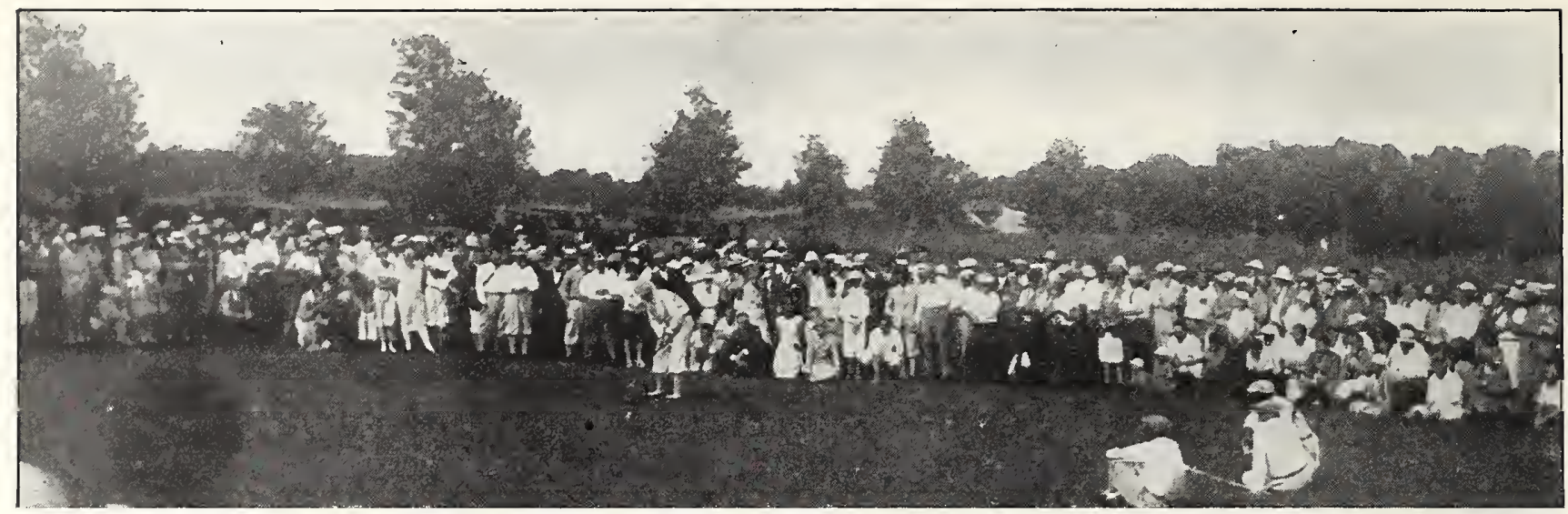

The Eighteenth Green, new course, Salisbury Golf Links, Salisbury Plains, L. I. (Lannin Realty Co., Inc., owners). Here are now five complete 18-hole golf courses in play. Grass seeds, fertilizers, and implements supplied by the Stumpp \& Walter Co.

\section{TURF FOR GOLF}

One of the secrets of fine turf is to use grass seeds of the highest purity and strongest vitality; seeds which are new, botanically true, and of maximum specific gravity; seeds which have been freed from weed seeds as far as modern machinery and care can remove them. Seeds of this high quality make up the following formulas:

\section{Putting-Green Formulas}

Use 1 pound to each 100 square feet; one-quarter to one-half this quantity for renovating.

\section{Special Putting-Green Bent Formula}

Recommended for well-prepared, rich soils. This is a blend of imported and domestic grass seeds of the finest quality-all of the highest purity and strongest germination. We include in the formula an increased proportion of the Bents, however, on account of their wonderful fineness and their suitability for golf. Lb. $\mathbf{\$ 1 . 1 0}$, 5 lbs. $\$ 5,25$ lbs. $\$ 22.50,100$ lbs. $\$ 85$.

\section{Standard Putting-Green Formula}

Recommended for light, dry soils. This is a blend consisting of imported and domestic grass seeds of fine quality - all of high purity and strong germination. The mixture includes the Bent grasses and Red Fescue, and is a well-balanced one; its use for more than twenty years has proved its reliability. Splendid for light, dry soils. Lb. 95 cts., 5 lbs. $\$ 4.50,25$ lbs. $\$ 20,100$ lbs. $\$ 75$.

\section{PLAY GOLF AT HOME!}

A miniature putting-green, clock course, or a chipping and putting course can easily be constructed on some part of your garden. Where space is limited, it may be merely a portion of the lawn to which you will give special care and on which holes may be sunk for putting.

With more space, shrubbery, hardy perennials, rock-gardens, or flower-beds may be worked into the scheme. Each little putting or chipping hole may have individuality, and we have a miniature flower course. Given enough distance, one or two holes may be planned to get in some mashie shots.

On an estate where some acres are available, the skilful placing of three or more greens, with tees arranged so that a variety of shots is possible, brings a private course to the residence. Nine holes of golf may be obtained with only three greens well designed and carefully placed.

House-owners with adjoining lawns may topdress and fertilize them, roll them frequently, and cut them closely, and, by sinking holes and installing small flags, the neighbors possess a community putting club.

Emerald Grass Fertilizer and our Putting Green and Fairgreen Formula Grass Seeds used on soil of good quality will produce the proper kind of golfing turf. Top-dressing with compost or fine soil from time to time, and more frequent and closer mowing than the average lawn receives, will keep the turf in playing condition.

Our 64-page book "Golf Turf" contains much information of value to the home golfer and greenkeeper. Ready February I, it will be sent free on application.

\section{Fairgreen Formulas}

Use 200 pounds to each acre; one-quarter to one-half this quantity for renovating.

\section{Fairgreen Formula, Superfine Quality}

A prescription of hardy yet fine grass varieties which will produce wonderful turf from tee to green.

Recommended for well-prepared, rich soils. This mixture contains Bent seed as well as Chewing's New Zealand Fescue, Kentucky Blue Grass, and Superfine Red-Top, all being mixed in their correct proportions. The weight of a measured bushel is 25 pounds. Lb. 75 cts., 5 lbs. $\$ 3.50,25$ lbs. $\$ 16,100$ lbs. $\$ 60$.

\section{Fairgreen Formula, Fine Quality}

Recommended for light, dry soils. Weight of a measured bushel of this formula, 20 pounds. This mixture contains only recleaned grasses of strong vitality, and will produce an even, tough and lasting turf. $\mathbf{L b}$. 60 cts., 5 lbs. $\$ 2.75,25$ lbs. $\$ 12$, 100 lbs. \$45.

\section{SENOLED. A Compound of Lead Arsenate for Grub-proofing Lawns and Gardens}

Lead Arsenate, when applied to the land, will destroy the Japanese Beetle, June Beetle, Wireworm, Cutworm, Maggots, and Earthworms. Its use discourages crab grass and other weeds in lawns, reduces $P o a$ annua, deepens the color of grass, and improves turf generally.

With a view to insuring an even distribution of Lead Arsenate we blend it with a proportion of Colloidal Phosphate, which is a fine earth rich in plant-foods; the colloidal properties of this material tend to hold the Lead Arsenate in the soil and delay its loss through leaching. This combination we term Senoled, and it is therefore designed not only to destroy pests and weeds over a long period, but also to feed the growing plants.

Senoled may be broadcast on old lawns for it will not burn grass. When making a new lawn, rake it in twenty-four hours before sowing seed; in the garden, apply it after digging. The amount employed is 25 pounds per I, ooo square feet, or onehalf ton per acre. It can be used at any time of the year with good effect, and up to 2,00o pounds per acre can be used with safety. 


\section{Grass Seeds for Golf}

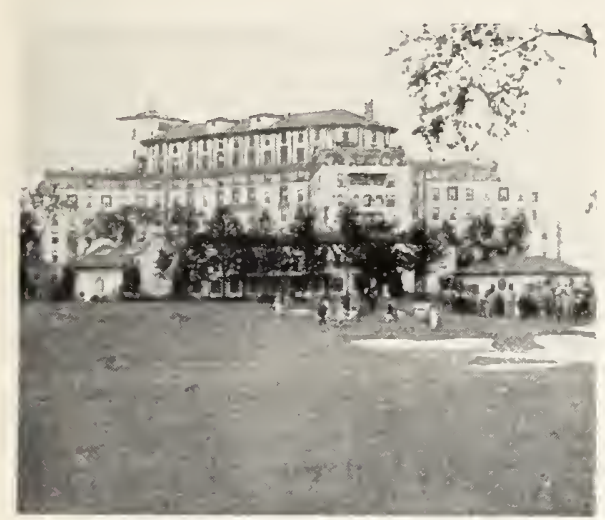

At the Westchester Country Club, N. Y.

Stumpp and Walter Seeds used

\section{SPECIAL DIVOT FORMULA \\ Always Keep a Bag in Stock}

A blend consisting of $(a)$ seeds of fine, strong wearing, permanent grasses suitable for fairways and tees, with $(b)$ seeds of the quickest growing plants we know that are of a temporary nature. The temporary plants grow immediately, and in a day or two you cannot locate the divot; in the course of a few weeks, with cutting, the temporary plants disappear, leaving the permanent grasses, now established, in full possession of the soil.

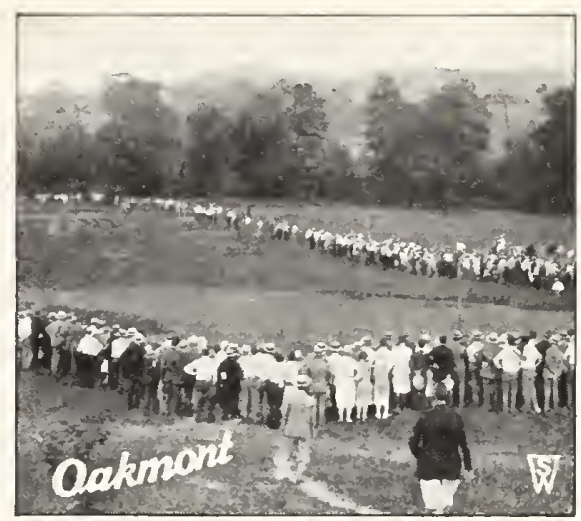

At the Oakmont Golf Club, Pa. Stumpp \& Walter Seeds used

How to Use Divot Formula. Take two pailfuls of screened soil; with one of them mix thoroughly $21 / 2$ pounds of Divot Formula. Fill the divot with unmixed soil, and scatter a $1 / 4$-inch layèr of the mixed soil and Divot Formula over it; press smooth with the foot. For ideal results tees should be inspected and treated in this way after each day's play, and fairways once a week.

Lb. 75 ets., 5 lbs. $\$ 3.50,25$ lbs. $\$ 16.50,100$ lbs. $\$ 65$

SPECIAL FORMULA FOR TEES. Our formula includes only those varieties which will stand rough usage and recuperate quickly after excessive wear Lb. 75 ets., 5 lbs. \$3.50, 25 lbs. $\$ 16,100$ lbs. $\$ 60$.

SPECIAL "ROUGH" FORMULA. Consists of the taller-growing hardy perennial grasses in combination witl gorse, yarrow, and other plants suitable for the purpose and least likely to give serious trouble as weeds, should their seed be carried by the wind and other agencies on to your greens or fairway's. Lb, 50 ets., 5 lbs. $\$ 2.25$. 25 lbs. $\$ 10,100$ lbs. $\$ 35$.

MIXED FESCUES FOR BUNKERS. A mixture of Red, Hard, Dwarf, Fineleaved, Various-leaved, and Tall Fescues. Excellent for mounds, bunkers, and exposed sandy situations in the "rough." Lb. 75 ets., 5 lbs. \$3.50, 25 lbs. $\$ 16,100$ lbs. $\$ 60$.

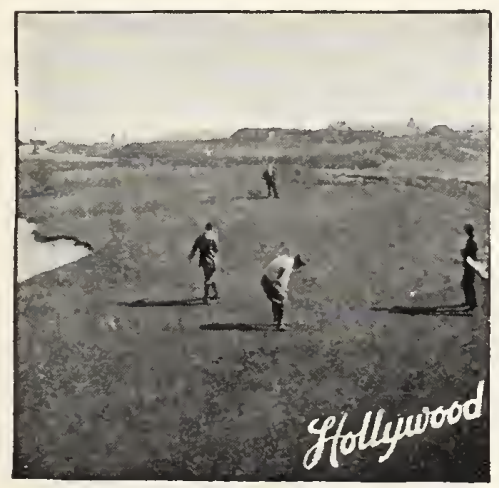

No. 17 Putting-Green, Hollywood Golf Club, N. J. Stumpp \& Walter Seeds used

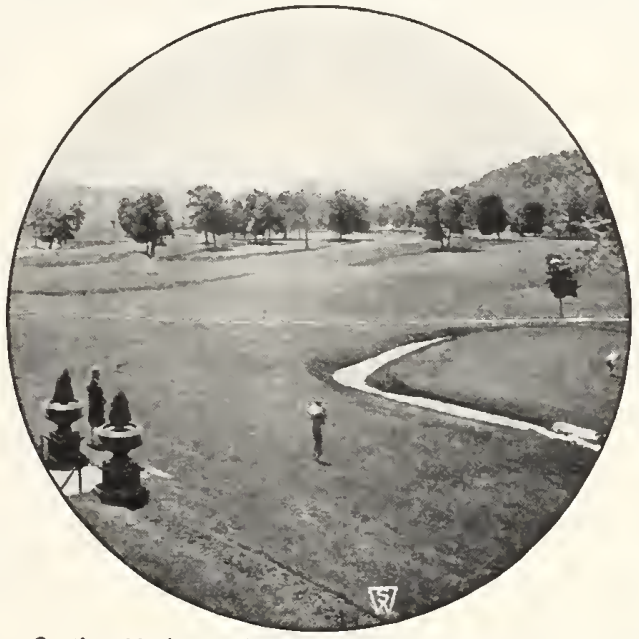

On the old nine, looking toward the new eighteen, at the Greenbrier, White Sulphur Springs, W. Va. Stumpp \& Walter Seeds used

\section{SEMESAN}

For the control of brown-patch in turf

Infected turf is first drenched with a solution of Semesan and afterwards it is either sprayed with the solution or and afterwards it is either

One pound of Semesan Powder is dissolved in a 50-gallon barrel of water, and this solution is applied at the rate of 5 quarts per square yard to the affected areas, using a water can; this drenches the turf. Later, at intervals of ten days, the turf is sprayed using 1 gallon of the solution to each 25 square yards. If preferred the powder may be dusted on dry instead of spraying, using 1 pound of the powder per dry instead of spra

The quantity of Semesan required for the first drenching depends upon the extent of the infected areas; the subsequent spraying or dusting should be over theas; the subsequent pounds of the powder in solution should be allowed to each average green; rather more is required if the powder is put on dry-allow 5 pounds to each average green. 2 ozs. 50 cts., lb. $\$ 2.75,5$ lbs. $\$ 13,25$ lbs. $\$ 56.25,100$ lbs. $\$ 220$.
WHITE CLOVER (Trifolium repens)

Do not use for putting-greens, but it is occasionally recommended for fairways and tees. IVe offer the finest sample procurable. Lb. 75 cts., 10 lbs. $\$ 7,25$ lbs. $\$ 16,100$ lbs. $\$ 60$.

GORSE or FURZE ( Llex europaus). This shrub makes British courses bright with its yellow blossoms in the spring. It is a slow grower and it will be some years before it will be effective. Broadcast ten pounds per acre over the "rough" and harrow in. Not recommended for the extreme North. Lb. $\$ 1.50$.

YARROW (Achillea millefolium). A deep-rooting, drought-resisting plant with delicate, fern-like leaves, sometimes used in mixtures for tees or polo fields. May be sown alone (when one pound is sufficient for an area of 40 by $40 \mathrm{ft}$.) or in combination with grass seeds. Lb. \$1.75, 10 lbs. \$16.

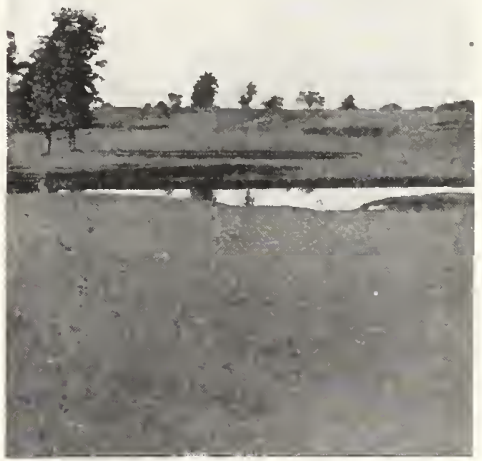

Waterhole, Essex County Country Club, N. Stumpp \& Walter Co.'s Seeds used 


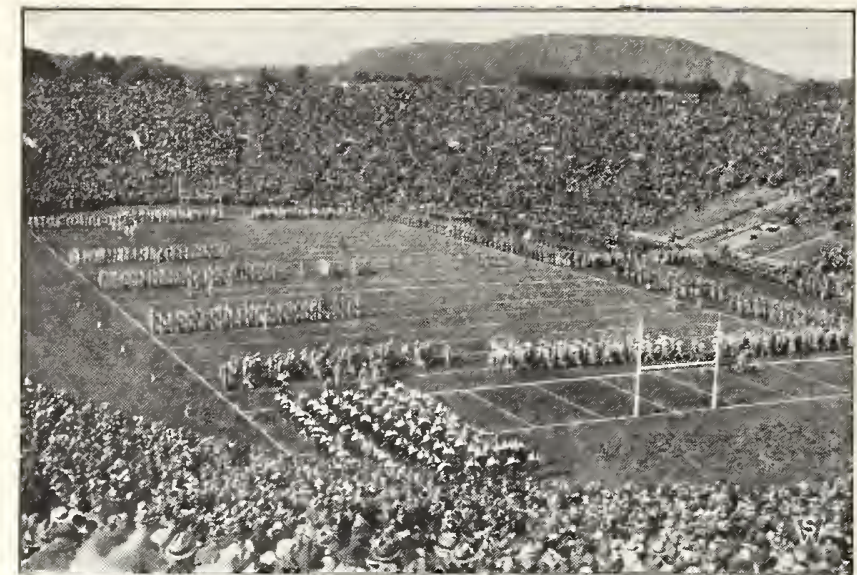

The Bowl at Yale University, New Haven, Conn. Stumpp \& Walter Co.'s Grass Seeds used and advisory recommendations made for Bowl as well as Golf Course, Football and Polo Fields.

\section{Turf for Football}

Football is especially exacting in its turf requirements. Excessive wear has to be provided for, and this wear is given at a season of the year when some varieties of grass are growing least actively. Prompt recovery after use at this unfavorable season, and the employment of grasses which will give the players a good foothold, are also essentials.

A rich, deep soil, medium light and well drained, gives a good field, and, to insure deep rooting, two tons of rotted manure per 2,000 square feet ( 50 by $40 \mathrm{ft}$.) should be worked into the land to a depth of 5 inches when making a new field; then roo pounds per 2,0oo square feet of Emerald Grass Fertilizer should be broadcast and raked in. Sow 15 pounds per 2,00o square feet of Stumpp $\&$ Walter Co.'s Touchdown Formula Grass Seeds

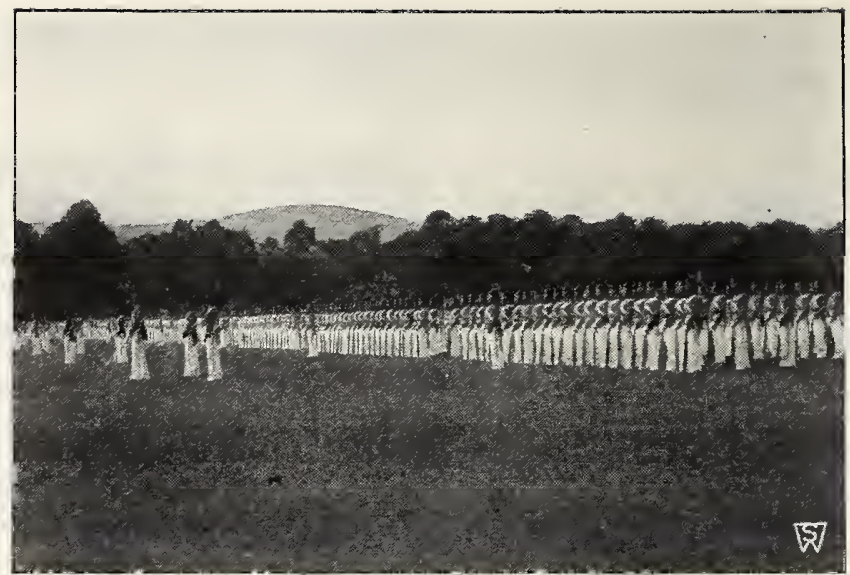

Stumpp \& Walter Co.'s Grass Seeds and Fertilizers are used on the Parade-Ground, Polo Field and Stadium at the U. S. Military Academy, West Point, N. Y.

Photo, White

Touchdown Football Formula. Consists of the most suitable varieties of grasses, properly proportioned. We vary the formula to suit your soil, which please describe when ordering. Use as just described on new fields, and one-half the quantity when renovating a field at the close of the season. $\mathbf{2 5}$ lbs. $\$ 16.50,100$ lbs. $\$ 62.50$.

Emerald Grass Fertilizer. Contains all the plant-foods most needed by grass. May be used as just suggested for new fields. For existing fields apply one-half the quantities there recommended twice a year: at the close of the playing season and again one month before the game begins. $\mathbf{1 0 0} \mathbf{l b s} \mathbf{\$ 5 . 5 0}$, $500 \mathrm{lbs} \$ 22$, ton $\$ 75$.

\section{Turf for Polo}

Only the toughest, deepest-rooting varieties of grass will survive the pounding and tearing of polo ponies, and this thought is before us when compounding our Hurlingham Formula. Maximum depth of root is obtained, too, by incorporating rotted manure with the upper five inches of topsoil; also, by daily mowing, but with the cutters set as high as the play will permitin other words, mow the grass as "long" as possible.

Tile-drainage is frequently desirable when building a polo field, and a slight crown to discharge surface water is an advantage.

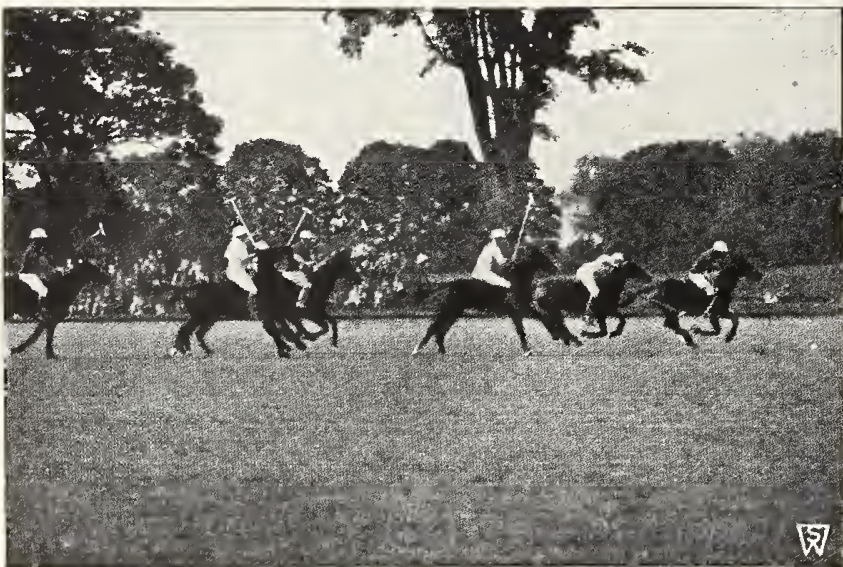

The turf of the Sands Point Polo Field is kept in its fine condition by occasional dressings of Stumpp \& Walter Co.'s Grass Seeds and Fertilizers
Hurlingham Polo Formula. The mixture used successfully for many years on the well-known English field. Where it is likely to be suitable in this country, we supply the same formula, but we change it to adapt it to other conditions where necessary. Use 200 pounds per acre for new fields, and Ioo pounds per acre is a fair allowance when renovating. $25 \mathrm{lbs}$. $\$ 16.50,100$ lbs. $\$ 62.50$.

Fairgreen Fertilizer. An excellent plant-food, which may be used at the rate of one ton per acre when building a field. Use one-ha'f ton per acre every spring and as a top-dressing. 100 lbs. $\$ 4,500$ lbs. $\$ 15$, ton $\$ 50$.

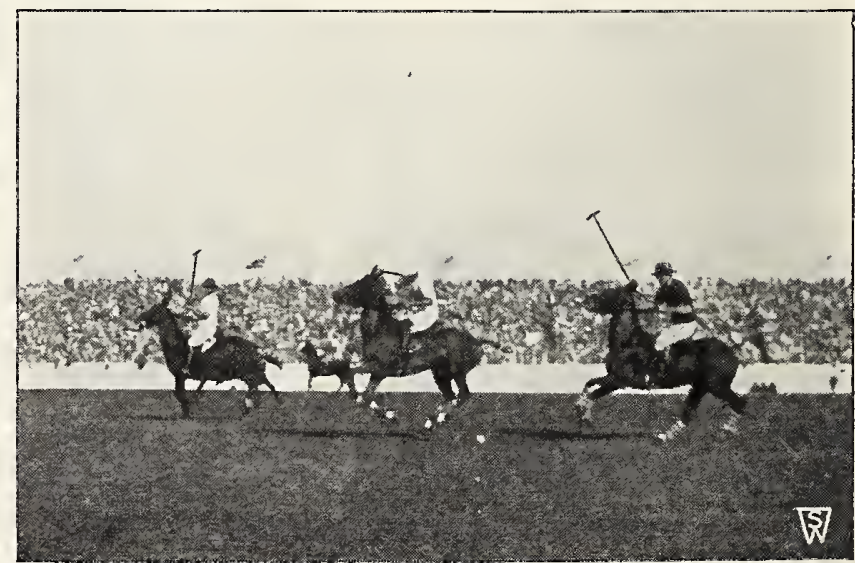

Meadow Brook Club, where Inteinational Matches were held last year. Seeds for this field supplied by the Stumpp \& Walter Co. 


STUMPP \& WALTER CO.'S SELECTED SEEDS

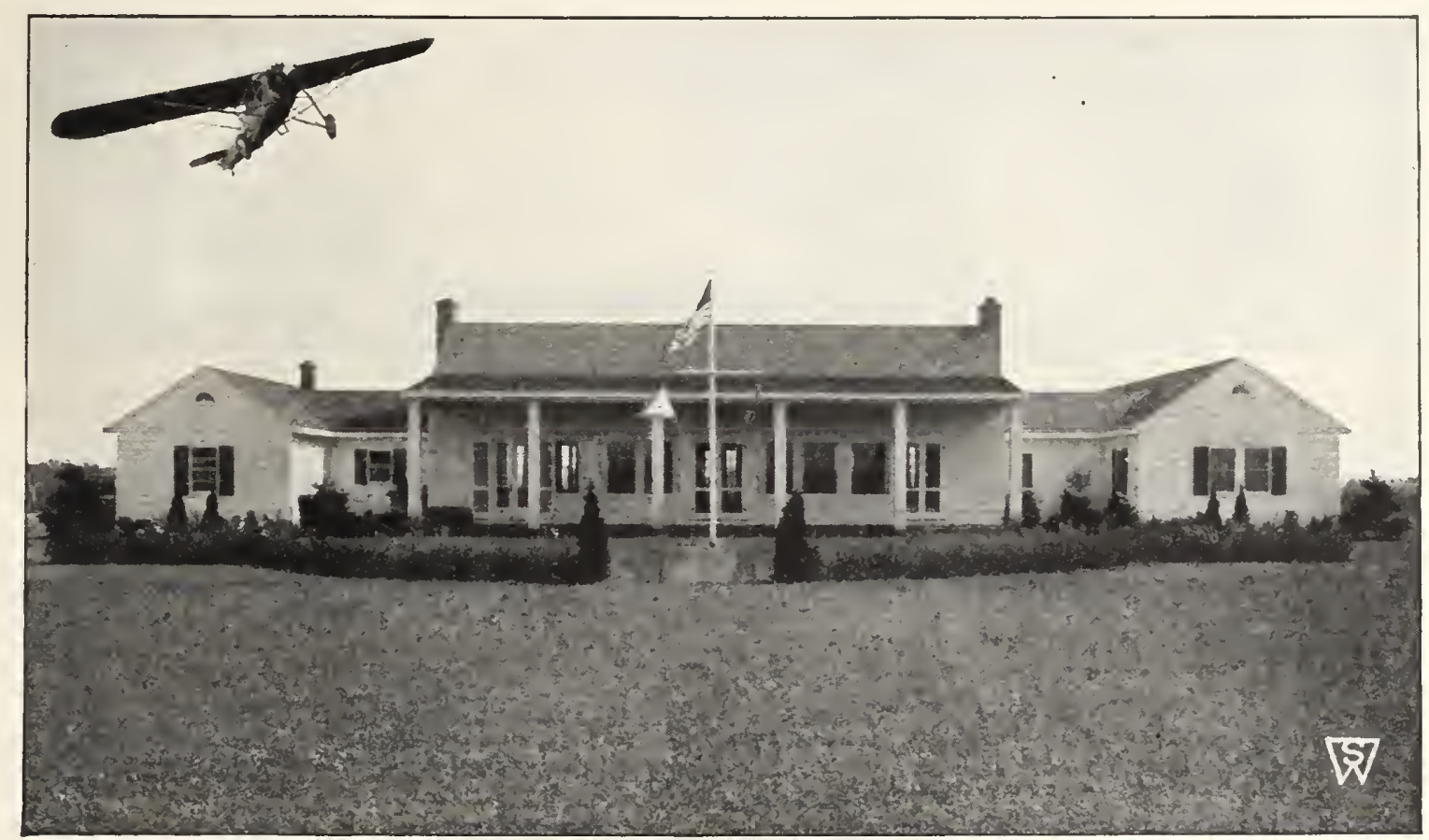

On the 5o-acre Landing-Field of the Long Island Aviation Country Club, Hicksville, L. I. Grass Seeds supplied spring, 1929, by Stumpp \& Walter Co.

\section{Turf for Airports and Landing-Fields}

The aviator recognizes that a smooth take-off and a perfect landing are impossible in heavy mud or on a dry, hard field, covered with ruts and tail-skid scars, but they are easily made on level grass-land, which has been kept closely mown. To cover a field with a matted, yielding, wear-resistant turf is not difficult in most cases, nor need it be costly; almost always it will be found a profitable investment. The Department of Commerce, in its ratings on landing-fields, gives a higher classification to those with grass turf. They are safer and more inviting to pilots, passengers, and visitors.

A good grass field is safe because in bad weather, as well as good, the surface is even. There are many different kinds of grasses, and by using varieties which have tough, wiry leaves and very deep roots, a sod can be obtained which will not readily develop ruts and mud-holes; thus will be prevented many a broken propeller, many a damaged plane, many an injury to the aviator. IVhere possible, a pilot will avoid a dangerous field in favor of a turf-covered one, which is safe, and the grass field will have additional revenue in consequence; its gas and oil concessions will boom and its hangars will be rented.

Level turf is fast. With no mud to slow up the plane, it can make a clean, quick take-off; and trees, wires, or buildings at the edge of this field present no problems to the pilot. In dry weather, dust is absent from a grass field. There are no stones to be caught up by the slipstream of the propeller to annoy passengers and damage wing surfaces; no grit to settle on motors and cause mechanical difficulties; and motor trouble is likely to happen with grit, in spite of the care with which many motors are shielded nowadays.

\section{Grass Seeds and Fertilizer for Airports}

Airport Formula, Superfine Quality. A special combination of the deepest rooting grasses that will Airport Formula, Superfine Quality. produce a strong, densely matted turf. When established, this turf is calculated to withstand the scarring of the tail-skid and not to form ruts under the heavy weight of modern planes. It gives a sward of a deep green color. Use I 50 lbs. to 250 lbs. per acre for quick results. $100 \mathbf{l b s} . \$ 55$.

Airport Formula, Fine Quality. A lower price formula than the above. Gives a tough, wear-resistant turf, Airport Formula, Fine Quality. but one which is gray-green in color. Use Ioo lbs. per acre. $100 \mathrm{lbs} . \$ 40$. Airport Fertilizer. A very concentrated grass food, high in quality but offered at a price that justifies its

A field with distinctive marking is helpful to the pilot, and, if wished, the airport may have runways of a dark color against a lighter green for the remainder of the field. When these deep green runways and a gray-green outer field are desired, use our Superfine Quality Airport Formula for the runways and our Fine Quality Airport Formula for the remainder of the field. This effect may be enhanced by applying Airport Fertilizer to the runways only, before seeding, and by top-dressing runways with Airport Fertilizer every spring and fall.

Our many years of technical service to golf clubs, polo fields, etc., has necessitated visits to all parts of the United States and Canada, thus placing us in a position to know what is required in your section for producing the proper turf, and the benefit of this experience is offered without cost to you. 


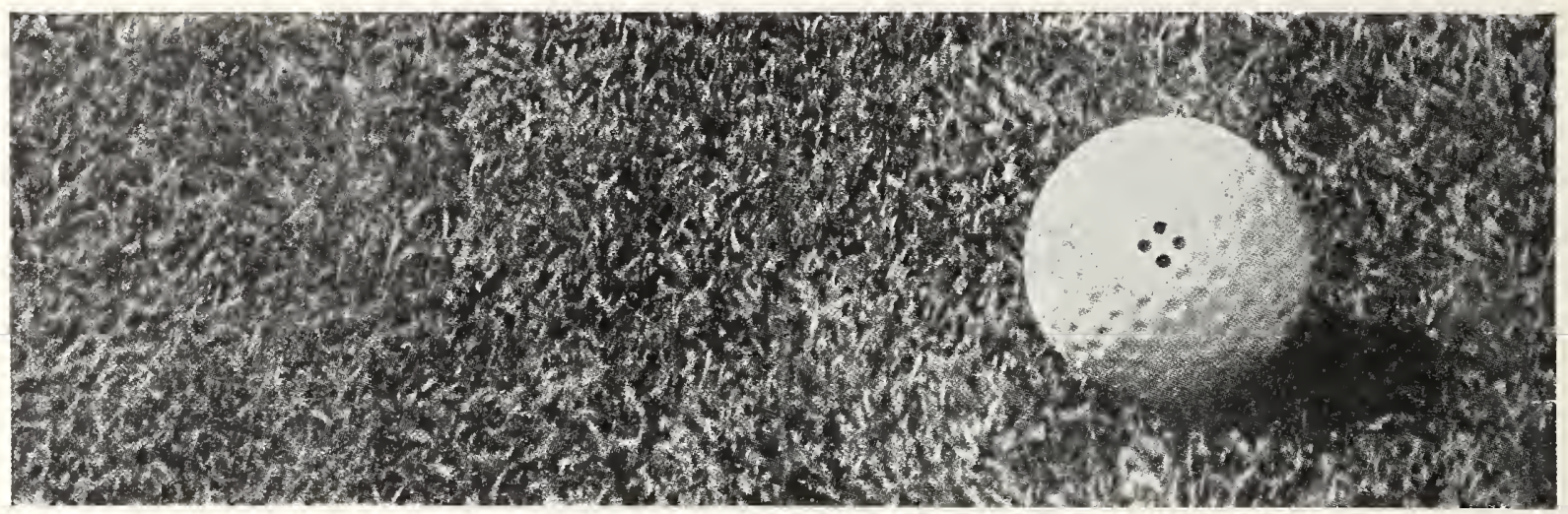

A Piece of Cocoos Creeping Bent Turf

\section{Individual Grass Varieties}

These individual grasses are employed in the compounding of our mixtures for Fine Lawns, Parks, Golf Courses, Polo Fields, Playgrounds, Hay and Pasture Fields. Occasionally they are used alone when special conditions indicate that one sort only should be sown.

We offer our seeds strictly as of proved maximum purity and maximum vitality. In other words, we do not allow them to leave our premises until the findings of our Analyst, supported by certificates of Federal and state testing stations, show the highest possible percentage of purity and germination. Purchasers may be assured of other points of superiority: botanical trueness, newness, high specific gravity, and, most important of all, practical freedom from seeds of harmful weeds.

\section{Agrostis Varieties or Bents $\begin{aligned} & 1 \text { lb. contains about } \\ & 4,000,000 \text { live seeds }\end{aligned}$}

COCOOS CREEPING BENT. A strongly creeping, densely matting grass which furnishes a turf of wonderful quality, beautiful dark green color, and extreme uniformity. The fine turf-producing quality of Cocoos Bent was first recognized on the Pacific Coast and has since been meeting with much favor in other sections, especially in the eastern states. Cocoos Bent is a superior strain of Agrostis maritima, but all strains of A. maritima are not Cocoos Bent. Lb. \$2.75, Io lbs. \$25, Ioo lbs. \$225.

November 15,1930

I consider Cocoos Bent the best putting-green grass today. One great thing about it is it grows quickly; if the land is well prepared you will get a good putting sur face in three months. The Cocoos Bent greens at Wildwood are wonderful and so are those at Johnstown.-EMIL LOEFFLER, Oakmont Country Club, Pennsylvania.

SOUTH GERMAN BENT or FIORIN. A natural mixture of Agrostis canina, A. capillaris, and A. palustris. Although the seeds are collected in Europe from plants which appear identical, analysis of German Bent and observation of experimental plots disclose the fact that the pure live seeds in good samples consist of three closely related valuable turf grasses, as much as 30 per cent Velvet Bent, 5o per cent Rhode Island or Colonial Bent, and 3 per cent Carpet or Creeping Bent. Under the name of German Creeping Bent, for many decades, good lawns and putting-greens have been sown with this seed, producing turf of exceedingly fine texture and pleasing color. Superfine... \$2 oo $\$ 18$ 50 $\$ 165$ oo Recleaned.. I 75 I6 50 I45 o0

VELVET BENT (Agrostis canina). A variety which is ideal for the finest lawns of all. This is the smallest of the turf grasses, producing a sward of exquisite, silk-like texture and bright emerald color. Most of the finest putting-green turf that has been produced in America since golf courses were first constructed consists of Velvet Bent. Only limited quantities of pure seed are procurable. Lb. $\$ 7.50$.

RED-TOP (Agrostis alba). A good pasture and hay grass and valuable as a nurse in lawns. If permitted to grow without cutting, it becomes coarse, but it is short-lived under mowing and does not become coarse if cut. Red-Top is recommended as an ingredient in most lawn seed mixtures. Lb. rolbs. roolbs.

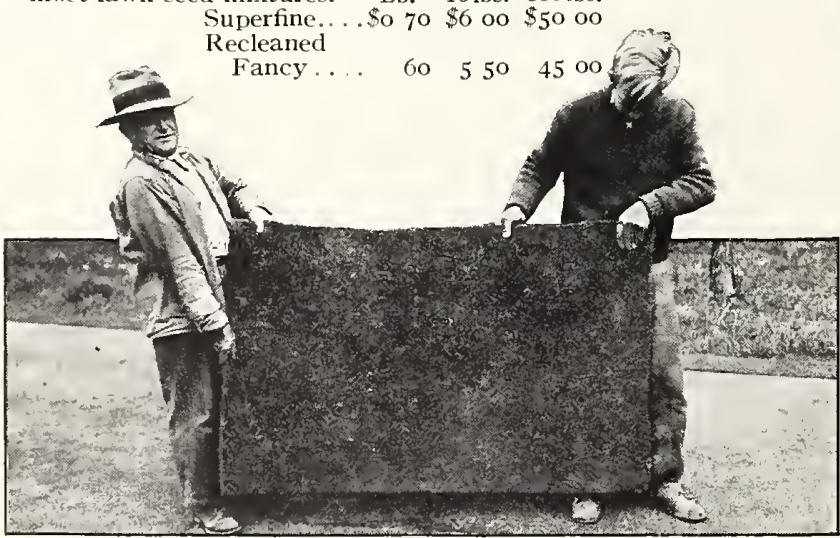

Cocoos Sod. Three-quarters of an inch thick, closely woven like an oriental rug and just as silk-like in texture
TRIPLE A BENT. A special variety of Agrostis capillaris producing a reinforced sod, stoloniferous and of the same pleasing color and texture as Velvet Bent. A wonderful grass, fine, silky, and bright in color even under adverse conditions. Triple A Bent has been re-machined specially for the elimination of weed seeds and it is remarkably free of them. It has been the outstanding plot in our trials. Lb. $\$ 2.50$, Io lbs. $\$ 22.50$, Ioo lbs. $\$ 200$.

COLONIAL BENT (Agrostis capillaris). Identical with native Rhode Island Bent. Makes excellent turf on moist land, and is strictly permanent under close cutting. Our seed contains less than one-tenth of I per cent of weeds. L b. \$I.65, Io lbs. \$I 5, Ioo lbs. \$I35.

RHODE ISLAND BENT (Agrostis capillaris). Produces a turf of good color, fine texture, and with considerable resistance to drought. poor soil, and cold. We offer a fine strain of this species harvested in the United States. Lb. \$1.75, Io lbs. \$16.50, Ioo lbs. \$1 45 .

CREEPING BENT STOLONS (Agrostis palustris). Metropolitan and Washington Strains. See page 5. 5 sq. ft. $\$$ I.75, Ioo sq. ft. $\$ 25$, I,000 sq. ft. \$225.

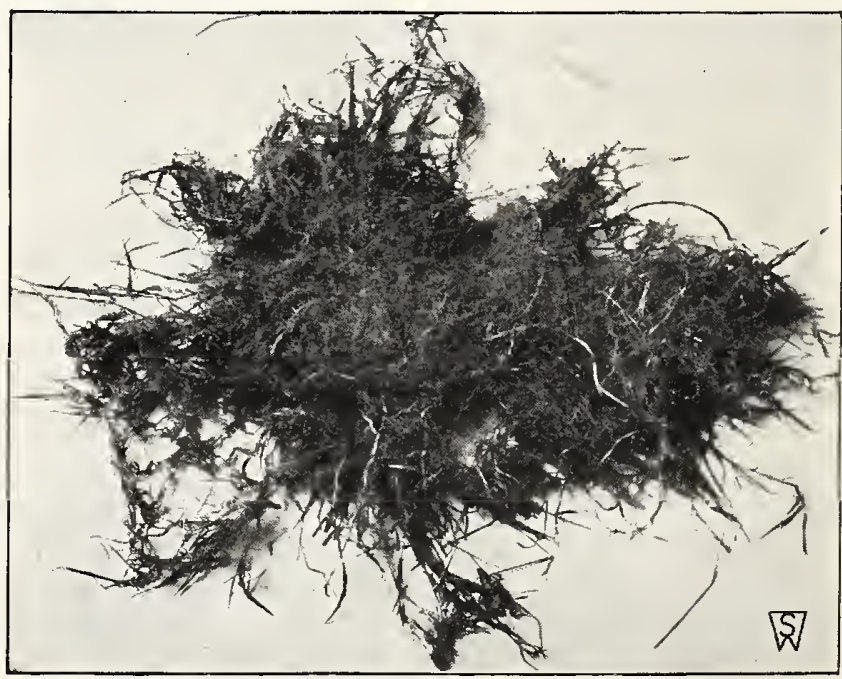

A sod of Triple A Bent Grass inverted, showing stolons and basal shoots. Note dense rooting-system 
INDIVIDUAL GRASS VARIETIES, continued

Fescue Varieties One pound contains from 500,000 to $1,000,000$ live seeds

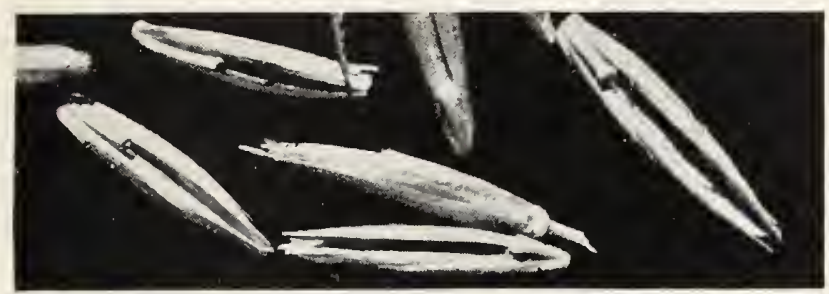

Seeds of Chewing's New Zealand Fescue magnified 5 diameters

CHEWING'S NEW ZEALAND FESCUE (Festuca rubra fallax) Produces a mat-like turf of a brownish green color. The leaves ar fine, needle-like, and bristly. Makes excellent putting-greens, golf fairways, and lawns, suits almost all soils, including those of a light nature, and does well in shade. The most resistant of all grasses to hard wear. Lb. 80 cts., Io Ibs. $\$ 7.50$, Ioo lbs. $\$ 65$.

FINE-LEAVED FESCUE (Festuca tenuifolia). A splendid grass for putting-greens, producing a beautiful, soft, velvety turf. The best grass for sowing in the spaces between flagstones in the garden path. Lb. 90 cts., Io lbs. $\$ 8.50$, I0o lbs. $\$ 75$.

RED FESCUE (Festuca rubra). European; similar to Chewing's Fescue, but not so desirable because occasional plants of Sheep's Fescue may be found in turf grown from inferior samples. Lb. 65 cts., Io lbs. $\$ 6$, I oo lbs. $\$ 50$.

CREEPING RED FESCUE. This has narrow, wire-like leaves, and is dark vivid green in color. It is not so dwarf a plant nor are the leaves so fine as those of Chewing's Fescue. Price on application.

SHEEP'S FESCUE (Festuca ovina). A wiry, stiff, blue-green grass suitable for turf on poor soils. Has a tendency to "tussock" and should always be sown in conjunction with other grasses. Ideal for bunkers and the rough on a golf course; valuable as a sheeppasturing variety. Lb. $55 \mathrm{cts}$., Io lbs. $\$ 5$, I $00 \mathrm{lbs}$. $\$ 40$.

HARD FESCUE (Festuca duriuscula). Similar to the above grass, and, like it, of more use to the sheep-farmer than to the lawnkeeper. Lb. 55 cts., Io lbs. $\$ 5$, I $00 \mathrm{lbs} . \$ 40$.

MEADOW FESCUE (Festuca pratentis). A flat, broad-leaved grass, furnishing an abundance of fodder as hay or pasture. Tall and grows quickly. Lb. $40 \mathrm{cts}$., Io lbs. $\$ 3.25$, Ioo lbs. $\$ 25$.

TALL FESCUE (Festuca elatior). A tall broad-leaved grass, useful in mixtures for the farm. Lb. $65 \mathrm{cts}$., Io lbs. $\$ 6$, Ioo lbs. $\$ 50$.

VARIOUS-LEAVED FESCUE (Fesluca heterophylla). Used to a limited extent in sports grass formulas and for hay and pasture. Lb. $95 \mathrm{cts}$., Io lbs. $\$ 9$, I 00 lbs. $\$ 85$.

\section{Sundry Varieties}

AWNLESS BROME GRASS (Bromus inermis). Grows 30 inches high and has creeping roots. Useful for binding embankments. A pasture grass for dry soils. Lb. $40 \mathrm{cts}$., Io lbs. $\$ 3.50$, IOo lbs. \$30.

CRESTED DOG'S.TAIL (Cynosurus cristatus). A good turf and pasture variety, but will thrive only in situations especially favorable to it. Lb. $60 \mathrm{cts}$., Io lbs. $\$ 5.50$, Ioo lbs. $\$ 45$.

MEADOW FOXTAIL (Alopecurus pratensis). As a field grass gives large yields early. Lb. \$1.IO, Io lbs. \$10, I0o lbs. \$95.

ORCHARD GRASS or COCKSFOOT (Daclylis glomerata). A large, bluish green plant, widely used for hay and pasture; thrives in partial shade. Lb. 45 cts., Io lbs. $\$ 4$, IOo lbs. $\$ 30$.

SWEET VERNAL (Anthoxanthum odoratum). A dwarf-growing grass, useful for lawns, pastures, and hay. Very fragrant when drying, its presence being responsible for much of the scent of new-mown lray. Lb. \$I.5O, Io lbs. \$I 3.50, Ioo lbs. \$I 25 .

TALL OAT GRASS (Avena elatior; Arrhenatherum elatius). A large plant, valuable for hay, pasture, and silage. Lb. 45 cts., Io Ibs. $\$ 4$, Ioo Ibs. $\$ 35$.

TIMOTHY (Phleum pratense). A quick-growing, tall, coarse grass, not recommended for inclusion in lawn mixtures, but of great value for hay and pasture; the most important American grass for these purposes. Lb. $35 \mathrm{cts}$., Io lbs. $\$ 3$, $100 \mathrm{lbs}$. $\$ 20$.

WHITE CLOVER (Trifolium repens). This familiar plant is sometimes used for lawns and by the farmer for pasturage. It grows quickly, forms a close herbage, and remains green throughout the season. Lb. $75 \mathrm{cts.,}$ Io lbs. $\$ 7$, Ioo lbs. $\$ 60$.
Poa Varieties One pound contains about

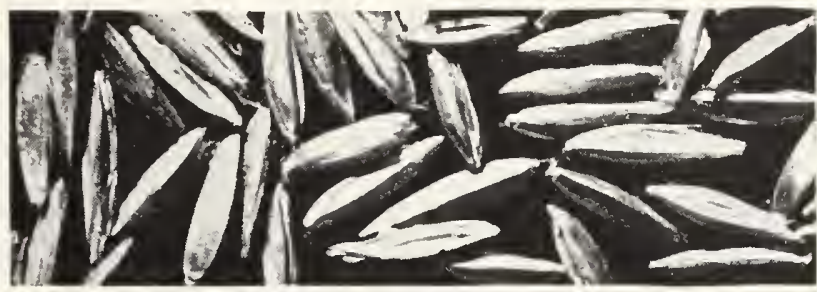

Seeds of Bird-Grass magnified 5 diameters

BIRD-GRASS or ROUGH-STALKED MEADOW GRASS ( $P \circ a$ trivialis). One of the few grasses that will grow in shaded situations. A desirable ingredient in shaded fairways and putting-greens. Resistant to drought. Lb. 85 cts., Io lbs. $\$ 8$, Ioo lbs. $\$ 70$.

KENTUCKY BLUE GRASS ( $P_{0 a}$ pralensis). Used for all lawn purposes in the northeastern states. Desirable as a golf fairway grass, particularly on rich soils that have been limed. A valuable pasture grass. In our Superfine Quality we offer seed 97 per cent pure, with less than one-tenth of I per cent of weed seeds.

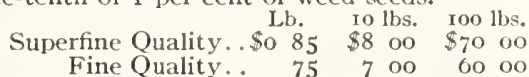

CANADA BLUE GRASS ( $P o a$ compressa). Similar to Kentucky Blue Grass but is of a less pleasing color. It is sometimes regarded as a cheaper substitute for Kentucky Blue Grass, but is useful because it will thrive in warmer climates than most of our northern grasses. Lb. $60 \mathrm{cts}$., Io lbs. $\$ 5.50$, I0o lbs. $\$ 45$.

WOOD MEADOW GRASS (Poa nemoralis). Lb. $\$$ I, Io lbs. $\$ 9.50$, IOo lbs. $\$ 85$.

\section{Rye Grasses One pound contains about}

ENGLISH RYE GRASS (Lolium perenne). A quick-growing, tall grass, sometimes included in mixtures for lawns as a nurse-grass and where immediate results are essential. Not permanent in turf, the close cutting causing it eventually to disappear, by which time the other sorts in the mixture are established. A valuable hay and pasture variety. Lb. $35 \mathrm{cts}$., Io lbs. $\$ 3$, Ioo lbs. $\$ 22.50$.

PACEY'S PERENNIAL RYE GRASS (Lolium perenne Pacey). A smaller-seeded, slightly dwarfer type of English Rye Grass and more suitable for lawns. Lb. 35 cts., Io lbs. \$3.25, Ioo lbs. \$25.

ITALIAN RYE GRASS (Lolium italicum). A coarse, tall grass, useful in the southern states for forming a winter turf, and in the Nortl as a mammoth producer of hay on irrigated, rich land. Lb. $30 \mathrm{cts}$., Io lbs. $\$ 2.50$, IOo lbs. $\$ 20$.

\section{Grasses for the South}

BERMUDA GRASS (Cynodon dactylon). Much used for a summer turf from Virginia south. Seeding is to be preferred to the planting of sprigs of Bermuda as producing a finer turf, and the best samples of seed are those containing a high proportion of the fine, dwarf type of Bermuda, known as the "Atlanta Strain." Lb. $70 \mathrm{cts}$. Io Ibs. $\$ 6.50$, IO0 lbs. $\$ 55$.

CARPET GRASS (Axonopus compressus). A coarse grass, useful for lawns and golf fairways in the South, especially on moist land. Lb. 65 cts., Io lbs. $\$ 6$, Ioo lbs. $\$ 50$.

RHODES GRASS (Chloris virgata). A large, broad-leaved grass, splendid for hay south of the Mason-Dixon Line. Lb. $95 \mathrm{cts}$. Io lbs. \$9, IOo lbs. $\$ 80$.

DALLAS GRASS (Paspalum dilalatum). A strong-growing perennial, furnishing good grazing summer and winter in the southern states. Lb. $80 \mathrm{cts.}$, Io lbs. $\$ 7.50$, Ioo lbs. $\$ 65$.

CENTIPEDE GRASS. See page $7 . \$ 4.50$ per 1,000 cuttings, $\$ 40$ per IO,O0o cuttings.

BULBOUS BLUE GRASS ( $P o a$ bulbosa), Similar to Kentucky Blue Grass, but produces a bulb instead of seed. Grows at a lower temperature than most grasses; dormant in summer but active in winter, except during severe cold. A permanent winter turf grass where not mown closely. Lb. \$2, Io lbs. \$I7.50, IOO Ibs. \$I 50 .

DOMESTIC RYE GRASS. A mixture of Italian and English Rye Grasses, produced in the United States and much used as a tentporary winter turf in the South on account of its low cost. Lb. $30 \mathrm{cts}$., Io lbs. $\$ 2.25$, I0o lbs. $\$ 15$. 


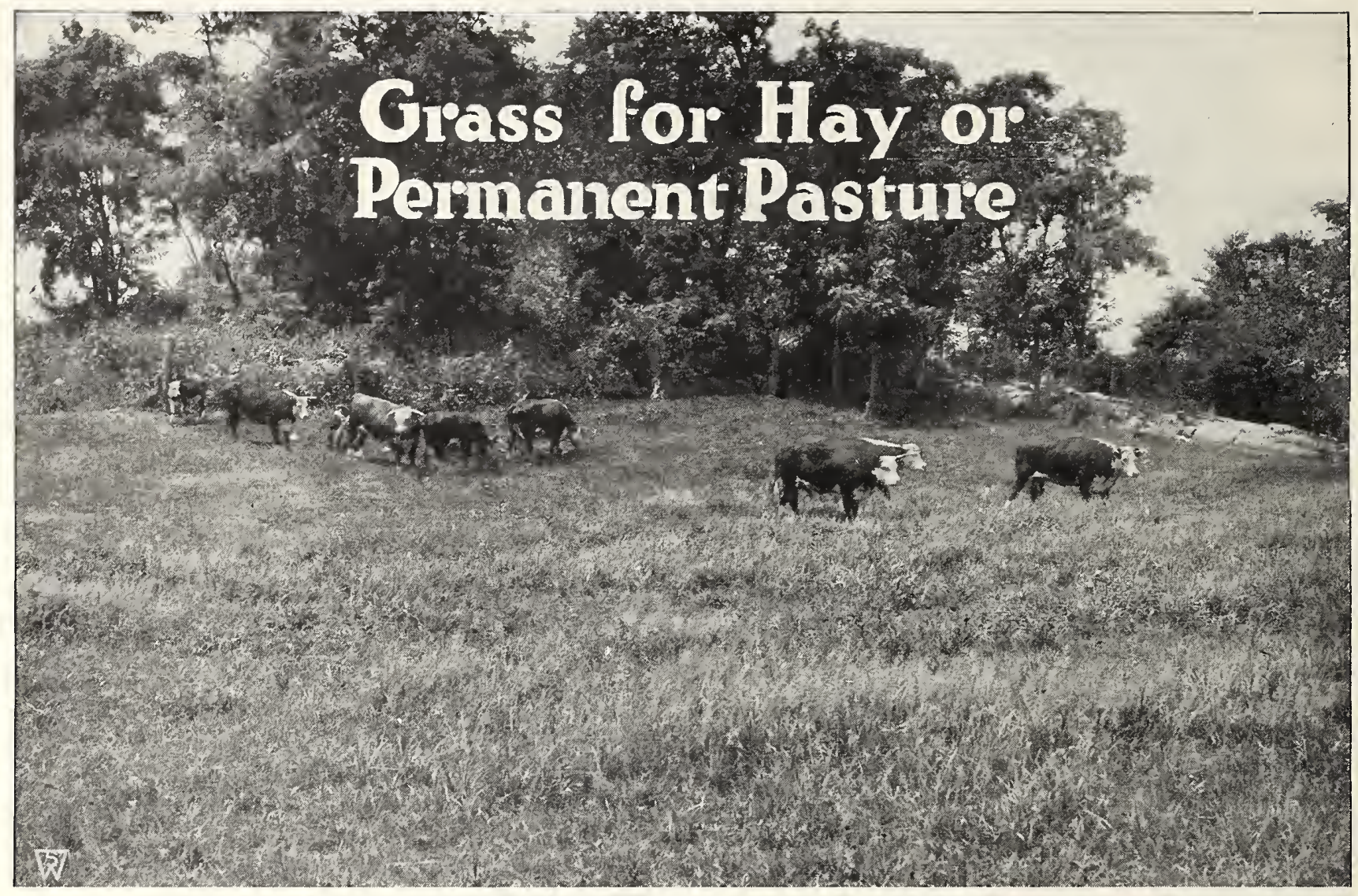

Timothy, Red-Top, and Red Clover have long formed the standard hay and pasture mixture for use on the American farm. It is not an ideal combination, but is inexpensive and we offer it tnder the heading of Timothy-Red-Top-Clover Formula. For large yield and nutrition, we recommend that a much wider variety than this be sown, using in addition to the above such types as Orchard Grass, Meadow Foxtail, Sheep's Fescue, Rhode Island Bent, Fiorin or German Bent, Cocoos and Triple A Bent, Sweet-scented Vernal, Meadow Fescue, the Rye Grasses, the Blue Grasses, Oat Grass, Red, Mammoth, White, Wild White and Alsike Clovers; each of these is suited especially to certain kinds of soil and climatic conditions; some do well on high ground, others prefer plenty of moisture. It is necessary that these be selected in proper proportions, suitable to the soil conditions and for the purpose required. We use the best recleaned seeds only in these mixtures.

CLOVER AND GRASS FORMULA. For high-quality hay or pasture. Includes a wide range of both grasses and clovers. Use 75 lbs. per acre when sowing new land. Lb. 55 cts., postpaid 65 cts.; 10 lbs. $\$ 5,100$ lbs. $\$ 45$.

ALL-GRASS FORMULA. For high-quality hay or pasture. Grasses only-no clovers. Use $851 \mathrm{bs.}$ per acre when sowing new land. Lb. 50 cts., postpaid 60 cts.; 10 lbs. $\$ 4.50,100$ lbs. $\$ 37.50$.

ALL-CLOVER FORMULA. For pasture. Use $25 \mathrm{lbs}$. per acre when sowing new land. Lb. 60c., postpaid 70c.; 10 lbs. $\$ 5.50,100$ lbs. \$50. TIMOTHY-RED-TOP-CLOVER FORMULA. For hay and pasture at low cost. Use 5o lbs. per acre when sowing new land. Lb. 40 cts., postpaid 50 cts.; 10 lbs. $\$ 3.50,100$ lbs. $\$ 27.50$.

For renovating ex sting fields, use one-half the above quantities

IMPORTANT. When ordering these seeds, tell us whether the field is to be used for hay or pasture, or both; please also describe the nature of your soil.

\section{S. \& W. CO.'S GRASS SEEDERS AND SOWERS}

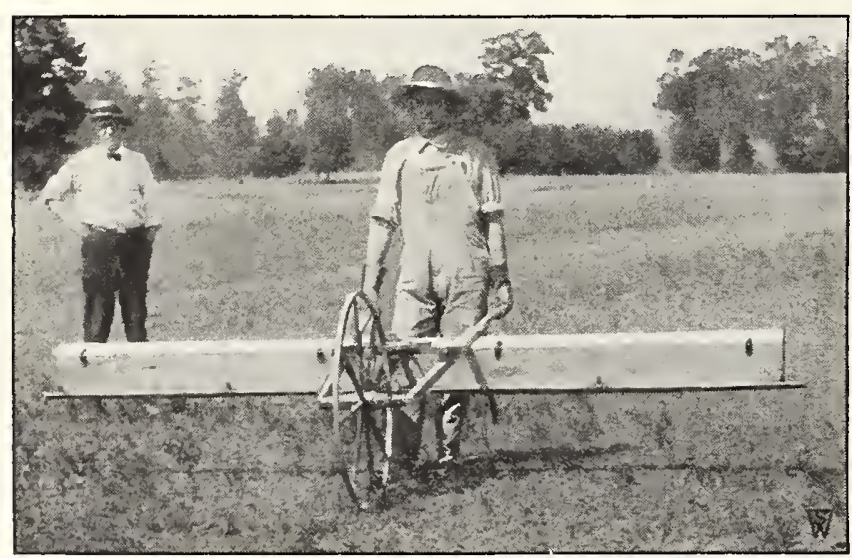

S. \& W. Co.'s Grass Seeder and Sower
The ro-foot hopper, holding $\mathrm{I} / 2$. bushels, will sow uniformly and accurately, without bunching, the desired quantities of any kind of hay, pasture or lawn-seed mixture. The hopper is carried beneath the handles and discharges close to the ground, so wind does not affect the sowing of even the lightest seeds. Sows from 50 to I25 pounds per acre. The machine also may be furnished for sowing dry powders and Vermol Worm Eradicator.

No. 1. For sowing grass seeds... $\$ 2000$

No. 2. For sowing dry powders

$2 \mathrm{I} 00$

No. 3. For sowing Vermol Worm Eradicator

2050

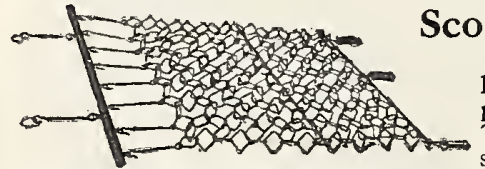

Scotch Chain Harrow

Hundreds of wrought-iron links are woven into what is practically a blanket of chain. This arrangement is ideal in smoothing land as a final preparation for grass seeds; it may also be drawn over the soil after seeds are distributed, for the purpose of covering them. Used on driveways and race-tracks, it smooths the surface, eliminating ruts and foot-prints. Small size, one-horse, $5 \times 6 \mathrm{ft}$., \$25; Medium, twohorse, $6 \times 71 / 2 \mathrm{ft}$., $\$ 35$; Large, tractor, $71 / 2 \times 71 / 2 \mathrm{ft}$., $\$ 45$. 


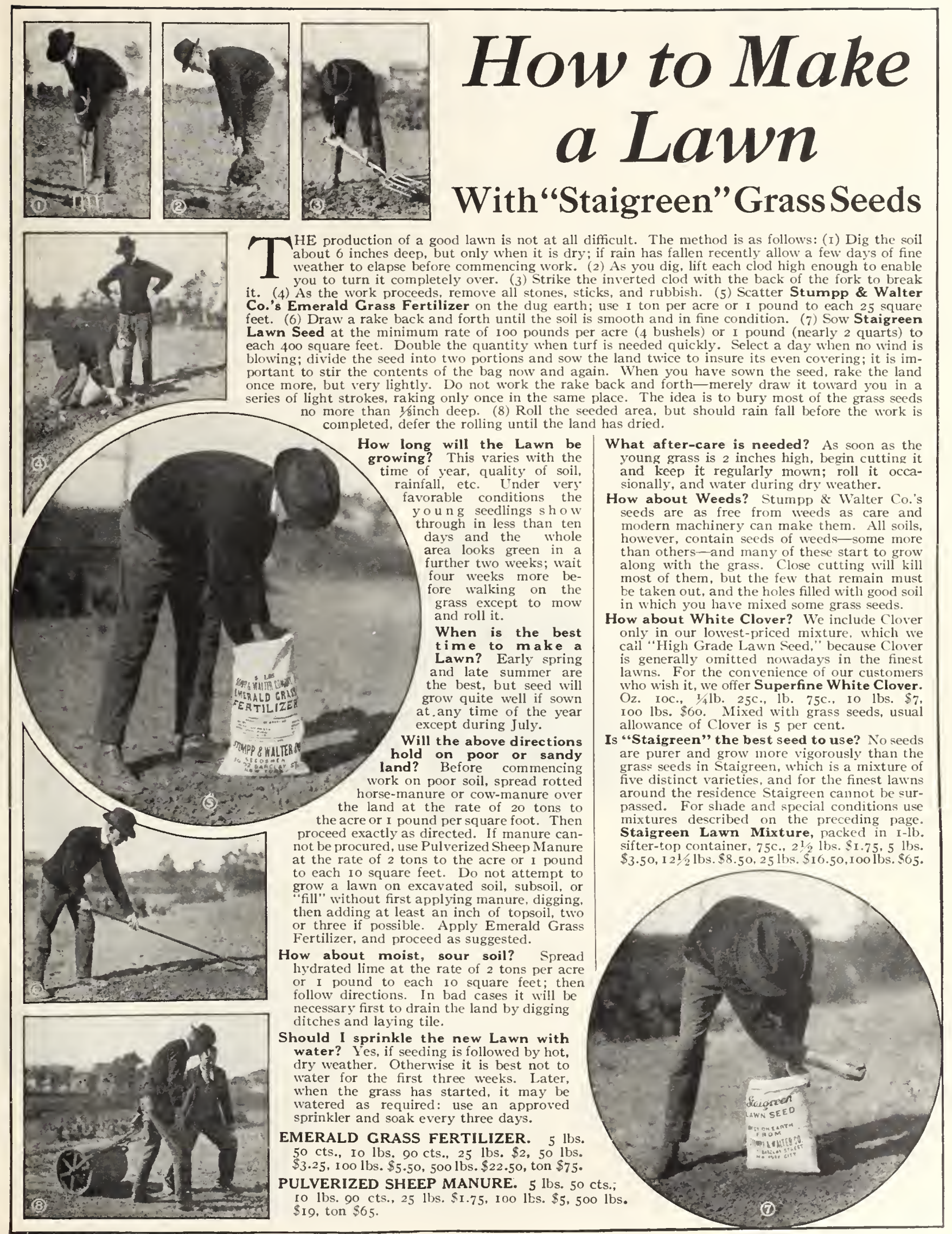




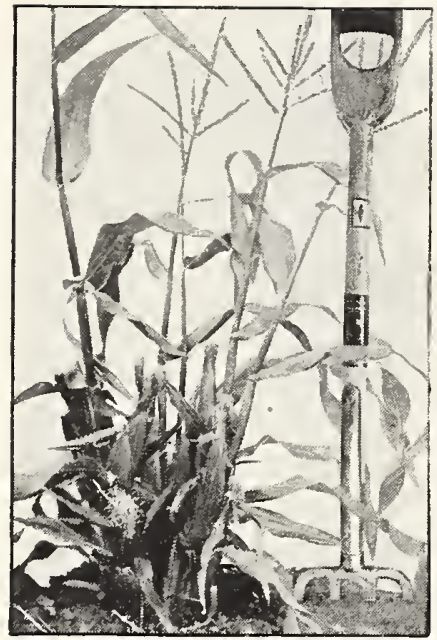

Midget Sweet Corn. See page I7
New Varieties, and Standard Sorts Made Better
WE recommend these to you if you seek the utmost in delicious flavor, and if you grow for exhibition.

\section{Pedigreed Mary Washington Asparagus}

Originally developed by the U. S. Department of Agriculture, further selected and improved. It is rust-resistant, particularly vigorous, and of wonderful quality. The shoots are large, straight, dark green in color and with a heavy purple over-tone; the tight, firm tips do not begin to open out until well out of the ground. Pedigreed Mary Washington Asparagus stands ahead of all other varieties as a standard for the home or market-garden. Extra-choice roots, $\$ 6$ per 100, $\$ 50$ per 1,000. Seed, pkt. 25 cts., $1 / 2$ oz. 85 cts., oz. $\$ 1.50,1 / 41 b$. $\$ 4.50,1 b . \$ 15$.

\section{Early Giant Bush Lima Bean}

A quick-growing variety. The short period in which this Bean matures enables it to be grown for succession, sowings being made from May is to July io in the neighborhood of New York. The flavor of this variety is particularly refined, and the fine, luscious Beans, which are large, thick and flat are produced in remarkable quantity. We suggest that our patrons give this variety a trial. Pkt. 15 cts., $1 / 2$ lb. 30 cts., 1 b. 55 cts., 2 lbs. $\$ 1,5$ lbs. $\$ 2.25,15$ lbs. $\$ 6.25$.

\section{New Garden Bean, Asgrow Valentine}

The result of twelve years' hybridizing and selection, mainly on the part of the late N. B. Keeney, to whom all growers are indebted as "The man who took the string out of String Beans." The original Black Valentine is an almost perfect Bean. Hardy, prolific, and early, the thick, fleshy green pods are produced all at once, and the cooking quality is of the best. We say almost perfect, for the Black Valentine Bean has one fault-the pods are slightly stringy and as they mat ure they become decidedly so. After twelve years' work the difficulty has been overcome. In Asgrow Valentine we have the same hardiness, large yield, and splendid quality of the original, and we have the strings entirely eliminated. Asgrow Valentine is absolutely stringless, and for the private estate and the commercial grower it is the perfect Bean. A few feet of row sown every two weeks during summer will furnish a constant supply of the finest Beans to the amateur's kitchen the season through. Pkt. 25 cts., 1/21b. 65 cts., 1b. $\$ 1.10,2$ lbs. $\$ 2,5$ lbs. $\$ 4.50$.

\section{Magpie Bush Bean}

Magpie is a svonderful Bean of European origin and is so named from the speckled black-and-white seeds of the variety. Plant is of very strong growth, stocky, and resistant to rust. The pods are long, meaty, and of the finest flavor. An enormous producer. Although largely grown as an outdoor sort it is suitable also for culture under glass. A great favorite on the large estates on the outer fringe of metropolitan New York. $1 / 2 \mathbf{l b}$. 45 cts., lb. 85 cts., 2 los. $\$ 1.50,5$ lbs. $\$ 3.40,15$ lbs. $\$ 9$.

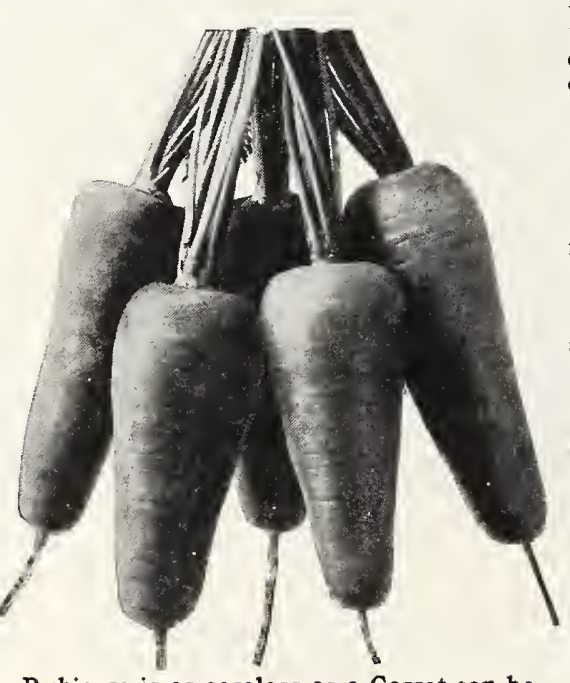

Rubicore is as coreless as a Carrot can be

\section{New Forcing Bean, The Prince}

Without a question, the finest forcing Bean yet introduced. It is quick to mature and crops enormously. The pods are without strings, meaty, of fine flavor and immense size-I I to 12 inches not being unusual. $1 / 2 \mathbf{l b} .50$ cts., 1 b. 90 cts., 2 lbs. $\$ 1.75$, 5 lbs. $\$ 4.25,15$ lbs. $\$ 11$.

\section{Golden Acre Cabbage}

A small but very fine variety, as early as Jersey Wakefield, but with round, solid heads. The few outer leaves are small, permitting close planting and making it very suitable for growth under glass and for the suburban gardener. Golden Acre produces uniform, tightly folded, and well-blanched heads of the best mild table quality. Pkt. 25 cts., $1 / 4$ Oz. 60 cts., $1 / 2$ oz. $\$ 1$, oz. $\$ 1.75,1 / 4$ lb. $\$ 6$.

\section{New York Market Sprouting Broccoli \\ True Italian Market Strain}

The sprouting Broccoli provides delicious, healthful boiling greens during summer, autumn, and early winter. The very choice variety which we offer has green, tender shoots and leaves, produced in the greatest abundance. Cultivation is the same as that for cabbage, sowing from March to early July, transplanting later, 2 feet or more apart. Broccoli is preferred by many to cauliflower. Pkt. 25 ets., $1 / 80 z .85$ cts., $1 / 40 z . \$ 1.50$, $1 / 2$ oz. $\$ 2.75$, oz. $\$ 5$.

\section{New Carrot, Rubicore}

Rubicore is a fine-flavored, new, early Carrot. It is a deep orangein cooking, and it is as tender and sweet as the root itself. Rubicore is thus as "coreless" as a Carrot can be. It is similar in shape to Chantenay, and the roots are $51 / 2$ to 6 inches long, 2 to $2 \frac{1}{2}$ inches at the shoulder, narrowing gradually to a blunt end. They are , smooth and free from eyes, and they all match up very well-uniform in size, shape, and color. The tops are medium small, but large and strong enough to bunch easily. Pkt. 15 cts., oz. 55 cts., $1 / 41 b . \$ 1.50,1 b . \$ 4$.

\section{The Best Early Cauliflower}

\section{S. \& W. Co.'s Best of All}

The easiest grown and surest heading Cauliflower offered today. In habit the plant is very dwarf, stocky, and erect. It has very few outer leaves and, as a consequence, the young Cauliflower plants may be planted less than 2 feet apart each way. All that is necessary is to select suitable soil, when every plant will form large, handsome heads, solid, fine-grained, pure white, and of good table quality. Plt. 25 cts., $1 / 8 \mathbf{o z}$. $\$ 1,1 / 4$ oz. $\$ 1.75,1 / 2$ oz. $\$ 3.25$, oz. $\$ 6$.

\section{Riverside Sweet Spanish Onion}

A handsome and very mild type of the large Spanish Onion, the fine-grained flesh of which is sweet and good. Quick-growing, it has a small neck, is very certain to bulb, and it ripens surely and evenly. The outer skin is an attractive, smooth straw-color. For a large Onion it keeps quite well. A diameter of 6 inches and a weight of over 2 pounds is not unusual with Riverside, when seed is sown early under glass and transplanted into deep, rich soil. Onions almost as big are obtainable by sowing seeds in the open. Pkt. 15 cts., 1/20z. 40 cts., oz. 75 cts., $1 / 4 \mathbf{l b}$. \$2.

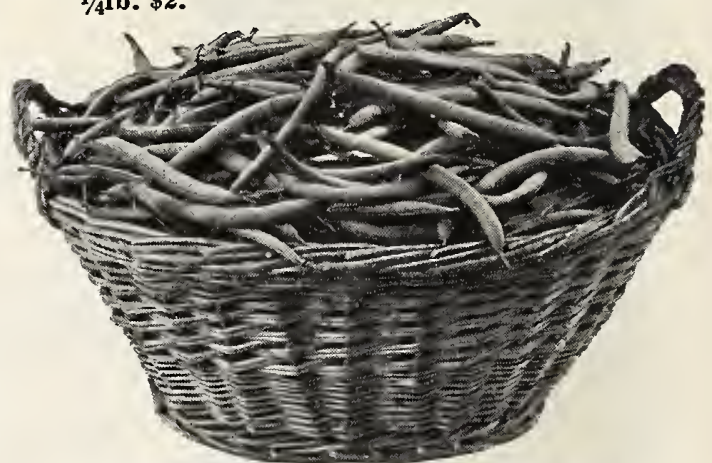

Asgrow Stringless Yalentine is the perfect Bean 


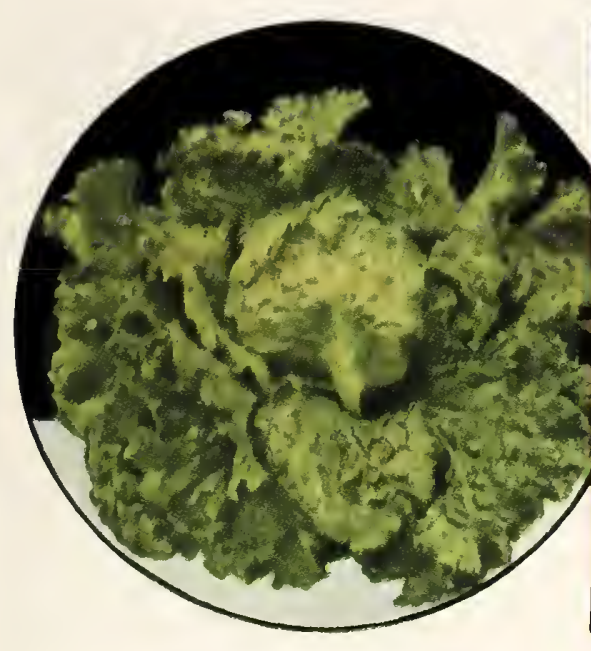

New York or Wonderful Lettuce

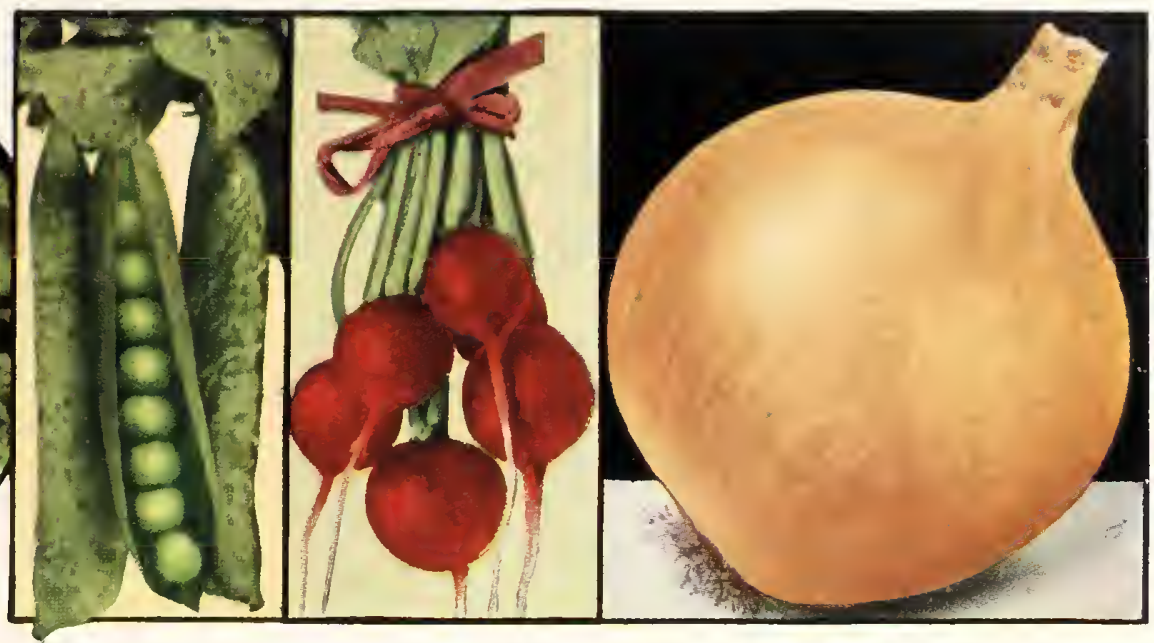

Delicious Peas Early Scarlet Globe Radishes

Gigantic Gibraltar Exhibition Onion

\section{Stumpp \& Walter Co.'s Special Vegetables}

\section{Improved Early White Spine Cucumber}

The fruits are nearly cylindrical in form, slightly pointed at the ends, perfectly smooth and of deep, rich coloring marked with distinct white lines at the blossom end. Will retain its color longer after pickling than most varieties, and is splendid as a table Cucumber because of its refreshing flavor and brittleness. Pkt. 10 cts., oz. 25 ets., 1/41b. 65 ets., 1b. $\$ 1.75$.

\section{Sicilian Fennel}

This vegetable is given the same general cultivation as celery, although it is not blanched to the same degree. An earthing of 3 inches or less, thrown up around the thickened leaf-stems, is sufficient. In this superior type the "bulb" is in section a thick oval, and not flat, as in the Florence Fennel. Pkt. 10 ets., oz. 30 ets., $1 / 41$ b. 80 cts.

\section{Earliest Selected White Kohlrabi}

A refined type of particularly delicate flavor. It is early, and has few leaves, seldom over 8 inches long. The "bulb" is of medium size and fine grain, ready to be eaten in ten weeks from the time of sowing. Particularly valuable for growth under glass as well as in the open ground. Pkt. 20 cts., oz. 65 cts., $1 / 41$ b. $\$ 1.75,1 b . \$ 5$.

\section{New York or Wonderful Lettuce (Superior}

It is so distinct that, with its crisply curled leaves, very dark color. and remarkable size, it may puzzle even the experienced grower if unacquainted with it. New York is a sure-heading variety, suitable both for spring and late summer planting; the big, compact, white heads are of the best possible quality. The heart is large, white, crisp and very compact. It needs 50 per cent more room " $n$ which to grow. Often called "Iceberg." Pkt. 15 cts., oz. 50 cts., 1/4lb. \$1.40, lb. \$4.

\section{Thanksgiving Day Lettuce}

The best Lettuce for sowing during the hot dar's of August to produce a crop in the late autumn. Under these severe conditions, most varieties will "bolt" into flowers and fail to form a head. This is not the case with Thanksgiving Day, however, which grows steadily along, to mature at a time when most garden crops are over. While the outer leaves of this variety take on the sere and yellow look of autumn, being fringed and brown in color, the close, tight head is of bright fresh golden green, good to look upon, crisp, short, and of splendid flavor. Pkt. 15 ets., oz. 50 ets., 1/4lb. $\$ 1.40,1 b$. $\$ 4$.

\section{Gigantic Gibraltar Exhibition Onion}

The most dependable strain of the giant type of Onion. Similar in appearance to Prizetaker, except that it is lighter in color, and, while larger in size, is a splendid keeper and of decidedly mild flavor In some cases Gigantic Gibraltar Onions have weighed $3^{1 / 2}$ pounds. To grow these large exhibition specimens, seeds are sown early in February, in a hotbed or greenhouse, and thc young seedlings are transplanted. Pkt. 20c., 1/20z. 45c., oz. 75c., 1/4lb. \$2, 1b. $\$ 5.50$

\section{S. \& W. Co.'s Exhibition Curled Parsley}

This Parsley is remarkable for its fine leaves and close habit. In flavor it is superior to that of any other known variety. Seed ofiered has been saved from exhibition plants. Pkt. 25 cts., 5 pkts. \$1.

\section{Emerald Gem Parsley}

A very dwarf compact variety, leaves intensely curled and very dark green. For the home garden and edging purposes. Pkt. 25 ets. 5 pkts. \$1.

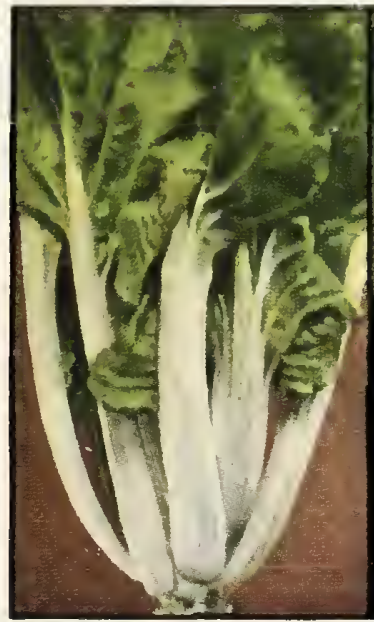

Mammoth N. Y. Swiss Chard

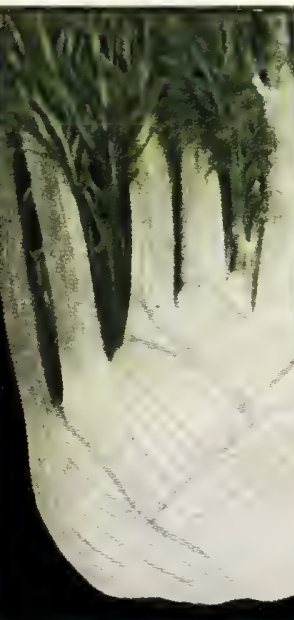

Sicilian Fennel

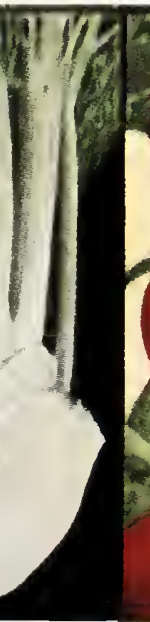

(1)

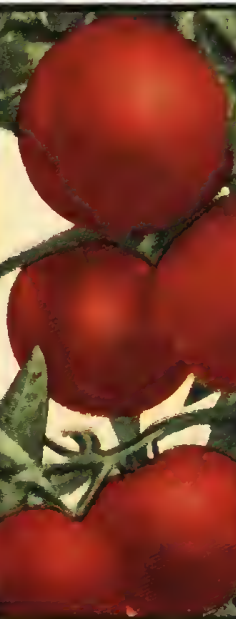

Essex Wonder Tomatoes 


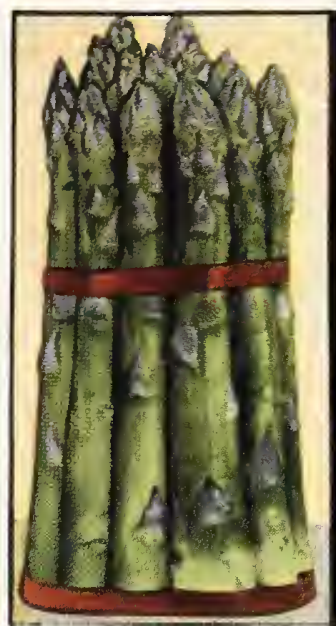

Washington Asparagus

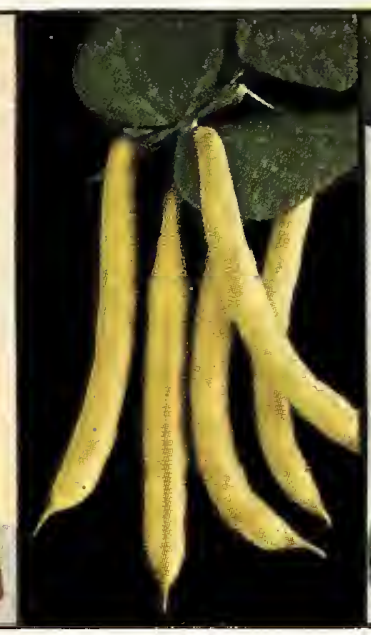

Hardy Wax Beans

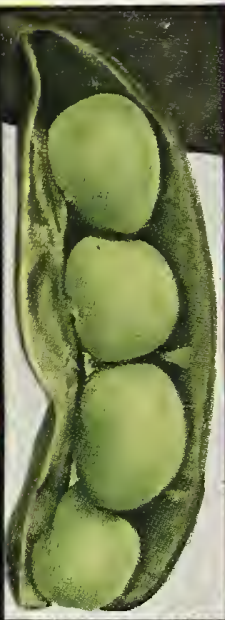

Early Giant Lima Bean

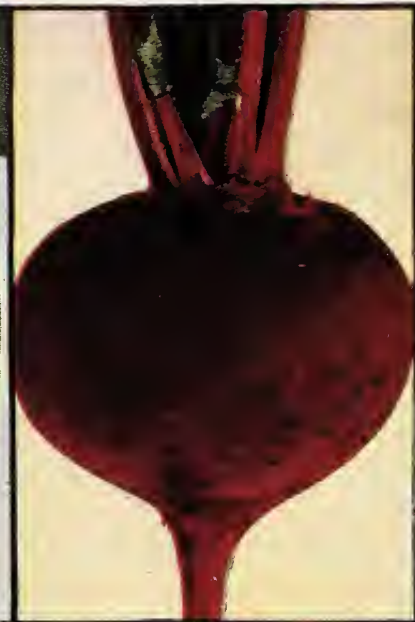

Early Wonder Beet

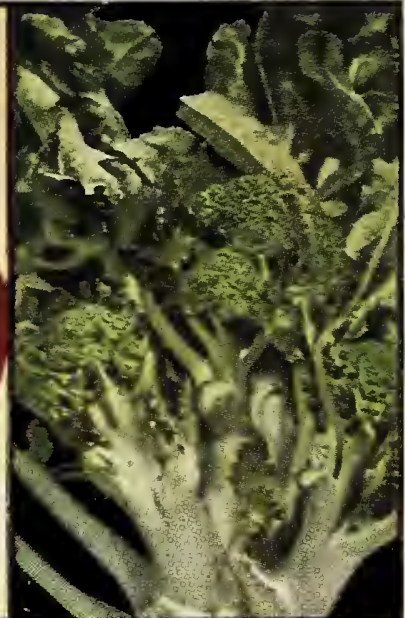

New York Market Broccol

\section{Stumpp \& Walter Co.’s Special Vegetables}

\section{Golden Wedding Corn}

A fine new sort, yielding two, and sometimes three, ears to each plant. It is a yellow variety, like Golden Bantam, but the ears are much larger and have $\mathrm{I} 2$ or more rows instead of the 8 rows of Golden Bantam. For sweetness and general refinement of flavor we consider it superior to the old Golden Bantam, and it is being served by many leading New York hotels. Pkt. 20 cts., $1 / 21$. 35 cts., $1 b .60$ cts., 2 lbs. $\$ 1.10,5$ lbs. $\$ 2.50$.

\section{S. \& W. Co.'s Midget Sweet Corn}

A miniature Sweet Corn that is markedly suitable for the small garden, city back yard, window-box, or for growth in pots, and adapted for culture under glass. The tiny plant grows no taller than about 30 inches, and the ears are only 3 to 4 inches long, but from two to five of these petite ears are produced on a single stalk. The ears are of fine quality - the kernels white, meaty, and very sweet, while the cob is small. The ease with which these tiny ears may be handled in the kitchen is alone sufficient to commend it to the housewife, while, in addition, the flavor is superior to a degree. A decided novelty. Pkt. 20 cts., oz. 35 cts., $1 / 41 b .90$ cts.

\section{A New Early Corn, Golden Gem}

A new golden variety developed by the North Dakota Experiment Station, which we offered for the first time last year in packets only. It is the earliest golden Corn on the market, at least ten days to two weeks earlier than Golden Bantam, but of the same fine eating quality and ears a trifle larger. Try Golden Gem and be the first to pick Corn in your section. Pkt. 25 cts., $1 / 21 b .50$ cts., 1 b. 90 cts., 2 lbs. $\$ 1.75$.

\section{New Celery, "Bokay"}

A new variety that we offered for the first time last year to the grower desirous of securing the finest green Celery on the market today. Bokay has been developed from Earligreen, which proved so popular for the home-gardener. The ribs are about same length as Golden Plume and are more fleshy and rounder than the Easy-Blanching. It has a good golden heart and the bouquet effect of the green ribs with the beautiful heart induced us to name this new variety Bokay. Bokay Celery is hardy, withstanding frost and drought and you will also find it splendid as a green Celery without bleaching. Pkt. 25 ets., $1 / 8$ oz. 85 ets., $1 / 4$ oz. $\$ 1.50,1 / 2$ oz. $\$ 2.75$, oz. $\$ 5$.

\section{Earligreen Celery}

Earligreen is the finest, earliest green Celery, and is a fitting counterpart to Golden Plume. The plant is surprisingly large for an earliest early sort, and although it is stocky in habit, it is not so markedly so as Golden Self-Blanching and Golden Plume. The outer leaves are green, and the very full heart is pure white, brittle, and of the most delicious flavor. It is of sterling merit, and we predict a fine future for it. The supply of seed is limited. Pkt. 25 cts., 5 pkts. $\$ 1$.

\section{Golden Plume Celery}

Golden Plume Celery fills a want that both amateur and professional gardeners have long felt. It is a much-improved form of Golden Self-Blanching, and the improvements are $(a)$ superior tabie quality, (b) wonderful golden color, (c) marked resistance to blight and rust, $(d)$ earlier maturity, (e) superior keeping qualities, $(f)$ increased size. It possesses a fine, nut-like flavor, and is handsome in appearance. Pkt. 25 cts., $1 / 80 z_{\text {. }} \$ 1,1 / 4$ oz. $\$ 1.75,1 / 20 z$. $\$ 3.25,0 z . \$ 6$.

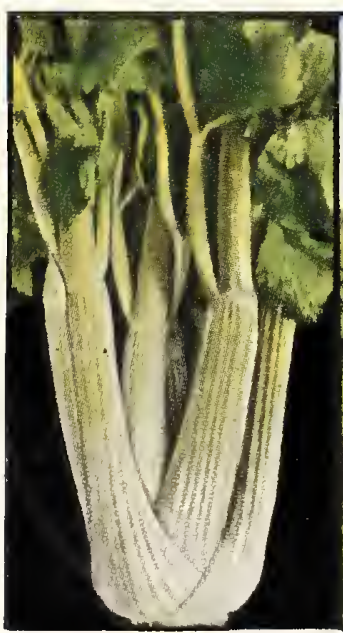

Earligreen Celery

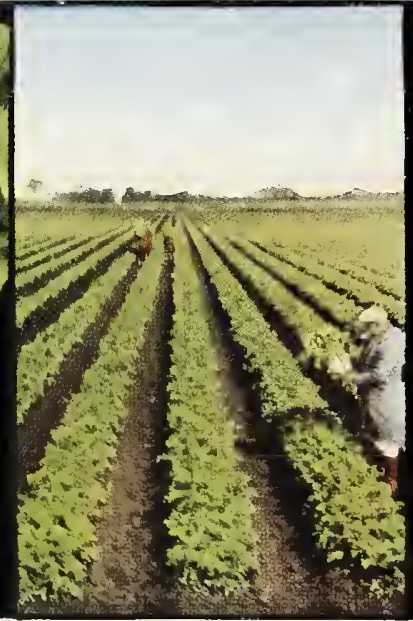

Golden Plume Celery
Melting Marrow Carrot

17

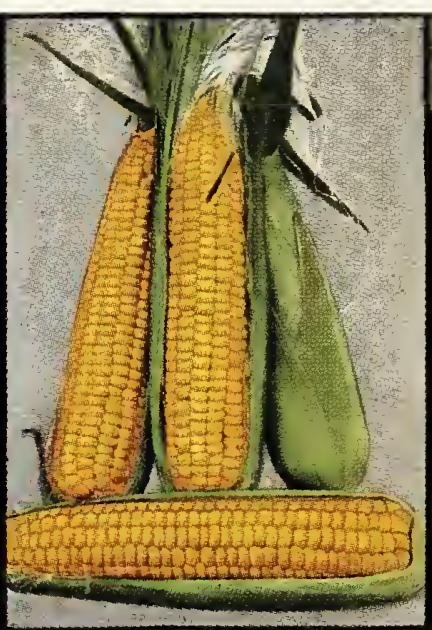

Golden Wedding Corn

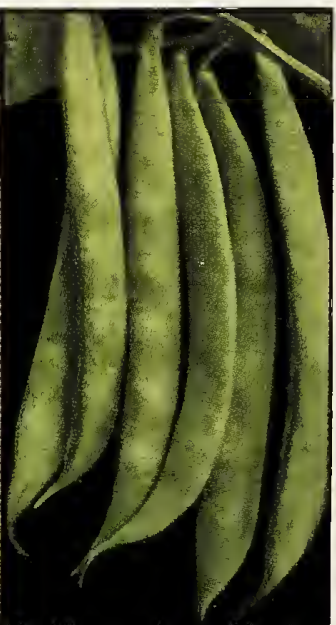

Magpie Bush Beans 


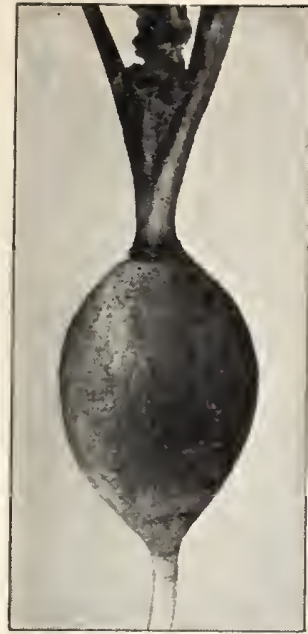

20-Day Leafless Radish

\section{STUMPP \& WALTER CO.'S Special Vegetables}

Three Splendid Peas

Eight Weeks. A remarkable super-first-early round-seeded Pea, I 8 inches high. other parts of the garden; the result will be w warm border when snow is still present in inain seedings. Pkt. 15c., 1/2lb. 30c., 1b. 55c., 2 lbs. $\$ 1,5$ lbs. $\$ 2.25,15$ lbs. $\$ 6.25$.

Market Surprise. On vines 3 feet tall, Market Surprise bears $3 \frac{1}{2}$-inch pods in the best Extra-Early, while the pods contain on an average two more Peas, and the Peas are larger. A round-seeded sort of truly remarkable sweetness. Home-gardeners and truckers will find this new sort a big surprise in every way. Pkt. 15 cts., $1 / 21 b .30$ cts., 1 b. 55 cts., 2 lbs. $\$ 1,5$ lbs. $\$ 2.25,15$ lbs. $\$ 6.25$.

Delicious. A splendid new and distinct wrinkled Pea. The dark green, stocky, dance of large, long, tightly filled pods; in them are as many as nine or ten big sweetly melting, delicious Peas. The crop may be gathered about 75 days after seeding; hence Delicious fills well the gap between early and late sorts. Pkt. 20 cts., $1 / 21$ lb. 35 cts., lb. 65 cts., 2 lbs. $\$ 1.25,5$ lbs. $\$ 3,15$ lbs. $\$ 8$.

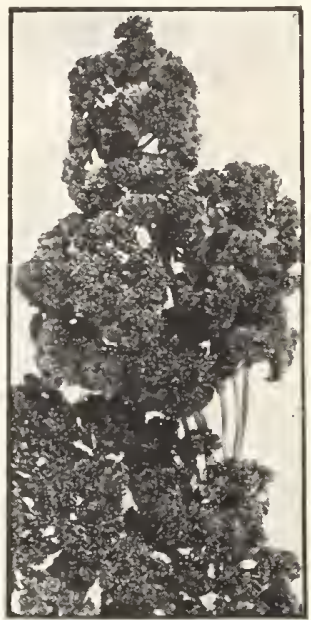

S. \& W. Co.'s Exhibition Parsley

\section{S. \& W. Co.'s Selected Exhibition Parsnip}

Large roots with a smooth outer surface; white, long and tapcring. The flavor is mild and sweet. Pkt. 25 cts., 5 pkts. \$1.

\section{Perfection Pimiento Sweet Pepper}

One of the best for the home-garden, to be used both green and ripc. Top-shaped, smooth, the flesh is twice as thick as that of ordinary Peppers, delicious in flavor, sweet and entirely free from pungency. Pkt. 15 cts., $1 / 20 z .50$ cts., oz. 85 cts., $1 / 41$ b. $\$ 2.50$.

\section{Early Scarlet Globe Radish}

We offer a superior strain of this general-purpose variety. Seed is produced from individually selected and transplanted Radishes. You will find this of distinct globe shape, bright attractive scarlet, shortleaved, flesh crisp and white, and ready in twenty-eight to thirtyfive day's. An excellent variety for forcing. Pkt. 10 cts., oz. 25 cts., $1 / 41$ lb. 65 cts., lb. $\$ 1.75$.

\section{Saxa Radish}

A speedy sort. One of the quickest Radishes to grow in the hotbed, coldframe, or greenhouse. It has an unusually small top. The root is spherical, bright scarlet, crisp, mild, and sweet. Saxa yields quickly and well in the open ground also. Plit. 15 cts., oz. 35 cts., $1 / 416.90$ cts., lb. $\$ 2.50$.

\section{Twenty-Day Leafless Radish}

The quickest maturing of all Radishes. Ready in 20 days. Radishes are oval, bright scarlet with a tip of white; flesh clear white. solid, crisp and of excellent flavor. The plant gives but two small leaves, just sufficient for bunching. Suitable fol forcing and outdoors in spring and fall. Pkt. 15c., oz. 45c., 1/4lb. $\$ 1.30,1 b$. $\$ 3.50$.

\section{S. \& W. Co.'s Emerald Standing Spinach}

A very large and vigorous type of compact, flat, spreading growth. The leaves are large, thick, slightly crumpled, very fleshy, and carried on long stems. The color is a very dark green. The most important point about this Spinach, however, is that it stands fully one month longer than any other variety before bolting to seed. In spite of this, it is quite early to mature, and is a variety to be recommended from every point of view. Pkt. 10 cts., oz. 20 ets., $1 / 41 b .55$ cts., 1 b. $\$ 1.50$.

\section{Perpetual Spinach}

The seed of this desirable plant may be sown any time from April to June, and in six weeks cutting may commence, to continue right tlurough into fall, for perpetual Spinach is highly resistant to frost. The "greens" furnished are similar in flavor to true Spinach, the leaves being very tender, even when allowed to grow large; they are both palatable and healthful. Cut the leaves about 3 inches from the ground. We offer a special strain of seed. Pkt. 15 cts., oz. 45 cts., $1 / 41 b . \$ 1.30,1 b . \$ 3.50$.

\section{Mammoth New York Swiss Chard}

This is a new and quite distinct sort. medium green in color, and of large size. The leaves are smooth, and the stalks are solid, thick, and of a pearly whiteness. The remarkable feature about Mammoth New York, however, is its superior flavor: careful breeding has entirely eliminated the earthy flavor which many Chards possess. Pkt. 20 cts., $1 / 20 z$. 55 cts., 02.95 cts., $1 / 4$ lb. $\$ 2.50$.

\section{Straightneck Squash}

A golden summer bush Squash of delicious flavor. selccted from the Giant Summer Crookneck, but with a straight neck, which is a great advantage to the trucker, who packs in crates and barrels. Fruits are warted, I 8 to 20 inches long, and of the same fine quality as Crookneck. Because of its straight neck it is easier to prepare for cooking; we offer a specially refined strain of this variety. Pkt. 15 cts., oz. 35 cts., $1 / 4$ lb. $\$ 1,1$ lb. $\$ 3$.

\section{Marglobe Tomato}

Resists Will and Rust. This is a large Tomato of the globe type, in color a fine scarlet, and of delicious table quality. It fruits early and continues to yield up to frost. Its remarkable feature is its strong. robust constitution; it resists wilt and is immune to rust, and will therefore produce healthy fruit during long periods of wet, unfavorable weatlier. Marglobe is recommended for the large estate and for the home-garden; for the market grower, the shipper of car-lots, and for the canncr. Also, it performs splendidly under glass, forcing well. Its deep globe shape fits it for economical slicing. Pkt. 20 cts., $1 / 2 \mathbf{o z}$. 60 ets., oz. $\$ 1,1 / 41 b$. $\$ 3.50$.

\section{Essex Wonder Tomato}

This variety has been evolved by an English grower, and combines extreme hardiness with high-quality fruit and heavy yield. It will withstand several degrees of frost without injury and may be set out a few days earlier than ordinary sorts, while late plantings will yield fruit along into October.

Seven trusses of fruit on a single-stem plant is not exceptional, and many trusses may consist of upward of twenty fruits, each weighing three to four ounces. Essex Wonder has a thin skin; its plum-like pulp, abundant juice, and freedom from tough, fibrous matter nake it good eating indeed. Recommended especially for the private grower and amateur. Pkt. (about 200 seeds) 50 ets.

\section{Zucchini}

The new Italian Squash or Vegetable Marrow that recently has been meeting with great favor in the leading Pacific coast hotels. It is a delicious summer variety, very prolific, tender, and of a mild flavor. The fruits should be picked when 5 to 8 inches in length May be prepared in the same manner as any other Squash, while if fried in the same way as eggplant, you will find it very delicious. Pkt. 20 cts., oz. 65 cts., 1/4lb. $\$ 1.75$.

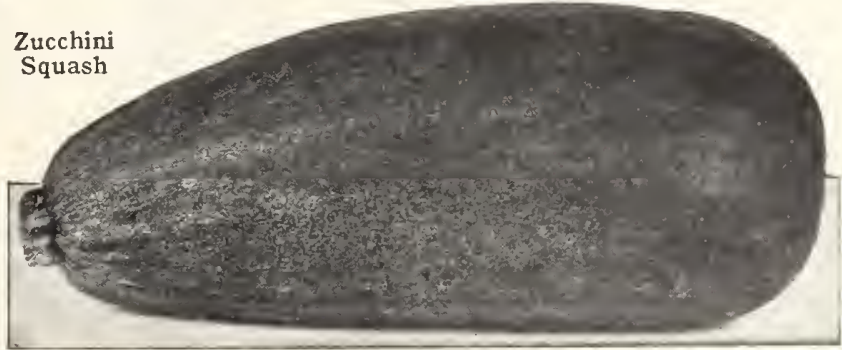




\section{Home-Grown Vegetables Are Better}

Home-grown Vegetables are better than those we buy because they may bc cooked perfectly fresh. Who has not enjoyed the tang of Golden Bantam Corn, so delicious when cooked as soon as gathered? Or fresh-picked Peas or Beans?

Home-grown Vegetables frequently taste better. The market-gardener selects varicties which fit his special needs, vegetables which pack weIl, will travel with the least injury, that may be easily tied in bunchcs, sorts that mature all at one time, or that will keep well. The home-gardener, on the other hand, can choose vegetables for flavor only, and usually he grows more palatable sorts than those produced commercially.

Home-grown Vegetables have more variety. Many sorts easy to grow are often hard to buy: Swiss Chard, Cardoon, Chervil, CoIlards, Beet Tops, New Zealand Spinach, Turnip Tops-these are rarely offercd for sale.

The owner of the smallest vegetable-patch is able, not only to enjoy kinds of vegetables beyond the reach of the householder who has to buy everything he eats, but, above all, those he does grow will be far superior if they are selected with carc.

The varicties offered hcrein are reliable and the seeds have been collected, graded, cleaned, tested, and packed with scrupulous carre. They may be sown with the utmost confidence.

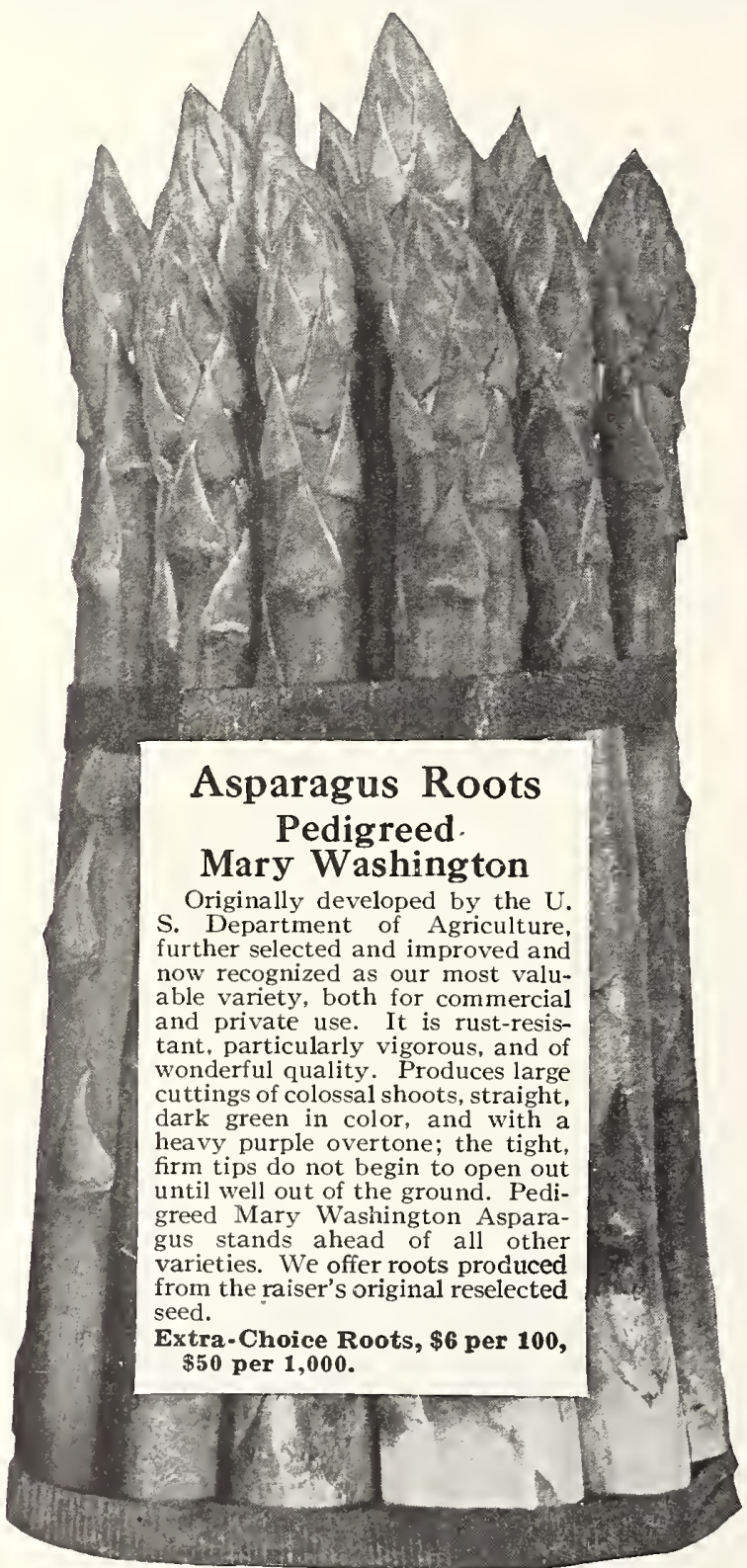

Mary Washington Asparagus

\section{ASPARAGUS ROOTS}

The demand for Asparagus as an early spring vegetable is becoming quite popular. It is generally thought that it requires too much space for growing, but a plot 6 feet wide and 50 feet long will be sufficient to plant roo of our Mammoth roots, sufficient for an ordinary family. Roots of this size should be planted, as they will yield Asparagus quickly.

CUlture.-Dig a trench I I/2 feet deep and I foot wide, and fill in about 4 inches with well-rotted manure, tread down firmly. On this put about 5 inches of good, rich soil, and then lay the roots in, about I 8 inches apart, taking care to spread well, having the crown in an upright position. Cover to within 4 inches of the top of the trench and, as the plants grow, gradually fill the trench to the surface. For spacing between the rows allow I 8 inches.

PEDIGREED MARY WASHINGTON.

Extra-Choice Roots.......................... $\$ 6_{00}^{100} \$_{50}^{\mathrm{I}, 000}$

CONOVER'S COLOSSAL. A mammoth bright green sort, the tips of which are often tinged purple. Very tender and of good quality-quite the best of the older standard kinds.

Mammoth Roots 100 1,000

\section{ASPARAGUS SEED}

One ounce will plant about 50 feet of drill

PEDIGREED MARY WASHINGTON. (Reselected Seed.) One of the diffculties in growing Asparagus is the damage often done by rust. Dusting with powdered sulphur when the plants are wet with oew is good practice, and spraying with Bordeaux Mixture is also to be recommended. The best procedure, however, is to plant only rust-resistant varieties, and Reselected Pedigreed Mary Washington is the most highly resistant type we know. Seed, pkt. 25 cts., $1 / 2 \mathrm{Oz} .85$ cts., oz. $\$$ I. 5 O, I $1 / 4$ lb. $\$ 4.50,1 \mathrm{~b}$. \$I 5 .

CONOVER'S COLOSSAL. The standard variety. Reliable. Seed, pkt. Io cts., OZ. 20 cts., I/4lb. 55 cts., $1 \mathrm{~b} . \$$ I.50.

Note.-For the Asparagus beetle, spray with arsenate of lead, offered on page I80.

\section{ARTICHOKE}

\section{One ounce will produce 500 plants}

The scales and bottom of the flower-heads are eaten, either boiled, or rav as a salad. The young suckers are sometimes tied together and blanched and served in the same manner as asparagus. The plants thrive best in deep, rich soil where the water will not lodge in winter-time. Sow seeds indoors, and pot up similar to tomatoes, setting out in May, in rows 3 feet apart, leaving 2 to 3 feet between the plants. Some flower-buds may be had the first year. Cover with ashes and leaves in winter. Usually bears best the second year.

Large Green Globe. The best variety. Pkt. 25 cts., 1/20z. $60 \mathrm{cts}$, oz. \$I, $1 / 4$ lb. $\$ 3$.

\section{ARTICHOKE TUBERS}

Jerusalem Artichoke. Distinct from the Globe, and propagated by and for the tubers. Plant in rows, 3 feet apart and I foot apart in the row, and cultivate occasionally. Allow the tubers to remain in the ground until needed. They are excellent served boiled, like new potatoes; valuable also for feeding stock. Qt. 50 cts., pk. $\$ 3$. 


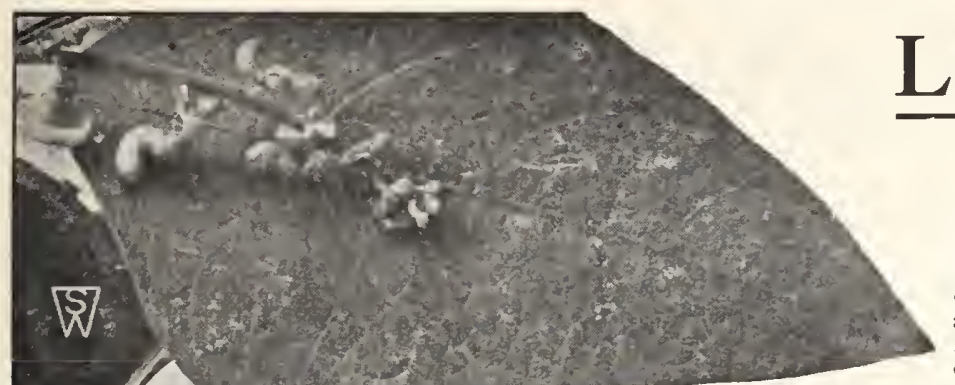

\section{LIMA BEANS}

\section{(Dwarf Bush)}

One pound will plant 50 to 100 feet of drill

Fordhook. A dwarf form of the popular Challenger or Fotato Lima, and earlier. Both pods and Beans are almost twice the size of the Kumerle or Dreer's Bush Lima. Pods measure 4 to 5 inches, frequently containing 4 fine Beans of the finest flavor. Pkt. 10 cts., $1 / 21$ lb. 30 cts., lb. 50 cts., 2 lbs. 90 cts., 5 lbs. $\$ 2.10,15$ lbs. $\$ 5.75$.

New Improved Bush Lima. Similar to Burpee's Bush Lima except that New Improved pods are larger in size and are well filled with larger and thicker Beans. A far greater producer; growth more vigorous; the blossombearing stalks are thrown well ont of the foliage, and the Beans are ready for picking a full week earlier. $1 / 21$ b. 25 cts., 1 b. 45 cts., 2 lbs. 85 cts., 5 lbs. $\$ 2,15$ lbs. $\$ 5.50$.

Early Giant. A quick-growing variety. The short period in which this Bean Early matures enables it to be grown for succession, sowings being made from May I5 to July Io in the neighborhood of New York. Other varieties of Lima Beans take so long to mature that more than one seeding is barely practicable with them. The flavor of this variety is particularly refined, and the fine, luscious Beans, which are large, thick, and flat are produced in remarkable quantity. Pkt. 15 cts., $1 / 21 b .30$ cts., lb. 55 cts., 2 lbs. $\$ 1,5$ lbs. $\$ 2.25,15$ lbs. $\$ 6.25$.

Henderson Bush Lima. Both pods and Beans are small, but they are produced in large quantities. The standard Lima for canning. 1/2lb. $25 \mathrm{cts}, 1 \mathrm{~b} .40 \mathrm{cts} ., 2 \mathrm{lbs}$. 75 cts., 5 lbs. $\$ 1.75$, I 5 lbs. $\$ 4.75$.

\section{CULTURE OF LIMA BEANS}

Don't waste your seed by sowing Lima Beans before all danger of frost is over and the soil is thoroughly warm. Sow Bush sorts in rows 2 feet apart and about 3 inches deep. putting the Beans 2 inches apart in the row "eye down," later thinning so that the plants stand 6 to 8 inches apart. For Pole varieties put six seeds in each hill, arranging the hills 3 feet apart each way. They require a pole 7 feet ligh, and when the vines have reached the top, pinch them and so increase the yield. Some gardeners plant under glass and transplant about the time seeds are usually sown. Limas always do best on a nice, rich, loamy soil. Surplus stock may be ripened on the vines, dried and kept for winter use.

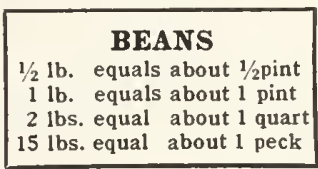

Fordhook Bush Lima Beans

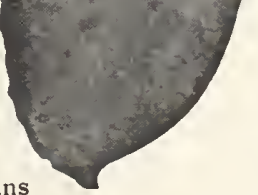

\section{LIMA BEANS (Pole)}

One pound will plant 50 hills

S. $\&$ W. Co.'s Green-seeded. The vine is very strong, of vigorW. Co.'s Green-seeded. ous growth, with many large runners or branclies, producing a great many fine pods which are closely filled with large Beans, many of the pods containing four. This is a broad-seeded Bean, much nearer to having every Bean perfect than any other Pole Lima. The green tint is a distinctive feature of this Bean, for it retains this tint in the dry state to a greater extent than usual, which indicates the good qualities which it possesses, being fineHavored and more tender when cooked than white-seeded Beans, and making it more pleasing to gardeners and housekeepers. It is the most perfect Pole Lima. $1 / 2$ lb. 30 cts., 1b. 55 cts., 2 lbs. $\$ 1,5$ lbs. $\$ 2.25,15$ lbs. $\$ 6.25$.

Early Leviathan. The earliest variety of Pole Lima; produces pods in Pkt. 10 cts., 1/21b. 25 cts., lb. 45 cts., 2 lbs. 85 cts., 5 lbs. $\$ 2,15$ lbs. $\$ 5.50$.

Challenger, or Potato. Early and more prolific than the large Lima; 30 cts., lb. 50 cts., 2 lbs. 95 cts., 5 lbs. $\$ 2.25,15$ lbs. $\$ 6.25$.

Ford's Mammoth. Very large pods, frequently measuring 9 inches long; Beans flat and large; fine for the home garden; productive and of good flavor. 1/21b. 25 cts., lb. 45 ets., 2 lbs. 85 cts., 5 lbs. $\$ 2,15$ lbs. $\$ 5.50$.

SPECIAL FREE DELIVERY, We deliver vegetable and United States when cash accompanies your order.

flower seeds anywhere in the

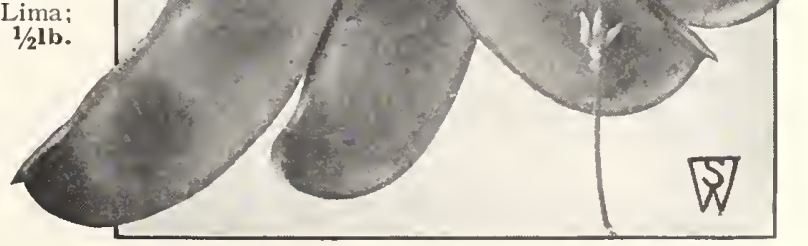

S. \& W. Co.'s Green-seeded Pole Lima Beans 


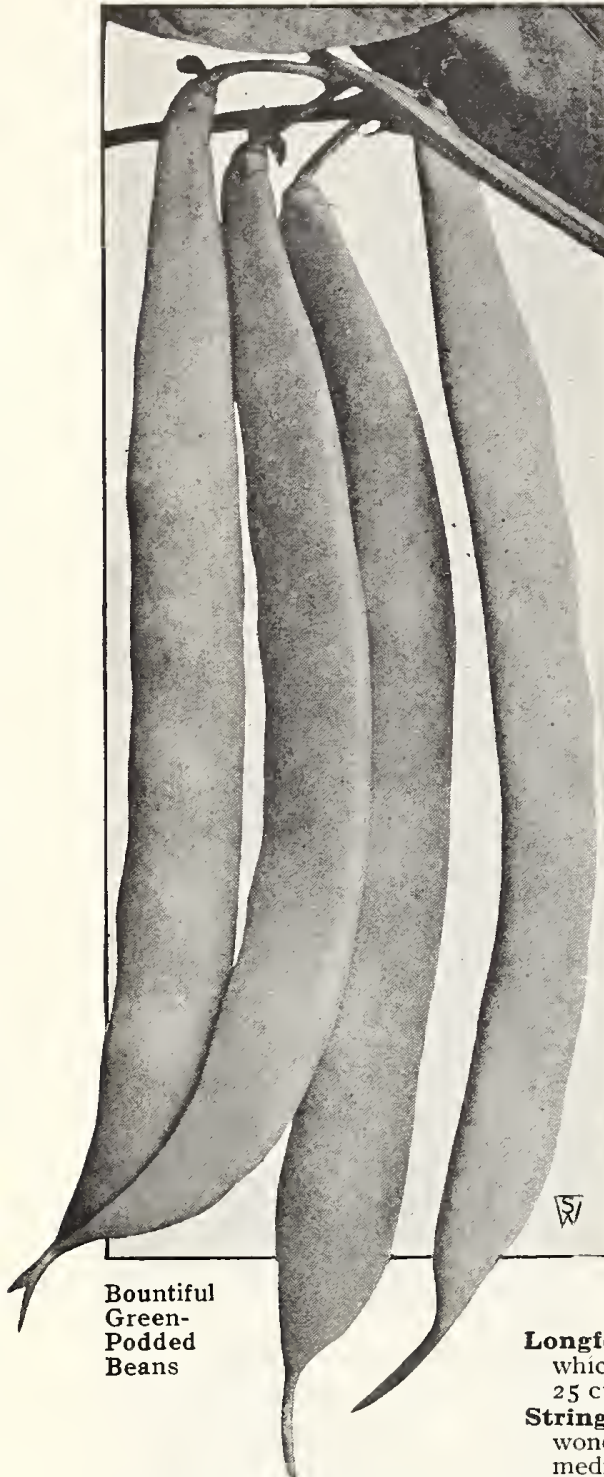

DWARF or BUSH BEANS $\begin{gathered}\substack{\text { one pound will plant } \\ \text { loo feet of drill }} \\ \text { Def }\end{gathered}$

CUlture.-Plant as soon as danger of frost is over, placing the seeds 2 to 3 inches apart in drills and about $2 \frac{1}{2}$ inches deep. The rows should be about $21 / 2$ feet apart, and the soil slightly hilled, to insure good drainage and to keep the Beans from touching the ground Most Beans should be picked when about 4 inches long. Frequent pickings insure a more prolonged bearing season. Avoid jerking the plant, as this frequently disturbs young feeding roots. Use the fingernails to sever the stems. Do not pick when bushes are wet, as this may cause blight and rust. For succession in the home garden plant 30 feet of row every other week up to August I.

\section{GREEN-PODDED BEANS}

Bountiful. To this Bean belongs the distinction of being one of the best flat, GreenBountiful. Podded Bush Beans; very prolific and a continuous bearer from early spring to late fall. It is tender and of delicious flavor. Is as entirely stringless as the breeder has been able to make a flat, green-podded Bean. Its pods contain a little more fiber than Stringless Green-Pod of like age, but they average large and are entirely stringless until they become longer than 5 inches. One of the earliest Bush Beans. Pkt. 10 cts., $1 / 21 b .25$ ets., lb. 45 cts., 2 lbs. 85 cts., 5 lbs. $\$ 2,15$ lbs. $\$ 5.50$.

Stringless Green-Pod. This Bean remains among the very best first-early roundaverages 5 inches long and is slightly curved. A handsome sort, borne on a healthy plant which stands dry weather well. $1 / 21$ b. 25 cts., $1 b .45$ cts., 2 lbs. 85 cts., 5 lbs. $\$ 2,15$ lbs. $\$ 5.50$.

Giant Stringless Green-Pod. Pods greatly resemble those of Stringless Green-Pod. Fully an inch longer in size but a trifle later. A variety that is largely grown for the market on account of its size and good shape. Splendid sort for succession when planted with Stringless Green-Pod. 1/21b. 30 cts., lb. 50 cts., 2 lbs. 95 cts., 5 lbs. $\$ 2.25,15$ lbs. $\$ 6.25$.

Black Valentine. A Bean used extensively in the South on account of its heat-resisting qualities. Matures early, producing long, round, straight pods, which are tender when young. Perfects the crop all at once, hence valuable as a market sort. Pkt. $10 \mathrm{cts} ., 1 / 21 b .25 \mathrm{cts} .$, lb. 45 cts., 2 lbs. 85 cts., 5 lbs. $\$ 2,15$ lbs. $\$ 5.50$.

Asgrow Valentine. (New.) A stringless Black Valentine sure to become very popular. See page I6. Pkt. 25 cts., $1 / 21 \mathbf{l b}$. 65 ets., lb. $\$ 1.10,2$ lbs. $\$ 2$.

Early Red Valentine. This variety is valuable on account of its earliness. Pods fleshy, round and saddle-backed, with slight strings. $1 / 21$ b. 25c., 1b. 45c., 2 lbs. 85 c., 5 lbs. $\$ 2$, 15 lbs. $\$ 5.50$.

Dwarf Horticultural. Pods medium length, slightly curved, and when nearly developed are splashed with bright red on yellow. The green-shelled Beans are of fair size, tender, and fine flavored. $1 / 2 \mathrm{lb} .25 \mathrm{cts} ., \mathrm{lb} .45 \mathrm{cts}$. 2 lbs. 85 cts., 5 lbs. $\$ 2$, I 5 lbs. $\$ 5,50$.

Full Measure. A fine, stringless Bean of splendid melt'ng quality, round-podded, excellent for the table and for preserving. $1 / 2 \mathrm{lb} .30 \mathrm{cts} ., \mathrm{lb} .50 \mathrm{cts}$. 2 lbs. 95 cts., 5 lbs. $\$ 2.25$, I 5 lbs. $\$ 6.25$

ongfellow. Extra-early, producing long, round, green pods which are tender, brittle, and stringless when young. $1 / 2 \mathrm{lb}$. 25 cts., lb. 45 cts., 2 lbs. 85 cts, 5 lbs $\$ 2$, I 5 lbs, $\$ 5.50$

tringless Refugee. A very heavy cropper; its flavor is wonderful and it is absolutely stringless. Valuable for immediate use, for pickling or for canning. $1 / 2 \mathrm{lb} .30 \mathrm{cts} ., \mathrm{lb}$ 50 cts., 2 lbs. 95 cts., 5 lbs. $\$ 2.25$, I 5 lbs. $\$ 6.25$.

Refugee or 1,000-to-1. One of the latest Beans. The pods are nearly round, light green, 5 inches long, terminating in a slender point; fleshy, brittle, with but slight strings. Pkt. Io cts., I $/ 2$ lb. 25 cts., lb. 45 cts., 2 lbs. 85 cts., 5 lbs. $\$ 2$, I 5 lbs. $\$ 5.50$.

\section{BEANS FOR DRY SHELLING}

Pea or Navy. A snowy white variety of uniform small size. The plants grow upright and bear the pods well off the ground. A field Bean of which large acreages are grown. $1 / 2 \mathrm{lb}$. 20 cts., lb, 35 cts., 2 lbs. 65 cts., 5 lbs. $\$ 1.50$, I 5 lbs. $\$ 4.25$

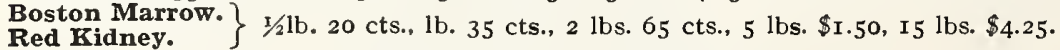

\section{FORCING BEANS}

The Prince. A new variety, quick to mature and cropping enormously. The pods The Prince. are without strings, meaty, of fine flavor and immense size-I I to I 2 inches being not unusual. $1 / 21$ b. 50 cts., 1 b. 90 cts., 2 lbs. $\$ 1.75,5$ lbs. $\$ 4.25,15$ lbs. $\$ 11$. S. $\&$ W. Co.'s Wonder. Of fine color and refined flavor. The pods are round, abundance. $1 / 21$ b. 35 cts., 1 b. 60 cts., 2 lbs. $\$ 1.10,5$ lbs. $\$ 2.50,15$ lbs. $\$ 6.50$.

Masterpiece. Of splendid constitution, a quick grower and very prolific, the pods attaining a length of over 7 inches, straight, tender, meaty and stringless. Bean thick-flat. $1 / 2$ lb. 45 cts., 1b. 85 cts., 2 lbs. $\$$ I. 5 O, 5 lbs. $\$ 3.40$, I 5 lbs. $\$ 9$.

Magpie. Largely grown under glass; suitable also for the open ground. Fine quality pods are produced in abundance. $1 / 2 \mathrm{lb} .45 \mathrm{cts} ., \mathrm{lb} .85 \mathrm{cts} ., 2 \mathrm{lbs} . \$ 1.50,5 \mathrm{lbs} . \$ 3.40,15 \mathrm{lbs}$. $\$ 9$

French Flageolet. Imported seed. $1 / 2 \mathrm{lb}$. $45 \mathrm{cts}$., lb. $85 \mathrm{cts.,} 2 \mathrm{lbs}$. $\$ 1.50,5 \mathrm{lbs} . \$ 3.40$.

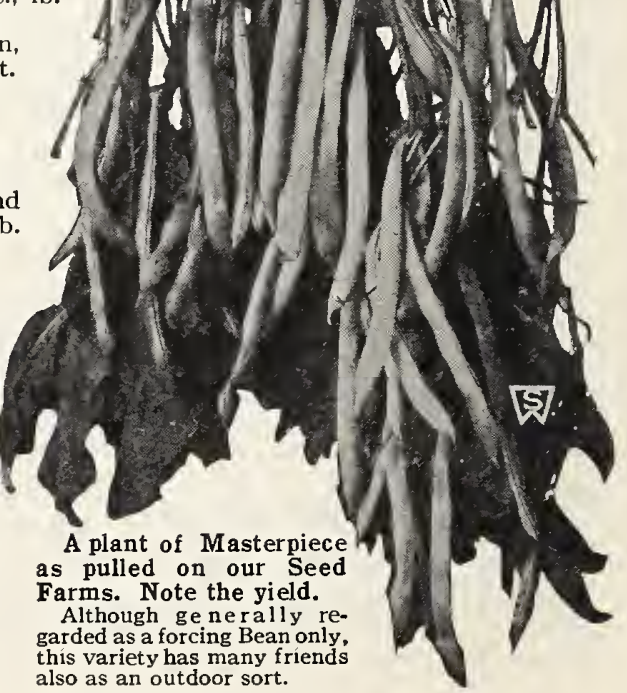




\section{DWARF or BUSH WAX-PODDED BEANS}

One pound will plant 100 feet of drill Sure-Crop Stringless Wax. The plant grows to a large size and, having a strong, stormy weather, thus protecting the pods from dirt and dampness. It is very productive, bearing in great abundance large, handsome, golden yellow pods which are stringless and tender at all stages of development. Being very hardy, the seed may be planted early. Sure-Crop is more rustproof and will stand a longer season of damp, wet weather than any other Stringless Wax Bean. $1 / 21$ b. 30 ets., lb. 50 cts., 2 lbs. 90 ets., 5 lbs. $\$ 2.10,15$ lbs. $\$ 5.75$.

Hardy Wax. One of the best round-podded stringless Wax Beans ever evolved. The plants marked degree. Within 65 or 70 days of planting, Hardy Wax bears immense crops of slightly curved deep yellow pods of excellent, brittle quality. Remains in bearing for a remarkably long period. 1/21b. 35 cts., lb. 60 cts., 2 lbs. $\$ 1.10,5$ lbs. $\$ 2.50,15$ lbs. $\$ 7$.

Brittle Wax. Without a doubt the earliest of all Wax Beans; also a great cropper. The bushes $\underline{\text { B }}$ are remarkably hardy and extremely prolific, while the pods are fleshy and entirely stringless, of ten measuring $4^{1 / 2}$ to 6 inches long. They are of fine flavor, round and solid, tender, brittle and entirely stringless at all stages of growth. The pods have white seeds showing Shell Beans. 1/2lb. 30 cts., lb. 50 cts., 2 lbs. 90 cts., 5 lbs. $\$ 2.10,15$ lbs. $\$ 5.75$.

New Kidney Wax. The fleshy pods are flattened in form, from 6 to 7 inches in length, 3/2inch new broad and 3/8inch thick; the color is a rich lemon-yellow. Under ordinary field culture the plants produce nearly twice as many pods as the Wardwell. The pods are remarkable for their meatiness, fine flavor, brittleness and absolute freedom from strings or tough fiber. $1 / 21$ b. 35 cts., 1 b. 55 cts., 2 lbs. $\$ 1,5$ lbs. $\$ 2.25,15$ lbs. $\$ 6.50$.

New Hodson Wax. A distinctly late variety, bearing enormous quantities of flat but fleshy bearing in from 80 to 85 days from date of sowing the seeds. The pods of this variety of ten measure 7 to 8 inches in length and are remarkably free from spot or rust. $1 / 21$ b. 30 ets., 1b. 50 ets., 2 lbs. 90 cts., 5 lbs. $\$ 2.10,15$ lbs. $\$ 5.75$.

Improved Golden Wax. A very early variety with flat, golden pods of excellent table quality. Pkt. Io cts., 1/2lb. 25 cts., lb. 45 cts., 2 lbs. 85 cts., 5 lbs. $\$ 2$, I 5 lbs. $\$ 5.50$.

Improved Black Wax. The pods are round, and they are yielded in large quantities; early and good. Pkt. Io cts., 1/2lb. 25 cts., lb. 45 cts., 2 lbs. 85 cts., 5 lbs. $\$ 2$, I5 lbs. $\$ 5.50$.

Davis White Wax. Long, straight, handsome pods. The seed is white and excellent for green shelling and for baking. $1 / 2$ lb. 25 cts., lb. 45 cts., 2 lbs. 85 cts., 5 lbs. $\$ 2,15$ lbs. $\$ 5.50$.

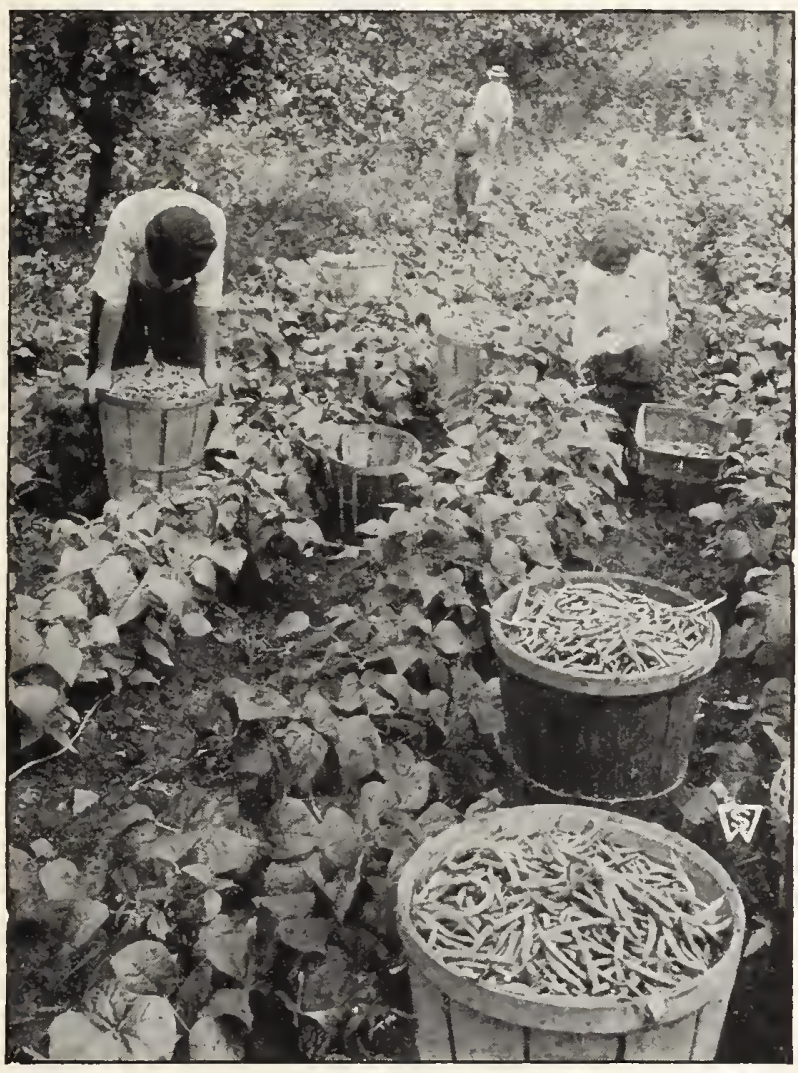

Hardy Wax. A new, stringless, round-podded variety remarkable for its heavy yielding properties. See text above.

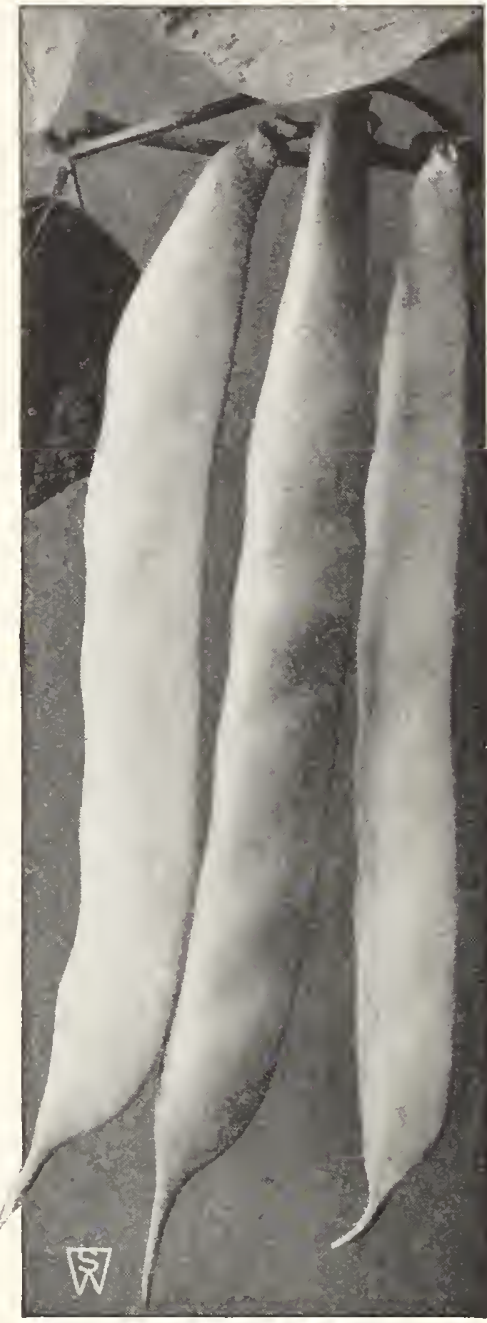

Sure-Crop Stringless. A fine flatpodded Wax Bean

English Windsor. $T$ h e heavy pods are produced

in pairs and contain three to four large Beans.

Each of the above, 1/21b. 30 cts., 1b. 50 cts., 2 lbs. 90 cts., 5 lbs. $\$ 2.10,15$ lbs. $\$ 5.75$.

\section{POLE SNAP BEANS One pound plants}

Old Homestead (Green Kentucky Wonder). An improved sort stringless and of silvery green color, hanging in large clusters from the top to the bottom of the pole. One of the most prolific. Pkt. 10 ets., $1 / 2$ lb. 25 cts., lb. 45 cts., 2 lbs. 85 cts., 5 lbs. $\$ 2,15$ lbs. $\$ 5.50$.

Golden Cluster Wax. The leading early Wax Pole Bean. Pods equal this as a "snap sort" while young, or as a dry, pure white Shell Bean for winter use. Pkt. 10 ets., 1/2lb. 30 cts., 1 b. 50 ets., 2 lbs. 90 cts., 5 lbs. $\$ 2.10,15$ lbs. $\$ 5.75$.

Lazy Wife. Green-Pod. The best late, green-podded Pole Bean. Pods medium dark green, broad, thick, very fleshy and entirely stringless. I $/ 2$ lb. 25 cts., lb. 45 cts., 2 lbs. 85 cts., 5 lbs. $\$ 2$, I 5 lbs. $\$ 5 \cdot 50$.

English Scarlet Runner. Well-known climber with scarlet flowers The green pods, though containing strings, are probably the best flavored of any Bean. $1 / 2 \mathrm{lb}$. 25 cts., 1b. 45 cts., 2 lbs. 85 cts., 5 lbs. $\$ 2$, I5 lbs. $\$ 5.50$.

Yard-Long Asparagus. A remarkable Bean, yielding narrow rounded pods of enormous length. The quality is excellent. Pkt. I5 cts., 1 $/ 2$ lb. 60 cts., lb. $\$ 1,2$ lbs. $\$ 1.85,5$ lbs. $\$ 4.50$.

NOTE. We now offer Beans by weight instead of measure: one pound is 


\section{BEETS one ounce vill sow 10 feet of}

Culture.-Seed should be sown the latter part of April. The ground should be spaded well and deep, placing rows about I 8 inches apart, and the drills I inch deep. Cover the seed carefully and firm in the ground by walking over the drills. When seedlings appear about 3 inches above ground, thin out to about 4 inches between the plants so as to give ample room for the proper development of the roots. Beets are best for pulling when about 2 inches in size. Successive sowings may be made up to the middle of July.

\section{ROUND TYPES}

Eclipse. An extra-early sort which produces Beets sixty days from sowing. Lclipse. Of uniform, dark rosy red; top-shaped; easily pulled. Flesh dark purplish red with rose zones; remains in table condition for ten days, when it becomes tough. Pkt. 10 cts., oz. 20 cts., 1/41b. 55 cts., 1b. $\$ 1.50$.

Extra-Early Egyptian. A variety which grows very quickly, producing are pulled when 2 inches in diameter. Pkt. 10c., oz. 20c., 1/4lb. 55c., 1b. $\$ 1.50$. Crosby's Original Egyptian. One of the most widely grown turnipWill produce Beets ready for pulling within two or thr ee days after Eclipse. The smooth, dark red roots are topped with light green foliage, which is prominently speckled with dark red. The flesh is carmine, handsomely marked with white zones, very tender and of uniformly sweet quality. Pkt. 10 cts., oz. 20 cts., 1/41b. 55 cts., lb. $\$ 1.50$.

Early Wonder. A variety which has Early Wonder. Aained wide popularity among market-gardeners, and one which the amateur may also grow with every confidence. It may be sown early, and it matures very rapidly. It is so uniform in growth that the crop can be lifted practically at one time, yielding the land early and quickly for the second crop. The root is nearly globular in shape, slightly flattened. The leaves are of medium size, and the color of the flesh is deep blood-red; sweet and free from strings. Pkt. 15 cts., oz. 35 cts., $1 / 41$ lb. $\$ 1,1 b . \$ 3$.

Detroit Dark Red. Extended experience has shown

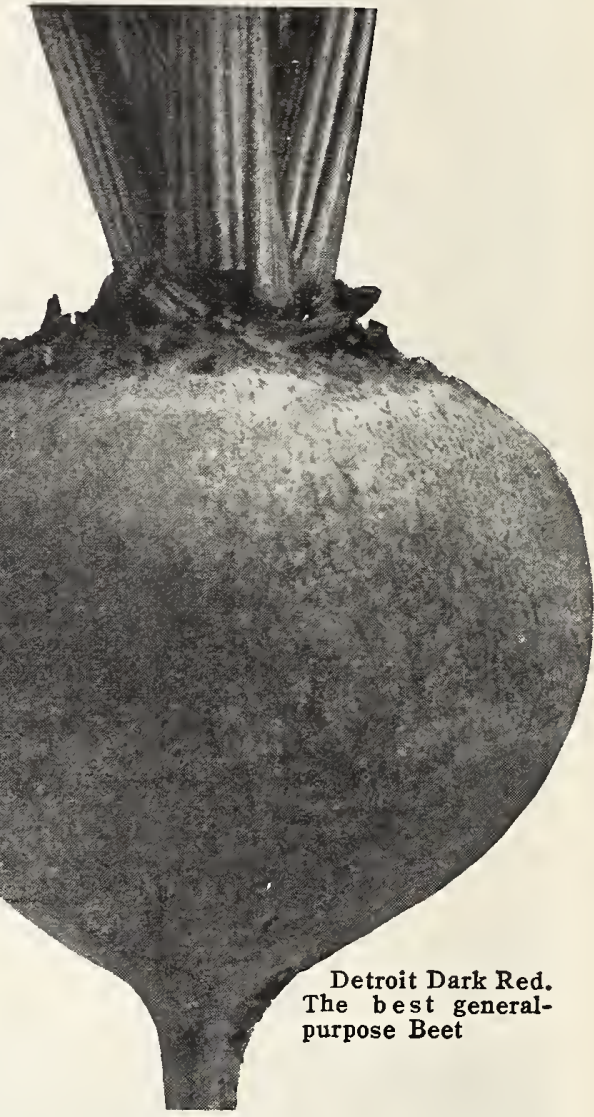

the ideal than any other, and where but one variety is used this should be the first choice. The round, dark red globe roots are uniformly smooth. The flesh of the very young Bats is almost black-red, turning to dark crimson with dark purple zones as the Beets grow larger. When cooked, the Beets are of an appetizing dark red and very sweet. Pkt. 10 cts., oz. 25 cts., 1/41b. 65 cts., $1 b . \$ 1.75$.

DETROIT DARK RED, Exhibition Strain. This is specially reselected for depth of color, uniformity of shape, and general refinement. It is developed particularly to meet the requirements of the exhibitor and market-gardener. Pkt. I5 cts., oz. $35 \mathrm{cts}$., $1 / 4 \mathrm{lb} .90 \mathrm{cts}$., lb. $\$ 2.50$.

Crimson Globe. In about 70 days from planting one-four th of the Beets in the Crimson Globe row will be ready for table use. A peculiarity of this and the next variety is that the Beets do not all come to the eatable size at the same time, some growing faster than others, thereby lengthening the period of perfection. Flesh bright red with light purple zones. Pkt. Io cts., oz. 25 cts., I/4lb. 65 cts., lb. $\$$ I.75.

Edmand's Blood Turnip. Very regular in shape, deep blood-red, and exceedingly sweet. Pkt. Io cts., oz. 25 cts., $1 / 4$ lb. 65 cts., lb. \$I.75.

S. $\&$ W. Co.'s Winter Keeper. A distinct strain of a main-crop, globe-shaped Beet produced by many years of painstaking selection on the part of a grower who takes particular pride in striving after high ideals in seed selection. Two leading characteristics make this Beet worthy of any gardener's time and space: the uniformly excellent flavor of its flesh at all stages of development and the remarkable manner in which this quality is preserved during winter storage. Beets are almost globe-shaped, tapering somewhat toward the root. The flesh is dark red,

Crosby's Original Egyptian. One of the most widely grown Beets in cultivation

sweet and tender at all stages of growth regardless of size. They may be stored in a cellar or pit until the spring and will cook more tender and sweet than ordinary varieties will when taken from the garden. Pkt. 20 cts., oz. 65cts., $1 / 41$. $\$ 1.75,1$ Ib. $\$ 5$.

\section{HALF-LONG AND LONG TYPES}

Half-Long Blood. An entirely distinct variety. The roots are symmetrical, somewhat pear-shaped, smooth and handsome; flesh a rich, dark red, very sweet, never becoming woody. Economical where little ground is a vailable. Pkt. 10 cts., oz. 25 cts., $1 / 41 b .65$ cts., $1 b . \$ 1.75$.

Long Dark Blood. (Out of ground.) A late variety the root of which is over a foot long. Five inches or more of this grows out of the ground, and the harvesting of the Beet is therefore not attended with much difficulty. The flesh is deep red in color, sweet, and of high quality; it keeps in fine condition through into the winter, and its size and shape obviously make it the most economical sort where garden space is limited. Pkt. I5 cts., oz. 25 cts., $1 / 4$ lb. 65 cts., lb. $\$$ I.75.

\section{Cow Beets (Mangels) and Sugar Beets}




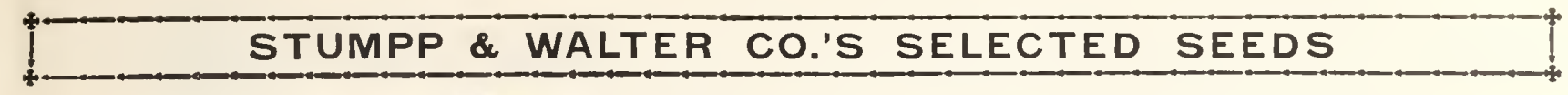

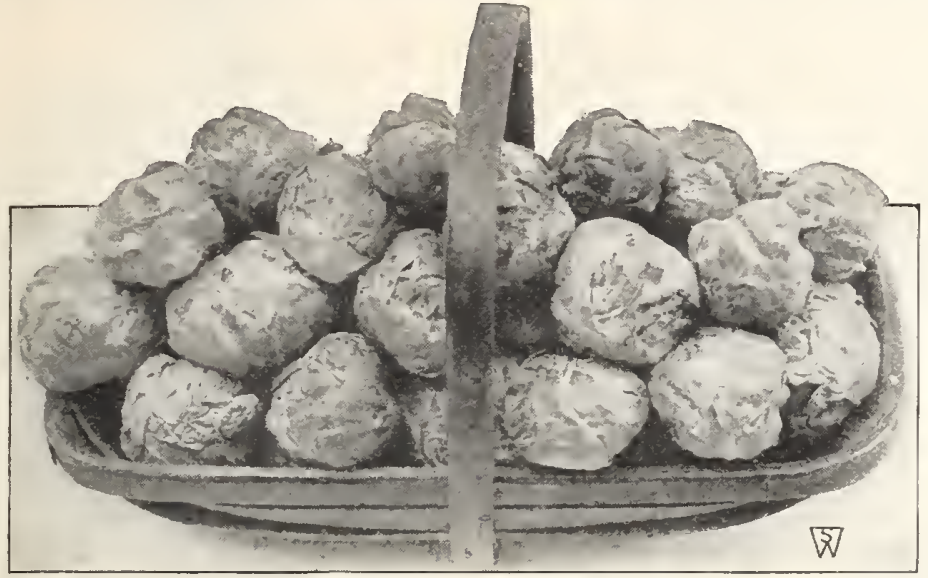

S. \& W. Co.'s Favorite Brussels Sprouts

\section{BRUSSELS SPROUTS}

\section{One ounce will produce about 3,000 plants}

Culture.- Sow in May, in shallow drills, I inch deep and $\mathrm{I} 2$ inches apart. Transplant in July. When the crown, or top sprout is beginning to head, pinch it out, to admit of the whole streng th being thrown into the side shoots. Very hardy. This is a delicious vegetable and should find a place in every garden; greatly improved by first frosts. S. \& W. Co.'s Favorite. Semi-dwarf, thickly covered with excellent sprouts by the end of September. Pkt. $20 \mathrm{cts}$., 1/20z. $60 \mathrm{cts.,}$ oz. \$I, $1 / 4 \mathrm{lb} . \$ 3.5 \mathrm{o}$.

\section{BROCGOLI}

\section{The True Italian Market Strain}

A comparatively new vegetable to the American table, but one which has found favor in Europe for many years. It is preferred by many to cauliflower, and while it is sometwhat akin to it, it has a more decided and distinctive flavor. It furnishes healthful and delicious boiling "greens" during summer, a utumn, and early winter.

The plant branches freely. At first it produces a closely massed head, the size of a cocoa-nut, of green buds; this is termed the "king" sprout. When the buds are lalf developed and before any burst into flower, the head is cut, with the surrounding leaflets, and together they are boiled and served exactly like cauliflower, except that more of the leaves are edible. Later, similar heads appear at the ends of the branches, to be gathered and served in a like manner

Cultivate like cabbage. Seed may be sown in February or March under glass, and in the open ground until July. Space the plants about $2 \mathrm{ft}$. each way. Light frosts improve it rather than otherwise. In warm sections south of New York, it may be grown to stand in the fields for an appreciable period of the early winter.

There is considerable variation in the strains of Broccoli, but we find that our selection is the one most in demand among Italian gardeners.

BROCCOLI, NEW YORK MARKET. PLt. 25 cts., 1/80z. 85 cts., $1 / 4$ Oz. $\$ 1.50,1 / 20 z$. $\$ 2.75,0 z . \$ 5$.

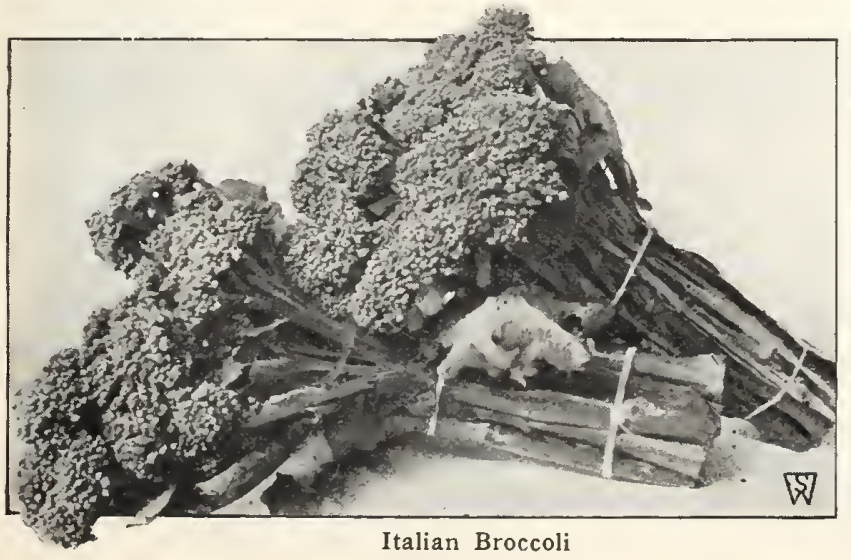

\section{GARDOON}

A vegetable that is grown somewhat like celery and served after the manner of asparagus. Sow in the open ground in May, and thin or transplant the seedlings so that they stand $21 / 2$ feet, one from the other, in rows 4 feet apart. A catchcrop such as beans, lettuce or beets may be taken between the rows. At the end of the summer, and two or three weeks before using, it is necessary to blanch the Cardoons. The heads of the plants are tied together, straw is piled against them, and the surrounding soil is then heaped up against the straw. Pkt. 15 cts., oz. 45 ets., 1/41b. $\$ 1.30,1$ b. $\$ 3.50$

\section{CHERVIL \\ One ounce will sow 150 feet of drill \\ Culture.-The curled Chervil is cultivated like parsley and used for garnishing and fla- voring soups and salads.}

Moss Curled Extra. Pkt. I $5 \mathrm{c}$. oz. 35c., 1/4lb. $90 \mathrm{c} ., 1 \mathrm{~b} . \$ 2.5 \mathrm{O}$.

\section{CRESS}

(Pepper Grass)

Curled, or Pepper Grass. The young seedlings are used for salads. In combination with seedlings of White London Mustard, they make delicious fillings for sandwiches. Crisp. tender, and pungent in flavor. Sow in early spring and again at short intervals for succession. Pkt. IO cts., Oz. 20 cts., 1/4lb. 55 cts., lb. \$I.50.

True Erfurt Water Cress. Pkt. I 5 cts., $I_{2} / 2 \mathrm{Oz}, 40$ cts. oz. 65 cts., $1 / 4$ lb. $\$ 1.75$, lb. $\$ 5$.

\section{CHICORY}

\section{Witloof, or French En-}

dive. A winter salad, most dive. delicious served with French dressing and eaten like Cos lettuce. The seed should be sown in the open ground not later than June, in drills $I 2$ to I 8 inches apart, thinning out the plants so that they will not stand closer than 3 inches. The plant forms long, parsnipshaped roots, which should be lifted in the fall, cutting off the leaves about $I \frac{1}{2}$ inches from the neck and shortening the roots by cutting off the bottoms to within 8 inches of the neck. The roots should then be planted in a trench 16 to 18 inches deep in a dark, warm cellar or under a greenhouse bench, and placed upright about $I \frac{1}{2}$ to 2 inches apart, which will allow the neck

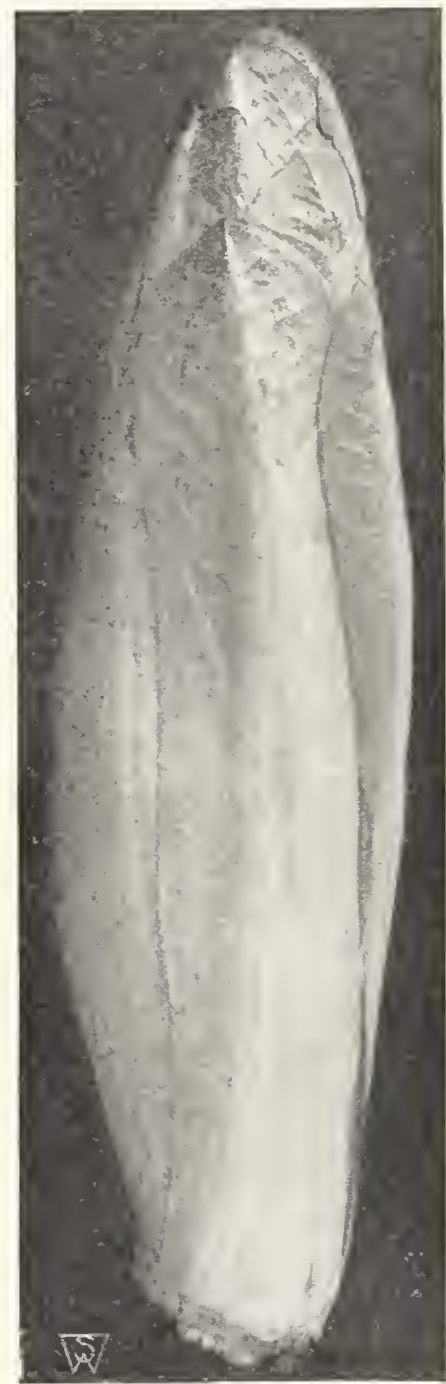

Witloof, or French Endive. From seeds sown in spring or early summer, roots are produced, and from these roots the wellknown Witloof is forced during winter. of the root to come within 9

inches of the level of the trench. The trench should be filled with a light soil, and if a quicker growth is desired, this can be accomplished by a mulch of fresh manure about 2 feet deep. It requires about one month to force the roots. Pkt. 15 cts., oz. $45 \mathrm{cts} .1 / 41 \mathrm{lb} . \$ 1.30$, lb. $\$ 3.50$.

Common or Wild (Barbe de Capucin). Pkt. I 5 cts., oz. 55 cts., Large. \$rooted lb. \$.4. Baltivated for the roots which are used as a coffee ingredient. Pkt. I $5 \mathrm{cts}$., Oz. $45 \mathrm{cts} ., \mathrm{I}_{4} \mathrm{lb} . \$ \mathrm{I} .30,1 \mathrm{~b} . \$ 3.50$.

For Endive, see page 34

WITLOOF ROOTS for forcing are offered on page 54 . 


\section{CABBAGE One ounce will produce}

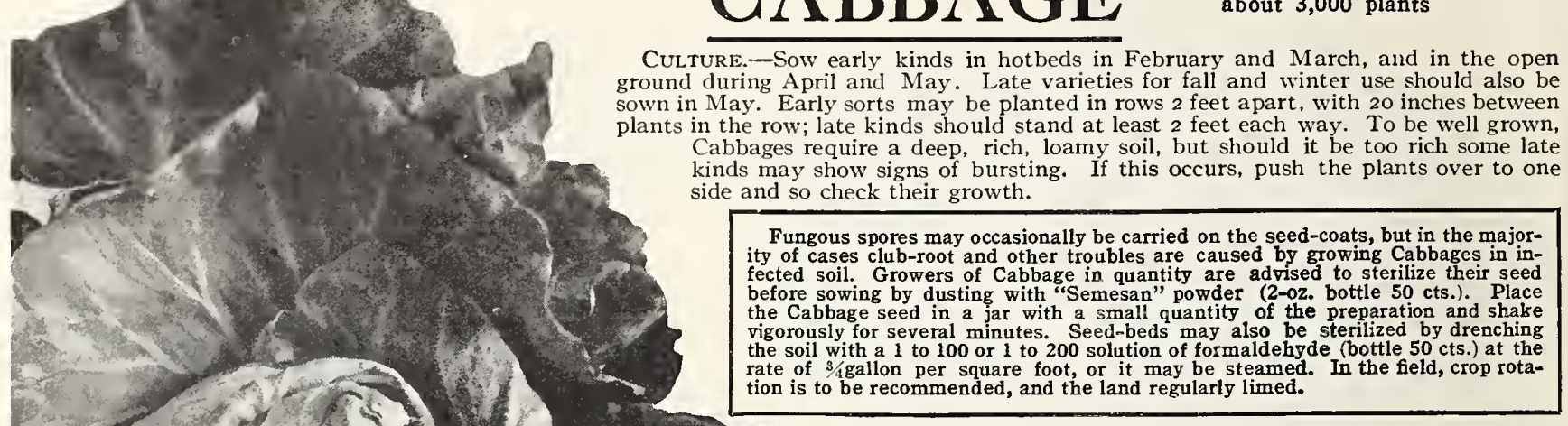

Q.

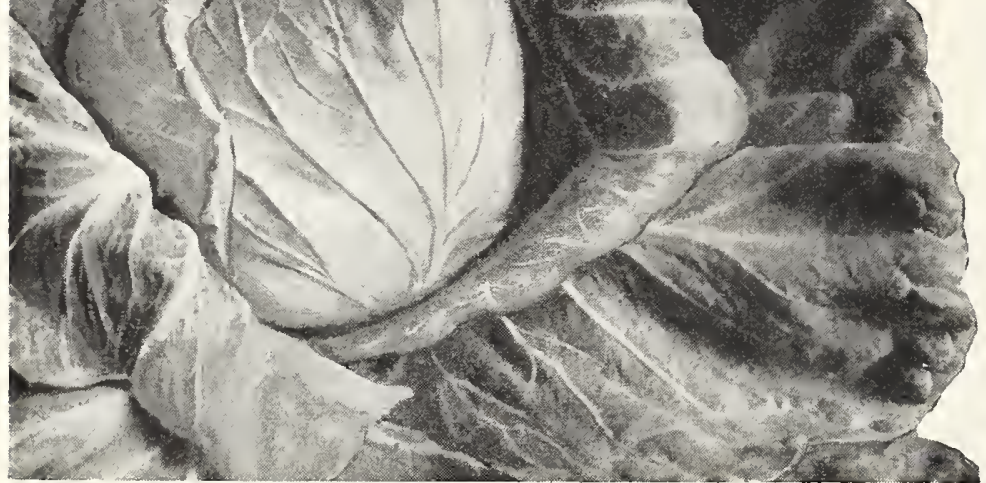

Improved Jersey Wakefield Cabbage

An extremely early variety of conical form, quite distinct from any other on the market. An ideal sort for private gardens, producing solid heads sooner than other varieties and requiring less space than most kinds. Pkt. 20 cts., $1 / 40 z$. 45 ets., $1 / 20 z$. 75 ets., oz. $\$ 1.25,1 / 41 b$. $\$ 4$.

Improved Early Jersey Wakefield. While this not quite so early as our Famous Early Conical, it has been long considered one of the best early conical-type Cabbages we have. The heads are hard and solid with just a few outside leaves, which are unusually thick, enabling them to stand cold. May be carried over winter in frames. Pkt. 10 cts., $1 / 2$ oz. 30 cts., oz. 55 cts., $1 / 4 \mathbf{l b}$. $\$ 1.50$.

Charleston, or Large-Type Wakefield.

Retains all the characteristics of the Improved Early Jersey Wakefield with the added advantage of greater size. Pkt. 15 ets., 1/20z. 45 cts., oz. 75 ets., 1/41b. $\$ 2$.

Babyhead. Extreme earliness and small size are charless than 6 inches across, round, firm, and of splendid mild

\section{LATE CABBAGES FOR}

\section{WINTER STORAGE}

Danish Drumhead. Averages larger two weeks earlier. The round heads are very solid, fine-grained and sweet-flavored. Pkt. 15c.. $1 / 40 z .40$ cts., $1 / 20 z$. 60 ets., oz. $\$ 1,1 / 41 b . \$ 3.50$.

Large Late Flat Dutch. One of the most reliable sorts in cultivation for winter use; produces immense heads of the finest quality; splendid keeper. Pkt. Io cts., $1 / 2 \mathrm{Oz} .30 \mathrm{cts}$., oz. $55 \mathrm{cts}$., I/ $/ \mathrm{lb}$. \$I.5O.

\section{RED CABBAGES}

Mammoth Rock Red. This is the best, largest and surest heading Red Cabbage. The plant is handsome, with numerous spreading leaves, large, round, and very solid heads. Pkt. I 5 cts., $1 / 4 \mathrm{oz}$. $40 \mathrm{cts}$., $1 / 2 \mathrm{Oz}$. $60 \mathrm{cts}$., oz. $\$ \mathrm{I}, 1 / 4 \mathrm{lb} . \$ 3.50$

Zenith Red. A small early sort. Very refined and unitormly dark red. Pkt. I 5 cts., $1 / 40 z$. 40 cts., $1 / 2 \mathrm{Oz}$. $60 \mathrm{cts}$., oz. $\$ \mathrm{I}, 1 / 4 \mathrm{lb} . \$ 3.5 \mathrm{o}$.

\section{CHINESE or "CELERY" CABBAGE}

A desirable vegetable, nearer to Mustard than Cabbage, but palatable and healthful. A cool weather crop; sow early in spring or in August for late autumn cropping.

Pe-Tsai. In appearance it is suggestive of a large Cos Lettuce, but its crisp leaves and midribs have a decided Cabbage flavor. Pkt. I5 cts., 1/20z. $30 \mathrm{cts}$., oz. $55 \mathrm{cts}$., $1 / 4 \mathrm{lb}$. $\$ \mathrm{I} .50$.

Wong Bok. A very compact plant, short and broad, needing less space in the garden than Pe-Tsai. Pkt. I 5 cts., I/20z. 30 cts., oz. 55 cts., 1/4lb. $\$$ I.5O.

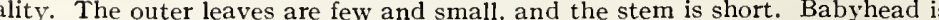
recommended as the first to reach the table when grown outdoors, and also for grow'th

Copenhagen Market. The best of all early Cabbages. Stands longer without its class, as the old favorite Danish Ballhead. The stem is short, the head round and solid. When ready for cutting. Copenhagen Market is the heaviest of the extra-early varieties, and if left until fully mature, frequently weighs 8 to ro pounds. The leaves are srained, compact and close to the head, so it will stand close planting. $1 / 2$ oz. 60 cts., oz. $\$ 1,1 / 4$ lb. $\$ 3.50$.

uccession. A splendid second-early, round-headed sort, with enormous heads of exceedingly tender quality. Pkt. $15 \mathrm{cts} ., 1 / 4 \mathrm{Oz}$.

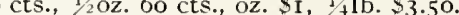

\section{SAVOY CABBAGES}

American Drumhead Savoy. Hearts solid, large, and well shaped, and in table quality ges. None the $1 / 4 \mathrm{lb} . \$ 2.75$

Early Cone Savoy. Has a cone-shaped head. Very refined Savoy of high quality. Pkt. $20 \mathrm{c}$.,
$1 / 4 \mathrm{Oz} .45 \mathrm{cts}$., $1 / 2 \mathrm{Oz}$. $75 \mathrm{cts}$., oz. $\$$ I.25, 1/4lb. $\$ 4$. 


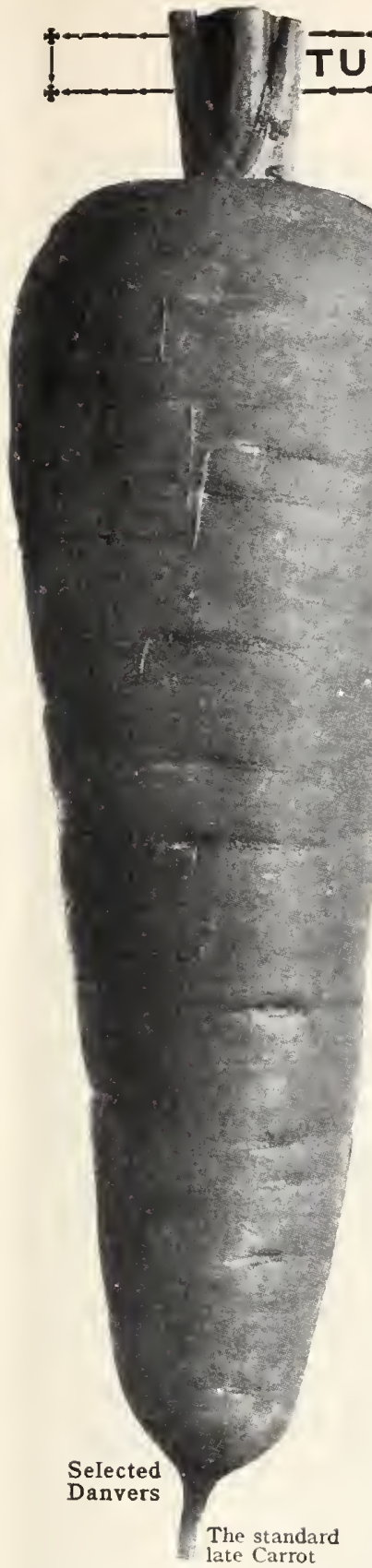

\section{\& WALTER CO.'S SELECTED SEEDS \\ CARROT \\ One ounce will sow 100 feet of drill}

Culture.-To produce the finest crop, the land should be thoroughly manured the previous season; forked roots will result if the seed is sown in freshly manured soil. Sow the early sorts in Mlarch and April, in drills I inch deep and $\mathrm{I} 4$ inches apart; thin out to 4 incles. For main crop sow in May or beginning of June. Care should be taken, at all times, to see that soil is firm over the seeds, either by using the feet, roller, or garden drill.

\section{BEST EARLY KINDS}

S. \& W. Co.'s Rubicore. Rubicore is a fine-flavored, new, early Carrot. It is a deep orangeretains in cooking, and it is as tender and sweet as the root itself. Rubicore is thus as "coreless" as Carrot can be. The roots are $5^{1 / 2}$ to 6 inches long, 2 to $21 / 2$ inches at the shoulder. narrowing gradually to a blunt end. They are refined in appearance, smooth and free from eyes, and they all match up very well-uniform in size, shape, and color. The tops are medium small, but large enough and strong enougl, to bunch easily. It will be found an ideal market-gardener's type, as well as an excellent one for the home garden on account of its superior qualities. Pkt. 15 ets., oz. 55 ets., 1/4lb. $\$ 1,50,1$ b. $\$ 4$.

S. $\&$ W. Co.'s Melting Marrow. A specially fine variety that is cylindrical in shape and of notice of the private gardener for exhibition purposes. It is, further, the best Carrot we know from the culinary standpoint. Pkt. 15 ets., oz. 55 ets., $1 / 4$ lb. $\$ 1.50,1$ b. $\$ 1$.

Selected Chantenay. A very splendid type of the half-long, stump-rooted Carrot. Average blunt end. The flesh is rich orange-red, free from core, tender, fine Havored, and of excellent table quality, Pkt. 10 cts., $0 z .30$ cts., $1 / 41$ b. 75 cts., $1 b . \$ 2$.

Early French Forcing. The earliest variety and the one largely grown for forcing purposes. It makes

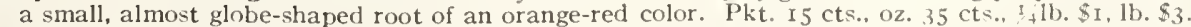

Early Half-Long Scarlet Nantes. The skin is smooth, flesh red, and without any core or heart. It is excellent for forcing, and for fine quality and perfect shape can hardly be surpassed. Pkt. I5 cts. oz. 35 cts., $1 / 41$ b. \$ I, lb. \$3.

Early Scarlet Horn. Favorite for early crop but not large. A good, general-purpose, all-season variety, since, sown late in the season, the roots are firm enough for winter storage. Sometimes used for forcing. Pkt. $15 \mathrm{c}, 0 \mathrm{Oz}, 35 \mathrm{c} ., 1 / 4 \mathrm{lb}, 90 \mathrm{c}, 1 \mathrm{~b}, \$ 2.50$.

Oxheart or Guerande. It is intermediate between HalfLong and fIorn varieties, and perfectly distinct. The shape is nearly oval and the color and quality all that can be desired. Pkt. ro cts., oz. 30 cts., I/ $1 \mathrm{~b} .75 \mathrm{cts} ., 1 \mathrm{~b} . \$ 2$.

\section{LATE SORTS Particularly Suitable}

Selected Danvers. A handsome, cylindrical-shaped rooted. It is of a rich, dark orange color, of excellent table quality, smooth, and has little core. It is a first-class Carrot for all soils, yields a greater weight per acre than any other variety, and is more easily harvested than the old long varieties. This selected stock we are now offering has been pecially grown for market-gardeners and is sure to give satisfaction. Pkt. 10 ets., oz. 30 cts., 1/4lb. 75 cts., 1 b. $\$ 2$. S. $\&$ W. Co.'s Improved Long Red Surrey. Larger, better-flavored, of a deeper orange color, and more certain to produce a crop than any type of long Carrot flesh very sweet and tender, and never becomes hard or woody at the heart. The roots grow very regular and smooth; they are of good size, being from 6 to 8 inches in length and 2 inches in diameter at the top, tapering gradually from the shoulder to the tip of the roots. Pkt. 15 ets., oz. 35 cts., $1 / 4$ lb. $\$ 1,1 b$. $\$ 3$.

Perfection. An excellent orange-red late sort, with very small core and exceptionally fitting companion to our Melting Marrow. Pkt. 15 cts., oz. 55 cts., 1/41b. $\$ 1.50,1 b . \$ 4$. Selected Long Orange Improved. One of the most desirable for either garden or field culture; it grows to a large size, fair specimens averaging $\mathrm{I} 2$ inches in length and 3 inches in diameter at the top. Pkt. Io cts., oz. $25 \mathrm{cts}$., I $_{4} \mathrm{lb} .65 \mathrm{cts} ., 1 \mathrm{~b} . \$ \mathrm{I} .75$.

S. \& W. Co.'s New Red Intermediate. It is one of the most uniform in shape that we know, and where the soil is favorable, it will always grow clean and free from side roots. The core is small and very tender, and there is no indication of woody character at any stage of its growth. It is also entirely free from any coarse, rank flavor so common with many sorts. Pkt. 15 cts., 0z. 35 cts., $1 / 1$ lb. $90 \mathrm{cts}$., 1b. $\$ 2.50$.

\section{TWO CARROTS FOR PRIZE-WINNING}

Exhibition Chantenay and Exhibition Danvers. Two fine strains of these standard varieties that have been specially grown and selected for exhibition purposes. Each, pkt. 15 cts., oz. 55 cts., 1/4lb. $\$$ I. $50,1 \mathrm{lb}, \$ 4$.

Grow More Root Crops. There is a wealth of satisfaction in being able during the winter months and dig up vegetables that sell on the market at io to 25 cents for a bunch of five. Their liberal use is most essential to our physical welfare. And they are so easy to grow that they may play quite a part in reducing the cost of living.

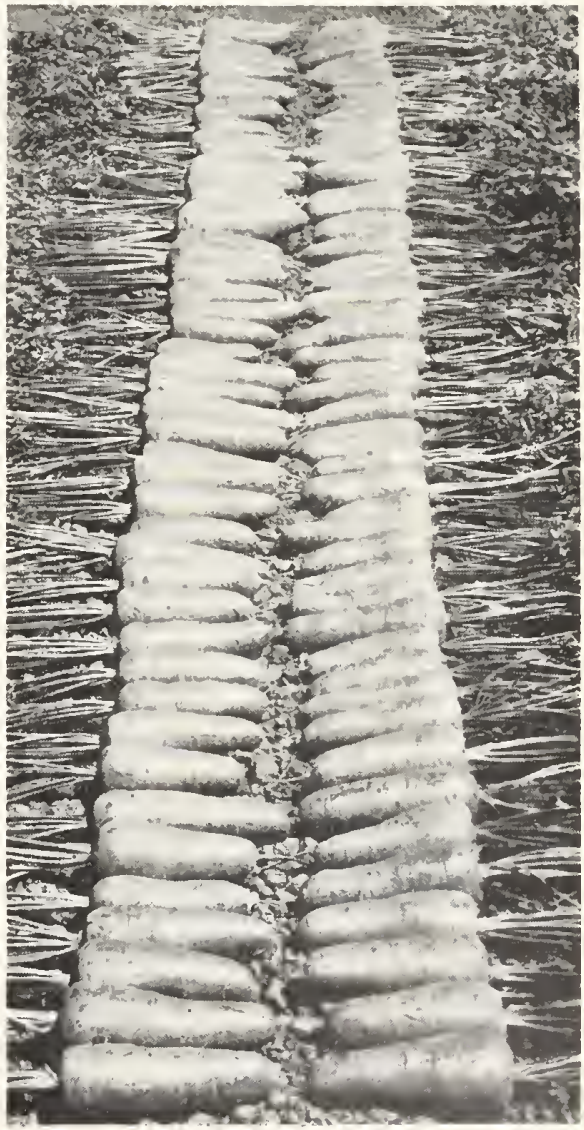

S. \& W. Co.'s Rubicore

As "coreless" as a Carrot can be; the ror tionally uniform as to size; the 


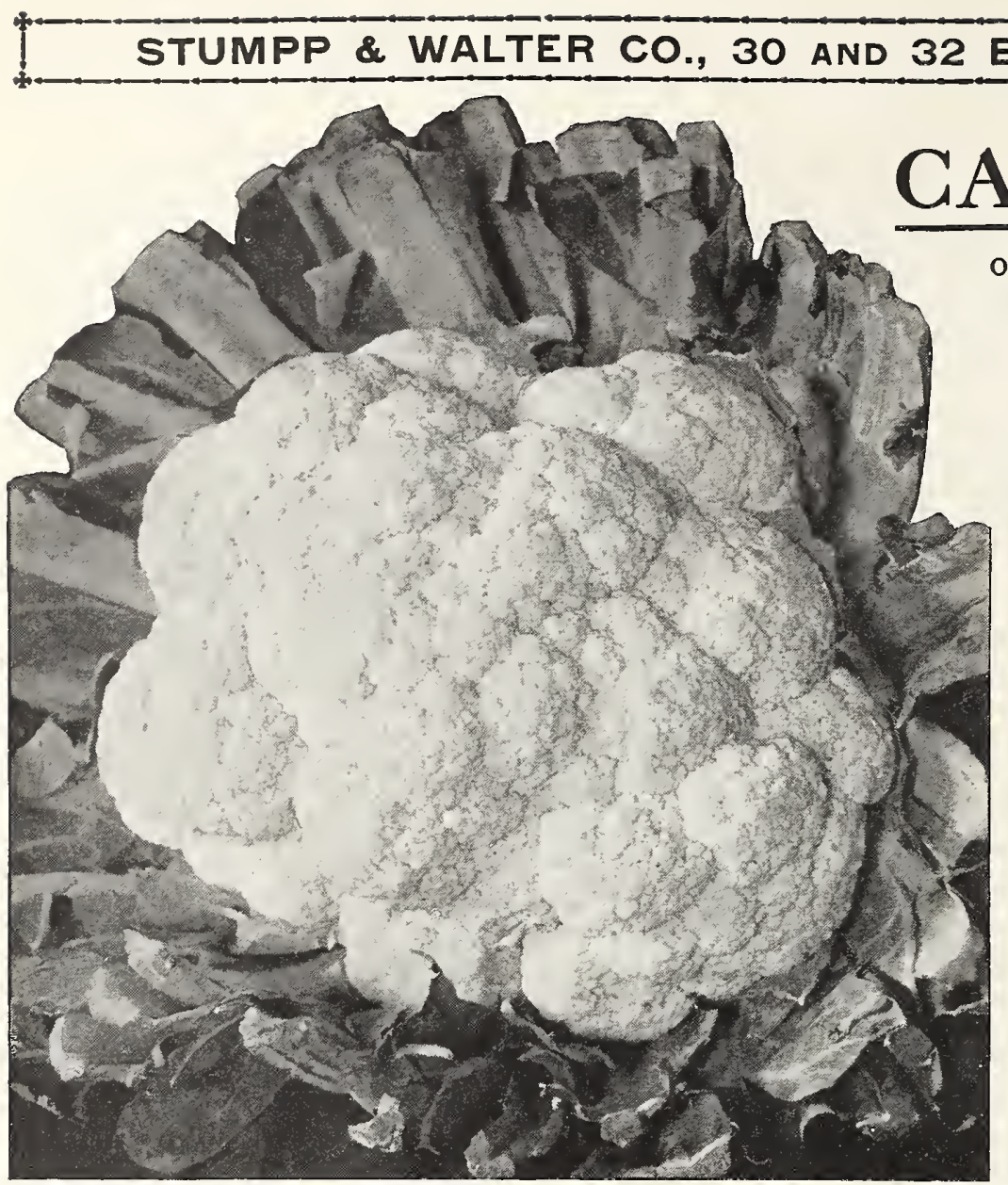

S. \& W. Co.'s Best of All Cauliflower

One ounce will produce about 3,000 plants

CurTuRE.-Sow the first week in May and prick out on a rich piece of ground; transplant in July. For wintering under glass sow in the second and last weeks in September; transplant thickly into a cold pit or frame; give plenty of air in mild weather, and cover up well when conditions are severe. Again sow in February in a hotbed and transplant in April. For Cauliflower the ground should be well prepared by trenching, incorporating at the same time a good share of rotten manure. Select new ground, if possible, as Cauliflower rarely succeeds on soil which has been cropped year after year with other kinds of vegetables. Plant in rows 20 inches apart and 2 feet between the rows. To be successful with this vegetable, rich soil and abundant moisture at all stages of development are absolutely essential. Cauliflower does not form solid heads in hot, dry climates.

\section{The Best Early Cauliflower, S. \& W.}

Co.'s Best of A11. The easiest grown and flower offered today. In habit the plant is very dwarf, stocky, and erect. It has very few outer leaves and, as a consequence, the young Cauliflower plants may be planted less than 2 feet apart each way. All that is necessary is to select suitable soil, when every plant will form a large, solid, perfect head of the finest table quality and of handsome appearance. Pkt. 25 cts., $1 / 8$ oz. $\$ 1,1 / 40 z$. $\$ 1.75,1 / 2$ oz. $\$ 3.25$, oz. $\$ 6$.

Early Snowball. This wonderful, sure-heading variety is of characteristic dwarf habit; the outer leaves are small, hence it is particularly adapted to growing under glass during winter and spring, also for spring planting outdoors. It is, too, an excellent autumn sort. Snowball is the most popular Cauliflower grown in America today, and the S. \& W. strain is used so largely by commercial growers because of the solidity and purity of its head, its large size, and its uniform reliability. Plst. 20 cts., 1/80z. 70 cts., $1 / 4$ oz. $\$ 1.25,1 / 2$ oz. $\$ 2.25$, oz. $\$ 4$.

Danish Dry Weather. Especially adapted to sections subject large size, are very solid, pure white, and of delicious flavor. It will prove valuable for growing in the southern states, where the climate is hot and long seasons of dry weather are experienced. Pkt. 20 cts., $1 / 8$ oz. 85 ets., $1 / 4$ oz. $\$ 1.50,1 / 2$ oz. $\$ 2.50$, oz. $\$ 4.50$.

Extra-Early Dwarf Erfurt. This Cauliflower is an extra-early sort, of dwarf habit, and desirable for forcing under glass or planting in the open ground. Pkt. 20 cts., I/80z. 70 cts., I/4Oz. $\$ 1.25$, I/2Oz. $\$ 2$, oz. $\$ 3.50$.

Autumn Giant. This is a larger and later type than the above varieties. It is popular in South America and the warmer parts of this country, though many growers in this section also find that it suits their requirements. Tall and sturdy, it needs more room to develop than the early types. Pkt. I5 cts., $1 / 40 z$. $40 \mathrm{cts}$, $1 / 2 \mathrm{Oz}$. $60 \mathrm{cts}$., oz. \$I.

One of the best ways to prepare land for Cauliflower is to grow and dig under a green crop. A list of suitable ones will be found on page 57

\section{SMALL VEGETABLES for SMALL GARDENS}

Vegetables which will grow in a small space are of Special interest to those of us whose gardens are limited in size. We here list a selection of tiny Vegetables which may be grown in narrower rows and closer together than normal sorts. They will occupy the minimum amount of room in the garden, and they enable us to obtain the maximum yield from a given area.

BEET, Early Wonder.

CABBAGE, Babyhead.

CARROT, Early French Forcing.

CORN, Midget.

KOHLRABI, Earliest Selected.

LETTUCE, Tom Thumb. (Sow in spring.)

Thanksgiving Day. (Sow in summer.)

MUSTARD and CRESS. (The seedlings, gathered a

week or two after sowing, form excellent salad.)

Mustard, White London.

Cress, Curled.

PARSLEY, Emerald Gem.

PEA, Little Marvel.

RADISH, Saxa.

TOMATO, Dwarf Stone.

These sorts are excellent for the city garden or for the small suburban garden. Spacing may be as follows: Lettuce, 8 inches apart; Cabbage. I 2 inches; Corn-hills, I 5 inches; Tomatoes, 24 inches; Radish (in rows), 6 inches from drill to drill; Beet, Carrot, Kohlrabi, and Parsley, in Io-inch rows; Peas, in I 8 -inch rows. The soil should be specially enriched by digging in General Garden Fertilizer before planting. As the plants grow, frequently dust this plant-food on the soil around them, and then hoe the land. Constant cultivation will insure good crops. 


\section{GELERY}

One ounce will produce 3,000 plants

Curture-Sow the seed in coldframe or dry border as early as the ground can be worked, in drills 8 to $\mathrm{Io}$ inches a part, covering the seed $1 / 4$ inch deep. When fairly out of the seed-leaf, they may be transplanted to another bed or thinned out 5 to 6 inches apart. and allowed to grow until wanted for transplanting out into the bed or trenches. Early in July is the proper time to set out the plants in the trenches, or as soon after early July as possible. Rows or double rows should be 3 feet apart and the plants set about 8 inches apart in the row. As the plants grow, they should be boarded or earthed up to blanch them. For keeping over the winter, they can be banked up with earth and covered with litter and boards.

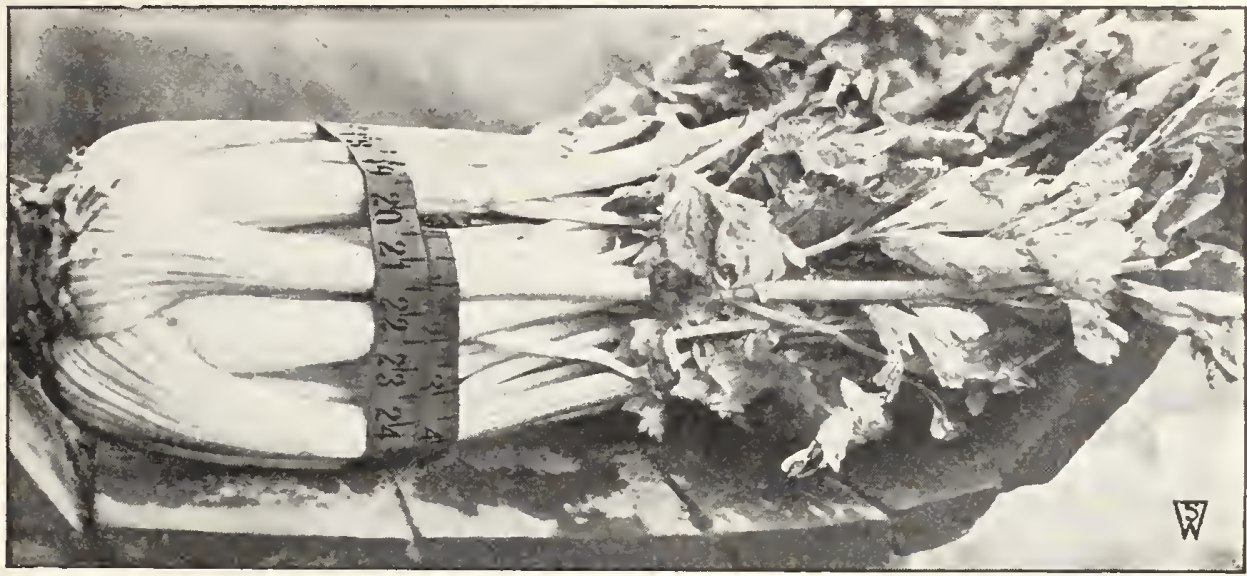

A Wheelbarrow Load of Golden Plume Celery. Earliness, crispness, and general refined quality are the characteristics of Golden Plume Celery. Under high cultivation tss, the varsety grows to a large size This head of Golden Plume measures 21 inches in circumference and weighs, $72 / 2$ pounds trimmed. It was grown at Port Monmouth, N. J

\section{EARLY QUICK-BLANCHING VARIETIES}

New Golden Plume. Fine flavor, extreme earliness, resistance to blight, and wonderful golden color characterize this variety which is the favorite of many market-gardeners. See also page 17 . Pkt. $25 \mathrm{cts} .1 / 80 \mathrm{Oz}$. \$I, $1 / 7 \mathrm{OZ}$. \$1.75, 1/20Z. \$3.25, OZ. \$6.

New Earligreen. The finest early green Celery that we know. It is stocky, with a remarkably full heart of delicious, nutty flavor. See also page I 7 . Pkt. $25 \mathrm{cts}$., 5 pkts. \$I.

Paris Golden Self-Blanching. Compact. stocky, with golden green leaves. The solid. brittle heart blanches quickly; fine, nut ty Havor. Grown by the French originator, our stock is free fron objectionable green plants. Pkt. $25 \mathrm{cts} ., 1 / 2 \mathrm{Oz} . \$ \mathrm{I}, \mathrm{Oz} . \$ \mathrm{I} .75,1 / \mathrm{tb} . \$ 5$. Improved White Plume. Onery best flavor. Pkt. 20 cts., 1/20z. 60 cts., oz. $\$ 1,1 / 41$ b. $\$ 2.75$.

\section{WELL-KEEPING WINTER VARIETIES}

Bokay. A green Celery of great merit. Round, fleshy ribs enclose a large and amateur gardener. Pkt. 25 cts., $1 / 8$ oz. 85 cts., $1 / 40 z . \$ 1.50,1 / 20 z . \$ 2.75,0 z . \$ 5$.

New Easy-Blanching. This variety is somewhat suggestive of Golden SelfBlanching, but it is green in color and a larger plant; the leaves blanch white. One of the easiest of all Celeries to grow, it is as good a keeper as any late sort, though maturing but two weeks later than Paris Golden. The flesh is crisp and brittle, the flavor particularly attractive. Pkt. $25 \mathrm{cts} .1 / 4 \mathrm{Oz} .75 \mathrm{cts} .1 / 2 \mathrm{Oz}$. $\$ 1.25 ; 0 z . \$ 2,1 / 4 \mathrm{lb}$. \$6.50.

Winter Queen. Medium large, light green in color. Solid crisp; blanches well and keeps well. Pkt. Io cts., $1 / 2 \mathrm{oz}$. $50 \mathrm{cts}$., oz. $85 \mathrm{cts} ., 1 / 4 \mathrm{lb} . \$ 2.50$.

Giant Pascal. A deep green selection from the Golden Self-Blanching Celery. The stalks are very large, thick, solid, and crisp. It has a fine, nutty flavor. Pkt. I 5 cts., I/2Oz. $50 \mathrm{cts}$., oz. $85 \mathrm{cts}$. I/4 lb. $\$ 2.50$.

Covent Garden Red. A splendid dark rose variety; large, brittle, and of specially nutty flavor. Pkt. $20 \mathrm{cts}$., $1 / 2 \mathrm{Oz} .75 \mathrm{cts}$., oz. $\$ \mathrm{I} .25,1 / 4 \mathrm{lb} . \$ 3.5 \mathrm{O}$.

Cutting Celery. (For Soup Greens.) A loose-growing type from which stalks may be cut continuously. Merely grow in good soil kept free from weeds; do not earth or blanch. Pkt. Io cts., oz. $35 \mathrm{cts}$., 1/4lb. \$1.

Celery Seed. For flavoring soups, etc. Oz. I 5 cts., I/4lb. $30 \mathrm{cts}$., lb. $75 \mathrm{cts}$.

CELERIAC, LARGE SMOOTH. A variety of celery with turnip-shaped roots, which are white-fleshed, tender, and possess the flavor of celery stalks. Pkt. 15 cts., oz. 55 ets., $1 / 4$ lb. $\$ 1.50,1 b . \$ 4$.

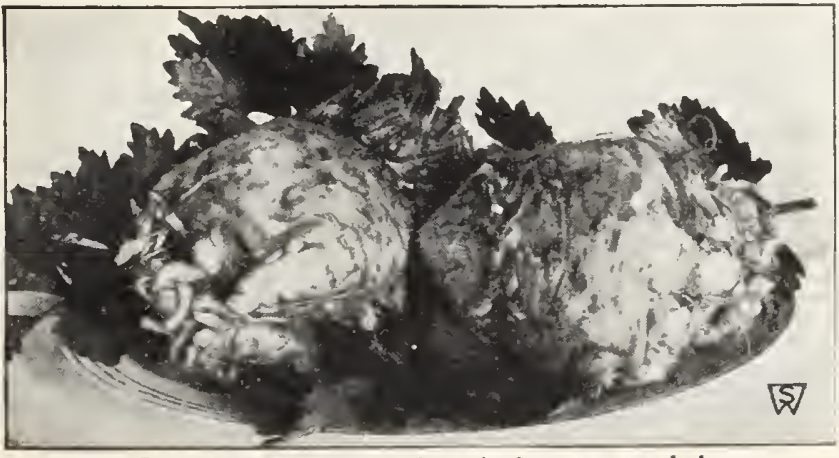

Celeriac may be served cooked or as a salad

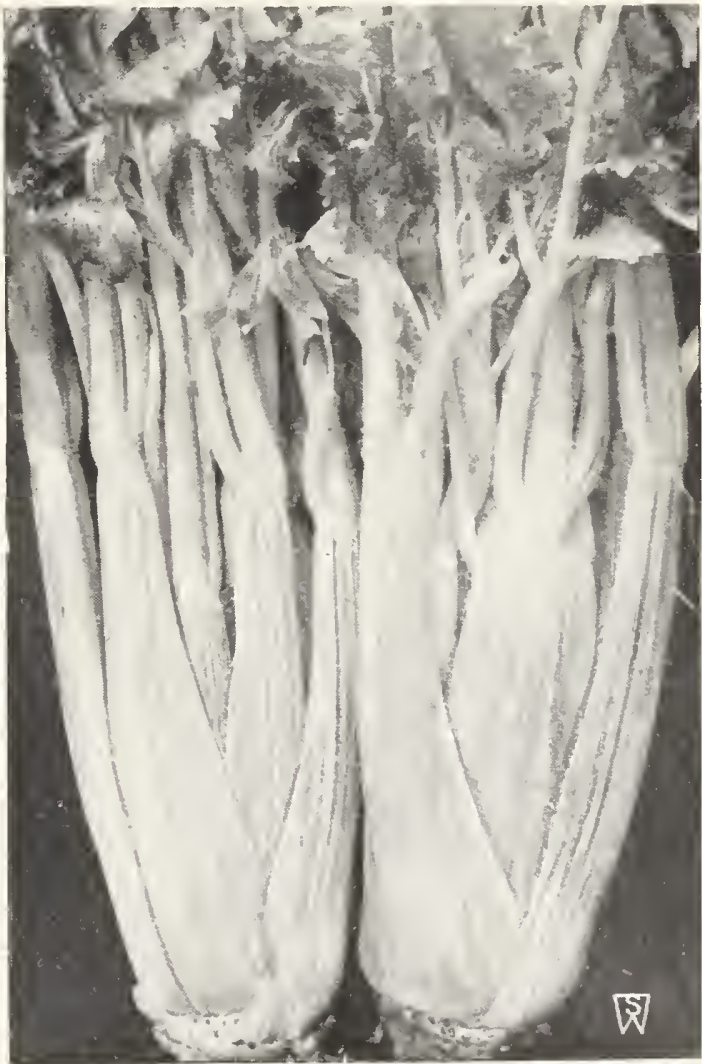

New Easy-Blanching may be whitened in a shorter time than any other Celery; will blanch up, in fact, in cold storage. It keeps better than most late varieties. 


\section{SUGAR CORN}

One pound will plant 200 feet of drill or 200 to 300 hills
NOTE.-The American Seed Trade generally has adopted the cental system of pricing Corn, Beans, and Peas. We therefore offer by weight instead of measure. One pound of Corn is equal to about $11 / 2$ pints; 2 pounds to about $11 / 2$ quarts; the average weight of a bushel of Sweet Corn is 45 pounds.

CulturE.-Plant for succession of crop every three weeks, from April to July, in hills 3 feet apart each way, and six seeds in a hill; cover about half an inch; thin out to three plants.

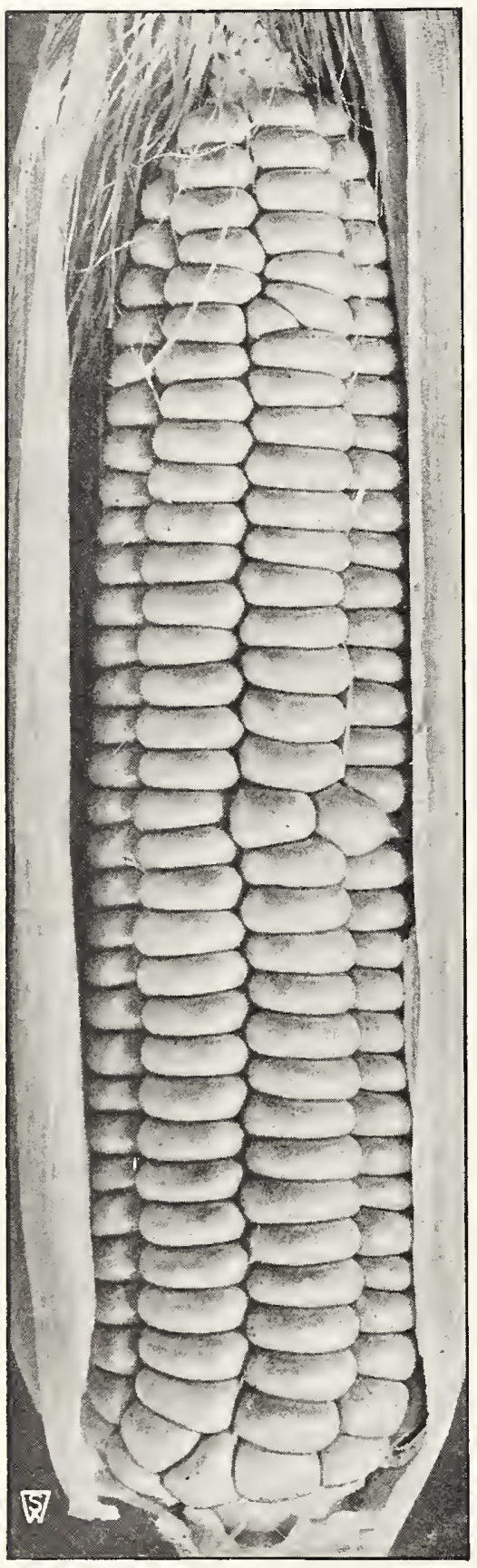

Golden Bantam. The standard for quality by which others are judged

\section{EARLY SORTS}

Early Mayflower. Is fully a week or Io days earlier than White Cory; and when we say ar that in size of ear, tenderness and sweetness of the kernels it is very noticeably superior to White Cory, we think we have said enough to indicate that the variety has distinct merits. The ears are long and well filled from tip to butt with large, tender, fineflavored, white kernels. $1 / 21 b .25$ ets., 1 b. 40 cts., 2 lbs. 75 ets., 5 lbs. $\$ 1.75,15$ lbs. $\$ 4.75$. Golden Bantam. Perhaps the sweetest Corn grown; the standard for quality by which mers are judged. Plant attains a height of only 3 to 4 feet, usually bearing two or more ears to the stalk. The ears are compactly filled with kernels which when ready for the table are cream-yellow. Golden Bantam is one of the hardiest varieties of Corn grown, therefore it can be planted with safety earlier than other varieties. This characteristic also adapts it to localities having cool summer weather, a continuous supply being maintained by successive plantings. (See illustration of a typical ear.) Pkt. 10 ets., $1 / 21$ b. 25 ets., 1 b. 45 ets., 2 lbs. 85 ets., 5 lbs. $\$ 2,15$ lbs. $\$ 5.50$.

Golden Gem. A new golden variety which we offered last year in packets only. It is the Gold earliest golden Corn on the market - at least Io to I4 days earlier than Golden Bantam. The ears are a trifle larger than Golden Bantam and produced on short stalks, but of the same fine eating quality. Plt. 25 cts., $1 / 21$ lb. 50 cts., lb. 90 cts., $21 b s . \$ 1.75$.

New Wonder Bantam. Grows 5 to 6 feet in height, bearing, high up on the stalk, ears Now wich measure 8 to 10 inches in length. The ears are filled with 8 rows of rich, golden yellow, sugar-sweet kernels. Wonder Bantam has all the good qualities of Golden Bantam but is more vigorous, more productive, and yields larger ears. 1/21b. 30 cts., 1b. 50 ets., 2 lbs. 90 cts., 5 lbs. $\$ 2.10,151$ bs. $\$ 5.75$.

Howling Mob. Is ready for use only 3 to 5 Cory when both are planted at the same time, but the ears are much larger in size, while the grains are much whiter and sweeter. As an early variety of large size, we cannot too highly praise Howling Mob. Pkt. 10 ets., $1 / 21 b .25$ cts., 1 b. 45 ets., 2 lbs. 85 ets., 5 lbs. $\$ 2,15$ lbs. $\$ 5.50$.

Metropolitan. Combines the three essentials Metropolitan. of a good Sugar Corn, namely. earliness, productiveness, and unusually superior flavor. The ro-rowed ears are 8 to 9 inches long and they are crowded with tender, melting grains. In our opinion the best early white Corn. $1 / 21$ b. 25 cts. 1b. 45 cts., 2 lbs. 85 ets., 5 lbs. $\$ 2$, 15 lbs. $\$ 5.50$. White-Cob Cory.

A standard first-

early variety.

For a quick-

growing sort

the ears are

large, and

they are well

filled with me-

d i u m-sized grains. A favorite with the market - grower for his earliest crop. $1 / 21 \mathrm{~b} .25 \mathrm{c}$. 1b. $40 \mathrm{c} ., 2$ ibs. 75 c., 5 lbs. $\$$ I. 75 I 5 lbs. $\$ 4.75$

Crosby's Early.

Ears good size;

fine quality.

I/2lb. 25c., lb.

40c., 2 lbs. $75 \mathrm{c}$.

5 lbs. \$1.75, I5 lbs. $\$ 4.75$.

Black Mexican.

Very sweet grains black. $1 / 2$ lb. 25 c., lb. $40 \mathrm{c}$. 2 lbs. 75 c., 5 1bs. $\$$ I. 75 , I5 lbs. $\$ 4.75$

S. \& W. Co.'s Midget. Dwarf variety with tiny ears. (See Novelties, page I7.) Pkt. 20 cts., oz. 35 cts., 1/4lb. 90 cts.

Semesan, Jr. Prevents and controls ear, root, and stalkCornes of Sweet Corn. Easily applied to Seed Corn at the rate of 3 ounces to the bushel of seed. $4.025 .50 \mathrm{cts.}$ lb. $\$ 1.75,5$ lbs. $\$ 8,25$ lbs. $\$ 31.25$.

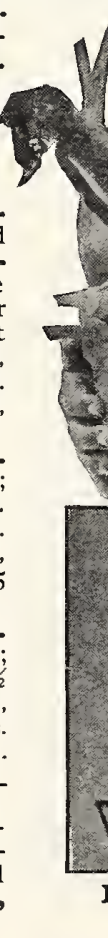




\section{SUGAR CORN, LATE SORTS}

Country Gentleman. Retains cate flavor and tenderness even when a little old, as the ears are encased in a heavy husk, which tends to keep the ear "in the milk" for several days longer than other varieties. The cob is unusually small and the pearly white kernels of great depth. Pkt. 10 cts., 1/21b. 25c., lb. 40 ets., 2 lbs. 75 ets., 5 lbs. $\$ 1.75$, 15 lbs. $\$ 4.75$.

Stowell's Evergreen. Now receverywhere as a standard variety, both for home use and market, and is the general favorite. The ears are of large size, grains deep, exceptionally tender and

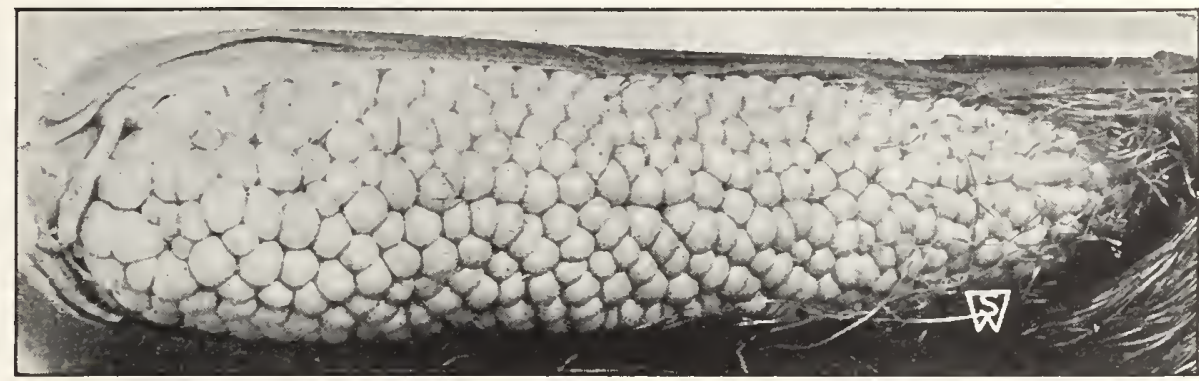

Country Gentleman is the "All meat" Corn. Its cob or core is smaller, and its grains are deeper than those of any other Corn

sugary, and have the advantage of remaining longer in the green state than any other. Our stock has been carefully grown and selected to avoid the tendency to a shorter grain and deterioration in the evergreen character of this best of all late sorts. Pkt. 10 cts., $1 / 2 \mathbf{l b} .25$ cts. lb. 40 ets., 2 lbs. 75 cts., 5 lbs. $\$ 1.75,15$ lbs. $\$ 4.75$.

Late Mammoth. Immense ears and verv sweet. I/2lb. $25 \mathrm{cts}$., lb. $40 \mathrm{cts} ., 2 \mathrm{lbs}, 75 \mathrm{cts} ., 5 \mathrm{lbs}$. $\$$ I. 75 , I $5 \mathrm{lbs}$. $\$ 4.75$.

Long Island Beauty. A favorite among New York market-growers. $1 / 2$ lb. $2.5 \mathrm{cts} ., 1 \mathrm{~b} .45 \mathrm{cts.,} 2 \mathrm{lbs}$. $85 \mathrm{cts}$., 5 lbs. $\$ 2$, I 5 lbs. $\$ 5.50$.

\section{Gather Corn Daily from June to October}

\section{WE OFFER FOUR SATISFACTORY SORTS IN A SPECIAL "COLLECTION"}

Our conception of the most reliable and sweetest varieties is represented in these Collections. They are prepared during November and December before our real spring selling season commences. We are thus able to give you the benefit of lower operating costs, and the purchase of these Collections is thus a real economy, the prices of the Collections being sensibly under the total cost were each sort purchased separately. The object of the Collection is defeated if changes are made, and we request that you do not ask us to make alterations.

The following four varieties are included in the assortment:

\section{GOLDEN BANTAM}

STOWELL'S EVERGREEN

We suggest that sowings of each of these varieties be made every two weeks from May io to July I5. This will ensure a continuous supply of delicious Sweet Corn from the latter part of June through until frost.

An explanation may be in order as to the meaning of the word "late" as applied to Sweet Corn and other vegetables. It does not mean that the variety should be sown late; it means that it takes longer to grow from seed than "early" sorts. It is often the correct thing to sow "late" varieties early, and it is good gardening to sow "early" sorts iate, the speed with which they mature enabling them to be used at a date when so-called "late" varieties would not have time to produce a crop.

\section{COLLECTIONS :}

One pkt. each of the above varieties, 35 cts. postpaid.

$1 / 2 \mathrm{lb}$. each of the above $v a$. rieties, $90 \mathrm{cts}$.

1 lb. each of the above varieties, $\$ 1.50$

2 lbs. each of the above varieties, $\$ 3$.

5 lbs. each of the above varieties, $\$ 7$.
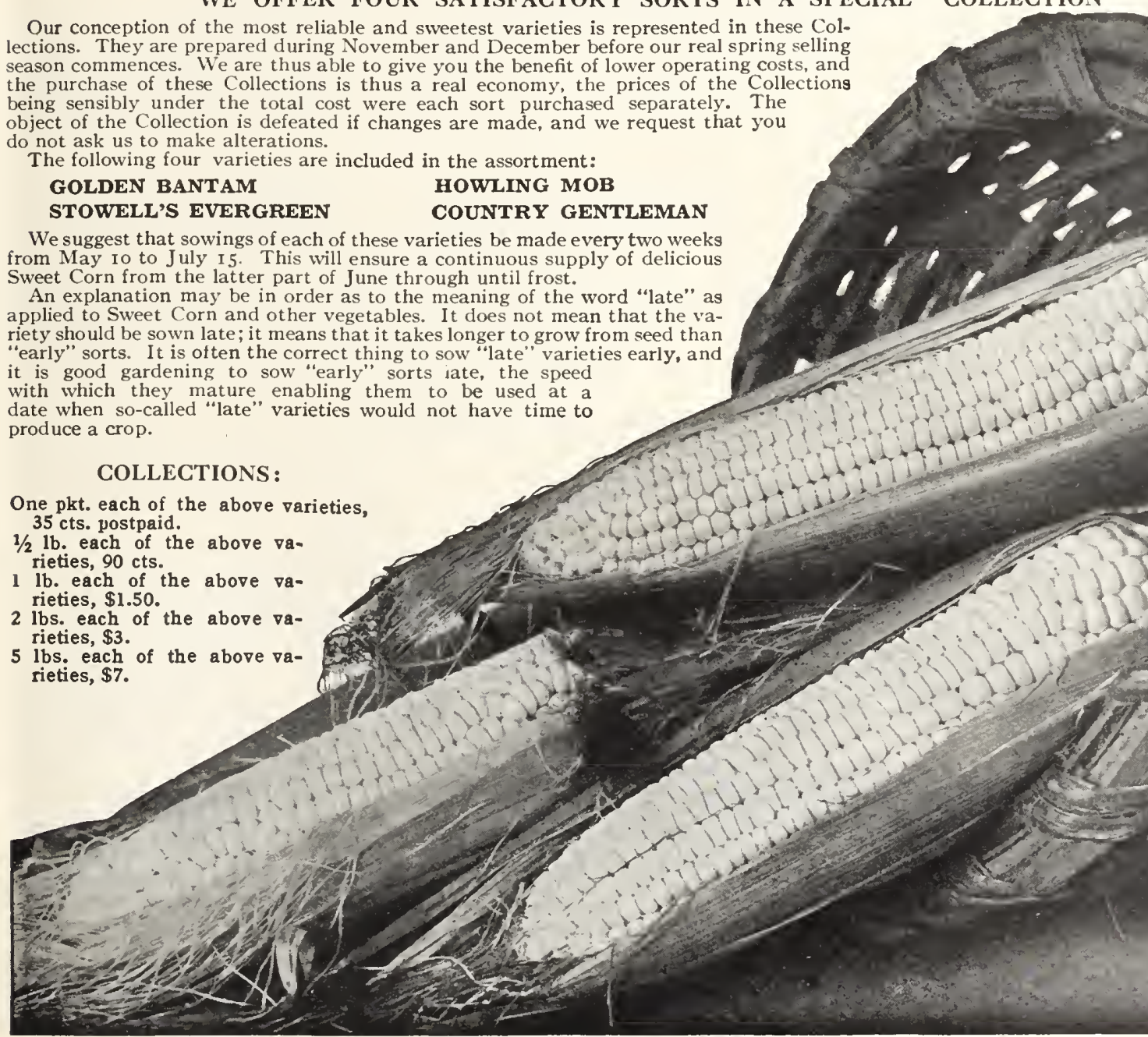


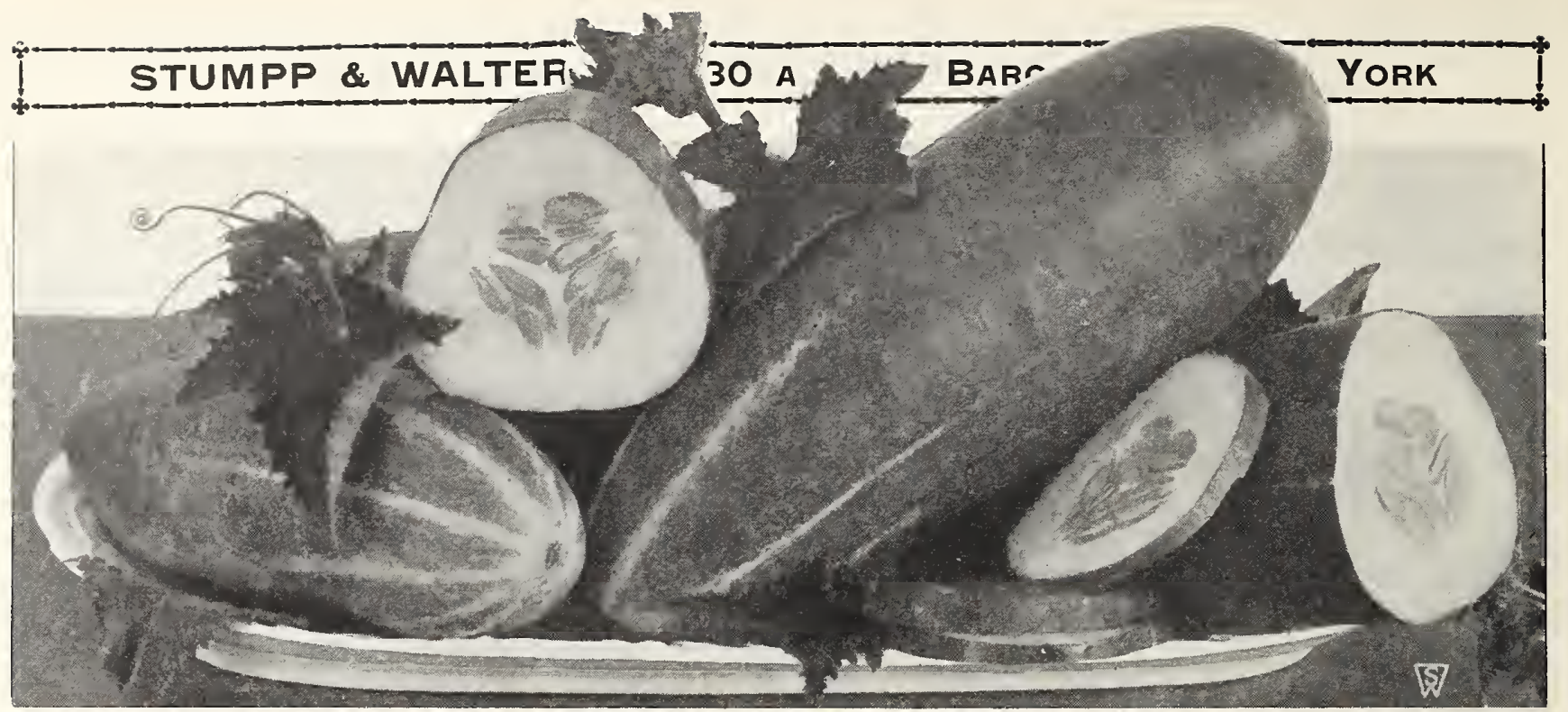

Improved Early White Spine Cucumbers

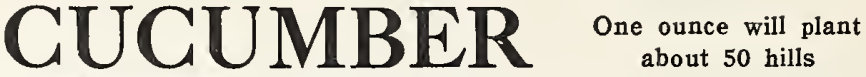

CUlturE.-The first planting should be made early in May, on partly spent hotbeds; inverted sods form an excellent medium for both planting in and carrying the young plants to their permanent location, or small paper pots can be used. Such plants are usually ready for transplanting to the open ground in from three to four weeks, and are seldom troubled with the striped bug. Transplanting, when practicable, should be done in the evening, into hills 4 feet apart each way. Thin out to about four plants to a hill when established. Seed also may be sown in hills late in May, thus giving a succession. For pickles, plant during the last two weeks of June. Bug Death, or an infusion of hellebore powder in water, will destroy the striped bug.

Nevy Davis Perfect. In color, a dark, glossy green; shape New Davis Perfect. slim and symmetrical, with an average length of Io to $I 2$ inches. Quality fine, as the seeds are very soft when fit for table use. Flesh tender and brittle, and of good flavor. Pkt. 10 ets., oz. 30 cts., $1 / 41 b .75$ cts., $1 b . \$ 2$.

Improved Early White Spine. The fruits are nearly cylinproved drical in form, slightly pointed at the ends, perfectly smooth and of deep, rich coloring marked with distinct white lines at the blossom-end. Will retain its color longer after pickling than most varieties, and is splendid as a table Cucumber. Pkt. 10 cts., oz. 25 ets., 1/41b. 65 cts., $1 b . \$ 1.75$. Cool and Crisp. An excellent pickling or slicing Cucumber, Cood size, tender and crisp; very early an exceedingly prolific. Pkt. 10 cts., oz. 30 cts., $1 / 4 \mathbf{l b}$. 75 cts., 1 b. $\$ 2$.

New Klondyke. This is a hybrid sort of the White Spine type which holds its dark green color longer than most other sorts. Averages 6 to 7 inches in size; ends are quite square and it is about 2 inches thick. Its extreme earliness, combined with its prolific and hardy qualities, makes it a very desirable variety for either market or private use. An excellent sort for slicing. When small, this variety is also an excellent pickling sort. Pkt. 10 cts., oz. 30 cts., $1 / 41 b .75$ ets., 1 b. $\$ 2$.
Extra-Long Green. A well-known standard variety about I foot in length, of most excellent quality, and when young makes the best of pickles. When ripe it is the best of any for sweet pickles. Vines vigorous and very productive. Our strain of this valuable sort is unsurpassed by any, being carefully selected from the best fruits. Pkt. Io cts., oz. 25 cts., 1/4lb. 65 cts., lb. \$I.75.

Japanese Climbing. Well adapted for pickling, as well as for slicing for salads. The great advantage of this variety lies in the fact that it can be trained on a pole or fence. The Cucumbers are a foot or more in length, with a smooth, dark green skin which turns brown and is netted when ripe. Pkt. Io cts., oz. 35 cts., 1/4/b. 90 cts., lb. $\$ 2.50$.

Fordhook Pickling. One of the best and most prolific variesize for both home and market use. Vines are very vigorous, yielding a large number of fruits, remaining in strong, healthy, growing condition longer than any other known variety. The skin is very tender and remains so when pickled. Pkt. 10 cts., oz. 30 cts., $1 / 41 b .75$ cts., $1 b . \$ 2$.

Early Green Prolific. This sort can be used for slicing, but is best for pickling on account of its uniform small size. Pkt. Io cts.. oz. 30 cts., 1/4lb. 75 cts., lb. $\$ 2$.

\section{GUCUMBERS FOR GROWING UNDER GLASS}

S. $\&$ W. Co.'s Improved Telegraph. By special arrangement, we have secured a selected strain of this variety, and have no dark green type which we have found from numerous tests to be the finest strain obtainable. Pkt. (10 seeds) 25 cts., $\mathbf{5}$ pkts. $\$ 1$.

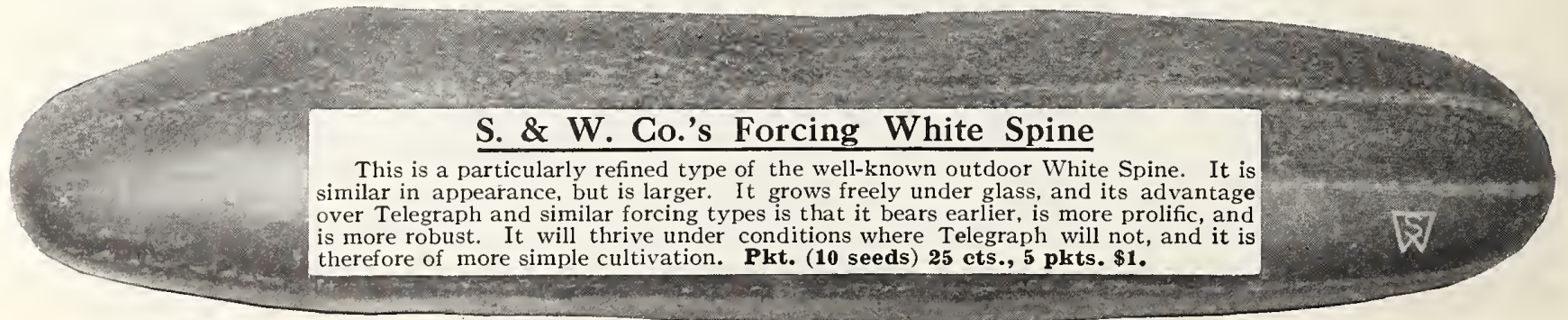



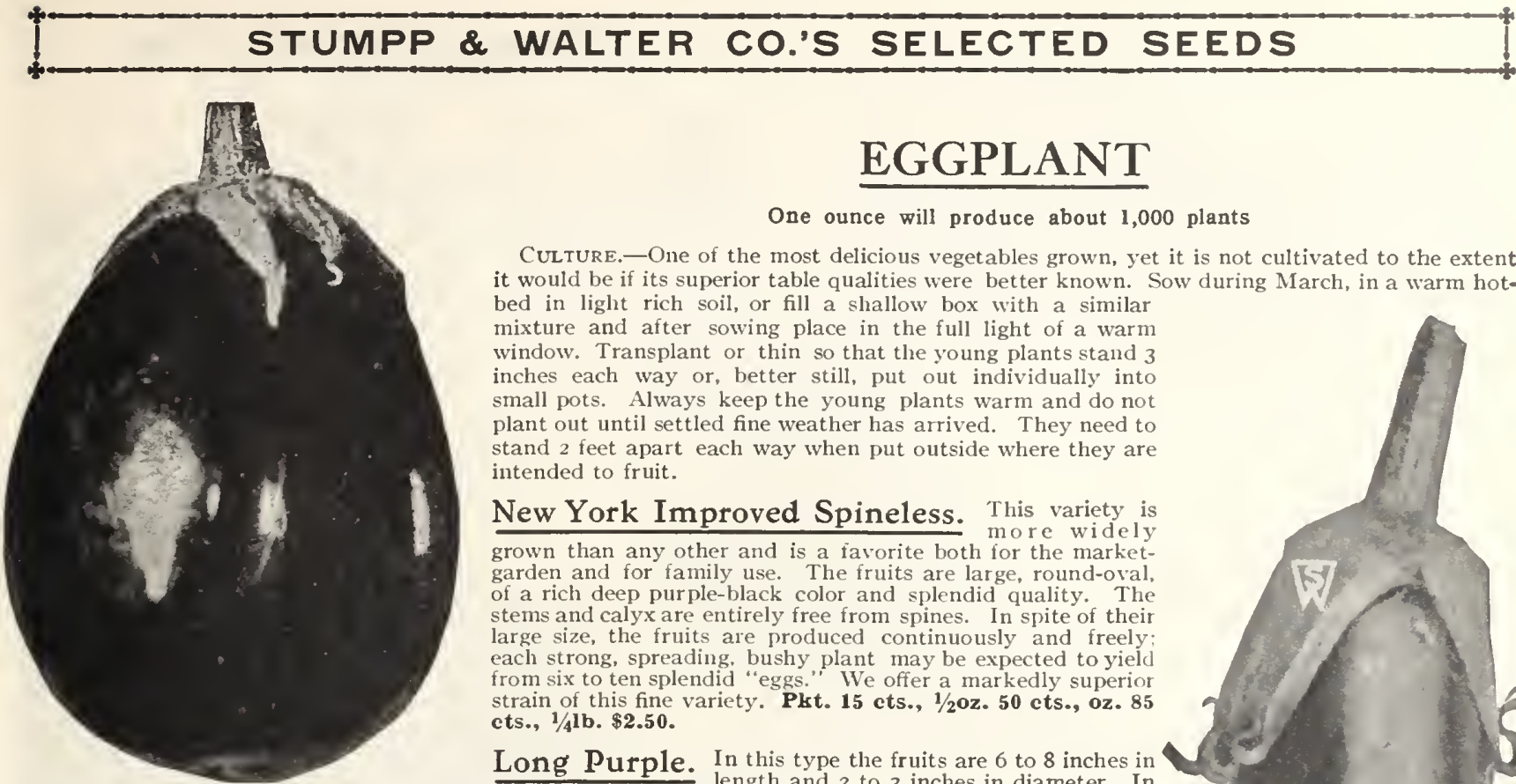

New York Improved Eggplant, much reduced. Fruits average 7 inches deep and 5 inches in diameter.

but it is darker in color and has a higher polish. It is also broader and thicker. Pkt. $20 \mathrm{cts}$.

I/2Oz. 60 cts., oz. $\$ 1,1 / 41$ b. $\$ 2.75$.

\section{GOLLARDS, GEORGIA}

One ounce will produce about 3,000 plants

A cabbage-like plant with a large, loose head. In the South it is widely used as a cooked vegetable, being prepared in a manner similar to spinach. The seed may be started under glass during March and transplanted, being treated like early cabbage. For a late crop, sowings in the open ground during July or August are usual. Plants should be at least 3 feet apart each way. Collards are used as a substitute for cabbage in those sections where cabbage cannot be raised. Pkt. 10 cts., oz. 30 cts., 1/4lb. 75 cts., lb. $\$ 2$.

\section{GORN SALAD}

One ounce will sow 150 feet of drill

CUlturE.-Seed may be sown thinly in drills i 8 inches apart in early spring, and sowings may be made

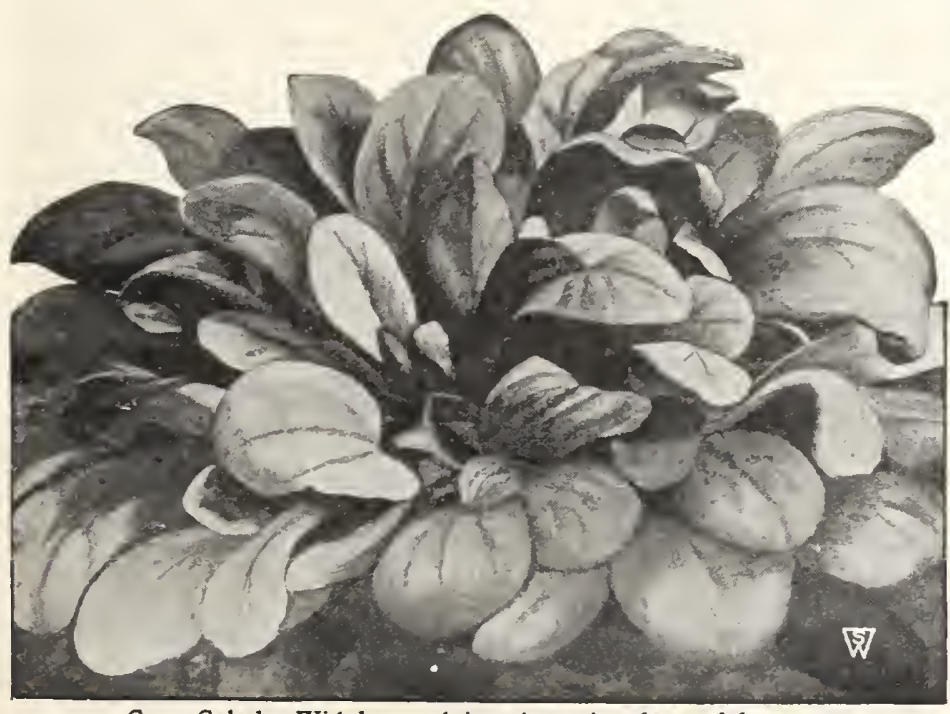

Corn Salad. Widely used in winter in place of lettuce later for succession as re- Long Pursle Eggplant. A very quired, although in hot weather it is difficult to obprolific and early sort tain satisfactory results, hence late summer and early fall seedings are preferred. The young plants from the latest sowings are covered with a light mulch and wintered exactly as spinach is often managed. Rich soil is necessary. Among artificial fertilizers to be recommended is S. \& W. Co.'s General Garden Fertilizer. This may be dug into the ground before seeding and later hoed frequently between the rows during growth, thus mixing it thoroughly with the soil.

Large-leaved. Tested seed of high vitality. Pkt. Io cts., oz. 30 cts., $/ 41 \mathrm{lb} .75 \mathrm{cts}$., lb. $\$ 2$.

\section{DANDELION}

One ounce will sow about 100 feet of drill

CulturE-Cow early in the year in drills $r$ foot apart. covering the seed no more than $1 / 4$ inch. Thin the plants to stand 4 inches apart. Dandelion may be blanched like endive, for salad purposes, or it may be sown later in the season, plants covered lightly with salt hay, and the following spring they will be fit for use as early greens.

Large Thick-leaved. Pkt. $25 \mathrm{cts} ., 1 / 20 Z .85 \mathrm{cts}, 0 z . \$ 1.50$, $3 / 4 \mathrm{lb} . \$ 4$.

French Garden. Pkt. ro cts., 1/20z. 35 cts., oz. $60 \mathrm{cts}, 1 / 4 / \mathrm{lb}$. $\$ 1.75$. 


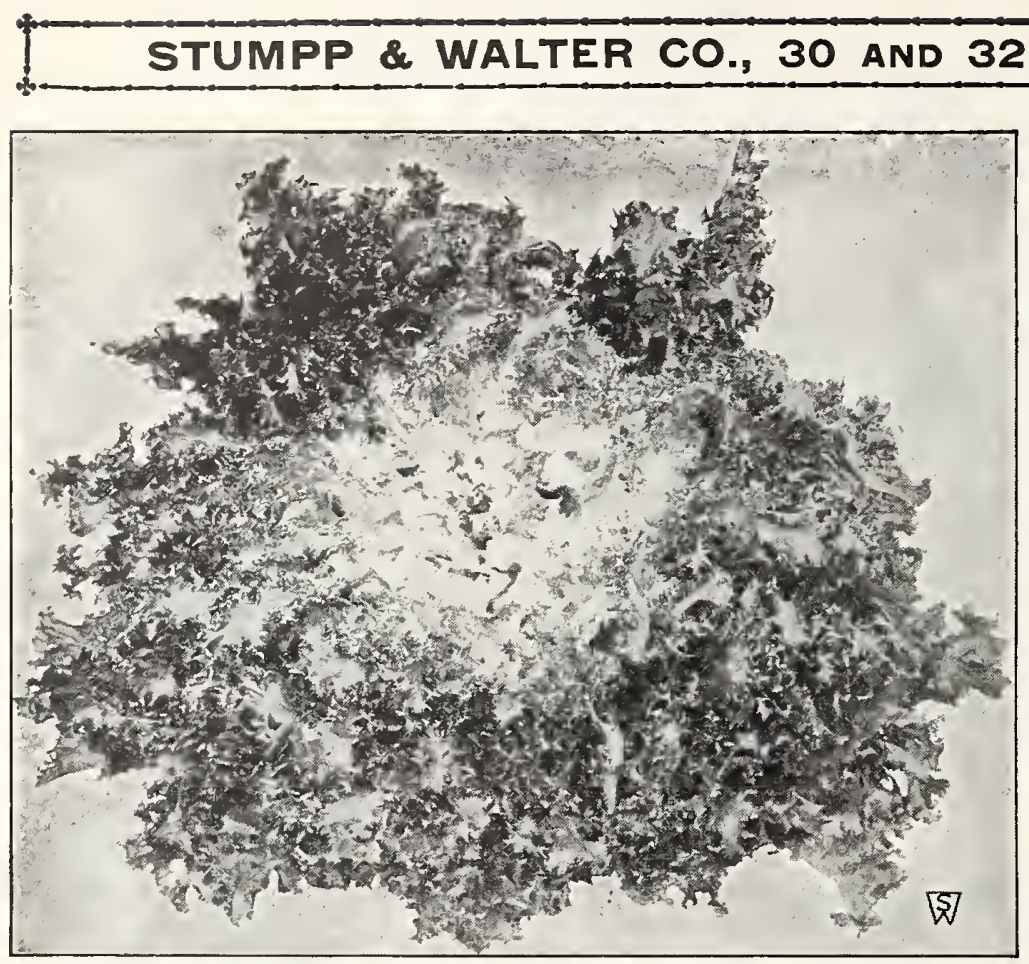

Green Curled Rose-Ribbed Endive. The most attractive of all autumn and winter salads

\section{ENDIVE, continued}

Green Curled. The hardiest and most vigorous variety. The leaves are bright green, finely cut and crinkled, giving the plant a handsome appearance. Blanches easily a creamy white. Pkt. Io cts., oz. $30 \mathrm{cts.,} 1 / 4 \mathrm{lb}$. $75 \mathrm{cts}$., lb. $\$ 2$.

White Curled. A variety which blanches readily and is very tender when young. It is similar to Green Curled, but the leaves are naturally of a light golden tint, and it is not essential that they be tied up to blanch them for table use. The flavor is very good. Pkt. I $5 \mathrm{cts}$., oz. $35 \mathrm{cts}$., $1 / 4 \mathrm{lb}$. $\$ \mathrm{I}, \mathrm{lb} . \$ 3$.

Broad-leaved Batavian (Escarolle). The leaves are broad and thick, Broad-leaved Batavian more or less twisted and waved, with round ends and are of a bright deep green with a nearly white midrib. They are much larger in size, thicker and more fleshy than those of the preceding sorts. The inner leaves form a fair head which blanches a creamy white. In its natural state Escarolle forms an excellent salad with an appetizing piquancy. It may be gathered fresh from the ground well into winter, thus furnishing salad at a season of the year when it is most welcome. Escarolle is also frequently served as spinach, when its flavor and health-giving properties render it of high value. Pkt. 10 cts., oz. 30 cts., $1 / 41 b .75$ ets., lb. $\$ 2$.

\section{KATI One ounce will produce}

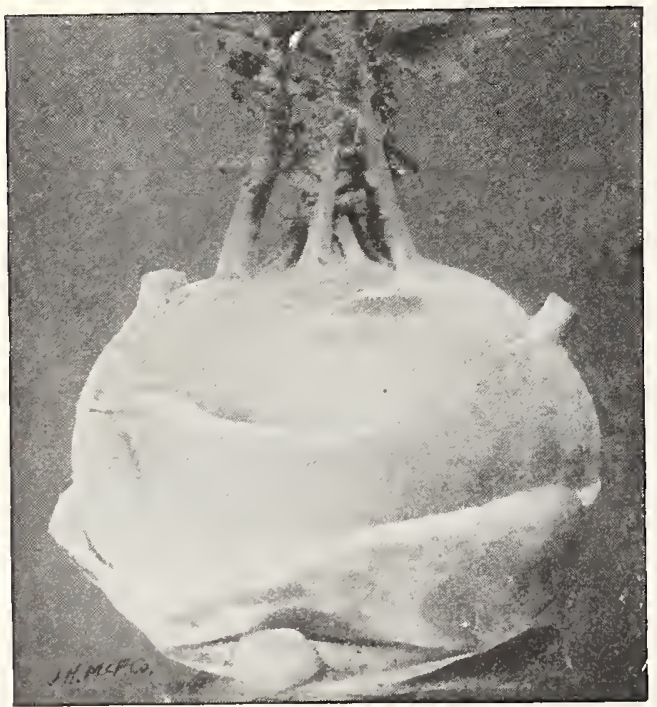

Earliest Selected Kohlrabi. Useful alike for forcing and for genersl culture

\section{ENDIVE}

One ounce will sow 200 feet of drill

Culture.-One of the most attractive of all autumn and winter salads. It is commonly known in restaurants as Chicorée, and is especially refreshing when served as lettuce with plain French dressing. Sow seed from middle of June till last of August. When the plants are fully grown, tie all the outside leaves together over the heart, to blanch the inner leaves, which will take about a week. Do not tie up when the leaves are wet, as they will then decay.

Green Curled Rose-Ribbed (Self-blanchto mature and more upright in growth than the ordinary type. Grown 6 inches apart, in good, rich soil, the plants quickly crowd one another to such an extent that the dense centers of the plants blanch themselves. The flavor is refined to a degree. Pkt. 15 cts., oz. 55 cts., $1 / 4$ lb. $\$ 1.50,1 b . \$ 4$.

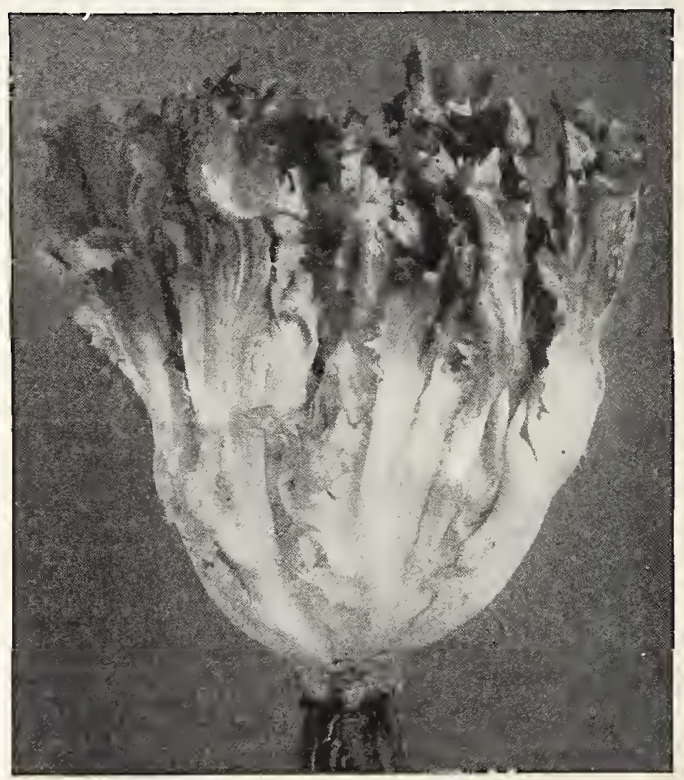

Escarolle (Broad-leaved Endive). Used widely as a salad and also like spinach

Culture.-Sow in May in shallow drills; when large enough, transplant singly into rows, allowing 24 inches between the plants.

Dwarf Green Curled Scotch. This withstands frost better than cabbage. Dwari Green Curled Scotch. In fact, it is not at its best until cold weather has set in. The leaves are curled like fine parsley. As boiled "greens," Scotch Kale is tender and of remarkably fine flavor. Pkt. 10c., oz. 30c., 1/41b. 75c., 1b. \$2. Siberian Kale or Sprouts. Is not so densely curled as the Scotch, but is also hardy and yields a heavy bulk of produce. Widely known as "German greens." Seeds should be sown in September and treated like spinach; it is fit to cut early in spring. Pkt. Io cts., Oz. $30 \mathrm{cts}$., I $/ 4 \mathrm{lb}$. $75 \mathrm{cts}$., $1 \mathrm{~b}$. $\$ 2$.

Dwarf Brown Kale. A beautiful curled variety, with spreading foliage; very hardy and of fine flavor. Pkt. Io cts., oz. $30 \mathrm{cts.,} \mathrm{I/41b.} 75 \mathrm{cts}$., 1b. $\$ 2$.

\section{KOHLRABI One ounce will sow about 200 feet of drill}

Curture.-This is a very delicious vegetable, and is increasing in popularity rapidly; combines the good qualities of the turnip and cabbage, but excels both in mutritive and productive qualities. Cooked the same as turnips, they are very tender and palatable. Sow in spring in rows 18 inches apart, and thin away the plants to 6 inches. Earliest Selected. A variety with few and small leaves; can be planted very

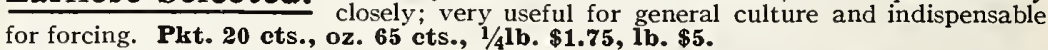

Early White Vienna. The earliest and best for either market or family use. Pkt. Ioc., oz. 35 cts., 1/4lb. $\$ \mathrm{r}, 1 \mathrm{~b} . \$ 3$.

Early Purple Vienna. Similar to the preceding, except in color, which is of a bluish purple. Pkt. Is cts., oz. 35 cts., $1 / 41 \mathrm{lb}$. \$I, 1b. \$3. 


\section{LEEK}

One ounce will sow about 100 feet of drill

CulturE.-Sow the seed very early in a seedbed in a sheltered place, if possible. When plants are about 6 inches long transplant them to trenches 6 inches deep, with very rich soil at the bottom. Fill up the trenches as the plants grow, and later draw soil up to them. As a result you will have fine, large Leeks blanched half a foot long, which may be kept all winter if dug up with the roots on and stored in moist sand in the cellar.

S. $\&$ W. Co.'s Exhibition. This is by far one of the best, long, blanched varieties we vegetable classes for some rears hast has ever offered. Seed furnished prominent exhibitors in Pkt. 25 ets., 5 phts. \$1.

Large American Flag. A large-growing type, desirable in every way. On account of its Last widely used variety for both family and market use. Pkt. 15 cts., oz. 35 cts., $1 / 41$ lb. $\$ 1,1 b . \$ 3$.

Musselburgh. (Winter.) A very hardy variety of extra-large size. The leaves are fan-shaped, of a dark green color. The edible stem is 6 to 8 inches long and 3 inches in diameter. Pkt. Io cts., oz. 35 cts., $1 / 4 \mathrm{lb}$. $90 \mathrm{cts}$., lb. $\$ 2.50$.

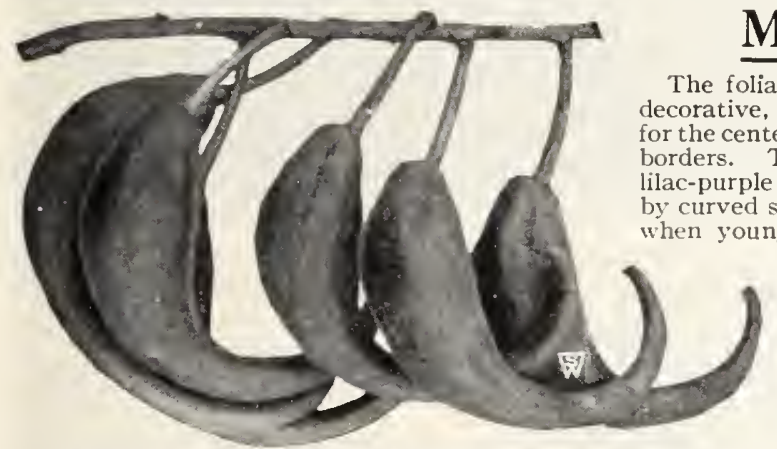

Martynia. These immature pods are used for pickles

\section{MUSTARD}

One ounce will sow 75 feet of drill

Curture.-Sow frequently through the spring, in drills from 8 to 12 inches apart.

Fordhook Fancy. A variety possessing densely

ing, in consequence, a handsome feathered appearance. Cooked and served as spinach, the flavor is inviting, while

the plant possesses healthful tonic properties. Pkt. 10 cts.

oz. 30 cts., $1 / 41 b .75$ cts., 1 b. $\$ 2$.

Giant Southern Curled. The plant grows 3

feet tall, and the broad, succulent leaves are cut and frilled. Pkt. Io cts., oz. $20 \mathrm{cts}$., 1/4lb. 55 cts., 1b. \$I.5o.

THE USE OF MUSTARD. The large leaves of the above two varieties are boiled, forming a most palatable, piquant, and healthful type of "greens." White London is sown quite thickly in fine soil and not covered but pressed lightly down. In little more than a week the overcrowded seedlings are about 2 inches long; cut them with scissors close to the soil, wash and use for sand. wich material. Curled Cress (see page 25 ), may be grown and used in the same manner. Both are suitable for growing in the house throughout the year in boxes of soil, sand, or even on moistened cloth.

WHITE LONDON MUSTARD. Pkt. IOc., oz. $20 \mathrm{c}$., 1/4lb. 55c., lb. \$I.50.

MARTYNIA aneet, in the Sow the seed when frost is over. and thin the plants or transplant them to stand 3 feet or more apart; or, if preferred, sowings

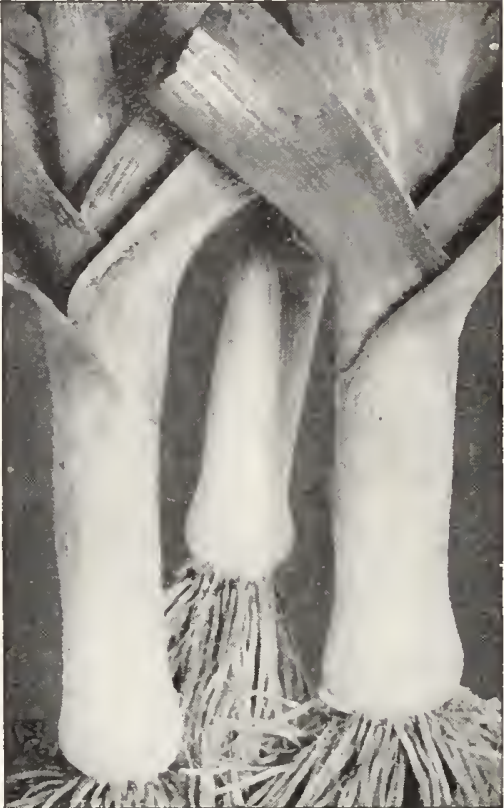

American Flag Leek. The standard variety for general use

in the open ground. Pkt. 15 cts., oz. 55 cts., $1 / 41 b . \$ 1.50,1 b . \$ 4$.

\section{Four Aids to Successful Gardening which SHOUld be included \\ WITH EVERY ORDER}

\section{SAWCO GARDEN FERTILIZER}

Use at the rate of Io pounds for a space $I_{5}$ by $I_{5}$ feet, or 500 pounds per acre. May also be dusted between the rows during growth.

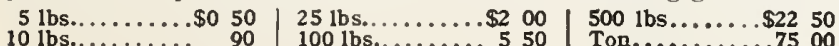

\section{SEMESAN}

Place a little Semesan with seeds in a jar and shake vigorously; bacteria and fungus spores adhering to the seeds will be killed. 2 ozs.........\$0 50 | Lb..........\$2 75 | 5 lbs...........\$13

\section{MAG-O-TITE}

Protects your crops against the ravages of the root-maggot, earthworm, and other pests. Mag-o-Tite is a powder which is mixed with the soil at seeding- and planting-time, and later sprinkled alongside your plants when growing.

2-1b. pkg......\$0 40 | 4-1b. pkg......\$0 70 | 8-1b. pkg...

.$\$ 125$

\section{STIMUGERM}

Supplies the nitrogen-fixing bacteria necessary for the successful growth of Beans, Peas, and Sweet Peas. Garden size, special composite culture, $25 \mathrm{cts}$., postpaid $35 \mathrm{cts}$. 


\section{LETTUCE}

Because the number of good sorts of Lettuce is so great as to prove bewildering to the majority of gardeners, we have selected for them the following, which, in our many years of experience, have never disappointed where the cultural directions were followed.

Culture. - About the middle of March sow either Big Boston, May King or Wayahead in the hotbed. When seedlings are about 2 inches tall, plant them 4 inches apart each way in a coldframe. By May $I$, after properly hardening them, set out in the garden, I foot apart in the row with a 2 -foot path between the rows. These plants should give you firmly folded, well-developed heads by Decoration Day. As soon as the ground can be worked outdoors, plant seeds of any of the early sorts in rows, $1 / 4$ inch deep. As soon as seedlings are 3 to 4 inches tall, thin them to stand 4 inches apart in the row. Later on remove every other one and do this again until the plants finally stand 16 inches apart in the row. Then hoe between the plants as well, in order to secure good heads. Af ter the middle of May, do not sow seeds of early kinds, but select sorts like All Seasons and Iceberg instead. Make repeated sowings of short rows to have a crisp product available constantly. In August sow Thanksgiving Day Lettuce.

\section{EARLY LOOSE-LEAVED LETTUCES}

Early Curled Simpson. A splendid curly-leaved sort. about the middle of March and transplanted about the middle of April will supply the table from May until the middle of June. Pkt. 10 ets., oz. 30 ets., 1/41b. 80 cts., lb. $\$ 2.25$.

Black-seeded Simpson (Loose Head). A popular curly-leaved

sort, similar to Curled Simpson, except that it is larger in size.

Pkt. Io cts., oz. 30 cts., $1 / 4$ lb. 75 cts., lb. $\$ 2$.

Grand Rapids. There is no better forcing variety among Rapids, and it is quite as good for outdoor culture as many others.

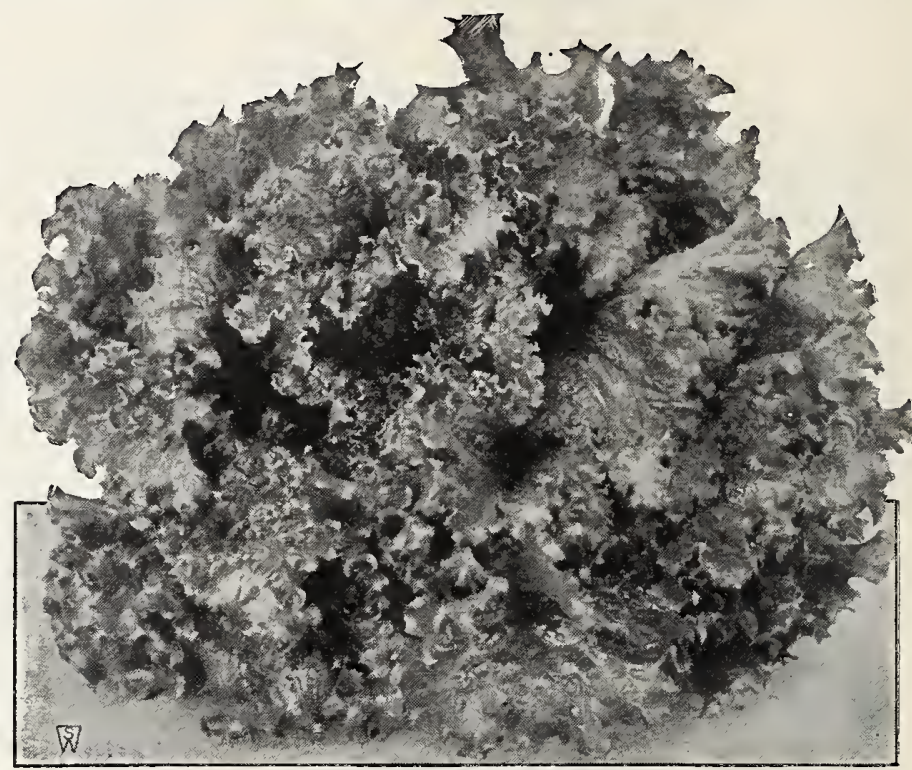

Grand Rapids Lettuce 75 cts., 1b. $\$ 2$.

\section{TEN FINE HEADING LETTUCES}

A suggestion in one of our prominent garden periodicals has given Ten Fine Lettuces for the amateur gardener to grow, whose garden space is small, and where crisp Lettuce is desired from April to December.

Golden Oueen. A small variety of compact habit, forming yellowish green heads. Seed may be sown about the middle of April outWayahead. Large and fine. Very similar to May King described below. If seed is sown about the same time as Golden Queen, it will

May King. Unquestionably one of the best all-round, early, outdoor Lettuces. Does remarkably well in cold or wet weather, forming solid Leads of bright green, the edges of the center leaves tinged reddish brown; the heart is clear yellow and of ideal flavor. If sown
the same time as Wayahead, May King will be ready about four to five days later.

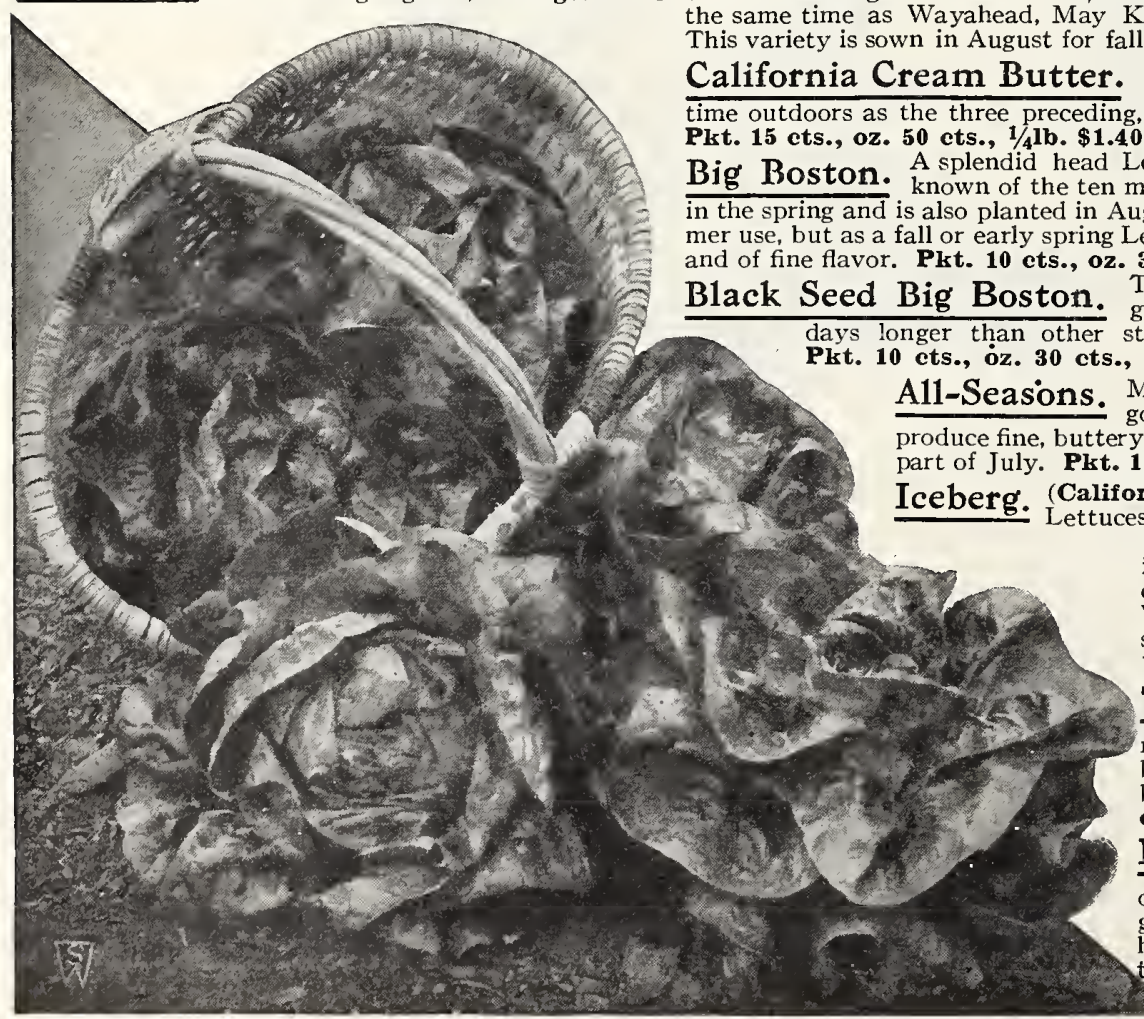

May King Lettuce Pkt. 15 ets., oz. 50 cts., $1 / 4$ lb. $\$ 1.40,1 b . \$ 4$. use. Pkt. 10c., oz. 35c., $1 / 41$ b. \$1, lb. \$3.

The largest and latest of the early varieties of time outdoors as the three preceding, will mature about ten days to two weeks later.

Big Boston. A splendid head Lettuce, perhaps the most generally and favorably n the spring and is also planted in August for late crop. Does not do well for midsummer use, but as a fall or early spring Lettuce is one of the best. Large heads; center crisp nd of fine flavor. Pkt. 10 cts., oz. 30 cts., $1 / 4 \mathbf{l b} .75$ cts., 1 b. $\$ 2$.

Black Seed Big Boston. The plants are of a uniformly darker shade of ens strains of Big Boston, before running to seed. A11-Seasons May be described as a black-seeded Deacon. A good heat-resister. If sown early in May will part of July. Pkt. 10 cts., oz. 35 cts., 1/41b. \$1, 1b. \$3.

ceberg. (California Simpson.) A splendid, crisp-head sort: Few resist the heat better. Has strong center ribs, it thoroughly blanched. Repeated sowing from early May, of this sort and New York or Wonderful, at intervals of three weeks, should supply the table well up to September I. Pkt. 10 ets., oz, 30 ets., 1/41b. 75 ets., $16 . \$ 2$.

Thanksgiving Day. The best Lettuce for sowing in summer to produce a late crop. Outer leaves are brown and fringed, but the firm, solid head is bright gold-green and of fine flavor. Pkt. 15 cts., oz. 50 cts., $1 / 41$ b. $\$ 1.40,1 b . \$ 4$.

New York or Wonderful. An enorquality. mous sort of wonderful quality. The outer leaves are dark green, with a large. crisp, very solid white heart. Frequently shipped as Iceberg, but the true Iceberg (see above) is lighter in color, slightly smaller and yellowish green. Pkt.
15 ets., oz. 50 ets., $1 / 4$ lb. $\$ 1.40,1 b . \$ 4$. 

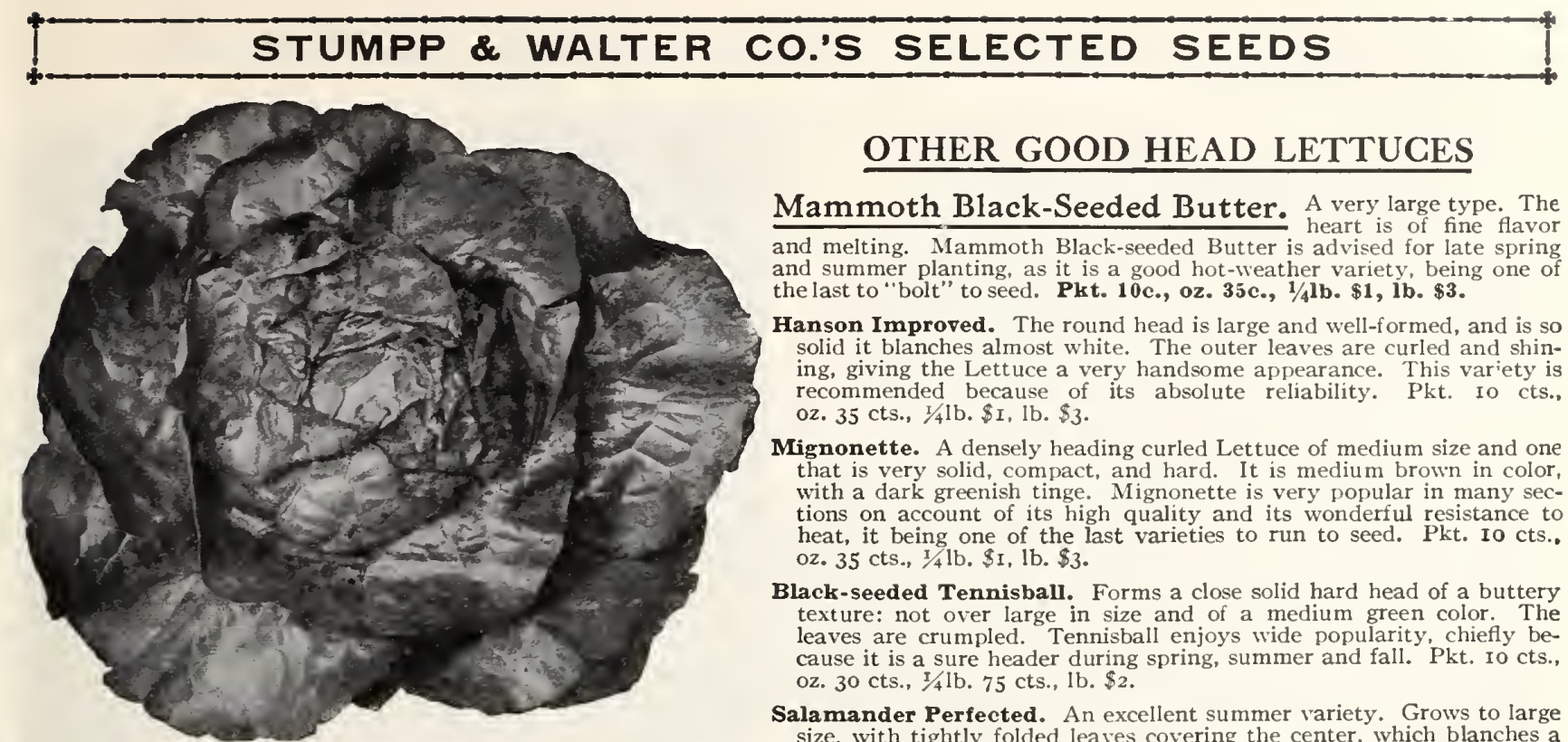

\section{OTHER GOOD HEAD LETTUGES}

Mammoth Black-Seeded Butter. A very large type. The and melting. Mammoth Black-seeded Butter is advised for late spring and summer planting, as it is a good hot-weather variety, being one of the last to "bolt" to seed. Pkt. 10c., oz. 35c., 1/4lb. $\$ 1,1 b . \$ 3$.

Hanson Improved. The round head is large and well-formed, and is so solid it blanches almost white. The outer leaves are curled and shining, giving the Lettuce a very handsome appearance. This variety is recommended because of its absolute reliability. Pkt. Io cts., oz. 35 cts., 1/4 Ib. $\$ I, 1 b . \$ 3$.

Mignonette. A densely heading curled Lettuce of medium size and one that is very solid, compact, and hard. It is medium brown in color, with a dark greenish tinge. Mignonette is very popular in many sections on account of its high quality and its wonderful resistance to heat, it being one of the last varieties to run to seed. Pkt. Io cts.. 02. $35 \mathrm{cts}$., $1 / 4 \mathrm{lb} . \$ 1,1 \mathrm{~b} . \$ 3$.

Black-seeded Tennisball. Forms a close solid hard head of a buttery texture: not over large in size and of a medium green color. The leaves are crumpled. Tennisball enjoys wide popularity, chiefly because it is a sure header during spring, summer and fall. Pkt. Io cts., oz. 30 cts., $1 / 4 \mathrm{lb}$. $75 \mathrm{cts} ., 1 \mathrm{~b} . \$ 2$.

Salamander Perfected. An excellent summer variety. Grows to large size, with tightly folded leaves covering the center, which blanches a light golden. Pkt. Io cts., oz. 35 cts., I/4 lb. $\$ 1,1 \mathrm{~b} . \$ 3$.

Big Boston. Everybody's Favorite for outdoor use and forcing

Unrivaled Summer. Forms uniformly large heads similar to Big Boston but lighter in color. Ready about a week earlier than Big Boston when sown at same time. May be sown throughout the season. Pkt. Iocts. oz. 35 cts., I $/ 4$ lb. $\$ I, 1 b . \$ 3$.

\section{A MINIATURE LETTUCE \\ S. \& W. Co.'s Tom Thumb.}

This miniature sort is just what the gardener wants for greenhouse or frame culture. The small, firm, cabbage-shaped heads are of excellent buttery quality, while the leaves are dark green and very crumpled. The owner of the small garden likes the tiny plants, which occupy but little space. Outdoors it is suitable for spring and fall use. The plant is practically all head. Pkt. 15 cts., oz. 45 cts., $1 / 4$ lb. $\$ 1.25,1 b . \$ 3.50$.

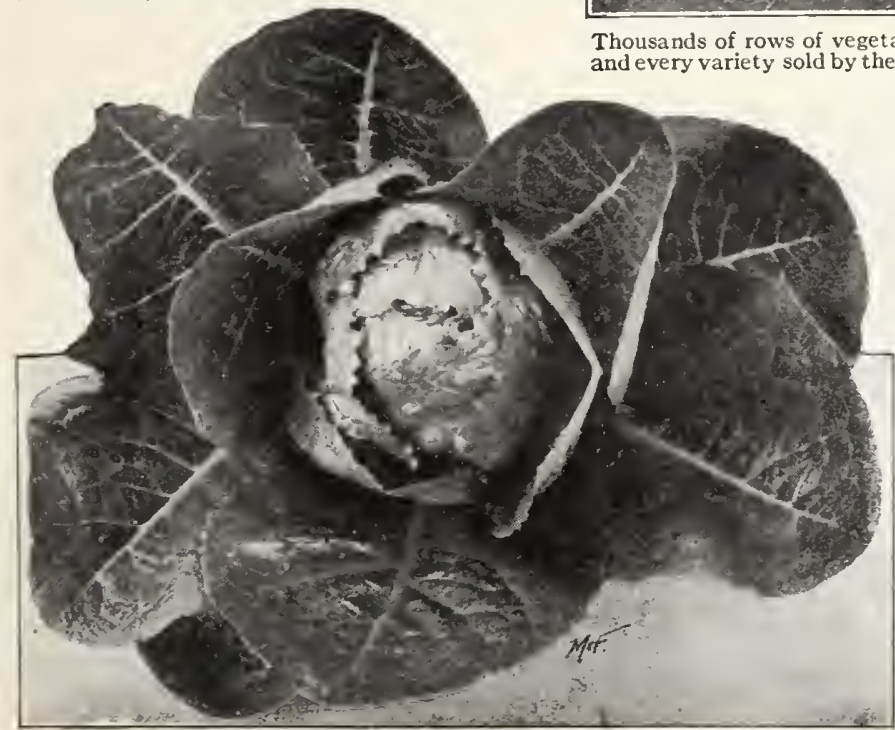

Paris White Cos Lettuce, or Romaine. Crisp, tender, and sweet

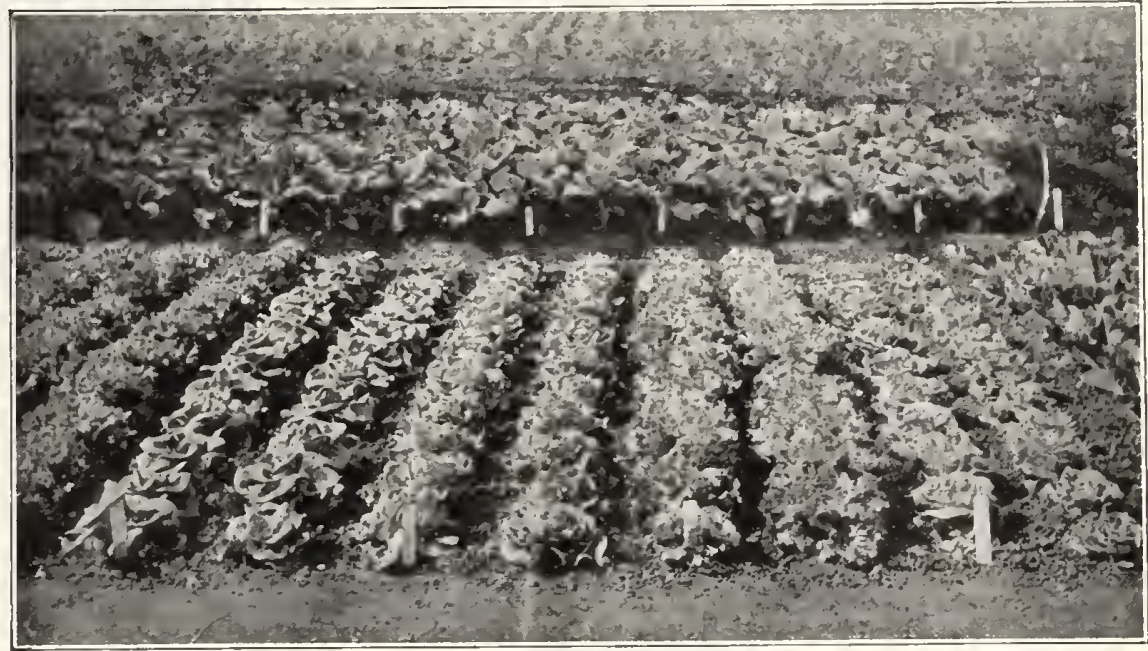

Thousands of rows of vegetables and flowers are grown to maturity on the S. \& W. Co.'s Trial-Grounds, and every variety sold by the Company is represented. Our view shows a portion of the Lettuce Trials.

\section{COS or ROMAINE LETTUCE}

Upright, distinct, and considered by many to be the most refined type of Lettuce. When about a week short of maturity, it is usual to draw the outer leaves together and tie them, blanching the inner heart and greatly enhancing its noted crispness and fine flavor. Experts have been developing plants which naturally tend toward a close, compact habit, and the necessity for tying is not so great with the following varieties.

S. \& W. Co.'s Dark Green Cos. A new mammoth resistant to cold. and slow to bolt during hot weather. The full, white, crisp heart is of the finest quality. Pkt. 15 cts., oz. 50 cts., $1 / 4 \mathrm{lb} . \$ 1.40,1 \mathrm{~b} . \$ 4$.

S. E W. Co.'s Giant White Cos. Although this fine tains a large size, the immense heart is crisp, tender and excellent; quite self-tolding. Pkt. 25 cts., 1/20z. 60 cts., oz. $\$ 1$.

Paris White Cos or Romaine. A splendid sort for quite erect. Pkt. 10 cts., oz. 35 cts., 1/4lb. $\$ 1,1$ b. $\$ 3$. Trianon Self-closing Cos. A large, strictly self-folding ty.pe with long, narrow oval leaves. The head is tender and crisp. Trianon is earlier than the above varieties, nuaking it commercially valuable. Pkt. $15 \mathrm{cts} ., 0 z .50 \mathrm{cts} ., 3 \mathrm{lb}$. \$I.40, lb. \$4. 


\section{MUSKMELON}

One ounce will sow about 80 hills

Culture.- Sow the seed in April underhand glasses or Hot kaps, and in the open air in May in hills 6 feet apart each way. Plant in each hill from 8 to Io seeds, covering half an inch deep. When the plants have produced their rough leaves, thin out to three plants. The hills should be prepared by trenching in rotten manure and sand. As soon as the plants make their appearance above ground, dust them with soot or Bug Death, to prevent the ravages of the bug.

\section{GREEN-FLESHED KINDS}

Rocky Ford. The fruits weigh from $I^{1 / 4}$ to $I^{1 / 2}$ pounds each. Rocky Ford. They are quite thick meated, with very thin rinds; skin light green, regularly ribbed and heavily netted, turning to a golden yellow as the melon ripens. Flesh light green in color, firm but melting, and of uniformly fine flavor. Pkt. 10 cts., oz. 30 cts., $1 / 41$ b. 75 cts., $1 b . \$ 2$.

"10/25" Salmon Tint. The Rocky Ford Muskmelon has of Professor Blinn of the Colorado Experiment Station, and "Io/25" is the best yet. The fruit is heavily and evenly netted, very uniform in size, rust-resisting, and early; the flesh is a rich gold in the center, shading out to emerald-green near the rind. The flavor is highly aromatic and pleasing to a degree. Pkt. 15 cts., oz. 35 cts., 1/4lb. $\$ 1,1 b . \$ 3$.

Honeydew. This variety, with its clear light yellow skin, is becom. ing quite familiar in the best markets. No other melon is quite so sweet as this, and it is not surprising that it should become so popular. The flesh is green, very thick, and, unlike some melons, it ripens uniformly to the rind. Pkt. I 5 c., oz. 35c., 1/4lb. $\$$ I, lb. $\$ 3$

Extra-Early Hackensack. Large, round and of fine quality. A standard variety. Pkt. Io cts., Oz. $25 \mathrm{cts}$., $1 / 4 \mathrm{lb}$. $65 \mathrm{cts}$., lb. \$I.75.

\section{GOLDEN or ORANGE-FLESHED SORTS}

\section{Bender's Surprise. An almost round melon of medium size,} with very thick, sweet, pink flesh of uscious, melting quality. The dark green, heavily netted skin ripens to an attractive gold. A sure cropper and a splendid all-round variety. Pkt. 15 ets., oz. 35 ets., $1 / 4$ ib. $\$ 1,1 b . \$ 3$.

Admiral Togo. This is an orange-fleshed Rocky Ford. The frit is small, with very thick flesh of splendid quality It possesses the fine netting, shape, size, and shipping quality of Rocky Ford. Pkt. 10 ets., oz. 35 ets., 1/41b. \$1, lb. \$3.

Banana. Narrow, curved, and as much as 30 inches in length, this old-time variety is well named. The flesh is a deep salmon, sweet, and of good quality. Pkt. Io cts., oz. 30 cts., I/4lb. $75 \mathrm{cts}$., lb. $\$ 2$.

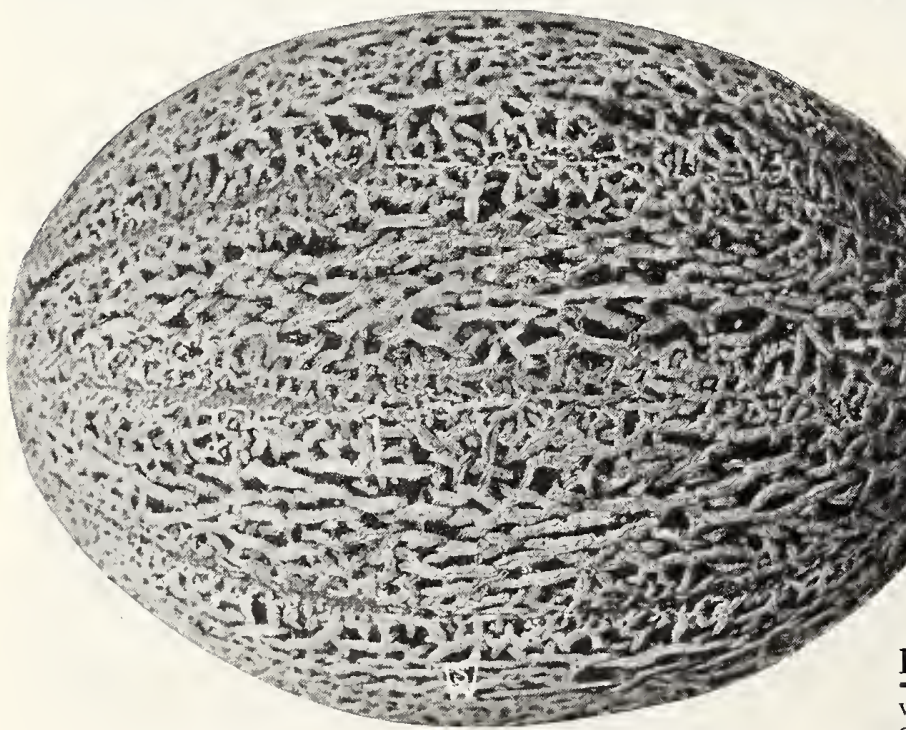

Admiral Togo. An ideal orange-fleshed melon

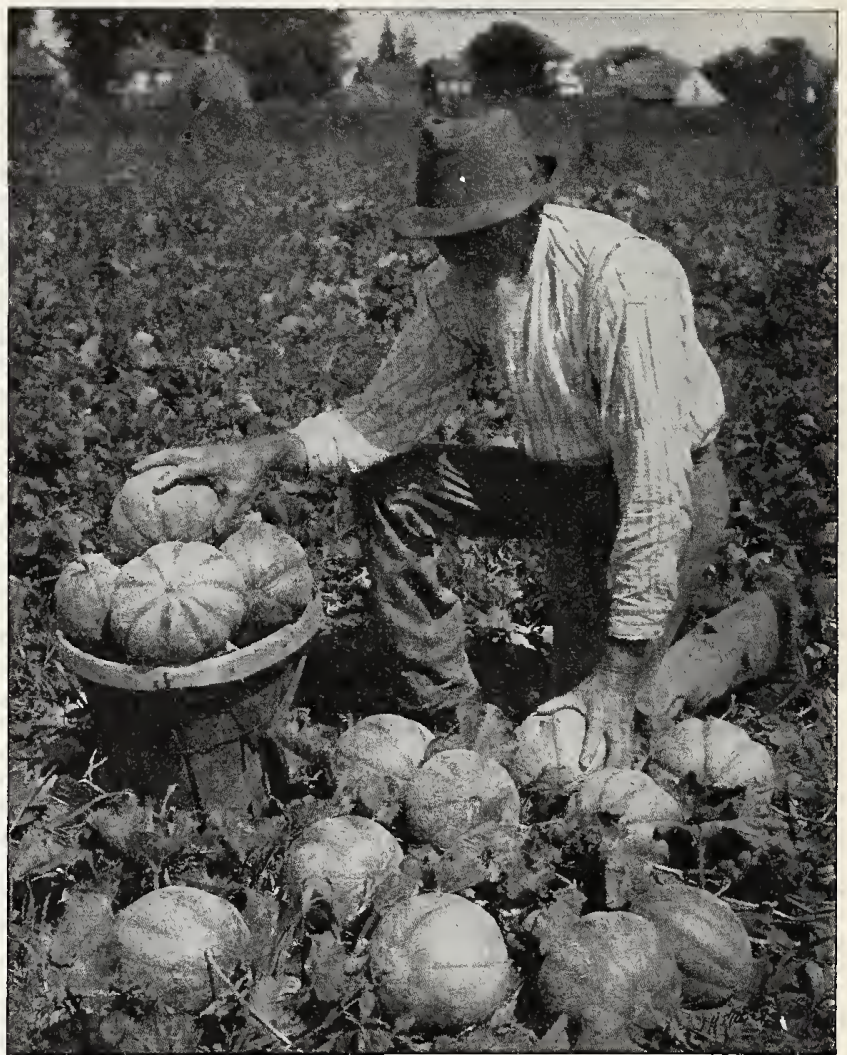

S. \& W. Co.'s Selected Stock, Rocky Ford. The most popular green-fleshed Muskmelon

Selected Emerald Gem. The skin is a rich deep green, and smooth; flesh salmon color and of delicious flavor. A very early and prolific variety and one that is very extensively grown for family use. Pkt. Io cts., oz. 30 cts., $1 / 4$ lb. 75 cts., lb: $\$ 2$.

Hearts of Gold or Improved Hoodoo. A new orange-fleshed variety, ideal as a shipping melon and of the very finest quality. Fruits uniformly of medium size. Rind thin yet very firm. Flesh very thick, firm, of fine texture and delicious flavor. Pkt. Io cts., oz. 35 cts., $1 / 41$ b. 90 cts., lb. $\$ 2.50$.

Tip-Top. The most productive melon known; having a sweet, juicy, fine flavor; solid flesh (but not hard) and edible to the outside coating. The fruit is of large size, nearly round, evenly ribbed and moderately netted. Pkt. IO cts., oz. $30 \mathrm{cts}$., $1 / 4 \mathrm{lb}$. $75 \mathrm{cts}$., $1 \mathrm{~b} . \$ 2$. Paul Rose. This new red-fleshed melon is sweet and highly flavored, and in it are combined all the good qualities of the Netted Gem and Osage, the varieties from which it originated. Pkt. Ioc., oz. 30c., I/4lb. 75c., 1b. \$2.

Supreme. Its color is a deep emerald-green outside, with more or less netting, while the flesh is a fine deep salmon of unusual thickness. It has a rich and most delicious; flavor, tender and melting; it is also highly aromatic. Pkt. 25 cts., 5 for $\$$ I.

\section{Cassaba Muskmelon}

To the lover of Muskmelons, it is a matter of disappointment that the varieties ordinarily grown will not keep for any length of time after ripening. Cassabas, however, will keep, and they are true winter melons. Cultivate similar to Muskmelons. Pkt. 15 cts., oz. 45 ets., 1/41b. $\$ 1.25$.

\section{FORCING MELONS}

Sedgewick Gem. (New.) A very large melon of English origin. The yellow skin is heavily netted, and the thick orange flesh is of excellent flavor. Pkt. 50 cts.

Royal Jubilee. A splendid, oval, green-fleshed melon, raised at the Royal Gardens, Windsor. Skin almost white, handsomely netted. The flesh is tender and of the most exquisite flavor. Pkt. 50 cts.

King George. Thick red flesh. Pkt. $50 \mathrm{cts}$. 


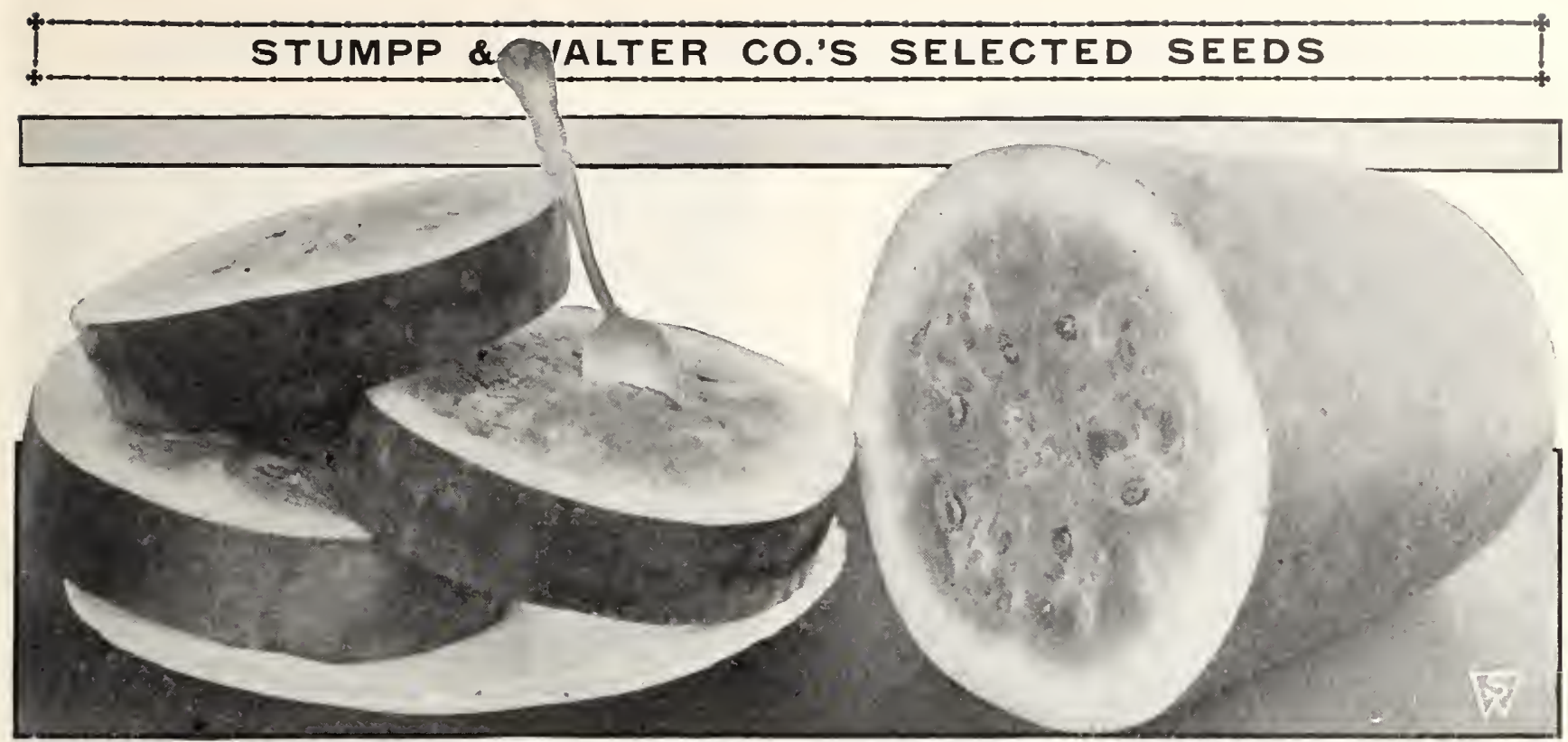

Kleckley Sweets. The sweetest of all Watermelons

\section{WATERMELON}

One ounce will plant about 50 hills

Culture.-Treat the same as muskmelon, except that the hills should be 8 to ro feet apart, according to variety. Cole's Early. A most delicious and productive variety for states, where melons were never matured before. The flesh is of a beautiful bright red color, crisp, and extremely delicate in texturethat granulated, cool, sparkling appearance that is so captivating to the eye; in flavor it is lusciously sweet and refreshing, no pithiness or stringiness. Pkt. 10 ets., oz. 30 cts., 1/4lb. 75 cts., lb. $\$ 2$.

Kleckley Sweets. The sweetest of all the Watermelons. Fine-flavored and grained, tender meat Fruits are large size; rind very thin and green, very brittle; flesh scarlet and firm; and a variety everyone should grow. Pkt. 10 ets., oz. 30 cts., 1/4lb. 75 cts., lb. $\$ 2$.
Stone Mountain. Wonderful for the private garden. Very large, dark green, nearly round. Flesh sweet, rich scarlet with few seeds. An already popular introduction. Pkt. Io cts., oz. $30 \mathrm{cts}$., I/4lb. $75 \mathrm{cts} ., \mathrm{lb} . \$ 2$

Early Fordhook. The quickest-maturing, large-fruited Watermelon grown, and therefore suitable for the North. Fruits are short and "stubby," though large. The flesh is bright scarlet, crisp, and of splendid quality. Pkt. Io cts., oz. $30 \mathrm{cts} ., 1 / 4 \mathrm{lb} .75 \mathrm{cts} .1 \mathrm{~b} . \$ 2$

Tom Watson. A large, long melon with a tough rind. Prolific; flesh rich red, sweet, and tender. Pkt. Io cts., oz. $20 \mathrm{cts}$., 1/4lb. $55 \mathrm{cts}$. Ib. $\$ 1.50$.

Citron. Used for preserves. Pkt. Ioc., 0z. 25c., Í1b. 65c., lb. $\$ 1.75$

\section{MUSHROOMS}

CULTURE. - You need (I) a shed or cellar which can be kept damp and at a temperature around 60 degrees; (2) fresh horse-manure from healthy animals, free of shavings, and with little straw; (3) some good garden soil; (4) some hay or straw; (5) high-grade Pure (uIture Spawn or Bottle Spawn; (6) a hotbed thermometer. Turn the manure for several days, keeping it slightly moist; make firm beds with it I foot thick, and let it steam. Try the temperature of the manure: it will go over $100^{\circ}$ and then fall; at $85^{\circ}$ plant spawn just under the surface and then cover the beds with hay. A mould will be noticed on the manure after a week; remove the hay and spread one inch of soil in its place. Keep the bed slightly moist, using warm water, and occasionally sprinkle the floors and walls. You should begin gathering Mushrooms in six weeks

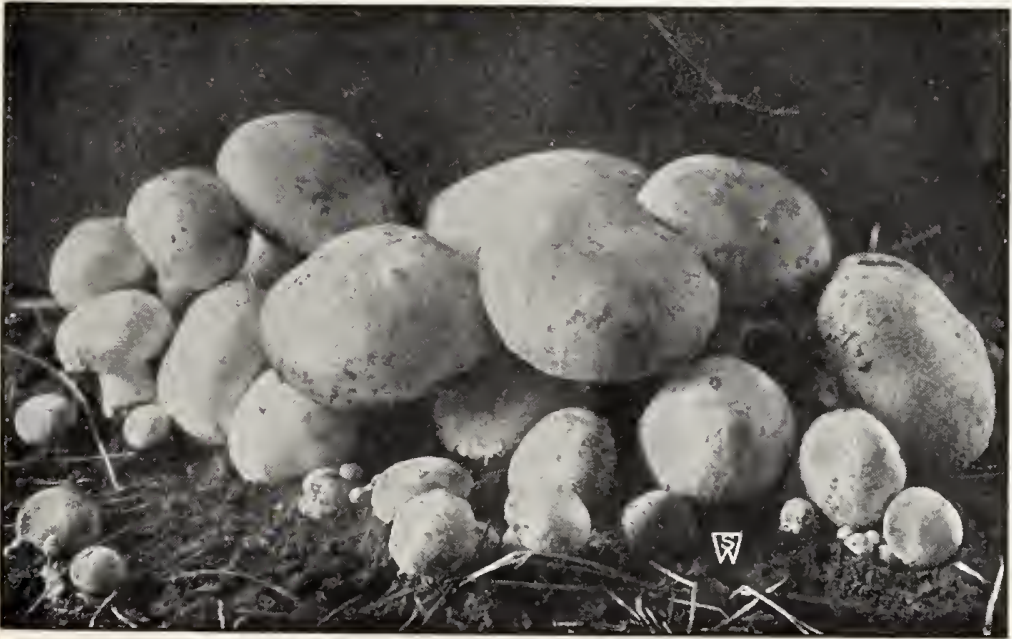

Bed of S. \& W. Co.'s Pure Culture Mushrooms Pieces of Mushrooin Spawn may be plugged into the lawn. If the land is rich, a good crop of Mushrooms may be expected in the autumn.

\section{Brick Spawn, American Pure Culture}

Ten bricks will spawn 100 square feet $(10 \times 10 \mathrm{ft}$.)

Spores have been selected from specimen Mushrooms and transferred to bricks of compressed manure and loam. Break the brick into pieces the size of a walnut and plant I foot arart each way.

Per Brick (about $\mathrm{I} 1 / 2 \mathrm{lbs}$ ) , 35c. Per 10 Bricks, $\$ 3.25$. Per 25 Bricks, \$7. Per 100 Bricks, \$25.

\section{Bottle Spawn, A New Process}

One quart will spawn 35 square feet

In this new method the spores are propagated in sterile glass bottles, the Spawn removed, dried, and packed in cartons. Excluded from the spawn are the spores of other fungous growths, many of which are highly poisonous; no insect eggs, flies, or weed seeds. Pieces the size of a nut are planted in the usual way. Produces white mushrooms. Qt. $\$ 1.25,6$ qts. $\$ 6.50$, 12 q ts. $\$ 12$. 


\section{ONIONS}

One ounce for 100 feet of drill; 5 to 6 pounds per acre

Curture.-Sow in rich, sandy soil, in drills I foot a part, as early as possible in the spring, cover with fine soil and firm well, either with roller or back of spade. When plants are strong enough, thin out to 3 or 4 inches. The largest Onions are produced by sowing the seed in a hotbed early in January or February and transplanting seedlings to the open ground 6 inches apart.

\section{MILD, WHITE VARIETIES}

S. \& W. Co.'s Southport White Globe. Produces and uniformly globe-shaped bulbs. The flesh is firm, fine-grained and of mild flavor. To produce the beautifully white Onions, so much sought in every market, one must, first of all, have good seed. Second, grow them well on rich land. Third, exercise great care in harvesting and curing the crop. In Southport, they "cord" up the Onions in long rows, the bulbs on the inside, and cover with boards so that the bulbs in the open air are well protected from rain or dew, which would be sure to discolor them. Pkt. 15 ets., $1 / 20 z$. 35 ets., oz. $60 \mathrm{cts} ., 1 / 4 \mathrm{lb}$. $\$ 1.60,1 \mathrm{~b}$. $\$ 4.50$.

White Portugal, or Silverskin. A mild-flavored varifor pickles. The Onions are tender and altogether fine. Pkt. 10 cts., $1 / 2$ oz. 30 ets., oz. 55 cts., $1 / 41 b$. $\$ 1.50,1 b$. $\$ 4$.

White Pickling. When matured, the tops die down, leaving beau-

tiful and perfect little bulbs. The color is pure white, flavor mild

and delicate, perfectly adapted for pickling and table use. Pkt.

I 5 cts., $1 / 2 \mathrm{Oz}$. 30 cts., oz. $50 \mathrm{cts}$., $1 / 4 \mathrm{lb}$. $\$ \mathrm{I} .35,1 \mathrm{~b}$. $\$ 3.75$.

White Bunching. For spring Onions, pulling Onions or "Scallions."

Use them when the thickness of a lead pencil, and they will be

found deliciously mild and sweet-healthful, too. Pkt. ro cts., $1 / 2$ Oz. 25 cts., oz. 45 cts., I/4lb. $\$$ I.3o, lb. $\$ 3.50$.

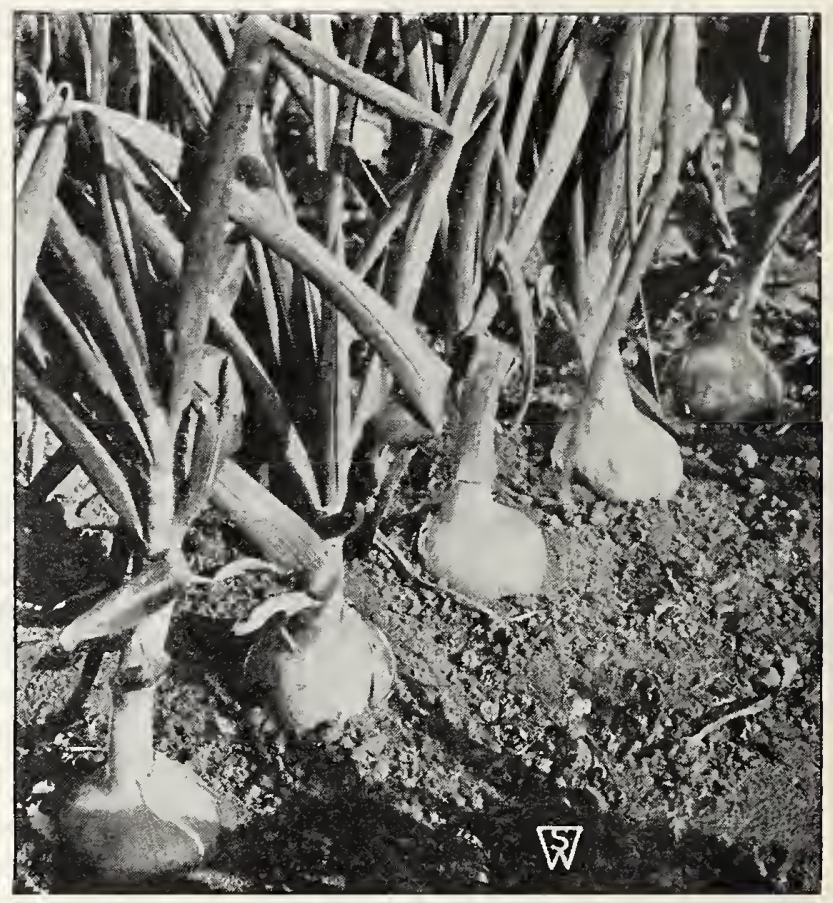

White Portugal Onions

\section{LEADING YELLOW KINDS}

S. \& W. Co.'s Southport Yellow Globe. The enormous quantities of this Onion annually sent to market prove its popularity, riority for our strain of seed; it produces large and uniformly spherical bulbs with very small necks. The largest diameter is below the center of the bulb. The color is a rich orange-yellow. Keeps splendidly. Pkt. 10 ets., $1 / 2 \mathbf{o z} .25$ ets., oz. 45 ets., 1/41b. \$1.30, 1b. \$3.50.

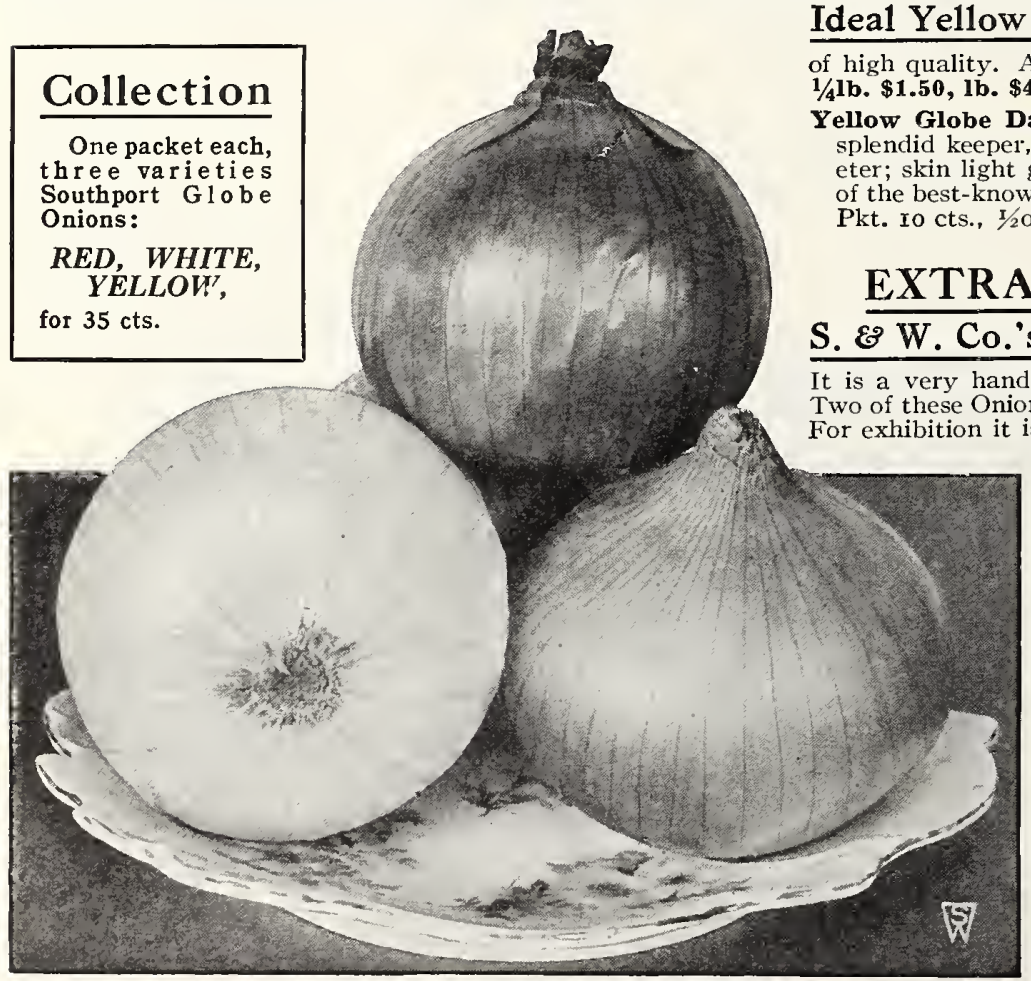

S. \& W. Co.'s Southport Globe Onions
Ideal Yellow Globe. An early Onion of the Southport type, dark yellow in color, of medium size, producing bulbs high quality. A good keeper. Pkt. 15 ets., 1/20z. 30 cts., oz. 55 cts.,

Yellow Globe Danvers. Of more globular shape than the Southport; a splendid keeper, producing well-rounded bulbs about $2 \mathrm{t} / 2$ inches in diameter; skin light golden yellow; flesh white, crisp, and mild in flavor. One of the best-known Onions, and recommended strongly for the general crop. Io cts., I/20z. 25 cts., oz. 45 cts., I/4lb. \$I.30, 1b. \$3.50.

\section{EXTRA LARGE-GROWING KINDS}

\& W Co.'s Selected Ailsa Craig. This Onion continues to ( Two of these Onions that weighed 8 pounds have been exhibited in England. unexcelled. To attain its largest size it should be sown in the greenhouse in January and transplanted to the open in April. For a large Onion it is a splendid keeper, and for those who like an Onion raw we recommend it highly on account of its mild flavor and crystal waxlike appearance. Pkt. 15 cts., 1/20z. 40 cts., oz. 65 cts., $1 / 41$ b. $\$ 1.75,1 b$. $\$ 5$.

Ailsa Craig. Originator's stock grown in England. Pkt. 50 cts.

Prizetaker. Uniform in shape; of immense size, measuring from 12 to 16 inches in circumference, while under special cultivation specimen bulbs have been raised to weigh from 2 to 3 pounds each; its pure white flesh is fine-grained, mild, and delicate. Pkt. $15 \mathrm{cts}$., $1 / 2 \mathrm{Oz}$. $30 \mathrm{cts}$., 0z. $55 \mathrm{cts}$., $1 / 4 \mathrm{lb}$. $\$ 1.50, \mathrm{lb} . \$ 4$.

S. \& W. Co.'s Riverside Sweet Spanish. The largest, sweetest, best-keeping, and most uniform of the Spanish Onions. Globular in shape, with golden yellow skin and white flesh; the strain we are offering is very mild. A great favorite in sections with long seasons and rich soil, where it will attain its maximum development. Pkt. 15c., $1 / 2$ oz. 40c., oz. 75c., $1 / 41 \mathrm{lb}$. $\$ 2$. Gigantic Gibraltar. See Novelties, page I8. 


\section{LONG-KEEPING RED ONIONS}

S. \& W. Co.'s Southport Red Globe. Very similar to Wetharsfield in color, having a deep red skin, but differing in shape, being almost a perfect globe Size large, flesh fine-grained, mild and tender. Pkt. 15 cts., $1 / 20 z .30$ cts. oz. 55 cts., $1 / 4$ lb. $\$ 1.50,1$ b. $\$ 4$.

Large Red Wethersfield. This is the standard red variety, and a favorite Onion in the East, where immense crops are grown for slipment. Bulb large, somewhat flattened, oval shape; skin deep purple-red; flesh purplish white, moderately fine-grained and stronger flavored than any of the other kinds. Very productive, the best keeper, and one of the most popular for general cultivation. It is more inclined to form large necks if planted on unsuitable soil than the Danvers, but is the better variety on poor or dry soil. Pkt. 10 ets., $1 / 20 z .25$ ets., oz. 40 ets., $1 / 41 b . \$ 1.25,1 b . \$ 3.25$.

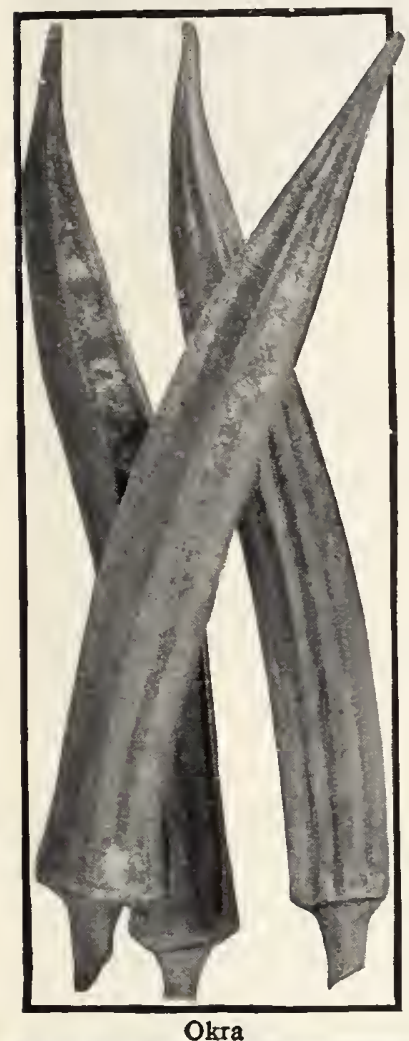

\section{BERMUDA ONIONS}

These are large, flat, quick-growing types, witl a pleasant, mild flavor. We offer new-crop imported seed.

Red Bermuda. Pkt. 20 cts., 1/20z. 45 cts., oz. 75 cts., 1/4lb. \$2, lb. $\$ 6$.

Crystal Wax. Pkt. $25 \mathrm{cts} ., 1 / 2 \mathrm{Oz} .55 \mathrm{cts}$., oz. $\$ \mathrm{I}, 1 / 4 \mathrm{lb} . \$ 3, \mathrm{lb} . \$ 8$.

\section{ONION SETS}

Sets will produce green, bunch or full-

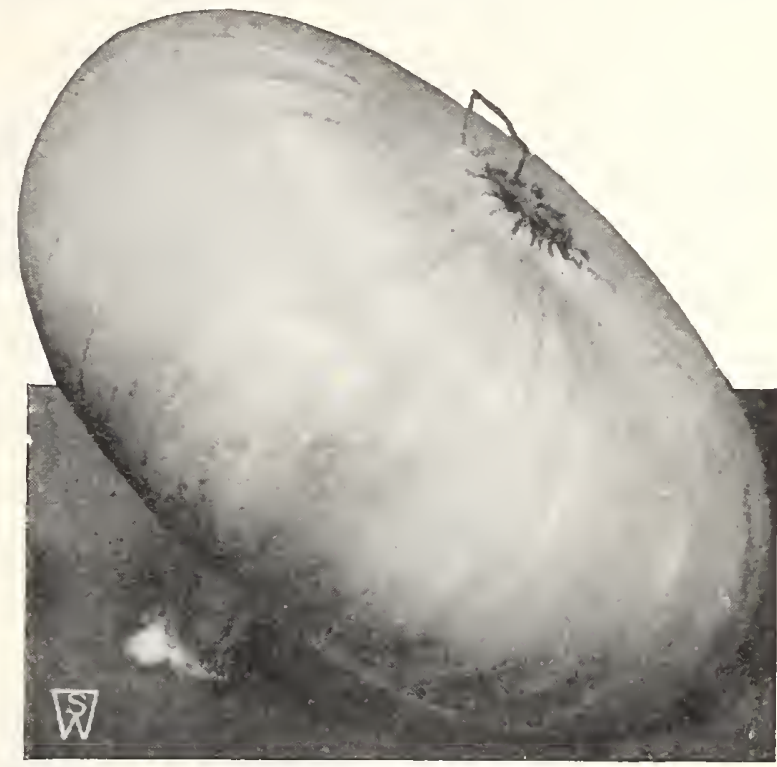

Large Red Wethersfield Onion

grown Onions much quicker than will seed. Multipliers, Potato Onions, and Shallots divide and increase in the soil. Egyptian Onions are hardy perennials, yielding green pulling Onions every spring

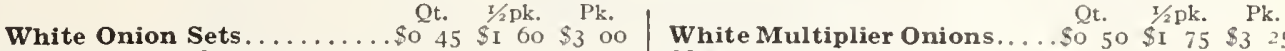
Yellow Onion Sets............ 40 I 50 r 75 Shallots.

Yellow Ebenezer or Japanese. 45 I $60 \cdot 3$ oo Egyptian Top Onions. Orders

Red Onion Sets............ 40 I $50 \quad 2 \quad 75$ booked for delivery in fall. . . 40 I $50 \quad 275$ Potato Onion Sets (True Potato). Lb. $50 \mathrm{cts} ., 5$ lbs. $\$ 2.25$, Io lbs. $\$ 4$

\section{Garlic Sets $\begin{gathered}\text { One pound will plant } \\ 200 \text { feet of drill }\end{gathered}$}

CUlture,-Garlic is used for a variety of flavoring purposes. Break up the sets or bulbs into the smallei scale-like portions and plant these 6 inches a part in rows I foot apart. As soon as the leaves have turned. the crop is matured, and may be harvested like the onion.

Garlic Sets. Lb. 50 cts., 5 lbs. $\$ 2.25$.

\section{OKRA or GUMBO One ounce will sow about} 100 feet of drill

CULTURE.-Sow when the weather is warm and settled, in drills I inch deep and 4 feet apart; thin out to I 2 inches apart in the drills. Okra requires 9 to Io weeks from seed to maturity.

Dwarf Green. A very prolific sort, and its habit commends it where garden space is limited. The short, deep green, corrugated pods are of fine quality. Pkt. Io cts., Oz. $20 \mathrm{cts} ., 1 / 1 \mathrm{lb} .45 \mathrm{cts}$., 1b. \$I.25.
Lady Finger. A new variety from the South, very. productive; extra-long, slender pods of fine round form. Pkt. Io cts., oz. 20 cts., 1/4lb. 45 cts., 1b. \$I.25.

Kleckley's Favorite. One of the best varieties. Pkt. IO cts., oz. $20 \mathrm{cts}$., 1/4lb. $45 \mathrm{cts} .1 \mathrm{~b} . \$ \mathrm{I} .25$

Long Green. Long ribbed pods; very productive. Pkt. IO cts., Oz. I 5 cts., $5 / 4$ lb. $40 \mathrm{cts} ., 1 \mathrm{~b}$. SI.

White Velvet. Very distinct in appearance; pods are perfectly round, smooth and of a white velvety appearance and of superior flavor. Pkt. Io cts., Oz. $20 \mathrm{cts} ., 1 / 4 \mathrm{lb} .55 \mathrm{cts} ., 1 \mathrm{~b}$. $\$ \mathrm{I} .5 \mathrm{O}$.

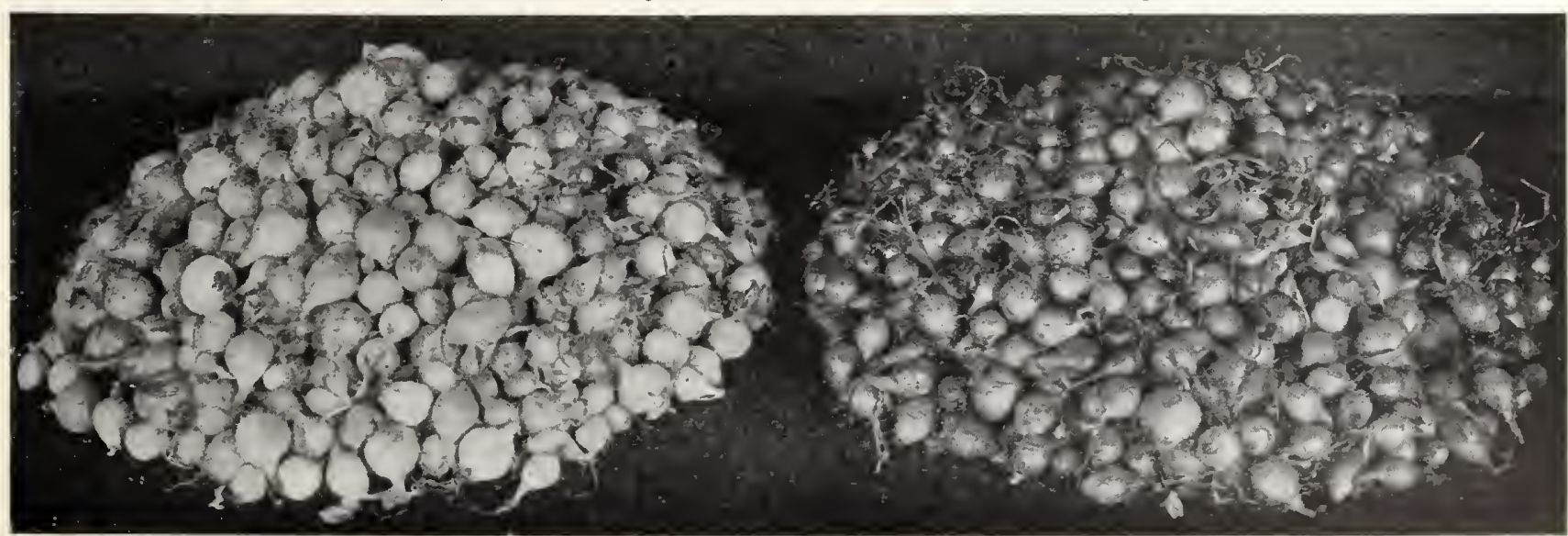

Globe Onion Sets 


\section{PARSLEY One ounce will sow about}

Culture.-Parsley requires a rich, mellow and deep soil. Soak the seed for a few hours in tepid water, and sow early in the spring in drills I foot apart and $1 / 2$ inch deep. Thin out the young plants to 4 inches. Hamburg Parsley should be treated the same as carrots.

Extra Double Curled. A standard market variety, used for garnishing and flavoring. The leaf is finely cut and curled and a vivid green in color. Handsome. Pkt. Io cts., oz. $20 \mathrm{cts}$., I/1b. $45 \mathrm{cts}$., 1b. $\$$ I.25.

Champion Moss Curied. A particularly beautiful type. As its name implies, a bed of this has the appearance of fine moss. Pkt. Io cts., oz. 20 cts., I $1 / 4$ lb. 55 cts., lb. \$I.5O.

Exhibition Curled. See Novelties. page I8. Pkt. $25 \mathrm{cts}$., 5 pkts. \$I.

Fern-leaved. This is a distinct variety, very different from the foregoing. We have the true type. Plkt. Io cts., oz. 30 cts., I/4lb. 75 cts., lb. $\$ 2$.

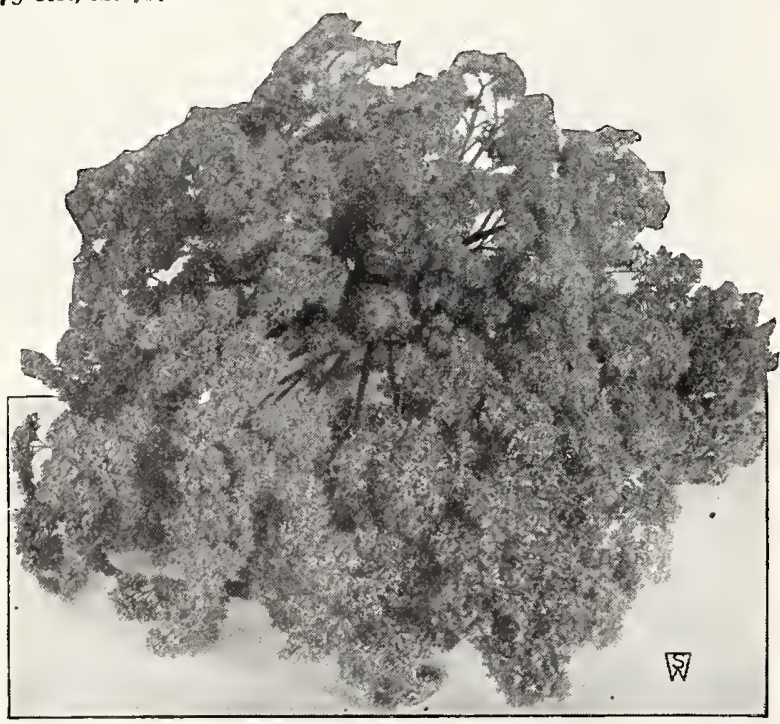

Extra Double Curled Parsley

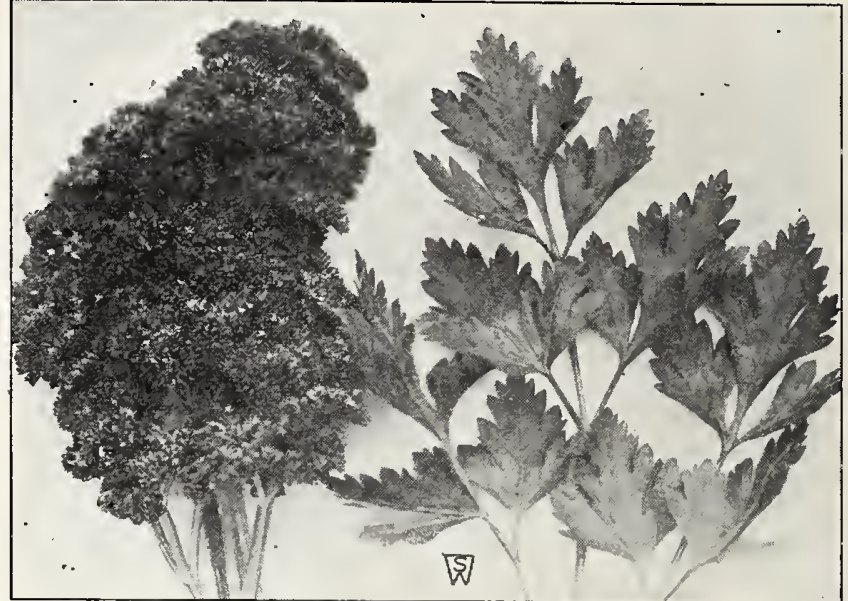

Champion Moss Curled and Plain Parsley compared

PARSLEY, continued

Plain. Known widely as Italian Parsley. Used for flavoring. (See illustration.) Pkt. Io cts., oz. $20 \mathrm{cts}$., I//1b. $55 \mathrm{cts}$., 1b. $\$ 1.50$

Hamburg or Rooted. The roots of this type resemble parsnips. They are served similarly or used for flavoring soups. Pkt. Io cts., oz. 25 cts., I/4lb. 65 cts., lb. $\$ 1.75$.

\section{PEANUTS}

CULTURE.-These require similar soil conditions to garden corn, and they take about as long to grow. Remove the outer shell carefully, taking care not to damage the kernels, and sow the latter in drills $21 / 2$ feet apart and $I \frac{1}{2}$ inches deep. Allow 9 inches between one "nut" and the next in the row.

Improved Spanish. Though small, this is a quick-growing sort and is therefore particularly suitable for northern gardens. Pkt. I $5 \mathrm{c} ., 1 \mathrm{~b} .45 \mathrm{c}$. California Long Red. Larger than the above but slower to mature. Plant this variety south of the latitude of New York. Plit. I 5 cts., lb. $45 \mathrm{cts}$.

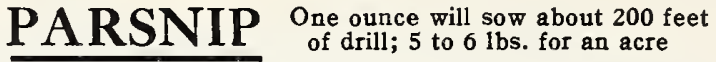

Curture.- Sow as early in spring as the ground can be worked, in drills 18 inches apart, covering with fine soil to the depth of $1 / 2$ inch. The soil should be rich and deeply dug. The quality of the roots is much improved after a severe frost; in fact, they may be allowed to remain in the ground throughout the winter, as they are perfectly hardy.

S. \& W. Co.'s Improved Hollow-Crown. A great improvement over the present Hollow-Crown variety; clean, well shaped . Smoothness in the root of a Parsnip is a matter of importance, as every housewife preparing it for the table will acknowledge. Excellent for table or exhibition. Pkt. 10c., 0z. 25c., 1/41b. 65c., 1b. \$1.75.

S. $\&$ W. Co.'s New Intermediate. The root is somewhat flattened and top-shaped, about 6 inches long and 4 inches across the ing spinach or lettuce; or if put in when long parsnips are sown, may be pulled soon after midsummer. Particularly suitable for shallow land which ordinarily produces misshapen or fanged root-crops. Pkt. 10 cts., oz. 30 cts., 1/41b. 75 cts., 1 b. $\$ 2$.

Selected Exhibition. An enormous Parsnip produced expressly for the grower for exhibition. Pkt. 25 cts., 5 pkts. \$I.

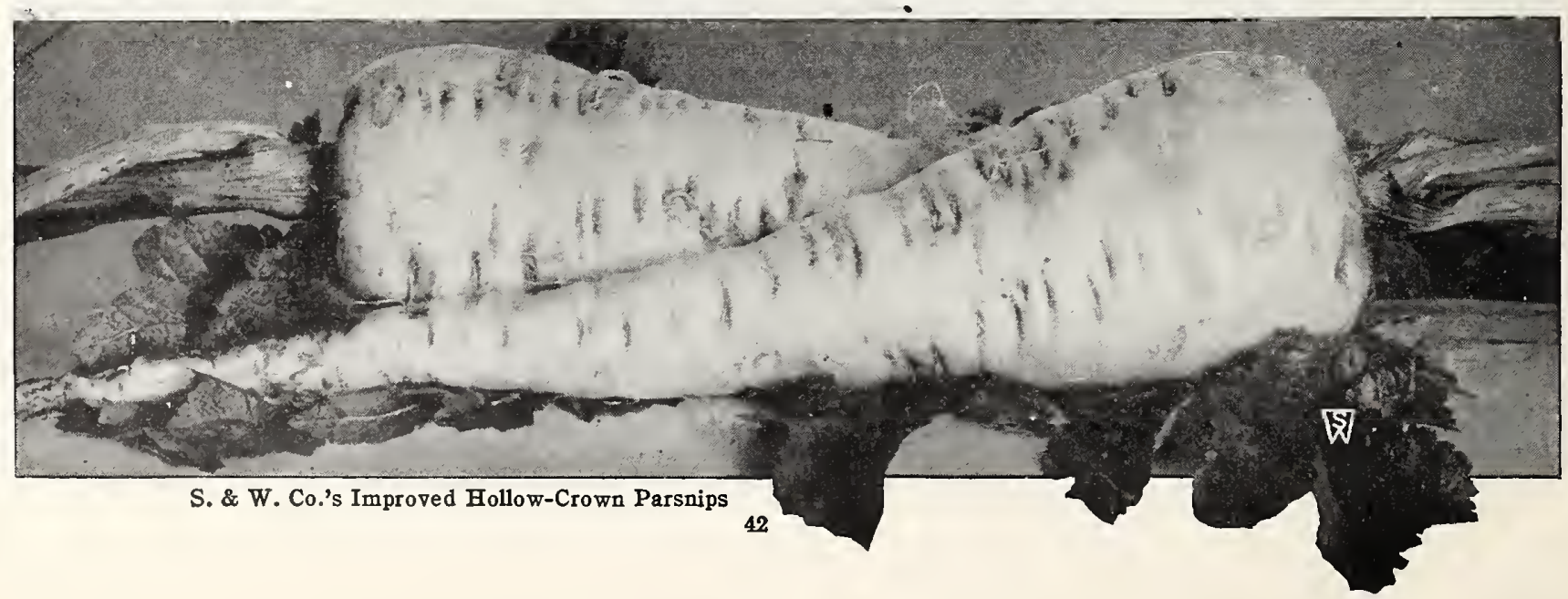




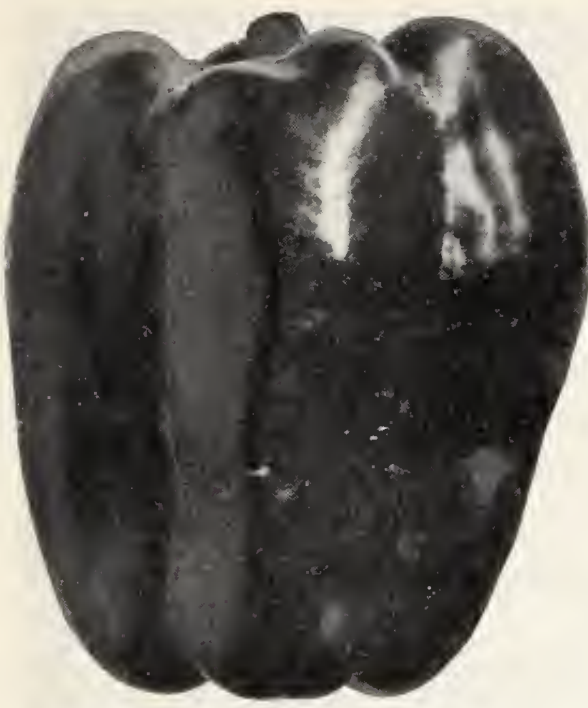

World Beater. Considered by many to be the best large sweet Pepper

Neapolitan (J e r s e y Sweet; White Cap). Very early and an extraordinary yielder. Its fruits grow upward, not pendent. They are bright red, sweet, fine, and tender. Commercial growers favor this Pepper. Pkt. 15 cts., 1/20z. 45 ets., oz. 75 ets., $1 / 41$ lb. $\$ 2.25$.

Golden Dawn. A yellow sweet Pepper of excellent table quality. Pkt. I 5 cts., $\mathrm{J} / 2 \mathrm{Oz}$. $60 \mathrm{cts}$., oz. \$I, I/4lb. \$2.75.

Sunnybrook Cheese. A very prolific and popular canning variety. Fruits average 3 inches in diameter and 2 inches deep. The skin is smooth and of deep scarlet color and the flesh is thick and sweet. Pkt. 15 cts., $1 / 20 z$. 5o cts., oz. 85 cts., I/41b. \$2.50.

\section{A WONDERFUL LONG SWEET PEPPER}

Anaheim Chili. A long type that is classed as a sweet Pepper; it has just sufficient suggestion of pungency to make it delicious. The fruits are very meaty, measuring 7 inches or more in length, with a diameter of I inch. It is highly valued as a green chili, canned chili made from it is a revelation, while ripe and red, served as a salad, it is excellent. Pkt. I5 cts., 1/20z. $65 \mathrm{cts}$., oz. $\$$ I.IO, $1 / 4$ lb. $\$ 3$.

\section{THREE HOT PEPPERS}

Long Red Cayenne. Fruits about 4 inches long and I inch thick, bright red in color; very prolific; very hot. Used for pickling, both when green and when ripe. Pkt. I 5 cts., 1/20z. $60 \mathrm{cts}$., oz. \$I, I/4lb. \$2.75.

Tobasco. For the market and for making the well-known Tobasco sauce. A sinal and very pungent type. Pkt. $20 \mathrm{cts}$., I/2Oz, $65 \mathrm{cts}$, oz. $\$ I_{1}$ I, $1 / 4 \mathrm{lb} . \$ 3$.

Cherry Red. Small, round fruit, rich scarlet in color, and extremely piquant. Pkt. I 5 cts., 1/2Oz. 60 cts., Oz. \$I, I/4lb. \$2.75.

FOR THE VEGETABLE GARDEN, USE STUMPP \& WALTER CO.'S SAWCO GARDEN FERTILIZER

5 lbs. 50 cts., 10 lbs. 90 cts., 25 lbs. $\$ 2,100$ lbs. $\$ 5.50$ $\$ 2.50$.

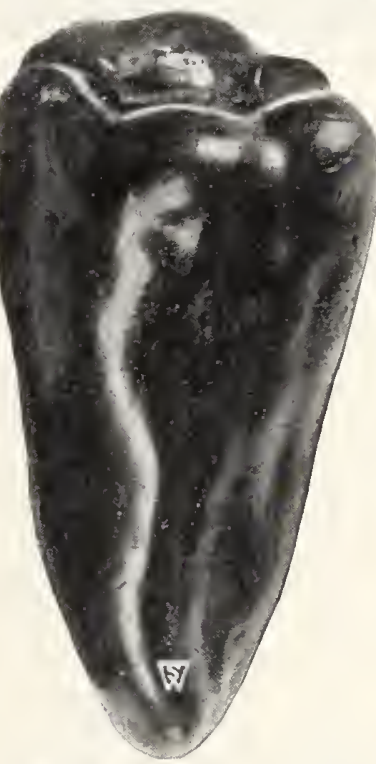

Neapolitan. A sweet Pepper noted for its earliness and extra-
ordinary yielding properties.

\section{PEPPER}

One ounce will produce about 1,000 plants

Culture.-Peppers are more sensitive to frost than most vegetables, and they should the planted out until settled warm weather has arrived. The seed should be sown in a (n) a vallable, a box in a windov; transplan later into rows 20 inches apart each way, and keep the soil clean and well stirred. Pro-

\section{NINE SPLENDID SWEET PEPPERS}

World Beater. This new high-quality variety is considered by many to be the best Penper today, and it is certainly one or the largest and most handtwo rell-known sorts, Ruby hing and Chinese Giant, ints of both. It produces its rruit as early as Ruby King and it is very suitable for the amateur. It interests the commercial grower, too,

Perfection Pimiento. The hull or meat is from 2 to 3 times as thick as that of the pungency. In color, when ripe, it is a beautiful scarlet-red. This very" productive Pepper is

Chinese Giant. This is the standard large sweet Chines. It is quite early to ripen and very productive for so large a variety. The fruits are 4 to 5 inches broad at the top, and of equal length. The flesh is mild and unusually thick, naking an excellent salad sliced and served like tomatoes. Color green, changing to a glossy scarlet when ripe. Pkt. 15 ets., $1 / 20 z .65$ ets. oz. $\$ 1.10,1 / 41 b . \$ 3$.

Ruby King. The handsome fruits are $4^{1 / 2}$ to 6 inche long, $3 \frac{1}{2}$ inches thick, and bright red Ruby King is used very largely for pickles, and it is equally suitable for slicing. The flavor of the fruits is mild and pleasant, with just a slight suspicion of piquancy, making them very tempting when served like cucumbers or tomatoes. Pkt. 10 ets., 1/20z. 45 ets., oz. 75 ets., 1/4lb. $\$ 2.25$.

Large Bell, or Bull Nose. A large, early variety of pleasant flavor, though mild. This is the variety for green stuffed Peppers. Pkt. Io cts., 1/20z. $45 \mathrm{cts.,} \mathrm{oz.}$ $75 \mathrm{cts} .,{ }_{\$}+\mathrm{lb} . \$ 2.25$.

Sweet Mountain. Fruits 6 inches long by 4 inches thick shining deep green when young and a handsome red when ripe, Pkt. I5 cts., 1/20z. $50 \mathrm{cts}$, oz. $85 \mathrm{cts}$, 1/4 $1 \mathrm{lb}$. $\$ 2.50$.

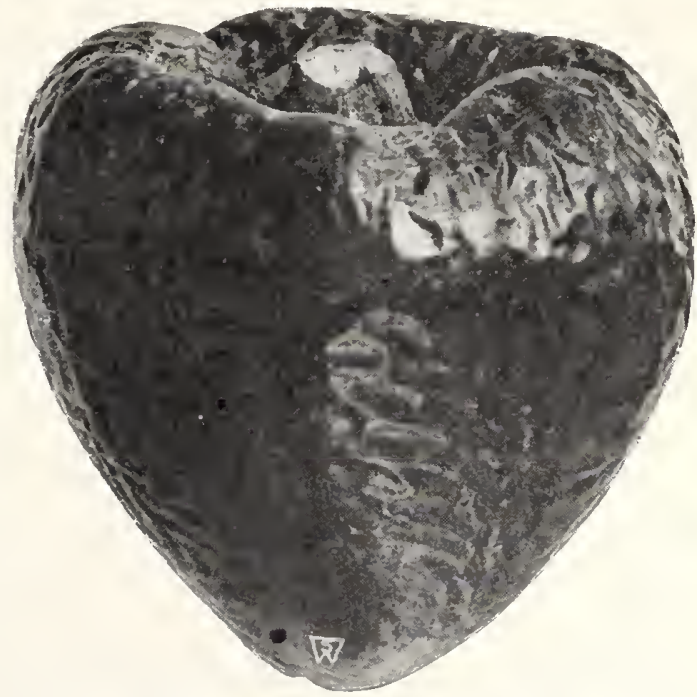

Perfection Pimiento. A fine variety, unique in shape and in its fine qualities 


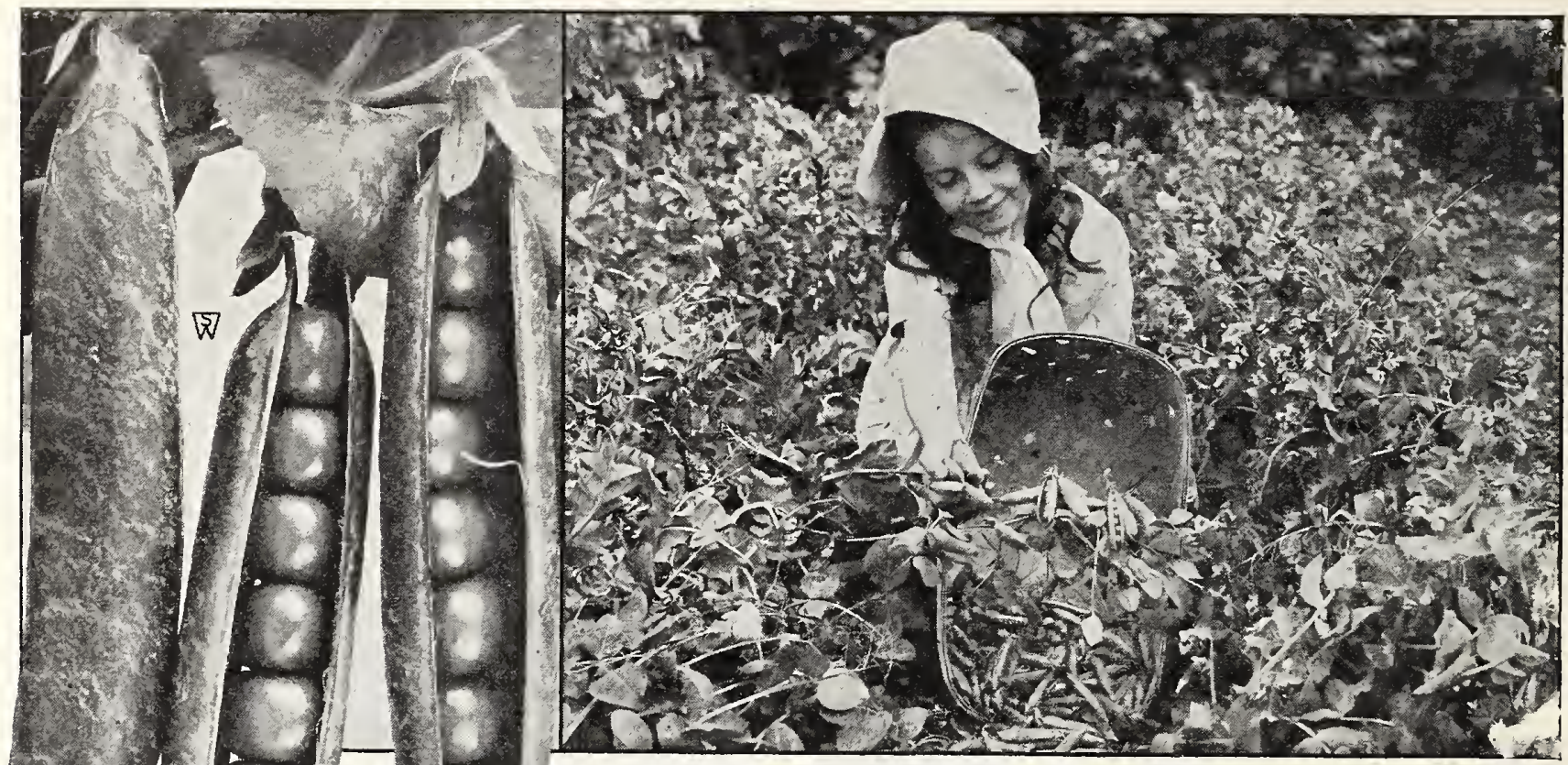

Laxtonian Pea. A wonderful medium dwarf variety that is unusually prolific. Full description on opposite page.

\section{PEAS NORTHERN}

One pound will plant 100 feet of drill

CULTURE.-For early crops sow as early in spring as practicable, and again two weeks later. Use several varieties at each seeding to insure a succession throughout the season. Plant in single or double rows, 4 feet apart and 2 inches deep. In dry weather soak the Peas over night before planting. In the vicinity of New York the extra-early Peas, if planted from the $r$ th to the last of August, will produce a moderate crop for late picking when they will be found most acceptable. Varieties marked * are wrinkled Marrows, and should be sown more thickly than the round Peas, and not until the ground has become warm, as they are more liable to rot. All wrinkled sorts are much superior in flavor to the round Peas.

\section{EARLY SMOOTH-SEEDED SORTS}

First of All or Pedigree Extra-Early. Extremely early. The first planting of Peas should be with First of All." It is a smooth seeded variety, a splendid cropper; Peas very tender, of good flavor and carried in long, tightly filled pods. Height $2 \frac{112}{2}$ feet. $1 / 2 \mathbf{l b}$. 25 ets., 1 b. 40 ets., 2 lbs. 75 ets., 5 lbs. $\$ 1.75,15$ lbs. $\$ 4.75$.

Early Bird. Combines the hardiness of the round-seeded types plant grows 4 feet high, and therefore requires the support of brush, or strings. Throughout its height it bears profusely 4 -inch pods closely packed with Peas of fine flavor. Early Bird is a few days earlier than Gradus when sown at the same time, but you may safely plant it ten days ahead of Gradus. 1/21b. 25 ets., 1 b. 45 cts., 2 lbs. 85 ets., 5 lbs. $\$ 2,15$ lbs. $\$ 5.50$.

Petit Pois. Imported seed. The delicious tiny Peas which are 1b. 65 ets., 2 lbs. $\$ 1.25$.

ught Weelss. $\{$ See Novelties, page 19. Pkt. 15 cts., 1/2lb. 30 cts., Market Surprise. $\}$ lb. 55 c., 2 lbs. \$I, 5 lbs. $\$ 2.25,15$ lbs. $\$ 6.25$.

\section{EARLIEST WRINKLED SORTS}

*World's Record. Among early main-crop Peas of medium lace; happily height, Gradus, or Prosperity, takes first place; happily named, indeed, on account of its high yield and superb flavor. In World's Record these points are more than maintained; the yield is as high and the quality, if anything, is enhanced. The great point in favor of the new sort is its earliness, the period from seed to maturity being less by a week than that of the standard Gradus. $1 / 21$ b. 30 ets., 1 b. 50 cts., 2 lbs. 90 ets., 5 lbs. $\$ 2.10,15$ lbs. $\$ 5.75$.
* Gradus, or Prosperity. Undoubtedly one of the most the present time. The vine has heavy stems, with large, light green leaves and grows about 3 feet high. It produces uniformly large pods. measuring from 4 to $41 / 2$ inches in length, nearly round and well filled with very large, handsome Peas of the finest flavor; very early, ready for picking after First of All is through, and leaves little to be desired. Height 3 feet. Pkt. 10 ets., $1 / 21 b .25$ ets., 1 . 45 ets., 2 lbs. 85 cts., 5 lbs. $\$ 2,15$ lbs. $\$ 5.50$.

*Little Marve1. A first-early Pea of the finest quality, better The vines of dwarf, even growth, average 18 inches high, and are heavily set with fine pods, usually in pairs. The pods average $31 / 2$ inches in length, are square at the bottom, and are well filled with quite large, deep green Peas. The Peas are ready for picking fully as early as American Wonder, but the pods are larger and the vines bear a much heavier crop. All who desire a fine crop of an early, choice variety of Peas will be delighted with Little Marvel. Begins to bear just as Gradus is at its best. Pkt. 10 ets., $1 / 21$ lb. 25 ets., $1 b .45$ cts., 2 lbs. 85 cts., 5 lbs. $\$ 2,15$ lbs. $\$ 5.50$.

*Thomas Laxton. A remarkably fine, early, wrinkled Pea, In many characteristics it resembles that excellent sort, but the pods differ in shape, and are certainly more numerous. The Peas are of extra-fine quality, tender and of a flavor not excelled by any other. It grows about 3 feet in height, but does not need brushing. Ready for picking at the same time as Sutton's Excelsior. It is a remarkably profitable market Pea, as it is always in demand and brings the best prices. Height 3 feet. $1 / 21$ b. 25 cts., 1 b. 45 ets., 2 lbs. 85 cts., 5 lbs. $\$ 2,15$ lbs. $\$ 5.50$.

*Sutton's Excelsior. A variety that calls for highest combut dwarf and considerably more productive. Ready for picking just after Gradus and Little Marvel. Height 18 inches. $1 / 2 \mathbf{1 b} .25$ ets., 1b. 45 cts., 2 lbs. 85 cts., 5 lbs. \$2, 15 lbs. $\$ 5.50$.

NOTE.-The American Seed Trade generally has adopted the cental system of pricing Peas, Beans, and Corn. We therefore offer by weight instead of measure. One pound of Peas is equal to about 1 pint; 2 pounds to about 1 quart. 


\section{PEAS ${ }_{\text {GROWN }}^{\text {NORTHER }}$}

\section{EARLIEST WRINKLED SORTS, Continued}

*Laxtonian. A very fine dwarf early Pea. Unusually large pods, borne on longfilled with large, luscious Peas. It is ready for use about a week later than the very early sorts. The plant grows about $\mathrm{I}^{1 / 2}$ feet high, and is of a rich dark green color which proves it to be of vigorous constitution, and this enables it to resist the extreme conditions to which Peas are subjected in many sections of the United States. (See photograph on opposite page.) 1/21b. 30 cts., lb. 50 cts., 2 lbs. 90 cts., 5 lbs. $\$ 2.10,15$ lbs. $\$ 5.75$.

*Laxton's Progress. A new Pea, and quite one of the best of the large-podded, early, wrinkled sorts. Planted at the same time as Laxtonian, it is ready to pick nearly a week earlier. The pods are 4 inches long an are filled with eight large, melting, sweet Peas. The plant grows 18 inches high. $1 / 2$ lb. 30 cts., lb. 55 cts., 2 lbs. $\$ 1,5$ lbs. $\$ 2.25,15$ bs. $\$ 6.25$.

\section{MIDSEASON AND MAIN-CROP}

*Delicious. See Novelties, page I9. Pkt. 20 cts., 1/21b. 35 cts., 1b. 65 cts., Delicious. 2 lbs. $\$ 1.25,5$ lbs. $\$ 3,15$ lbs. $\$ 8$.

*Admiral Beatty. The parents of this splendid recent English introduction Admiral Beatty. are Gradus and Alderman, and it is intermediate between

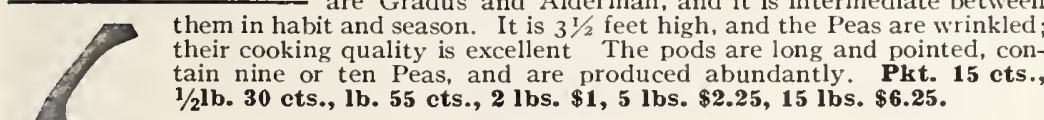
*Alderman. A distinctly different Pea in habit from those described Alderman. in the Early list. On generous soils it grows to a height of 5 to 6 feet, and should be supported with brush or trellises. The pods contain seven large, elongated, dark green Peas of the highest quality, and follow in the wake of Thomas Laxton. The plants bear very profusely and the Peas bring the highest price in market. Height 5 feet. $1 / 21$ b. 25 cts., 1 b. 45 cts., 2 lbs. 85 cts., 5 lbs. $\$ 2$, 15 lbs. \$5.50.

*Quite Content. One of the largest-podded Peas in existence Quite Content. and in season similar to Alderman. This variety is preferred by many growers to Alderman on account of its large pods. Height 5 feet. 1/21b. 30 cts., 1b. 55 cts., 2 lbs. $\$ 1,5$ lbs. $\$ 2.25,15$ lbs. $\$ 6.25$.

*Boston Unrivaled, or Telephone. This variety is Alderman, with vines fully as tall. pods slightly smaller, and bears right up to the season of the very late sorts. The yield of pods is

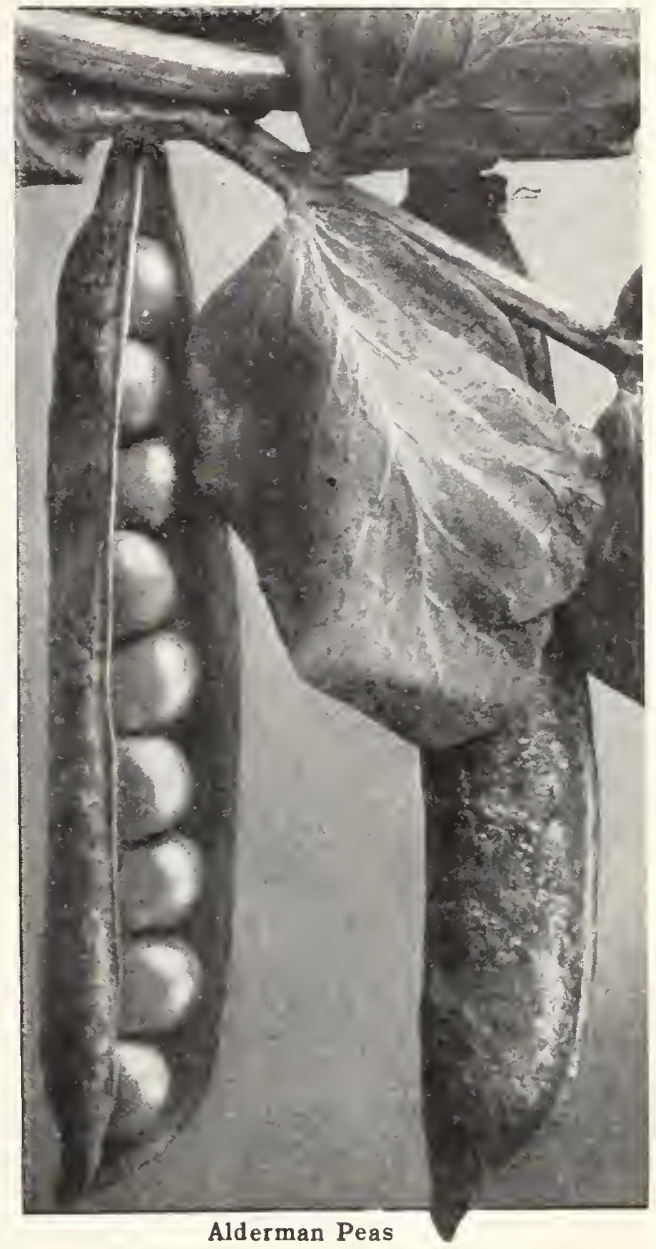
not so great and they are not so well filled as Alderman. The Peas are every bit as tender, but lighter green in color and sweet. Height 5 feet. Pkt. 10 cts., $1 / 21$ lb. 25 ets., 1 b. 45 cts., 2 lbs. 85 cts., 5 lbs. $\$ 2,151 b s . \$ 5.50$.

*Potlach. Really an improved Stratagem and, without a doubt, the best dwarf, extremely late Pea. Healthy bluish Preen vines, bearing loads of deep green pods; frequently an average of eight pods in pairs containing an average of seven fine, large Peas of superfine flavor. A continuous bearer from July $\mathrm{I}$ to $\mathrm{r} 5$ in most seasons. Height 2 feet. Pkt. 10 ets., 1/21b. 25 cts., lb. 45 ets., 2 lbs. 85 cts., 5 lbs. $\$ 2,15$ lbs. $\$ 5.50$.

*Champion of England. Vines grow 4 to 5 feet high. Peas of excellent quality and delicious flavor. 1/2lb. $25 \mathrm{cts}$., lb. 45 cts., 2 lbs. 85 cts., 5 lbs. $\$ 2$, I 5 lbs. $\$ 5.50$.

\section{EDIBLE-PODDED SUGAR PEAS Used in the same manner}

Luscious Melting Sugar. Large, broad pods, which are so brittle that they snap without any string. Height 5 feet. $1 / 2$ lb. 30 cts., lb. 55 cts., 2 lbs. \$I, 5 lbs. \$2.25, I 5 lbs. $\$ 6.25$.

Very Dwarf White Sugar. Unusually dwarf; very similar in habit to Little Marvel. The pods are of excellent melting quality. 1/2lb. 30 cts., lb. 55 cts., 2 lbs. $\$ 1,5$ lbs. $\$ 2.25$, I 5 lbs. $\$ 6.25$.

\section{Collections of Garden Peas}

These collections embody our ideas of the best and most representative varieties. They are considered by experienced growers to be the most reliable sorts for both the amateur and professional gardener. We suggest that two sowings be made of each varietythe first as soon as the ground is ready and the weather is right, and the second two weeks later. The result will be a maximum yield, and the grower should be able to gather Peas daily over a period of five weeks.

\section{The Following Five Varieties Comprise the Collections}

Market Surprise. A wonderful, round-seeded variety, yielding in about 70 days from seed. Height 3 feet.

* Gradus. The standard early wrinkled Pea, yielding generally in 80 days. Height 3 feet.

*Little Marvel. A wrinkled sort, I I 12 feet high. Requires about 85 days from seeding to maturity.

*Telephone. The standard late tall wrinkled Pea. Produces its pods in about 90 days from seed. It grows 5 feet high.

*Potlach. An extremely late wrinkled variety, yielding in 95 days from seeding. Height 2 feet.

Quite Content One of the largestpodded Peas in cultivation.

\section{THE COLLECTIONS}

One packet each of above five Peas

Postpaid One pound each of above five Peas

.$\$ 050$ Two pounds each of above five Peas.

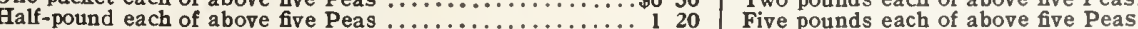

Please do not ask us to make changes in these Collections. The fact that they are prepared in advance of our. ables us to offer them at a lower price than that of the separate varieties purchased in the usual way.
Postpaid $\$ 210$ 400
950 


\section{SEED POTATOES}

Culture.-Any good, well-drained, fibrous loam will produce Potatoes under right climatic conditions. For early Potatoes, which mature in eight to ten weeks from planting, the soil must be particularly rich. A rich clover sod, manured and broken the year before and planted to corn, beans, peas, oats, etc., is in best shape for giving a good yield of nice, clean Potatoes. Stable manure had better be applied to the land the year before. S. \& W. Co.'s Potato Manure, at the rate of up to I,00o pounds to the acre if applied broadcast, or 400 to 600 pounds if applied mostly in the rows, may be used directly for the Potato crop. Open furrows 3 feet apart and 3 to 4 inches deep. Apply the fertilizer and run the furrower or small plow again in the furrow to mix the fertilizer with the soil and leave a mellow seed-bed. Then plant good-sized pieces, each containing not less than two or three eyes, I 5 inches apart in the furrows for early Potatoes, and 18 inches apart for late ones. Return the soil with a coverer, small plow or other suitable tool. About I I bushels or 4 barrels will plant an acre. A barrel contains $23 / 4$ bushels (I65 pounds).

SEMESAN Bel. It controls diseases of seed potatoes, producing sprouts of healthy vigor, from which tubers, 4 ozs. 50 cts., lb. $\$ 1.75,5$ lbs. $\$ 8,25$ lbs. $\$ 31.25$.

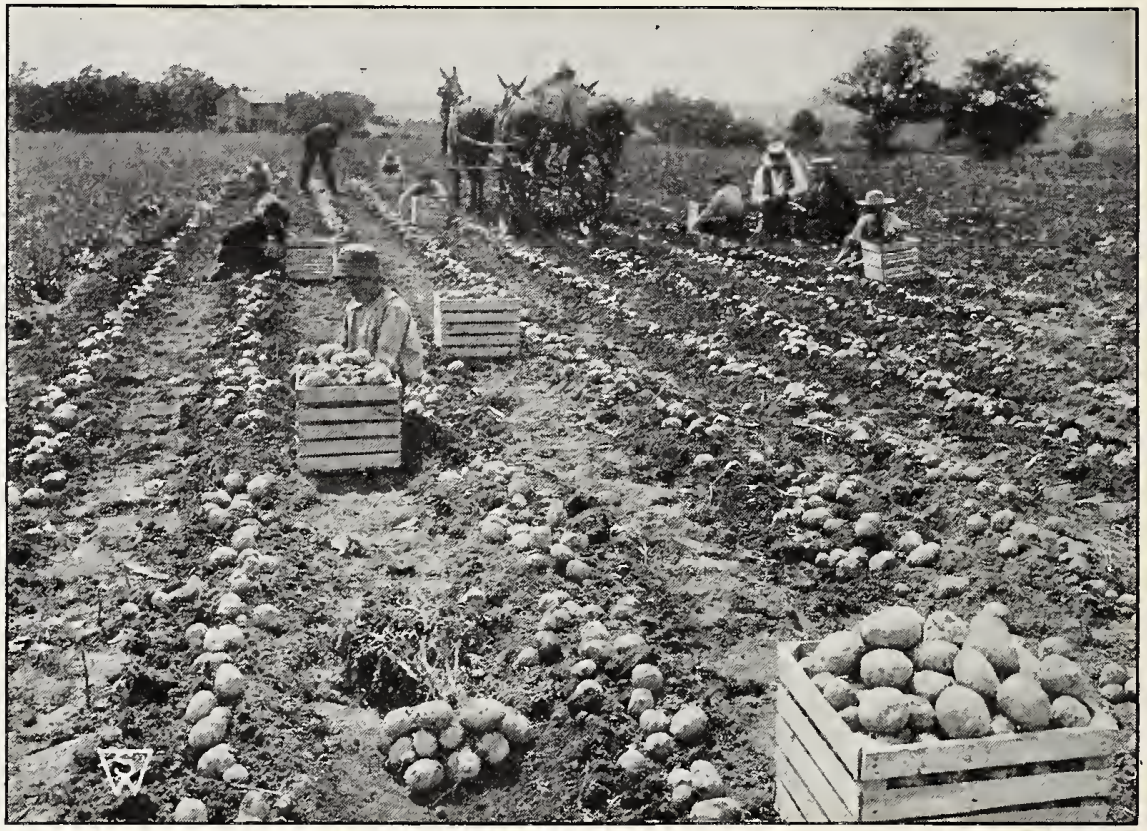

BEST EARLY POTATOES

Early White Albino. This wonderful new early Potato is a Early White Albino. good cropper. The skin and flesh are extremely white, of exceptionally good cooking quality and very prolific, fully as early as the old Early Rose in maturing, and particularly valuable for the early market by reason of its fine shape and early maturity. The vines grow erect, and it is one of the best early varieties to withstand blight and disease. Plant this Potato early in good soil, give it good cultivation, and pleasing results will be sure at harvesttime. One grand thing in favor of this early Potato is its great keeping quality which makes it a valuable sort for the home- or marketgarden. $1 / 2$ pk. $\$ 1$, pk. $\$ 1.50,1 / 2$ bus. $\$ 2.50$, bus. $\$ 4$, bbl. $\$ 9$.
Irish Cobbler. A variety that is more largely used as an early A vety than any other. The flesh white and bbl. $\$ 7.50$.

Early Bovee. (Selected.) Somewhat earlier than Early Rose. A medium-sized Potato; very productive. The dwarf growth of vines permits easy cultivation, insuring a good yield. $1 / 2 \mathrm{pk} .75 \mathrm{cts}$., pk. $\$ 1.25,1 / 2$ bus. $\$ 2.25$, bus. $\$ 3.75$, bbl. $\$ 8$.

Early Rose. (Selected.) A variety which has been grown extensively in some sections. A Potato of good size and fine quality. $1 / 2 \mathrm{pk}$. 75 cts., pk. $\$ 1.25$, I $/ 2$ bus. $\$ 2.25$, bus. $\$ 3.75$, bbl. $\$ 8$.

\section{BEST MAIN-GROP POTATOES}

Russet. Considered the finest Potato extant. The haulm is dark green and very distinct, while the variety seems to be as near blightRusse. proof as a Potato can be. The tubers are round to oblong, very large, and from 6 to Io are ordinarily obtained from a hill; the flesh is pure white and the skin has a roughened russet ap

Gold Coin. A splendid main-crop variety of remarkable productiveness and finest table quality; slightly oblong form; light golden skin; flesh pure white, fine-grained; cooks very dry. $1 / 2 \mathrm{pk} .75 \mathrm{cts}$. pk. $\$ 1.20,1 / 2$ bus. $\$ 2$, bus. $\$ 3.50$, bbl. $\$ 7.50$.

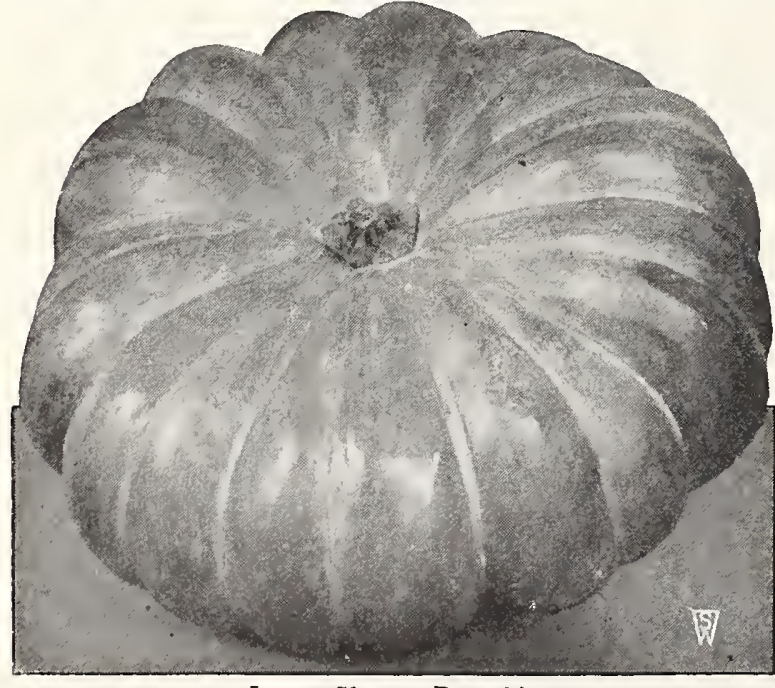

Large Cheese Pumpkin
Green Mountain. (Selected Stock.) A late, heavy cropper of excellent quality; skin smooth and white; shape roundish flat; eyes few and shallow; a good keeper. $1 / 2 \mathrm{pk}$. $75 \mathrm{cts}$., pk. $\$ 1.20,1 / 2 \mathrm{bus} . \$ 2$, bus. $\$ 3.50$, bbl. $\$ 7.50$.

\section{PUMPKINS One oucco will plant}

Culture.-Plant in April or May, among corn, or in the garden, in hilis 8 to Io feet apart, and otherwise treat in the same manner as melons.

Large Cheese: A most popular variety. Fruit flattened, the diameter being two or three times more than the length, skin mottled light green and yellow, changing to rich cream-color as it matures; flesh tender and of excellent quality. Pkt. 10c., oz. 25c., 1/4lb. 65c., 1 b. $\$ 1.75$. Sweet or Sugar (New England Pie). The fruits are medium to small in size, of a bright orange color, and in shape are round, flattened at the ends. The flesh is of remarkably good cooking quality, very thick, and deep yellow in color. Pkt. Io cts., oz, 25 cts., $1 / 41 \mathrm{~b} .65 \mathrm{cts}$., lb. $\$ 175$.

Winter Luxury. Best pie Pumpkin; productive; keeps weil. Finely netted and russet in color. Pkt. Io cts, oz. $35 \mathrm{cts}$., 1/4lb. 9o cts., lb. $\$ 2.50$.

Mammoth Tours. An enormous Pumpkin The skin is pale gray-green in color, marbled deeper green, smooth and slightly ribbed. The flesh is yellow and of fair quality. Pkt. Io cts., oz. 35 cts., $1 / 41 \mathrm{lb}$. $\$$ I, $1 \mathrm{~b} . \$ 2.75$.

Golden Cushaw or Jonathan. Has an enlarged, fleshy neck. A thickmeated Pumpkin of good table quality. Pkt. Io cts., oz. $30 \mathrm{cts}$., $1 / 4 \mathrm{lb}$. 75 cts., 1 b. $\$ 2$.

King of the Mammoths. Recommended where size is the chief consideration-200 pounds or more being not an unusual weight for a single specimen. The fruit is flat-round; the skin is yellow, as also is the thick flesh. Pkt. Io cts., oz. 35 cts., 1/41b. \$1, lb. $\$ 2.75$.

Connecticut Field. Good for pies and for canning; also largely grown for stock feeding. Pkt. Io cts., oz. 20 cts., 1/4lb. $45 \mathrm{cts}$., 1b. $\$ 1.25$. 


\section{RADISH}

As early in the spring as the soil can be worked, sow any of the early round or olive-shaped varieties in rows, $1 / 2$ inch deep, with a foot to 18 inches between the rows. Sow thinly. If seedlings appear closer than one inch apart, they should be "thinned out." Hoe frequently to encourage rapid growth which insures high quality. The early spring sorts serve the purpose until June I5, when Icicle and Cincinnati Market are at their best. The summer sorts are good until frost from repeated planting. The winter varieties should be pulled after light frosts and stored like beets. Both summer and winter Radishes should be "thinned" to stand from 4 to 6 inches apart in the row. After the middle of May, do not sow the flat, round, and olive-shaped spring sorts. Sow White Icicle, Cincinnati Market, and Chartier. These resist hot weather well. About July I, sow the winter varieties.

\section{EARLY ROUND AND OLIVE-SHAPED VARIETIES}

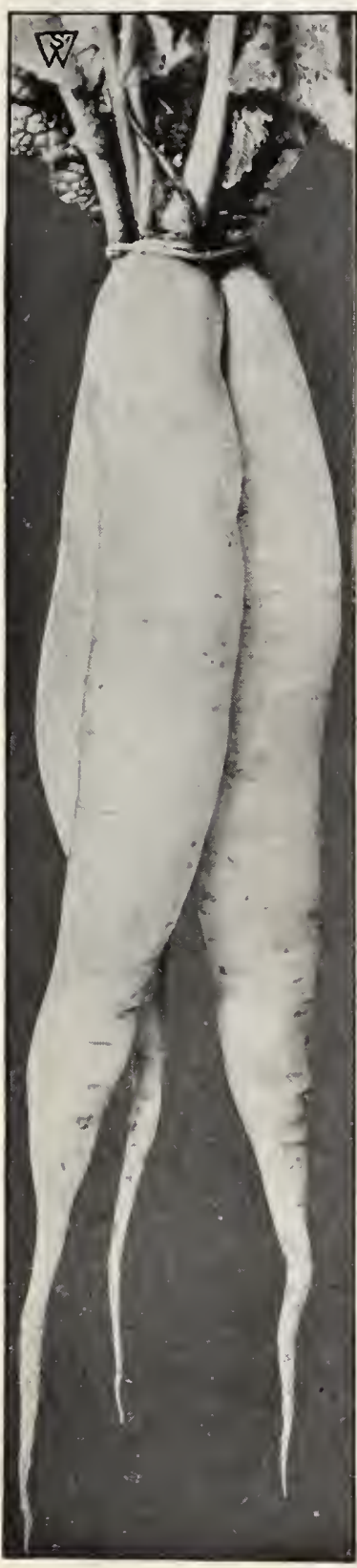

White Icicle Radishes
Early Scarlet Turnip. Within 25 days from date of fowing it perfects handsome, meter by $1 / 2$ inch deep through. Pkt. 10 cts., oz. 20 cts., $1 / 4$ lb. 45 cts., 1b. $\$ 1.25$.

Sparkler. Of rich carmine-scarlet color, with a very prowhen fully developed, are solid, crisp and sweet. It is equally well adapted for forcing in frames or growing in the open ground. While the leaves are small, they are sufficiently large for bunching. Plst. 10 cts., oz. 25 cts., $1 / 41$ b. 65 cts., lb. $\$ 1.75$.

Early Scarlet Globe. The best general-purpose variety in this class, perfecting handsome roots, as illustrated alongside, in from 28 to 35 days after sowing. Of distinct shape, brilliant color, short-leaved, crisp and white; an excellent variety for forcing. Pkt. 10 ets., oz. 25 cts., $1 / 4$ lb. 65 ets., 1b. $\$ 1.75$.

White Box. An almost globe-shaped sort, slightly flattened, White Box. with pure white skin and crisp flesh. Unlike most other early sorts, it remains in fine table condition until quite overgrown. Ready in from 35 to 40 days. Pkt. 10 ets., oz. 20 cts., $1 / 4$ lb. 55 cts., $1 b . \$ 1.50$.

Olive-shaped Scarlet. Flesh bright and crisp. Pkt. Io cts. oz. 25 cts., $1 / 4 \mathrm{lb}$. 65 cts., lb. $\$$ I.75.

Olive-shaped White. Pkt. IOc., OZ, 25c., I/4lb. 65c., lb. \$I.75. French Breakfast. The olive-shaped counterpart of Sparkler among the early round sorts, as described above. Mild and crisp. Pkt. Io cts., oz. 20 cts., 1/4lb. 45 cts., lb. $\$ 1.25$.

Twenty-day Leafless. (See Novelties, page (9.) Pkt. I5 cts.; oz. 45 cts., $3 / 4$ lb. $\$$ I. 30, lb. $\$ 3.50$.

\section{BEST EARLY LONG SORTS}

White Icicle, The "best all-round" Radish for all purmarket and splendid for growing under glass. Within 30 days from sowing seeds, the roots attain a length of 4 to 5 inches, by $3 / 4$ inch in diameter at the thickest part. The skin is thin, the flesh crisp and mild. It remains in fine table condition longer than any other early sort, regardless of shape. (See illustration.) Pkt. 10 cts., oz. 20 cts., 1/4lb. 55 cts., 1 b. $\$ 1.50$.

Cincinnati Market. By far the best strain of the long, scarlet, short-top Radishes. Roots 6 to 7 inches long, an inch thick through, are produced within 35 days after sowing and they remain in perfect condition for the best part of a week. Skin rosy scarlet, blending into pure white at the tip. It is well to remember that the long sorts require a deep, rich soil, free from stones and of a loose, santy nature, in order to develop perfectly. Pkt. 10 cts., oz. 20 c's., $1 / 4$ lb. 55 cts., lb. $\$ 1.50$.

\section{SUMMER VARIETIES}

Long Scarlet Chartier, or Shepherd. This might be considered "the connecting link" between the foregoing sorts and the very much later kinds that follow. Long Scarlet Chartier is ready in about 45 days after sowing. The color at the top is crimson, running into pink about the middle, and from thence downward is a pure white. Pkt. Io cts., oz. $20 \mathrm{cts}$., $1 / 4 \mathrm{lb}$. 55 cts., lb. \$I.50.

Early Golden Yellow Oval. Absolutely unsurpassed in heatresistance. When ready for use, the Radishes average $I I / 2$ to 2 inches in diameter and have a beautiful, golden yellow skin, which should be removed when preparing roots for table. Flesh pure white, mild, crisp, and solid. Pkt. Io cts., $0 z .30 \mathrm{cts}$., $1 / 4$ lb. 75 cts., lb. $\$ 2$.

White Strasburg. Shape tapering; skin and flesh both white; excellent summer variety. Pkt. IOc., oz.20c., I/41b.45c., 1b. \$1.25.

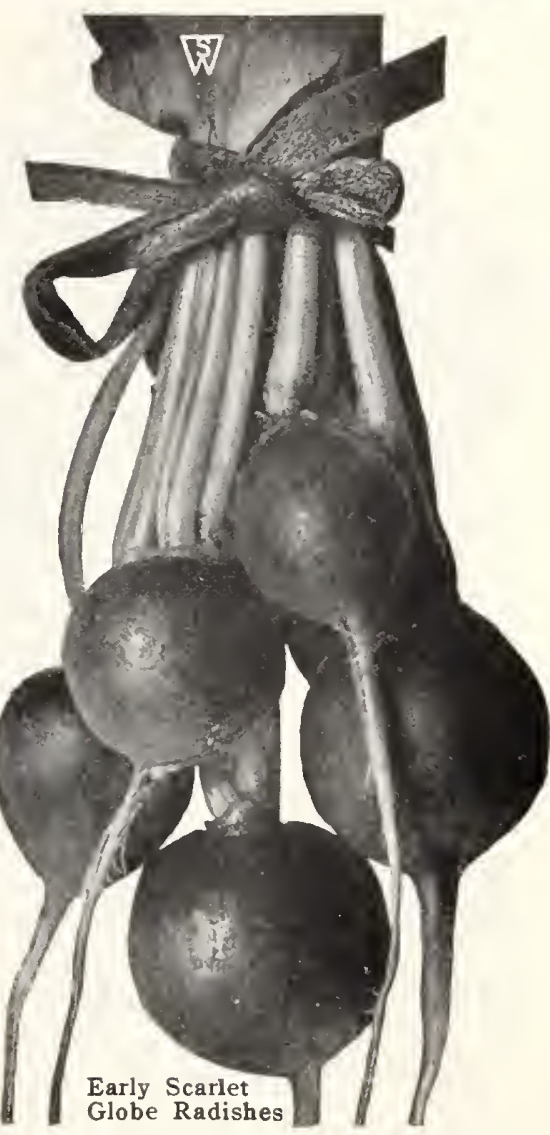

LONG-KEEPING WINTER RADISHES

Sakurajima. A Japanese sort which reaches truly remarkable size. The circumference of some is 43 inches, the length $2 \mathrm{I}$ inches. The skin is white and the flesh is always crisp and tender. The taste is more delicate than our American varieties. Pkt. Io cts., oz. 35 cts., $1 / 4 \mathrm{lb} . \$ 1, \mathrm{lb} . \$ 3$.

California Mammoth White Winter. A white-fleshed Radish of excellent quality. Pkt. Io cts., oz. 35 cts., $1 / 4 \mathrm{lb} .90 \mathrm{cts}$, lb. $\$ 2.50$

Rose China. Bright rose color; flesh firm and piquant; fine for winter use. Pkt. IOc., Oz. $20 \mathrm{C}$., ${ }^{\mathrm{I} / 4 \mathrm{lb}}, 55 \mathrm{c} ., \mathrm{lb} . \$ \mathrm{I} .50$.
Long Black Spanish. The popular winter sort. Pkt. Io cts., oz. 25 cts., I/4 lb. 65 cts., 1b. \$I.75.

Round Black Spanish. Thick black skin and pure white flesh. Pkt. Io cts., oz. 25 cts., I/4lb. 65 cts., Ib. $\$ 1.75$.

\section{RHUBARB}

Culture.-Plant the roots in well-manured land, 3 feet apart. Sow seed in spring in drills a foot apart; transplant the following season 3 feet apart. One ounce of seed should produce about I, ooo roots. Rhubarb Roots. I 5 c. each, \$I . 50 per doz. \$IO per I00; extra-strong clumps, $25 \mathrm{C}$. each, \$2.50 per doz., \$20 per 100; forcing clumps, 5oc. ea., $\$ 5$ per doz., \$35 per 100. Rhubarb Seed. The variety Victoria; has given good results for many years.
Pkt. Io cts., oz. $35 \mathrm{cts}$., $2 / 4 \mathrm{lb} . \$ \mathrm{I}, \mathrm{lb}$. $\$ 3$. 


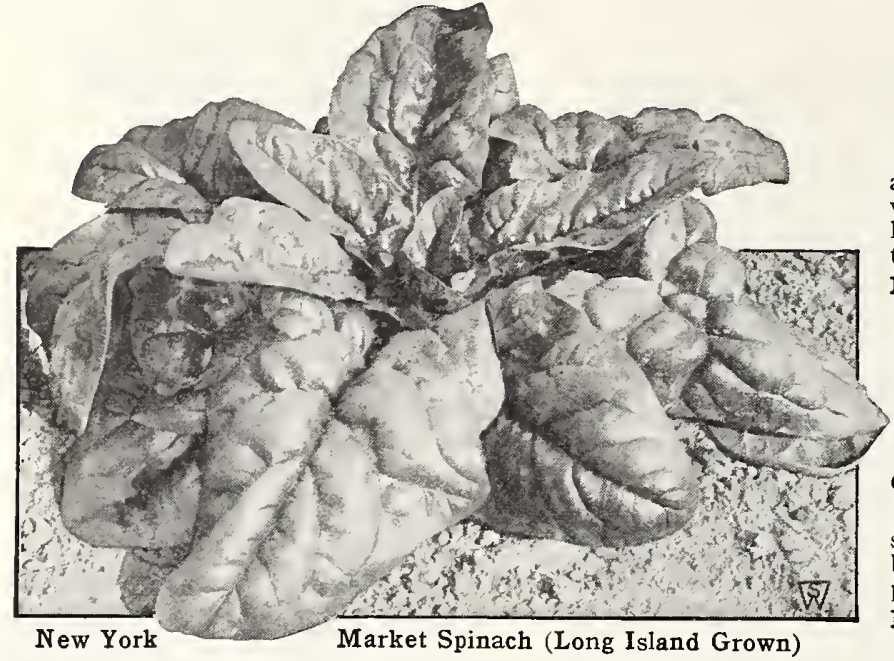

\section{SALSIFY (Vegetable Oyster)}

CULTURE.- Sow the seed early in spring, in drills 12 inches apart and $I$ inch deep, thinning out the young plants to 6 inches. The roots will be ready in October, when a supply should be taken up and stored like carrots. Those remaining will suffer no injury by being left in the ground until spring.

Mammoth Sandwich Island. Tender and delicious. Superior to all other sorts. Pkt. Io cts., oz. $35 \mathrm{cts}$., I/4lb. $\$$ I, lb. $\$ 3$.

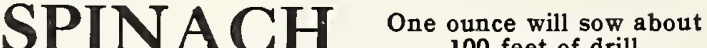 100 feet of drill}

Culture.-Sow in March or April in drills an inch deep and 14 inches apart; again in August or September. Spinach delights in very rich soil-in fact, it is of no use sowing in a poor one.

S. $\&$ W. Co.'s New York Market. This Spinach grows rapidly and produces unusually large, thick, manured, the plants very of ten measure 2 feet across, and stand the winter better than any other sort of Spinach. Pkt. 10 cts., oz. 20 cts., $1 / 41$ b. 55 cts., 1b. $\$ 1.50$.

S. E W. Co.'s Savoy-1eaved. A variety highly valued alike by market-growers and home-gardeners. . The leaves are wrinkled and crumpled, resembling, to an extent, the Savoy cabbage. The variety is profitable on account of the heavy yield of produce, is particularly hardy, and ours is a special strain of the long-standing type. Pkt. 10 cts., oz. 15 cts., $1 / \mathbf{4 l b . ~} 30$ cts., lb. 75 cts.

S. $\&$ W. Co.'s Large Thick-leaved. A splendid variety for the market-grower and trucker. The leaf is large and very thick. The fact that Thick-leaved is a type that is slow to run to seed makes it a favorite for late spring and early fall seedings. Pkt. 10 cts., oz. 15 cts., $1 / 41 b .30$ ets., 1 . 75 cts.

Princess Juliana. Delicious table quality is the outstanding feature of this fine Spinach. Also, it sowing in midsummer and stands longer without runnins to seed than other kinds, and is therefore excellent for

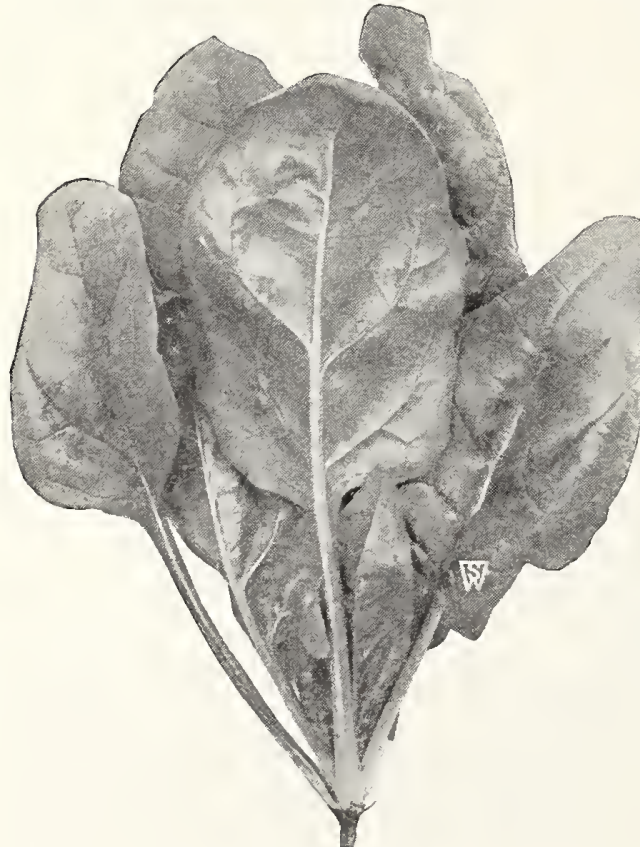

Large Thick-leaved Spinach. A variety that is slow to "bolt" to seed wrinkled leaves of a lush, deep green. Excellent in every

way. Pkt. 10c., oz. 20c., 1/4lb. 50c., lb. \$1.25.

Long Season. A distinct variety, standing from two to three weeks longer than any of the other sorts in this climate without going to seed. Pkt. Io cts., oz. I5 cts., 1/4lb. 30 cts., 1b. 75 cts.

Monstrous Viroflay. A fine selection of the old lettuceleaved Spinach. Excellent for summer use. Pkt. Io cts. oz. I 5 cts., I/4lb. $30 \mathrm{cts}$., lb. 75 cts.

Victoria Long-Standing. A variety suitable alike for spring and fall seeding. It is of low, compact habit; leaves shining dark green and heavily crumpled, forming a dense, flat rosette with very short petioles. Victoria is a great favorite with the market-grower on account of the slowness with which it shoots to seed. Pkt. Io cts., oz. $15 \mathrm{cts} ., 1 / 4 \mathrm{lb} .30 \mathrm{cts} ., \mathrm{lb} .75 \mathrm{cts}$.

Prickly or Winter. The hardiest Spinach, and a variety of actual merit. Used chiefly for latest fall seedings. Pkt. Io cts., OZ. I 5 cts., 1//4lb. 30 cts., lb. 75 cts.

S. \& W. Co.'s Emerald Standing. See Novelties, page 19. Pkt. Io cts., oz. 20 cts., I $/ 4$ lb. $55 \mathrm{cts}$., lb. $\$ 1.50$.

Perpetual Spinach. See Novelties, page I9. Pkt. I 5c., oz. 45 c., 1/4 1b. $\$ 1$.30, lb. $\$ 3.50$.

\section{NEW ZEALAND SPINACH}

\section{(Tetragonia expansa)}

A half-hardy annual cultivated for its young leaves which form an excellent substitute for Spinach. The plants grow very vigorously, do not run to seed, and withstand drought much better than Spinach. New Zealand Spinach should therefore find a place in every garden, to furnish a summer supply of green boiled vegetables. It is recommended for use, also, on soils too poor to carry Spinach of the true type, as it grows naturally on dry upland situations.

Sow during May, in drills which should be at least 2 feet apart, as the plants spread rapidly. Thin to 9 inches between the plants in the row. Pkt. Io cts., oz. $20 \mathrm{cts}$., 1/4lb. $55 \mathrm{cts} ., 1 \mathrm{~b}$. $\$ 1.50$. 


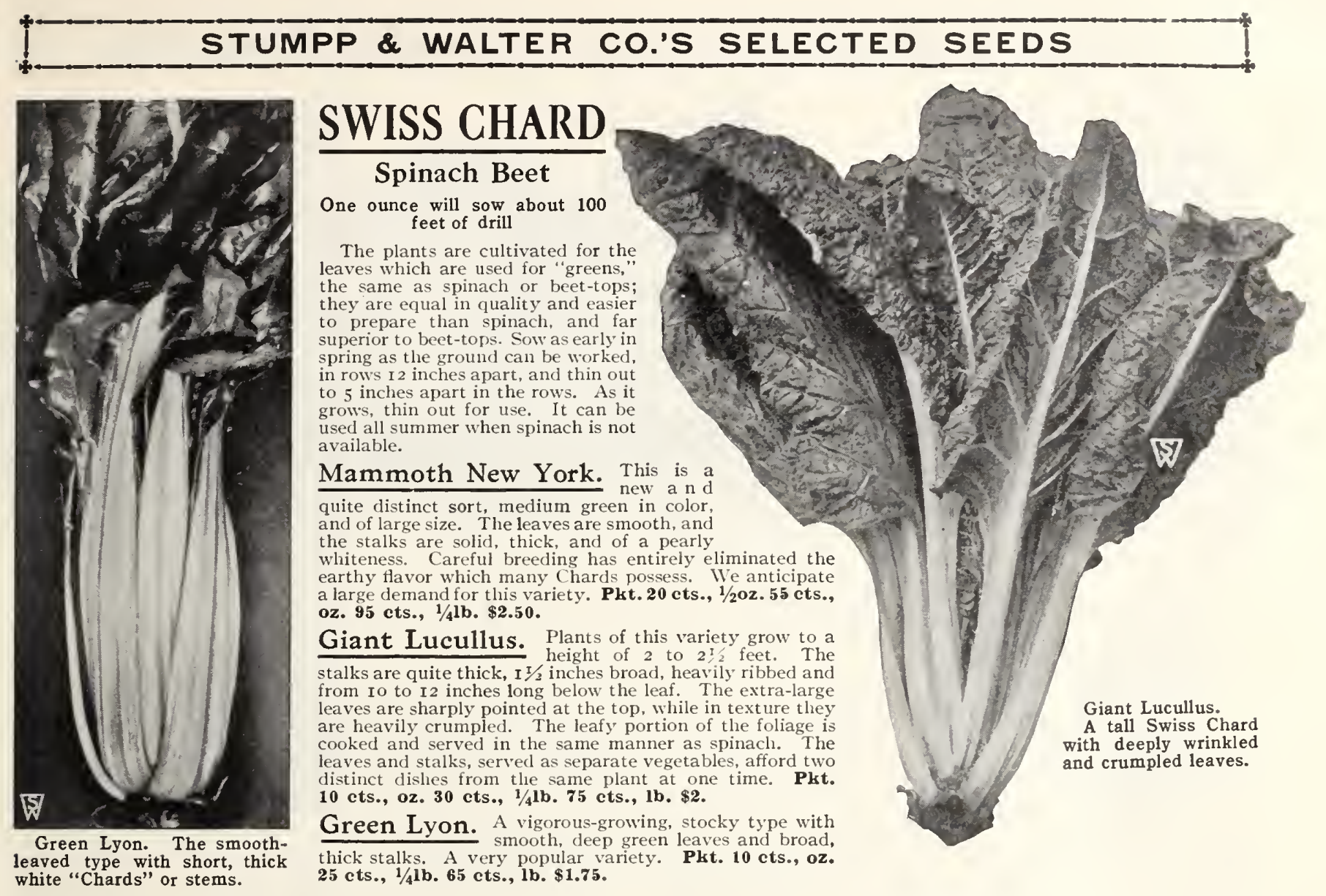

\section{SEA KALE}

One ounce will produce about 300 plants

Sow in drills 2 feet apart, thin out to 6 inches, and the next spring plant in hills I 8 inches. apart. The blanched leaf-stalks are boiled and served with cream sauce. A very usual method of cultivation is to dig the roots and "force" them during winter in the same way as Witloof. Pkt. $20 \mathrm{cts}$., 1/20z. $50 \mathrm{cts}$., oz. $90 \mathrm{cts}$., I $/ 4$ lb. $\$ 2.40,1 b . \$ 6.50$.

\section{SORREL}

One ounce will sow about 100 feet of drill Curture - Sow early in the spring in drills 6 to 8 inches apart.

Garden. Used for salads, and much esteemed on account of its pleasant acid flavor. Also widely used in many sections of the country as a boiled vegetable. The plant is perennial, and will yield for several years. Pkt. $20 \mathrm{cts.0}$ oz. $65 \mathrm{cts}$., I $/ 4$ lb. $\$$ I.75, lb. $\$ 5$.

\section{TOBACCO $\begin{gathered}\text { One ounce of seed will produce } \\ \text { sufficient plants for one acre }\end{gathered}$}

Sow under glass during February and plant out, 3 feet apart each way, during early June.

Connecticut Seed-Leaf. A variety which can be used for cigar Narrow-Leaf Oronoko. This is widely used in Virginia for cigar wrappers and for general purposes. Pkt. Io cts., $0 z .75 \mathrm{cts}$.

fillers and as a cigarette tobacco. Pkt. Io cts., oz. $75 \mathrm{cts}$.

\section{Vitamins in Vegetables}

Vitamins are elusive chemical substances that are present in minute quantities in some foods. They have little nutritive value in themselves, but their presence is necessary before foods nourish us.

We have always known that plenty of fresh vegetables make for good health, but only now are we learning that it is the Vitamins in them which are responsible; that they are more abundant in some vegetables than others; that Vitamins are found in these vegetables mostly when fresh.

We obtain most Vitamins when we eat salads, and we should partake of them freely-mixed salads, with plenty of lettuce, endive, radish, and mustard and cress seedlings. Tomatoes, too, should be used freely for they have so much of a!l the Vitamins that their juice is equal to orange-juice for growing children; the juice of rutabaga is similarly excellent for the young. Celery should be included, for it has Vitamin B and happens, also, to be helpful in rheumatism and nerve-troubles, and do not forget pulling-onions, or, better still, chives. Then, we should not omit the cooked vegetables, served chilled with salads: asparagus, rich in Vitamin A; celeriac with Vitamin $B$; parsnips with both $A$ and $B$; and turnips with both $B$ and $C$

In the cooked "greens," also, we find health, but it is better to steam them than to boil them, because cooking quickly dissolves Vitamin $C$, and that is why water used for cooking vegetables should always be saved and used as a base for soups. The most important of these "greens" is spinach, rich in all the Vitamins and furnishing the valuable minerals, iron and lime, as well; but equally good are beettops, turnip-tops, broccoli, swiss chard, kale, and brussels sprouts.

The more substantial cooked vegetables-beans, carrots, etc.supply us with abundant food-values in addition to Vitamins. Snap beans and peas, both rich in lime, give us Vitamins $\mathrm{A}, \mathrm{B}$, and $\mathrm{C}$, while the sprouted beans, which are a feature of Chinese cooking, are especially rich in Vitamin $\mathrm{C}$; carrots, yielding phosphorus, furnish $\mathrm{A}$ and $\mathrm{C}$; sweet corn, $\mathrm{A}$ and $\mathrm{B}$; while kohlrabi has $\mathrm{C}$.

Vitamin A promotes healthy growth, its absence from the diet being responsible for rickets in children. Vitamin B maintains normal bodily functions, and when it is missing we suffer from digestive troubles, neuritis, and anæmia. Scurvy appears and we lack stamina when the supply of Vitamin $C$ is cut off.

The greater variet $y$ we have in regetables the better, and the fresher they are the more Vitamins they contain. Enjoy the widest variety, fresh from the garden; in other words, Grow Plenty of Vegetables. 


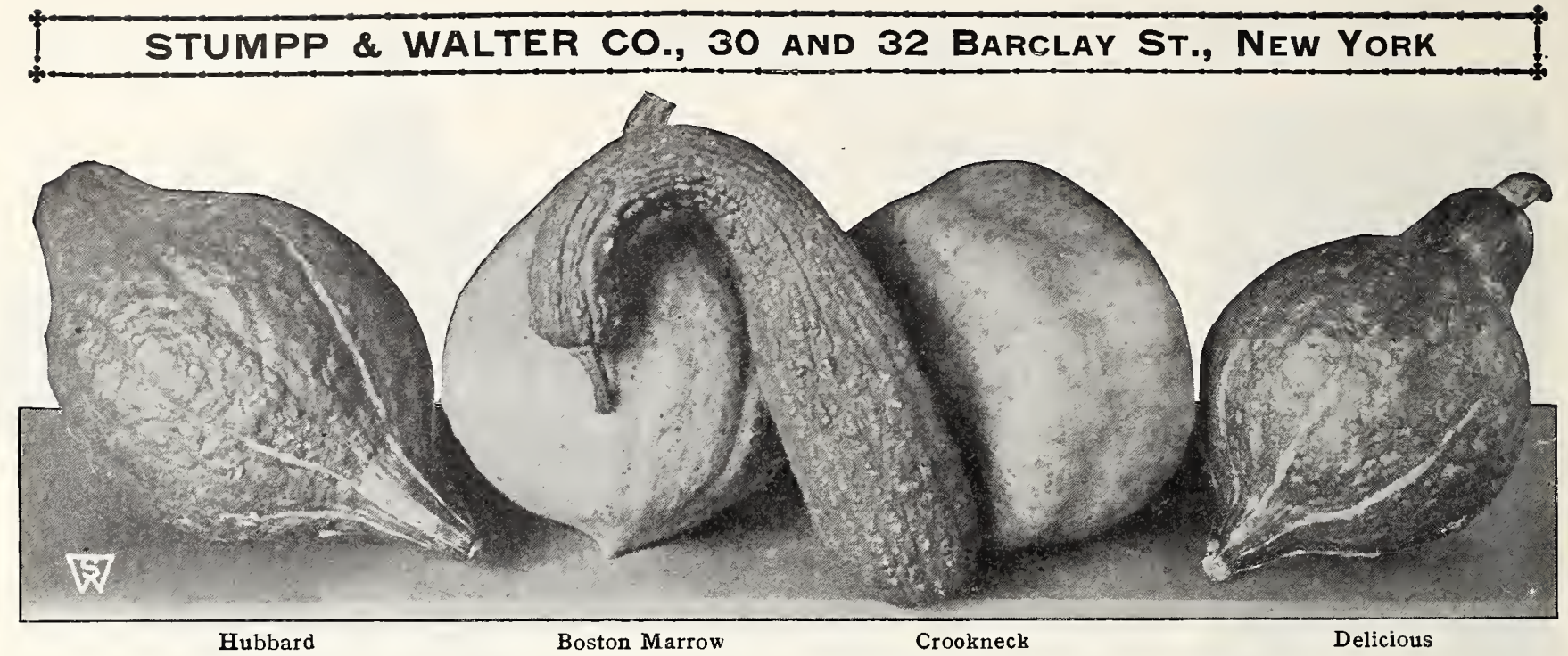

\section{$0 \bigcirc A$ A $10 \begin{aligned} & \text { One ounce of Early Squash will plant about } 25 \text { hills } \\ & \text { One ounce of Vegetable Marrow will plant about } 50 \text { hills }\end{aligned}$}

Note.-Although Pumpkins and Squash have been reclassified, we are continuing for this year to place them under their more commonly known headings.

CULTURE. - It is not advisable to plant before May 15. Sow in hills in the same manner as cucumbers and melons.

\section{SUMMER VARIETIES}

Long Island White Bush. A selection of the Old White improvement upon it, having less prominent ridges and being much deeper. In addition to this, it is of finer quality and very prolific. Pkt. 10 cts., oz. 30 cts., $1 / 4$ lb. 75 cts., 1 b. $\$ 2$.

Giant Bush Summer Crookneck. The Crookneck surpasses in quality any of the summer varieties, and in the Giant Bush we have the delicious buttery flavor of the original sort, but of just double the size. Pkt.10c., oz. 25c., 1/4lb.65 cts., 1b. $\$ 1.75$.

Table Queen. An early Squash, small in size (the fruits averaging 6 by 4 inches), but produced in great abundance. The flesh is refined, dry, and rich. Table Queen may be gathered when the skin is dark green, or may be left on the vines to ripen into a bright orange. Pkt. Io cts., oz. 35 cts., $1 / 4 \mathrm{lb}$. $\$ \mathrm{I}, 1 \mathrm{~b}$. $\$ 3$.

Fordhook. Although a summer Squash, Fordhook will also keep well for winter use. The fruits are pointed, nearly a foot long, and about 5 inches in diameter; the rich, buttery flavor is quite distinct and very fine. Pkt. Io cts., oz. $30 \mathrm{cts}$., 1/4lb. $75 \mathrm{cts}$., lb. $\$ 2$.

Golden Custard. Mammoth strain of the Early Yellow Scalloped Bush. Quality excellent. Pkt. Io cts., oz. 30 cts., 1/4lb. 75 cts., $1 \mathrm{~b} . \$ 2$.

\section{FALL OR WINTER VARIETIES}

Chicago, or Warted Hubbard. A selection of the largest Chicago, or Warted Hubbard. and best rough-skinned specimens of Green Hubbard. Ideal for the home market. Vines of strong, robust growth; fruits large, heavily warted, splendid shape and dark green; flesh :ich and dry. Pkt. 10 cts., 02.30 cts., $1 / 41 b .75$ cts., lb. $\$ 2$.

Golden Hubbard. For the private garden. The fruits are of Golden Hubbar. the same shape as the Green Hubbard, except that they average one-half to one-third less in size. Flesh deep gold, much richer in color than Hubbard. Cooks dry and of rich flavor. Pkt. 10 cts., oz. 30 cts., 1/4lb. 75 cts., lb. $\$ 2$.

Hubbard. Bluish green color, occasionally marked with brownish Hubbard. orange. Will keep from September to May. Pkt. 10 cts., oz. 30 cts., 1/41b. 75 cts., lb. $\$ 2$.

Boston Marrow. A very popular Squash for fall or winter use. Bright orange color, flesh yellow; oval in form. A splendid keeper and excellent for pies. Pkt. Iocts., oz. 30 cts., $1 / 4$ lb. 75 cts., 1 b. $\$ 2$.

Delicious. No Squash approaches it in its remarkable combination of fineness and compactness of grain, dryness, sweetness, and exceeding richness of flavor. It grows to weigh from 5 to Io pounds, and is in its prime in mid-autumn and early winter. Pkt. Io cts., oz. 35 cts., $1 / 41$ b. 90 cts., lb. $\$ 2.50$.

\section{VEGETABLE MARROW}

A type of Squash that always occupies an important place in European gardens, and one which is considered superior in many respects to our American varieties of Summer Squash. Cultivation is similar, although to obtain quickest and largest yields it is often grown on spent hotbeds or in a few inches of soil placed on a manure-pile. The Marrows are gathered before they ripen-usually in about a similar stage of maturity to that of cucumbers when gathered for slicing. They are peeled, divided, and the seeds are removed; then cut into 3 -inch squares, boiled until tender and served as a melting and delicious side dish with cream sauce.

Long Green Trailing. The fruits are about 20 inches in length and 3 to 4 inches in diameter. The skin is dark green, marbled with a paler shade. Pkt. 15 cts., oz. 35 cts., $1 / 4$ lb. $\$ 1,1$ lb. $\$ 3$.

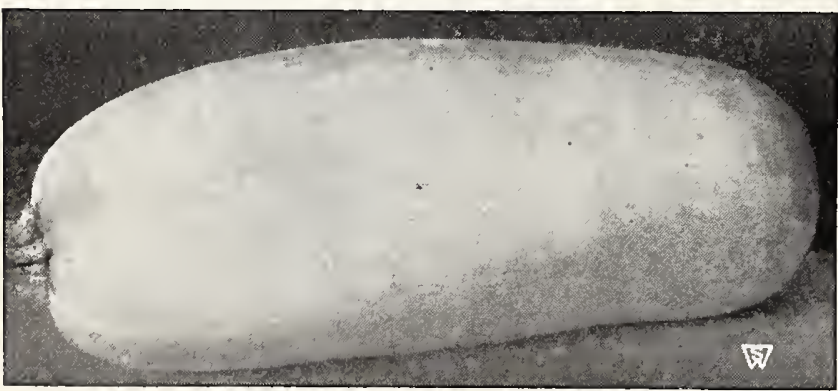

Long White Trailing Vegetable Marrow
Long White Trailing. The fruit is a little shorter than the it is similar in shape. The skin is smooth and of a yellowish white. The flesh is remarkably tender. Pkt. 15 cts., oz. 35 ets., $1 / 4 \mathbf{l b}$. $\$ 1$, lb. $\$ 3$.

Moore's Cream. An improved small-fruited variety; the fruits are oval in shape, cream-colored and of a very delicate flavor. Pkt. I5 cts., oz. 45 cts., 1/4lb. $\$$ I.3o, 1b. $\$ 3.50$.

Italian Vegetable Marrow (Cocozelle Squash). A nonfruits a foot in length and about 5 inches in diameter; handsomely mottled dark green and light. A great favorite. Pkt. 10 cts., oz. 35 cts., $1 / 4$ lb. $\$ 1,1 b . \$ 3$.

Zucchini Squash. See Novelties, page I9. Pkt. 20 cts., oz. 65 cts., $1 / 4$ lb. $\$ 1.75$,

Mixed Vegetable Marrow. Trailing and non-trailing, all varieties in combination. Pkt. I $5 \mathrm{cts}$., $0 z .35 \mathrm{cts}$., $1 / 4 \mathrm{lb} .90 \mathrm{cts}$., $1 \mathrm{~b} . \$ 2.50$. 


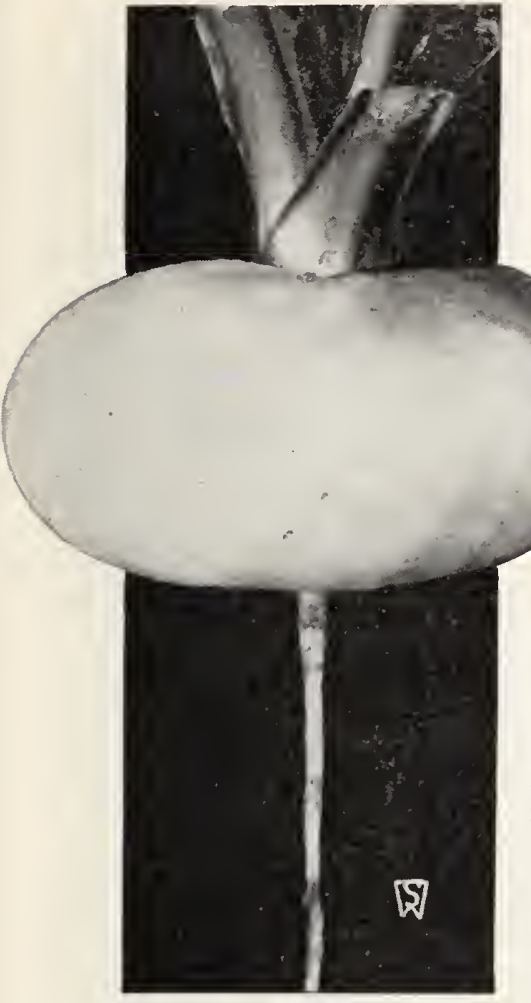

Early White Milan Turnip. One of the earliest varieties in cultivation

\section{TURNIP}

One ounce will sow about 150 feet of drill

CUlture.-For early Turnips, sow as soon as the ground opens in spring. Rutabagas should be sown from any time in June to first of August; but the other kinds, for winter use, nay be sown from the middle of July to the end of August. Turnips are generally sown broadcast, but much larger crops are obtained (particularly of the Rutabagas) by cultivating in drills I 8 inches apart, and thinning to 6 inches in the drill. Sow in drills, one pound to the acre; broadcast, two to three pounds to the acre.

\section{FINE WHITE-FLESHED TYPES}

Early White Milan. As early as Purple-Top Milan and possessing all of its good qualities. The entire "bulb," inside and out, is clear ivory-white in color; the outer surface is perfectly smooth. It grows so quickly that even the outer surface of the "bulb" is quite tender. Its table qualities are unequaled, being of the most delicate flavor and tempting appearance. Pkt. 10c., oz. 30c., $1 / 4$ lb. 75c., 1b. $\$ 2$.

Purple-Top White Globe. This variety may be large size without developing signs grown to quite a spherical shape, the skin white with the upper one-third colored reddish purple. The flesh is pure white, firm, finegrained, and of superior flavor. A handsome looking bulb, rapidly taking the lead of all other varieties of early Turnips for market and home-gardening purposes. It is one of the best sorts to store for winter, and, in addition to its fine table qualities, it is excellent and economical for stock feeding. Pkt. 10 cts., oz. 20 cts., $1 / 41$ lb. 45 cts., $1 b . \$ 1.25$.
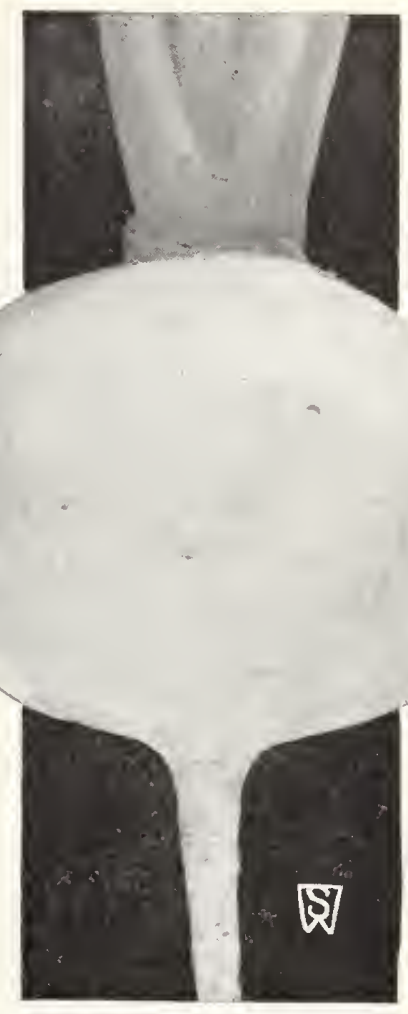

Snowball. A particularly refined table Turnip

Snowball. An excellent first-early, globe-shaped root; smooth, clean, and free from all coarseness. A variety that is recommended par-

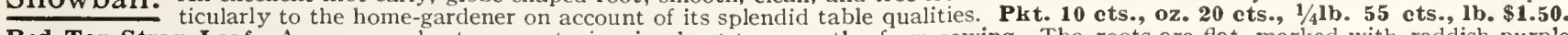
Red-Top Strap-Leaf. A very popular type, maturing in about two months from sowing. The roots are flat, marked with reddish purple on the upper portion; the flesh is pure white and of fine quality. Pkt. Io cts., oz. $20 \mathrm{cts} ., 1 / 4$ lb. 45 cts., lb. $\$ 1.25$.

Early Purple-Top Milan. An excellent smooth-skinned flat Turnip; the upper portion is tinted purple, but the flesh is pure white, delicate, and sweet. Pkt. Io cts. oz. $25 \mathrm{cts} ., 1 / 4 \mathrm{lb} .65 \mathrm{cts} ., \mathrm{lb}$. $\$$ I. 75 .

Long White, or Cow Horn. A quick-growing, long-shaped variety; flesh fine-grained and sweet, excellent for table use. Pkt. Io cts., Oz, $20 \mathrm{cts}$. 1/4lb. $55 \mathrm{cts}$., lb. $\$$ I. 50 .

White French, or Sweet German. A delicate-flavored variety; an excellent keeper and fine for table use. Pkt. Io cts., oz. I5 cts., 1/4lb. $40 \mathrm{cts} ., 1 \mathrm{~b} . \$ 1$.

\section{YELLOW-FLESHED TYPES}

Golden Ball, or Orange Jelly. This is the most distinct yellow Turnip we making it one of the best table varieties. know. The flesh is of a very fine texture, for it the synonym of "Orange Jelly," which well describes its appearance when ready for the table. The bulb is of medium size, with small tap-root, and is early in maturing. Pkt. 10 cts., oz. 20 cts., $1 / 4$ lb. 55 cts., 1 b. $\$ 1.50$.

Yellow Aberdeen. A very hardy and productive variety of fine form and excellent quality. It has a purple top, keeps remarkably well, and is excellent both for the table and for stock. Pkt. Io cts., OZ. $20 \mathrm{cts}$, 1/4 lb. $45 \mathrm{cts}$., lb. \$I. 25.

Yellow Stone. In shape a perfect globe, uniform, and of medium size; the color is pale yellow, and the quality is of the best, being very melting and buttery. A favorite variety that is to be recommended. Pkt. Io cts., oz. I 5 cts., 1/4lb. 40 cts., lb. \$I.

\section{AN ALL-LEAF TURNIP}

Seven Top. In this variety there is but little development of root. The leaves, however, are very numerous and large, and the vegetable is recommended to those who esteem "Turnip-tops," as a particularly healthful and palatable green cooked vegetable, many considering it superior to spinach. Pkt. 10 ets., oz. 20 cts., $1 / 41$ b. 45 cts., 1b. $\$ 1.25$.

\section{RUTABAGA (Russian or Swedish Turnip)}

S. \& W. Co.'s Long Island Improved. This special strain of Rutaby a very careful grower. It is of a remarkably uniform shape and fine quality, and is also a splendid keeper. It grows to a large size, the skin is smooth, and flesh is beautiful yellow and fine-grained. Pkt. 10 cts., $0 z .20$ cts., $1 / 41$ b. 45 ets., $1 b . \$ 1.25$.

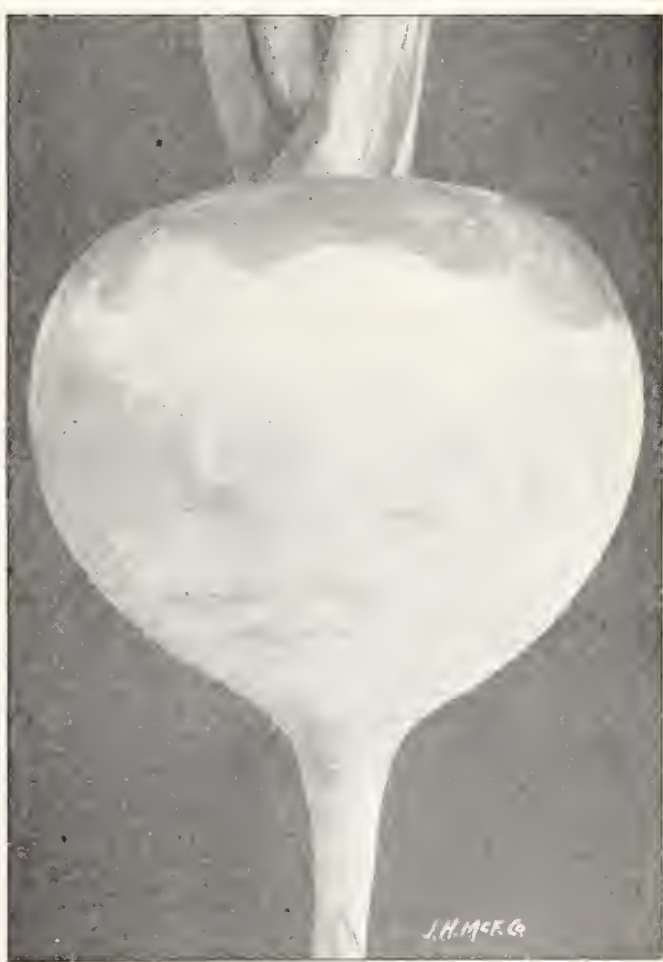

Purple-Top White Globe Turnip 


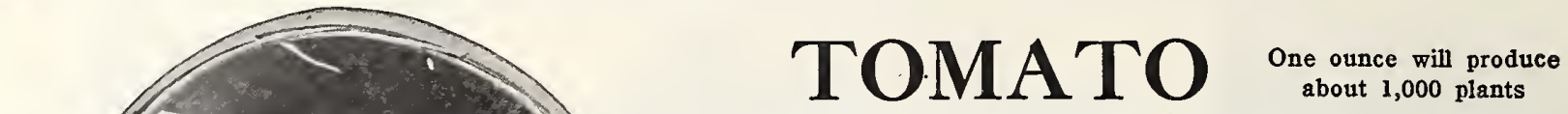

Culture.- The seed may be sown in a hotbed from about the second week in February up to the end of April, in drills 5 inches apart and $1 / 2$ inch deep. When the plants are about 2 inches high they should be transplanted about 4 inches apart, or planted in 4-inch pots, allowing a single plant to a pot. About May 15, the plants may be set out in the open ground, 3 feet apart. Water freely at the time of transplanting. Sufficient plants for a small garden may be started by sowing a few seeds in a shallow box or flower-pot and placing it in a sunny window. For a final seeding it is not too late to sow seed during June, using early varieties and sowing in the open ground. The fruit is greatly improved in quality if the vines are tied to a trellis or to stakes.

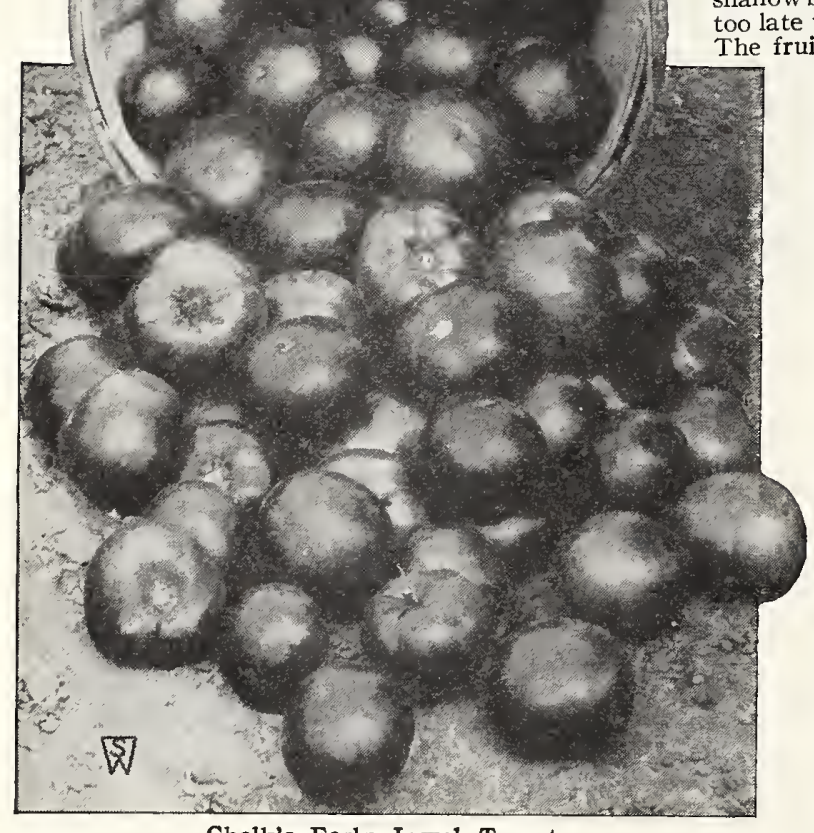

Chalk's Early Jewel Tomato

Stone. By far one of the best and most reliable of the main-crop red Tomatoes and the standard and general favorite with truckers and canners. The plant is very vigorous and the deep red fruits are produced freely; they are uniform, large, round, smooth, meaty, and possess very little core. The flavor is fine and non-acid. Stone is superior to any other main-crop Tomato for its heavy yield and high quality. We offer a specially selected stock. Pkt. 15 cts., oz. 65 cts., $1 / 41$ b. $\$ 1.75,1 b . \$ 5$.

Earliana. The Earliest Red Tomato. The plants are of compact . growth, with short, close-jointed branches, setting the fruit very freely in the center. The Tomato is of uniform size, averaging 3 inches in diameter, and from 2 to $2 \frac{1}{2}$ inches in depth; solid, with few seeds, making a splendid variety for shipping. Pkt. 10 cts., $1 / 20 z .40$ cts., oz. 65 cts., $1 / 4$ lb. $\$ 1.75, \mathrm{lb} . \$ 5$.

Ponderosa. Enormous size is the chief characteristic of this variety. Few Tomatoes equal it in this respect, and while slightly ribbed, it is very solid and luscious, making it fine for the family garden. The fruit is deep purple, oblong in form, ridged or ribbed, and with small seed-cells. They frequently weigh one pound or more each. The flavor is good, and we recommend Ponderosa for the home-garden. Pkt. 15 cts., $1 / 2$ oz. 60 ets., oz. $\$ 1,1 / 41 b$. $\$ 3.25,1 b$. $\$ 10$.

Crimson Cushion or Beefsteak. The largest of the bright red Tomatoes. Crimson Cushion is more symmetrical in shape than Ponderosa and is much thicker through from stem to blossom end; in fact, so marked is this characteristic that it is frequently almost round. The color is brilliant scarlet-crimson, untinged with purple, and the fruit ripens up almost to the sterı. The flesh is firm and "meaty," and of superb quality. Pkt. 15 ets., 1/20z. 50 ets., oz. 90 cts., 1/41b. $\$ 2.75$, lb. $\$ 8$.

Bonny Best. Considered among the best of the early sorts. The fruits

CHALK'S EARL Y JEWEL. About a week later than Earliana. It is of uniformly toes throughout the season, and for quantity and quality of fruit it is easily without a rival among the best extra-earlies. Pkt. Io cts., I/20z. 40 cts., oz. 65 cts., $1 / 41 \mathrm{~b} . \$ \mathrm{I} .75$,
lb. $\$ 5$.

MATCHLESS. The color is rich cardinal-red. The skin is so tough that it is a splendid keeper and shipper, and is less liable to crack in wet weather than any other large Tomato. Unsurpassed for market or for table. The plant is a strong grower and is very productive, bearing with undiminished vigor until frost. The fruit is free from core, and the seed-spaces are comparatively small. In flavor among the best. Pkt. Io cts., $1 / 2 \mathrm{Oz}$. $40 \mathrm{cts}$., oz. $65 \mathrm{C}$, I $/ 4 \mathrm{lb} . \$ 1.75, \mathrm{lb} . \$ 5$.

S. \& W. CO.'S EXHIBITION STRAIN OF NEW GLOBE. Considered the best type of Globe Tomato. Very smooth, solid, firm, delicious, with few seeds, and ripens evenly. Color a beautiful glossy rose, tinged purple, and a splendid shipping variety. Pkt. 20 ets., $1 / 2$ oz. 60 cts., oz. $\$ 1,1 / 41 b . \$ 3$.

ESSEX WONDER. A heavy-yílding, popular English variety. See page I9. Pkt. 50 cts.

\section{A NEW TOMATO}

\section{Resists Wilt and Rust}

Marglobe. This is a large Tomato of the globe type, in color a fine scarlet, and of delicious table quality. It fruits early and continues to yield up to frost. Its remarkable feature is its strong. robust constitution; it resists wilt and is immune to rust, and will therefore produce healthy fruit during long periods of wet, unfavorable weather. Marglobe is recommended for the large estate and for the homegarden; for the market grower, the shipper of car-lots, and for the canner. Also, it performs splendidly under glass, forcing well. Pkt. 20 ets., $1 / 2$ oz. 60 ets., oz. $\$ 1,1 / 41$. $\$ 3.50$.
It is of uniformly
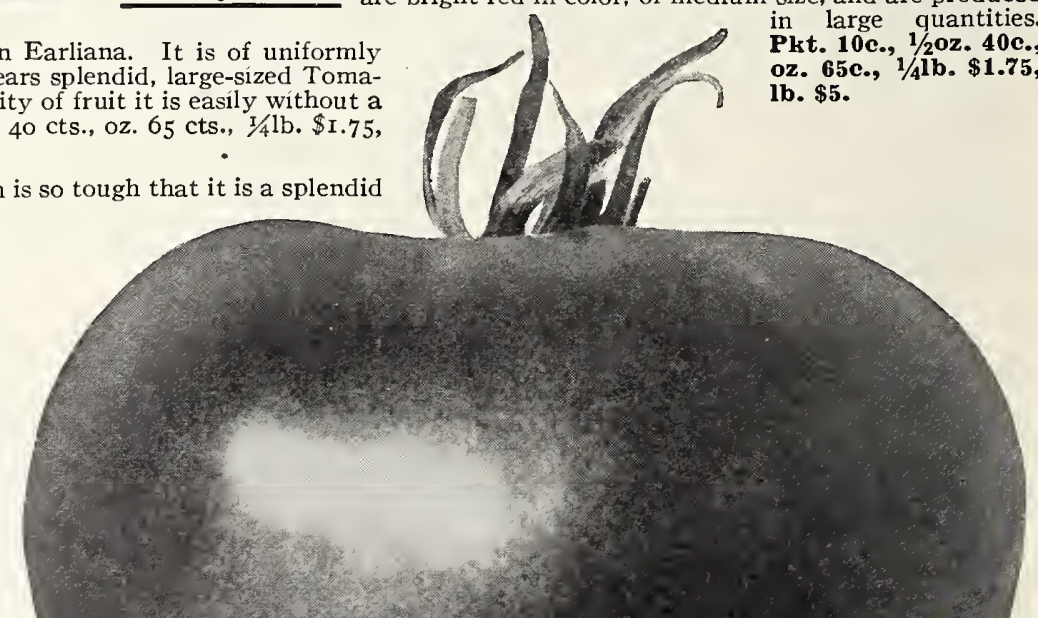
in large quantities. Pkt. 10c., 1/20z. 40c.,

lb. $\$ 5$.
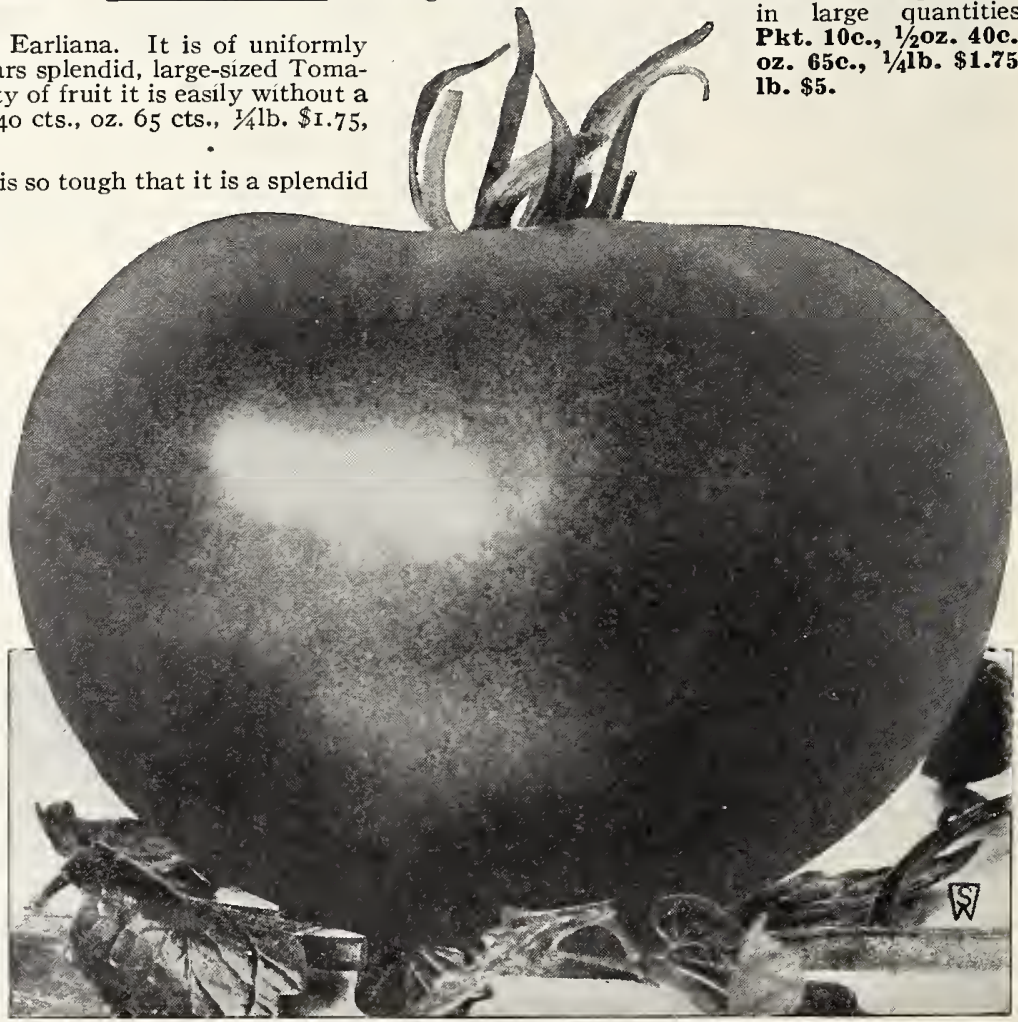

Crimson Cushion or Beefsteak Tomato 
STUMPP \& WALTER CO.'S SELECTED SEEDS

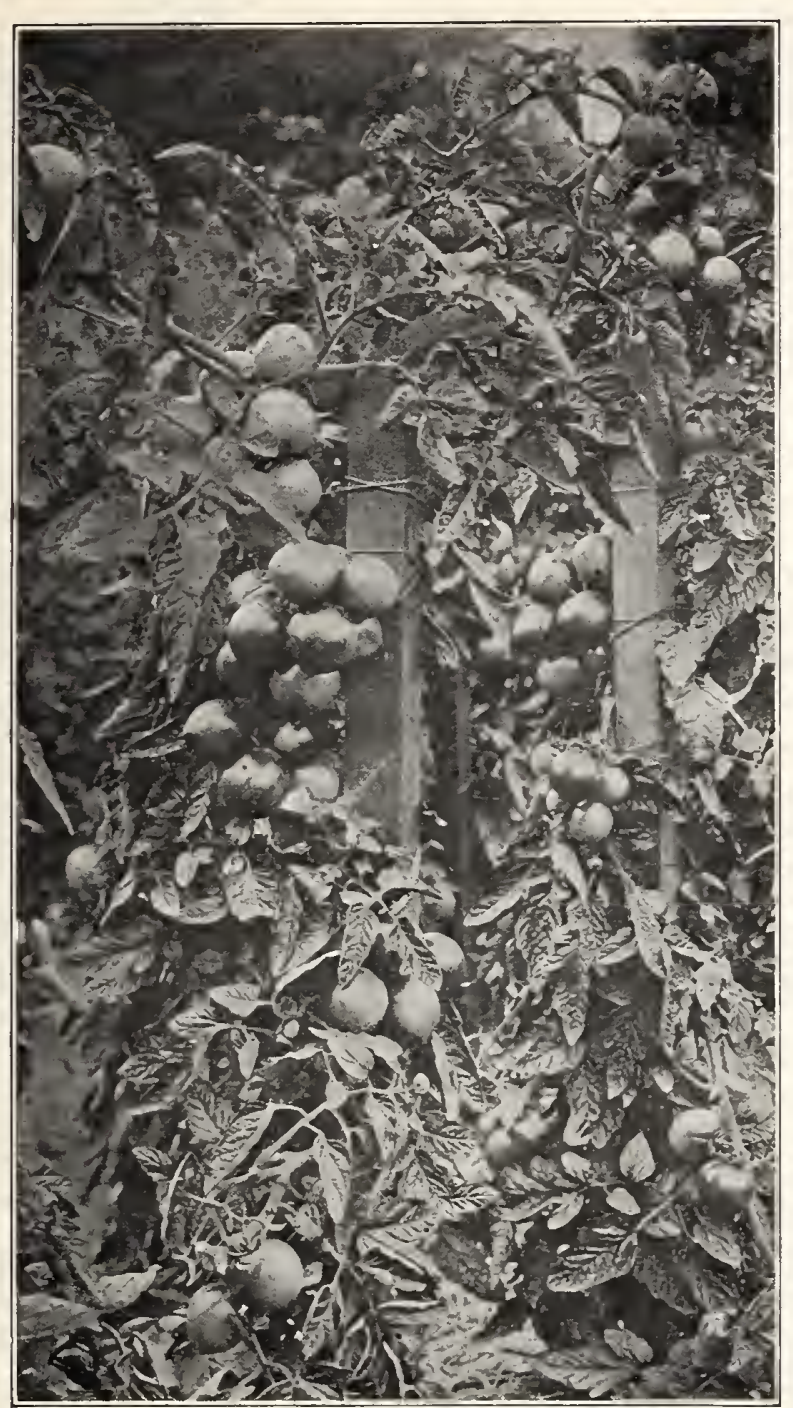

John Baer Tomato. The plants have been trained to a single stem

\section{A Remarkable Tomato}

John Baer. An early, bright red Tomato of wonderful quality. ohn Baer. But little later than Earliana, it far surpasses that variety in size and quality; it is, further, one of the heaviest-yielding sorts we know. The flesh is solid, possessing a fine flavor, free from acid. The fruits contain remarkably tew seeds, and in this connection it is interesting to note that for seed purposes we find it requires over seven bushels of hand-selected, perfect fruits to produce one pound of seed. A special strain which has been grown under our personal supervision. Pkt. 15 ets., $1 / 202.50$ ets., oz. 90 ets., 1/41b. $\$ 2.75$, 1b. $\$ 8$.

\section{The Best Yellow Tomatoes}

Golden Ponderosa. A large golden yellow Tomato of exripens early. In shape very much like the Scarlet Ponderosa. Golden Ponderosa, served sliced and accompanied by a high-class scarlet variety, similarly sliced, presents an appetizing combination difficult to resist. Pkt. 15 cts., $1 / 2$ oz. 60 ets., oz. $\$ 1,1 / 41 b . \$ 3,1 b . \$ 10$.

Golden Queen. An excellent type for slicing. Rich golden superior flavor. Pkt. 15 cts., oz. 65 cts., $1 / 41 \mathbf{l b}$. $\$ 1.75,1 \mathbf{b}$. $\$ 5$.

\section{Two Dwarf Tomatoes}

Dwarf Champion. Distinct potato-like foliage and a sturdy, stocky plant; fruits medium size and purplish pink in color. Pkt. $15 \mathrm{cts.,}$ $1 / 2$ Oz. 40 cts., oz. 65 cts., 1/4lb. $\$ 1.75,1 b . \$ 5$

Dwarf Stone. The fruits, produced in clusters of three to five, average 4 inches in diameter and $2 \frac{1}{2}$ inches in depth. Pkt. I 5 cts., $1 / 2$ Oz. 40 cts., oz. 65 cts., $1 / 4$ lb. $\$$ I. 75 , Ib. $\$ 5$.

\section{Small-Fruiting Tomatoes}

The fruits of these are much used for making fancy pickles, preserves, etc., while their size, shape, color. and flavor make them desirable additions to salads. The plants are extremely productive.

King Humbert. In shape and size, King Humbert is suggestive of a hen's egg. The fruits are briglit scarlet in color and are frequeritly produced in enormous clusters. Pkt. I5 cts., $1 / 202.45$ cts., oz. 75 cts., $\pi / 4 \mathrm{lb} . \$ 2.75$
Yellow Cherry

Red Currant

Peach
Red Cherry

Above eight varieties: Pkt. $10 \mathrm{cts}$., $1 / 2$ oz. 35 cts., 0 z. $60 \mathrm{cts}$, $1 / 4$ lb. $\$ 1.75$

Strawberry or Husk Tomato. The plants are of dwarf, spready growth and very productive. The fruit is yellow, about the size of a good-sized strawberry and is enclosed in a liusk. Pkt. Io cts., $1 / 20 z .35$ cts., oz. $60 \mathrm{cts.}, 1 / 41 \mathrm{lb}$. \$1.75.

\section{Forcing Tomatoes}

Varieties recommended for cultivation under glass, yielding during winter and spring.

S. E W . Co.'s Best of All. A variety of matchless form smooth round and wonderfully prolifits and color. Fruits beautiful, Color rich scarlet-red. Equally good for outdoor culture as for forcing. Pkt. 20 cts., $1 / 40 z .50$ cts., oz. $\$ 1.50$.

Comet. Grown very largely by both private and market-garstem. The Tomatoes are of medium size; deep scarlet. Pkt. 15 cts., $1 / 4$ oz. 30 cts., oz. $\$ 1$.

Stirling Castle. A very superior variety for either forcing or Stiring Castle. outdoor culture. Very heavy cropper, of medium size, smooth and round. Color a clear red. Remarkable for its free setting qualities and delicious flavor. Pkt. 15 cts., $1 / 4$ oz. 30 cts., oz. $\$ 1$.

Sunrise. A fruit of fine quality, medium in size, perfectly round, and produced in characteristic long clusters. It is considered by many growers to be the best indoor Tomato grown, and the best outdoor variety where a small "whole-salad" type of fruit finds favor. Sunrise has won many awards and prizes. Pkt. 20 cts., $1 / 40 z$. 40 cts., oz. $\$ 1.25$.

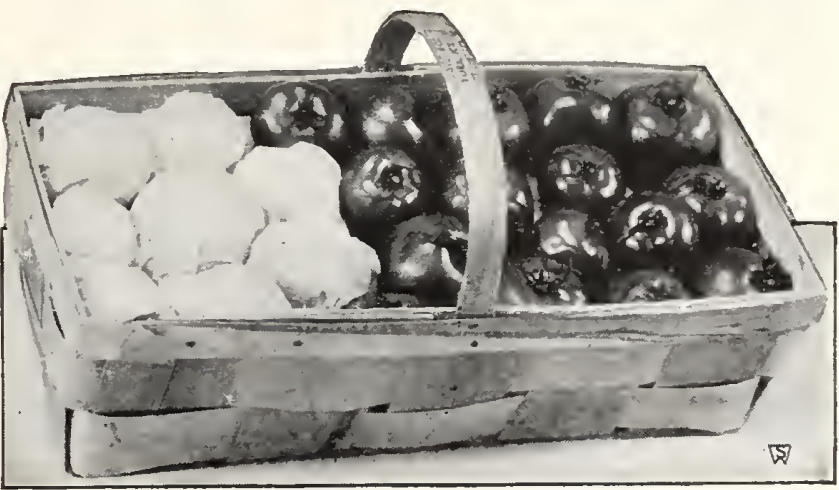

Greenhouse-grown Tomatoes as shipped during the winter months into the New York market

Uniform containers holding Io pounds are used, and the individual fruits are wrapped in tissue paper. A suitable Tomato weighs 4 ounces, and in shape is a deep globe, the color bright scarlet. Best of All, Comet, and Stirling Castle are varieties largely used under glass. 


\section{Vegetable Roots and Plants}

Artichoke Roots, Jerusalem. See page 20.

Asparagus Roots. For full description, culture and prices, see page 20.

Chives. Used for flavoring. We supply large, growing clumps. $25 \mathrm{cts}$. each, $\$ 2.50$ per doz.

Horse-Radish Roots. Will produce good Horse-Radish, fit for use in one season's growth. Plant

the root so that the top will be 2 inches under the ground. $25 \mathrm{cts}$. per doz., \$1.50 per roo.

Mint Plants. Selected pot plants. Used for Mint sauce and juleps. $25 \mathrm{cts}$. each, $\$ 2.50$ per doz.

Rhubarb Roots. See page 47.

Sweet Potato Plants. Red or Yellow variety. Ready in June. \$1.50 per Ioo, \$10 per I, 00o.

Tarragon Plants. Used for seasoning. Strong pot plants, $35 \mathrm{cts}$. each, $\$ 3.50$ per doz.

Thyme, English Broad-leaved. Pot plants, $\$ 3$ per doz., $\$ 20$ per ioo.

\section{Vegetable Roots for Winter Forcing}

Send for circular giving descriptions and cultural treatment

Asparagus. Extra-large clumps of Pedigreed Washington. $\$$ I.50 per doz., $\$$ Io per I0o, $\$ 90$ per I,000.

Rhubarb Roots. Extra-large clumps of Giant Crimson Victoria. Excellent for forcing in the cellar or greenhouse during the winter months. $50 \mathrm{cts}$. each, $\$ 5$ per doz., $\$ 35$ per Ioo.

Witloof Chicory Roots. Extra-selected roots for forcing. $75 \mathrm{cts}$. per doz., $\$ 5$ per I oo, $\$ 40$ per I,ooo.

\section{Aromatic, Medicinal and Pot Herbs}

Anise (Pimpinella Anisum). Seeds aromatic and carminative....... Po so 80 . Arnica (Arnica montana). Valuable medicinal qualities. . ...

Balm (Melissa officinalis). For culinary purposes. 20

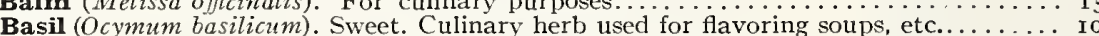

Bene (Sesamum orientale). The leaves used for dysentery.....

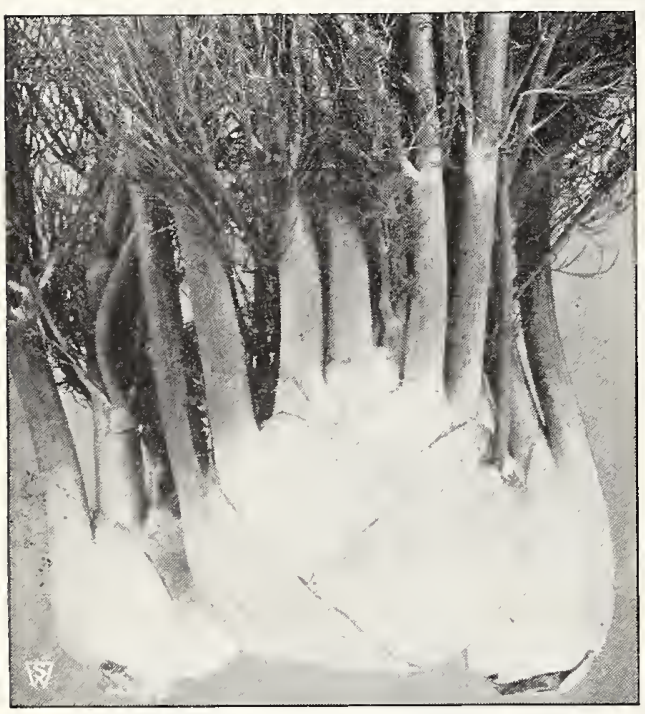

Sicilian Fennel or Finocchio
Borage (Borago officinalis). Leaves used as

Burnet (Poterium Sanguisorba). Used in the ....... I/4lb. \$I.50, lb. \$5..\$0 I 5 \$o 40 Caraway (Carum Carvi). Used in flayoring liquids acture of cooling drinks.. Io 25 Catnip (Nepeta cataria). Has medicinal qualities................ I5 40

Chamomile (Anthemis nobilis). Has both tonic and febrifugal properties. I5 Chives (Allium Schonoprasum). Used as a substitute for onions in soups and

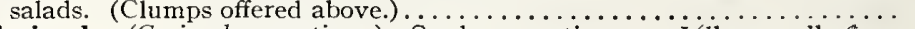

Coriander (Coriandrum sativum). Seeds aromatic....... I/4lb. 35c., Ib. \$1 .

Cumin (Cuminum cyminum). Known also as Fennel Flower. Seeds are

used as an ingredient in curry powder, pickles, soups, and pastry...... I0

Dill (Antheum graveolens). Seed used for flaviorng vinegar.... . 1/4 lb. 65c... I0

Fennel (Sicilian). True variety; rounded thickened leaf-bases. . 1/4lb. 80c... I0

Hop (Humulus lupulus)....................................... 25

Hyssop ( Hyssopus officinalis). Has medicinal qualities.............. I5

Lavender (Lavandula vera). True. For oil and distilled water............ I5

Marjoram (Origanum Majorana). Sweet. Used in seasoning............. I 5

Rosemary (Rosmarinus officinalis). Yields an aromatic oil and water..... I5

Rue (Ruta graveolens). Said to have medicinal qualities.............. I5

Saffron (Carthamus tinctorius). Used for medicine and also in dyeing ..... I5

Sage (Salvia officinalis). Common. A culinary herb; also used in medicine.. I I5

Savory (Satureia hortensis). Summer. Used as a culinary herb......... I5

Savory (Satureia montana). Winter. Employed in the kitchen for seasoning. I5

Tansy (Tanacetum vulgare). For flavoring; has some medicinal value...... 20

Thyme (Thymus vulgaris). English Broad-leaved. Employed for season-

ing; the oil is sometimes used in perfumery .................. I 5

Thyme (Thymus vulgaris). French. A small-leaved, less hardy type than

the above. Used for the same pur poses................... I5

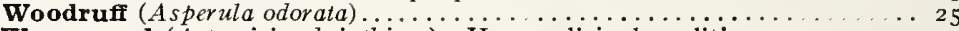

Wormwood (Artemisia absinthium). Has medicinal qualities .......... I5
I 00

I5

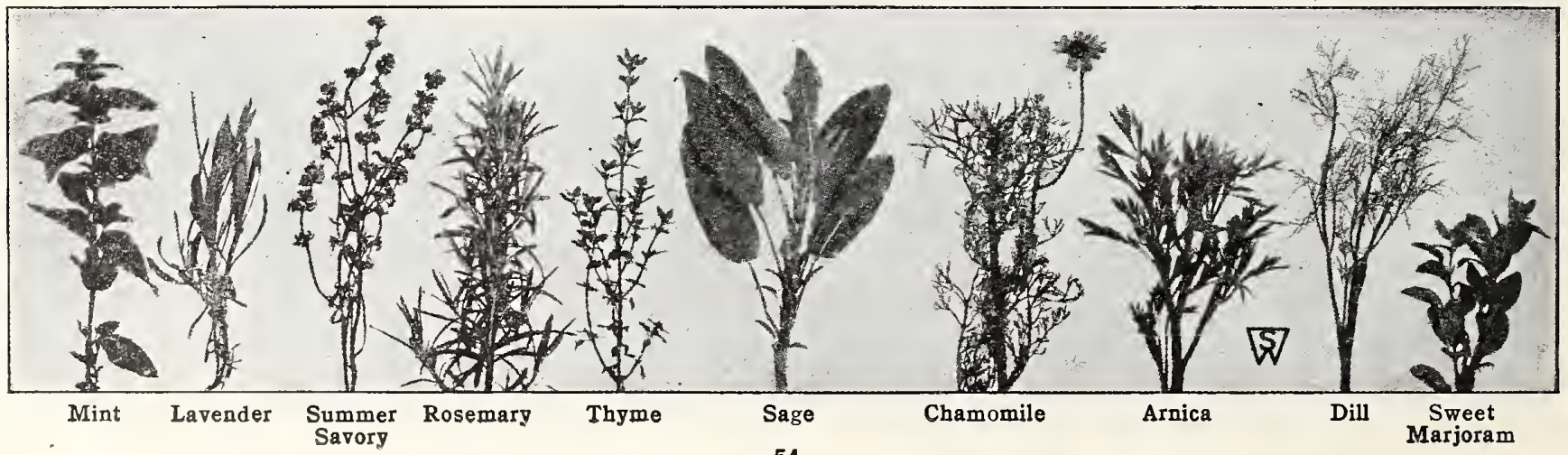




\section{STUMPP \& WALTER CO.'S SELECTED SEEDS \\ S.\&W.CO.'S SELECTED STRAINS OF FIELD CORN}

The various Field Corns offered on this page have had our personal inspection in their production. They are grown especially for us in territory that is free of European Corn Borer; our customers may therefore plant our seed with the fullest confidence. Prices are subject to change without notice. For better crops treat seed with Semesan Jr.

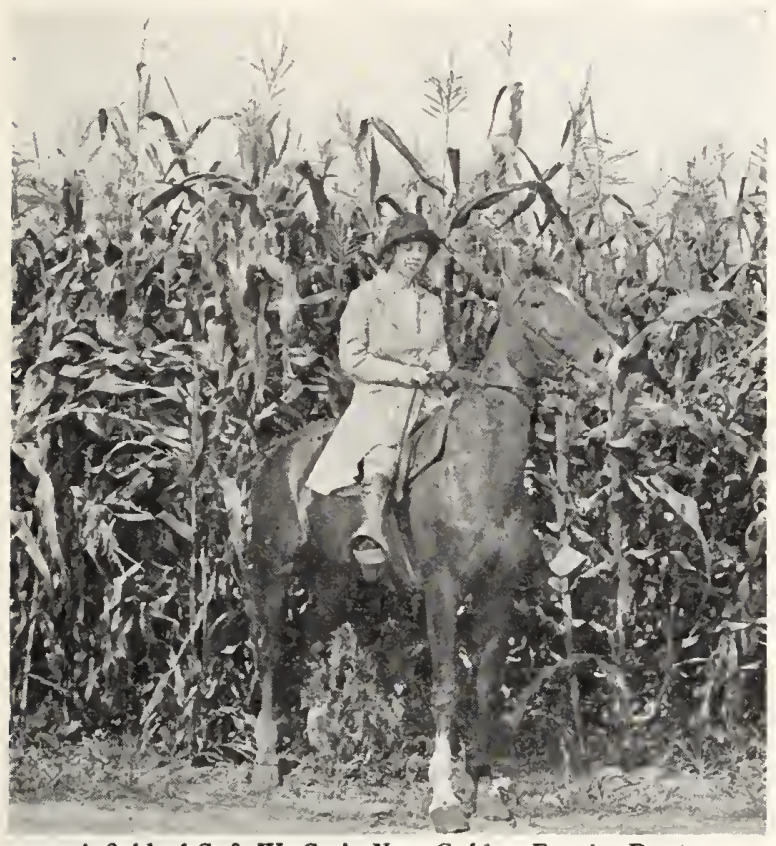

A field of S. \& W. Co.'s New Golden Eureka Dent

\section{New Golden Eureka Dent (IMPROVED}

We offer a specially select stock of this fine Corn, which has been meeting with great favor. It is a tremendous yielder. IVe have had reports of yields of over I 50 bushels of shelled Corn to the acre. The plants grow from 12 to $\mathrm{I} 5$ feet high, a great proportion of them bearing two ears to the stalk, the ears averaging I 2 to I 5 inches long, with i 8 to 22 rows of deep rich yellow grains and small cob. Seventy pounds of ears frequently yield 60 pounds of shelled Corn. While not so quick to mature as a Flint Corn, where Ioo days of "Corn weather" are assured, it is the best Corn to grow. A very fine variety for ensilage, and frequently produces 25 tons of good Corn silage per acre.
Qt. 25 ets., postpaid, 40 cts. ; pk. $\$ 1.50$, bus. $\$ 1.50,10$-bus. lots, $\$ 4.25$ per bus.

For better crops treat seed with Semesan Jr.

\section{Early Smoky Dent}

The earliest Dent Corn in cultivation. Many growers claim that it has every variety of Corn surpassed for early maturity, large size of ears and splendid quality; ears are 8 to Io inches long and have 12 to 16 rows of kernels on the cob. Stalks average, on good ground, 8 feet or more, and it matures generally in about 90 days from date of planting. It is thus a splendid dual-purpose Corn, valuable both for crib and silo purposes. Qt. 25 ets., postpaid, 40 ets.; pk. $\$ 1.50$, bus. $\$ 4.50,10$-bus. lots, $\$ 4.25$ per bus.

SEMESAN JR. A corn-disinfectant. Protects seed against rotting, increases germination, controls blight

Jumbo Silage

A first-class ensilage variety. Grows 12 to 15 feet high, with mammoth stems in proportion, and an enormous growth of leaves. Under favorable conditions it will produce ears a foot or more long, yielding two of them to a plant. Jumbo Silage Corn is recommended for rich, low lands, where it yields heavy fodder. Qt. 30 ets., postpaid, 45 ets.; pk. $\$ 1.50$, bus. $\$ 5,10$-bus. lots, $\$ 4.50$ per bus.

\section{Luce's Favorite}

The favorite for Long Island, eastern New York, and northern New Jersey. A Dent Corn which is a early as the Flint varieties, yet one that yields two to thrce ears per plant. The ears are crowded with 8 to I2 rows of broad dented golden kernels. The plant is a strong grower, and the leaves are broaa and long, making it an excellent sort for fodder and the silo. Qt. 30 cts., postpaid, 45 cts.; pk. $\$ 1.50$, bus. $\$ 4.75,10$-bus. lots, $\$ 4.25$ per bus.

Improved Early Horsetooth. Same as Southern Horsetooth, but better selected and earlier. Small stalks; much foliage, but rarely produces ears in northern U. S. Qt. 25 cts., postpaid, $40 \mathrm{cts}$; pk. $\$ 1.35$, bus. $\$ 4$, Io-bus. lots, $\$ 3.50$ per bus.

\section{Longfellow Flint}

This beautiful eight-rowed Flint often yields two good ears to the stalk. Ears sometimes 5 inches long Cobs small, kernels of good size. Safe for planting as far north as Massachusetts. Our stock of seed is of the best selection and has given a yield of over 100 bushels to the acre. Selected stock, qt. 25 cts., postpaid, 40 ets.; pk. $\$ 1.50$, bus. $\$ 4.50,10$-bus. lots, $\$ 4.25$ per bus.

\section{Pop-Corn}

Treatment is similar to that of field or sweet corn. Care given in curing determines the popping qualities place the ears under cover in thin layers with free access to the air. Sow 5 pounds per acre, in hills.

White Rice. Rough kernel. Recommended as the best general-purpose variety on account of its keeping better than others. Lb. 25 cts., postpaid, 35 cts.; Io lbs. \$2, Ioo lbs. \$ I 5 .

White Pearl. The kernels of this variety are small and smooth. Lb. $25 \mathrm{c}$., ppd., 35c.; Io lbs. \$2, IOO lbs. \$I 5 . Crow Repellent Seed Preserver for Corn, Large Can (2-bus. size) \$1.50; Small Can $\$ 1$

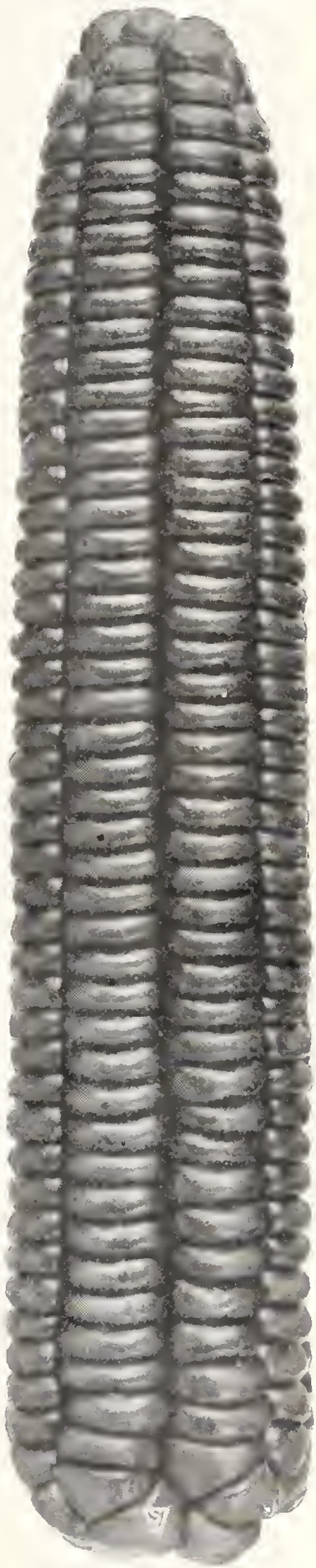

Longfellow Flint Corn 


\section{ROOT CAROPS FOR STOCK-FEEDING}

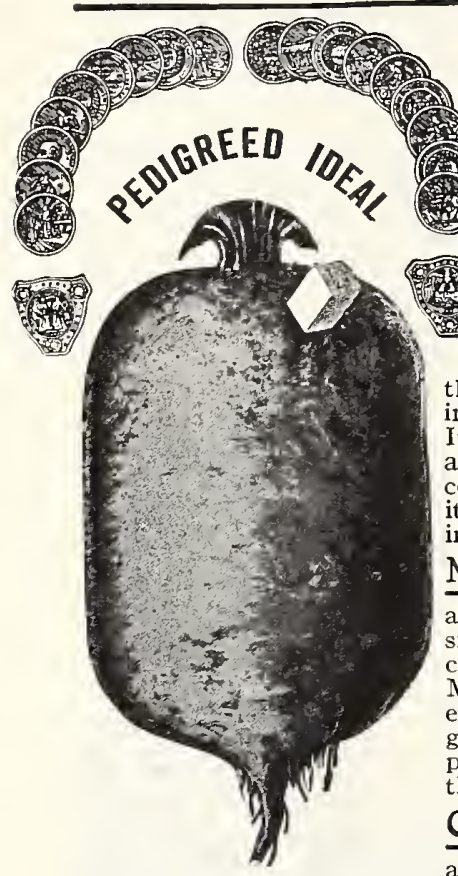

We recommend strongly to the cattle breeder, dairy farmer, and poultry raiser, Mangels, Carrots and Rutabagas. A palatable, easily stored, easily digested, and nutritious food is yielded in large quantities per acre. They stimulate the flow of milk of high grade; their cultivation ensures the thorough cleaning of the land; and they may be stored into the winter in root-cellars or outdoor "pits" with but little trouble.

\section{MANGEL-WURZEL}

Curture.- - Sow in drills during May or June, about 2 feet apart; thin out to 9 to 2 inches in the rows. The long varieties are best suited to a deep soil, and the globe sorts succeed better than the long sorts on shallow land. 6 to 8 pounds are required for one acre. Use Sawco General Garden Fertilizer.

Pedigreed Ideal. The food value of a Mangel depends upon the quantity of sugar and dry peding matter contained in its flesh. Forty years of patient breeding has so increased the sugar and dry matter in Pedigreed Ideal Mangel that it contains 50 per cent more than ordinary roots; in other words, one ton of Pedigreed Ideal is equal as food to one and a half tons of non-pedigree Mangels. It is formed like a cylinder, grows high out of the ground, and has but a single tap-root. It may thus be lifted at harvest-time with little effort, and it is suitable for growing in shallow soils. The root has a yellow skin, covering flesh which is white, crisp, and with a flavor that is exactly what stock desire: it is high in vitamines and its use promotes an increased flow of untainted milk. We offer seed produced in Europe by the originator. Oz. 20c., $1 / 41 \mathbf{1 b}$. 55c., lb. $\$ 1.50,101 b s . \$ 12.50$. Mammoth Long Red. This is the giant among Mangels, and the are of enormous size, very uniform in shape, smooth and clean, with but small top growth. The skin is bright, rich red, and under favorable growing conditions the roots may reach a length of 3 feet. Ordinary strains of long Mangels grow so deeply into the ground and their roots branch to such an extent that their harvesting is a problem, but our Mammoth Long Red grows from one-half to two-thirds out of the ground, hence the roots may be pulled with moderate effort. The maximum tonnage per acre is produced by this variety. Oz. 15 cts., $1 / 41$ lb. 40 ets., 1 b. 95 ets., 10 lbs. $\$ 9$.

Champion Yellow Globe. Occupies the same position among among cattle in that the roots are of only moderate size but of high quality. The skin is a rich, deep yellow; the flesh is fine, white, and solid, highly nutritious and palatable to stock. Not only does its shape lend itself to easy lifting, but two-thirds of the root grows above ground, hence it is a good variety where the soil is shallow. Its feeding value is high and it is a good keeper.

$1 / 4$ lb. 40 cts., 1 b. $\$ 1,10$ lbs. $\$ 9$.

Pedigreed Ideal. years' breeding has increased the dry matter and sugar in this Mangel by 50 per cent.

BARRE'S SLUDSTRUP. Has been recommended as holding the record for dry-matter content. This

Mangel has been awarded a First-Class Certificate several times by the Danish government, the highest honor in Denmark, where Mangels are as important as corn is here. Sludstrup is a long, reddish yellow ovoid root, growing more than half above the ground. Easily harvested and is considered to excel most

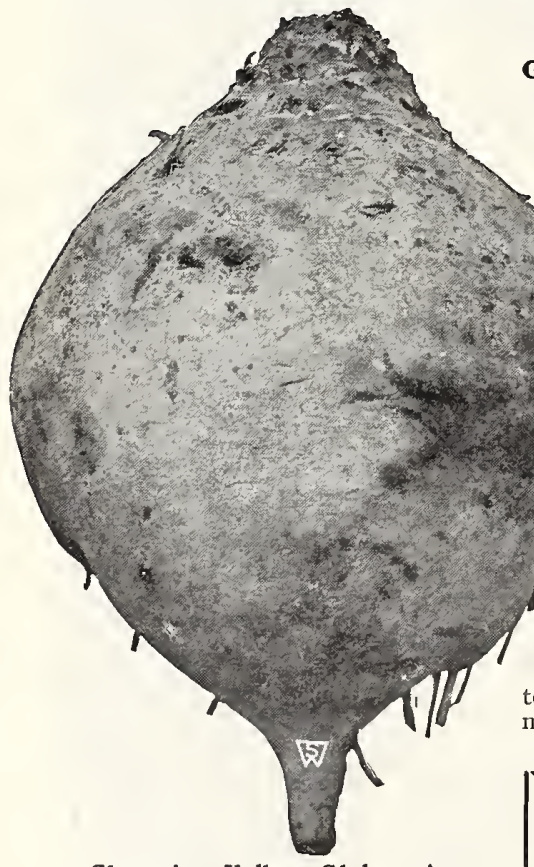

Champion Yellow Globe. A refined type, of convenient shape and high nutritive value. varieties in both weight and feeding value. $1 / 4 \mathrm{lb}$. $40 \mathrm{cts}$., lb. $\$ I_{\text {, }}$ Io lbs. \$9.

GOLDEN TANKARD. Smooth, yellow flesh; small, yellow-stemmed top; length I 5 inches, diameter 5 inches, shape cylindrical. Usually grows half out of the ground. Easily pulled, good yielder; very hardy and nutritious. I//4lb. $40 \mathrm{cts}$., lb. $\$$ I, Io lbs. $\$ 9$.

MAMMOTH LONG GOLDEN. The root is long and cylindrical, tapering gradually at each end. The skin is golden yellow, with a greenish shade above ground; flesh is white, sweet, and firm. A deep soil in which analysis shows the presence of a fair proportion of lime suits this variety. In spite of the large size of the root, its shape and the fact that a large proportion of it grows out of the ground enables it to be lifted without difficulty. $1 / 4 \mathrm{lb}$ 4o cts., lb. \$I, Io lbs. \$9.

HALF-SUGAR ROSE. A variety combining the best qualities of sugar beets and Mangels. They are about the same shape as Long Red, but have white skin at the bottom, rose at top. Easier to harvest than sugar beets I $/ 4$ lb. 30 cts., lb. 85 cts., Io lbs. $\$ 8$.

\section{SUGAR BEET}

Klein Wanzleben. This variety is cultivated on a Sugar Beet. larger scale than any other Sugar Beet. Root is conical, straight and even, large at
top and rapidly tapering. Contains a heavy percentage of saccharine matter. Oz. 15 cts., 1/41b. 40 cts., 1 b. $\$ 1,10$ lbs. $\$ 9$.

\section{A USEFUL BOOK FOR THE FARMER}

Fertilizers and Crops. By Lucius L. Van Slyke, Chemist of the New York Agricultural Experiment Station. 7 Io pages, illustrated. A veritable mine of information on this subject. Clear; interesting; authoritative. Postpaid. $\$ 3.25$.

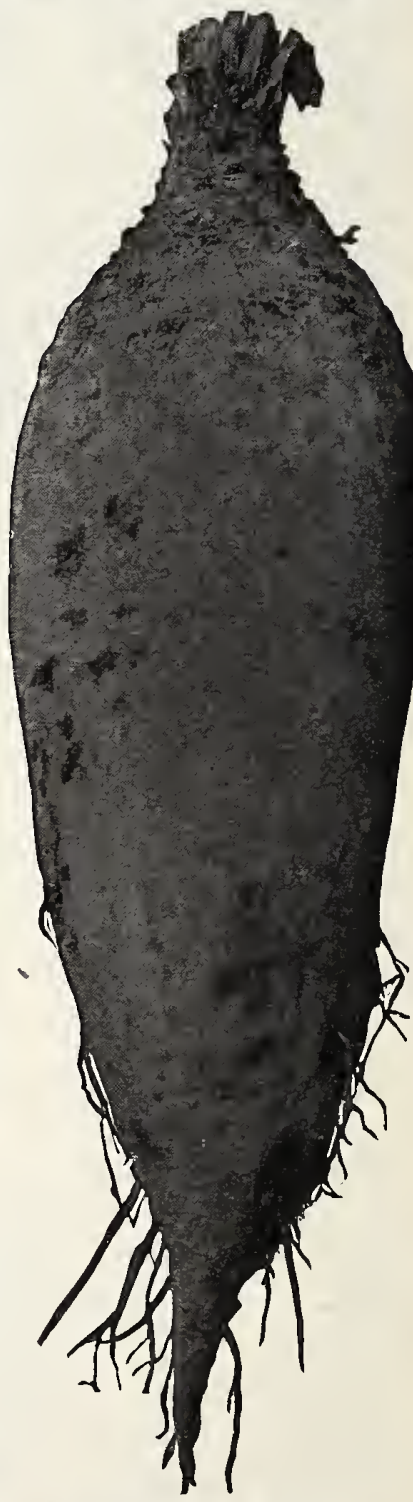

Mammoth Long Red. The Giant among Mangels 


\begin{abstract}
ROOT GROPS FOR STOCK-FEEDING

\section{Stock Carrots}

Carrots are very valuable for all kinds of domestic animals, and are better for horses than any other root-crop. W'hen fed alternately with oats to work-teams on the farm, the value of Carrots has been found to equal the oats they displace. Succulent food, in part, will always prove beneficial. Sow 4 pounds to the acre, from the middle of May to July I for main crop. Allow I foot apart between rows, and thin out to 7 inches in the rows.

Danvers Half-Long. Deep orange color, half-long, tapering uniand although of medium length, this strain will give a large yield to the acre. $1 / 41 \mathrm{lb} .45 \mathrm{cts}$., 1 b. $\$ 1.25,10 \mathrm{lbs}$. $\$ 11$.

Long Orange. A very desirable type for field culture where the soil the usual length, with a diameter of 3 inches at the top. Its economy is apparent. $1 / 41$ b. 45 ets., 1b. $\$ 1.25,10$ lbs. $\$ 11$.

Mammoth White Belgian. We offer the best stock we know of this popular type. The root is about I6 inches long, a quarter of which is above ground. The skin is white below and is greenish where it grows above ground. Its narrow shape enables it to be grown closely together in rows with profit, and its yield is therefore enormous. Excellent as a winter ration for horses and cattle. $1 / 4 \mathrm{lb} .35 \mathrm{cts} ., 1 \mathrm{~b}$. \$I, Io $1 \mathrm{bs} . \$ 9$.
\end{abstract}

\section{RUTABAGA (Russian or Swedish Turnip)}

Sow 4 pounds to the acre, in June, in drills 2 feet apart.

Improved American Purple-Top. A particularly fine type dish purple top. It is almost spherical in shape, and in consequence is easily lifted. The yellow flesh shows on analysis a very high percentage of dry matter; in other words, its feeding value is remarkably good. In our opinion our strain of Improsed American PurpleTop is the best type of Rutabaga on the market today. We recommend it for stock-feeding rather than for table use. $1 / \mathbf{4} \mathbf{l b}$. 45 cts., 1b. $\$ 1.25,10$ lbs. $\$ 11$.

S. E W. Co.'s Long Island Improved. This special strain of Rutabaga is grown on Long Island by a very . E careful grower. It is of a remarkably uniform shapeand finequality,

Long Orange and is also a splendid keeper. It grows to a large size, the skin is smooth, and flesh is beautiful yellow and fine-grained. We Carrot recommend it both for table use and for stock. Pkt. 10 ets., oz. 20 cts., $1 / 41$ b. 45 ets., 1 b. $\$ 1.25,101 b s$. $\$ 11$.

\section{Suggestions for Soil Improvement}

Broadcast General Garden Fertilizer at the rate of I ton per acre or I pound to each 25 square feet. fork under and sow one of the undernoted crops. It will retain plant-food, hold moisture, and is the best adjunct to - or substitute for-animal manure. Do not allow even the smallest amount of land to remain idle, but sow a cover crop as soon as a space becomes available, allowing the cover crop to grow for a while and then plowing or digging it under.

Suitable crops to plant for turning under are:

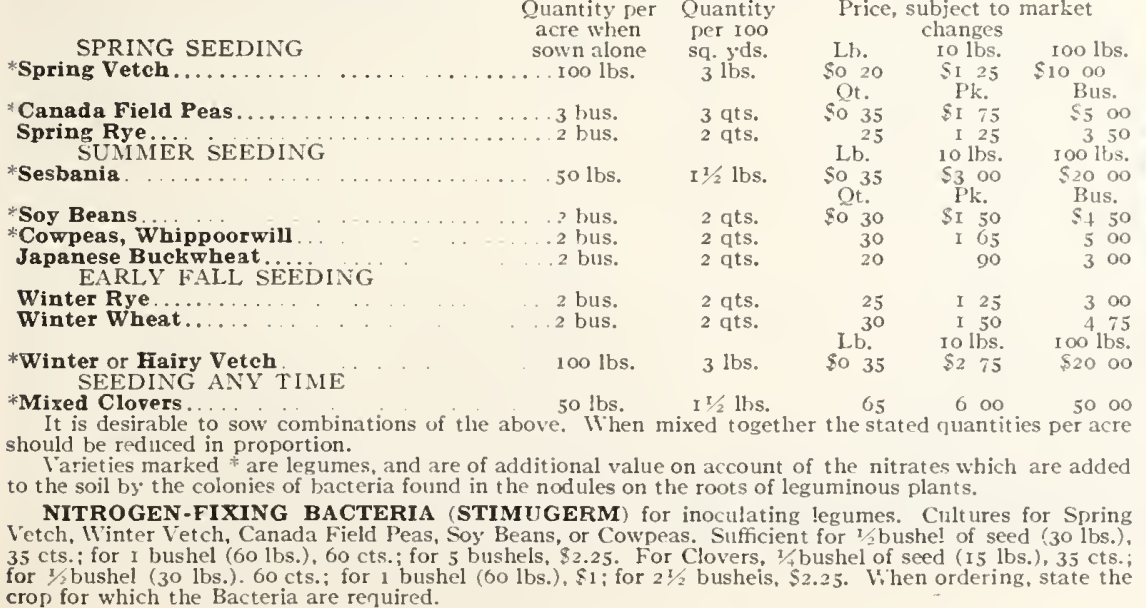
Quantity per Quantity
acre when Der roo roo lbs. 2 bus.

$?$ bus.

2 bus.

2 bus.

$100 \mathrm{lbs}$

3 lbs.

35

acre It is desirable to sow combir

Varieties marked * are legumes, and are of additional value on account of the nitrates which are added

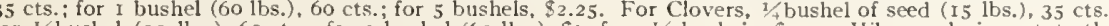
crop for which the Bacteria are required.

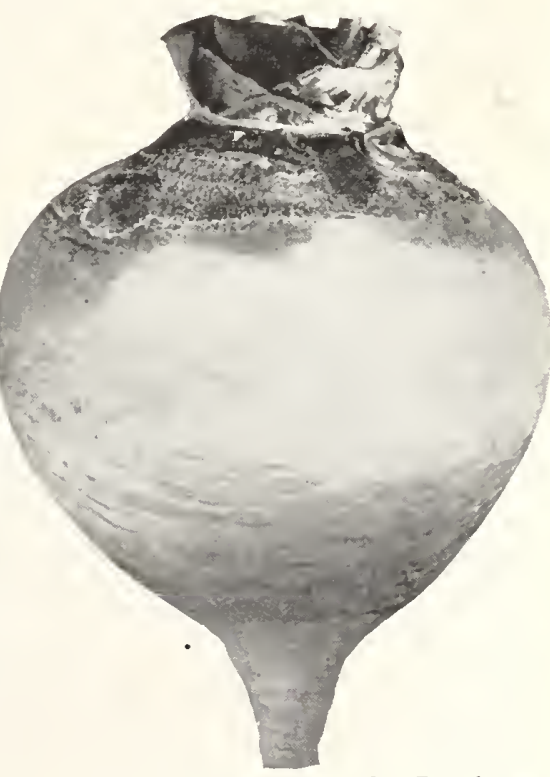

Improved American Purple-Top Rutabaga 
Sold at the standand weight of 32 pounds to the bushel. Several varieties of Oats offered below weigh up to 40 pounds to the measured bushel, but all Oats are purchased and sold at the standard weight of 32 pounds to the bushel.

Storm King. An exceptionally fine grade of the Long's TarStorm King. tar. Kernels are large and plump. The straw is long and stout, and does not easily lodge. Heads are from 8 to IO $1 / 2$ inches in length. Our grower in New Jersey reported a yield of over roo bushels per acre. Suitable for all soils. Pk. 85 cts., bus. (32 lbs.) $\$ 2.65,10$ bus. $\$ 24 ; 100$ bus., $\$ 2.25$ per bus.

Welcome Oats One of the heaviest, handsomest, and most Dhite varieties grown. It stools heavily, with extra-strong, straight straw, standing well. Succeeds well in a wide range of climate, and under a great variety of soils and methods of culture. Pk. 65 cts., bus. (32 lbs.) $\$ 2,10$ bus. $\$ 19 ; 100$ bus., $\$ 1.75$ per bus.

White Tartar. This is a western Oat which, when grown in Wast in past years, has done remarkably well. Its yield was well in excess of the Swedish and Lincoln varieties. It is a heavy Oat, with long, stout straw, which stands up well without lodging. The heads are large; the grains are thick and very heavy, with a thin hull. Our seed is selected and grown especially for us. Pk. 85 cts., bus. (32 lbs.) $\$ 2.65$, 10 bus. $\$ 24$; 100 bus., $\$ 2.25$ per bus.

White Cross (Wiscons:n Pedigree No. 19). A new Oat; White Cxtra-early, heavy yielder, with a large kernel and white instead of yellow. First premium at Wisconsin State Fair, and headed the list of all varieties in yield per acre at the Wisconsin Experiment Station. Pk. 75 ets., bus. (32 lbs.) $\$ 2.50,10$ bus. $\$ 23 ; 100$ bus., $\$ 2.10$ per bus.

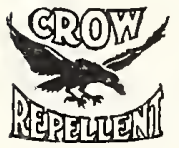

SEED PRESERVER FOR CORN insures your seeds. It prevents crows and other birds taking the seed; it protects against ground-rot and smut. It is non-poisonous and does not retard germination.

Large can, enough for 2 bushels of seed corn.

Small can, enough for 1 bushel

$\begin{array}{rr}\$ 1 & 50 \\ 1 & 00\end{array}$

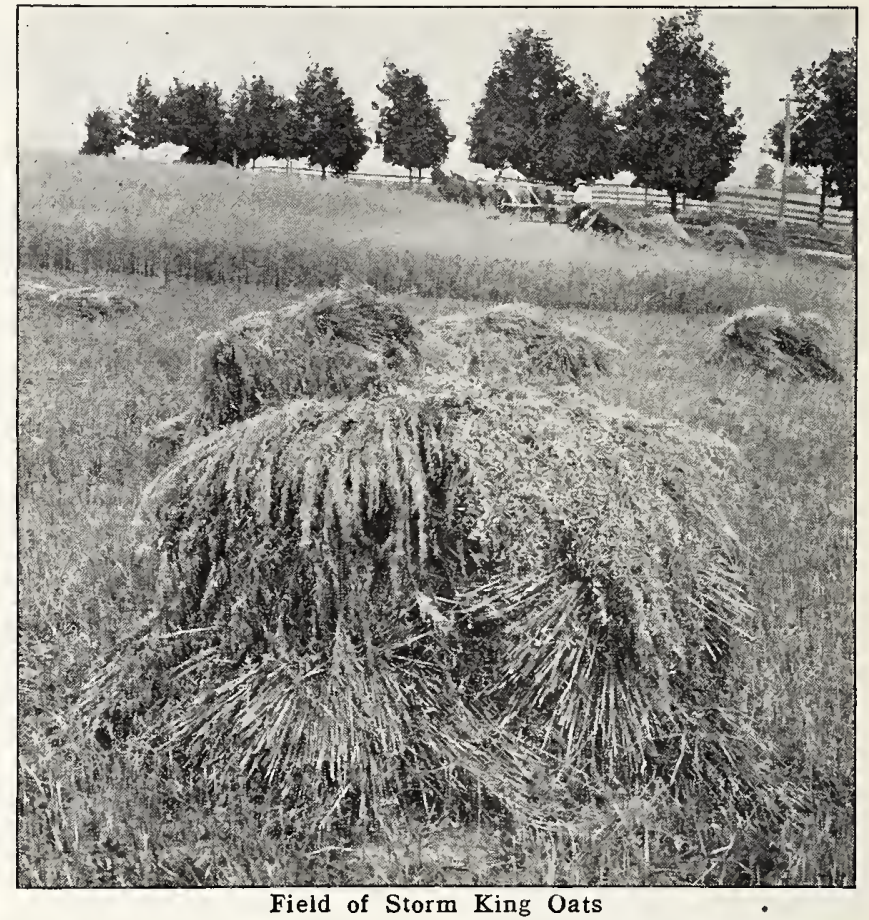

\section{SPRING WHEAT}

Marquis. The favorite sort in this locality, used on account of its prolific, vigorous growth and early qualities. Sow in April or May, I $1 / 2$ to 2 bushels per acre broadcast or in drills. Qt. 30c.,pk. \$I.35, bus. (6o lbs.) \$4; I o bus. and over, \$3.50 per bus.

\section{SPRING RYE}

Used as a catch-crop to sow where winter grain failed. Qt. 25 c., pk. $\$ 1.25$, bus. (56 lbs.) $\$ 3.50$; 10 bus. and over, $\$ 3.25$ per bus.

For Winter Wheat and Rye, refer to our Fall Catalogue

\section{ALPHA SPRING BARLEY}

The experiments of the New York and New Jersey Agricultural Stations show that Alpha is the highest-yielding and most satisfactory variety introduced up to the present time. It is a two-row variety, medium tall, stiff-strawed, yielding as high as 75 bushels to the acre. The kernels are large, plump and heavy. Splendid for sowing with Oats as a mixed grain crop. Or for the dairy farmer, one bushel each of Oats, Canada Field Peas, and Alpha Barley to the acre. When used alone sow I $1 / 2$ to 2 bushels to acre, May I 5 to July I. Qt. 20 cts., postpaid, 30 cts.; pk. $\$ 1$, bus. (48 1bs.) \$3.25, 10 bus. $\$ 30$.

\section{SORGHUMS}

EARLY AMBER SUGAR CANE. Sow 50 pounds per acre. Most valuable for dairy farmers; a favorite in the Northwest. Lb. 20 cts., postpaid, 30 cts.; Io lbs. \$I.25, I oo lbs. \$IO.

SUDAN GRASS. A quick-growing hay and pasture crop. Sow 30 pounds per acre. Lb. 25c., postpaid, 35c. ; Io lbs. \$I.75, Ioo lbs. \$I 5 .

FETERITA. Sow 20 pounds per acre. It gives excellent results, particularly in dry seasons. Lb. $20 \mathrm{cts}$, postpaid, $30 \mathrm{cts}$; IO lbs. $\$$ I.25, I OO lbs. \$IO.

BROOM CORN. Sow 20 pounds per acre. Lb. 40 cts., postpaid, 50 cts.; Io lbs. \$3, IO0 lbs. $\$ 25$.

Ceresan. A cereal disinfectant. Controls and Rye-Smut, also Seed-borne Scab. A dust treatment, easy to apply. Lb. 75 cts., 5 lbs. \$3, 25 lbs. \$I2.50.

\section{KAFFIR CORN}

A substitute for corn in semi-arid regions. The grain is used for poultry, for feeding horses and fattening hogs and cattle, while, if the plants are cut for hay, a great deal of forage is obtainable. Kaffir Corn is not suitable for pasture. Culture is similar to field corn; use I 5 pounds of seed per acre if grown in rows and 50 pounds if broadcast. Lb. 15 cts., postpaid, 25c. 10 lbs. \$1, 100 ibs. \$8.

\section{MILO MAIZE}

Used for soiling and fodder. Seed I 5 pounds per acre. Lb. 15 cts., postpaid, 25c.; 10 lbs. \$1.15, 100 lbs. \$9.

\section{MILLETS}

These are recommended as catch-crops, that is, quick-growing varieties to take the place of corn, wheat, or other crops which may have failed. They are chiefly grown for feeding green, silage or hay; seed may be sown during May, June, and July.

Golden Millet. Grows 4 to 5 feet high and yields a heavy crop. Use 50 pounds of seed per acre. 5o lbs. to bus. Lb. 20 cts., postpaid, 30 cts.; Io lbs. \$I.Io, Ioo lbs. $\$ 9$.

Hungarian Millet. The crop is heavy, and is considered equal in value to timothy hay. Use 50 pounds of seed per acre. Lb. 20 cts., postpaid, $30 \mathrm{cts}$; Io lbs. $\$ \mathrm{I} .25$, IOO lbs. \$IO.

Japanese, or Barnyard Millet. Yields more heavily than almost any other forage plant. Grows 8 feet high. Use 25 pounds of seed per acre. 35 lbs. to bus. Lb. 20 cts., postpaid, $30 \mathrm{cts}$.; Io lbs. $\$$ I.25, IOO lbs. $\$$ IO. 


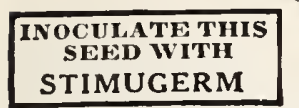

想S PRICE .

STIMUGERM

\section{CLOVERS} yielded, they all result in an improved condition of the soil.

\begin{abstract}
Algot Red Clover. An improved strain produced by a taking effort. Algot Red Clover yields a heavier crop to the measured acre than the ordinary type. It will endure a greater degree of cold without injury and it is resistant to mildew. Most of all, it will thrive on land which would be "Clover-sick" to common Red Clover. This is a distinct type, very uniform and flowering late. Lb. $\$ 1.25,10$ lbs. $\$ 11.50,100$ lbs. $\$ 100$.
\end{abstract}

Medium Red Clover. This is the most popular and is the Clover family. It makes two crops each year. The first is usually cut when it is in blossom for hay; the last crop may be harvested for seed, cut for hay or plowed under to add fertility to the soil. It may be sown either in the spring or fall, and if no other grasses are used, at the rate of from twenty to twenty-five pounds to the acre. Hardy American-grown Seed. Lb. 65 cts., postpaid, 70 cts.; 10 lbs. $\$ 6,100$ lbs. $\$ 42.50$.

Mammoth Red Clover. Grows larger and lasts longer Mammoth Red Clover. than the preceding variety, and by some is considered superior to it for forage. Americangrown Seed. Lb. 70 cts., 10 lbs. \$6.25, 100 lbs. \$45.

Alsike or Swedish Clover. This is one of the hardiest varieties known; it will do better on moist land than any other variety of Clover. It is frequently sown both with Medium Red Clover and with Timothy, and the quality of hay thus produced is excellent. It is finer and more leafy than Medium Clover, although it does not grow so high. Lb. 55 cts., postpaid, 65 ets.; 10 lbs. \$5, 100 lbs. $\$ 37.50$.

White or Dutch Clover. This variety should be inpasture and it is the best sort for lawns; it forms a close herbage and remains green throughout the season. Lb. 75 cts., postpaid, 85 cts.; 10 lbs. $\$ 7,100$ lbs. $\$ 60$.

Wild White Clover. Genuine Wild White Clover seed more permanent in character than those originating from commercial seed: the plants are smaller and they spread very much farther than the "cultivated" type. Being more robust, they withstand clover-sickness and they thrive on soils that would be too poor to support ordinary White Clover. Wild White Clover plants assist other Clovers and grasses growing alongside them, and European experience shows that the inclusion of so small a quantity as one pound of seed per acre in mixture with other Clovers and grasses for hay-fields and pastures is followed by an increase in yield amounting in some cases to 50 per cent or more. On breaking up a pasture in whicl it is included, the increased benefit to the soil is very marked. Oz. $\$ 1,1 / 4 \mathbf{l b}$. $\$ 3, \mathbf{l b} . \$ 10$.

Alfalfa or Lucerne. Alfalfa possesses a wonderful rootquently it is a great drought-resister. Our seed is Americangrown, produced in those northern sections of the country where Alfalfa has endured the extreme cold of winter in high altitudes. Lb. 50 ets., ppd., 60 ets.; 10 lbs. $\$ 4.50,100$ lbs. $\$ 35$. Grimm Alfalfa. There is some disagreement as to how Grimm Alfalfa obtained its hardiness, but there is no difference of opinion that it is hardy. Because of its root-system, it will grow well over a hardpan soil, and is adapted to a wetter soil than the common Alfalfa. We recommend i 5 pounds of the seed, sown broadcast, to the acre, as its stooling habit requires less seed to be sown than the ordinary type. Lb. 80 cts., postpaid, 90 cts.; 10 lbs. $\$ 7.50,100$ lbs. $\$ 65$.

Crimson or Scarlet Clover. This is an annual plant. time from June to October, at the rate of fifteen to twenty pounds to the acre, and makes the earliest possible spring pasture, blooming the latter part of April or May, and for feeding as hay, should be cut just before coming into full bloom. Lb. 35 cts., postpaid, 45 cts.; 10 lbs. $\$ 3,100$ lbs. $\$ 20$.
Sweet Clover or Bokhara Clover. White Melilotus. ing this Clover to quite a considerable extent on light, sandy land, where other Clovers do not take well. They hope, by sowing Sweet Clover, to get a good growth to turn under to improve the land and also to inoculate the soil so that it will produce good crops of Crimson Clover and Alfalfa from seedlings of these to follow the Bokhara. For feed or forage it should be cut when quite young, for when it gets old, cattle do not relish it, and it is not of very high nutritive value. It is also largely used for sowing for bees. Lb. 30c., postpaid, 40 c. ; $10 \mathrm{lbs}$. \$2.50, $100 \mathrm{lbs}$. \$17.50. Yellow Sweet Clover. A yellow-flowered counterpart of 45 cts.; 10 lbs. $\$ 2.75,100$ lbs. $\$ 20$.

Hubam. Annual White Sweet Clover. Hubam is a variety of Bokhara or White Sweet Clover which was discovered a few years ago by the lowa Experiment Station; most other Clovers, do not give a profitable return until the second year from seeding, Hubam will produce a bumper crop and attain mature growth in the first season. It will in six months yield a growth of from 3 to 7 feet, and in some cases 8 and 9 feet, this depending upon the locality, soil, and season. Hubam is even more drought-resistant than the ordinary type, and, like it, is the greatest bee-pasture known. We offer scarified seed Lb. 60 cts., postpaid, 70 cts.; 10 lbs. $\$ 5,100$ lbs. $\$ 45$.

Sainfoin. A deep-rooting leguminous plant, which thrives on poor dry hillsides and on limestone soils, but gives splendid results also on good land. Usually sown in spring as a one-year crop, although it is perennial in some sections. Sow $50 \mathrm{lbs}$. per acre, either alone or with a nurse crop. Lb. 35 ets., postpaid, 45 cts.; 10 lbs. $\$ 3.25,100$ lbs. $\$ 30$.

Melilotus indica (Annual Yellow Sour Clover). A legume Melilotus indica that is well adapted for a plow-under crop excellent for building up soils deficient in vegetable matter. Used extensively in the Southwest. Sow $50 \mathrm{lbs}$. per acre. Lb. 25 cts., postpaid, 35 cts.; 10 lbs. $\$ 2.25,100$ lbs. $\$ 15$.

Japan Clover or Lespedeza. A pasture and hay plant ern States, where it will give good results even on the poorest soils. Used quite largely for lawn purposes in the territory suited to it. Use 25 pounds of seed per acre. Lb. 50 ets., postpaid, 60 ets.; 10 lbs. $\$ 4.50,100$ lbs. $\$ 37.50$.

Mixed Clovers. For pasture and hay-fields. Use 25 pounds renovating existing fields, use wo pounds. Lb. 65 cts., postpaid, 75 cts.; 10 lbs. $\$ 6,100$ lbs. $\$ 50$.

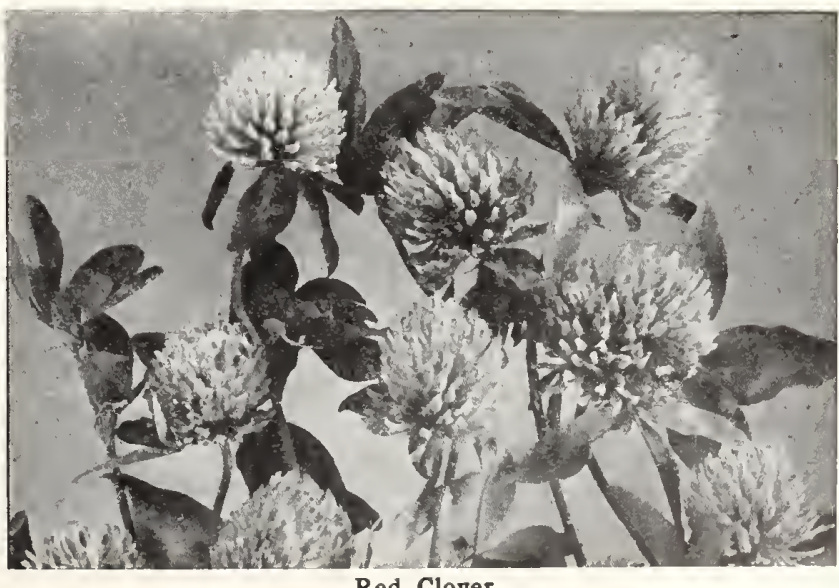




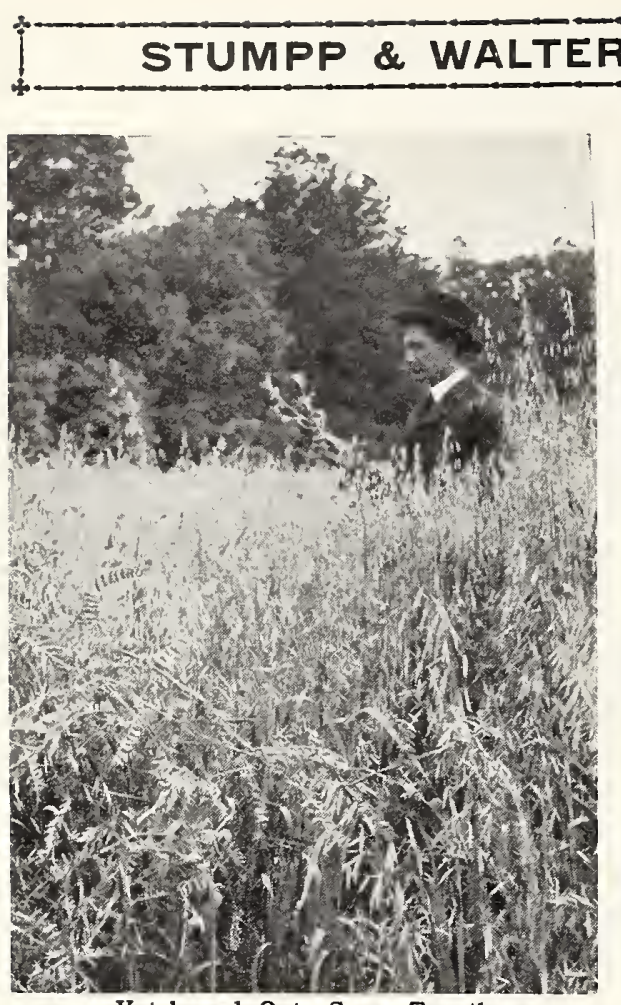

Vetch and Oats Sown Together

\section{CANADA FIELD PEAS}

\section{INOCULATE THIS \\ SEED WITH \\ STIMUGERM}

Canada Field Peas are a profitable crop in a variety of ways; if grown to maturity and threshed, a yield of from 30 to 60 bushels per acre of dried Peas may be expected. A combined crop of Peas and Oats is frequently grown; at maturity they may be threshed at one time and separated in cleaning. They are most widely grown in conjunction with oats and fed green, when a surprising amount of fodder is produced.

If sown alone, use 3 bushels of seed per acre; when sown with oats, use $I \frac{1}{2}$ bushels of Peas and 2 bushels of oats, sowing the Peas first, plowing under 4 inches deep and then drilling in the oats. Qt. 35 cts., postpaid, 45 cts.; pk. $\$ 1.75$, bus. (60 lbs.) $\$ 5,10$-bus. lots, $\$ 4.75$ per bus.

\begin{tabular}{|l|}
\hline INOCULATE THIS \\
SEED WITH \\
STIMUGERM \\
\hline
\end{tabular}

\section{COWPEAS}

Used for improvement of soils by plowing under; also make valuable hay, when sown alone or with soy beans, during May, June or July, at the rate of two bushels to the acre or one bushel of Soy Beans and one of Cowpeas. 60 pounds to a bushel.

New Era. The Peas are dull lead-colored, not quite so large as Whippoorwill, but vine is somewhat stronger; earlier than other varieties. Qt. 30c., postpaid, 40c.; pk. $\$$ I .65, bus. $\$ 5$.

Whippoorwill. An early, bunch-growing Pea; has brownspeckled seed. Qt. 30c., postpaid, 40c.; pk. \$I.65, bus. $\$ 5$.

\section{INOCULATE THIS
SEED WITH STIMUGERM}

for silage, for the production oi hay, and
for use as pasture, especially for hogs. They are also valuable as a crop for plowing under for green manure.

Planted in rows $2 \mathrm{r} / 2$ feet apart, 6 to 8 plants to the foot of row, requiring four to eight pecks to the acre; they yield fifteen to twenty tons of fodder. 60 pounds to a bushel.

Mammoth Yellow Soy Beans. Ordinarily does not produce seed in vicinity of New York but gives a wonderful yield for hay, silage, or green manure. Qt. $30 \mathrm{cts}$., postpaid, $40 \mathrm{cts}$; pk. $\$$ I. 50 , bus. $\$ 4 \cdot 5$, Io bus. $\$ 40$.

Wilson (Black). Qt. 30 cts., postpaid, 40 cts.; pk. \$1.65, bus. $\$ 5$, Io-bus. lots, $\$ 4.75$ per bus.
AND 32 BARCLAY ST., NEW YORK

\section{INOCULATE THIS \\ STIMUGERM}

Vetches are relished by live stock of all kinds; they are excellent for milk-produc-

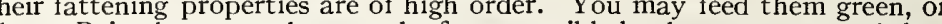
, keeping them away from the ground, and much increasing the crop.

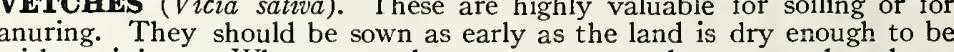
worked without injury. When sown alone, use I50 pounds per acre broadcast, or Ioo pounds in drills. If grown with oats, wheat, or rye, use $1 / 2$ bushel of the cereal for both spring and autumn seeding, and if intended to stand over the

STIMUGERM Seed Inoculant hen ordering be sure to state which or wish to inoculate. For vetches, (2) size 35 cow peas, and soy beans or clovers and alfalfa: $1 / 4-b u$ u. $\$ 2.25$. 1/2-bus. 60c., 1-bus. $\$ 1,21 \frac{1}{2}$-bus. $\$ 2.25$. 

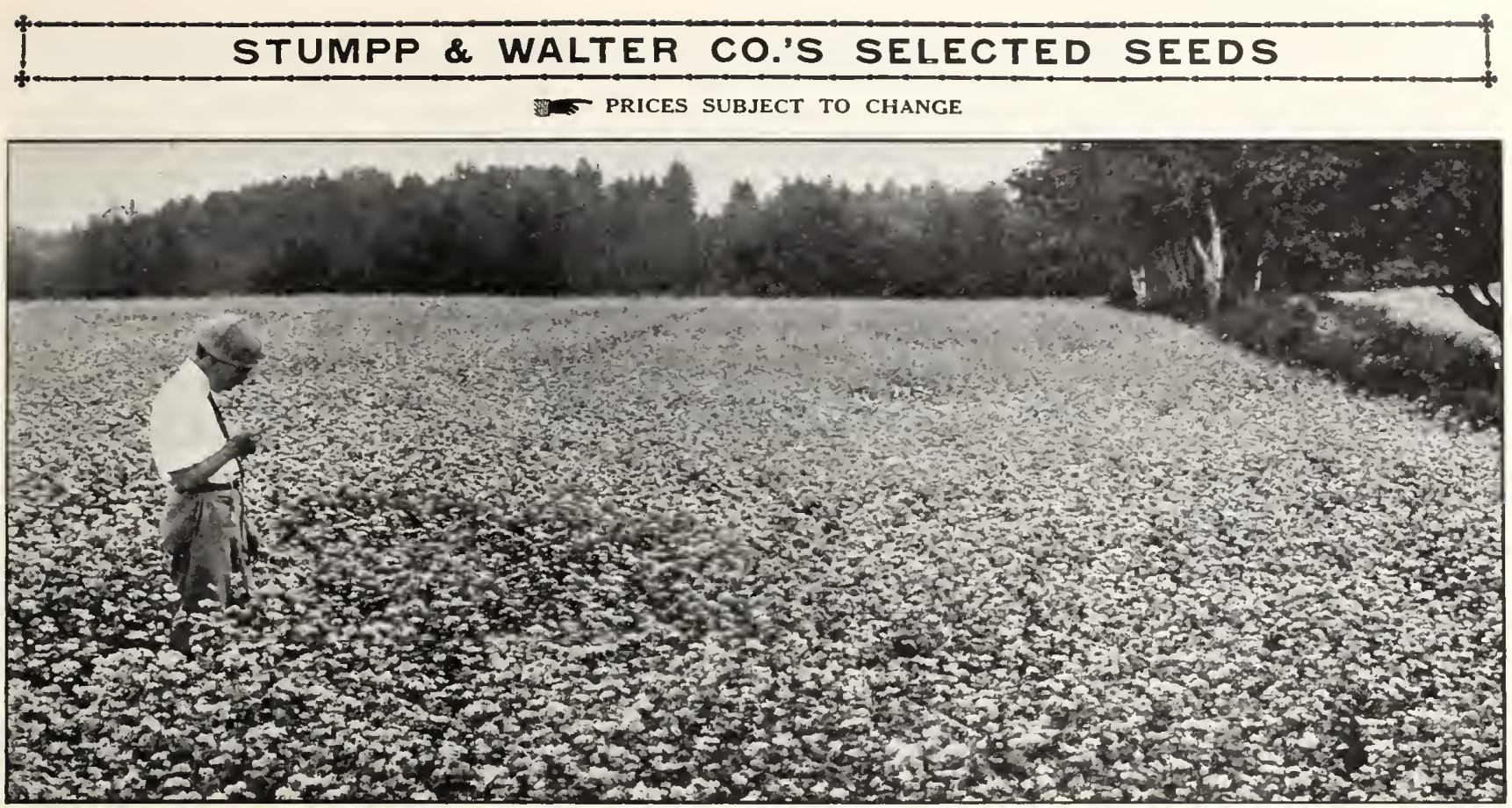

A field of Japanese Buckwheat

\section{JAPANESE BUCKWHEAT}

This is a superior variety, is more prolific, and yields double the weight per acre of other sorts. The grains are nearly twice as large as those of Silver Hull, and of fine color. This variety is always in demand, millers preferring it to all other sorts, and it makes the finest flour. Sow about the middle of June, broadcast, I to I $1 / 2$ bushels to the acre. 48 pounds to a bushel. Qt. 20 cts., pk. 90 cts., bus. $\$ 3 ; 10$ bus., $\$ 2.90$ per bus.

\section{THOUSAND-HEADED KALE}

An exceedingly valuable food for sheep and lambs. The crop may be drilled in in rows 2 feet apart, and the plants hoed to stand a foot apart, or occasionally the seeds are sown in a nursery bed and the seedlings transplanted. In the first case 8 pounds of seed per acre are used, and in the second 4 pounds will be found sufficient. Lb. $\$ 1.50$.

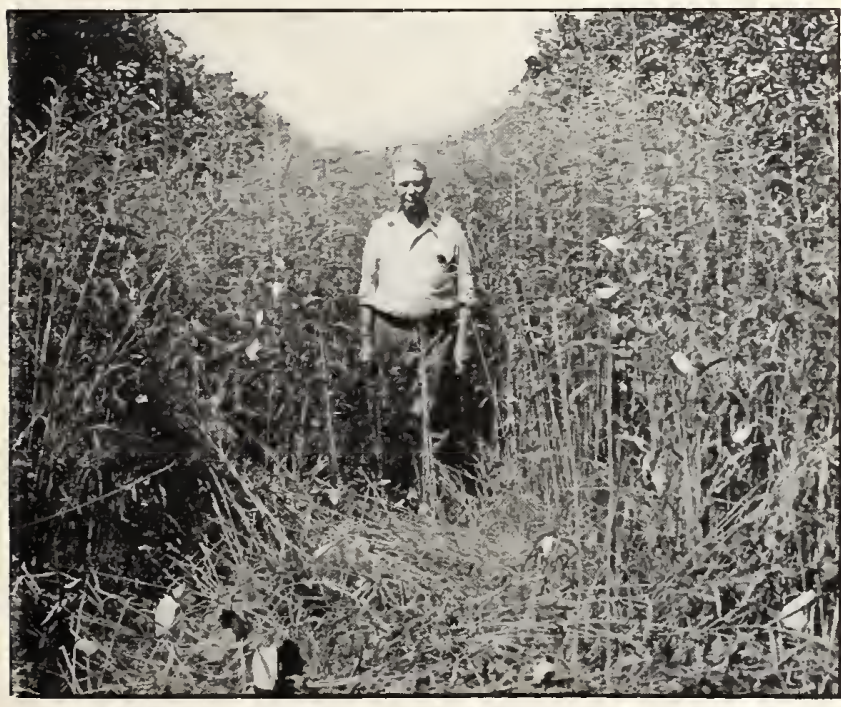

Sesbania growing for cover-crop between trees in an orange grove
SUNFLOWER, MAMMOTH RUSSIAN Selected Seed. Specially Grown for Seeding

Highly valued as an excellent and cheap food for fowls. It is the best egg-producing food known. It can be raised cheaper than corn. Four pounds of seed will plant an acre. Lb. 35 cts. postpaid, 45 cts.; 10 lbs. \$3, 100 lbs. \$25.

\section{SESBANIA}

A vigorous-growing annual legume. Thrives only in warm weather and will grow on alkali and other poor soils. Plants attain height of 4 to 8 feet with rather slender stalks; root system covered with nodules. A fast grower and of value only as a green manure plant, especially in the Southwest and South. Broadcast same time as cowpeas, 20 to 25 pounds to acre. Lb. 35 cts., postpaid, 45 cts.; 10 lbs. $\$ 3,100$ lbs. $\$ 20$.

\section{FLAX or LINSEED}

This crop is grown primarily for the seed for which there is a constant demand for pressing for oil and the making of cake and meal. Sow 75 pounds of seed per acre. Lb. 20 cts., postpaid, 30 cts.; 10 lbs. \$1.75, 100 lbs. \$14.

\section{WHITE LUPINS}

A legume valued most for green manure, as well as a good fodder plant. Mainly used on dry land; does well on the poorest soil. Use about I 50 pounds to an acre. Lb. 40 cts., postpaid, 50 cts.; 10 lbs. $\$ 3.50,100$ lbs. $\$ 20$.

\section{DWARF ESSEX RAPE}

The true Dwarf Essex Rape is valuable as a fattening food for pasturing sheep in autumn and it is relished also by hogs and cattle. It is particularly adapted as a "catch-crop," for it grows best late in the season. In the northern states it can be sown at any time from May until the end of August, but in the southern states it should not be sown until September or October, for winter pasture. Its fattening properties are said to be twice as good as clover. Sow ten to twelve pounds to the acre broadcast,
or four to five pounds per acre in drills I5 inches apart. The plant grows very vigorously, and feeding can commence about two months after the seed is sown. Stock are turned right into the standing crop, and the expense of harvesting is avoided. Successional seedings will maintain a continuous supply. 56
pounds to a bushel. Lb. 25 cts., 10 lbs. $\$ \mathbf{1 . 7 5}, 100$ lbs. $\$ 12.50$. 


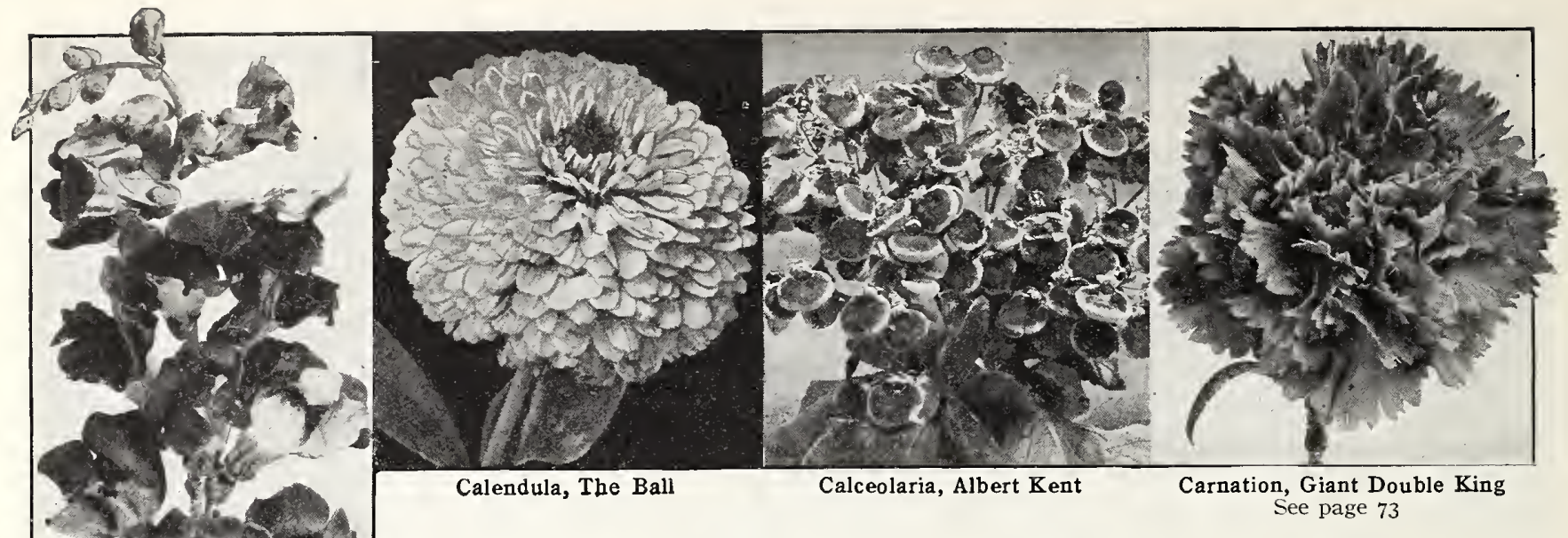

\section{S. \& W. Co.'s Novelties and}

\section{Aster, New Giant Peony-flowered}

Super-Giant Snapdragons

\section{Ageratum mexicanum nanum, Venus}

This plant forms a dense bush about I foot high, which is profusely covered with flowers. The buds are red, opening to flowers whose petals are white, contrasting well with the soft red center. An exceptionally fine variety, not only for pots, but also fine for bedding. Pkt. 25 cts., $1 / 80 z$. $\$ 1$.

\section{Antirrhinum, Semi-Dwarf, Flame}

The finest new Snapdragon of recent introduction. As a bedding or border variety, it has no peer. Under ordinary cultivation the plants grow from I $1 / 2$ to 2 feet high. The individual florets are of good size, well placed on fine, showy spikes, and the color is a rich, dazzling scarlet, giving the impression of a brilliant flame. It is a lively and fascinating shade which we cannot, we believe, overpraise. Pkt. 25 ets., $1 / 8$ oz. $\$ 1,1 / 4$ oz. $\$ 1.50$, oz. $\$ 5$.

\section{Antirrhinum maximum \\ (Super-Giant Snapdragons)}

Each year we are greeted with numerous new varieties of this beautiful flower. Specialists vie with one another to produce finer strains. We have given trial to many of the recent introductions and find the following varieties of excellent merit. The plants attain a height of 3 feet and the individual flowers are very large and the colors very distinct.

Salmon Rose. (New.) This is always the most popular color Maximum group. It is a most beautiful shade of salmon combined with the begonia-rose color. Pkt. 50 cts., 5 pkts. $\mathbf{\$ 2}$.

\section{BEST SIX POPULAR VARIETIES}

Apple Blossom. Apple-blossom-pink.

Canary Bird. Canary-yellow with deeper yellow lip.

Copper King. Bronzy copper color.

Golden Queen. Rose on yellow ground.

Snowflake. Dazzling white.

Wallflower. Dark wallflower-red.

Mixed. A mixture of all shades.

Each, pkt. 25 cts., $1 / 80 z$. $\$ 1,1 / 40 z$. $\$ 1.50$

\section{ANew Aster (California Sunshine)}

Plants of this new race grow 3 feet high and bear blossoms on long, stiff stems, admirable for cutting. The individual blooms are enor mous - 4 to 5 inches in diameter.

The lovely light yellow disk and the encircling guard petals, in varying shades of enchantress-pink, apple-blossom, deep rose, blue and lavender, produce color contrast at once startlingly beautiful in the ensemble, stamping this glorious new strain as one of the outstanding novelties of modern times. Pkt. 50 ets.

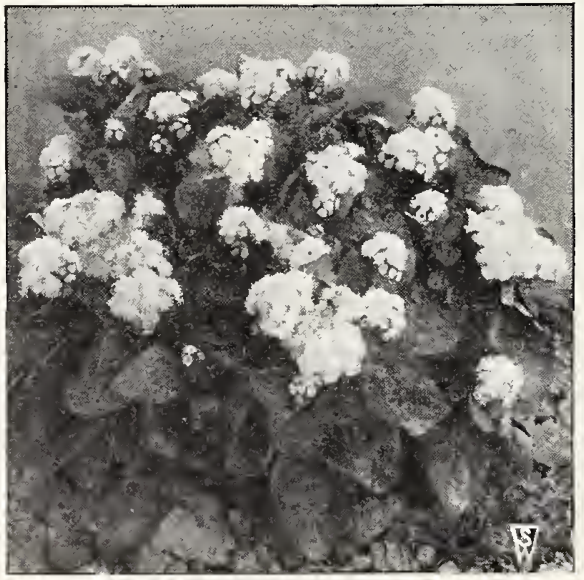

Ageratum mexicanum nanum, Venus

\section{Calceolaria, Albert Kent}

This fine Calceolaria grows about $\mathrm{I} / 2$ feet high and bears immense trusses of bloom from the beginning of May onward through the summer. The individual flowers are about $I^{1 / 2}$ inches across. They are graceful in shape, like a falling drop of water, and of a bright golden yellow color with a rich maroon-red blotch. A prominent feature of Albert Kent is that it can be utilized both indoors and out. It comes about 75 per cent true from seed. Pkt. 25 cts., 5 pkts. \$1.

\section{Calceolaria lignosa (Bunch of Gold)}

One of the finest of all Calceolarias for bedding purposes. The plants grow about I foot high and produce several bunches of beautiful golden yellow flowers continuously all summer. Pkt. 50 cts., 5 pkts. \$2.

\section{Three New Giant Calendulas} The Ball. A special giant strain of Orange Calendula. The center, are borne on long stems, and come uniformly double. This is an exceptionally fine Calendula for greenhouse growing. Pkt. 25 cts., $1 / 40 z$. 75 ets., oz. $\$ 2.50$. Campfire (Sensation). This new type has been thoroughly tested under glass and has been accepted as the best forcing Calendula for that use. The flat blooms are, undoubtedly, larger than those of any other type previously introduced. Its color is a brilliant orange, with a scarlet sheen, and a full yellow center. Pkt. 25 cts., 1/40z. $\$ 1.50$, oz. $\$ 5$.

Radio. The florets are beautifully quilled and the flower is very globular in shape. In color it is a warm, deep yellow. Pkt. 25 ets., $1 / 40 z$. $\$ 1.50$, oz. $\$ 5$.

\section{Calliopsis, The Sultan}

The best Calliopsis of recent introduction. For bedding or borders, the plants growing I to $\mathrm{I} / 2 \mathrm{feet}$ high. The flowers are very large and of a rich maroon-crimson. Pkt. 35 cts., 3 pkts. $\$ 1,6$ pkts. $\$ 1.75$. 


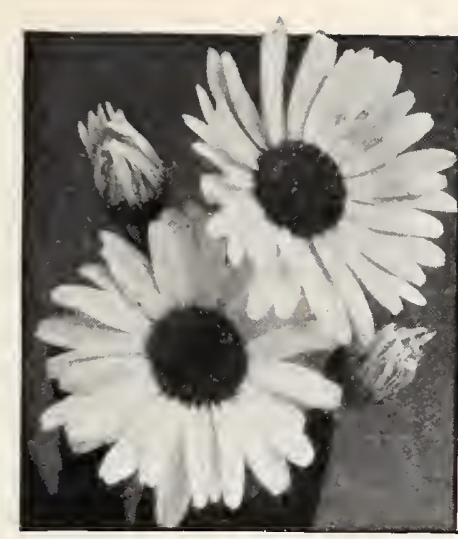

Shasta Daisy

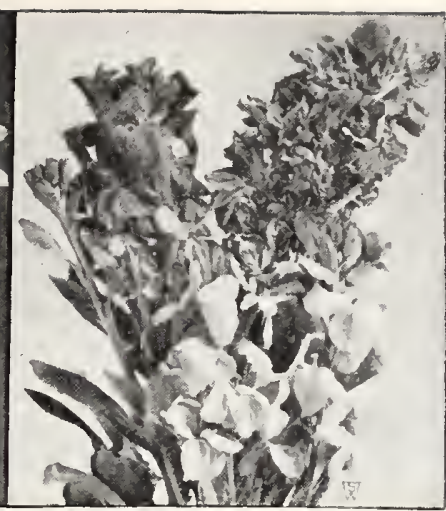

Cheiranthus Kewensis

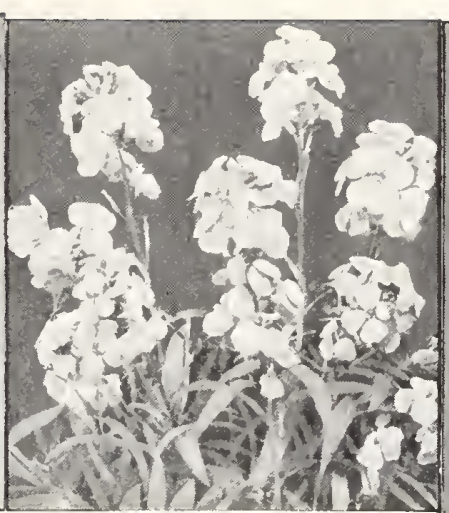

Cheiranthus Allioni

\section{Specialties in Flower Seeds}

\section{Campanula Piperi}

A variety worth having in every rock-garden. Plants grow I foot ligh, bearing light blue, bell-shaped flowers in great profusion during the entire season. The variety does quite well in partial shade. Pkt. 50 cts., 5 pkts. \$2.

\section{Cheiranthus Allioni}

\section{Siberian Wallflower}

The increasing interest in rock-gardens in America suggests the use of many perennial plants not commonly grown in most gardens. In presenting this beautiful little early-flowering perennial Vallflower, with gorgeous orange flowers, we suggest it as a splendid little plant for the rock-garden or as a dwarf border plant. IVill bloom throughout the summer if seed-pods are removed. May be sown in the open ground in September where required to flower the following spring, or will bloom first season from seed, if sown in a hotbed in March and transplanted outdoors in May. Pkt. 25 cts., 1/8oz. \$1, $1 / 4 \mathrm{Oz}$. $\$ 1.50$.

\section{Cheiranthus Kewensis}

\section{Greenhouse Wallflower}

A valuable, half-hardy, hybrid Wallflower for growing under glass. The flowers are light yellow on opening and change to mauve when more mature. The plants are freely branched, each stem carrying a long spike of flowers, and they grow 2 feet high. Pkt. 25 cts., 5 pkts. \$1.

\section{Cheiranthus linifolius}

Especially recommended for rock-gardens, growing 9 to $\mathrm{I} 2$ inches high, and covered with mauve flowers. Pkt. 25 cts., $1 / 8$ oz. $\$ 1,1 / 40 z$. $\$ 1.50$.

\section{Two Fine New Hardy Chrysanthemums} Shasta Daisies Mrs. C. Lothian Bell. A very large Marguerite which has prorluced flowers measuring 6 inches across. Blooms a month later than the well-known variety, Alaska (offered on page $85)$, hence the two sorts may well be planted together to give a succession of bloom. Pkt. 25 cts., $1 / 4$ oz. 75 cts.

Dwarf Avalanche. A low-growing, white perennial Daisy. When in plants are a mass of bloom, making a most effective display and at the same time the blossoms are excellent for cut-flower purposes. May be planted toward the front of the hardy border. Pkt. 35 cts.

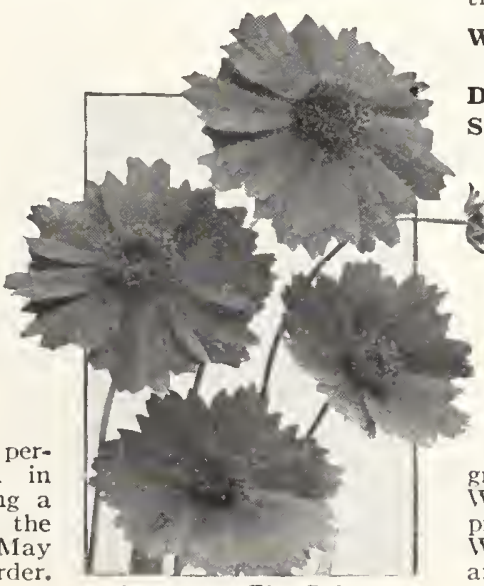

Calliopsis, The Sultan

\section{Dahlia,}

Coltness Hybrids

A splendid new class of single Dahlias. They are of neat, compact habit, averaging only about I 8 inches high, and bearing a full and continued succession of bloom from July until frost. The flowers have flat or slightly fluted petals, and vary in size, being mostly about 3 inches in diameter. Their varied colors embrace light and dark scarlet, crimson, blood-red, yetlow, white, purple, mauve, and brick-red; bizarre combinations, such as scarlet tipped white, yellow striped white, yellow flushed red, also occur. Excellent as a novel bedding plant. Pkt. 50 ets., $1 / 4 \mathrm{Oz}$. $\$ 1.50,0 z . \$ 5$.

\section{New Hollyhock Strain Delphinium}

A fine mixture of all light shades, pale clear blue predominating. Large flowers, truly double, are well placed on long, pyramidal spikes. Their sturdy appearance reminds one of the Hollyhock-hence the name. Pkt. 35 cts., $1 / 8$ oz. $\$ 3.50$.

\section{Delphinium, S. \& W. Co.'s Super Gold Medal Hybrids}

Specialists in America and Europe vie with one another in the improvement of this wonderful and, without a doubt, "the most popular hardy perennial." The varieties of yesterday are mere caricatures compared to the strain we are offering. The plants are of strong and vigorous habit and the spikes frequently attain the height of 6 feet, with flowers of very large size. The individual florets are quite distinct, and diversified in form, and the colors range from the most delicate sky tints to darkest blue.

Wave Crest Blue Shades. A very delicate and charming strain of pale and light blues.

Delft Blue Shades. True blues of special beauty.

Salon Blue Shades. This strain abounds in rich,

Royal Art Tints. A very desirable mixture of Subtle shades.

Any of above colors, pkt. 50 cts., $1 / 80 z$. \$2 $1 / 4 \mathrm{Oz}$. \$3.50

SPECIAL COLLECTION: One pkt. each of the above 4 colors, $\$ 1.50$

\section{Erinus Alpinus, Magenta}

This little plant is a veritable gem for rockeries, growing 6 inches high, with dark green foliage. When in bloom the whole plant is covered with a profusion of small, brithiant magenta-red flowers. IVill thrive in almost any kind of soil or situation and requires but very little care. Pkt. 25 cts., 5 pkts. $\$ 1$. 


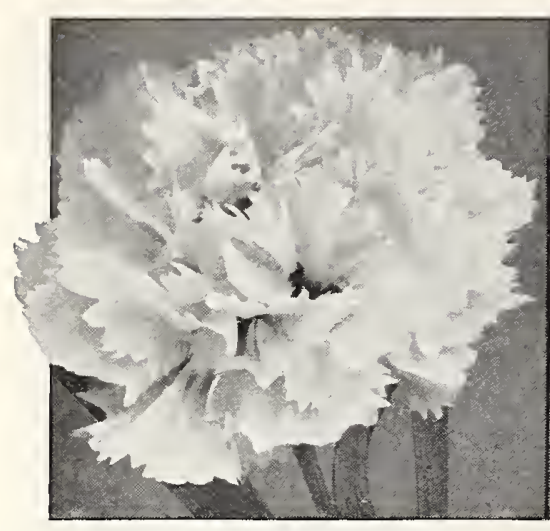

Perpetual Border Carnation See page 82

\section{Two New Exhibition Eschscholtzias} California Poppies

Ramona. (Frilled.) Glittering, coppery gold with pink shadings Ramona. - a decided novelty. The flowers are single, but they are delicately frilled, giving them the appearance of semi-double blossoms. Pkt. 25 cts., $1 / 80 z$. $\$ 1,1 / 40 z$. $\$ 1.50$.

Buttercup. (Double.) This is a true double Eschscholtzia and 3 pkts. \$1.

\section{Three New Gaillardias}

\section{Hardy Perennials}

The Dazzler. The largest and most attractive giant red with a bright orange tip on the end of each floret. Pkt. 25 cts. 1/4oz. $\$ 1$, oz. $\$ 3.50$.

Portola Hybrids. The flowers produced by this strain are mormous and the color-range is fairly wide, centering around reddish bronze and gold. Plants are particularly robust. Pkt. 25 cts., 1/40z. $\$ 1,0 z$. $\$ 3.50$.

Tangerine. This strain of Gaillardia, although a great imvariable. However, there is a very large percentage of the true Tangerine in it. It may be described as a medium-sized flower of various shades of tangerine-orange. The color and general structure of the flower make it very graceful in appearance and useful for modern decorations, as well as for cutting purposes. Pkt. 25 cts., $1 / 8$ oz. $\$ 1,1 / 4$ oz. $\$ 1.50$, oz. $\$ 5$.

\section{Gerbera, Jamesoni Hybrids}

\section{Transvaal Daisy}

These are beautiful, daisy-like plants, slender and graceful. Wellknown greenhouse subjects that are largely used for conservatory decoration, but capable also of being grown in the open ground if the protection of a coldframe is given the plants over the winter months. We offer a splendid mixture of hybrids of this beautiful flower, embracing many shades of red, cerise, salmon, orange, yellow, and white. Pkt. 50 cts.

\section{Giant Shirley Foxglove}

(Digitalis)

A new and magnificent strain of Foxgloves raised by the late Rev. W. Wilkes, who originated the Shirley Poppy. It is considered by plantsmen as being the greatest improvement ever made in Foxgloves. The very vigorous plants attain the height of 5 to 7 feet, with spikes of bloom ranging in color from the purest white to dark rose, handsomely spotted and blotched with crimson, maroon, and chocolate. This is certain to supersede all other strains of Foxglove. Seed sown this spring should produce plants which, if properly grown outdoors this summer and placed in their permanent positions before autumn, will make a glorious show next season. Pkt. 25 cts., 1/40z. \$1.50.

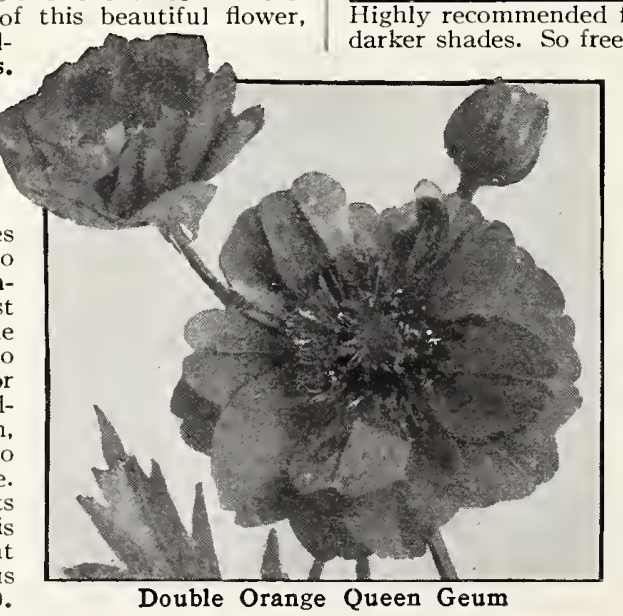

64

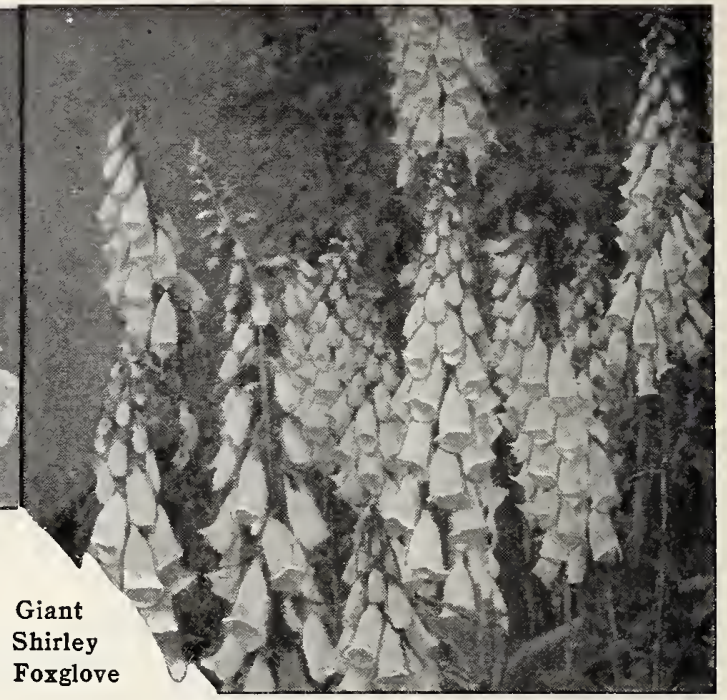

\section{GEUMS}

Three Fine New and Rare Double Varieties

The following three new large-flowering Geums are among the best hardy perennials of recent introduction.

DOUBLE ORANGE QUEEN. We are pleased to offer what has hitherto baffled the hybridists and selecters to produce, namely, a Geum of a shade intermediate, so to speak, between that of Mrs. Bradshaw and Lady Stratheden. The plants are similar in habit to both of these highly popular sorts, and as they are quite as large and free-blooming, we have no doubt that Orange Queen, in coming to complete a splendid trio, will soon acquire an equal share of public favor. Height, I $1 / 2$ feet. Pkt. 25 cts., 5 pkts. $\$ 1$.

DOUBLE MRS. BRADSHAW. The very large, full flowers are an attractive shade of orange-scarlet. They come quite true from seed and bloom the first year, if sown early. Height, I $1 / 2$ feet. Plit. 15 cts., $1 / 8$ oz. $\$ 1,1 / 4$ oz. $\$ 1.50$.

DOUBLE LADY STRATHEDEN. Fine rich golden yellow flowers. A splendid companion to Orange Queen and Mrs. Bradshaw. Height, I $1 / 2$ feet. Pkt. 25 cts., 5 pkts. $\$ 1,1 / 8$ oz. $\$ 1.50,1 / 40 z$. $\$ 2.50$.

\section{New Dwarf Godetias}

We are pleased to offer two new varieties of this charming annual of easy culture. The plants are of distinct and graceful habit. They grow to the height of $I$ to $I I / 2$ feet and are excellent as a border plant.

Scarlet, Edged White. An attractive variety of dwarf growth and producing very large flowers. Scarlet with an edging of white. Pkt. 15 cts., $1 / 40 z .60$ cts., oz. $\$ 2$.

Dwarf Double Azalea-flowered, Carminea.

Highly recommended for pot culture. Pink, strikingly marked with -blooming that when it is in full flower it is a veritable mass of bloom. May be called an annual Azalea. Pkt. 15 cts., 1/40z. 60 ets.; oz. \$2.

\section{Helianthus (Sunflower) Dwarf Maroon Prince}

The best red Sunflower on the market at the present time. A dwarf type, from 2 to 3 feet high, it is a valuable subject for the annual border. Pkt. 15 cts., $1 / 40 z .60 \mathrm{cts}$. , oz. \$2.

\section{Humea Elegans}

A graceful, half-hardy biennial, growing 4 feet high, with sweet-scented foliage and graceful, feathery, purple-brown flowers. Well-grown specimens are very impressive for sub-tropical bedding and for conservatory decoration. Pkt. 25 cts., 5 plsts. $\$ 1$, 


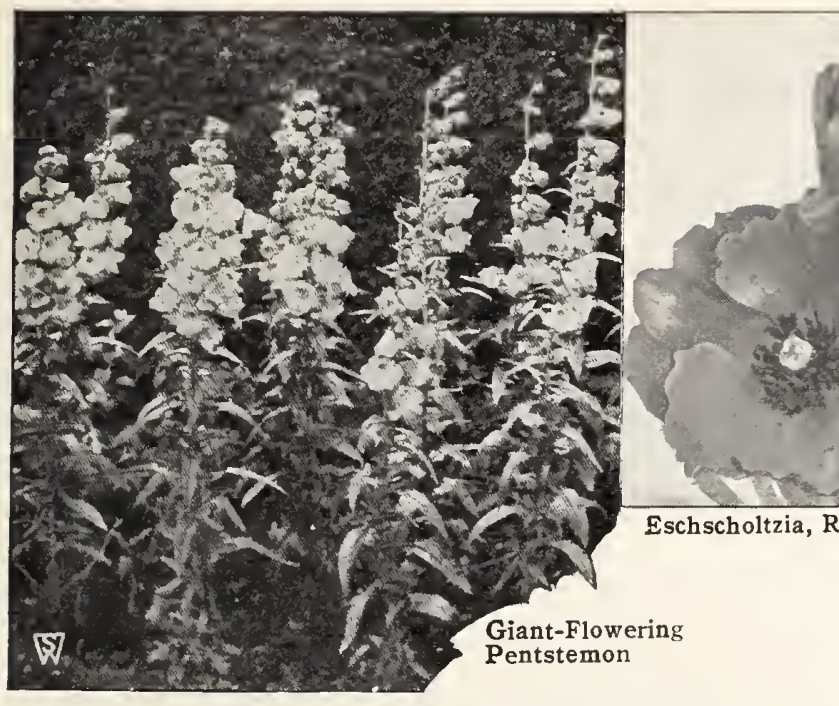

\section{New Hollyhock, Double Exquisite}

A new strain of Hollyhock which will prove a delight to all those who enjoy this old-fashioned flower in an entirely new form. The large blooms are beautifully fringed and frilled or deeply dentate, and the colors are charmingly fresh and bright. They are so well placed on tall, stately spikes that mucl of the stiff effect to be noted in the older types is entirely lacking in this truly exquisite new strain. Contains a fine selection of colors. Pkt. 25 ets., $1 / 80 z$. $\$ 1.50,1 / 40 z$. $\$ 2.50$, oz. $\$ 7.50$.

\section{New Annual Larkspur}

For the past several years our growers have been trying to produce an Annual Larkspur with the habit of the Delphinium. Last year we offered three of these types and this vear we are able to offer three new sorts, namely Carmine King, Blue Spire, and Lilac Spire.

All these varieties have the characteristics of the Delphinium, that is, the base-branching form and the long flower-stalk, and we feel sure that they will in time supersede the old stock-flowered type.

La France. A pleasing salmon-pink-the best color for conservatory decoration, while a bed or border of this easily grown annual is indeed beautiful. The double flowers are large and well formed, and the plant is more vigorous and tallergrowing than other light shades of stock-flowered Larkspur. Pkt. 25 cts., 5 pkts. $\$ 1,1 / 40 z$. $\$ 1.50$, oz. $\$ 5$.

Exquisite Pink Improved. Exquisite in color and perfect possesses the shape, compact and in form, this annilal Larkspur delightful shade of pink meets exactly the florist's requirements. Pkt. 25 cts., 5 pkts. $\$ 1,1 / 4$ oz. $\$ 1,0 z$. $\$ 3.50$.

White Spire. A new, dazzling, pure white, double Larkspur, Whessing the shape of the Delphinium. The individual florets are quite large and the flowers well placed on long stems, making it an excellent cut-flower. Pkt. 25 ets., 5 pkts. \$1, $1 / 40 z . \$ 1.50,0 z . \$ 5$.

Blue Spire. Similar to the above except deep Oxford blu in color, which is an intense $1 / 4 \mathrm{oz} . \$ 1.50$.

Lilac Spire. Beautiful shade of lilac Pkt. 25 cts., 5 pkts. $\$ 1,1 / 4$ oz. $\$ 1.50$.

Carmine King. A beautiful shade of Pkt. 25 cts., 5 pkts. $\$ 1,1 / 4$ oz. $\$ 1.50$.

\section{New Marigold,}

\section{African Orange, Alldouble}

Any strain of African Marigold that will come 70 per cent double is considered good85 per cent is excellent. We are pleased to be able to offer a strain of Orange Marigold which has come roo per cent double for the past two years. Pkt. 25 cts., 1/80z. \$1, $1 / 40 z$. $\$ 1.50$.

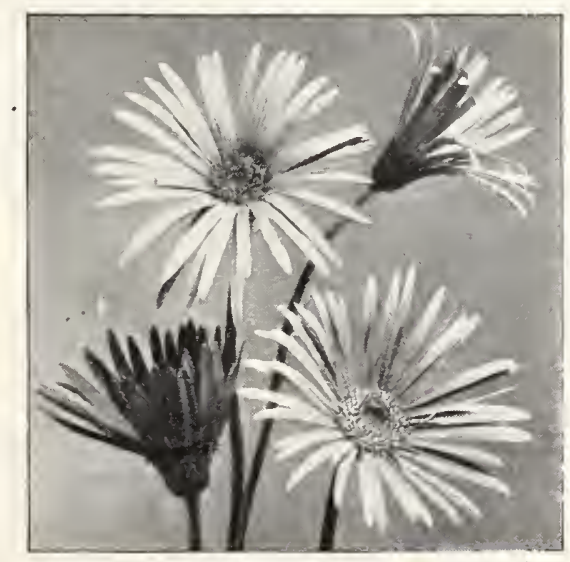

Gerbera Jamesoni Hybrids. See page 64.

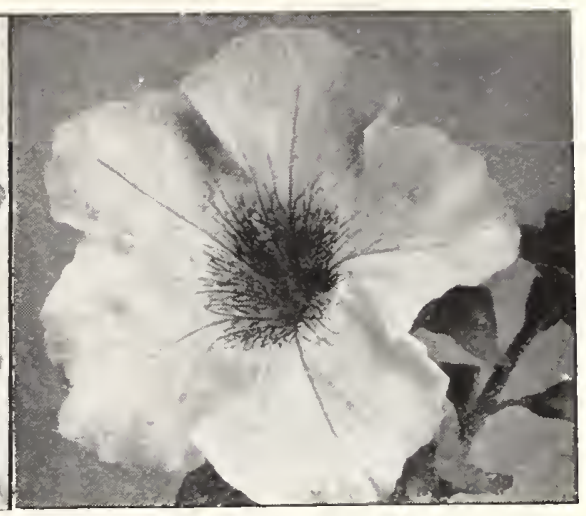

Balcony Petunia

\section{Pentstemon, S. \& W. Co.'s Giant-Flowering}

Hybrids, Mixed

This is one of the finest bedcling plants in cultivation. It grows 2 to 3 feet high, each brancl bearing a spike of large, gloxinia-like Pkt. 25 cts., $1 / 8$ oz. $\$ 1,1 / 40 z$. $\$ 1.50$.

\section{New Balcony Petunia, Star of California}

This is a magnificent new Petunia, bred with extra-long branches for window-boxes and hanging-baskets. The flowers are velvety violet, with a touch of crimson, starred with five pure white blotches. Pkt. 50 cts., 5 pkts. $\$ 2, \frac{1}{16}$ oz. $\$ 3.50$.

\section{BALCONY FRINGED}

Splendid, free-flowering type, either for bedding or window-boxes. The flowers average 3 inches across.

White Beauty. White.

Pink King. Light rose.

Any of the above, pkt. 25 cts., 5 pkts. \$1

\section{Two Fine Bedding Petunias}

Pink Beauty. This is a grand acquisition to the single bedding Petunias. The flowers are very large, of hand Of very rapid throat lightly suff used yellow. grown this Petunia in beds, borders, or rockery proclaim it the best they have ever seen. Pkt. 15 ets., $\frac{1}{16}$ oz. \$1.

Fimbriata cærulea (Steel-Blue Fringed). This very attractive and unique fringed Petunia can large throat of deeper blue. The outer part of the throat has the appearance of being overlaid with veins of darker blue. It is very deeply fringed, and the most attractive light blue Petunia in cultivation Pkt. 25 ets., 5 pkts. $\$ 1$.

Petunias for Pot Culture S. \& W. CO.'S NEW GIANT-FLOW ERING DWARF. This strain produce the largest flowers of any dwarf type of Petunia on the market today. They are of handsome shape with open throats, heavily marked and delicately veined. The plant is compact, strong and vigorous. Pkt. 25 cts., 5 pkts. $\$ 1$.

\section{New Primula obconica,} Glory of Farmingdale

This new development of Primula $a b$ conica is of special interest to those who cultivate Primulas under glass. Its flowers are a pleasing shade of bright rose, individually large. and well set on strong, sturdy plants. The grower will have few discarded plants with this strain, and ve recommend it with every 


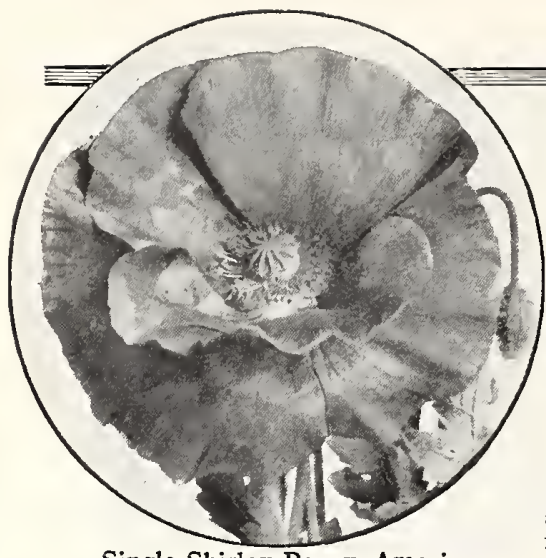

Single Shirley Poppy, American Legion

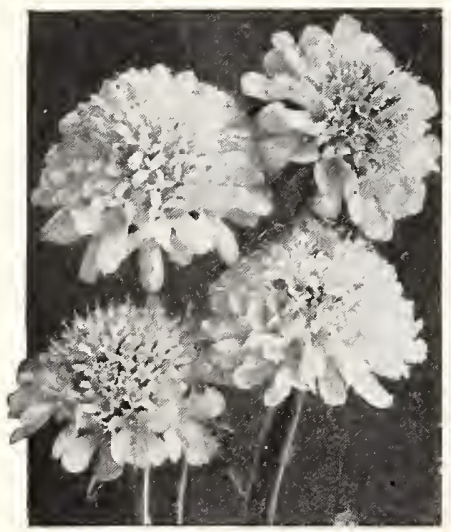

Scabiosa, Giant Loveliness
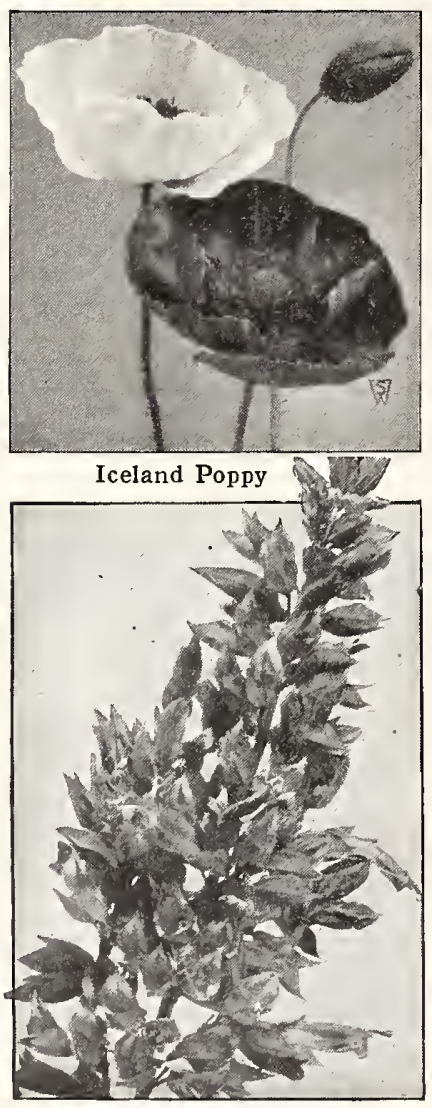

Ostrich-Plume Salvia

\section{Two New Iceland Poppies}

Tangerine

This is a deep tangerine-orange, with flowers of enormous size, twice as large as any other strain ever introduced. The flowers are borne on long, wiry stems and come true from seed. Excellent for cutting. Pkt. 25 ets., 5 pkts. $\$ 1,1 / 80 z$. $\$ 1.50$.

\section{Coonara Pink}

A variety of Papaver nudicaule recently introduced from Australia. Rose-pink and salmon are blended to give us flowers of rare shades, while the petals are slightly ruffled. The flowers are borne on long, wiry stems. A valuable addition to our hardy perennials. Pkt. 25 cts., 5 pkts. $\$ 1,1 / 80 z$. $\$ 3.50$.

\section{Single Shirley Poppy}

\section{American Legion}

This new single Shirley is a dazzling orangescarlet, of enormous size, borne on long, stout stems. The plants are of very erect, robust growth. Highly commended by the Royal Horticultural Society of Great Britain. Pkt. 15 ets. $1 / 4 \mathrm{oz} .75$ ets., oz. $\$ 2.50$.

\section{New Double Shirley Poppies, \\ Mixed Colors (Hardy Annuals)}

This is a new, semi-double type of the beautiful Shirley or Ghost Poppy. The color-range is very wide, including carmine, rose, salmon, and white shades, while the flowers are very beautiful and graceful, being carried well above the plant on strong stems. Pkt. 25 ets., 5 pkts. \$1.

\section{Oriental Poppy}

New Double Hybrids

For the first time we are able to offer seed of a double Oriental Poppy, and we feel sure it will become a very popular perennial. One of its most valuable features is that it blooms very early, at a time when there is still a lack of cut-flowers. The plant itself is of bushy habit, with thick, feathery foliage, and bears numerous flowers in a glowing, very striking, orange-scarlet. When fully expanded, the flowers measure 6 inches across and are borne on stems 3 feet high. Pkt. 50 ets. 5 pkts. \$2.

\section{Ranunculus}

\section{Asiaticus, Palestine Strain}

Originating from a wild, large-flowered Ranunculus found in Palestine, a variety of colorsreds, yellows, orange, etc.-have been produced many are marked with green. The mixture includes singles, semi-doubles, and doubles, the flowers making the plants a blaze of color. A bed of these is a remarkable sight. Pkt. 50 ets.

\section{NEW SALVIAS}

HARBINGER. It is a true, dwarf, large-flowering Salvia which commences blooming in July from early-sown seed and continues until hard frost. It makes beautiful symmetrical plants about $\mathrm{I}_{5}$ inches high, and is densely clothed with long sprays of large, brilliant scarlet flowers. Pkt. 25 cts., 5 pkts. $\$ 1$.

AMERICA Or GLOBE OF FIRE. A new variety of this popular flower. The bushy plants do not grow over is inches high, with the large spikes of brilliant scarlet flowers thrown well above the plant, making a total height of about 2 feet. An acquisition on account of its uniformity of height. Pkt. 25 ets., $1 / 8$ oz. $\$ 1,1 / 40 z . \$ 1.75$. OSTRICH-PLUME. The habit of the bush resembles the Splendens type but, unlike Splendens, the bush is well covered with plumes of blossom. As a cut-flower one of these scarlet plumes alone makes a delightful decoration. Comes 75 per cent true from seed. Pkt. 25 ets., 5 pkts. $\$ 1$.

\section{New Annual Scabiosas}

GIANT LOVELINESS. A glorious new color in Annual Scabiosas. The blooms range through varying tones of soft, delicate salmon-rose. This is undoubtedly the most beautiful Scabiosa ever introduced. It is unsurpassed as a cut-flower, having long, stiff stems and a delightful fragrance, but its crowning beauty is its glorious salmon-rose color. Pkt. 25 ets., 1/80z. 60 ets., $1 / 4 \mathrm{Oz}$. \$1.

\section{Two Large-Flowering Varieties}

SHASTA. Pure white, with immense blooms from 3 to 4 inches in diameter. The stems are exceptionally long, and the variety is invaluable for cutting. Plit. 25 ets., 1/40z. 75 ets.

PEACH BLOSSOM. A lovely new shade of peach-blossom-pink. The flowers are large, borne on long stems, and are therefore exceilent for cut bloom. Peach Blossom was "highly commended" by the Royal Horticultural Society of England. Pkt. 25 cts., 1/40z. 75 cts.

\section{Two New Perennial Scabiosas}

\section{Giant Hybrids of Scabiosa Cau-}

casica. (Isaac House Strain.) Characteristic of this new type are larger flowers with heavier petals and on longer stems. In this mixture it is natural for delicate lilac and mauve to predominate, but pure white and several shades of dark blue also occur. These hybrids are splendid for the hardy border, and we also recommend them as a florists' cut-flower. Pkt. 35 cts., 1/40z. $\$ \mathbf{2 . 5 0}$. Columbaria. A splendid novelty from South Srabion. While reminiscent of Scabiosa caucasica, it is entirely distinct, being quite dwarf in habit. It produces flowers 2 to $2 \mathrm{I} / 2$ inches in diameter, on long, strong stems. Excellent for cut bloom for the florist. We offer it in two shades: Pink, Lavender. Each of these shades, pkt. 35 ets., $1 / 8$ oz. $\$ 2.50$.

\section{Four New Stocks}

\section{S. \& W. Co.'s Early Giant Imperial Type}

Antique Copper. Rich hellebore-red, overa pleasing old reddish antique copper effect. The flowers are fully double.

Old Rose. A very beautiful shade of old-rose similar to the very popular Old Rose in the Nice group. It is very double and has extremely large individual florets.

Elk's Pride. An intense royal purple. Growing over 2 feet high, this stately plant is a mass of large, sweetly perfumed, double flowers.

Golden Rose. A rich light rose, enhanced Golden effect in the by the addition of a pleasing wonderful cut-flower; large and very double.

Each of the above, pkt. 25 cts., 1/80z. $\$ 1.50$

\section{Ursinia anethoides}

\section{New Hybrids}

The daintiness and exquisite blending of colors of this beautiful annual will appeal to all flowerlovers. The plants grow about 2 feet high and carry a hundred or more fully expanded flowers at one time. All have petals of a delightful rich orange tone, but it is the central coloring surrounding the disk that shows wonderful variations. The width of the rings varies from $1 / 8$ to $3 / 4$ inch, and tone from ruby-red to dark purple, spangled with the distinctive jewel-like dots. From seed sown in April, plants commence flowering in June and continue until September. Pkt. 25 ets., 5 pkts. $\$ 1$. 


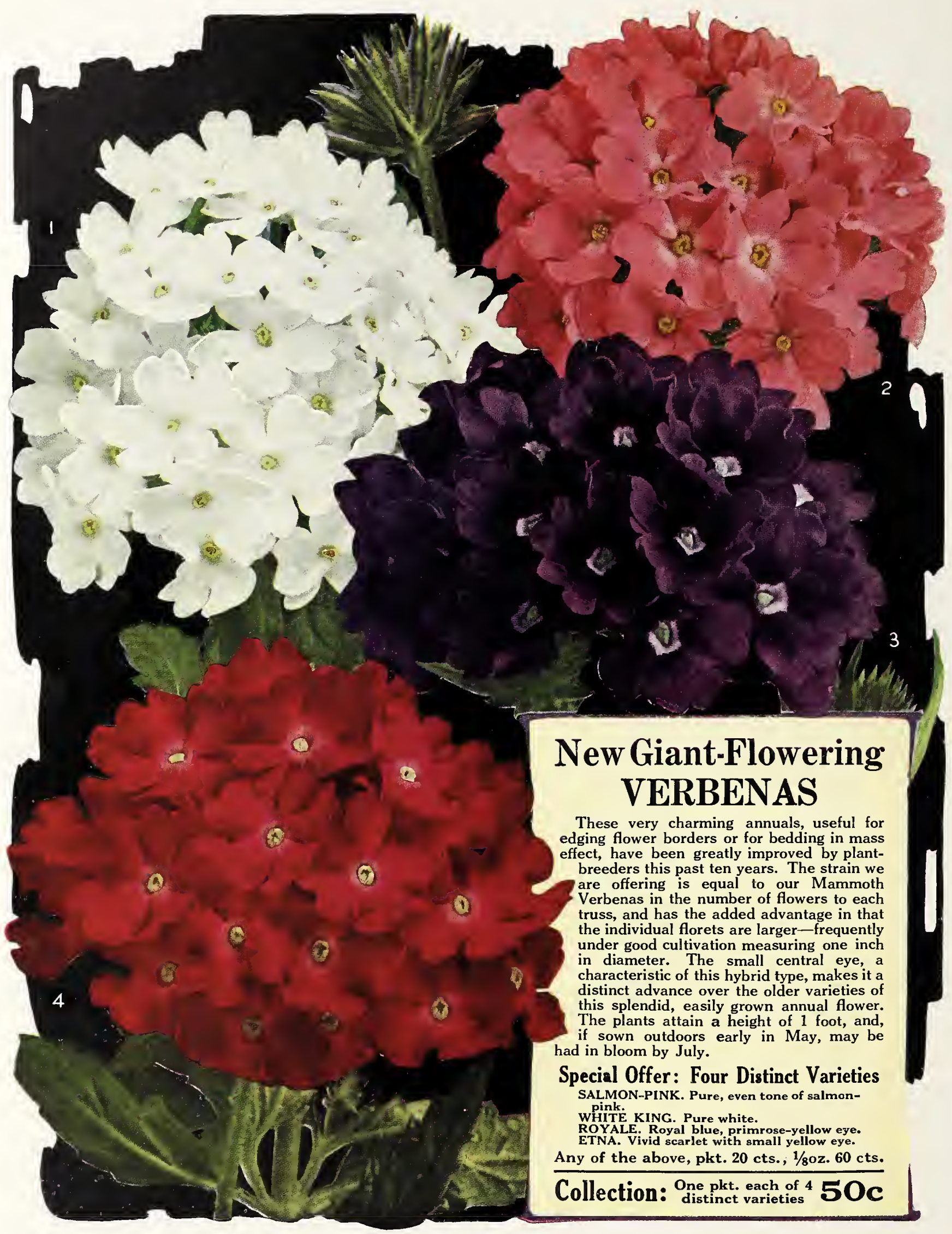




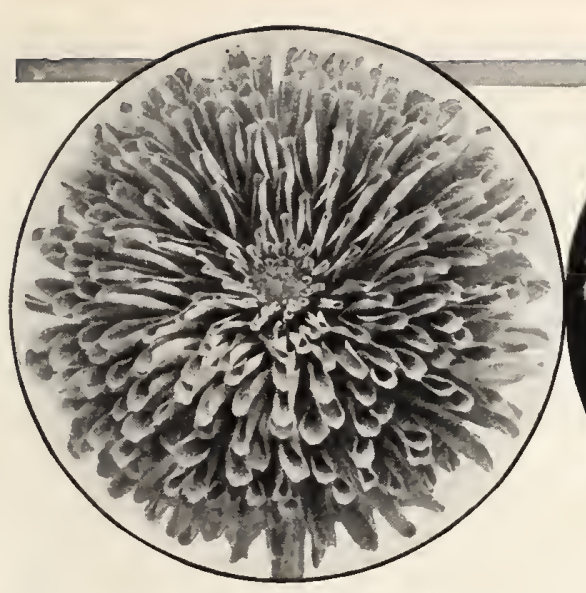

Victory Quilled Zinnia

\section{NEW VERBENAS}

\section{Dwarf Compacta, Fireball}

A dwarf, compact Verbena, growing about 6 inches high and literally covered with bright scarlet flowers. Blooms the entire summer, which makes it ideal for botl pots and bedding purposes. Pkt. 25 ets., 1/80z. \$1.50, 1/40z. \$2.50.

\section{Giant-Flowering Varieties}

These very charming annuals, useful for edging flower borders or for bedding in mass effect, have been greatly improved by plant-breeders this past ten years. The strain we are offering is equal to our Mammoth Verbenas in the number of flowers to each truss. and has the added advantage in that the individual florets are larger-frequently under good cultivation measuring one inch in diameter. The small central eye, a eharacteristic of this hybrid type, makes it a distinct advance over the older varieties of this splendid, easily grown annual flower. The plants attain a height of I foot, and, if sown outdoors early in May, may be had in bloom by July.

Salmon-Pink. Pure, even tone of salmon-pink. White King. Pure white.

Royale. Royal blue, primrose-yellow eye.

Etna. Vivid scarlet with small yellow eye

Luminosa. Shades of salınon, flesh, and coral on a ground of flame-pink.

Mixed. A mixture of all shades.

Each, pkt. 20 cts., $1 / 8$ oz. 60 cts., $1 / 4$ oz. $\$ 1$, oz. $\$ 3.50$

New Annual Wallflower, Extra-

\section{Early Double}

If seed of this variety is sown in early spring, it will be in full bloom by the end of May. The flowers are equal in size to those of the perennial double varieties, and they are delicately perfumed. Canary - Yellow Dark Brown

Golden Yellow

Mixed

Each of the above, pkt. 25 cts., 5 pkts. $\$ 1$

\section{New Zinnia, Pumila Picotee}

\section{Delight}

This Zinnia is the result of crossing Dwarf Double Salmon-Rose with the tall Picotee. The plants are of compact growth and very floriferous. The petals are ruffled and curled, giving a light. dainty effect, and, in addition, each is beautifully picoteed, making a most attractive flower. Its color-range includes salmon shades, cream, buff, biscuit. golden yellow, lavender, and, in fact, a eollection of colors most suitable for any use. Fist. 25 ets., $1 / 80 z$. $\$ 1.50,1 / 40 z$. $\$ 2.50$.

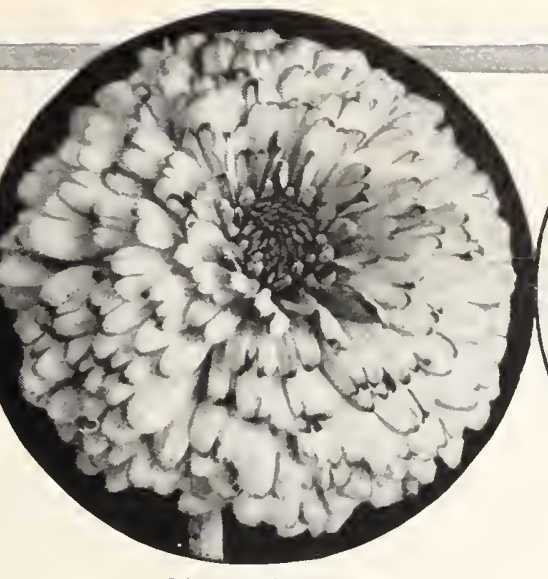

Picotee Zinnia

\section{ZINNIA}

Giant Double Dahlia-flowered

The plants attain the height of 3 feet, producin mammoth flowers averaging 6 inches across by 3 to 4 inches in depth, similar in shape to the Decorative dahlia, with the same fullness of the petals.

\section{Two Fine New Varieties}

Golden Dawn. The flowers are a golden color in the Double Giants, or a shade between Golden State and Canary Bird in the Dahliaflowered type. They are of enormous size and of the most perfect type.

Youth. This Zinnia is three or four shades a beautiful tint of soft rose. The flowers are wel formed, of true Dahlia-flowered type, grown on the usual robust Dahlia-flowered plant. It is a very vigorous and free-flowering variety.

Each, pkt. 25 cts., 1/40z. $\$ 1$, oz. $\$ 3.50$

\section{Best Popular Varieties}

Buttercup. Very large flowers of deep creany yellow.

Crimson Monarch. Immense flowers of flaming crimson.

Dream. Deep lavender-blue - a remarkable shade. Exquisite. Light rose, with deep rose center.

Oriole. A striking two-color flower-orange and gold.

Polar Bear. Large, pure white.

Scarlet Flame. Bright scarlet, blended with range.

Mixed. A mixture of all shades.

Any of the above, pkt. 25 cts., 1/40z. $\$ 1,0 z . \$ 3.50$

Picotee. The flowers of this new type of Picotee. Zinnias are not so large as those of the Giant Double varieties but are very effective. from that of the body of the flower. Plants attain a height of $I / 2$ feet. We offer them in a splendid mixture of eolors. Pkt. $25 \mathrm{cts} ., 1 / 4 \mathrm{oz} . \$ 1$.

Victory Quilled. This new type of Zinnia form to the cactus dahlia. The petals have a rather refined looking appearance and are very graceful. Plants attain a height of $1 \mathrm{I} / 2$ feet. We offer them in a good mixture of eolors. Pkt. 25 cts., $1 / 40 z$. $\$ 1$.

Dwarf Double Salmon-Rose.

While the Giant Double and Dahlia-flowered Zinnias are in great demand for cutting purposes, we wish to recommend this very beautif $u$ l variety for bedding or as a dwarf border variety or fo table decoration. The color is a brilliant salmonrose. Pkt. 15 cts., $1 / 40 z .50$ cts., oz. $\$ 1.50$.

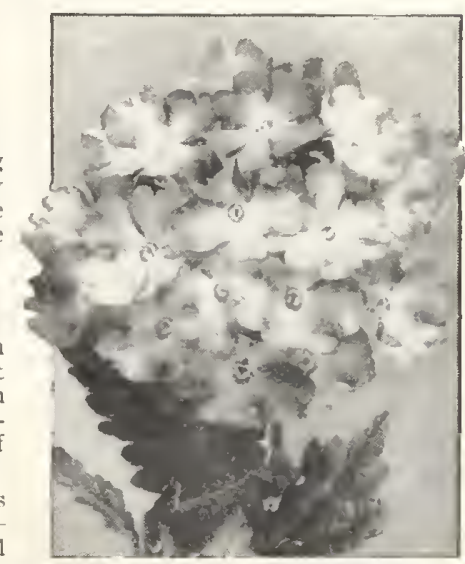

Giant-flowering Verbena

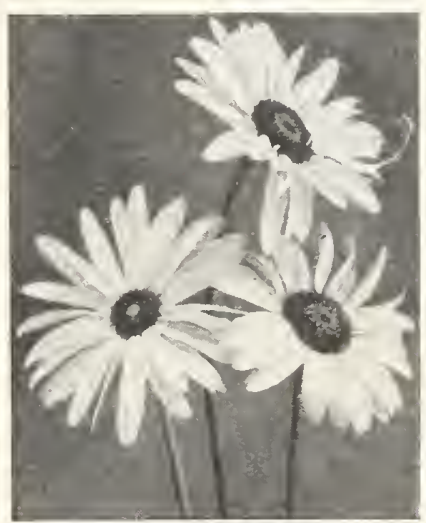

Ursinia.

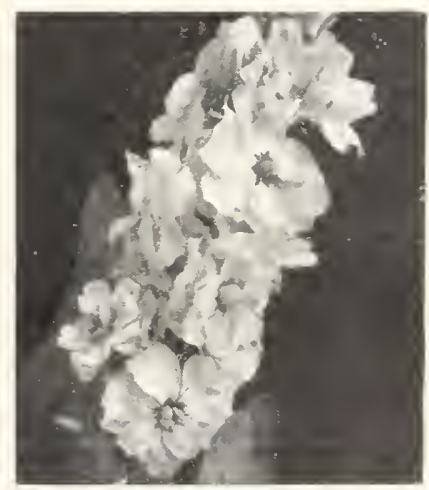

New Stock, Elk's Pride. See page 6 


\section{FINEST EXHIBITION SWEET PEAS}

\section{LARGE-BEAUTIFUL-SWEETLY PERFUMED}

Each year the Sweet Pea enthusiasts of Europe and America offer a list of Novelty Sweet Peas. There are now several hundred good varieties in commerce, many of them of splendid merit, but in many cases the varieties are much alike. We have listed on pages I 5 and I 6 of our catalogue, forty-one of the most distinct sorts which we respectfully recommend. Many of our customers, however, are desirous of growing a limited number of varieties but want these to be the very best. It is with this in mind that we offer the following:

\section{The Best Ten of the New Spencer Varieties}

Celebrity. The most vigorous-growing, orangeunusually large and the stems long and strong. The color is uniform in standard and wings, and bright rather than dark. We cannot recommend this variety too highly...................\$ 25

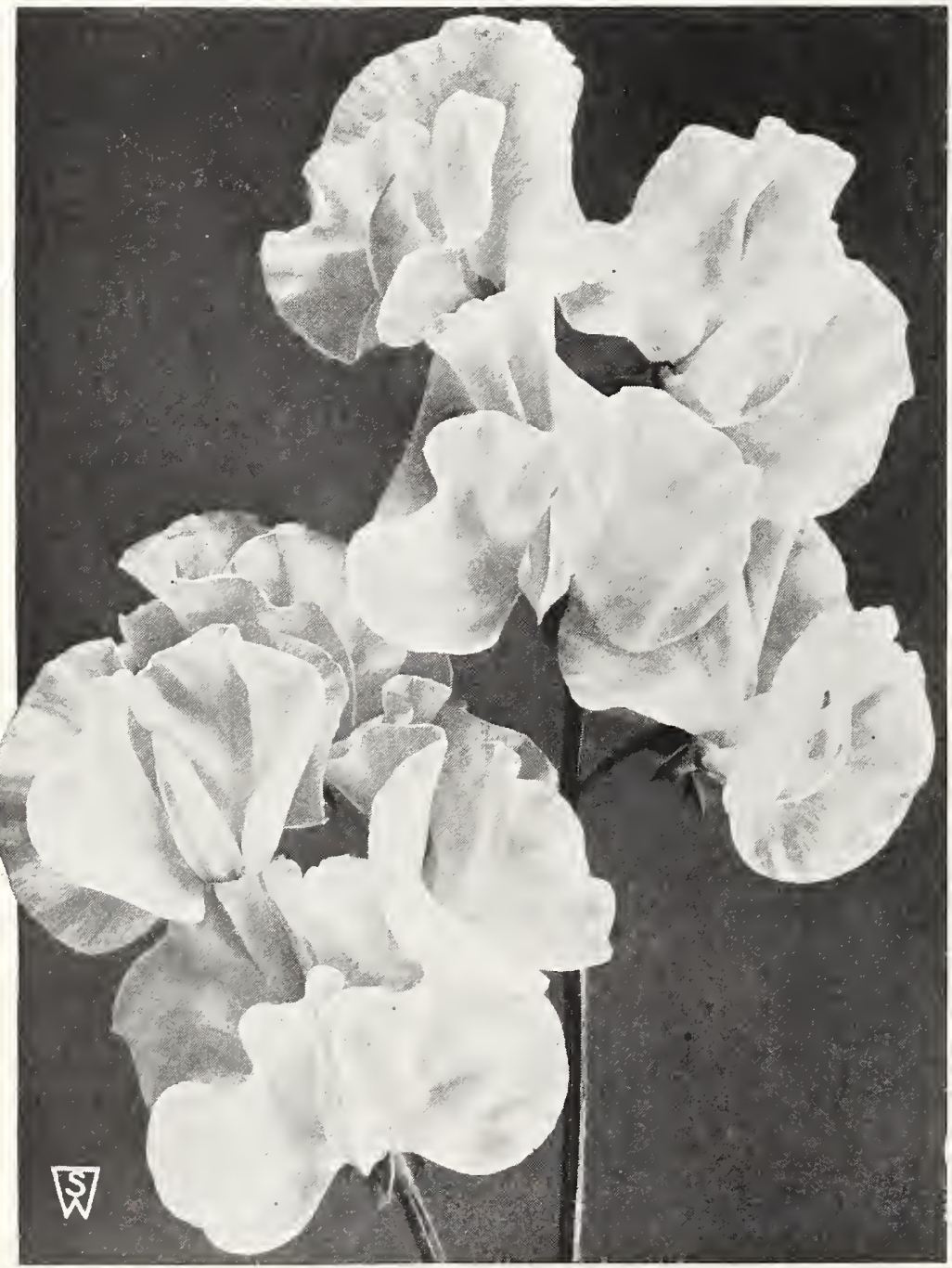

Sweet Pea, Duplex Type, Vectis

Oz. Blue Flame. The largest dark blue Sweet Pea Pkt. Oz. anything in the Mrs. Tom In existence. It is deeper than stems, and the flowers are very sweet-scented.....\$O $25 \quad \$ 100$ Conqueror. A magnificent, large, clear glowand wings are alike in brightness of color. Vines are vigorous and the flowers are borne on fine strong stems....

Eosine. This variety, according to Eosine. the chart, is a beautiful tone of eosine-pink, with a soft flush of salmon. The flowers are very large and well placed on long, stout stems. .

Good Cheer. This is a beautiful Good Cheer. shade of deep begonia-rose. The flowers are very large and well placed on long stems and the vines are vigorous growers. This is one of the most outstanding Sweet Peas ever introduced................

Hero. A new shade, difficult to deHero. scribe because of its subtlety. In diffused light it is a brilliant cerise, but in artificial light, or when the sun is shining upon it, the effect is one of a rich suffusion of salmon. The flower is delicately waved.............. Kitty Pierce. (D u plex Type.) charming of Sweet Peas. Both wings and standard are of a soft, light lilac, and spreading through the flower is a delicate suffusion of blush-pink....... Pinkie. This appears to be the Pinkie. largest Sweet Pea in cultivation. The plant is vigorous and stout; strong stems bear a profusion of flowers throughout the season. Deep rose-pink waved blossoms.......... Sunkist The wings and standard Sunkist are clear rich cream, but on the edges they appear to have been flecked with the rays of the setting sun The flower is large, of thick substance, and handsomely waved; three and four of the flowers are borne on strong stems. Vectis. (Duplex Type.) Enormous Vectis. flowers of the purest white, with a distinct almond-like perfume. A splendid acquisition, and the finest white Sweet Pea in cultivation.......

What Are Duplex Type Sweet Peas? There are, as yet, no true Double Sweet Peas, but careful breeding has proare Duplex Types, and we offer two of these in the above selection of Ten Finest Exhibition Sweet Peas. For General List of Sweet Peas, see pages I 5 and I 6 . 


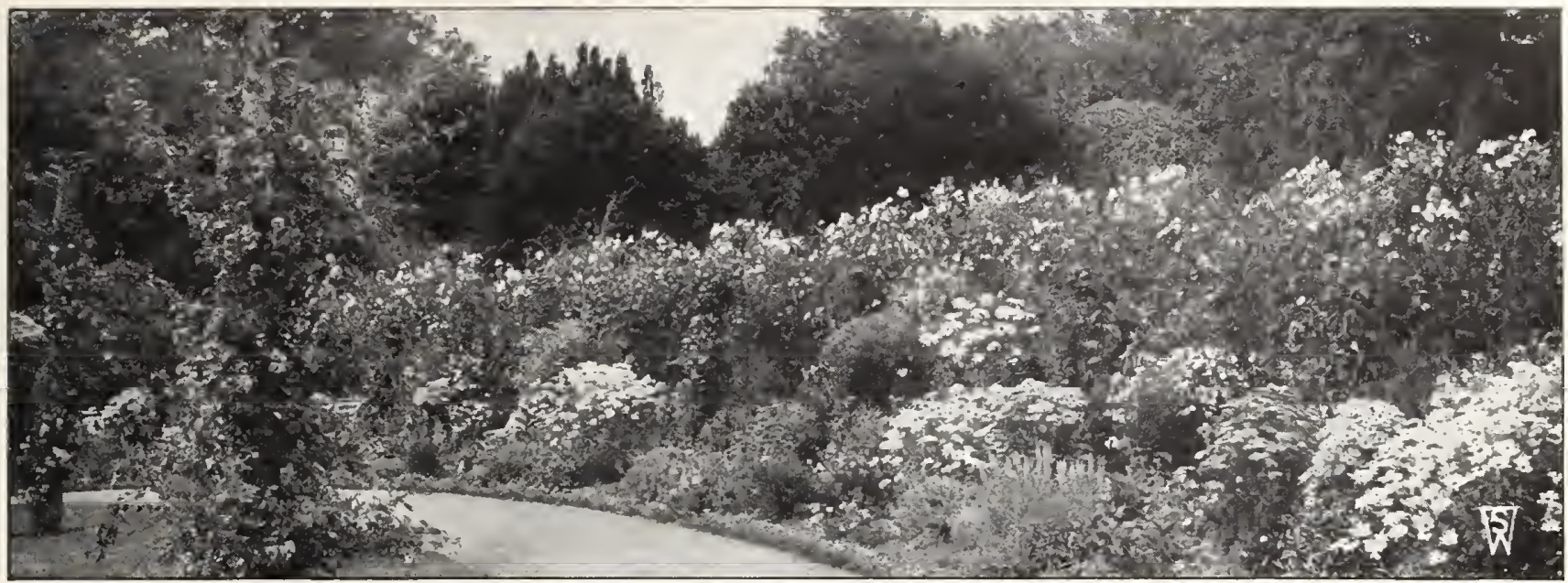

\section{GENERAL LIST OF FLOWER SEEDS}

In presenting this list of Flower Seeds for your attention, every care has been taken to secure seeds from sources of supply known to us, and from our experiences and from our tests a t our trial grounds, to be of the lighest possible merit. Our Flower Seeds are selected with an idea of superiority of strain and we handle only the highest possible types in each respective class.

We mail all Flower Seeds FREE OF COST to any Post Office in the United States.

\section{ABUTILON (Flowering Maple)}

Finest Mixed. Attractive coolhouse shrub and window-plant, and valuable for summer bedding. Perpetual-blooming, bearing lovely, bell-shaped flowers. Height 4 feet. Pkt. $25 \mathrm{cts} ., \frac{1}{32} \mathrm{Oz} . \$ \mathbf{I}$.

\section{ABRONIA}

Verbena-like plants, very fragrant, especially toward evening. Charming trailers for vases, rockwork, etc. Half-hardy annuals. Umbellatum. Rosy pink. Height 9 inches. Pkt. Io cts.

\section{ACANTHUS (Bear's Breech)}

Mollis latifolius. Hardy perennial. Grows 3 feet high, and has rose-colored flowers in August and September. Pkt. I5 cts.

\section{ACHILLEA}

Ptarmica, The Pearl (Sneezewort). Hardy perennial. Bears a profusion of small, double, white flowers during the entire season. Fine for cutting. Height $21 / 2$ feet. Pkt. $25 \mathrm{cts}$., $1 / 80 \mathrm{Oz}$. $\$ 2$.

Filipendula. Yellow. Height 3 feet. Pkt. I5 cts.

Millefolium roseum. Pink. Height $I^{1} / 2$ feet. Pkt. I 5 cts., $1 / 80 z$. \$I.

\section{ACONITUM (Monkshood or Wolfsbane)}

Wilsoni. The most handsome of the Monkshoods, and especially useful on account of its late blooming season. Its long spikes of beautiful, light blue flowers are produced from summer until November. Hardy perennial. Height 5 feet. Pkt. 25c., $\frac{x}{16} \mathrm{Oz} . \$ 1$.

Napellus. A hardy perennial producing long spikes of curiously shaped blue flowers. Well adapted for planting among shrubber Height 3 to 5 feet. Pkt. I $5 \mathrm{cts}$. 1/80z. $60 \mathrm{cts}$. I/40z. \$I

Fischeri. Dwarf; pale blue. Height I $1 / 2$ feet. Pkt. I5 cts., 1/80z. $\$ 1$ Finest Mixed. All colors. Pkt. IO cts., 1/80z. $60 \mathrm{cts}$., 1/40z. \$I.

\section{ADLUMIA (Mountain Fringe)}

Cirrhosa. A very graceful, hardy, biennial climber. The foliage somewhat resembles the maidenhair fern. Flowers are tube-shaped, white or purplish, reminding one of the bleeding-heart and entirely cover the plant. For trellises or old stumps of trees. Flowers first season from seed, if sown early. Pkt. I5 cts., 1/80z. \$I.

\section{ADONIS}

Estivalis (Pheasant's Eye). Hardy annual. Dark Pkt. green foliage; scarlet flowers. Height i foot...... \$o Io Autumnalis (Flos Adonis). Small, crimson flowers, with dark center; globose. Height I foot.

Vernalis (Spring Adonis). Hardy perennial, with large, yellow flowers in the early spring. Height i foot...

\section{AGERATUM (Floss Flower)}

One of the very best bedding plants, being literally a sheet of bloom from early summer till frost. Unlike many bedding plants, these flowers are not likely to be spoiled by rain, nor do the colors fade out. Easily raised from seed, which is usually started in a horbed or window and transferred to the open ground in May. Can also be sown outdoors in May.

Blue Perfection. Large heads of deep blue flowers produced in abundance. Fine for cutting. Pkt. Io cts., $1 / 40 \mathrm{Oz}$. $50 \mathrm{cts}$.

Little Blue Star. A very dwarf variety used largely for edging, growing about 4 to 5 inches high; bright blue flowers. Pkt. 25 cts. ${ }_{16} \mathrm{OZ}$. \$1.50, $1 / 8 \mathrm{O} Z$. \$2.50.

Little Dorrit, Blue. This variety grows about 6 inches high; flowers bright blue. Pkt. Io cts. $40 z$. 50 cts., Oz. \$1.50. Little Dorrit, White. Same in

Mexicanum Capella. Distinct growing about 9 inches high; flowers rosy chamois. Pkt. I5 cts., 2 pkts. $25 \mathrm{cts}$., I/80z. \$I.5O, I/40z. \$2.5O.

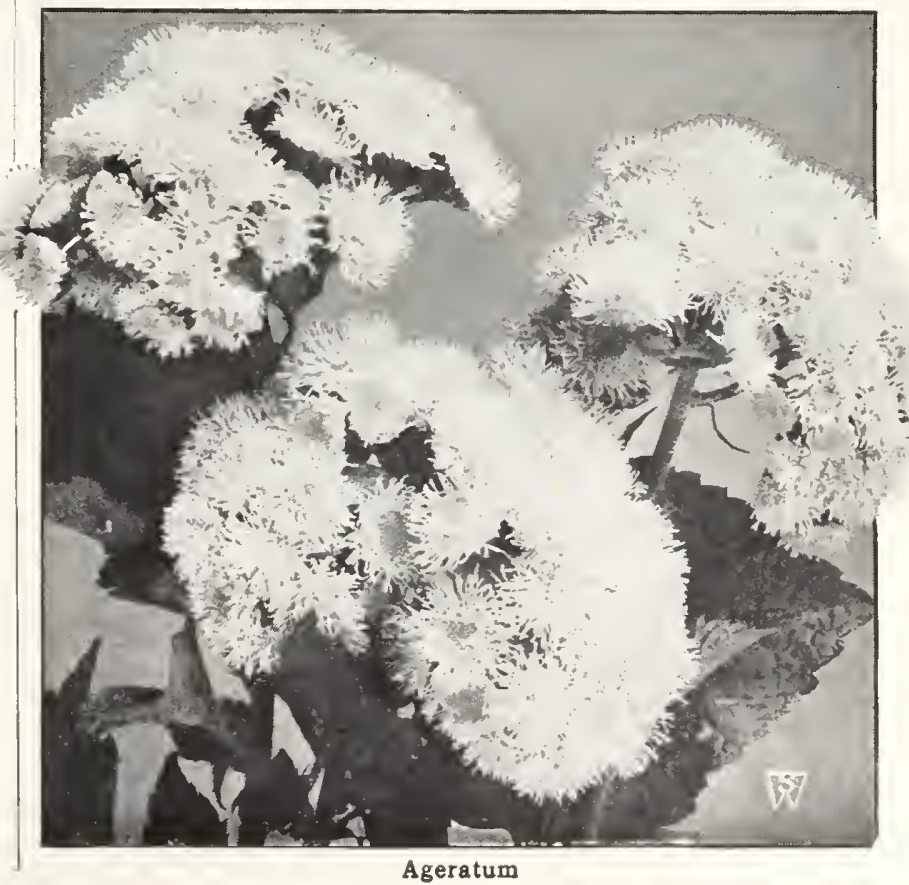




\section{AGATH EA (Blue Daisy)}

Cœlestis. A tender perennial, with beautiful blue flowers. Fine pot plant for winter blooming in conservatories. Height $\mathrm{I}$ foot. Pkt. I 5 cts., 2 pkts. 25 cts., $1 / 40 z$. 75 cts.

\section{AGROSTEMMA}

Coronaria (Rose Campion; Mullein Pink). Hardy perennial. Flowers dark blood-red and very large; foliage silvery. Height 2 feet. June to September. Pkt. Io cts., 1/40z. 50 cts.

Coronaria alba. White. Pkt. Io cts., 1/40z. $50 \mathrm{cts}$.

Coronaria, Mixed. Pkt. Io cts., $1 / 40 \mathrm{Oz}$. $50 \mathrm{cts}$.

Flos-Jovis. Pink. Height I foot. Pkt. Io cts., 1/40z. $50 \mathrm{cts}$.

\section{ALYSSUM}

Little Gem (A. maritimum). Plants grow only 3 to 4 inches high, and each plant completely covers a circular space of 12 to 20 inches. Pkt. Io cts., $1 / 4 \mathrm{Oz} .25 \mathrm{cts}$., $\mathrm{oz} .75 \mathrm{cts}$.

Sweet Alyssum (A. Benthami). The well-known fragrant white variety. Pkt. Io cts., $1 / 4 \mathrm{oz} .20 \mathrm{cts}$, , oz. $50 \mathrm{cts}$.

White Carpet $(A$. compactum procumbens). Purc white; grows only 2 to 3 inches high and flowers profusely. Pkt. IOC., $1 / 4 \mathrm{Oz}, 30 \mathrm{O} ., \mathrm{Oz} . \$ \mathrm{I}$.

Lilac Queen. Furnishes an abundance of lilac-colored flowers. As an edging plant, it makes a fine combination with White Carpet. Pkt. Io cts., 1/40z. $30 \mathrm{cts}$., oz. \$I.

Saxatile compactum. Hardy perennial. Excellent rock or border plant, bearing bright yellow flowers from April to June. Height 9 inches. Plit. I 5 cts., $1 / 40 z .75 \mathrm{cts}$., oz. $\$ 2.50$.

\section{AMARANTHUS}

Brilliant-foliaged annuals, growing from 3 to 5 feet high, some of the varieties bearing curious racemes of flowers. All are useful in borders of tall plants, or for the centers of large beds. They thrive best in a hot, sunny location and not too rich soil.

Caudatus (Love-Lies-Bleeding). Blood-red; drooping. Pkt. Io cts. Cruentus (Prince's Feather). Dark red, feathery flowers. Pkt. Io cts.

Sunrise. Considered the most brilliant of this family. The foliage is a bronzy crimson, each branch terminating with a tuft of bright scarlet-carmine leaves. Pkt. I 5 cts., 2 pkts. 25 cts.

Tricolor (Joseph's Coat). Leaves red, yellow, and green. Pkt. Io cts.

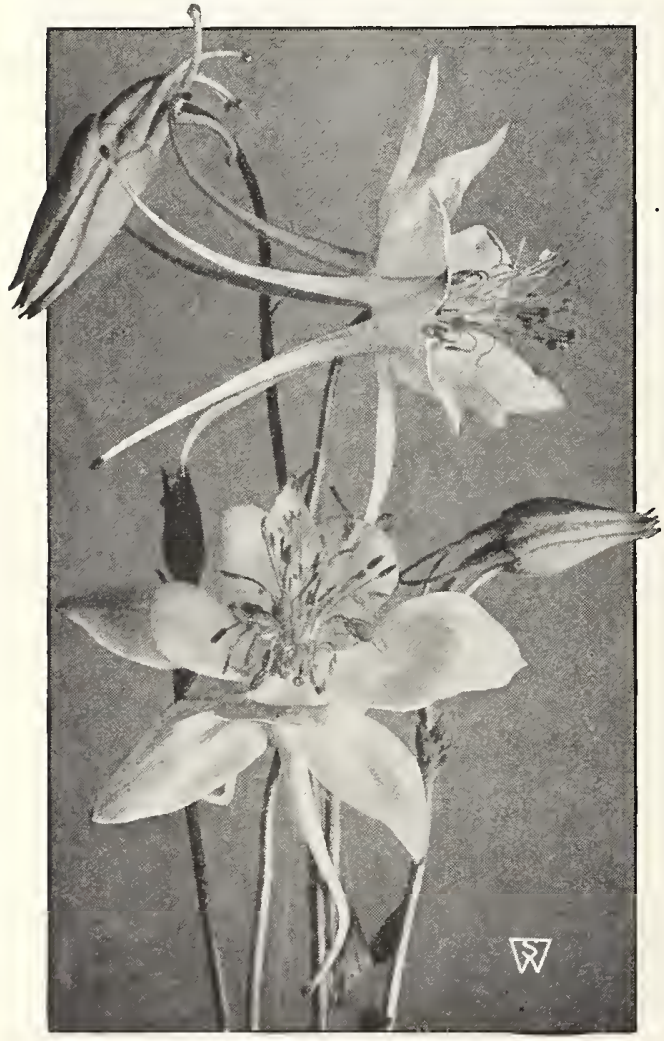

Long-spurred Aquilegias

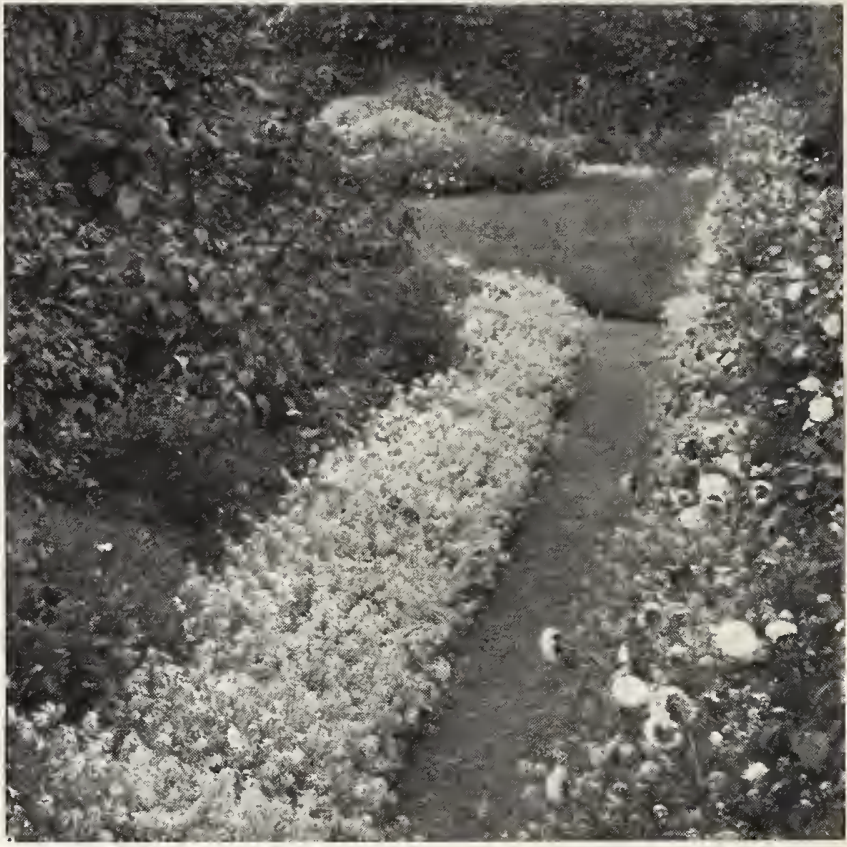

Border of Alyssum, Little Gem

\section{ANEMONE}

Single Giant de Caen (Windflower). Half-hardy perennial. The giant French Anemone. Excellent for cutting. 9 inches. Pkt. Io cts., $1 / 4 \mathrm{Oz} .75 \mathrm{cts}$.

St. Brigid (Irish Anemone). A great variety of colors. Pkt. 25 cts., $1 / 40 z, \$ 2$.

\section{ANCHUSA}

Capensis. Biennial. Flowers azure-blue, I $\mathrm{t} / 2$ feet. July and August. Pkt. Ioc., $\mathrm{T} / \mathrm{Ooz} .5 \mathrm{cc}$ Italica, Dropmore Variety. A hardy perennial whose bright blue, forget-me-not-like flowers are borne on graceful stems during the entire season and late into the fall. It is a great improvement over the existing varieties. Height 4 to $5 \mathrm{ft}$. Pkt. I5c., $1 / 4 \mathrm{Oz}$. $\$ \mathrm{I}$.

Opal. A very beautiful hardy perennial, similar in all respects to Dropmore, but the flowers are pale blue. Pkt. 35 cts., 3 pkts. $\$$ I.

New Annual, Blue Bird. A dwarf, compact type, I8 inches high, with vivid indigo-blue blossoms. Flowers two months after sowing seed. Pkt. 25 cts., I/80z. $\$ 1,1 / 40 z . \$ 1.50$.

\section{ANTHEMIS}

Kelwayi (Marguerite). Hardy perennial. Large, daisy-like yellow flowers; good for cutting. Height 2 feet. July to September. Pkt. Io cts., $1 / 40 z .75 \mathrm{cts}$.

Nobilis. White. 2 feet. Pkt. Io cts., 1/40z. 75 cts.

Tinctoria. Fine-cut foliage, with marguerite-like yellow flowers from June to October. Pkt. 25 cts., $1 / 40 z$. $\$ 1.50$.

\section{AQUILEGIA (Columbine)}

The Aquilegias are fine, free-flowering, hardy border plants. Seed may be planted in the open ground early in the spring.

S 8 W Co.'s Giant Long-spurred. The seed of this splendid strain of . W. Columbine is grown for us by a specialist known for his painstaking efforts to produce a superior class. The plants are of strong, thrifty growth, are perfectly hardy, and bear long-spurred flowers of large size.

Blue Shades. A splendid selection of all shades from light to dark blue.

Pink Shades. Contains the various tones from light pink to darkest rose.

Scarlet Shades. Blooms range through all the colors of light scarlet, dark scarlet, and crimson.

Mixed Shades. Including all shades from pure white to pink, rose, red, yellow, crimson, blue, and various bi-colored flowers of superb quality and form.

Each, pkt. 25 cts., $1 / 80 z$. $\$ 1.50,1 / 40 z$. $\$ 2.50,0 z . \$ 7.50$

Californica hybrida. Beautiful flowers, principally yellow and orange shades. Pkt. I 5 cts., 1/80z. \$I, 1/40z. \$1.50.

Chrysantha. Canary-yellow. About 3 feet. Pkt. IOC., $1 / 8 \mathrm{Oz}$. 75C., 1/40z. $\$$ I.25.
Cærulea. Violet-blue and white. About 2 feet. Pkt. $15 \mathrm{cts}$., $1 / 8 \mathrm{Oz} . \$ 1.25,1 / 4 \mathrm{Oz} . \$ 2$

Rose Queen. Rose shades with white centers and yellow anthers; beautiful 3 feet. Pkt. 25 cts., $1 / 8$ Oz. $\$$ I, $1 / 4$ Oz. $\$ 1.75$. 


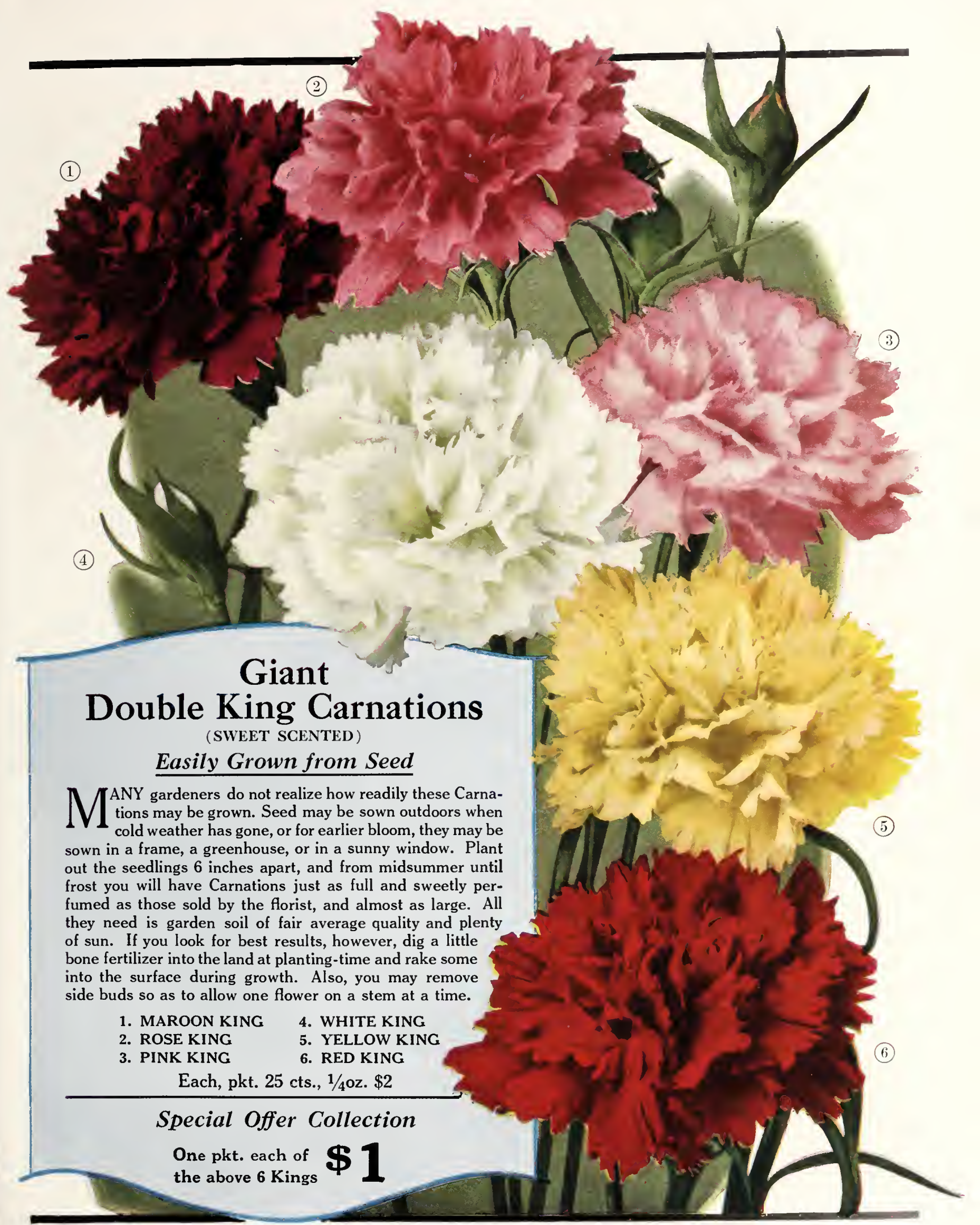




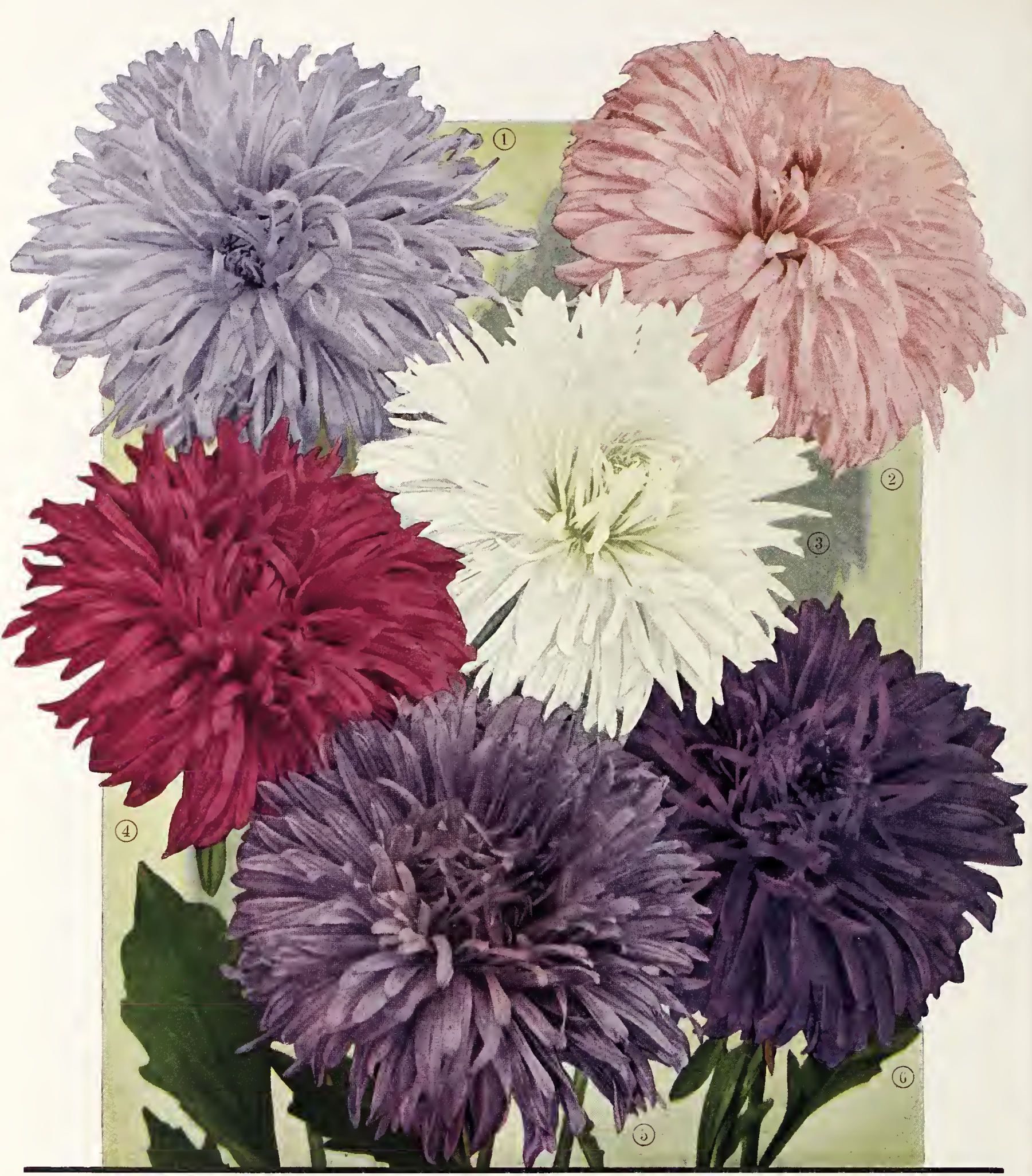

\section{NEW ASTERS}

\section{S. \& W. Co's Midseason Giants}

WE BELIEVE this new type to be the best Aster in cultivation today. The sturdy, upright plants produce giant flowers often 6 inches across, fully double, and of great substance, on long stems. For decorative effect in the garden and for cut bloom the Midseason Giants are unsurpassed.
1. Light Blue Giant

2. Peach-Blossom Giant

3. White Giant

4. Rich Rose Giant

5. Light Purple Giant

6. Dark Purple Giant

Each, pkt. 25c., 1/40z. $\$ 1.50$

\section{COLLECTION}

One pkt. each of the above 6 Midseason

Giants...
$\$$ 5 


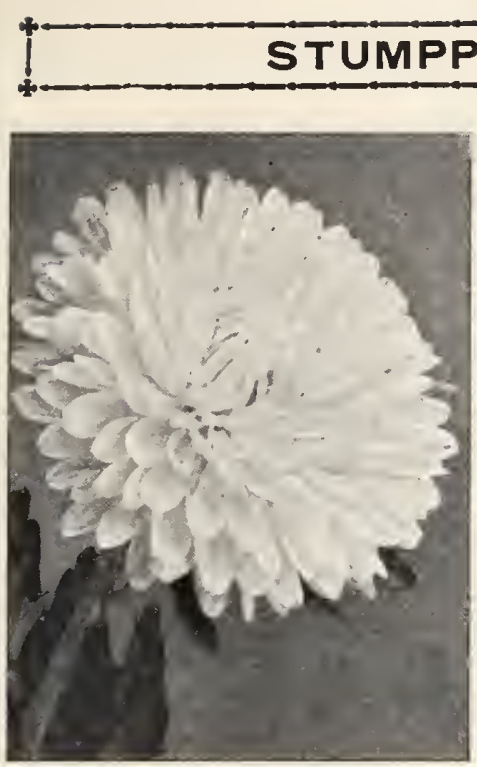

Queen of the Market Aster

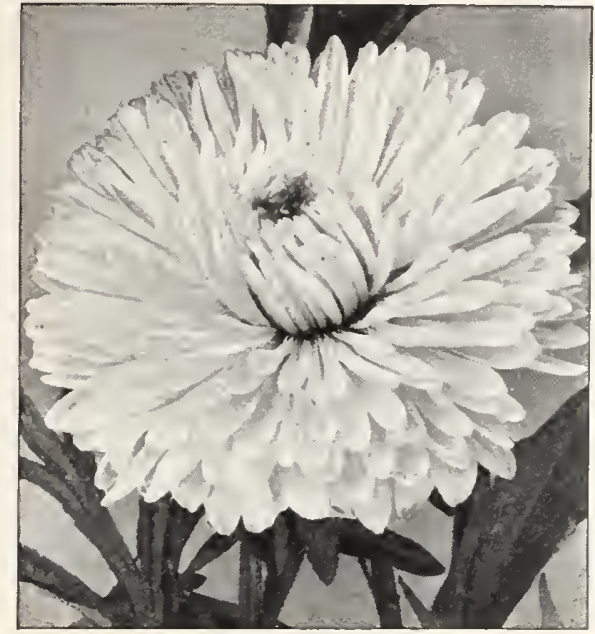

Early Royal Aster

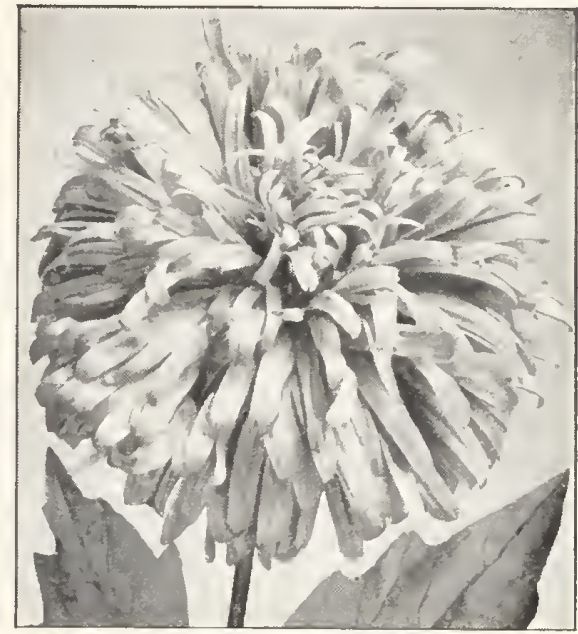

Improved Crego Aster

\section{S. \& W. CO.'S SUPERB ASTERS}

Asters will thrive in any good soil, prepared in the same way as you would for a crop of vegetables, but it is well to remember that any extra care taken in the preparation of the soil is repaid by finer plants, larger blooms, with longer stems and more profuse flowering. They should have an open, sunny position, and prefer a good, heavy, loamy soil enriched with a liberal quantity of Bone Dust No. 2, and an addition of airslaked lime, and we do not advise growing them on the same ground two years in succession; it is better to change each season. For early flowering, seeds should be started in a sunny window, hotbed or coldframe in April and transferred to their place in the garden as soon as danger of frost has gone by. For August (midseason) and September (late) sow seeds outside in finely prepared ground in May, thinning out to I foot in the rows and 2 feet between. With the above prescribed treatment and frequent cultivation of plants to insure a steady growth until flowering, excellent large blooms with long stems can be obtained.

For the purpose of aiding our patrons in making easy selections of the kind of Asters they desire to grow, we are listing the varieties under the headings Early, Midseason, and Late. The early sorts, such as Early Wonder, Queen of the Market, Lavender Gem, and Early Royal, begin blooming in July, followed by the midseason varieties, such as the Kings, Improved Cregos, California Giants, White Perfection and the Astermums. Then come the late-flowering varieties, such as S. \& W. Co.'s Late Branching, The Beauty Type, Autumn Glory, Heart of France, and Pink Enchantress which come into bloom from the end of August on through September into October. It is quite easy, therefore, with a little care in the selection of the varieties, to have Asters in bloom from early July to hard frost.

\section{EARLY-BLOOMING ASTERS}

Early Wonder. We consider this the earliest Aster in our list, Early Wonder. Howering in early July from seeds sown in the open ground at the end of April, or, if sown indoors in March, can be had in bloom before the close of June. The flowers are of good size, quite double, and are borne on good, long, stiff stems, which, added to their extremely early flowering, makes them of great value for cutting.

$\begin{array}{lll}\text { Carmine-Rose } & \text { White } & \text { Light Rose } \\ \text { Light Blue } & \text { Dark Blue } & \text { Mixed }\end{array}$

Light Blue

Any of the above colors, or mixed, pkt. 15 ets., $1 / 40 z .75$ cts. COLLECTION: One pkt. each of above 5 colors, 50 cts.

Queen of the Market. This well-known, early-flowering about Aster is of a branching habit, growing $\begin{array}{lll}\text { White } & \begin{array}{l}\text { Crimson } \\ \text { Dark Blue } \\ \text { Mose }\end{array} & \begin{array}{l}\text { Flesh-Pink } \\ \text { Light Blue }\end{array}\end{array}$

Any of the above colors, or mixed, pkt. 10 cts., 1/40z. 50 ets. COLLECTION: One pkt. each of above 6 colors, 50 cts.

Early Royal. (Branching Type.) This type of Aster is of re- cent development and is best described as an early-flowering form of our Superb Late Branching Aster, having all the good qualities of the latter, but coming into bloom in early August.

$\begin{array}{lll}\text { White } & \text { Rose-Pink } & \text { Shell-Pink } \\ \text { Lavender } & \text { Purple } & \text { Mixed }\end{array}$

Any of the above colors, or mixed, pkt. $15 \mathrm{cts} ., 1 / 40 z .75 \mathrm{cts}$.

COLLECTION: One pkt. each of above 5 colors, 50 cts.

Dwarf Queen. A beautiful strain of early, dwarf-growing pots or for the border.

\begin{tabular}{|c|c|}
\hline $\begin{array}{l}\text { Flesh Color } \\
\text { Brilliant Rose }\end{array}$ & $\begin{array}{l}\text { Crimson } \\
\text { Light Blue }\end{array}$ \\
\hline
\end{tabular}

Any of the above colors, or mixed, pkt. 25c., $1 / 40 z$. $\$ 1.50,0 z . \$ 5$.

\section{MIDSEASON-BLOOMING ASTERS} Improved Crego, or Ostrich-feathered. (Improved Type.) This is considered to be the finest and largest of all the Comet Asters. The flowers are borne on long, stiff stems and are of a fluffy character, frequently measuring 5 inches and over in diameter. They are splendid for cutting purposes on account of their good keeping qualities.

$\begin{array}{llll}\text { White } & \text { Purple } & \text { Lavender } & \text { Crimson } \\ \text { Azure-Blue } & \text { Pink } & \text { Deep Rose } & \text { Mixed }\end{array}$

Any of the above colors, or mixed, pkt. 15 ets., 1/40z. 75 cts. COLLECTION: One pkt. each of above 7 distinct colors, 75 ets. The Six King Asters. This magnificent class of Asters is acter of the flowers. The long, narrow petals are folded lengthwise, appearing almost as though quilled, and the flowers are of great size and substance, lasting longer when cut than any other class. Their season for blooming is just after the earliest varieties and before the Late Branching types.

$\begin{array}{llll}\text { Lavender King } & \text { Violet King } & \text { Rose King } & \text { Mixed }\end{array}$

Any of the above colors, or Mixed, pkt. $15 \mathrm{ets.,} \mathrm{1/40z.} \$ 1.25$ COLLECTION: One pkt. each of above 6 distinct colors, 75 cts.

Astermums. A splendid new race of American-raised Asters upright growth frequently having twelve to fifteen strong, sturdy stems $11 \%$ to 2 feet long, each carrying enormous flowers of splendid form, the petals completely covering the center so as to give the impression of one of the large Japanese chrysanthemums. This Aster has been grown with excellent success tliis past season.

Snow-White

Rose-Pink

Lavender

Any of the above colors, pkt. $15 \mathrm{cts} ., 1 / 4 \mathrm{oz}$. $\$ 1$

COLLECTION: One pkt. each of above 3 colors, 35 cts. 


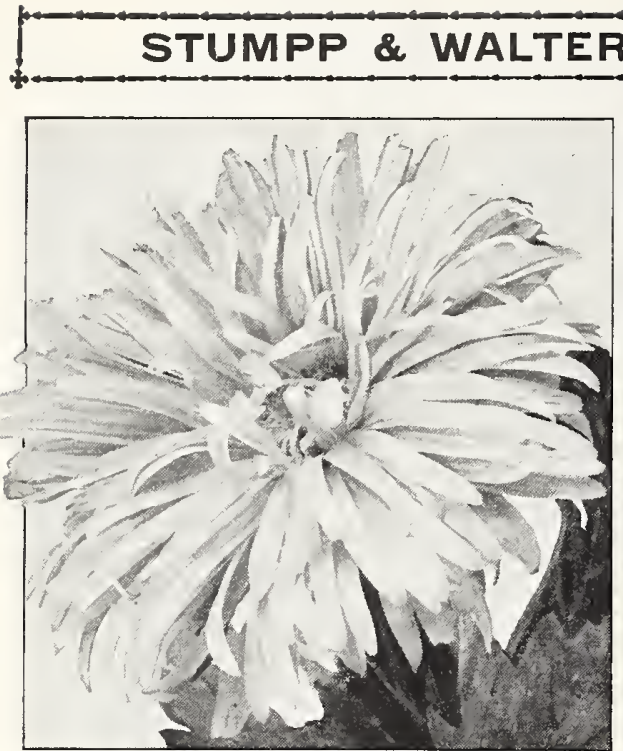

Astermum. See page 75

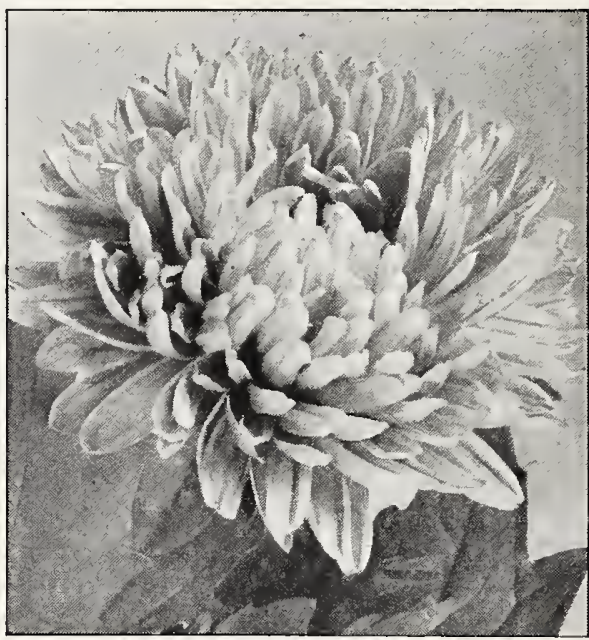

Late Branching Aster

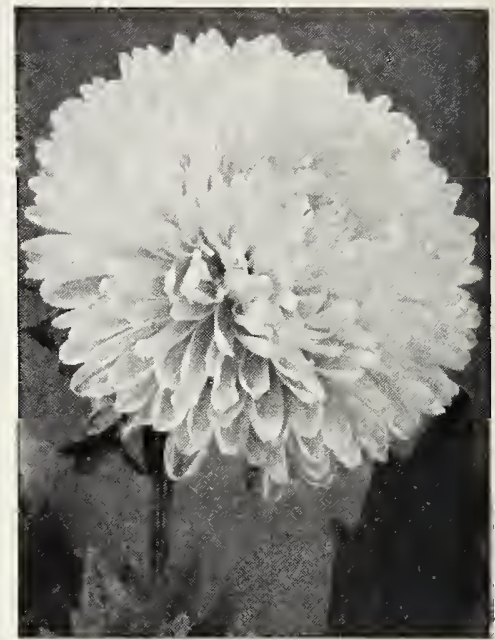

Beauty Aster

\section{S. \& W. CO.'S SUPERB ASTERS}

\section{LATE-BLOOMING ASTERS}

\section{S. \& W. Co.'s Late Branching Asters}

Although we placed this variety on the market only a few years ago, today every florist has a fine stock of the flowers in his window just before the chrysanthemum comes in; and it is of ten mistaken for the chrysanthemum, which it so much resembles. The flowers are of extraordinary size-much larger than other varieties-and stand erect on long, graceful stems, well above the foliage; flower-stems I 5 to 20 inches long. Grand for cutting. Plants extra large and of strong growth.

$\begin{array}{lll}\begin{array}{l}\text { Pure White } \\ \text { Shell-Pink }\end{array} & \begin{array}{l}\text { Rose-Pink } \\ \text { Lavender } \\ \text { Mixed }\end{array} & \begin{array}{l}\text { Purple } \\ \text { Crimson }\end{array}\end{array}$

Any of the above colors, or Mixed, pkt. $10 \mathrm{cts}, 1 / 4 \mathrm{oz} .50 \mathrm{cts}$.

COLLECTION: One pkt. each of above 6 colors, 50 cts.

\section{Beauty Asters}

This is a recently developed late-flowering strain, coming into bloom late in September and being at its best through October. The plants grow nearly 3 feet high and bear their very large. densely covered flowers on long, strong stems. Excellent for cutting.

$\begin{array}{lll}\text { Light Blue } & \text { Carmine-Rose } & \text { Purple } \\ \text { Light Pink } & \text { White } & \text { Mixed }\end{array}$

Any of the above colors, or Mixed, pkt. 15 cts., $1 / 4$ oz. $\$ 1$

COLLECTION: One pkt. each of above 5 colors, $60 \mathrm{cts}$.

\section{Single Comet Asters}

This type of Asters has met with considerable demand recently. From a decorative point of view the possibilities are immense. Their large blooms, often measuring 5 to 6 inches across, make them truly conspicuous.

$\begin{array}{lll}\text { White } & \text { Light Rose } & \text { Scarlet } \\ \text { Light Blue } & \text { Dark Blue } & \text { Mixed }\end{array}$

Any of the above colors, or Mixed, pkt. $15 \mathrm{cts} ., 1 / 4 \mathrm{oz} . \$ 1$ COLLECTION: One pkt. each of above 5 colors, 60 cts.

\section{New Sunshine Asters}

Suggestive somewhat of the Single Comet Asters, but the center is a button of a lighter color: white, ycllow, or flesh. The outer ring of tubular florets making up the center is lengthened. The whole effect is very graceful and pleasing.
White
Pink
Lilac
Blue
Mixed

Any of the above colors, or Mixed, pkt. 25 cts., $1 / 40 z . \$ 1.50$

COLLECTION: One pkt. each of above 4 colors, 75 cts.

\section{MISCELLANEOUS ASTERS}

Aurora. This Aster is an innovation and quite different from any Aurora. other. The center of the flower is bright yellow, with an outer circle of delicate blue, forming a very striking contrast. The plants are of robust growth, averaging 2 feet in height. Pkt. 15 cts., $1 / 402$. \$1.25.

Heart of France. This recent introduction is the largest plants grow about 2 feet high, are nicely branched, and bear their long, rich, deep ruby-red flowers on long, strong stems. Blooms with the late-blooming sorts. Pkt. 25 cts., $1 / 4$ oz. \$2.

Lavender Gem. Truly a gem and easily the finest early lavender. In the full, double flower, the feathery effect of the ostrich-feathered type is enhanced by the fact that it bears long, partly tubular florets that are irregularly cut and slashed, resembling ragged chrysanthemums. Pkt. 15 cts., $1 / 40 z$. $\$ 1.25$.

New Fancy Yellow. A splendid new Aster with flowers - sometimes 5 inches across. It has a border of curled, recurved, strap-shaped florets of pure white; the center consists of recurved and incurved disc-florets of deep yellow. The whole effect is novel and beautiful. Pkt. 15 cts., 1/40z. \$1.25.

Pink Enchantress. This beautiful Aster is a pleasing shade of salmon-pink, similar to the Enchantress carnation. It blooms about a week earlier than Autumn Glory. The flowers are full, double, of medium length, and very broad. A splendid variety for cutting. Pkt. 15 cts., 1/40z. \$1.25.

White Perfection. Finest midseason white Aster in cultidiameter and exquisite in vation. The flowers are 4 inches in of the late upright Asters. When first open the entire flower is whorled, producing a charming effect; the broad petals are slightly folded lengthwise, making them appear rather narrow. The plants are extremely vigorous, and they carry about twelve large flowers on strong stems free from side branches. Pkt. 15 cts., $1 / 40 z$. $\$ 1.25$.

\section{Hardy Perennial Asters (Michaelmas Daisies)}

Single, fall-flowering, hardy herbaceous plants which thrive in any good garden soil. We offer them in four colors, as well as in a mixture. Alpinus. Large bluish purple flowers in May and June. Good rockgarden plant. Height 9 inches. Pkt. I 5 cts., I/8Oz. \$I, $1 / 4 \mathrm{Oz}$. \$I.5O Alpinus albus. White form of above. Pkt. I $5 \mathrm{C}$., $1 / 8 \mathrm{Oz}$. $\$ \mathrm{I}, 1 / 4 \mathrm{Oz} . \$ \mathrm{I} .50$. Amelius bessarabicus. Large, rich violet flowers in profusion in August and September. Height 2 feet. Pkt, Io cts., $1 / 80 z$. $\$ 1.50$.

Novæ-angliæ, Mixed. Good-sized flowers in September and October. Height 4 feet. Colors, Violet-purple, Reddish Crimson, and Pink. Pkt. Io cts., 1/80z. \$I, 1/40z. \$I.50.

Subcæruleus. Compact, tufted plants with solitary, glowing purple flowers 2 to 3 inches across, on I 8-inch stems, in June and July. Pkt. 25 cts., $1 / 80 z$. $\$ 1.50$. 


\section{ANTIRRHINUM (Snapdragon)}

The Tall varieties are seen to best advantage in long borders, making splendid backgrounds, while the Half-High types are suitable for bedding. Seed may be sown in the open ground early in May and be had in bloom in summer, but it is best to start tle plants indoors in pots or flats or in a frame in March and transplant the seedlings out-of-doors as soon as weather will permit.

\section{Giant-flowered Half-High Varieties Height about} *Apricot Queen. Pink, white Lube. *Firebrand. Scarlet, with yellow lip. *Carmine Queen. Rose-carmine. *Golden Queen. Rich, pure yellow. Empress. Rich velvety crimson. *Purity. Pure white

Fascination. Pearly pink self. Mauve Queen. Lilac-mauve.

*Fawn. Rose and gold. Rose Dore. Rose suffused orange.

Named varieties, each, pkt. 15c., 1/40z. 75c.; mixed, pkt. 10c., 1/40z. 60c. COLLECTIONS: $\left\{\begin{array}{l}\text { One pkt. each of above } 10 \text { fine varieties, } \$ 1 \\ \text { One pkt. each of } 6 \text { varieties marked } * \text {, } 75 \text { cts. }\end{array}\right.$

\section{Giant-flowered Tall Varieties $\underset{3 \text { feet }}{\mathrm{H} \text { feeut }}$}

Harmony. Terra-cotta-orange, shaded rose. Rose. Beautiful rose-pink. Rose King. Deep rose self.

Queen Victoria. White.

Scarlet. Bright scarlet.

Yellow. Rich golden yellow.

Named varieties, each, pkt. 15c., 1/40z. 75c.; mixed, pkt, 10c., 1/40z. 60c. COLLECTION: One pkt. each of above 6 distinct colors, 75 ets.

\section{Forcing Antirrhinums for Greenhouse Use}

Afterglow. New large-flowering bronze. Pkt. \$2,3 pkts. $\$ 5,6$ pkts. $\$ 9$.

Ceylon Court. New early-flowering yellow. Pkt. $\$$ I. 50,3 pkts. $\$ 4,6$ pkts. $\$ 7$.

Rose Queen. Best new dark pink in cultivation. Pkt. \$2, 3 pkts. \$5, 6 pkts. \$9.

Orlando (bronze), Helen (salmon), Jennie Schneider (Columbia rose-pink),

Geneva Pink, Penn-Orange. Any of these varieties, pkt. $\$ 1,3$ pkts. $\$ 2.50$.

Judd's New Early Light Pink, Keystone (pink), White Rock. Any of

these varieties, pkt. 75 cts., 4 pkts. $\$ 2.50$.

Silver Pink, Philadelphia Pink, Nelrose (deep pink). Pkt. 50 cts., 5 pkts. $\$ 2$.

\section{Arenaria (Sandwort)}

Montana. A dwarf hardy perennial for the rock-garden or for edging. A trailing carpet of green covered with white flowers. Height 6 inches. Pkt. 25 cts.

\section{ARCTOTIS GRANDIS (African Daisy)}

A remarkably handsome annual. It forms much-branched bushes 2 to 3 feet high: its flowers are large and showy, being pure white on the upper surface, lilacblue beneath. It may be started in the hotbed, in the house or in the open ground; plant it in a sunny situation. Pkt. 15 ets., $1 / 402.75$ ets.

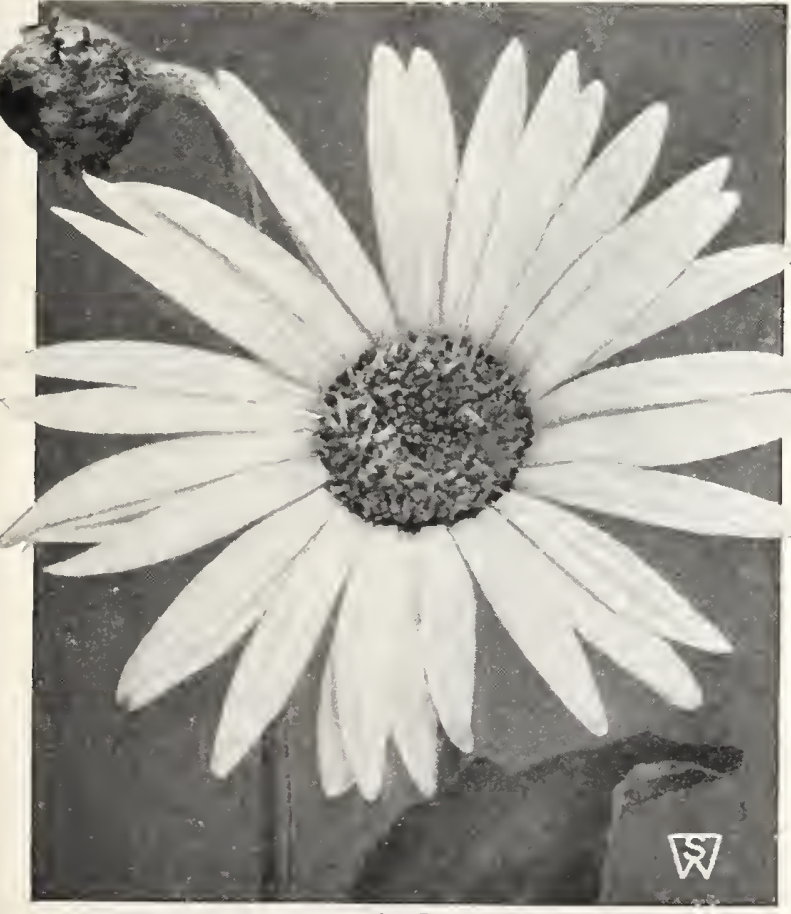

Arctotis Grandis

\section{ARGEMONE (Mexican or Prickly Poppy)}

Mexicana. A very interesting and highly ornamental plant, both in and out of bloom. The plants are of sturdy character, attaining a height of 3 feet. The ornamental spiny foliage has a clear silvery mid-rib, a splendid color contrast. The flowers are poppy-like, of satiny texture, over 3 inches across, in various shades of rich yellow to creamy white. It blooms early in July and continues until November. Pkt. Io cts., $1 / 40 z .50 \mathrm{cts}$.

Platyceras rosea. A recent introduction similar in habit of growtl and foliage to the above with rich ruby-rose flowers. Pht. I5 cts., $1 / 40 \mathrm{Oz}$. $50 \mathrm{cts}$.

\section{ARTEMISIA (Sage Bush)}

Argentea. Plants grow about 4 feet high, with beautiful silvery foliage. Excellent for cutting. August and September. Pkt. 25 cts., 5 pkts. \$I.

\section{ARMERIA (Sea Pink)}

Dwarf plants that will thrive almost anywhere. From clumps of bright green foliage, the pink or red flowers are borne on wiry stems. Fine for the alpine garden or for use as an edging plant. Hardy perennials. Height 9 in. Formosa. Pink. Pkt. I5 cts., I/80z. \$I, 1/40Z. \$I.50.

Laucheana. Double; rose-crimson. Pht. $25 \mathrm{cts} ., 1 / 80 \mathrm{O}, \$ 2,1 / 40 \mathrm{oz} . \$ 3.50$.

Maritima. Red. Pkt, 25 cts., I/80z. \$2, I/40z, \$3.50

\section{ASPARAGUS}

Plumosus nanus. A graceful pot plant for house or conservatory". Finely cut foliage. Pkt. $25 \mathrm{cts}$., I 00 seeds $\$$ I, 500 seeds $\$ 3.50$, I, 00o seeds $\$ 5$.

Sprengeri. Drooping foliage, adapted for hanging-baskets or cutting. Pkt. 25 cts., 1/20Z. \$I, OZ. \$I.5O.

\section{ASCLEPIAS (Butterfly Weed)}

Curassavica. Hardy perennial with very showy orange flowers. Height 2 feet. Pkt. 25 cts.

Tuberosa. Orange-scarlet. Pkt. I 5 cts. 


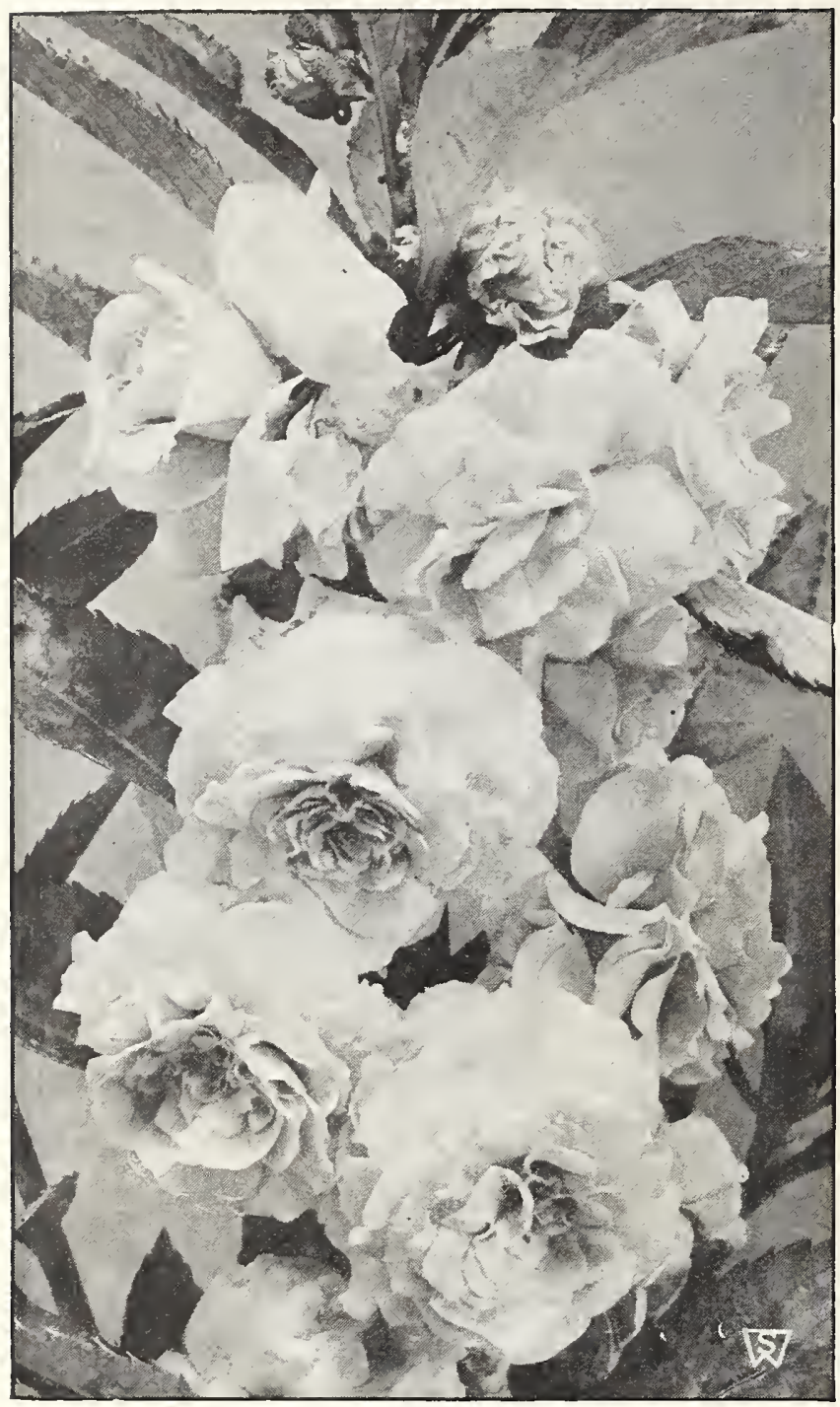

Double Camellia-flowered Balsam

\section{DOUBLE CAMELLIA-FLOWERED \\ BALSAM (Lady's Slipper)}

An old and favorite garden flower, producing its gorgeous masses of beautiful, brilliant-colored, double flowers in the greatest prof usion of easiest culture; succeeds in a good, rich soil. Tender annual. 2 feet. Start the seed indoors in April, or sow out-of-doors in May. When specimens are wanted, plant at least $\mathrm{I} 8$ inches apart; splendid when grown in pots.

White Perfection. Large; double; white........\$o io $\$ 0$ Po 50

Scarlet King. Glowing, fiery scarlet; large, double

flowers

Salmon Queen. Deep rose-pink; large, double flowers.

Lilac Gem. Beautiful pale lilac.

Purple King, Double; rich purple.

Primrose Gem. Double; beautiful primrose; the best

yellow variety to date.

IO 50

IO 50

IO 50

IO 50

COLLECTION: 1 pkt. each, 6 named varieties, 6 pkts., 50 cts.

S. E W. Co.'s Double, Mixed. A mixture of selected beautiful, spotted, blotched and striped varieties. Pkt. 10 ets., $1 / 4$ oz. 50 ets., oz. $\$ 1.50$.

\section{ASPERULA (Sweet Woodruff)}

Odorata. Hardy perennial. Handsome creeping plant, with deep green, whorled foliage and pretty white flowers. Especially usetul for carpeting in shady situations. Height 6 inches. June and July. Pkt. Io cts., $1 / 4 \mathrm{Oz}$. $50 \mathrm{cts}$.

\section{AUBRIETIA (False Wall Cress)}

Pretty, dwarf-growing rock plants, forming broad masses of silvery green foliage and sheets of flowers in spring and early summer. Bougainvillei. Showy purple flowers. Pkt. I5 cts.

Deltoidea purpurea. Purple. Height 6 inches. Pkt. I 5 cts.

Græca. Light bluc. 6 inches. Pkt. I 5 cts.

Leichtlinii. Bright reddish crimson. Pkt. I 5 cts.

\section{BEGONIAS}

\section{TWO FINE NEW EVER BLOOMING BEGONIAS}

\section{Christmas Cheer}

A magnificent novelty in the Everblooming or Semperflorens type of bedding Begonias. This variety bears flowers of enormous size, attaining a diameter of 2 inches, the plants being covered with a mass of blooms throughout the entire season. The color is a beautiful shade of bright cherry-red. This variety is particularly adapted for bedding purposes, being quite hardy and will thrive in either full sun or partial shade.

\section{Christmas Pink}

Same as above, except in color, which is a beautiful shade of bright pink.

Each, pkt. 25 cts., 5 pkts $\$ 1, \frac{1}{64}$ oz. $\$ 5$

\section{Everblooming Bedding Varieties}

The following varieties of Begonia semperflorens and B. gracilis take rank as bedding plants with geraniums and coleus, doing equally well in full sunlight, and surpassing both in positions partially or wholly in shade. They are of sturdy growth, growing about I foot high, and forming dense bushes which, from May until frost, are completely hidden with flowers. As pot plants for winter flowering they are superb, being a mass of bloom throughout the entire year. Easily raised from seed, which should be started either indoors or in a hotbed. Pkt.

Gracilis, Primadonna. Carmine-rose; brown-tinted foliage. .\$o 25 Gracilis, Bonfire. Scarlet; metallic brown foliage......... 25 Gracilis luminosa. Brilliant dark scarlet; very effective.... 25 Semperflorens Erfordii. Rosy carmine; green foliage...... I 5 Semperfiorens, Triumph. Pure, glistening white....... I 5 Semperforens, Vernon. Bright orange-carmine; red foliage.. I5 Tuberous-rooted Single, Mixed. Excellent for indoor cul-

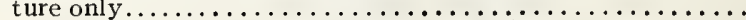

Tuberous-rooted Double, Mixed. The double form..........

\section{BALLOON VINE (Love-in-a-Puff)}

This rapid-growing annual climber succeeds best in a light soil and sunny situation. The flowers are white and the seed-vessels which resemble miniature balloons, are very interesting to children. Seed should be sown as soon as ground becomes warm, in an open situation. 8 feet. Pkt. Io cts., $1 / 4 \mathrm{Oz} .25 \mathrm{cts}$.

\section{BAPTISIA (False Indigo)}

Australis. Hardy perennial. Free-growing plant, with deep green cut foliage and lupine-like dark blue flowers in long racemes. 3 feet. June and July. Pkt. I 5 cts., I/40z. \$1.50.

\section{BARTONIA}

Aurea. Hardy annual. Very bright golden flowers from July to September. Fine for cutting. I foot. Pkt. Io cts., $1 / 4 \mathrm{Oz}$. 50 cts. 


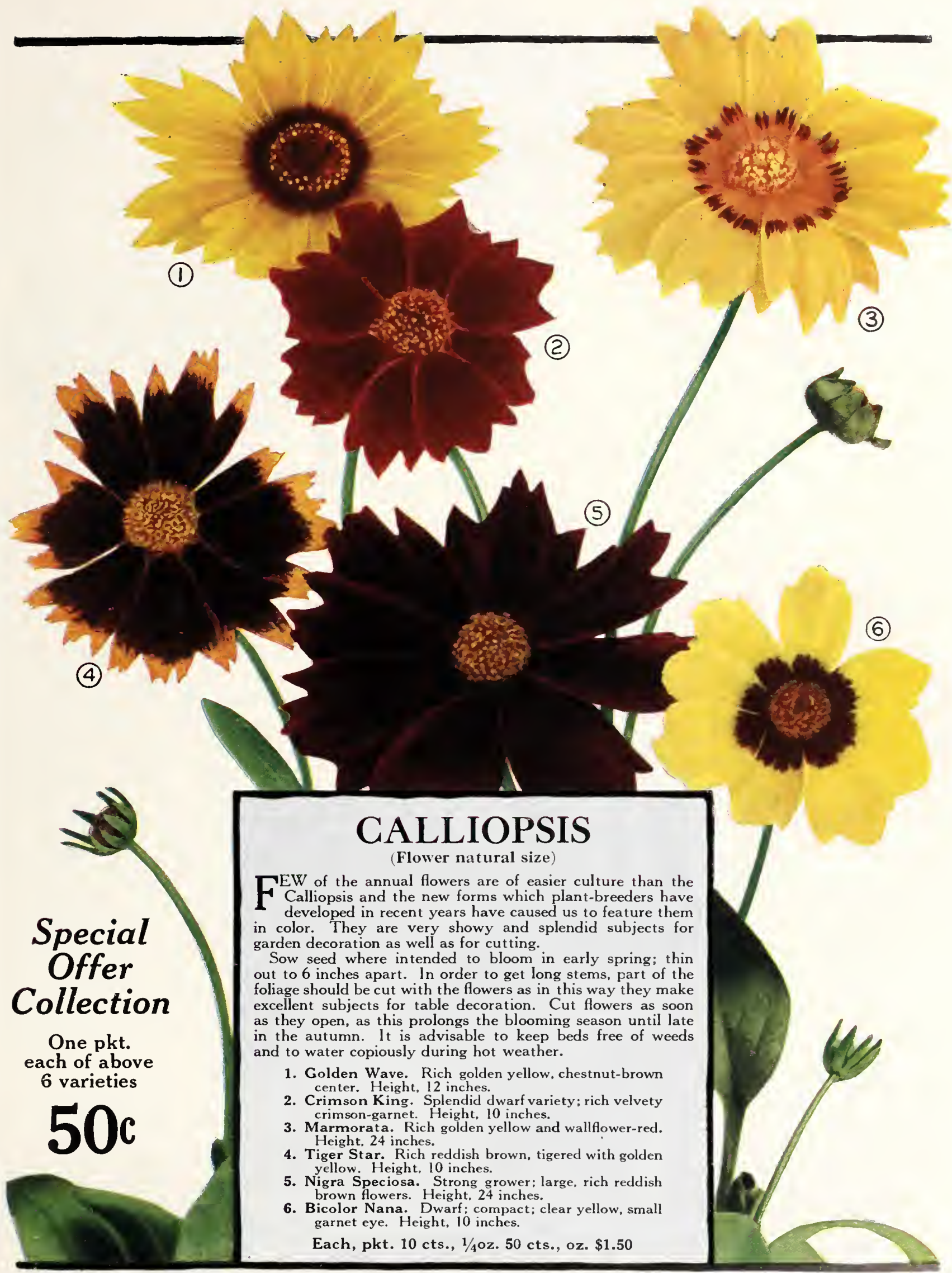




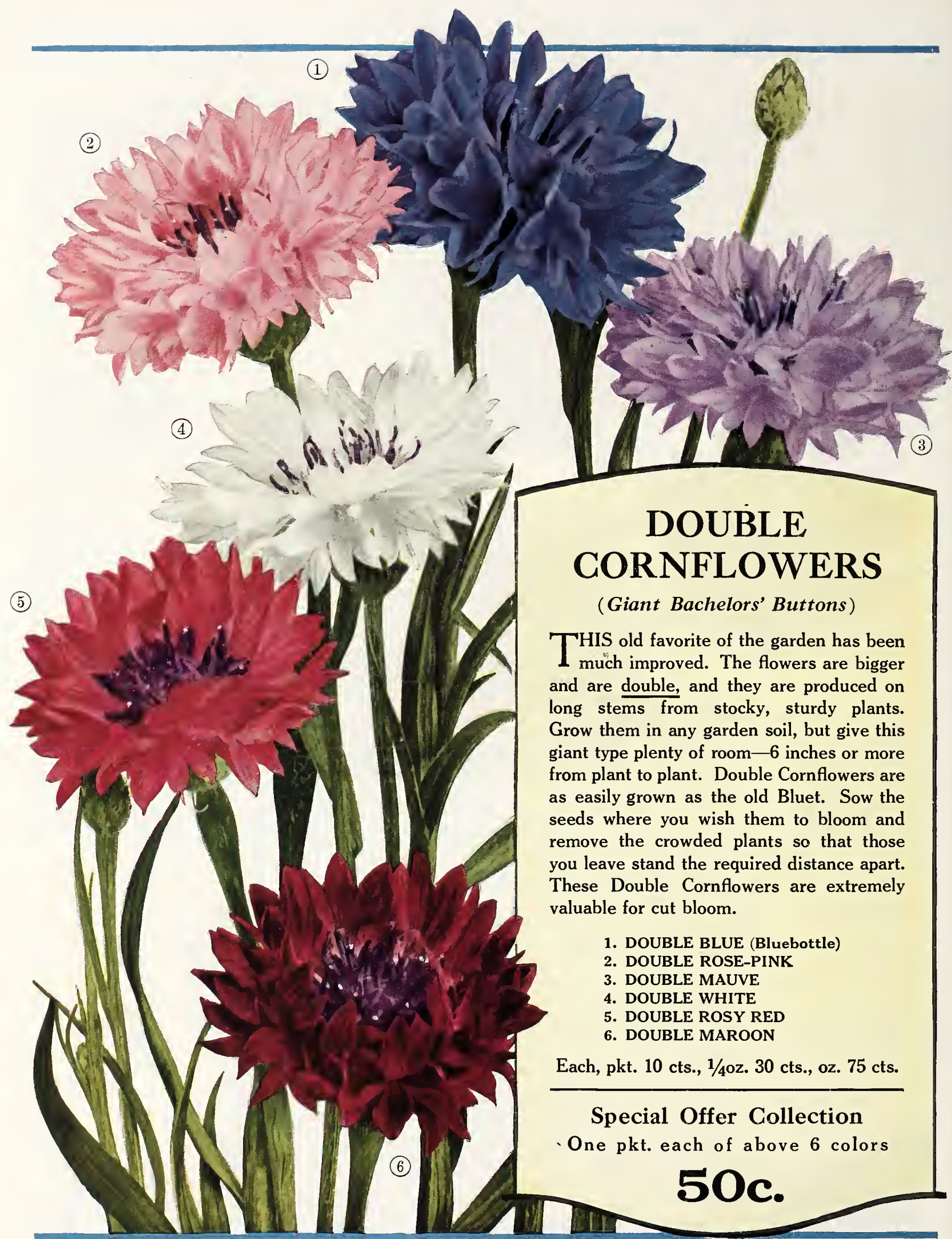




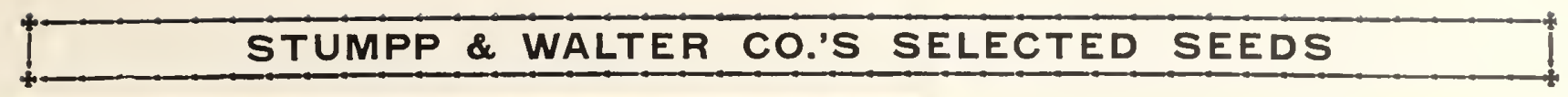

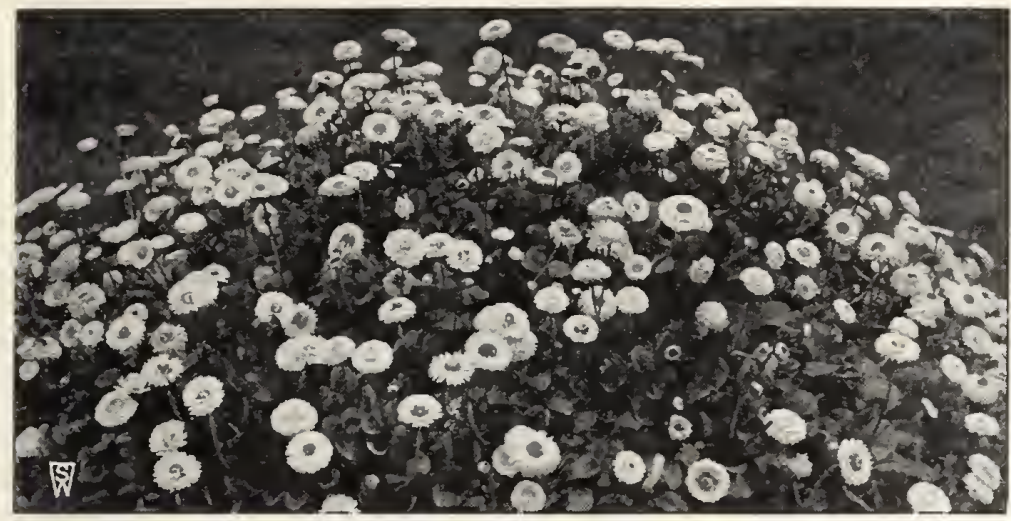

Bellis perennis

\section{BROW ALLIA (Amethyst)}

One of our favorite profuse-blooming bedding plants, covered with rich, beautiful, winged flowers during the summer and autumn months, supplying a very uncommon shade of intense blue; grows freely in any rich soil; blooms finely in the winter if the plants are lifted in autumn and cut back.

Speciosa major. A beautiful flowering variety of the most brilliant ultramarine-blue - a rare color. Does finely outside in the border, or in hanging-baskets or vases, but is especially valuable as a pot plant for winter and early spring flowering. Pkt. $25 \mathrm{cts}$.

\section{BRA CH YCOME (Swan River Daisy)}

Free-flowering, dwarf-growing annual covered during the greater part of the summer.with a profusion of pretty blue, red, or white flowers, suitable for edgings, small beds or pot culture. Height 9 inches.
Blue Star Red Star Star Each, pkt. $15 \mathrm{cts} ., 1 / 4 \mathrm{Oz} .75 \mathrm{cts}$.

\section{BIDENS}

A favorite perennial, which will stand the winter if given the protection of a little litter. In bloom from early spring until well on in the summer. Easily raised from seed, which may be sown any time from spring until August. For best results, new plants should be raised from seed each year.

Giant-flowering White, Pink, and Mixed ........ \$o 25 S $1 / \mathrm{oz}$.

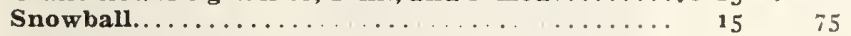

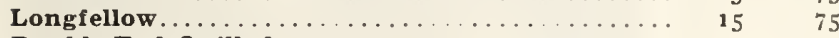
Double Red Quilled................. $25 \quad 3$ oo

\section{BOCCONIA (Plume Poppy; Tree Celandine)}

Cordata. Effective. laardy perennial for single specimens or groups on lawns. Foliage glaucous green; bears freely spikes 2 to 3 feet long of cream-colored flowers; easily raised from seed. 5 feet. Pkt. 10 cts., $1 / 40 z$. 50 cts.

\section{BOLTONIA (False Chamomile)}

One of the showiest of our native hardy perennials, growing 4 to 6 feet high, with daisy-like flowers, borne in great numbers from July to September.

Asteroides. White. Pkt. Io cts.

Latisquama. Lilac-pink. Pkt. Io cts.

\section{CALLIOPSIS (Coreopsis)}

Showy and beautiful, free-flowering annuals and perennials, of the easiest culture doing well in any sunny position, blooming all summer, and excellent for cutting and massing. Sow where they are to bloom, thinning out to stand 6 to 12 inches apart.

\section{ANNUAL VARIETIES (Calliopsis)}

Bicolor nana. Dwarf. compact, clear yellow, small garnet eye. Height 10 inches. Crimson King. Splendid; dwarf; rich velvety crimson-garnet. Height Io inches. Golden Ray. Dwarf, compact plants not over 9 incles high, densely covered with rich maroon flowers edged golden yellow, the petals twisted like the cactus dahlia. Golden Wave. Rich golden yellow, chestnut-brown center. Height i foot.

Marmorata. Tall grower: rich golden yellow and wallflower-red flowers. 2 feet.

Nigra speciosa. Strong grower; large flowers of rich reddisl maroon. Height 2 feet. Tiger Star. Rich reddish brown, tigered with golden yellow.

Tinctoria. A very striking tall-growing variety. The flowers are a bright yellow and maroon, evenly divided in color combination. Height 2 feet.

S. \& W. Co.'s Mixture. A select mixture of tall varieties.

Each, pkt. 10 cts., $1 / 4$ oz. 50 cts., oz. $\$ 1.50$

\section{PERENNIAL VARIETIES (Coreopsis)}

Grandifiora. Deep golden yellow, cup-shaped flowers, on fine stems for cutting. Height 2 feet. All summer. Pkt. Io cts., $1 / 40 z$. $40 \mathrm{cts}$.

Grandiflora flore-pleno. A re-selected strain producing semi-double (sometimes double) flowers which are a great improvement on the old type, being larger. They possess, however, the rich yellow color and graceful appearance which make Coreopsis so valuable for bedding or cut-flower purposes. Pkt. I $5 \mathrm{C}$., 1/40z. $75 \mathrm{C}$., oz. $\$ 2.5 \mathrm{o}$.

Lanceolata grandiflora. Same as above except flower is lanced. Pkt. Ioc., $1 / 4 \mathrm{Oz} .75 \mathrm{C}$

Mayfleld Giant. A fine hardy perennial of Australian origin. The plant is taller and more vigorous than the type, with larger flowers on longer stems, and the color is mere intense yellow. Reconmended for the border and for cut-bloom. Pkt. 50 cts. 


\section{CASTOR-OIL PLANT (Ricinus)}

The Ricinus are tall, stately growing plants of tropical appearance; their luxuriant foliage renders them exceedingly ornamental. Free-growing, tender half-hardy annuals of easy cultivation.

Africanus. Very large green foliage.

Pkt. $\quad \mathrm{Oz}$.

Zanzibarensis. New Giant Castor-Oil Plant from Africa..... \$o lo \$o 25

Borboniensis arboreus. Handsome green foliage. 15 feet..

Communis (Castor-Oil Plant). Green foliage. 6 feet.

Gibsoni. Dark, purplish-red foliage. 6 feet.

Cambodgensis. Leaves bronzy maroon; red veins; stems black

Duchess of Edinburgh. Dark red foliage. 6 feet

Mired. Tricolor, red spotted; fruit in clusters, Io feet..

\section{CELOSIA}

\section{Celosia cristata (Cockscomb)}

Free-blooming annuals, growing best in rather light soil, not too rich; make grand border plants and are attractive for pots. Seed can be sown under cover in early spring and planted out in May, or may be sown outdoors in May. If dwarf growth is desired, do not crowd.

Empress. Rich crimson. I foot. Pkt. I5 cts., 1/0z. \$I.

Glasg ow Prize. Dark crimson. I foot. Pkt. I5 cts., 1/4oz. \$I.

Golden Yellow. A rich shade. I foot. Pkt. I5 cts., $1 / 40 z$. \$I.

Dwarl Mixed. I foot. Pkt. Io cts., $1 / 40 z, 75 \mathrm{cts}$.

\section{Celosia plumosa (Feathered Cockscomb)}

Make fine plants for large beds or groups, and the plumes or flowers can be cut and dried for winter bouquets. Should be treated same as Cockscomb described above.

Ostrich-plumed, Crimson. Pkt. Io cts., $1 / 402.50 \mathrm{cts}$.

Ostrich-plumed, Yellow. Pkt. Io cts., $1 / 40 \mathrm{Oz} 50 \mathrm{cts}$.

Ostrich-plumed, Mixed. Pkt. Io cts., $1 / 40 \mathrm{Oz} .50 \mathrm{cts}$.

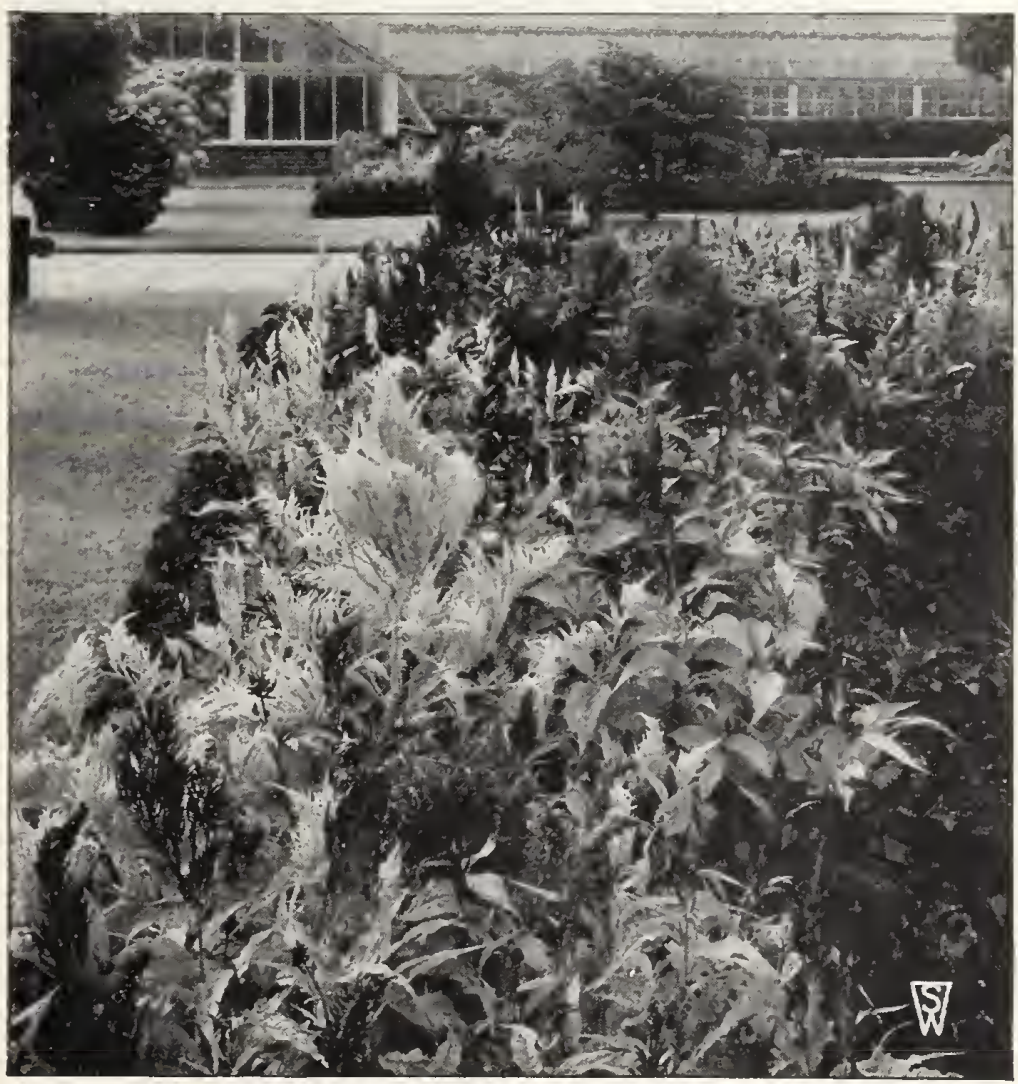

Celosia, Pride of Castle Gould

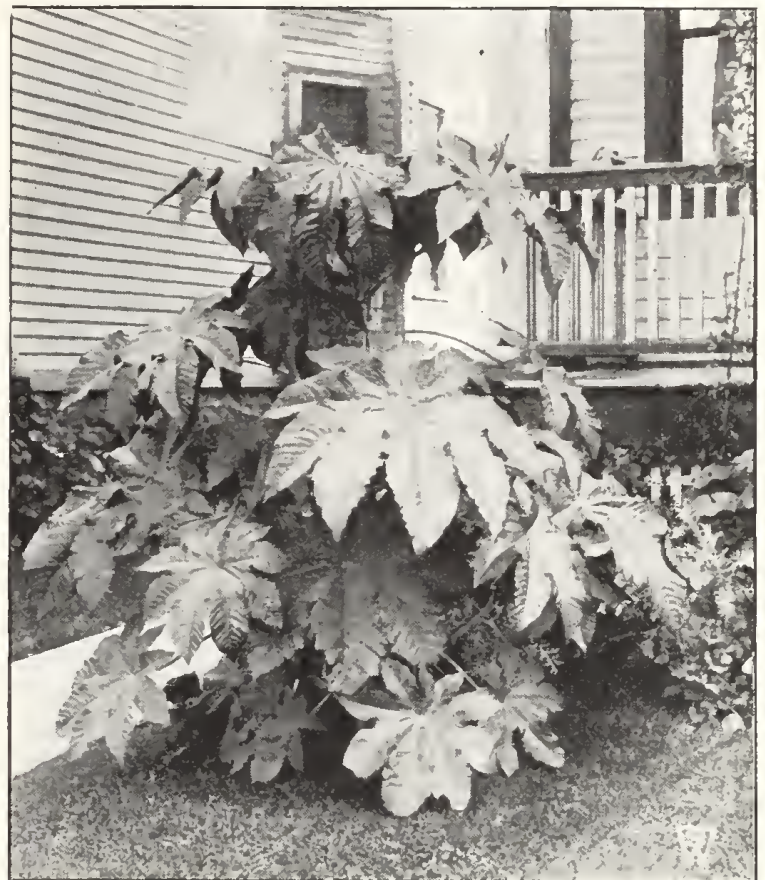

Castor-oil Plant

\section{Celosia Thompsonii magnifica}

Improved Strain of Feathered Cockscomb

Thompsonii magnifica is of pyramidal growth, of ten attaining the height of 3 feet, and producing graceful, feathery plumes of the most magnificent shades.

Thompsonii magnifica, Crimson. Bright crimson. Pkt. I5 cts., $1 / 40 z$. \$I.

Thompsonii magnifica, Yellow. Beautiful yellow. Pkt. I 5 cts., I/4OZ. \$I.

Thompsonii magnifica, Mixed. Pkt, Io cts., $1 / 4 \mathrm{Oz} .75 \mathrm{cts}$.

\section{Celosia, Pride of Castle Gould}

A distinct type of Celosia pyramidalis and surpassing by far anything yet on the market. The compact, pyramidal plants grow from 2 to 3 feet high, with immense feathered heads of all colors: Blood-red, wineled, scarlet, carmine, salmon, orange, and gold.

This illustration is from a photograph taken on the estate of Mr. M. C. D. Borden, Oceanic, N. J. (William Turner, Supt.). The following is a description by Mr. Turner: "Celosia Castle Gould is admirably adapted for growing along in pots for decorative purposes or for planting out in beds, provided the beds are situated to receive full benefit from the sun's rays. Castle Gould is a decided improvement over all other Celosias, both for richness of colors and the massive plumes this variety produces. Being a free, vigorous grower, it is not necessary to sow the seed for outdoor planting until say the middle of March." Per pkt., mixed shades, 25 cts., $1 / 80 z$. $\$ 1,1 / 40 z$. $\$ 1.50$.

\section{Celosia Childsii (Chinese Woolflower)}

This is a unique form of the feathered Cockscomb, growing 2 to 3 feet high and about the same size in diameter. Each branch is terminated with a large head of rich crimson flowers that look as if made out of some silky wool material. A very effective annual for beds and borders. May be used to excellent advantage as a cut-flower as well.

Crimson. Very rich color. Pink. Dark pink Mixed.

Each, pkt. 15 ets., 2 pkts. 25 cts., 1/40z. \$1. 


\section{GENTAUREAS}

There is, perhaps, no more popular annual than the Centaurea. Will grow well anywhere and as a cut-flower is much in demand.

\section{Double Cornflowers (Centaurea Cyanus)}

These are also known as Blue Bottle, Bachelor's Buttons, Ragged Sailor, Bluet, and sometimes referred to as Ragged Robin. As Ragged Robin is also a name given to Lychnis, we suggest patrons ordering by botanical name to avoid confusion. We offer a much improved strain of this beautiful flower in a better range of colors, with larger flowers. The seed may be sown outdoors in April, and several sowings will give a succession of bloom. For best results, thin out plants to stand 8 inches apart.

Blue Rose-Pink

White

Maroon

$$
\text { Mauve }
$$

Rosy Red

Any of the above colors, pkt. 10 cts., $1 / 40 z .30$ cts., $0 z .75$ cts. COLLECTION: One pkt. each of above 6 colors, 50 cts.

Double Mixed. A mixture of all the above colors... \$o Io $\begin{aligned} & \text { Plt. } \\ & \text { \$o } 25\end{aligned}$

\section{Giant Sweet Sultans (Centaurea imperialis)}

This beautiful class is undoubtedly the finest of all the Sweet Sultans for cutting purposes. Beautiful, deliciously sweetscented flowers are borne on long, strong stems and are particularly striking, lasting several days after cutting. We recommend sowing in succession every two weeks from May until July, thereby giving a continuous bloom from summer to fall.

Imperialis, White. Large and exquisitely sweet-scented. Imperialis, Pink. Pink, with tinge in center.

Imperialis, Purple. Brilliant rosy purple.

Imperialis, Lilac. Beautiful lilac.

Imperialis, Red. New. Deep amaranth-red.

Imperialis, Yellow (Suaveolens). Bright yellow.

Imperialis, Mixed. A select Mixture of above colors.

Any of the above colors, or mixed, pkt. $15 \mathrm{cts} ., 1 / 40 z .50 \mathrm{cts}$. COLLECTIONS: One pkt. each of above 6 colors, 50 cts.

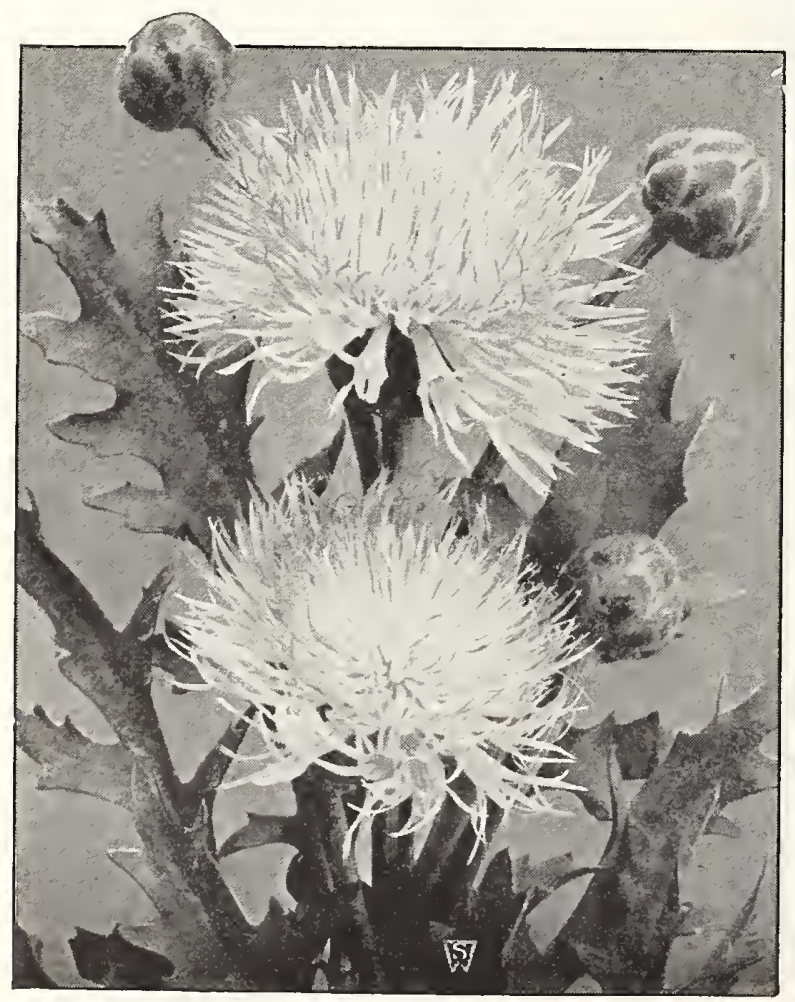

Giant Sweet Sultans (Centaurea imperialis)

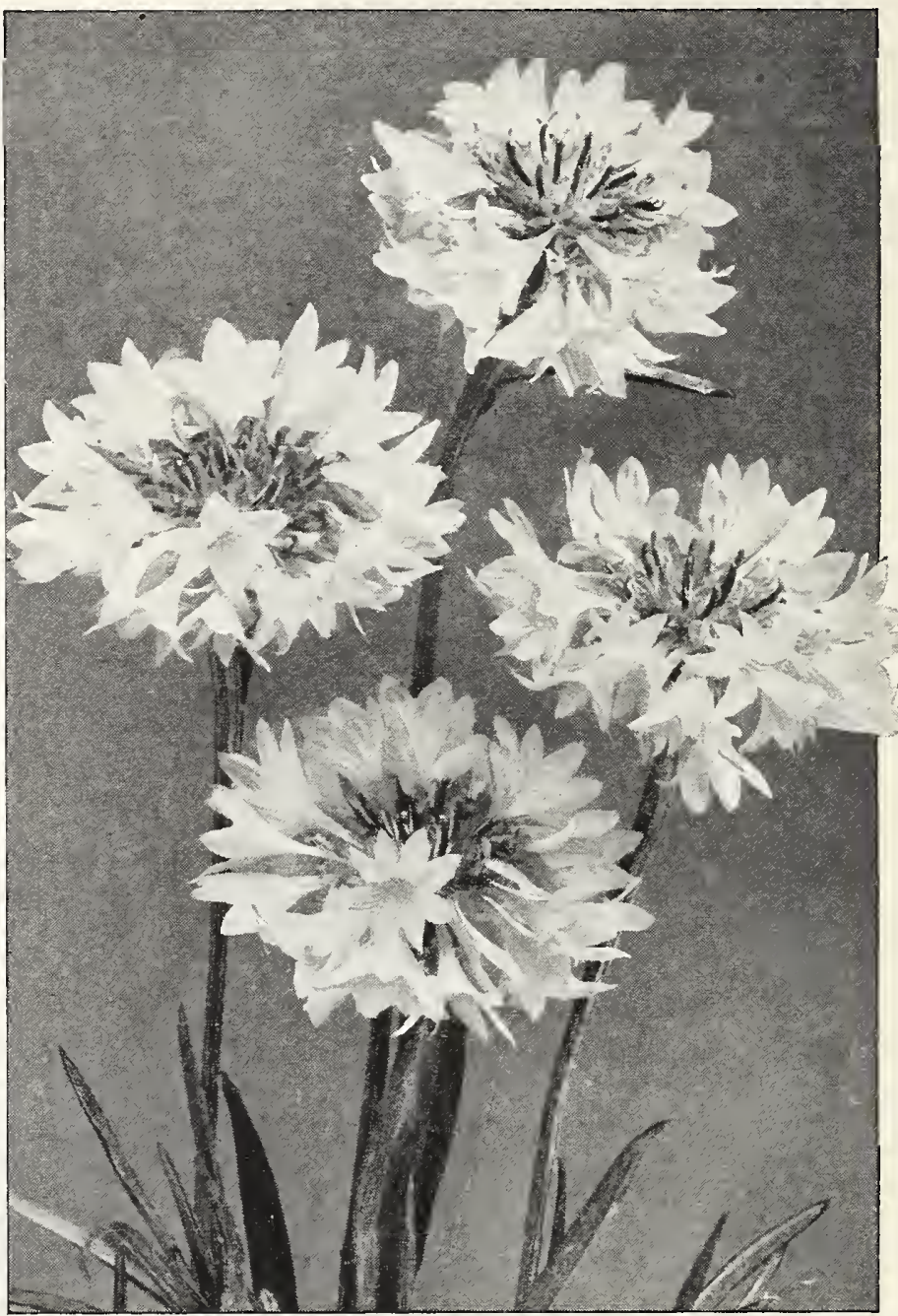

Double Cornflowers (Centaurea Cyanus)

\section{White-leaved Centaureas Dusty Millers}

Extensively used for edging of beds or borders of the flower-garden. The glistening white, contrasted with the bright color of the coleus, salvia or red canna, is very striking.

Candidissima. This hardy, rapid-growing annual is only Pkt. 1/40z. grown for its foliage which is very lanced and silver coated.

An excellent edging plant...................... so so

Gymnocarpa (Dusty Miller). Leaves fern-like; a trifle taller

than Candidissima......................... Io

\$o 75

\section{Various Centaureas}

Americana. The stems, foliage, and flowers of this Cornflower are Pkt. gigantic in size compared with the regular sorts. The flowers, which appear thistle-like, attain the size of 4 inches when fully expanded and are of a splendid, deep lavender color, making an excellent subject for garden decoration or cuttings. Like the Cyanus, it is easily flowered from seed sown outdoors; plants should be placed at least I foot apart. Height 3 feet..............1/40z. 50 cts. . \$o I5

Americana alba. A splendid white form of the above. . $1 / 4 \mathrm{oz} .75 \mathrm{cts}$. I5

Macrocephala. This is a hardy perennial variety with large, thistlelike, golden yellow flowers, useful for cutting and fine for the hardy border. Blooms during July and August. $31 / 2$ feet....1/40z. $50 \mathrm{cts}$. .

Montana (Perennial Cornflower). Grows 2 feet high, bearing large, violet-blue flowers from July to September........ 1/40z. 50 cts.. Montana alba. Large, white form of the above......1/40z. $75 \mathrm{cts}$. . 


\section{CHRYSANTHEMUMS}

\section{ANNUAL VARIETIES}

We offer a choice selection of the best varieties of this showy hardy annual. They are splendid subjects for the border or for cutting. The plants average 2 feet in height, and bear their daisy-like flower in great profusion on strong stems.

Burridgeanum (Beaconsfield). White petals, zone of rich brownisls red, inner zone yellow.

Chameleon. The colors vary, but generally are brown and yellow. A fine variety.

Eastern Star. Clear yellow petals with dark disc.

Evening Star. Yellow petals, dark disc.

Morning Star. Petals canary-yellow, with a halo of deeper yellow, disc darker.

Northern Star. Large, daisy-like flowers, 3 inches in diameter; pure white, fringed petals with canary-yellow zone around a dark brown eye.

The Sultan. Rich wallflower-red with a narrow yellow zone around the brown disc.

Each, pkt. 15 cts., 2 pkts. 25 cts., $1 / 40 z .75$ cts.

COLLECTION: One pkt. each of above 7 varieties, 75 ets.

Golden Queen. Double; golden yellow........... \$o I 5 \$o 50

White Queen. Double; pure white.

Single Annual Varieties Mixed. A choice.................

Double Annual Varieties Mixed. Mixture of double

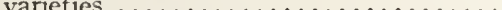

I0 50

PERENNIAL VARIETY (Shasta Daisy)

Chrysanthemum Leucanthemum, Alaska. A splendid hardy perennial variety, with flowers frequently 5 inches across, of the purest glistening white, with broad, overlapping petals.............

\section{CHELONE (Turtlehead)}

Beautiful hardy perennial; very decorative; fine for cutting; should be grown in every garden.

Barbata coccinea. Red. Summer. 3 feet.

Barbata Torreyi. Coral-red. Summer. 3 feet

Plt. $\quad 1 / 40 z$. \$o 10 \$o 50

\section{CINERARIA}

Seed should be sown from May to September where a succession is desired. When sown at this time, fine plants may be secured. The main point in the culture of Cinerarias is to secure as hardy a growth as possible with leaves of medium size. Seed may be transferred direct from seed-pans to thumb-pots. After planting, place in coldframe facing north, if possible. As pots become full of roots, shift to larger ones until flowering size is reached.

\section{Giant-flowering Exhibition Strain}

This strain of prize Cinerarias, grown for us by a famous specialist. produces numerous individual flowers, exceeding 5 inches in diameter with petals I to I $1 / 4$ inches wide. The giant blooms are borne in immense, compact trusses on well formed plants having dark green foliage.

Exhibition Strain, Blue Shades. Selected with utmost care.

Exhibition Strain, Crimson and Carmine Shades. This magnificent selection is especially brilliant under artificial light.

Exhibition Strain, Salmon Shades. One of the loveliest developments, appealing strongly to those fond of the daintier tints.

Exhibition Strain, Mixed. All the above in pleasing proportions to make the best showing. The whole color range of our rich strain. Any of the above, pkt. $50 \mathrm{cts}$.

S. $\mathcal{E}$ W. Co.'s Stellata. This variety has delicate, star-like . Wlooms in great profusion on long stems. It is excellent for cutting as well as decorative purposes; all shades.

Tall and Dwarf Mixed. Each, pkt. 50 cts.

Multiflora Nana, Potsdam. An extra-choice, dwarf-growing strain with the plants completely covered with brightly colored flowers.

Cærulea. Sky-blue. Crimson. Mixed.

Azurea. Dark blue. Rose.

Pkt. 50 cts.

Matador. A new large-flowering, deep scarlet; adds brilliance to a collection. Pkt. 50 ets.

\section{CATANANCHE}

Bicolor. Hardy perennial; blue and white flowers. Height $3 \mathrm{ft}$. Pkt $25 \mathrm{C}$. Cærulea. Blue. Height 3 feet. Pkt. $25 \mathrm{cts}$.

\section{CERASTIUM}

Tomentosum. Hardy perennial. A pretty dwarf, white-leaved edging plant; small white flowers. Pkt. I5 cts., $1 / 4 \mathrm{Oz} . \$ 1.50,0 z . \$ 5$.

\section{CLARKIA ELEGANS}

A mighty handsome annual, which should be far more widely known. It is of easy cultivation, graceful in habit of growth, and lends itself as well to bedding as for cutting. Flowers in long racemes which all open in water when cut. Plt. $\quad$ szoz. Single Rose

Single White

Single Mixed

$$
\begin{array}{rr}
\text { Pkt. } & \multicolumn{1}{l}{\text { \&oz. }} \\
\text { So Io } & \text { \$o } 30 \\
\text { Io } & 30
\end{array}
$$

\section{DOUBLE YARIETIES}

Salmon Queen. Salmon. .

Brilliant King. Crimson.

Purple King. Purple...

Scarlet King. Scarlet....

White King. White....

I0 25

COLLECTION: One pkt each of above 5 Double Clarkias, 50

Double Mixed........................... I5 40

\section{CLEOME (Spider Flower)}

Gigantea. Annual. Singular-looking, rose-colored flowers; the stamens look like spiders' legs, and present a very attractive appearance. This plant is now used extensively in many of the public parks, planted among shrubbery, and is very effective. Sow seed outdoors in May and thin out to stand 2 feet apart. Height 3 feet. Pkt. Io cts., I/40Z. $50 \mathrm{cts}$.

\section{$\mathrm{COB} A \mathrm{EA}$ (Cup-and-Saucer Vine)}

A climber of rapid growth, attaining a height of 30 to 50 feet during the season, valuable for covering trellises, arbors, trunks of trees, etc.; will cling to any rough surface. In sowing, place seeds edgewise and merely cover lightly with soil; to get early results, start the seed indoors in March or April; can also be sown out-of-doors in May. Scandens. Large bell-shaped purple flowers. Pkt. 1oc., $1 / 4 \mathrm{Oz} .50 \mathrm{o}$. Scandens alba. Pure white. Pkt. I5 cts., $1 / 4 \mathrm{Oz} .75 \mathrm{cts}$.

\section{CONVOLVULUS (Morning-Glory)}

Dwarf Bedding Varieties. Mixed. Pkt. Io cts., $0 z .30 \mathrm{cts}$. Tall or Climbing Varieties. Mixed. Pkt. Io cts., oz. $30 \mathrm{cts}$ See I pomoea for other varieties of Morning-Glories.

\section{CUPHEA (Cigar Plant)}

Platycentra. Pretty, half-hardy perennial. Bears long tube-shaped scarlet flowers. Pkt. 15 cts., 2 pkts. 25 cts.

\section{CYNOGLOSSUM}

(Chinese Forget-me-not; Hounds Tongue)

Amabile. Hardy annual. A highly perfumed plant of easy culture, suitable for bedding and cut-flowers. Height 20 inches. Blue, White and Pink. Each, pkt. $25 \mathrm{cts}$, 1/40Z. \$I .

\section{CYCLAMEN (Giant-flowering)}

The following varieties are European-grown. They have been developed by one of the greatest specialists in this excellent pot plant. They make very beautiful house plants. Seed is usually sown in the autumn.

Bright Red

Pure Rose.

White with Carmine Eye.

Lavender

Salmon Color, Dark

Salmon Color, Light

Salmon-Rose, Improved.

Salmon-Scarlet (Christmas Color)

Saffron-Red.

Pure White. .

Mixed. All varieties.

$\begin{array}{rrrrr}\text { Pkt. } & \text { 50 seeds } & \text { IOo seeds } \\ \text { 80 } 25 & \text { \$I } & 50 & \$ 2 & 50 \\ 25 & \text { I } & 50 & 2 & 50 \\ 25 & \text { I } & 50 & 2 & 50 \\ 25 & 2 & 00 & 3 & 50 \\ 25 & 2 & 00 & 3 & 50 \\ 25 & 2 & 00 & 3 & 50 \\ 50 & 2 & 50 & 4 & 00 \\ 50 & 3 & 00 & 5 & 00 \\ 50 & 2 & 50 & 4 & 00 \\ 25 & \text { I } & 50 & 2 & 50 \\ 25 & \text { I } & 50 & 2 & 50 \\ & & & & \end{array}$




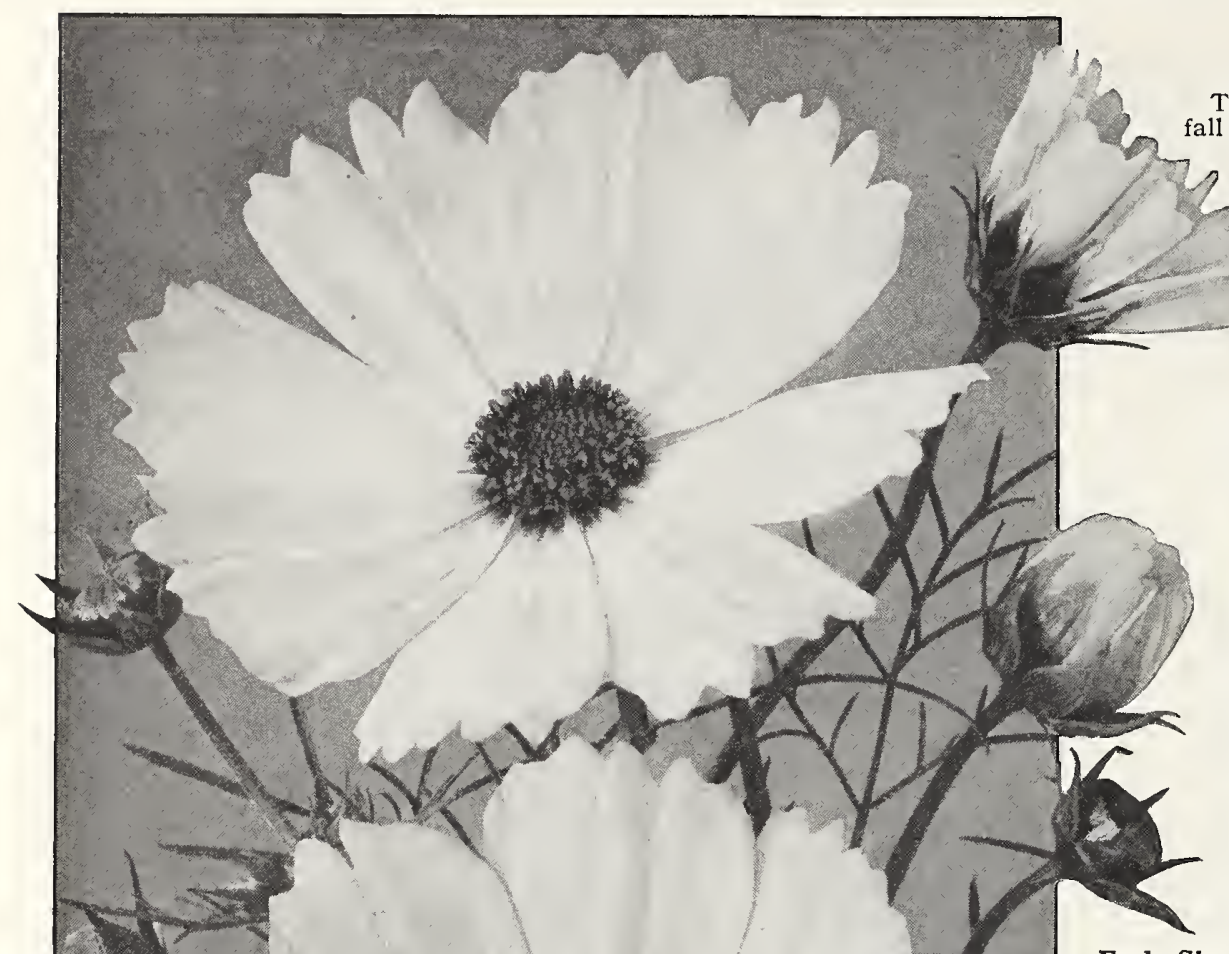

\section{COSMOS}

This is one of the most notable summer and fall flowers, the specialists' skill having added much to its beauty.

We recommend the sowing of Cosmos about the first of May, outdoors in rows, covering the seed about $1 / 4 \mathrm{inch}$. and when the plants are about 3 inches high, thin out or transplant to not less than 2 feet apart. Any garden soil will grow Cosmos to perfection; frequent cultivation around the base of the plants will greatly benefit them.

Early Single Dwarf Cosmos, Summer-Flowering Type

Frequently the amateur finds that the Cosmos of the Late-flowering Tall type, selected by him for growing in borders or beds with other annual flowers, is unsuitable because of it flowering late in the summer, and also growing to the height of 6 to 8 feet. We, therefore, take pleasure in offering this new Early-flowering Dwarf Cosmos, which, if sown outdoors about the first of May, will give an abundance of cutflowers for the table or home decoration from July until cut down by frost.

This type of Cosmos grows about 4 feet high, and while the flowers are not quite so large as the Late Mammoth-flowering type offered on this page, they are admirably adapted to the use of the suburbanite whose garden-space is small.

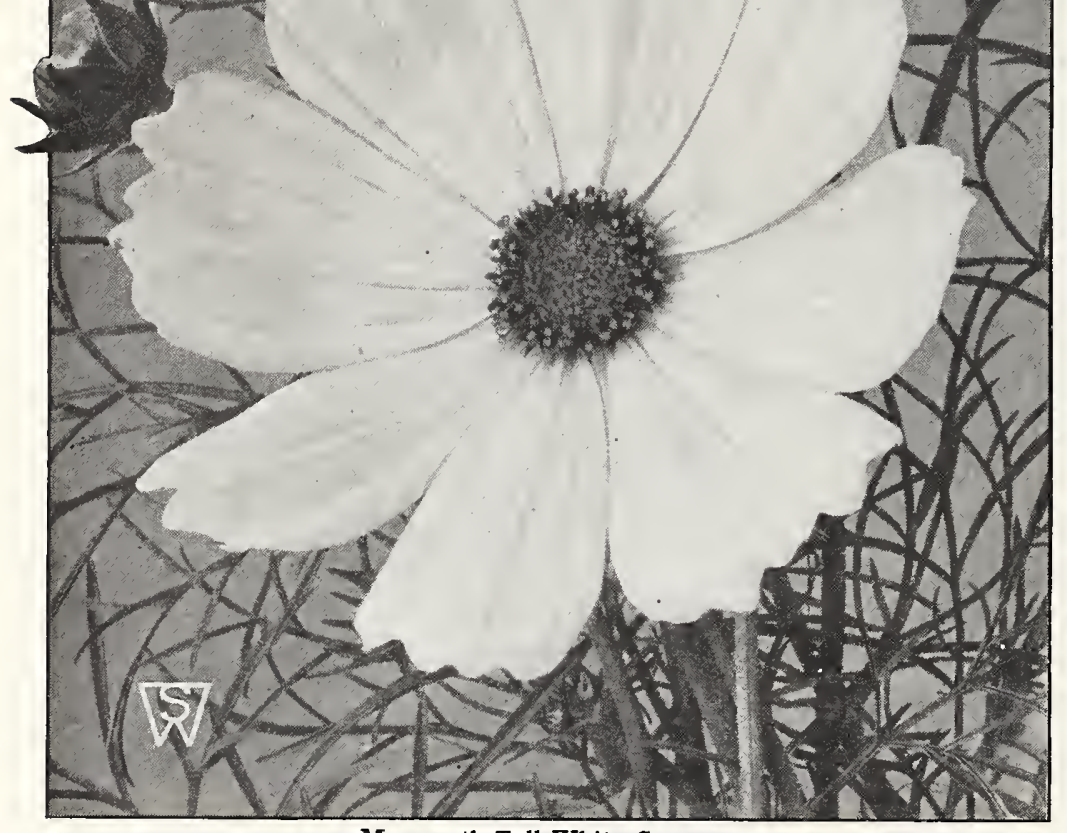

Mammoth Tall White Cosmos

Early Single Dwarf, White.

66 66 66

COLLECTION: Pkt. each of above 3 colors 25 cts.

\section{Early Double Dwarf Cosmos, New}

\section{Double Crested Type (Beauty)}

The Extra-Early Double strain of Cosmos has been very much improved in this crested type. Its flowers are unusually large, and they come into bloom fully as early as the Early Single sorts.

Early Double, Pink Beauty.

$$
\begin{aligned}
& 6{ }_{66} \text { White Beauty. Wach, pkt. } 25 \text { cts. } \\
& \text { 66 66 Crimson Beauty. } 1 / 40 z \text {. } \$ 1.50 \text {, } \\
& \text { 66 } 6 \text { Mixed Beauty. }
\end{aligned}
$$

COLLECTION: Pkt. each of above 3 colors $60 \mathrm{cts}$.

\section{Late Single Tall Cosmos, Mammoth- Flowering Type}

This type of Cosmos, which has been greatly improved over the old tall, small-flowering varieties, blooms late in the summer-usually September in this latitude-and coming at this season of the year, when nearly everything in the garden has finished blooming, it is a very desirable addition.

Late Single Tall White, Pink, Crimson, and Mixed. Each, pkt. 10 cts., $1 / 40 z .30$ cts., oz. $\$ 1$. COLLECTION: Pkt. each of above 3 colors 25 cts.

Lady Lenox. This is the very latest development of this popular autumn flower, bearing gigantic flowers, the petals having a wide overlapping character and of splendid substance; its beautiful, deep rosy pink color and splendid form make this Cosmos one of the most widely grown. Pkt. 10 cts., $1 / 40 z$. 50 ets., oz. $\$ 1.50$.

Lady Lenox, White. Similar to above, but white. Pkt. Io cts., I/40z. 50 cts., oz. $\$$ I.5o.

\section{Late Double Tall Cosmos, Crested Type}

Some years ago, when we first offered this splendid new form of Cosmos, which was of Australian origin, we considered it a notable addition to this beautiful family of easily grown annuals for cutting. We are pleased to announce, however, that due to the painstaking effort on the part of an American grower, this strain has been further improved upon, in size of flower, greater degree of doubleness, and general vigor of the plant. Late Double Tall, Pink. Beautiful rose-pink. Late Double Tall, Crimson. Rich rose-crimson.

Each, pkt. 15 cts., 1/40z. 75 cts., oz. $\$ 2.50$

COLLECTION: Pkt. each of above 3 colors 30 cts. 

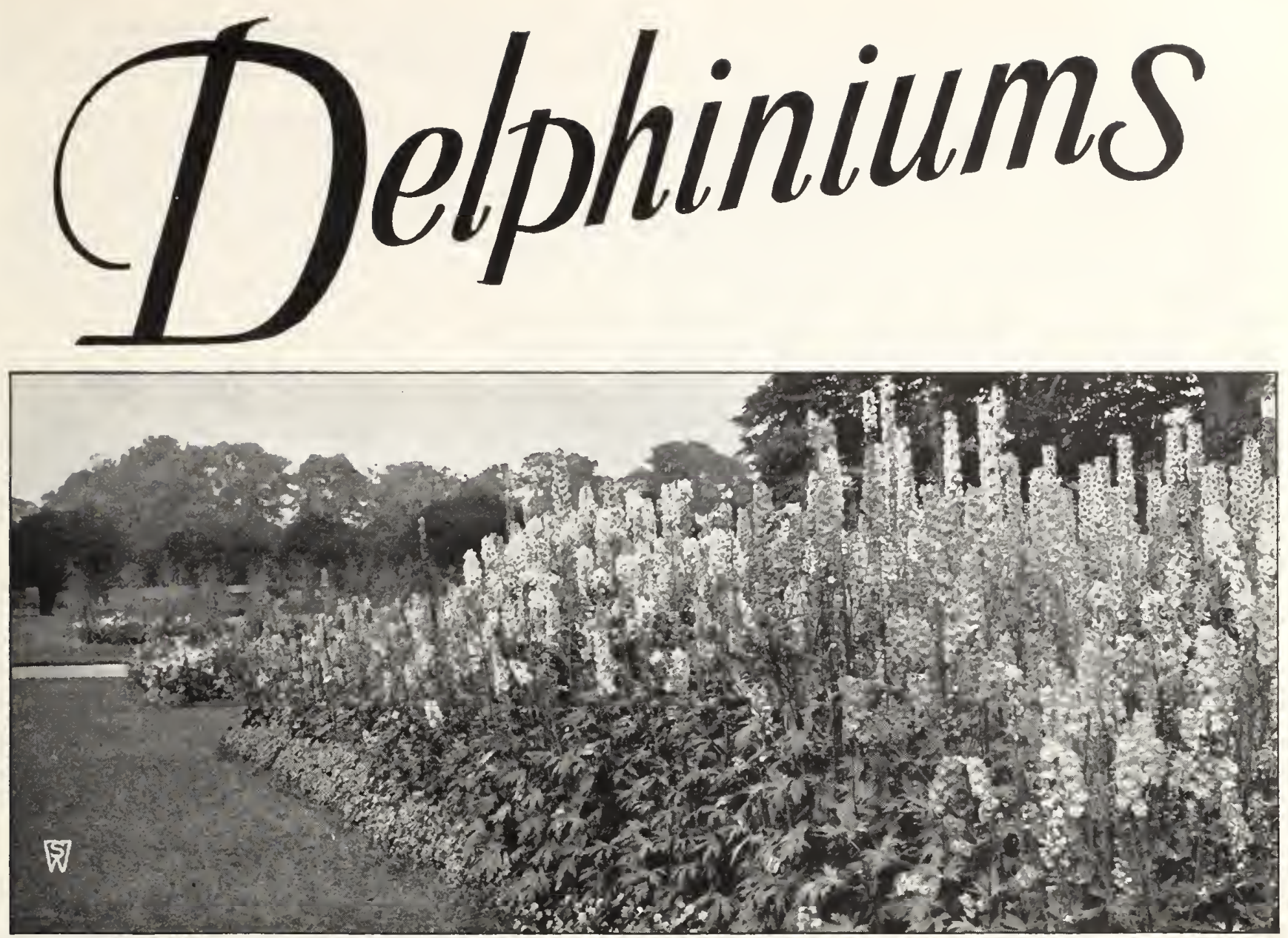

Stumpp \& Walter Co.'s Super Gold Medal Hybrids

\section{Where the Blues Begin}

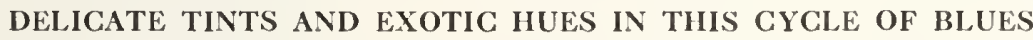

\section{S. \& W. Co.’s Super Gold Medal Hybrid Delphiniums}

We have finally reached the zenith of perfection in the cultivation and hybridization of Delphiniums. These highly desirable and popular perennials bear ponderous blooms of giant florets showing marvelous shadings and tints. They will readily lend themselves to the esthetic taste of the most discriminating flower connoisseurs and enhance the judgment of those who use them for cut-flowers. Wave Crest Blue Shades. A very delicate and charming strain Royal Art Tints. A very desirable mixture of subtle shades. of pale and light blues.

Delft Blue Shades. True blues of special beauty.

Salon Blue Shades. This strain abounds in rich, dark, velvety SPECIAL COLLECTION: 1 pkt. each of the above, $\$ 1.50$. Each of the above, pkt. $50 \mathrm{cts} ., 1 / 80 z . \$ 2,1 / 40 z$. $\$ 3.50$

Super Gold Medal Hybrids, Mixed. This Mixture is prepared so as to give our patrons all the best colors. Pkt. $25 \mathrm{cts}$., I/80z. \$I, I/40z. \$I.50.

\section{Various Varieties}

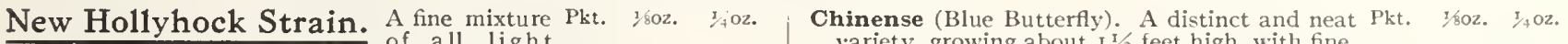

shades, pale clear blue predominating. Large variety, growing about $I^{1 / 2}$ feet high, with fine. feathery foliage, and producing freely spikes of large blossoms of intense gentian-blue........ \$o Io \$o 75 \$ I 25 flowers, truly double, are well placed on long. pyramidal spikes. Their sturdy appearance re-

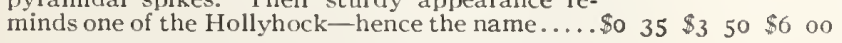
Belladonna (Everblooming Hardy LarkAlbum. The white-flowered form of the preCardinale. A very beautiful cardinal-scarlet; plants grow about $1 \frac{1}{2}$ feet high............. continuous-biooming hardy Larkspurs. Clear tur-

Formosum. Large; rich dark blue, white center; quoise-blue flowers, unequaled for delicacy and

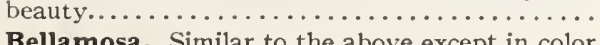

which is a beautiful shade of dark blue........

$\begin{array}{lllll}25 & \text { I } & 00 & \text { I } & 50 \\ 25 & \text { I } & 00 & \text { I } & 50\end{array}$
borne on spikes 2 to 3 feet tall; one of the most popular varieties.

Formosum cœlestinum. Beautiful sky-blue, white center; similar in habit to the above..... 25 I 00 I 75 


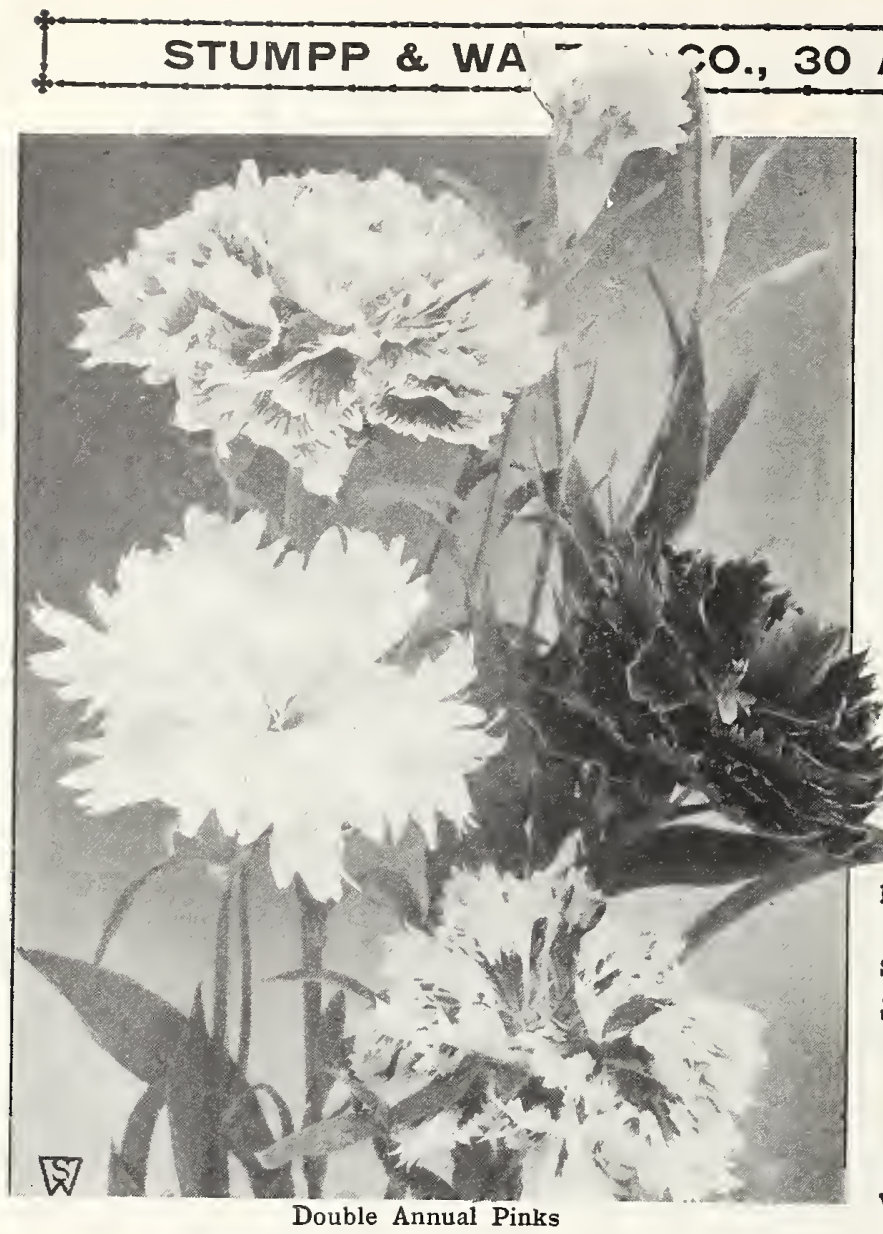

AND 32 BARCLAY ST., NEW YORK

\section{DIANTHUS (Pinks)}

In tlis large and greatly varied genus are some of our most beautiful and best-loved flowers, unsurpassed for color and fragrance. Mostly they are hardy biennials that bloom finely for the first season, remaining green all winter and blooming the next year also, if lightly protected. Seed may be sown in the open in early spring when the danger of frost is past, and if the situation is open and the ground is well prepared they will flower luxuriantly in a few weeks' time and continue until hard frost. They average $I$ foot in height and are splendid for borders and for cutting.

\section{DOUBLE ANNUAL VARIETIES}

Chinensis fl.-pl. (China or Indian Pink). Flowers Pkt. 1/4oz. are borne in clusters, very double and in a large range of bright colors....................... \$o ro $\$ 0$

Diadematus fl.-pl. (Double Diadem Pink). Beau-

tiful double flowers in various tints of lilac,

crimson, purple; outer edges fringed.............

Fireball. New. Extra double brilliant dark scarlet;

very beautiful............................... (Double Japan Pink). Double

Heddewigii f.-pl. (Double Japan Pink). Double
mixed, colors varying from richest crimson to

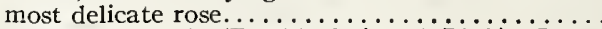

Laciniatus fl.-pl. (Double Fringed Pink). Large double flowers in a great variety of colors; edges

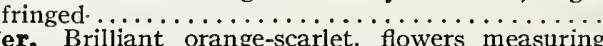

Lucifer. Brilliant orange-scarlet, flowers measuring about 2 inches across; very dazzling and popular variety; nicely fringed $\ldots \ldots \ldots \ldots \ldots \ldots \ldots \ldots$

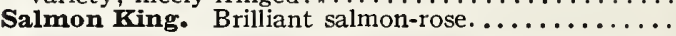

Snowbal1. This splendid variety of the Dianthus or Pink family is one of the finest of all

this genus for cutting. It is classed as a biennial but may be treated as an annual and sown outdoors when all danger of frost is past. It requires a rich soil and an abundance of sunshine. The plants grow about a foot high and are excellent for beds or

borders. Large, double, white flowers ...........

Violet Queen. A rich violet-rather unusual shade...

$\begin{array}{lll}\text { I5 } & 75 \\ \text { I5 } & 75 \\ & & \\ \text { I0 } & 50 \\ & \\ \text { I5 } & 75 \\ & \\ \text { I5 } & 75 \\ \text { I5 } & 75\end{array}$

\section{SINGLE ANNUAL VARIETIES}

Among these single sorts are many beautiful varieties, and the flowers often measure 2 to 3 inches in diameter.

Crimson Belle. Rich crimson. Height, I foot....... Pkt. $1 / 40 z$. Eastern Queen. Delicately marbled rose and mauve flowers........ Queen of Holland. Beautiful white.......... 10 5 Laciniatus (Single Fringed Pink). A great variety of colors......... Salmon Queen. Beautiful fringed flowers of brilliant salmon color

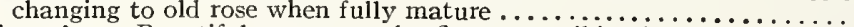
vesuvius. Beautiful orange-scarlet flowers; striking in beds or borders.

10 50
S. $\&$ W. Co.'s Special Mixture of Annual Sorts. A grand collec. brilliancy and rich variety of color; they bloom in perfect succession during the whole summer and autumn. Mixed colors. Pkt. 10 cts., 1/40z. $50 \mathrm{cts}$.

COLLECTION OF ANNUAL SORTS: One pkt. each of 10 choice Dianthus, 5 named Double and 5 named Single sorts, for $75 \mathrm{cts}$.

\section{HARDY GARDEN PINKS}

These form low, bushy tufted plants, above which are produced, on long stems, the beautiful fringed and fragrant flowers so valued in "old-fashioned" gardens. For permanent beds and borders these Pinks are unrivaled.

Allwoodi. This new hardy half Carnation and half Pink is looked upon with great a noted English favor by British flower-lovers. We offer seed direct from the originator, a noted English specialist in Carnations. The plant combines all the good qualities of the Carnation with the delicious clove scent of the Pink. No plant can be hardier. It is adaptable for gardens, rockeries, window-boxes, and pot culture in conservatories. In a mixture of all colors, except yellow. Pkt. 25c., 5 pkts. $\$ 1,250$ seeds $\$ 3.50$.

Deltoides. Rosy purple. Invaluable for the rock-garden. Height 6 inches.

Latifolius atrococcineus f.-pl. Hardy perennial. A hybrid between ... \$o 25

China Pink and Sweet William. The heads of brilliant red flowerween the

double Will flower furt

Plumarius, Double Mixed. Fringed, fragrant flowers of white, crimson. or purple shades, spotted and variegated. Height, I foot.......... I/4oz. \$I . Plumarius, Single Mixed. Large, fragrant flowers of beautiful colors and

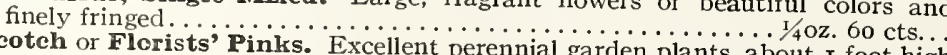

Scotch or Florists; Pinks. Excellent perennial garden plants, about $\mathrm{I}$ foot high when in bloom. They are vigorous, very hardy, and flower profusely during spring and early summer. The flowers are very large, very double, beautifully fringed, and emit a grateful clover-like perfume. Mixed colors....1/40z. $\$ 1.50 .$.

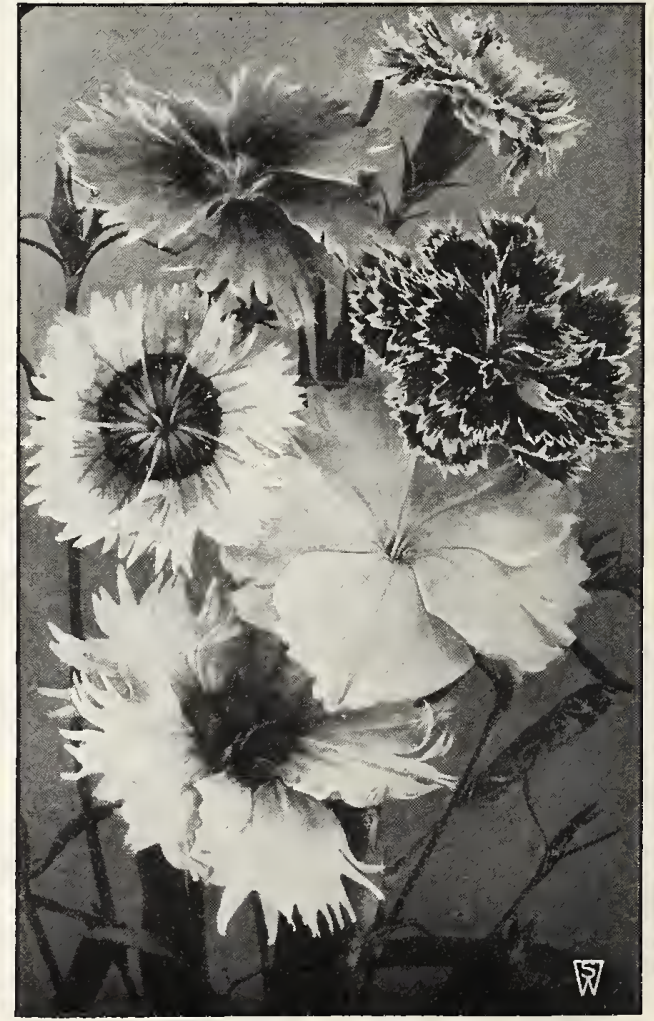

Single Annual Pinks 


\section{CYPRESS VINE}

(Ipomoea Quamoclit)

One of the most popular of annual climbing plants with very delicate fern-like foliage, and masses of beautiful, small, star-shaped flowers. It is advisable to soak sced in water for a few hours before planting out in order to hasten the germination. Frequently attains a height of 15 feet; sow outdoors in May. We offer it in three colors, also a mixture.

Crimson White Rose Mixed Each, pkt. 10 cts., 1/40z. 25 cts.

\section{DAHLIA}

Half-hardy perennial. The seed we offer has becn saved from a superb collection of the finest named varieties.

Giant Peony-flowered, Mixed. Saved from Pkt. finest blooms..................... \$o 50 Cactus, Mixed. Saved from a choice collection. 50 Double-flowering Exhibition Strain, Mixed.

Saved from fine Show sorts.............

\section{DATURA}

Cornucopia (Trumpet Flower). A grand annual plant. The flowers average 8 inches long by 5 inches across; French white inside, purple outside; delightfully fragrant. Started early, will flower from early summer until fall. Pkt. IOC., $1 / 4 \mathrm{oz}$. 50c.

\section{DIASCIA}

Barberæ. An old and not so frequently grown annual which we have listed in an endeavor to give it a wider acquaintance with flower-lovers. The plants average 9 to $I 2$ inches in height and the dainty spurred flowers are freely produced in sprays on wiry stems. The flowers are 7 sinch in diameter and of a soft salmon-rose. Pkt. 25 cts., 5 pkts. $\$ 1,1 / 80 z . \$ 1.50$.

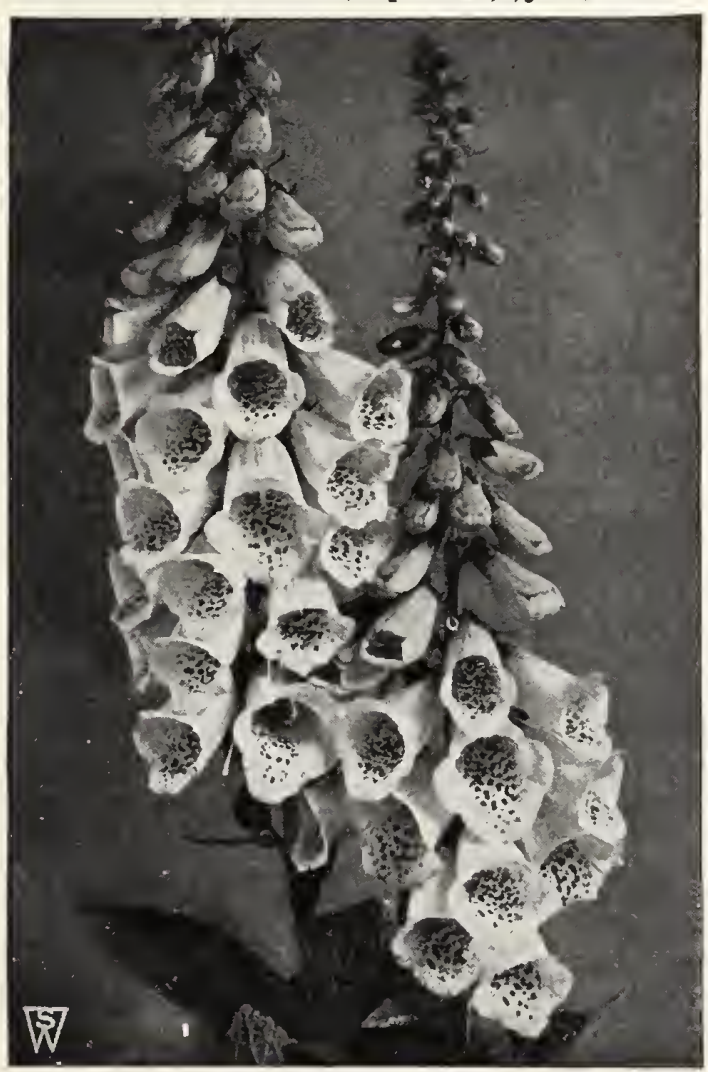

Digitalis Gloxiniæflora

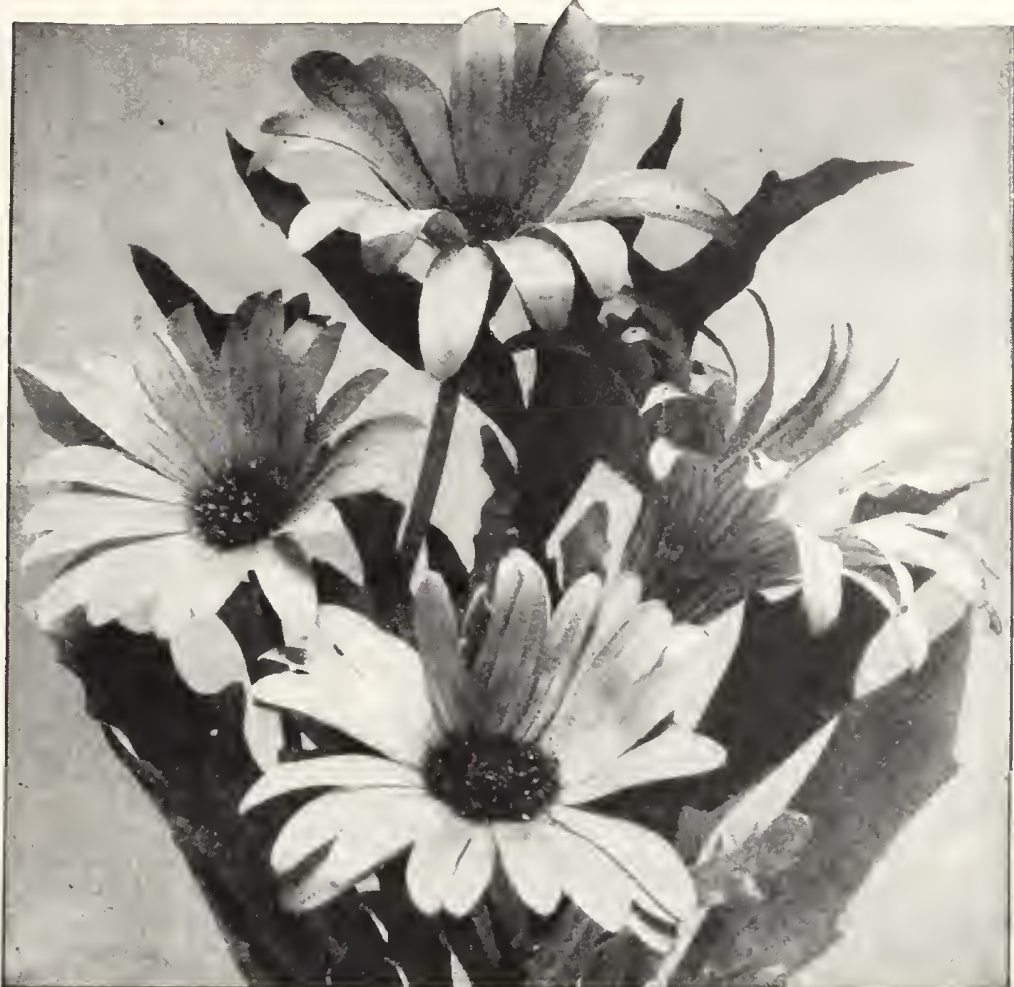

Dimorphotheca (African Golden Daisy)

\section{DICTAMNUS (Gas Plant)}

Albus (Fraxinella alba). Hardy perennial, producing white flowers during June and July. Height $2 \frac{1}{2}$ feet. Pkt. I $5 \mathrm{cts}$.

Pink ( $F$. rubra). Same as the above, except in color which is a dccp pink. Pkt. I 5 cts.

\section{DIDISCUS (Queen Anne's Lace Flower)}

Cærulea. This pretty annual, which was cultivatcd extensively in the gardens of our grandparents, has been brought to prominence again. Queen Anne's Lace Flower grows into an upright, very much-branched plant about 2 feet high. Each branch ends in an umbel of sky-blue flowers, which sprcad out in an umbrella-like fashion, crowning each shoot with a beaussul and delicate head of flowers. It is easily grown and a splendid cut-flower, lasting unusually long in water. Seed may be sown outdoors in a well-prepared seed-bed when trecs are out in lcaf; water copiously during hot weather. Pkt, $25 \mathrm{cts} ., 1 / 40 z . \$ 1$.

\section{DIGITALIS (Foxglove)}

This ornamental hardy plant is uscd extensively for naturalizing in shrubbery borders and along the edges of woods. It grows well under almost all conditions. giving a wcalth of bloom during June and July.

Gloxinizefora. This is an improved strain of the ordinary Foxglove, D. purpurea, with handsome spotted Gloxinia-like flowers on long spikes.

Alba. White ground. Rosea. Rose ground.

Purpurea. Purple ground. Lutea. Yellow ground.

Mixed.

Each, pkt. $10 \mathrm{cts} ., 1 / 4 \mathrm{oz}, 50 \mathrm{cts}$.

Monstrosa (Mammoth Foxglove). Long spikes surmounted by one enormous flower; all colors mixed. Pkt. I5 cts., 1/4 Oz. \$I.

\section{DIMORPHOTHECA (African Golden Daisy)}

The plants are of branching habit, growing about I5 inches high. An easily cultivated annual.

Aurantiaca. Golden orange.

or a pleasing true salmon shade.

Aurantiaca Hybrids. Beautiful new hybrids of the African Golden

Daisy and similar in habit to the parent. The flowers are equally as

large, but vary in color from the purest white through the various

shades of yellow and orange to rich salmon shades, many being

zoned with several of these colors around the black disc.

So Io \$o 50

I 5 


\section{STUMPP \& WALTER CO., 30 AND 32 BARCLAY ST., NEW YORK}

\section{DOLICHOS (Hyacinth Bean)}

A rapid-growing annual climber, flowering freely in erect racemes, followed by ornamental seed-pods. Fine for covering arbors, trellises, etc. Sow the seed in the garden in beds where it is to remain. Height Io feet.

Daylight. This grand Hyacinth Bean comes from Japan. In our Pkt. trial-grounds, plants from seed sown late in May had, by the middle of July, attained a height of over Io feet, and were covered with spikes of snow-white, pea-shaped blossoms from then until late fall. The heart-shaped foliage is bright green and not affected by insect

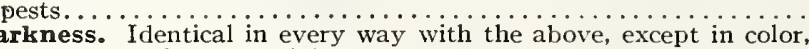

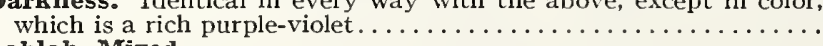
Lablab, Mixed.

\section{DORONICUM}

Caucasicum. An old favorite hardy perennial which should have a place in every hardy border. The handsome, yellow, daisy-like flowers are sometimes 2 to 3 inches across. Height 2 feet. Pkt. $25 \mathrm{cts}$.

\section{ECHINOPS (Globe Thistle)}

Ritro. Striking hardy perennial plants, with handsome, silvery, thistle-like foliage and fine steel-blue flowers in round heads, which can be used for cutting. Excellent for the back of the hardy border. Height 3 to 5 feet. Pkt. Io cts., 1/40z. $50 \mathrm{cts}$.

\section{ECHINOCYSTIS (Wild Cucumber Vine)}

Lobata. One of the quickest-growing annual vines we know of; splendid for covering trellises, old trees, fences, etc. Clean, bright green foliage and sprays of white flowers during July and August. Pkt. Io cts., oz. 50 cts.

\section{ERIGERON (Midsummer Daisy)}

Speciosus. An attractive hardy border plant, producing clear mauve, daisy-like flowers, with bright golden yellow centers. Height 18 inches. Pkt. $25 \mathrm{cts}$., $1 / 4 \mathrm{Oz}$. $\$ 2$.

\section{ERINUS}

Alpinus. A dainty little hardy perennial plant with pale purple flowers, suitable for the rock-garden, growing in the crevices of stone walls, etc. Height 2 inches. Pkt. 25 cts.

\section{ERYNGIUM (Sea Holly)}

Amethystinum. Handsome, ornamental hardy plants, growing 2 to 3 feet high, with finely cut, spiny foliage and beautiful, thistle-like heads of amethystine blue; fine for winter bouquets. Pkt. I 5 cts., I/8Oz. \$I.

Planum. Steel-blue flowers. Height 2 feet. Pkt. $25 \mathrm{cts}$.

\section{ERYSIMUM (Hedge Mustard)}

Orange Beauty. A hardy annual of the easiest culture, producing its orange-yellow flowers a few weeks after seed is sown. Height 2 feet. Pkt. I 5 cts., $0 z, 50 \mathrm{cts}$.

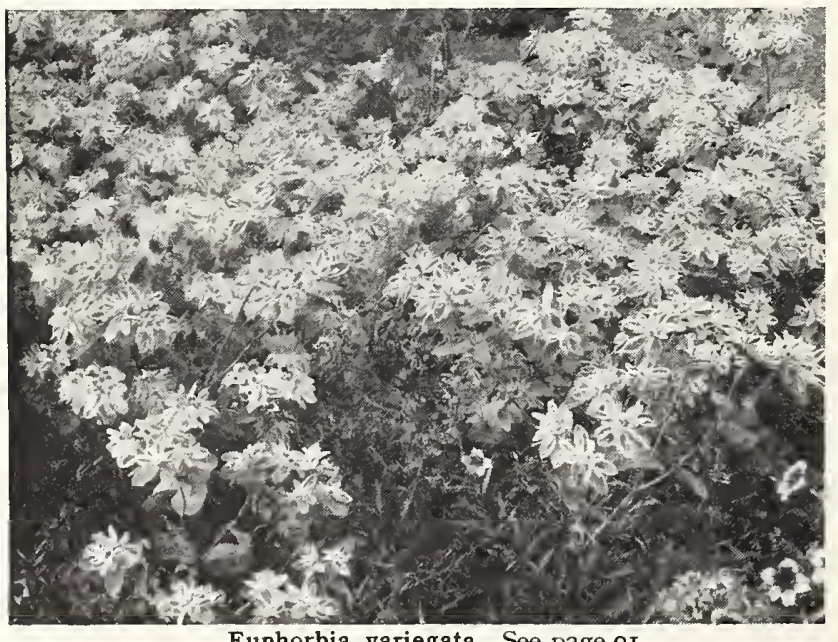

Euphorbia variegata. See page 9 I

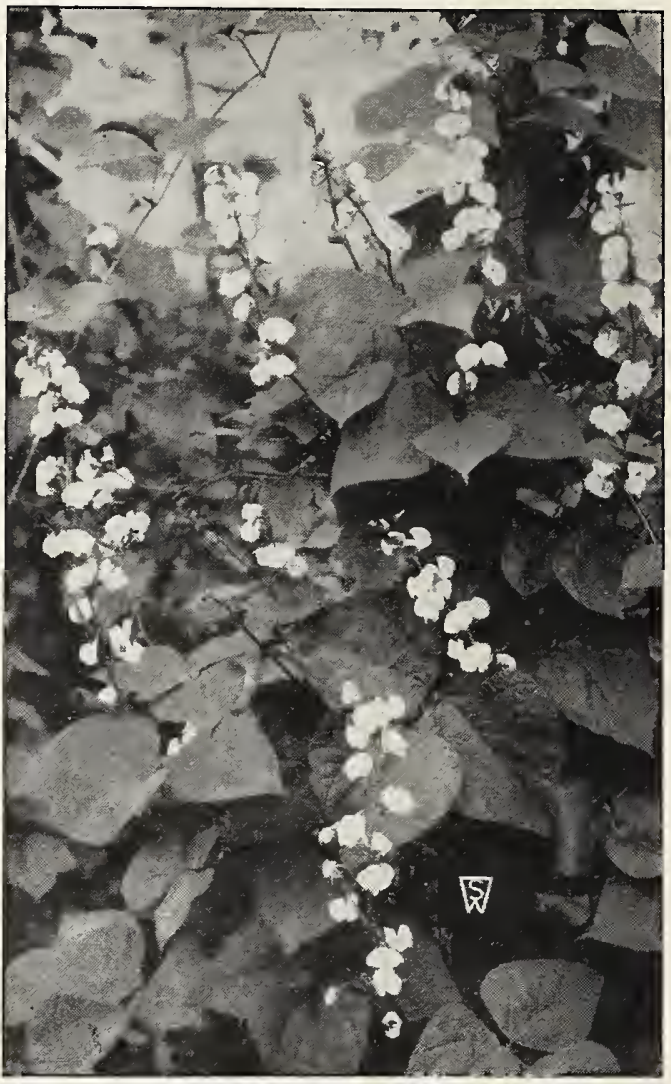

Dolichos (Hyacinth Bean)

\section{EUPATORIUM (Thoroughwort)}

Strong-growing, hardy perennials, well suited for naturalizing and deserving of a place in every hardy border. They will grow and thrive in any location.

Fraseri. A very pretty dwarf variety, producing clusters of snowwhite flowers, fine for cutting and bouquets. I I/2 feet. Pkt. I 5 cts., I/8OZ. \$I.25.

Purpureum. A striking variety, growing 6 to 8 feet high, with heads of purple-blue, daisy-like flowers from August to October. Pkt. 25 cts., I/8OZ. \$I.5O.

\section{ESGHSCHOLTZIA (California Poppy)}

Profuse-blooming annuals for beds, edging, or masses, blooming from early summer to frost.

Pkt. 1/40z.

ul shade of carmine-rose... \$o Io \$o 50 deeply

Geisha. Rich golden orange inside, orange-scarlet

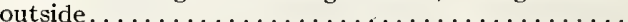

*Golden West. Bright yellow, dark orange at the base

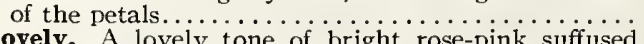
Lovely. A lovely tone of bright rose-pink suffused

Purple Glow. Undoubtedly the greatest advance that has been made in Eschscholtzias. It is a bright reddish purple, the darkest shade that has been

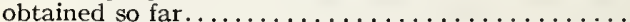

* Scarlet Beauty. Petals deep scarlet inside, lighter

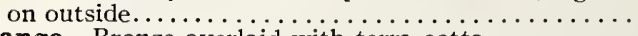

Tango. Bronze overlaid with terra cotta.............

*Vesuvius. Rich coppery red which glistens in the

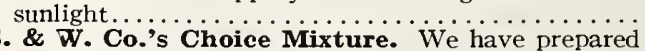
a mixture of named sorts covering all the colors in this pretty annual....................... Io 50 COLLECTION OF CALIFORNIA POPPIES: Pkt. each of varieties marked (*) above, with the Giant Tulip Poppy (Hunnemannia), 6 varieties in all, 50 cts.; $1 / 40 z$, each of these varieties, $\$ 2.50$,

$\begin{array}{ll}\text { Io } & 50 \\ \text { Io } & 50 \\ \text { Io } & 50 \\ \text { Io } & 50 \\ & \\ \text { Io } & 50 \\ \text { Io } & 50 \\ \text { I0 } & 50 \\ \text { Io } & 50 \\ & \\ \text { Io } & 50 \\ \text { each of } \\ \text { ppy (Hun- } \\ \text { of these }\end{array}$




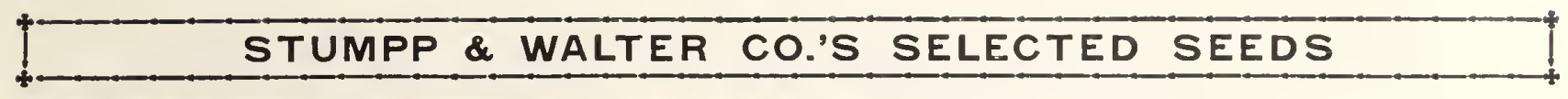

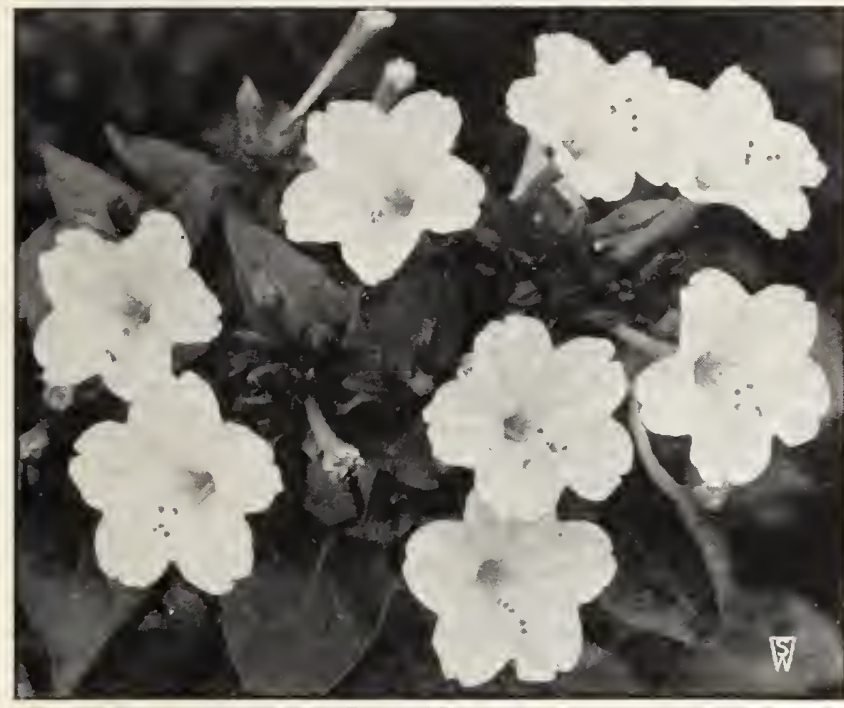

Four o'Clocks

\section{EUPHORBIA}

Strong-growing annuals, suitable for beds of tall-growing plants or mixed borders. The flowers are inconspicuous; the foliage, however, is exceedingly ornamental.

Variegata (Snow-on-the-Mountain). Attractive foliage, veined and margined with white. 2 feet. Pkt. Io cts., 1/40z. $25 \mathrm{cts}$.

Heterophylla (Annual Poinsettia). An annual which resembles in color the bcautiful hothouse poinsettia. The plants grow 2 to 3 feet high, of branching, bush-like form, with smooth, glossy green leaves which about the middle of the summer, turn to a beautiful orange-scarlet, presenting a striking and brilliant appearance. Pkt. $15 \mathrm{cts} ., 1 / 80 \mathrm{O}$. $50 \mathrm{cts}$.

EVERLASTING FLOWERS. See page I2I.

\section{FOUR O'CLOCK (Mirabilis)}

Well-known, free-flowering plants. Called Four o'Clock because they open their blossoms at that hour in the afternoon; also called Marvel of Peru. Hardy annuals. 2 feet.

Fine Mixed. All colors. Pkt, Io cts., oz. $50 \mathrm{cts}$.

\section{GEUM (Avens)}

Atrosanguineum fl.-pl. Beautiful hardy perennial, bearing Pkt. profusely large, showy, double, dark crimson flowers all through the summer; an elegant flower for bouquets.

Mrs. Bradshaw. Large, double, brilliant oran flower throughout the entire summer............................

\section{GAILLARDIA (Blanket Flower)}

\section{ANNUAL VARIETIES}

Very showy annuals of easy culture. The flowers are borne freely and are brilliant in tone. Excellent for borders and do best if sown in May. Flower in great profusion from July to November.

Amblyodon. Rich blood-red. 2 fcet...........\$o io \$o 50

Aurea. Rich yellow, 2 feet.

Picta Lorenziana. A mixture of various colors. The

flowers are double and excelent in form.... Io 50

Picta, Indian Chief. A new variety. Finebronzy red. 15

The Bride. This is a pure white selection from the

Lorenziana type; very double and, like the variety

montioned above, is excellent for cutting . .

OZ. $50 \mathrm{cts} .$. I5

$15 \quad 75$

\section{PERENNIAL VARIETIES}

The perennial varieties of this family are grown in most hardy borders. They thrive in any position or soil, require little or no protection, and take care of themselves. If sown early, they begin flower ing in July, and continue to be a mass of bloom until cut down by frost; fine for cutting. Heiglit 2 feet.

Kermesina splendens. Center rich crimson, narrow canary-yellow border. Pkt. $15 \mathrm{cts}$., $1 / 4 \mathrm{Oz} . \$ 1.50$

Grandiflora compacta. A compact variety forming bushy plants I2 to I5 inches high, and bearing its long-stemmed flowers wel above the foliage. In coloring the flowers are as brilliant and varied as the tall-growing sorts. Pht. I5 cts., 2 pkts. $25 \mathrm{cts}$., 1/40z. $\$ 1$.

Grandiflora, Copper-Red. A striking new color in this popular perennial. Pkt. I5 cts., 2 pkts. $25 \mathrm{cts}$., 1/40z. \$I.

S. $\&$ W. Co.'s Hybrids. This strain of Hybrid Gaillardia who has developed a splendid typc, covering only the best varieties. The flowers are as large as sunflowers. Pkt. 25 cts., 1/80z. 75 cts.

\section{GENTIANA (Blue Gentian)}

Acaulis. One of the most desirable of the hardy alpine plants, growing about 4 inches high. The flowers are a rich blue. As seeds oftcn are slow to germinate, it is advisable to soak them well before sowing. Pkt. $25 \mathrm{cts}$.

\section{GILIA}

A vcry graceful annual, growing about 2 feet high, with fine feathery foliage, and bearing freely over a long season, globular heads of bloom about 1 inch across. We offer a lavender-blue and white form. A splendid annual, lasting well when cut.

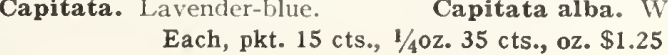

\section{GLOXINIA}

S. E W. Co.'s Large-Flowered. These very remarkable ful selection, now been so far fixed that 40 per cent of the scedlings come true. The ground-color of the large, erect, and widely opened flowers is a velvety purple-crimson, with a rosy white throat. On the often seven-lobed corolla appear more or less sharply defined bands, spots and stripes, charactcristic of this new class, the latter mostly of a violet hue. Pkt. 50 ets.

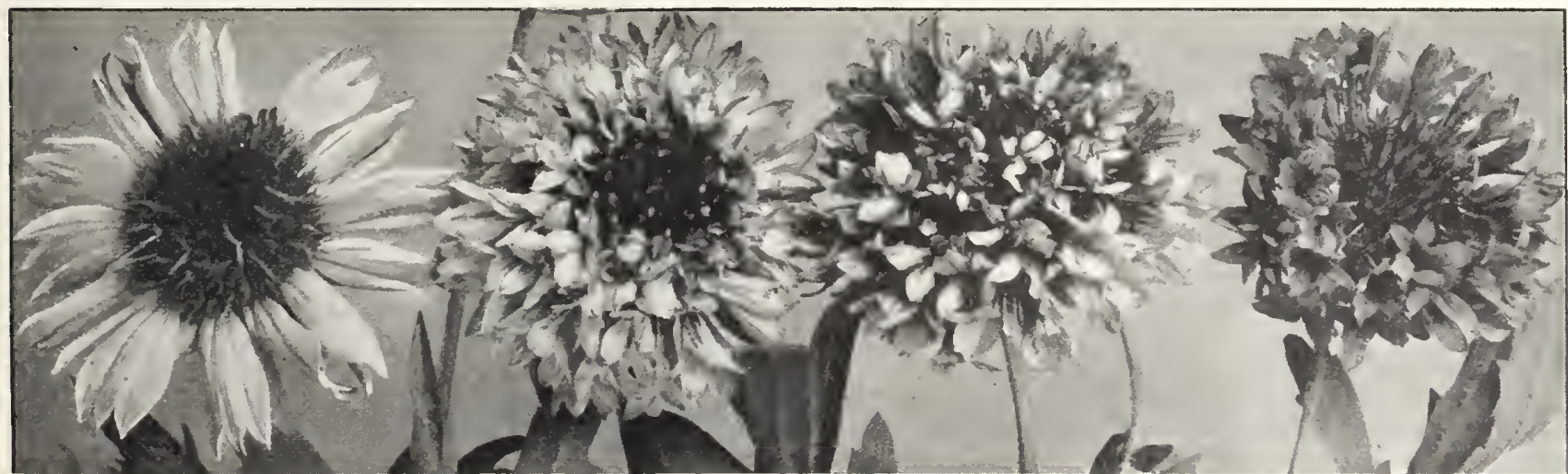

Types of Gaillardia 


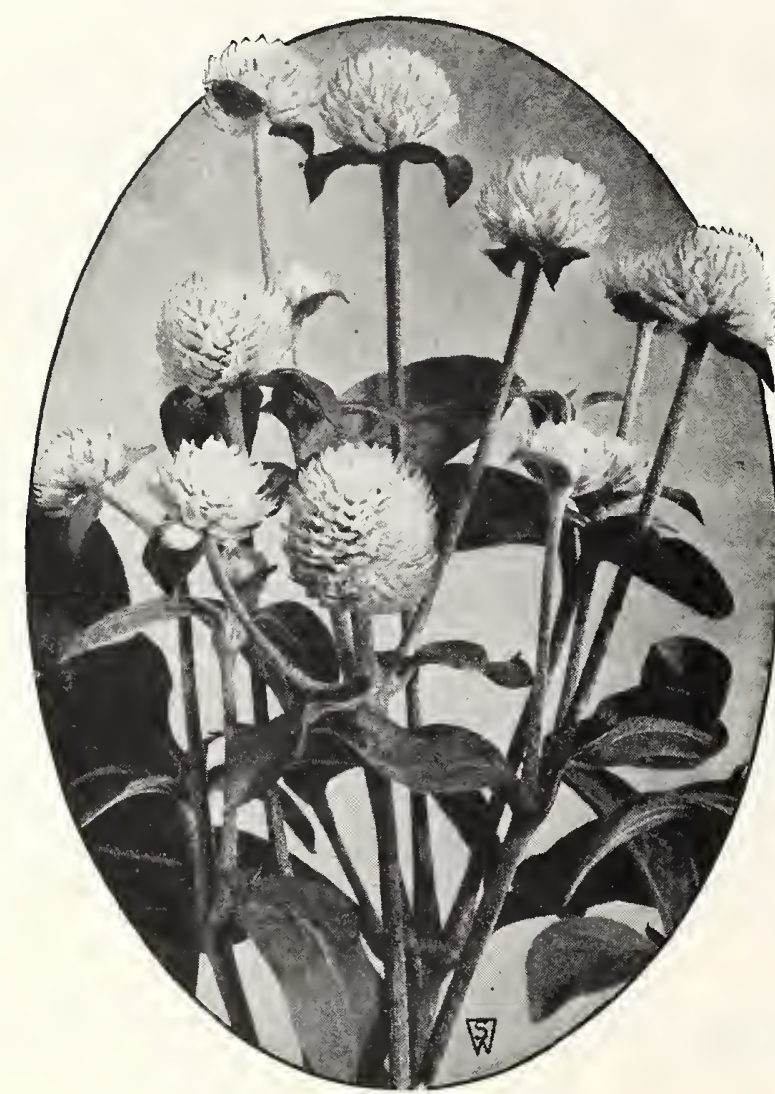

Globe Amaranth (Gomphrena)

\section{GLOBE AMARANTH}

(Gomphrena)

Popularly known as "Bachelor's Button." A first-rate bedding plant. The flowers resemble clover heads and can be dried and used in winter bouquets. Cornflowers and a number of other flowers are also known as Bachelor's Buttons, and in ordering it is well to order by name to prevent errors. We offer them in separate colors and in a mixture as well.
Rose
White
Purple
Mixed
Each, pkt. 10 ets., 1/40z. 25 cts., oz. 75 ets.

\section{GODETIA}

This beautiful hardy annual deserves more extensive cultivation. The plants bloom profusely and are splendid for bedding. We also recommend that those with greenhouse facilities try growing these as a pot-plant for winter decoration. We offer the single-flowering sorts, which grow about I foot high, and the double varieties, which attain the height of 2 feet.

Duchess of Albany. Satiny white...........\$० Io \$o 50

Lady Satin Rose. Brilliant carmine.............. no

Princess of Wales. Beautiful pink .............. Io

Sunset. Dwarf; compact; rosy carmine.

Tall Double Pink. Beautiful salmon-pink.

Tall Double Rose. Deep rose.

Tall Double Carmine. Carmine.

Tall Double Crimson. Crimson.

Tall Double Mauve. Mauve......

Tall Double Mixed.

\section{GNAPHALIUM}

(Edelweiss)

Leontopodium. Seed should be sown early and kept cool and moist. Pkt. 25 cts.

\section{GOURDS}

A vigorous class of plants, with curiously formed and often strangely colored fruits. The foliage is abundant and often curious. Pkt. Oz.

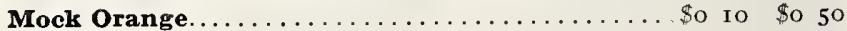

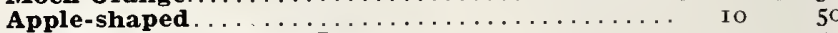
Dish-Cloth or Chinese Luffa ............. Io 50

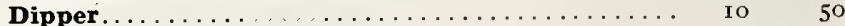

Hercules; Club ...................

Mixed. All sorts..................

\section{GREVILLEA (Silk Oak)}

Robusta: Very graceful foliage; highly valued as a decorative plant for the table, and, when large, for tropical effects. 3 to 5 feet. Pkt. I5 cts., $1 / 4 \mathrm{Oz} .75$ cts., oz. $\$ 2.50$.

\section{GYPSOPHILA (Baby's Breath)}

Pretty, free-flowering, elegant plants, succeeding in any garden soil. Their misty white panicles of bloom are largely used for mixing with other cut-flowers.

Elegans grandiflora alba. This is an improved, large- Pkt. flowering, pure white form of the annual Baby's Breath; of free, easy growth, and grown by the acre in the suburbs of Paris and London for use with other cut-flowers. Several sowings should be made during the season to keep up a supply....... I $/ 4 \mathrm{lb}$. \$I.50..\$o Io \$o 50

Elegans grandiflora rosea. Delicate rose. $1 / 4 \mathrm{lb}$. $\$$ I.50. Io 50 Muralis. An annual sort which forms mounds of green 8 to Io inches high, thickly studded with little pink flowers from early in the season till frost; fine for edging.................... 1/40z. $50 \mathrm{cts}$.

Paniculata. White flowers; fine for bouquets; one of the favorite hardy perennials; blooms first year if sown early. 2 feet............... 1/40z. $30 \mathrm{cts}$.

Paniculata fl.-pl. The new double-flowering Baby's Breath, and one of the finest hardy plants for cutting. I/8 oz. \$I.

$\mathrm{Oz}$.

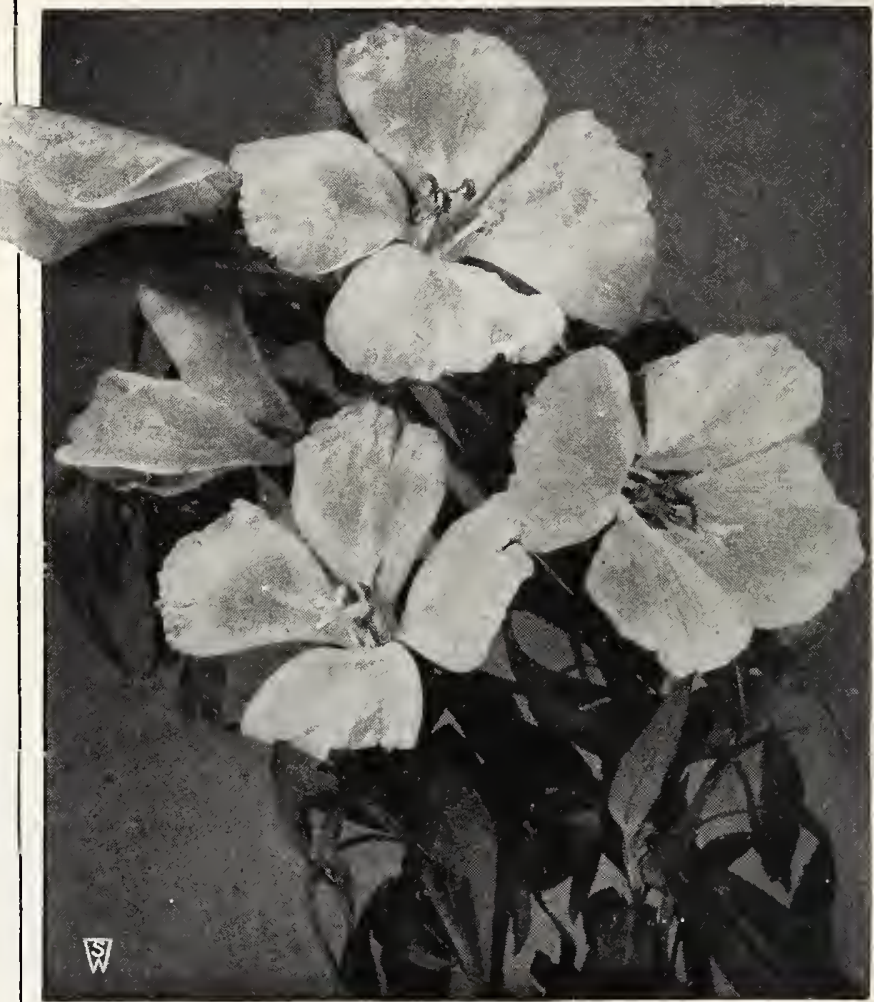

Godetia 


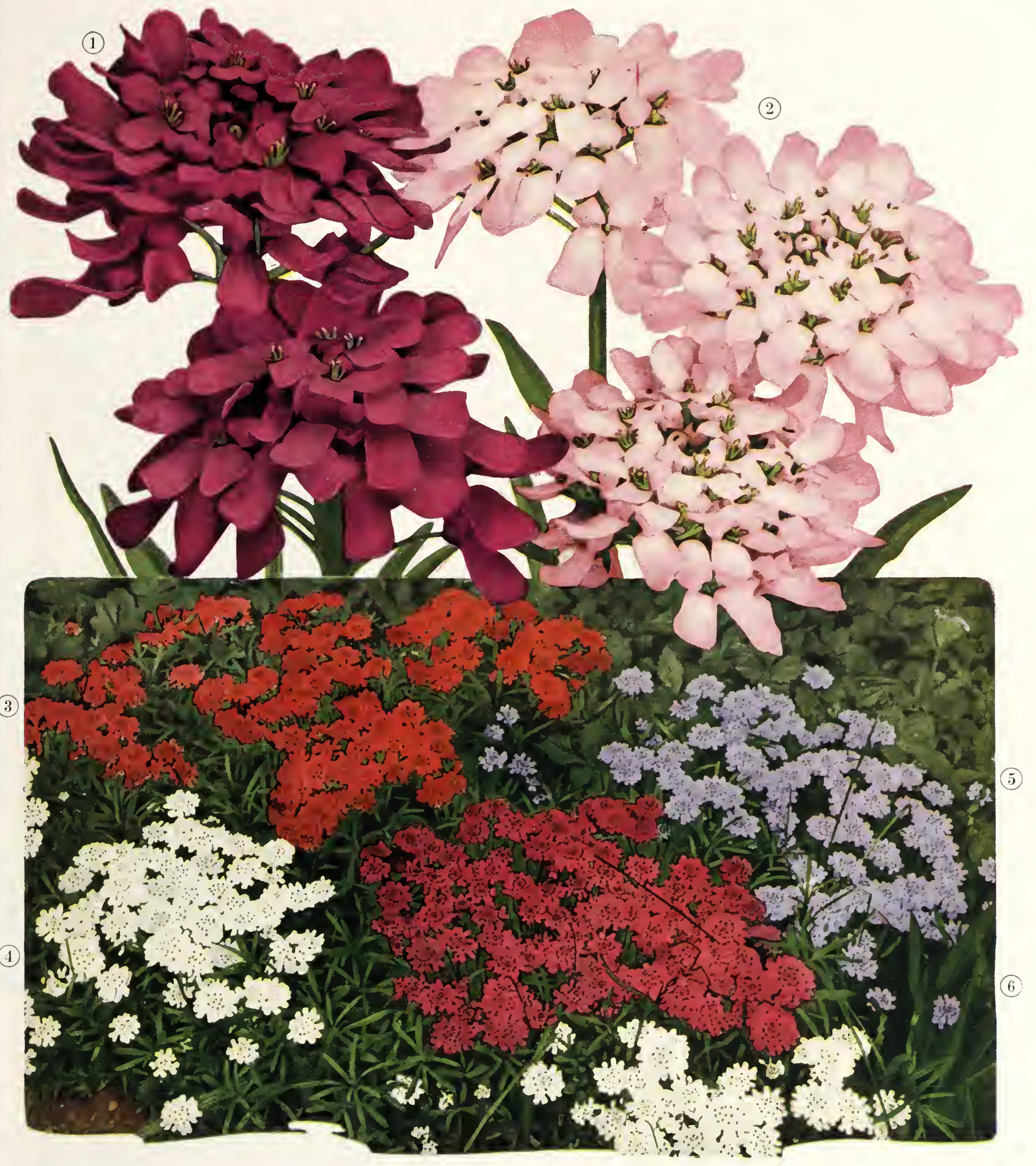

\section{S.\&W. Co.'s Mammoth-Flowered Candytuft}

NO ANNUAL is of easier cultivation, and few give so effective a display with so little effort. Sow in the spring as soon as the land is workable, and thin out so that the individual plants stand 5 inches or more apart; replant in other parts of the garden the plants you remove. Candytuft will grow anywhere and will bloom continuously if the matured flowers are kept gathered so as to prevent the formation of seed.

Our Mammoth-flowered is an improved type, with extra-large blooms, but of uniformly dwarf habit. We offer in a wide range of color.

1. Carmine

2. Flesh-Pink

3. Rose-Cardinal

4. White

5. Lavender

6. Crimson

Each, pkt. $15 c$.

$1 / 4$ oz. 50c., oz. $\$ 1.50$
COLLECTION

Pkt.

each

of above

6 colors
76 


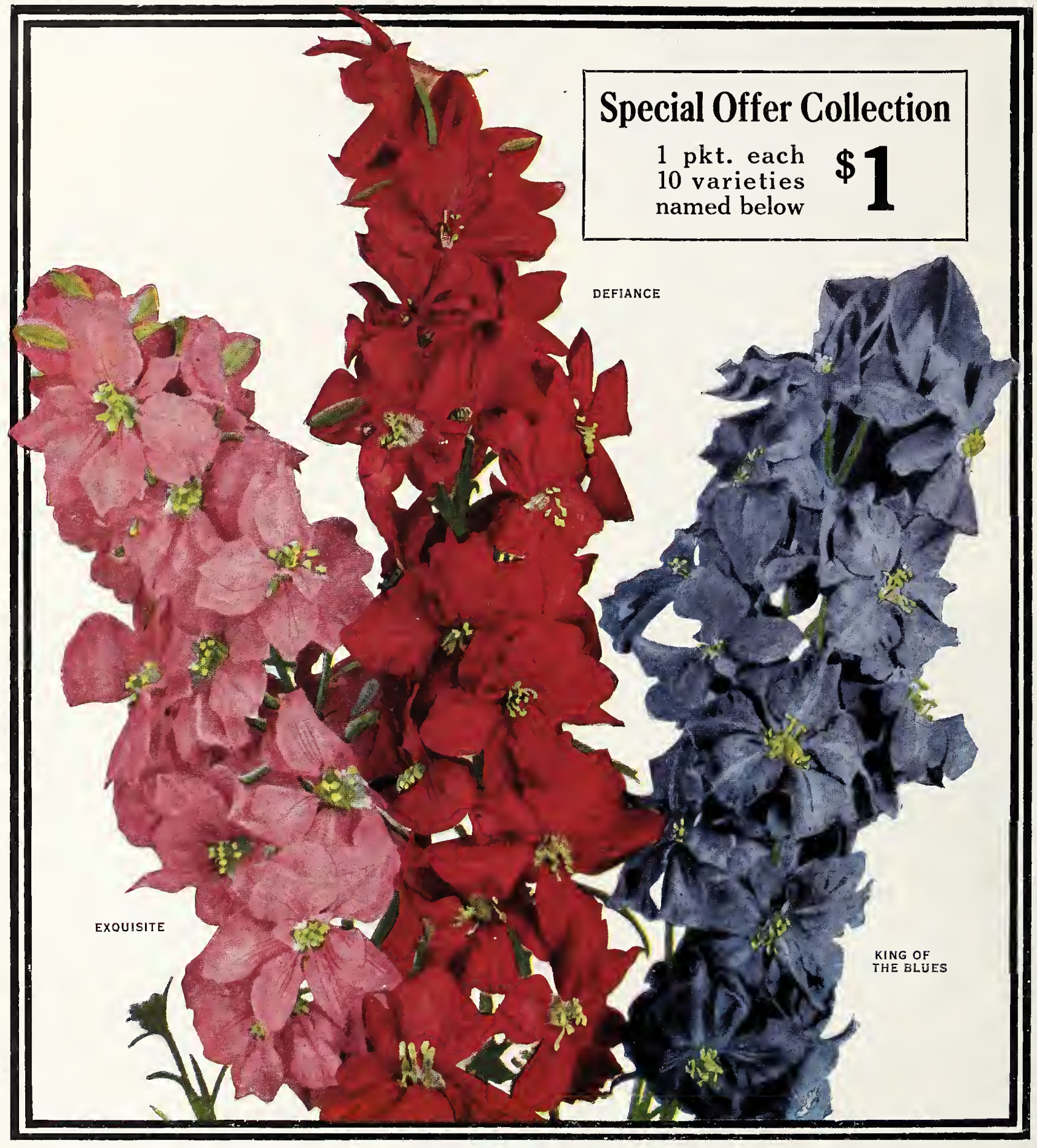

\section{ANNUAL LARKSPURS}

—EW annuals are more satisfactory for garden display or for cutting than the Larkspur. Plant-breeders have produced wonderful -1 improvements in size and color and the varieties we are offering are a distinct advance in habit of growth, size of spikes and color over any strains we have tried in comparison. Seed sown in the open ground in April will produce plants which will bloom continuously from July to frost. They are splendid for beds or borders, their graceful habit and bright colors making them very effective.

\section{TEN FINE VARIETIES}

Attraction. Bright rose. Defiance. Scarlet. Exquisite. Soft pink.
King of the Blues. Dark blue. Lilac Perfection. Lilac. Each, pkt. 15 cts., $1 / 4$ oz. 50 cts., oz. $\$ 1.50$
Loveliness. Shell-pink. Snowstorm. Pure white.
Stella. Sky-blue.

Tricolor. Variegated. Violet Queen. Violet. 


\section{GYPSOPHILA, continued}

Acutifolia. A strong-growing hardy perennial sort, 3 to 4 feet Pkt. $1 / 40 z$. high, with large panicles of small white flowers in July.... \$o ro \$o 50

Repens. A dwarf, white-flowered hardy perennial that is fine for rockwork

Repens rosea. Same as above, but has pink flowers........... Is I

\section{HELENIUM (Sneezewort)}

Hardy perennial; blooms in late summer; useful in the hardy border; very free-blooming. Height 5 feet.

Autumnale superbum. Golden yellow...

Riverton Beauty. Lemon-yellow.

Riverton Gem. Wallflower-red...

\section{HELIANTHUS (Sunflower)}

Much-prized annuals and perennials for cutting; the tall sorts are largely used in the perennial border; the dwarf sorts make good edgings to the tall.

\section{ANNUAL SUNFLOWERS}

The annual sorts of Sunflowers are indispensable for cutting. Sown in a sunny location in April or early May, they come to bloom early in the summer and flower continuously until cut down by frost.

Cut-and-Come-Again, Mixed. A mixture of the tall-grow-Pkt. $1 / 40 z$. ing, large-flowering types for cutting................ so no \$o 50 Cucumerifolius (Miniature Sunflower). Small, single, rich yellow flowers; an abundant bloomer. 4 feet.

IO

30

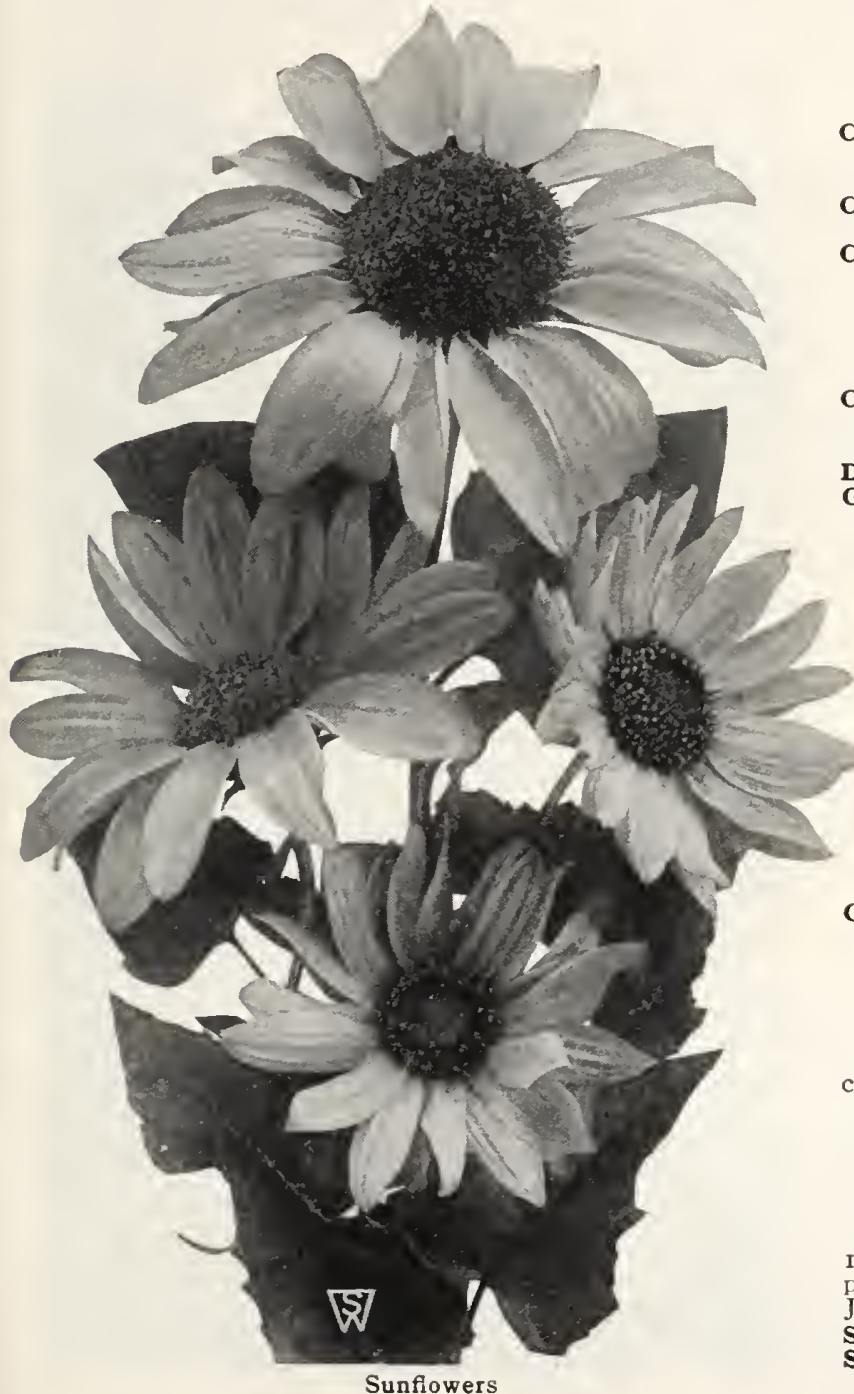

Cucumerifolius, Stella. Different from the above with its Pkt. 1/4oz. larger and better-formed flowers of purest golden yellow with black center.

Cucumerifolius, Orion. A new variety of the Stella. The petals are twisted like a cactus dahlia.

Cucumerifolius, Perkeo. A charming dwarf variety of the Miniature Sunflower. The plants form compact buslies about I 2 inches high by 14 inches through. There are nany positions, such as the front of borders or beds of plants of medium height, where this can be used to good advantage, flowering as it does from the end of June until cut down by hard frost.

Cucumerifolius fl.-pl. The double-flowering form of the popular Miniature Sunflower. The flowers, while double, are quite free and graceful; of a bright golden yellow...............

Dwarf Double (Globe of Gold). Dwarf; double; vellow. $4 \mathrm{ft}$.

Globosus fistulosus (Globe or Dahlia Sunflower). Flowers large, double and of a rich saffron. 6 feet

Gigantic Russian. The large-flowering Russian variety. Oz. Io cts., $1 / 4 \mathrm{lb} .25 \mathrm{cts} ., 1 / 2 \mathrm{lb} .40 \mathrm{cts} ., 1 \mathrm{~b} .75 \mathrm{cts}$.

\section{HARDY SUNFLOWER}

Perennial Sorts, Mixed. A mixture of the best perennial varieties carefully selected. Pkt. $25 \mathrm{cts}$.

\section{HELIOPSIS}

Pitcheriana (Orange Sunflower). Valuable lardy perennial for the border, thriving in any good soil. Flowers cup-shaped, deep yellow: on long. stiff stems. 3 to 4 feet. June to October. Pkt. Io cts. I $40 \mathrm{z} .75 \mathrm{cts}$.

\section{HERACLEUM}

Giganteum. A giant, hardy perennial plant, useful for the wild garden, for large open spaces, or on lawns where a bold and striking object is desired. Should not be allowed to seed. Pkt. I $5 \mathrm{cts} ., 0 z .50 \mathrm{cts}$.

\section{HESPERIS (Sweet Rocket)}

Favorite hardy perennials. The plants form large clumps 2 to $3 \mathrm{ft}$. high,

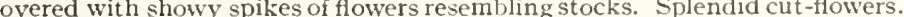
Matronalis, Red. Matronalis, White. Each, pkt. 10 ets., 1/4oz. 50 ets., oz. $\$ 1.50$

\section{HEUCHERA (Alum Root or Coral Bells)}

Most desirable, dwarf, compact, bushy plants of easy culture, growing $I / 2$ to 2 feet high. and bearing graceful spikes of flowers. Excellent hardy plant for the border or rock-garden. Splendid for cutting. Blooms during July and August.

Sanguinea. Coral-red.

Sanguinea alba. White.

Sunfowers Any of the above, pkt. 15 ets., 2 pkts. 25 ets.
Sanguinea gracillima rosea. Carmine-rose. 


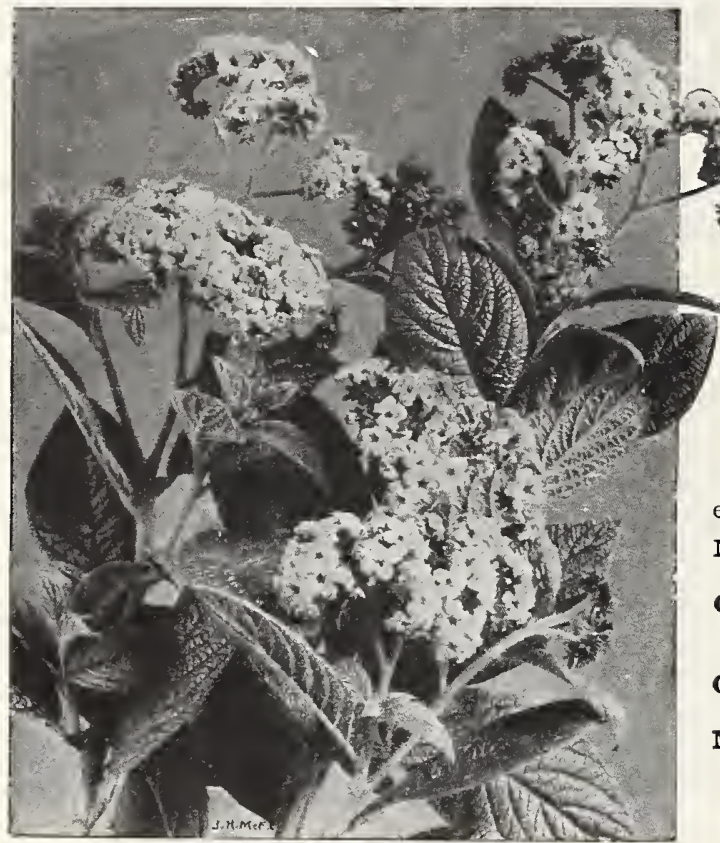

Heliotrope, Lemoine's Giant

\section{HELIANTHEMUM (Sun Rose)}

One of the most beautiful perennials suitable for the rock-garden. Height I foot.

Mixed. Including Yellow, Red, White, and Pink.

Pkt. 25 ets.

\section{HOLLYHOCKS}

One of the most popular of hardy garden plants. The beautiful color effects produced by the planting of these flowers, combined with their dignified and stately appearance, render them indispensable for either the old-fashioned garden or the well-planned herbaceous border. As a background for other flowers or planting among shrubbery, they are without an equal. As the plants are affected with rust occasionally, we recommend frequent spraying in springtime with "Semesan."

\section{GHA'TER'S SUPERB DOUBLE}

$\begin{array}{lll}\text { Chamois } & \text { Newport Pink } & \text { Scarlet } \\ \text { Deep Rose } & \text { Pure White } & \text { Sulphur-Yellow } \\ \text { Maroon } & \text { Salmon-Rose } & \text { Superb Mixed }\end{array}$

Each, pkt. 25 cts., 5 pkts. $\$ 1,1 / 40 z . \$ 2$

S. $\&$ W. Co.'s Double Mixed. This is an excellent strain. The great care from the strongest plants and brightest colors. Pkt. 15 ets., $1 / 80 z$. 75 cts.

\begin{tabular}{llll} 
& CHATER'S & SUPERB SINGLE & \\
\cline { 2 - 3 } & Apricot & Yellow & Mixed \\
Crimson & Lilac & Purple &
\end{tabular}

S. \& W. Co.'s Single Mixed. Pkt. ro cts., $1 / 80 z .50 \mathrm{cts}$.

\section{HUMULUS (Japan Hop)}

A rapid summer climber which in three to four weeks' time attains a height of 20 to 30 feet, resembling the common Hop, but, being an annual, attains full perfection the first season. The foliage is luxuriant, making a dense covering. It is one of the best plants for covering verandas, trellises, etc., producing grateful shade and being very ornamental. Heat, drought

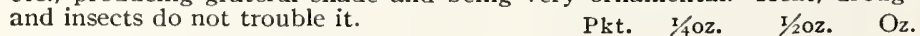
Japonicus .................... \$o ro \$o 30 \$o 50 \$o 75 Variegatus. Variegated variety........... ro 50 ro 75 I 25

\section{HONESTY (Moonwort)}

Hardy biennial, admired for its silvery seed-pouches, which are used for house ornaments; beautiful and curious purple flowers. Sow seed in open in May and protect over winter. 2 feet. Pkt. 10 cts., 1/40z. 50 cts.

\section{HELIOTROPE} A half-hardy perennial, flowering during the whole season. Its delightful
perfume makes it a most desirable bouquet flower. A splendid bedding plant, or can be trained as a greenhouse climber. Seed started indoors in the spring will make fine plants for summer blooming. Can also be sown

Lemoine's Giant. Of robust growth and produces heads of Pkt. $1 / 40 z$. Queen Marguerite. Large; dark blue................. White Lady. Largest white................. ro I 00 1 00
75

\section{HIBISCUS (Marshmallow)}

tal plants, for mixed beds or shrubbery borders. Hardy pernial, but will bloom first year from seed if sown early.

Golden Bowl. Giant yellow, cup-shaped flowers, from 6 to 9 inches in diam-

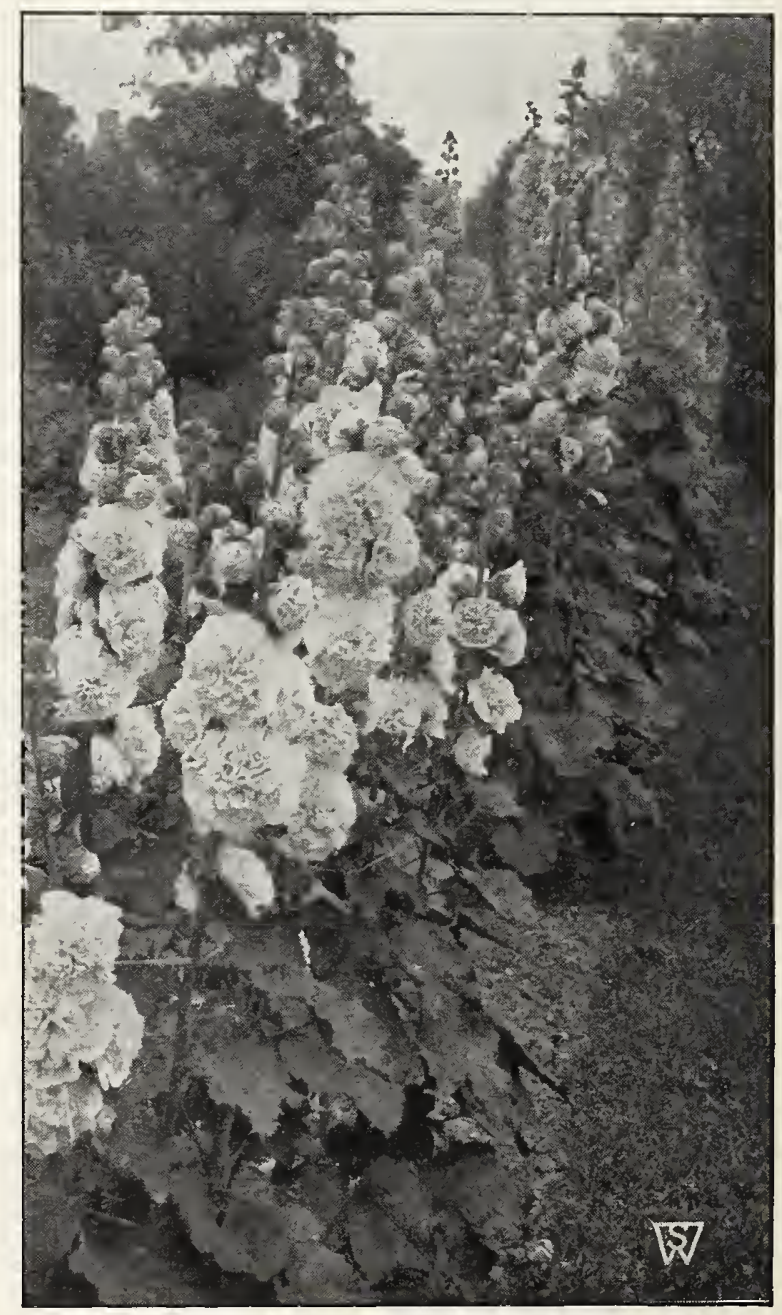

Chater's Superb Double Hollyhocks 


\section{HUNNEMANNIA}

(Giant Yellow Santa Barbara Tulip Poppy; Bush Eschscholtzia)

Fumariæfolia. This is by far the best of the Poppy family for cutting, remaining in good condition for several days. Seed sown early in May will, by the middle of July, produce plants covered with their large, buttercup-yellow, Poppy-like blossoms, and never out of flower until hard frost. The plants grow about 2 feet high, are quite bushy, with beautiful, feathery. glaucous foliage. Pkt. Io cts., 1/40Z. $50 \mathrm{cts.,}$ oz. \$1.50.

\section{HYPERICUM (St. John's-Wort)}

Polyphyllum. A dwarf, hardy perennial with large, golden yellow flowers and almost evergreen foliage. Suitable for the rock-garden. Pkt. 25 cts.

\section{IMPATIENS}

Sultani. One of the most beautiful of decorative plants. It thrives in stove heat, greenhouse, and in open border during the summer. The flowers are of a brilliant rosy scarlet, $I \frac{1}{2}$ inches in diameter. Mixed. Pkt. 25 cts.

Holstii. A very handsome plant from East Africa, forming bushes I $1 / 2$ to 2 feet in height, with 1. brilliant scarlet flowers, which measure from $I \frac{1}{4}$ to I $1 / 2$ inches across. It is an elegant pot-plant, also valuable for bedding out in partial shade. Pkt. 25 cts.

\section{INCARVILLEA}

Delavayi. Hardy perennial. Rather new; originated in northern China, and is one of the prettiest perennials known. It produces divided pale green leaves about 2 feet in length, much like acanthus. The flowers are borne on long, stout stems, tube-shaped, and appear almost like gloxinias. Color bright rose. $2 \frac{1 / 2}{2}$ feet. June to August. Pkt. 25 cts.

Variabilis Hybrids. This hardy perennial blooms the first season if sown early. The tubeshaped flowers are white and various shades of pink and yellow. Pkt. $25 \mathrm{cts}$.

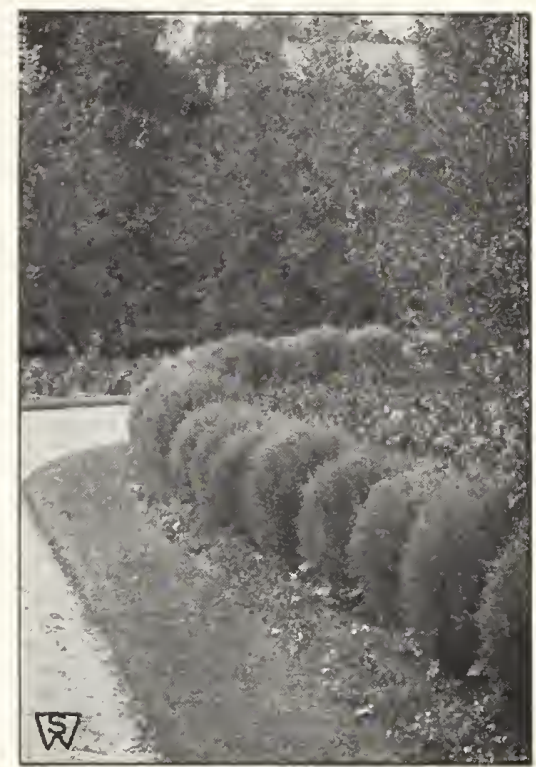

Kochia trichophylla

\section{IPOMAEA}

Climbers of rapid growth, with beautiful and varied flowers. For covering walls, trellises, arbors, or stumps of trees they are invaluable. Bona-nox (Evening-Glory). Rosy lilac flowers, expanding in the evening; of very rapid growth. Pkt. Io cts., oz. $75 \mathrm{cts}$

Grandiflora mexicana alba (Moonflower). At night and during dull days the plants are covered with an abundance of large, pure white, fragrant flowers, 5 to 6 inches in diameter. It grows rapidly and will cover a large surface. Pkt. ro cts., oz. $75 \mathrm{cts}$.

Hederacea grandiflora superba. Sky-blue, margined white. Pkt. ro cts., oz. 75 cts.

Hederacea grandiflora superba alba. White. Pkt. Io cts., oz. $75 \mathrm{cts}$.

Leari. Dark blue. Pkt. Io cts., oz. \$3.

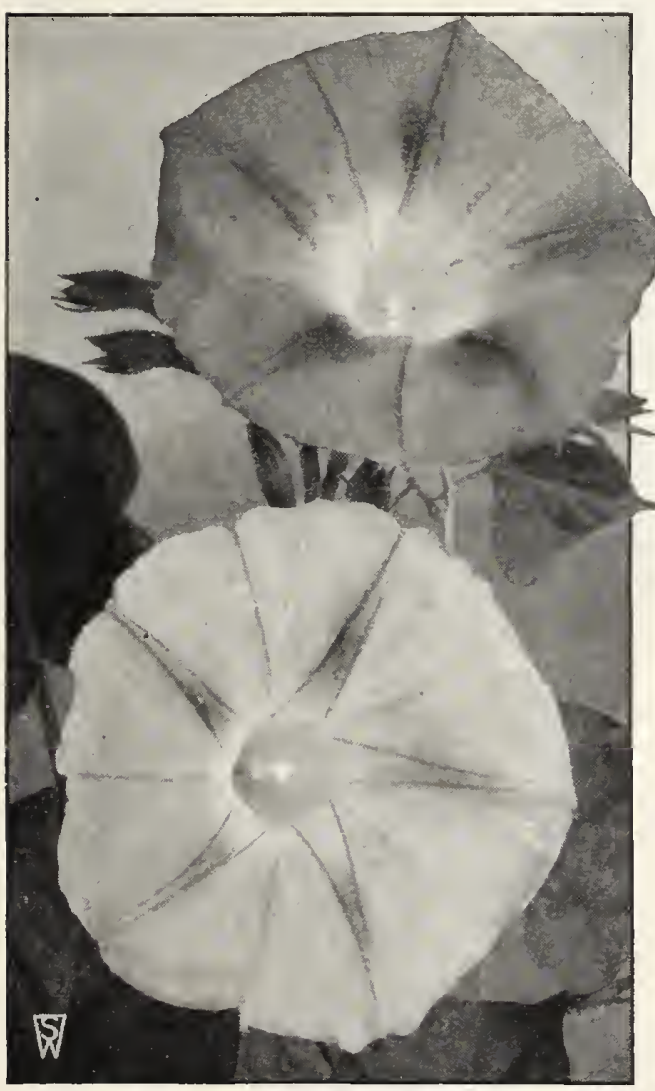

Imperial Japanese Morning-Glory (Ipomœa)

Rubra cærulea (Heavenly Blue). Immense flowers of bright sky blue, very beautiful. Pkt. I 5 cts., 2 pkts. 25 cts. $1 / 2$ oz. $\$ 1.25,0 z . \$ 2$.

Setosa (Brazilian Morning-Glory). Flowers of pleasing rose-color, borne very freely, in large clusters, from August to frost. As a quick-growing vine it has no equal, covering an enormous space in a short time. Pkt. Io cts., oz. \$I.

Mixed Imperial Japanese (Emperor Morning-Glory). These are beyond question the handsomest of all Morning-Glories. Of the easiest culture; can be sown in the open ground in a sunny situation when the weather has become warm and settled. They soon cover a large area, and even before flowering are decidedly interesting on account of the varied forms of the foliage and their markings. The flowers are of gigantic size and their colorings beyond description. The self or solid colors range from snow-white to black-purple, with all the possible intermediate shades; there is also an endless number having flowers spotted, marbled, striped, flaked, splashed, etc. Pkt. Io cts., oz. 50 cts., $1 / 4 \mathrm{lb} . \$ 1.50$.

For other varieties of Ipomcas, see Cypress Vine and Convolvulus

\section{KOCHIA (Summer Cypress; Mexican Firebush)}

Trichophylla. A pretty half-hardy annual, 2 to 3 feet in height, which grows into a perfect pyramidal-shaped cypress bush, with small, feathery, light green foliage, deepening as the season advances until it becomes a lovely crimson hue about September. Excellent for edging or hedging. Pkt. Io cts., I/40z. $25 \mathrm{cts}$, $0 z .75 \mathrm{cts}$.

\section{LANTANA}

One of the most desirable half-hardy greenhouse or bedding plants, which bloom constantly. The flowers are borne in Verbena-like heads of orange, white, rose, etc. Mixed colors, pkt. I5 cts., 1/40z. 75 cts.

\section{LA THYRUS (Everlasting or Hardy Sweet Pea)}

Hardy climbers, growing 6 to 8 feet ligh when trained on a trellis. The flowers are borne in large clusters. They are peculiarly adapted to rough places, to scramble over rocks and bushes; splendid cut-flower.

White. Pkt. Io cts.

Delicata. Rosy flesh-color. Pkt. Io cts. Mixed Colors. Pkt. Io cts.

\section{LAVENDER}

Lavandula vera. Well-known, hardy perennial; sweet-scented; should be grown extensively in mixed borders. Height 3 feet. Pkt. Io cts., $1 / 40 z .50 \mathrm{cts}$. 


\section{ANNUAL LARKSPURS}

These are among the best-known garden flowers, and in recent years a vast improvement has been effected by careful selection in size and color of the blossoms and the general habit of the plant. Seeds sown in the open ground before the close of April will produce flowering plants by the beginning of July, and give a continuous succession of flowers from then until frost, a record that is not surpassed by any other annual. They make handsome beds or lines, and their free, gracef ul habit and bright colors are very cffective when interspersed in the old-fashioned flower or shrubbery border.

\section{DOUBLE \\ STOCK-FLOWERED}

This is the finest variety of this vary popular annual, with beautiful double flowers. Height $2 \frac{r}{2}$ to 3 feet.

Snowstorm. Pure white.

Stella. Sky-blue.

Loveliness. Shell-pink.

Attraction. Bright rose.

King of the Blues. Dark blue

Violet Queen. Violet.

Lilac Perfection. Lilac.

Tricolor. Variegated.

Exquisite. Soft pink; very beautiful

Defiance. A decided improvement Der the Newport Scarlet. This Larkspur is of the same habit as our Double Stock-flowered; the plants, however, are a trifle taller in growth.

Each, pkt. 15 cts., $1 / 40 z .50$ cts., oz. $\$ 1.50$ COLLECTION: One pkt. each of the above 10 varieties $\$ 1$

Tall Stock.flowered, Mixed. A select mixture of our famous strain. Pkt. Io cts., $1 / 4 \mathrm{Oz} .30 \mathrm{cts}$,. Oz. $\$ \mathrm{I}$.

Dwarf Stock-flowered, Mixed. Finest double flowers. Mixed. I $1 / 2$ to 2 feet. Pkt. I Oc., $1 / 4 \mathrm{Oz}$. 3 Oc., oz. \$I.

\section{S. \& W. Co.'s Emperor}

This grand type of Annual Larkspurs grows about 2 feet high and is of candelabra habit. When planted in borders of the flower-garden the plants will prove most effective.

Apple-Blossom White, Striped Brilliant Rose Brilliant Carmine Black-Blue Pink Delight

Azure-Blue

Violet

Dark Blue

Pure White

Pkt. 10 ets., 1/40z. 30 cts., oz. $\$ 1$

COLLECTION: One pkt. each of the above 10 varieties, 75 cts.

\section{LAVATERA (Annual Mallow)}

Trimestris grandiflora rosea. A very beautiful and showy annual, growing about 2 feet high and covered during the entire summer with large, cup-shaped salmon-pink flowers; for beds or borders they are very effective. Sow seed in May where they are to bloom and later thin the plants out to $\mathrm{I}$ foot apart. Pkt. IOc., $1 / 40 z$. 5oc.

\section{LEPTOSYNE}

Maritima. Rich golden yellow flowers on long stems; will bloom in

\section{LIATRIS (Blazing Star; Gay Feather)}

Pycnostachya. A very attractive, native, hardy perennial. The purple and rosy purple flowers are borne on long spikes. Excellent for cutting. 3 to 4 fect. July to September. Pkt. $25 \mathrm{cts}$.

\section{LINARIA}

Cymbalaria (Kenilworth Ivy), Lavender and purple. A charming, neat, hardy perennial trailing plant, suitable for baskets, vases, pots, or rockeries. Pkt. I 5 cts., 2 pkts. 25 cts.

Macedonica speciosa. Yellow. Height 3 feet. Pkt. $25 \mathrm{cts}$.

Maroccana, Excelsior. Annual. An erect type, growing a foot high. A mixture of colors-white, purple, and violet. Pkt. I5 cts., $1 / 80 z$. $\$$ I, $1 / 40 Z$. $\$ 1.50$.

\section{LILIES from Seed}

Most Lilies will produce flowers the second year from seed. In other words, give them the same treatment as other hardy perennials.

regale (The Royal Lily)

Martagon Hybrids (Turk's-Cap Lily).

Martagon album (White Turk's-Cap Lily).

columbianum (Columbia Lily).

monadelphum szovitzianum (Great Caucasian Lily).

Washingtonianum (Washington Lily).

dalmaticum Hybrids.

giganteum (Himalaya Lily). I $4 \mathrm{ft}$.

Any of the above, pkt. 50 cts., 5 pkts. $\$ 2$

\section{LINUM (Flax)}

Grandiflorum rubrum (Scarlet Flax). One of the most effective and showy hardy annuals; bedding plants, of long duration, having fine foliage and delicate stems; brilliant scarlet flowers. Height I foot. Pkt. Io cts., $1 / 4 \mathrm{OZ} .25 \mathrm{cts}$.

rerenne. Bright blue. Height $\mathrm{I} / 2$ feet. Pkt. Io cts., $1 / 40 z$ oz 35 cts.

Perenne album. White. Height I foot. Pkt. Io cts., $1 / 40 z .35$ cts.

\section{LOBELIA}

These bloom very quickiy from seed and flower all through the season. For beds, edgings, baskets, and pots there is nothing prettier. Sow outdoors in early spring, where the plants are to grow, and thin moderately; or transplant several inches apart in rich, open soil. Almost all are also good winter conservatory plants of trailing habit. The perennial or tall varieties are handsome, showy plants.

Barnard's Perpetual. Deep blue with white eye; trailing. Pkt. Io cts., $1 / 4 \mathrm{Oz}$. $\$ \mathrm{I}$.

Crystal Palace Compacta. Rich deep blue; dark foliage. The finest variety for bedding. Pkt. IOc., I/80z. $\$$ I.25, 1/40z. $\$ 2$.

Emperor William. A very compact variety with sky-blue flowers. Pkt. Io cts., I $/ 4 \mathrm{OZ}$. \$I.5O.

Lindleyana. Rose, with white eye; trailing. Pkt. Io cts., $1 / 402$. \$I.

Pumila splendens. Dark blue, with clear

white eye; compact. Pkt. Io cts., $1 / 4 \mathrm{Lz}$. $\$$ I.5O.
umila alba. Pure white. Pkt. Io cts. $1 / 4 \mathrm{Oz}$. $\$$ I.5O.

Speciosa. Dark blue; dark foliage; trailing. Pkt. ro cts., $1 / 4 \mathrm{oz}$. $\$$ I.

\section{Lobelia tenuior compacta, Improved}

This handsome annual has hitherto hardly received the attention it deserves. The imported strain, which we now offer, grows 8 to 9 inches high is of ere tt, elegant habit, and thickly covered with large, dark blue flowers having a distinct white eye. As it remains a long time in bloom, it is a very effective plant for summer bedding. Pkt. 25 cts., 5 pkts. $\$ 1$.

\section{HARDY VARIETIES}

Tall-growing, hardy perennials with long spikes of brilliant flowers, unrivaled for permanent beds and borders. 2 to 4 feet. Pkt. $1 / 30 z$. Cardinalis (Cardinal Flower). Scarlet; green foliage..\$0 $25 \quad \begin{array}{lllll}\$ 3 & 50\end{array}$ Queen Victoria. Brilliant scarlet; bronze foliage..... 50 


\section{LUPINUS (Lupine)}

This very interesting class of plants is of easy culture and produces beautiful leaves and pea-shaped flowers. It should be inore generally cultivated. The annual varieties may be sown out in the open in May and as plants grow, thin out, leaving about I foot between the plants.

\section{ANNUAL VARIETIES \\ Rich Blue White Rose Yellow Mixed}

Each, pkt. 10 cts., 1/2oz. 25 ets., oz. 50 ets.

PERENNIAL VARIETIES

Polyphylus, White

Polyphyllus, Blue.

Polyphyllus, Mixed

Lupinus polyphyllus, Golden Spire. The tall, stately spikes of make this subject a fitting companion to the blue types of $L$. polyphyllus. Pkt. 25 ets., $1 / 40 z$. $\$ 2$.

Lupinus polyphyllus roseus. The plants of this beautiful halfhabit. hardy perennial are of robust, branching habit. An excellent subject for the herbaceous border, flowers being produced in long spikes of soft rose-pink. Pkt. 15 cts., $1 / 40 z .35$ ets., oz. $\$ 1$.

Lupinus polyphyllus, Excelsior. This fine strain of perennial Lupines the hardy perennial section, embracing, as it does, a splendid assortment of colors ranging from very pale to deep rose, and various shades of lavender, mauve, and blue. A really fine mixture. Pkt. 15 cts., $1 / 40 z .35$ cts., oz. $\$ 1$.

Downer's Hybrids. A special strain of hardy Lupines. Flowers are large, t/40z. \$1, oz. \$3.50.

with an exceptionally fine color range. Pkt. 25 cts.

\section{LYCHNIS}

Handsome hardy perennial plants of easy culture, for massing in beds or borders. blooming first year from seed if sown early.

Alpina. Splendid dwarf variety for rock-gardens, growing but 6 inclies high. Pkt. Rose-colored blooms in June......................... 25 Arkwrighti Hybrids. New improved strain, growing $2 / 2$ feet high. Mixed

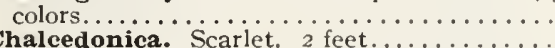

Chalcedonica, Salmon Queen. 'Salmon. 2 feet.

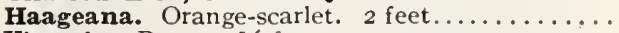

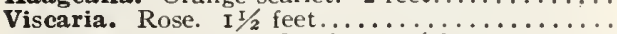

Viscaria splendens. Scarlet. I I

\section{MARIGOLD}

The African and French Marigolds are old favorite free-flowering annuals of easy culture; both are extremely effective. The former have uniformly large, yellow or orange-colored flowers, and are well adapted for large beds or mixed borders; the latter are dwarfer in growth, with beautifully striped flowers, and are better suited for bedding purposes and for pot culture.

\section{DOUBLE AFRICAN}

Giant Show Lemon. This highly meritorious strain of the African MariEurope who selects only the finest blooms and plants of unusually good constitution for seeding purposes. Height $21 / 2$ feet. Pkt. 25 cts., $1 / 40 z$. $\$ 1$.

Giant Show Orange. The darker form of the preceding variety. Height Giant Show Mixture. Yellow and orange shades. Pkt. $25 \mathrm{cts} .1 / \mathrm{oz} . \$ \mathrm{I}$.

Eldorado. Flowers very large, imbricated, and extremely double, in all shades of yellow. Pkt. Io cts., 1/40z. $40 \mathrm{cts}$.

Lemon Quilled. Deep, double, lemon-yellow flowers, daintily quilied. Pkt. Io cts., $1 / 4 \mathrm{Oz}$. $50 \mathrm{cts}$.

Orange Quilled. Similar to above but orange-yellow. Pkt. Io cts., 1/40z. $50 \mathrm{cts}$

\section{DWARF FRENCH}

Few annuals are as effective as the French Marigold, or bloom for as long a period. They form compact bushes I foot high, excellent for borders or beds.

Brunea. Double, quilled flowers of rich brown with a narrow thread-like edge of yellow.

Gold-striped. Double, golden yellow flowers, each petal striped brownish red.

Gold-edged Brown. Double golden yellow flowers, narrow margin of velvety brown.

Golden Ball. Double, pure golden yellow.

Legion of Honor (Little Brownie). A charming single-flowering Marigold forming dense, compact bushes about 9 inches high. They begin to bloom in June and continue until frost. The flowers are golden yellow marked with a large blotch of velvety crimson at the base of each petal.

Lemon Ball. Double lemon-yellow flowers.

Mahogany. Double, rich velvety mahogany-brown blooms.

Mixed. A mixture of all shades.

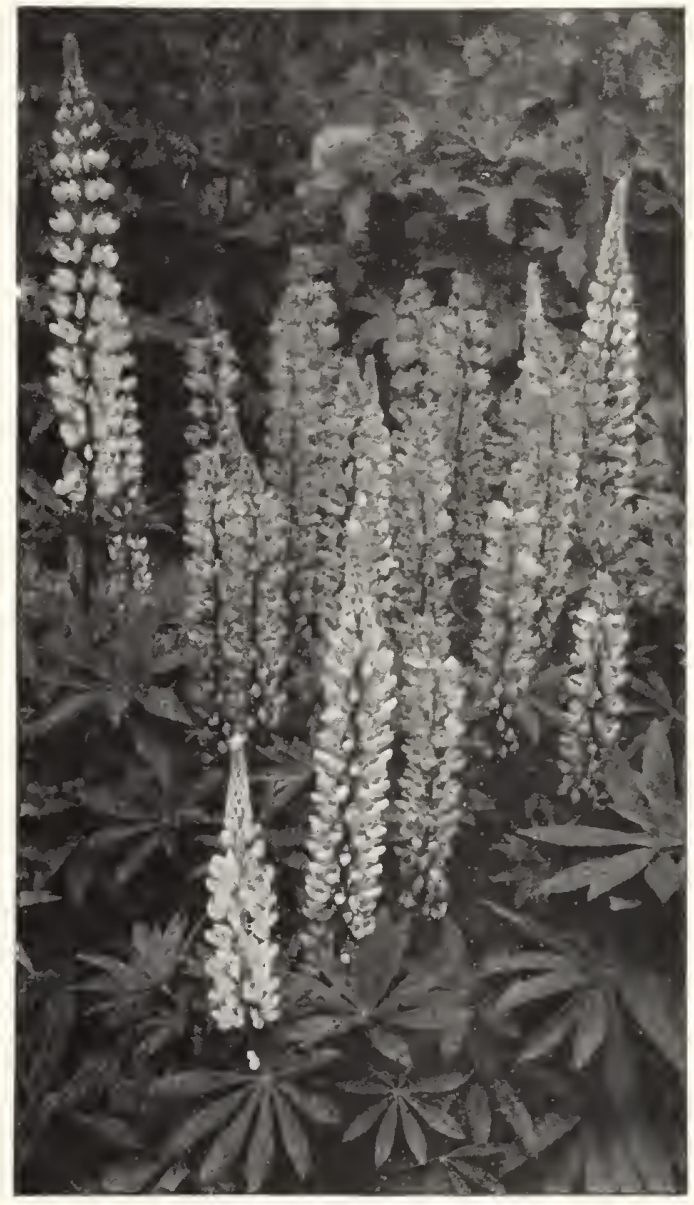

Lupinus polyphyllus roseus

\section{LYTHRUM \\ Loosestrife}

Salicaria roseum superbum. Striking hardy perennial with rose-colored flowers from July to September. Height 3 feet. Pkt. I5 cts.

Virgatum. Rosy purple. Height 3 feet. Pkt. $25 \mathrm{cts}$.

\section{MALVA}

Alcea (Hollyhock Mallow). Pink.\$o io \$o 50 \$I 50 Moschata

Moschata flore-albo.

\section{MATTHIOLA}

Evening-scented Stock

Bicornis. This old-fashioned annual has no beauty to recommend it, the flowers being a dull purplish lilac, but it is well worth growing for the entrancing fragrance which it emits during the evening. I ft. Plit. Io $\mathrm{cts} ., 1 / 40 \mathrm{O} .50 \mathrm{cts}$.

\section{MAURANDIA}

Rapid-growing, half-hardy perennial climbers that can be treated as annuals. Fine for garden or green house; bloom all summer in hanging-baskets and vases or on trellises. Io feet.

Barclayana. Blue

Barclayana alba. White.

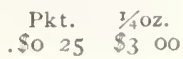

OO 


\section{MATRICARIA (Feverfew)}

Grandiflora fl.-pl. eximia. Half-hardy perennial, which should be treated as an annual. Double, pure white flowers are borne on slender stems 15 inches high, which are excellent for cutting. Pkt. Io cts., $1 / 4 \mathrm{Oz}$. 50 cts., oz. $\$ 1.75$.

Golden Ball. Compact-growing variety with golden yellow flowers. Excellent for bedding. I foot. Pkt. $25 \mathrm{cts} ., 1 / 4 \mathrm{OZ}$. \$I.5O.

\section{MESEMBRYANTHEMUM}

Crystallinum (Ice Plant). Dwarf, trailing annual plants; flowers white. Prized for its singular icy foliage. Pkt. Io cts., 1/40z. $50 \mathrm{cts}$., oz. \$1.50.

\section{MIGNONETTE (Reseda)}

Well-known little hardy annual plants, with sweet-scented flowers; at home everywhere, either in the greenhouse, garden or sitting-room.

S. $E$ W. Co.'s Triumph. One of the choicest varieties for winter forcing. In are more compact and the individual florets are much larger in size. Seed of this grand variety is grown in our greenhouses, and is saved from the best spikes. Pkt. 25 cts., $1 / 802$. $\$ 1,1 / 40 z . \$ 1.75$.

Allen's Defiance. This gorgeous Mignonette has qualities heretofore unknown in large flowering varieties, being deliciously fragrant. When grown under favorable conditions and with proper care, its spikes will be from 12 to 15 inches long. The individual florets are of remarkable size and stand out boldly, forming a graceful as well as compact spike. Its remarkable strength is accompanied by extraordinary keeping qualities; the spikes have been kept in a vase three weeks after cutting, retaining their grace and fragrance until every bud opened. Pkt. ro cts., 1/40z. 5o cts., oz. \$I.5O.

Improved Large-flowering. Pkt. Io cts, 1/40z. 25 cts.

Golden Queen. Yellow-tinted flowers. Pkt. Io cts., 1/40z. 25 cts.

Machet. A dwarf French variety, with broad spikes of very fragrant red flowers; one of the best varieties for either garden or pot culture. Pkt, Io cts., I $/ 40 z .50 \mathrm{cts}$.

Machet, Ruby. A fine new Machet Mignonette, with coppery scarlet flowers. Pkt. Io cts., $1 / 4$ oz. $50 \mathrm{cts}$.

Odorata maxima, Goliath. Bears very large flowers, the center spikes being often 8 inches long. The plant grows in candelabra form and produces fiery red flowers on firm, upright stalks. Pkt. Io cts., $1 / 4 \mathrm{Oz}$. $50 \mathrm{cts}$.

\section{MIMOSA (Sensitive Plant)}

Pudica. A very curious plant, the leaves of which instantly close up when touched. It is a tender annual, easily grown in the garden during summer. Pkt. Io cts., $1 / 40 z$. 50 cts.

\section{MIMULUS (Musk Plant)}

Moschatus. The plants of Mimulus are beautiful and tender-looking, with almost Pkt. transparent branches. They luxuriate in damp, shady situations; musk-scented. Tender annual, I foot

Splendid Annual, Mixed

Cupreus (Monkey Flower). $\mathrm{A}$ hardy perennial, the flowers of which resemble somewhat the snapdragon in shapa; in color, yellow at first, when fully open, copper-red. .

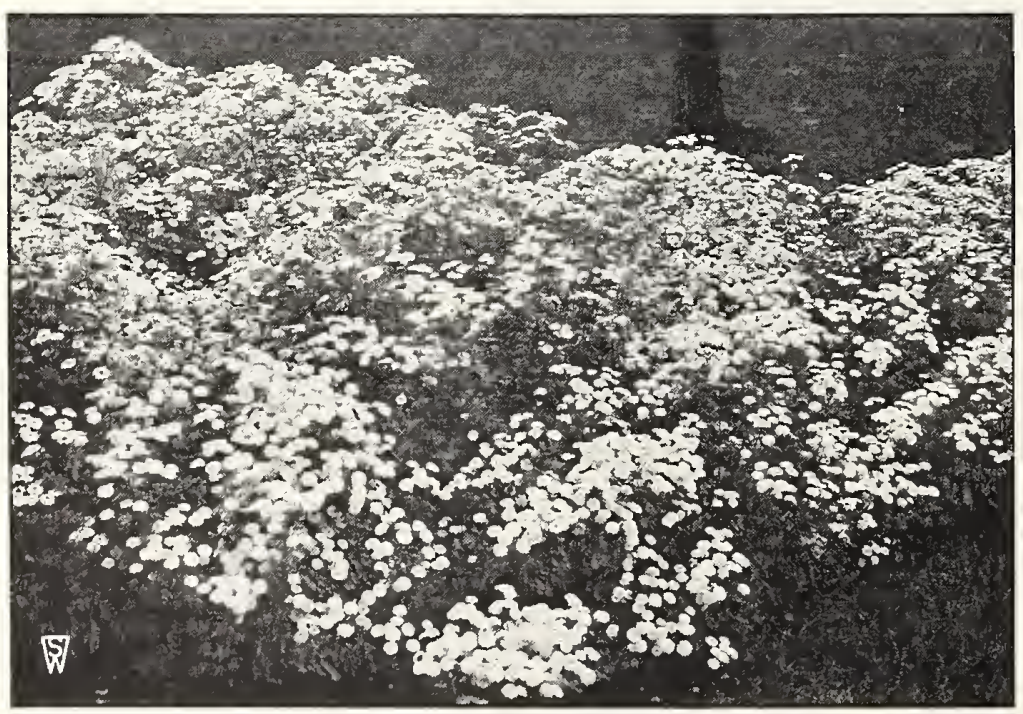

Matricaria (Feverfew)

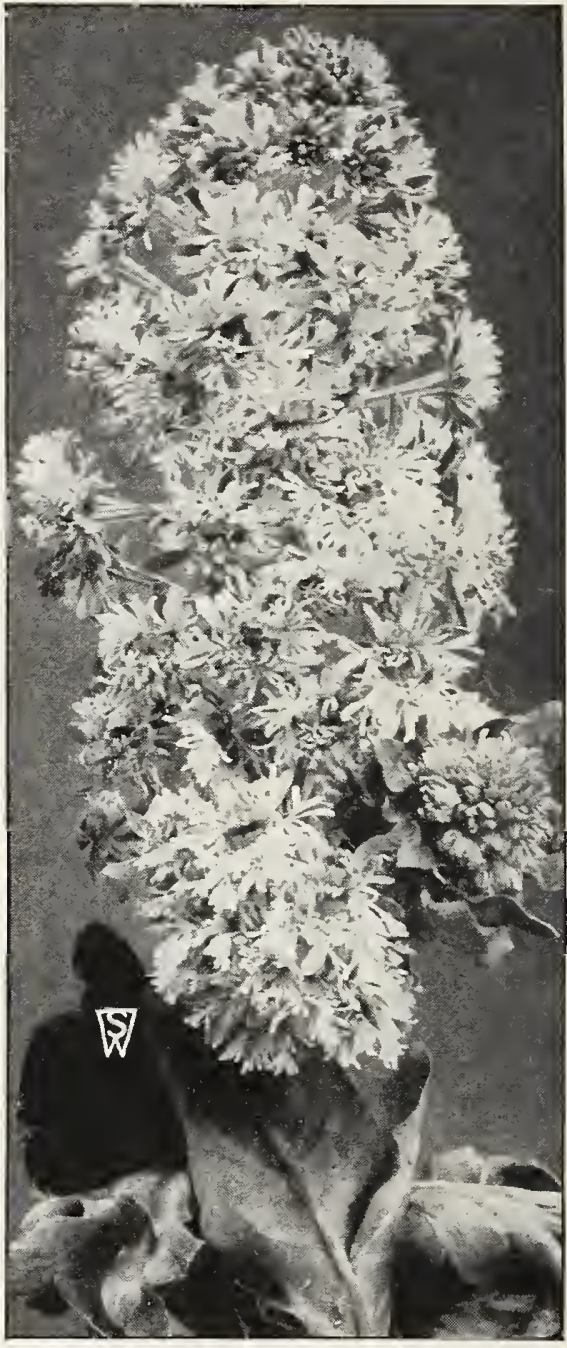

S. \& W. Co.'s Triumph Mignonette

MONARDA (Bee Balm; Bergamot)

Hybrida. A fine mixture of this well-known hardy perennial, growing 3 feet high, and producing crimson flowers from July to September. Pkt. I5 cts., $1 / 4 \mathrm{OZ}$. $\$ 1.50$.

\section{MOMORDICA}

\section{Balsam Apple; Balsam Pear}

Luxuriant annual climbers, with large leaves, making dense shade. The flowers are followed by ornamental, large fruits of orange or copper color, which burst and expose an interior of red, which is highly effective. 15 to 20 feet.

Balsamina (Balsam Apple). Orange fruits. Pkt. Io cts., oz. $75 \mathrm{cts}$.

Charantia (Balsam Pear). Coppery scarlet fruits. Pkt. Io cts., oz. $75 \mathrm{cts}$.

\section{MUSA (Abyssinian Banana Tree)}

Ensete. A foliage plant of magnificent proportions; for subtropical massing, or as single specimens it is strikingly effective. Seeds sown early in the house will produce plants io to I 2 feet high the first season. Pkt. 25 cts., 25 seeds 75 cts., Ioo seeds $\$ 2.50$. 


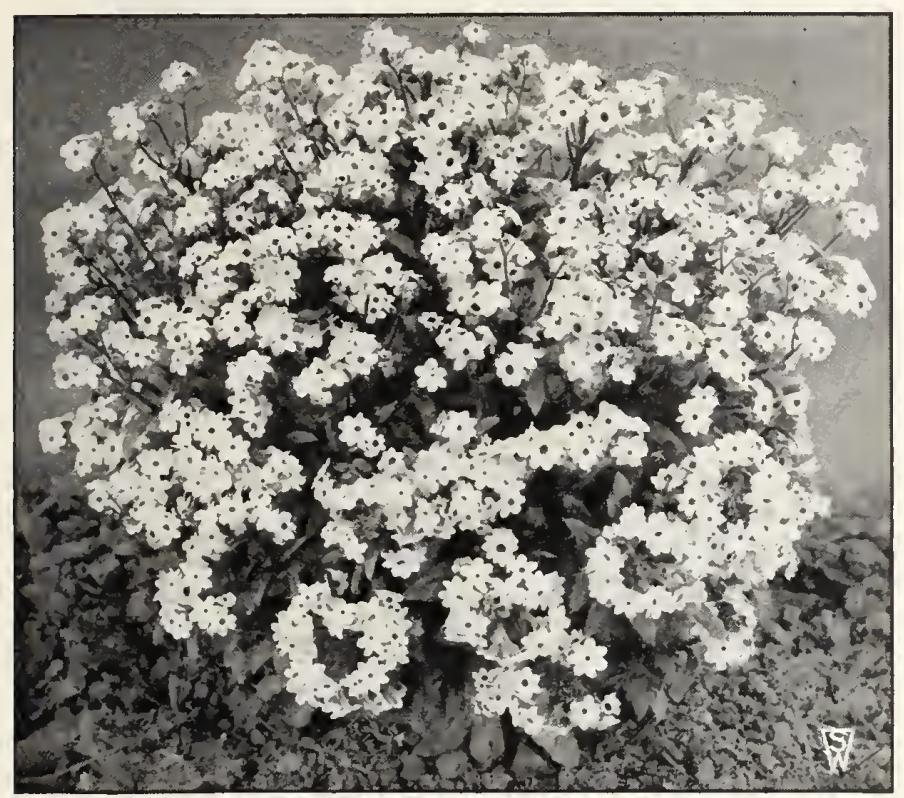

Myosotis, Ruth Fischer (Forget-me-not)

\section{MYOSOTIS}

\section{Forget-me-not}

Few spring flowers are more admired than the lovely Forget-me-not, which is especially effective for mass planting. It is perennial and hardy if given slight protection through the winter. Seed may be sown from spring until midsummer. The Alpestris varieties and Dissitiflora come into bloom in April, with the spring-flowering bulbs; the Palustris sorts bloom in May, and continue till fall.

Alpestris, Royal Blue. Rich indigo-blue flowers. The finest and most Pkt. effective dark blue variety; grows about 9 inches high............ a height of about Io inches with good heads of clear Forget-me-notblue flowers.

Alpestris, Victoria, Blue. $A$ favorite variety with fine heads of clear azure-blue flowers; plants bushy and compact. Makes a fine edging

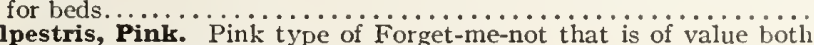

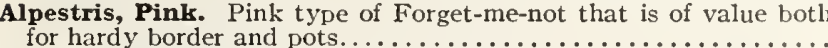

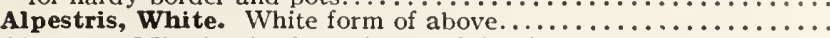

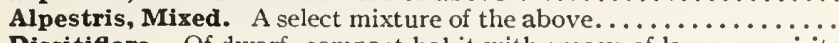

Dissitiflora. Of dwarf, compact habit with sprays of large, exquisite blue flowers, especially adapted for beds of late-flowering tulips, etc. Palustris semperflorens (Everblooming Forget-me-not). Large, clear blue flowers in pretty sprays...

Ruth Fischer. One of the finest and largest-flowered Forget-me-nots yet sent out, producing flowers up to $1 / 2$ inch in diameter, of true Forget-me-not-blue. Plants of strong, vigorous growth, of exceptional value for pot culture and spring bedding $\ldots .5 \mathrm{pkts} . \$ 1, \frac{1}{16} \mathrm{OZ} . \$ 4$.

Isolde Krotz. A large-flowered Myosotis. Under favorable conditions, the individual blossoms are nearly an inch in diameter. Excellent both for greenhouse use and for growth in the open.

Pkt. $1 / 40 z$.

IO

$10 \quad 75$

I 5 I 50

$20 \quad 250$

$20 \quad 250$

$10 \quad 50$

15 2 oo

I5 200

\section{NICOTIANA}

Sanderæ, Crimson King. The color of this beautiful Nicotiana is a dark, velvety crimson-red. Pkt. $25 \mathrm{cts}$., 1/80z. \$I, 1/40z. \$1.50.

Afrinis. An annual with sweet-scented, pure white, star-shaped flowers, 3 inches across, blooming continually. 2 to 3 feet. Pkt. Io cts., 1/40z. $25 \mathrm{cts}$., $0 z$. 75 cts,

Giant Red-flowered. Magnificent annual of tropical effect; large, luxuriant leaves and immense clusters of rich crimson flowers. 5 feet. Pkt. IOc., 1/40z. 50c. Sanderæ Hybrids. New types in a variety of colors. Pkt. $10 \mathrm{cts} ., 1 / 40 z .50 \mathrm{cts}$.

\section{NIGELLA}

Damascena, Double Mixed (Love-in-a-Mist). Pretty garden Pkt. annuals with feathery green foliage, in which large, double, charming blue or white flowers are set. I to 2 feet $\ldots \ldots \ldots \ldots \ldots \ldots$

Miss Jekyll. A lovely variety with cornflower-blue blossoms; splendid for cutting. Hardy annual. About 2 feet.............. ro

\section{NEMESIA}

We are pleased to offer a splendid strain of this beautiful ardy annual, principally the large-flowered varieties and \& W. Co.'s Orange. Rich orang

W. Co.'s Rose. Rich rose.

\& W. Co.'s Mixed. Rich mixture of all the lovely color .

Each, pkt. 25 cts., 5 pkts $\$ 1,1 / 80 z . \$ 2.50$

\section{NEMOPHILA}

lendid trailing annuals for garden decoration; bright-colored owers, in shades of blue, white, and violet. I foot.

blue. Pkt. Io cts., $1 / 4 \mathrm{Oz} .50 \mathrm{cts}$.

\section{NEPETA (Ground Ivy)}

ussini. Hardy perennial with blue flowers in May and June. Height I foot. Pkt. $25 \mathrm{cts}$., I/80z. $\$ 1.50,1 / 40 z . \$ 2.50$.

\section{NOLANA}

axa $(N$ atriplicifolia). A luxuriantly growing creeping (a) suitable as a ground-cover or edging plant Sky-blue

\section{CENOTHERA (Evening Primrose)}

\section{Perennial}

raseri. Beautiful yellow flowers. July to October Pkt. $\$ 1 / 40 z$.

.............. $80 z, \$ 2 \ldots \$ 025 \$ 350$

ruticosa Youngi. Yellow. Height is inches... 25

issouriensis. Yellow. Height 12 inches....... 25

peciosa. White. Height 18 inches.............

to 5 feet....................... 50
75

0

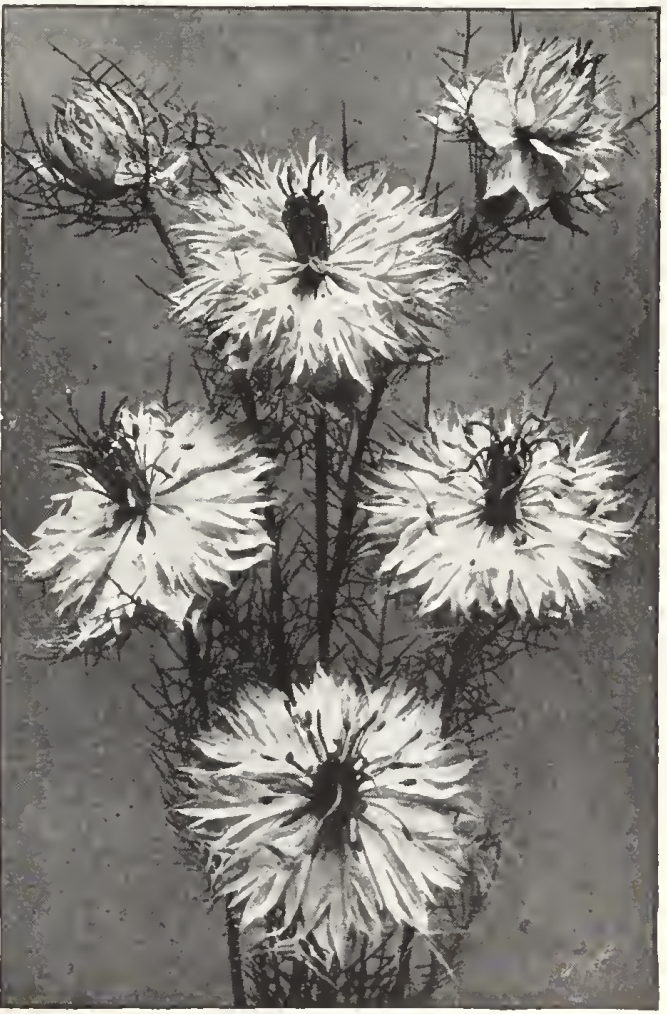

Nigella, Miss Jekyll 


\section{Stumpp \& Walter Co.'s Superb Nasturtiums}

Few garden annuals respond with as little care as the Nasturtium. For ease of culture, duration of bloom, brilliancy of coloring and general excellence, they are unexcelled. All they need is a moderately good soil, in a well-drained, sunny position, and from within a few weeks from the time they are sown until hard frost comes there is an endless profusion of their gorgeous blossoms. The varieties offered below were selected, after exhaustive trials, from a very large number of sorts as being the best and most distinct.

\section{NEW LARGE-FLOWERING}

The plants arc strong and vigorous, with very large, bright green leaves, measuring from 5 to 8 inches across. The flowers, which are very numerous, measure 3 inches in diameter, and are borne on long stems well above the foliage. They are exquisitely formed, with overlapping, crinkled petals. They are produced in great numbers and have a most striking effect. Their fine color, long stems, great size,

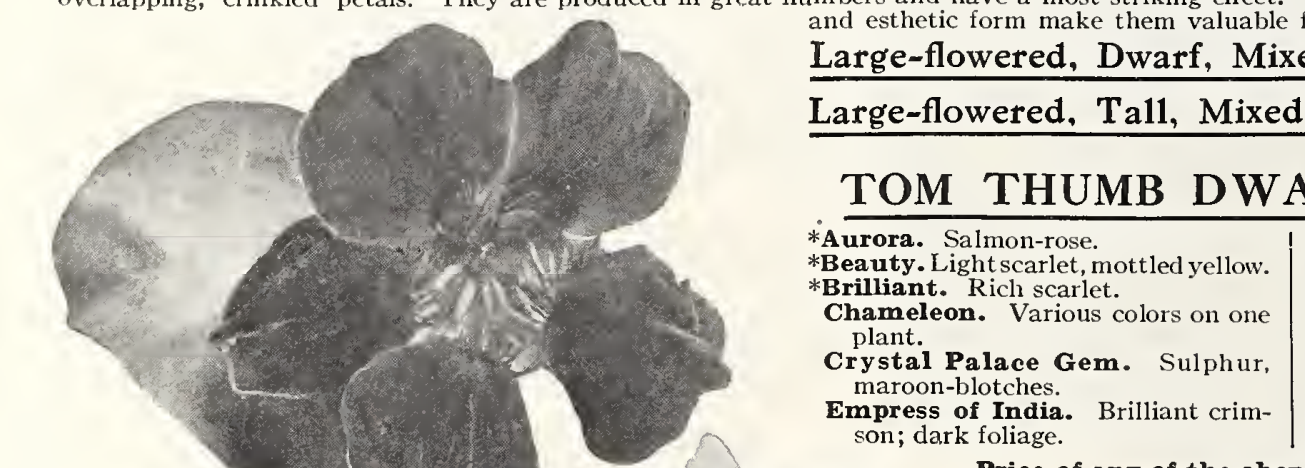
them valuable for cutting.

Large-flowered, Tall, Mixed. Pkt. 15 cts., oz. 25 cts., $1 / 41$ lb.

\section{TOM THUMB DWARF OR BEDDING}

*Aurora. Salmon-rose

.

*King Theodore. Deep crimsonmaroon; dark foliage.

King of Tom Thumbs. Dark scarlet; dark foliage.

Lady Bird. Orange-yellow, spotted red.

*Luteum. Pure, light yellow.

*Pearl. Pure white.

Ruby King. Light ruby-red.

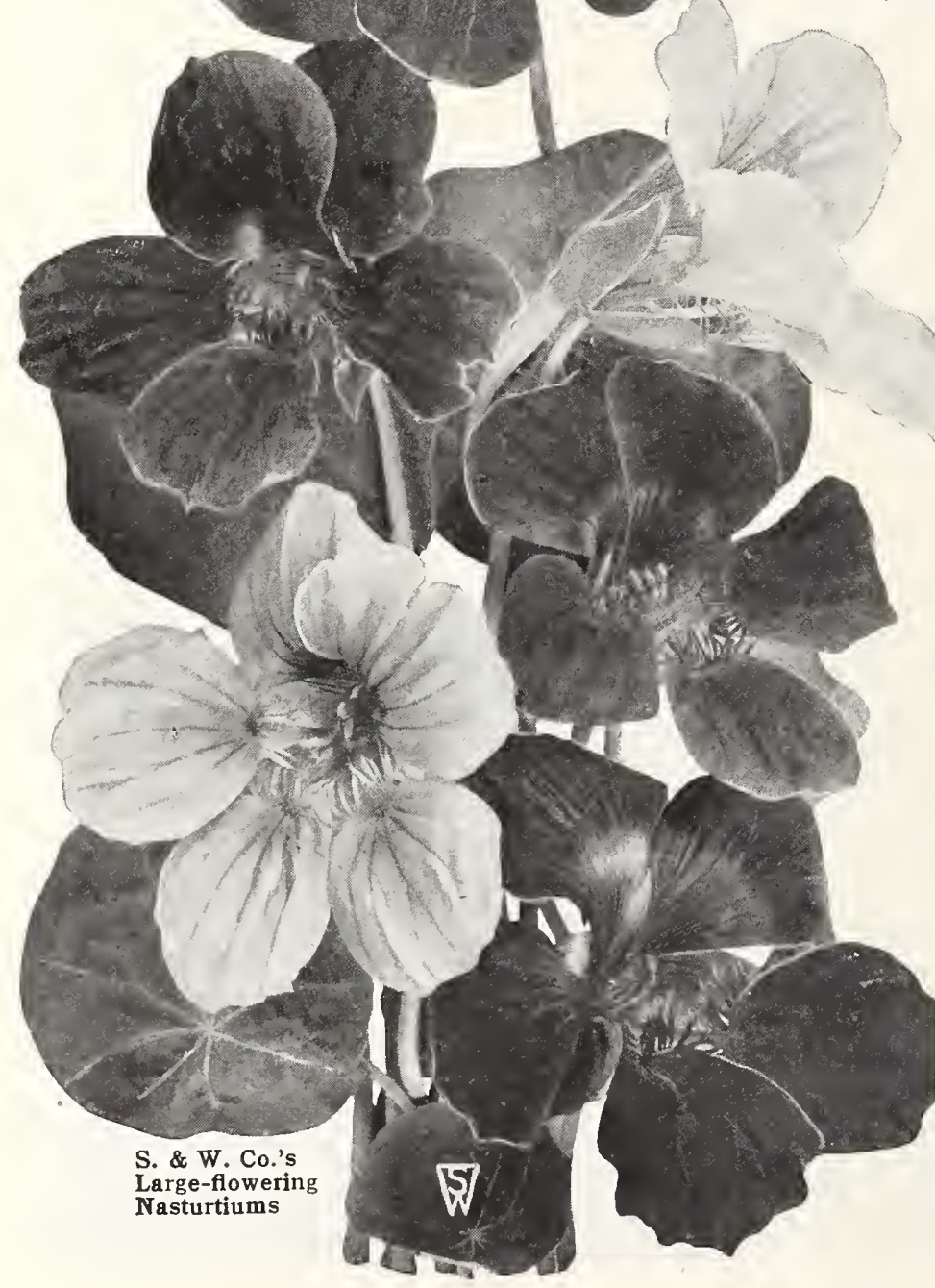

Price of any of the above named Dwarf sorts, pkt. 10 cts., oz. 20 cts., $1 / 4$ lb. 60 cts.

Special Collections: 1 pkt. each of 6 of varieties marked $*, 50 c$. 1 pkt. each of 12 named varieties, $\$ 1$.

Dwarf, Mixed. A mixture of above-named sorts. Pkt. Io cts., oz. I 5 cts., $1 / 4 \mathrm{lb}$. $50 \mathrm{cts}$.

Dwarf, Ivy-leaved. Beautiful, dark green, ivy-like folithe lovely flowers of various colors. Mixed Colors. Pkt. 15 cts., oz. 25 cts., $1 / 4$ lb. 75 cts.

Dwarf, Variegated-leaved. These comparatively new ardeties are equally thrifty and robust in growth and produce freely as beautiful flowers in various colors as the plain green-leaved Nasturtiums, with the added merit of ornamental foliage, which renders them beautiful objects even out of flower. We offer in a mixture of best colors. Pkt. 15 ets., oz. 25 ets., $1 / 41$ b. 75 ets.

\section{TALL OR CLIMBING VARIETIES}

Elegant and luxuriant climbers for verandas, trellises, etc. May be used to cover unsightly railings and to trail over rough ground with fine effect. The seed-pods can be gathered while green and tender for pickling; 6 to Io feet.

*Chameleon. Differently rich-colored flowers on the same plant.

*Crimson. Rich and vclvety.

*Dunnett's Orange. Rich golden orange, garnet blotches.

King Theodore. Deep crimson-maroon, dark foliage.

$*$ Pearl. Creamy white.

Prince Henry. Cream, spotted and tipped scarlet.

* Rose. A lovely shade of ruby-rose.

Scarlet. Glowing vermilion.

*Yellow. Pure yellow.

Any of the above, pkt. 10 cts., $0 z .20$ cts., 1/4lb. 60 cts.

Jupiter. Magnificent flowers of a brilliant golden yellow. Pkt. ro cts., oz. $20 \mathrm{cts}$., $\mathrm{r} / 4 \mathrm{lb} .75 \mathrm{cts}$.

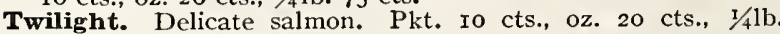

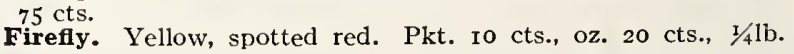
75 cts.

Special Collections: 1 pkt. each of 6 varieties marked $*$, 50c. Special Collections: 1 pkt. each of 12 named varieties, $\$ 1$.

Tall Mixed. A mixture of the above-named sorts. Pkt. ro cts., oz. I 5 cts., $1 / 4 \mathrm{lb} .50$ cts.

Tall. Ivy-leaved. Similar in type to the Dwarf Ivy-leaved Tall, Ivy-learleties. Mixed Colors. Pkt. 15 cts., oz. 25 cts., $1 / 41 b$. 75 cts.

Tall, Variegated-leaved Similar in type to the Twarf Variegated-leaved, in Tall-growing sorts. Mixed Colors. Pkt. 15 cts., oz. 25 cts., $1 / 4 \mathbf{l b} .75$ cts. 


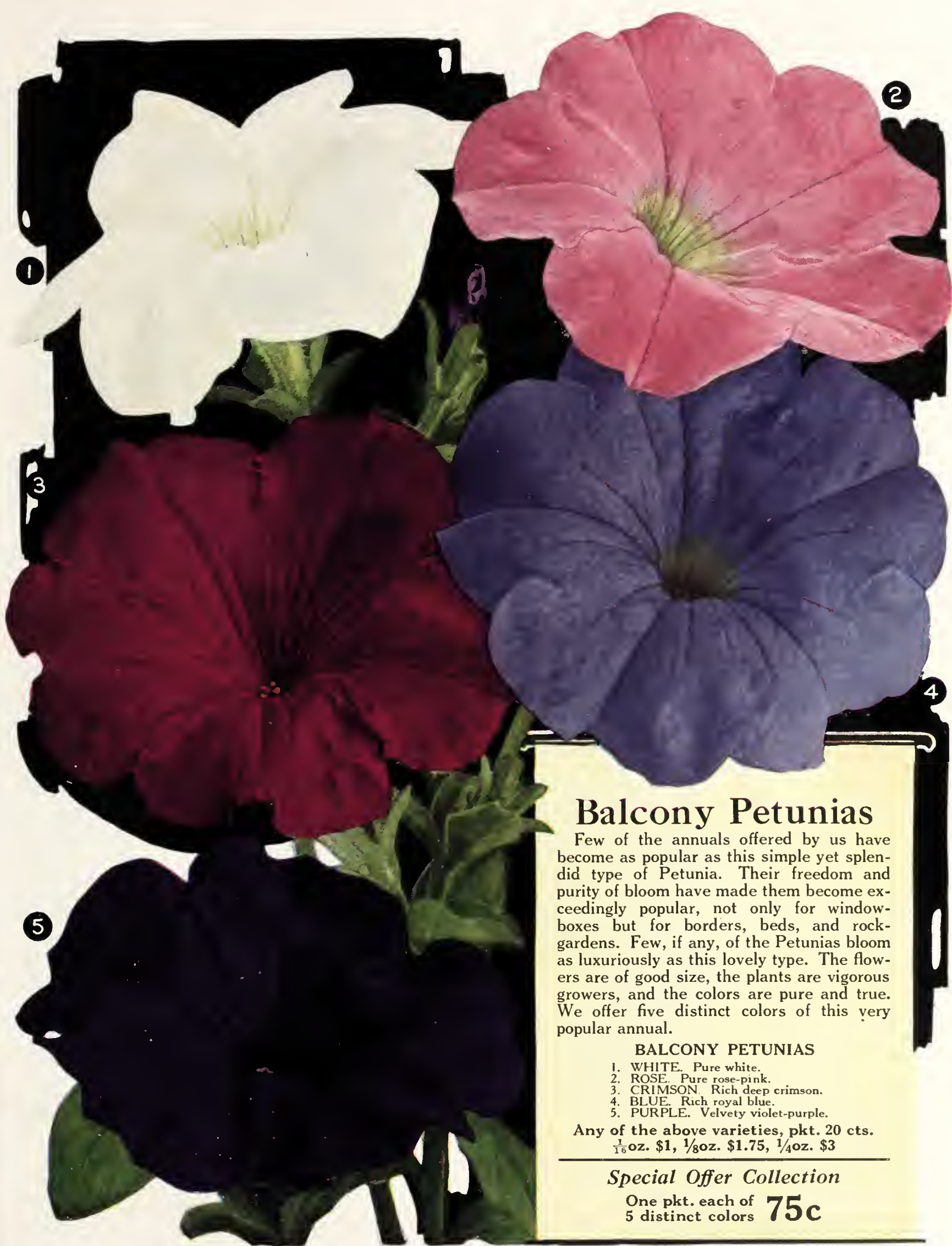




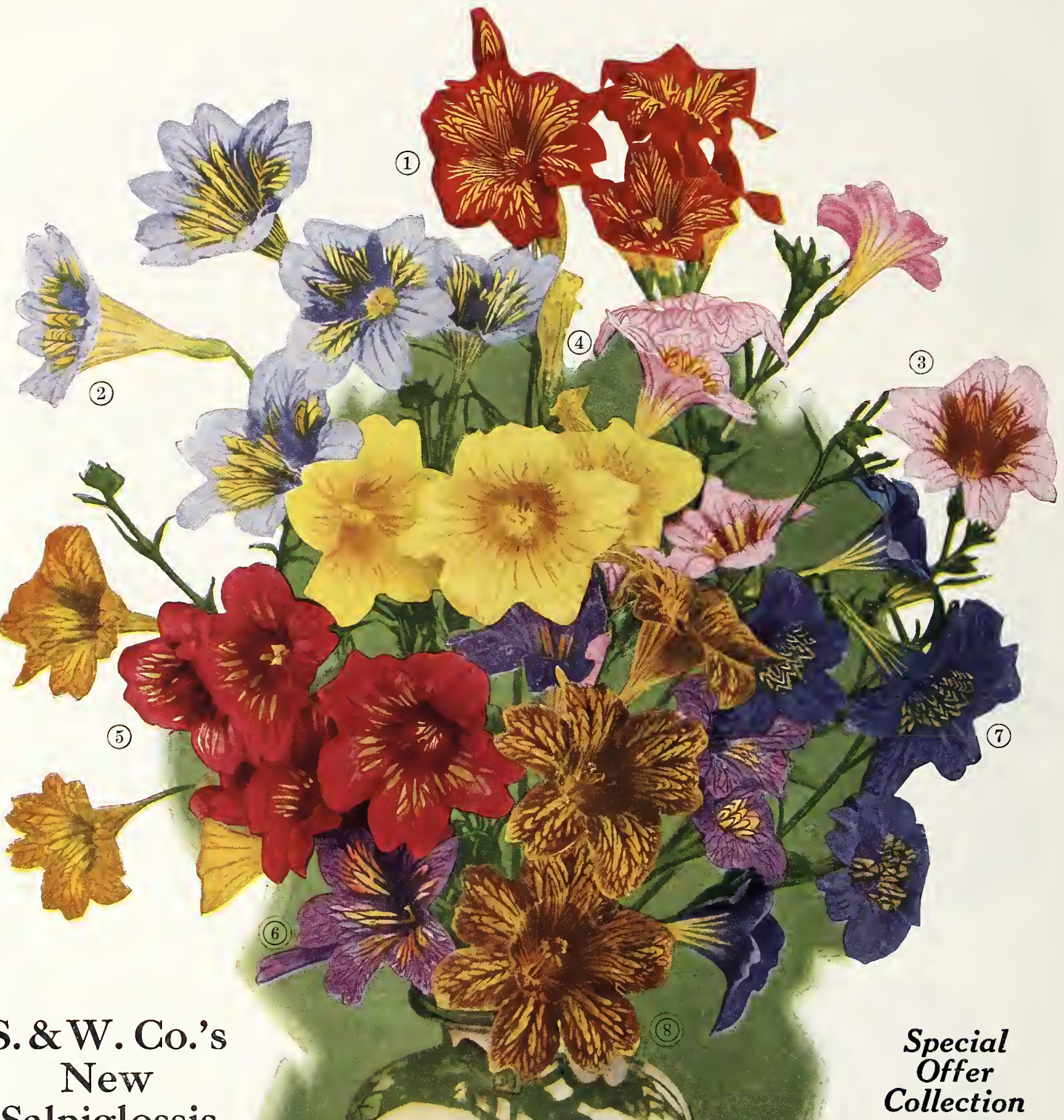
Salpiglossis (Painted Tongue)

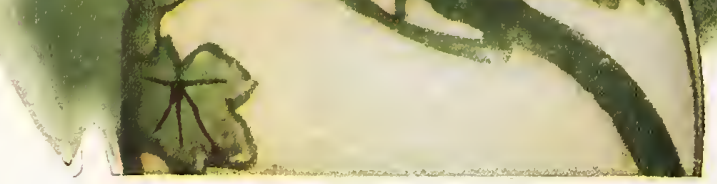
One pkt.
each of above
8 colors 8 colors

$\square$ EW annual flowers give us such an abundance of bloom from - early summer until cut down by frost. Only in recent years 1 have American gardeners become better acquainted with this beautiful flower. For cut bloom it has become highly prized, while it is invaluable for mass effect in the garden. The trumpet-shaped blooms are exquisitely marked with veins of gold or silver running through the groundwork of the flowers; and their orchid-like, or lilylike appearance makes them instant favorites.

Their culture is simple: seeds may be sown in the open ground in spring, or for earlier flowering they may be sown in a hotbed or sunny window. When all danger of frost is past, plant them in the garden, allowing 9 inches between the seedlings.
SPECIAL OFFER. New Hybrids of Salpiglossis superbissima, Orchid-flowering
1. SCARLET AND GOLD
5. CRIMSON
2. LIGHT BLUE AND GOLD
6. PURPLE AND GOLD
3. ROSE AND GOLD
4. PRIMROSE
7. VELVETY VIOLET
8. BROWN AND GOLD

Ear.h, pkt. 15 cts., $1 / 4$ oz. 75 cts., oz. $\$ 2.50$ 


\section{Stumpp \& Walter Co.'s Giant Pansies}

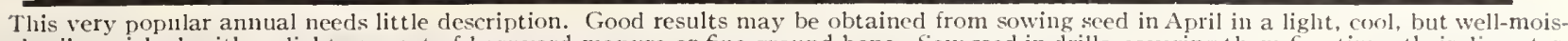

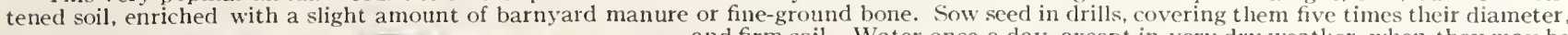

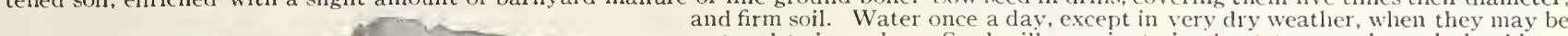

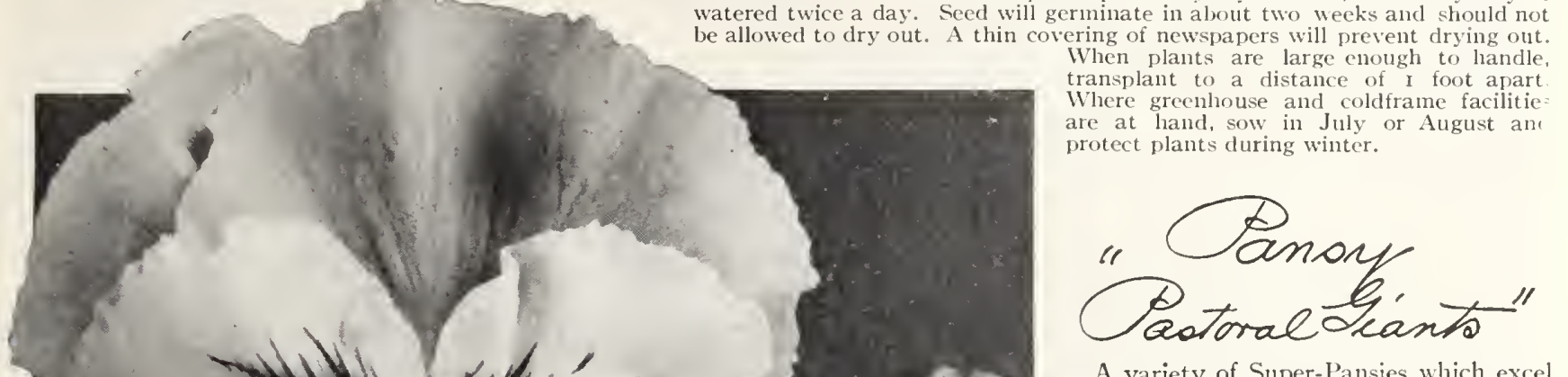

A variety of Super-Pansies which excel in hardiness, length of stem, and size of flower. These magnificent flowers have the most ponderous blooms and are the strongest and silkiest ever propagated. They come in a multitude of harmonious and enchanting shades.

Pure Golden Yellow.

Lavender (light).

Pure Snow-White.

Mahogany.

Emperor William, Blue (dark).

Bronze.

Yellow, Dark Eye.

Wine-Red.

Mixed. Contains every conceivable color.

Each of the above, pkt. (about 500 seeds) $50 \mathrm{cts}$.

\section{Stumpp \& Walter Co.'s World's Best Mixed Exhibition Strain}

This mixture of Giant Pansies has been prepared from the finest varieties grown, with blooms of gigantic size. splendid texture, and plants of robust constitution, holding their majestic blooms well above the foliage. Every conceivable color and combination of colors has been included. Pkt. $50 \mathrm{cts}$., $\frac{3}{16} \mathrm{oz}$. $\$ 2.50,1 / 80 Z, \$ 4,1 / 402 . \$ 7, I_{2} \mathrm{OZ} . \$ 10,0 z . \$ 20$. ( $\frac{1}{16} \mathrm{Oz}$, contains about 2,000 seeds.)

\section{Stumpp \& Walter Co.'s Non Plus Ultra Mixed}

A mixture of Pansies for the critical buyer who desires his beds to look of uniform quality, giving every color and combination of colors that exists in this highly meritorious flower. Pkt. $25 \mathrm{cts}$., 1/80z. \$I.25, $1 / 4 \mathrm{Oz}$. \$2, 1/20z. $\$ 3.75$, oz. $\$ 7.50$. ( $\frac{1}{16} \mathrm{oz}$. contains about 2,000 seeds.)

\section{Giant Mastodon Strains}

\section{New Varieties}

Golden Gate. Neu'. A monster golden yellow, unequaled in size and beauty.

Mastodon Striata. Dark and rose-pink shades, mottled and beautifully striped in true sunburst fashion.

Separate Colors of Giant Mastodon Pansies

Black Mastodon. Nearly all jet-black.

White Mastodon (dark center). The largest Pansies ever seen.

Mme. Perret. Edges of petals frilled and bordered white. Colors wine, pink and red. Prince Henry. A splendid dark blue. Above 7 varieties, each, pkt. $25 \mathrm{cts}$., $\frac{t}{26} 0 \mathrm{z}$. $\$ 1,1 / 80 \mathrm{z}$. $\$ 1.75,1 / 4 \mathrm{oz} . \$ 3,1 / 20 \mathrm{zz} . \$ 5,0 z . \$ 10$
Mastodon, Mme. Steele. Elk's purple; immense blooms. A perfect self.

Improved Beaconsfield. Bluish purple with lavender tinge on upper part of petals.

Mastodon, Adonis. Light blue, baby blue, and lavender shades.
Mlle. Irene. A shade entirely new to Pansies-a henna-red.

Improved Isabelle. A superb, ruffled bronze and yellow; long stems; very large.

Above 4 varieties, each, pkt. $50 \mathrm{cts}$., $\frac{7}{160 z .} \$ 2.50$, $1 / 80 z$. $\$ 4,1 / 40 z . \$ 7,1 / 20 z, \$ 10,0 z . \$ 20$ 


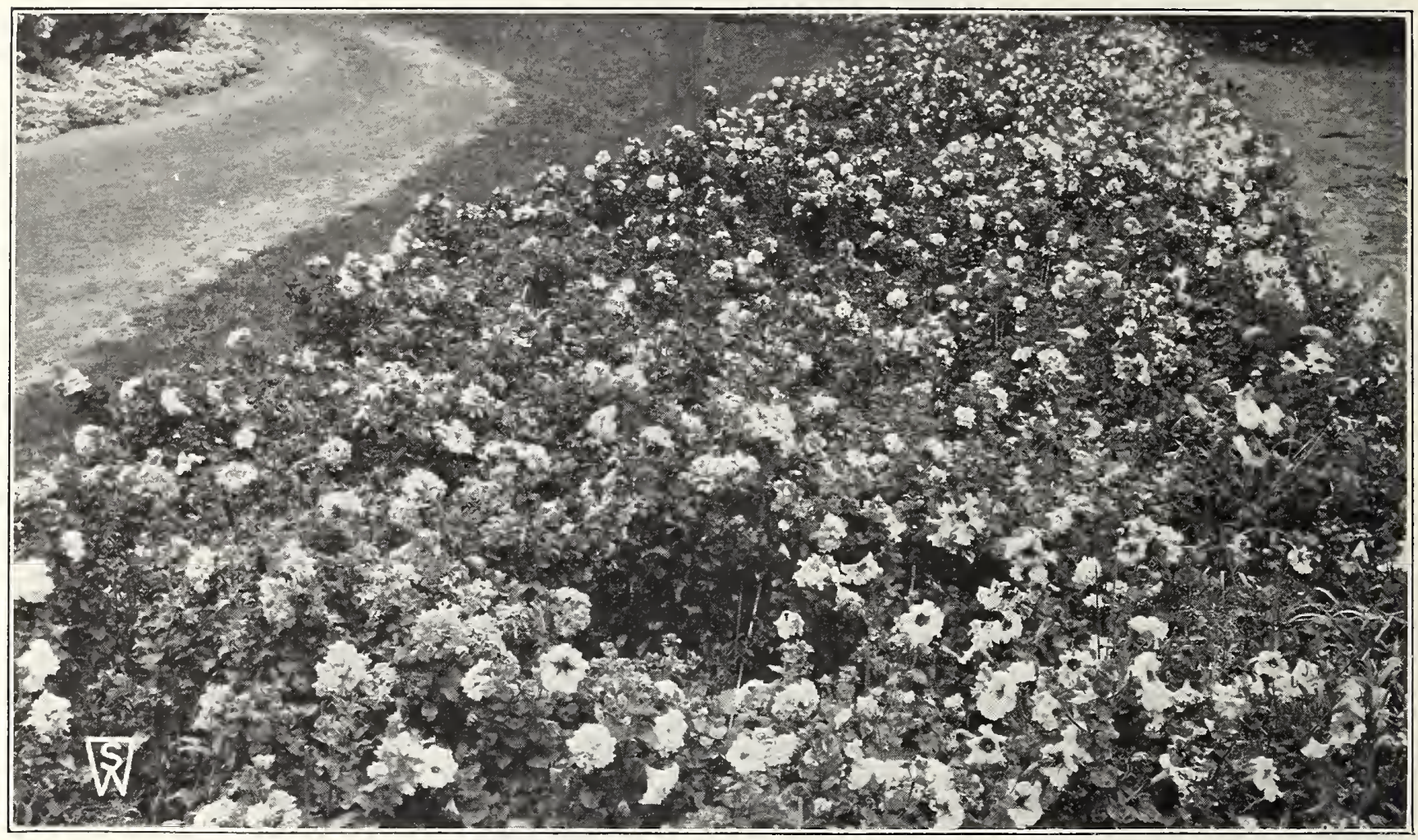

\section{PETUNIA}

Petunias cannot be equaled by any other plant for outdoor decoration. They will flower the first season, even if sown in the open ground, but usually not before June. Those sown in the house or hotbed in April will bloom in June and be larger and finer plants. Half-hardy annual.

S. \& W. Co.'s Giant-flowering Petunias. The demand for a mixture comprising the best representative types of singleand elimination prepared a special mixture. Where a mixture of the giant single fringed and plain-edged varieties is desired, as well as an assortment of the various colors and shades, our customers will find them for bedding purposes the fnest procurable. Pkt. 25 ets., 5 pkts. $\$ 1$.

\section{GIANT-FLOWERING FRINGED PETUNIAS \\ SINGLE VARIETIES \\ DOUBLE VARIETIES}

Under this heading we have listed the finest possible varieties of the now-popular large-flowering fringed Petunias. Whether desired for bedding, cutting, or general display, the varieties listed are the best by test of the Fimbriata, or fringed large-flowering class.

Single Fringed, White. Pure glistening white

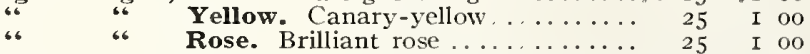
“ " Crimson. Dazzling crimson...... 25 I 03

Single Fringed Mixed. A mixture of best fringed varieties including the above, toge her with many additional new colors and shades.

Should be grown by everyone desiring the best. Pkt. 25 c., 5 plsts. \$I.
It has been a well-established fact that seed saved from the most carefully hybridized flowers produces some double, some semi-double and some single flowers. It is important to save the weaker seedlings, as these invariably produce the finest double flowers. Pkt. 5 pkts.

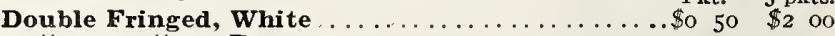

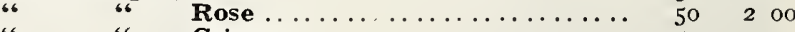
" " Crimson .................. 50 . 2 oo

Double Fringed Mixed. A superb mixture of the finest double fringed varieties. Pkt. 50 cts., 5 pkts. $\$ 2$.

Theodosia. This is a very fascinating fringed Petunia, of a softer rose than Pink Triumph, slightly larger, with a more open throat and beautifully veined. Pkt. $25 \mathrm{cts}$., 5 pkts. $\$ \mathrm{I}$.

\section{BEDDING VARIETIES}

Countess of Ellesmere. Dark rose with fine white throat. Pkt. Io cts., 1/80z. $75 \mathrm{cts}$., $1 / 4 \mathrm{OZ}$. $\$ I .25$

Howard's Star Improved. Crimson with white star in center. Pkt. I5 cts., $1 / 80 z$. \$I, 1/40z. \$I.50.

Inimitable Compacta. Bushy little plants covered with striped and star-shaped flowers. Pkt. Io cts., I/80z. 75 cts., I $+0 z$. \$I.25.

Rose of Heaven. Sinilar to Rosy Morn but more brilliant. Pkt.

$1 / 80 Z$. \$I.50, 1/40Z. \$2.50.

Rosy Morn. Carmine-pink. Pkt. I5 cts., 1/80z. \$1, 1/40z. \$1.50.
Silver Blue. Enchanting shade of light silvery blue. Pkt. $25 \mathrm{cts}$. $1 / 80 z . \$ 1.50,1 / 40 z . \$ 2.50$.

Snowball. An excellent, compact variety, producing satiny white flowers. Pkt. I5 cts., 1/80z. \$I, 1/4 OZ. \$I.50.

Snow Queen. Similar to Snowball but not quite so dwarf. Pkt. $25 \mathrm{cts}$., I/80z. $\$ \mathrm{I} .5 \mathrm{O}, 1 / 4 \mathrm{Oz} . \$ 2.5^{\circ}$

Special Bedding, Mixed. All colors. A very effective show may be had by sowing broadcast. Pkt. Io cts., 1/40Z. 40 cts., Oz. \$1.50, I $/ 4 \mathrm{lb} . \$ 4$. 


STUMPP \& WALTER CO.'S SELECTED SEEDS

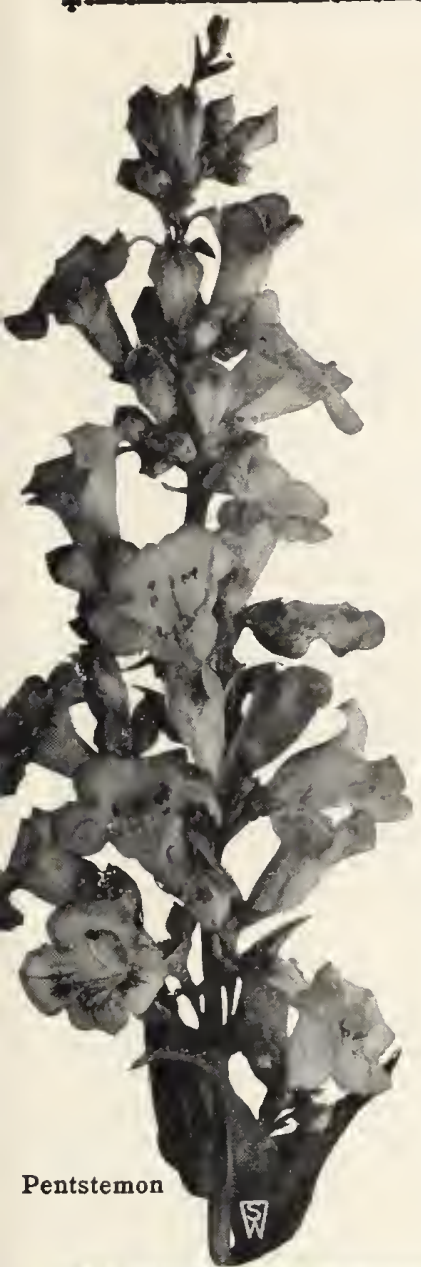

\section{PHLOX DRUMMONDII $\underset{\text { Annual) }}{\text { (Hardy }}$}

Among our best annuals, flowering freely all the summer. For richness of color they cannot be surpassed. They are invaluable for beds and ribbon-gardening, therefore no garden should be without them. They should be sown outdoors in May, in a situation well open to the sun, and they will flower and be a mass of color in July and continue until late autumn. Seeds may be sown in a hotbed in March and flowers be had in June.

\section{Large-flowering Tall Varieties}

This is the finest type, having the largest heads of bloom as well as the largest individual flowers; o strong, sturdy growth, attaining a height of about I5 inches.

Brilliant. Finest crimson.......... \$o Io \$o 75

Carmine. Carmine with white eye... Io

Chamois-Rose. Shell-pink.

Isabellina. Tea-rose yellow

Kermesina. Scarlet-striped.

Leopoldii. Rose with white eje.

Purple. Deep purple.

Purple King. Purple, white

Rosea. Enchantress-

Splendens. Deep crimson, white eye. Io

*White. Pure white.

$\mathrm{Oz} . \$ 2$

Special Collections, One pkt. each of

Special Collections, varieties marked *. .\$0 50

One pkt. each of 12 named varieties....... 100

\section{PASSION FLOWER}

Handsome, rapid-growing perennial climber for greenlouse decoration or sunny positions in the open ground in summer. Pkt. Cærulea. Large flowers of violet and blue....\$0 I5 Alba. Large, white flowers...

\section{PHYSALIS (Chinese Lantern Plant)}

Franchetii. Hardy perennial forming dense bushes about 2 feet high, producing bright orangescarlet lantern-like fruits. May be had in flower frst year from seed if sown early; the fruits are often displayed in florist shops and are very interesting. and of splendid decorative value. Pkt. $25 \mathrm{cts}$., $1 / 4 \mathrm{Oz}$. 75 cts., Oz. $\$ 2.50$.

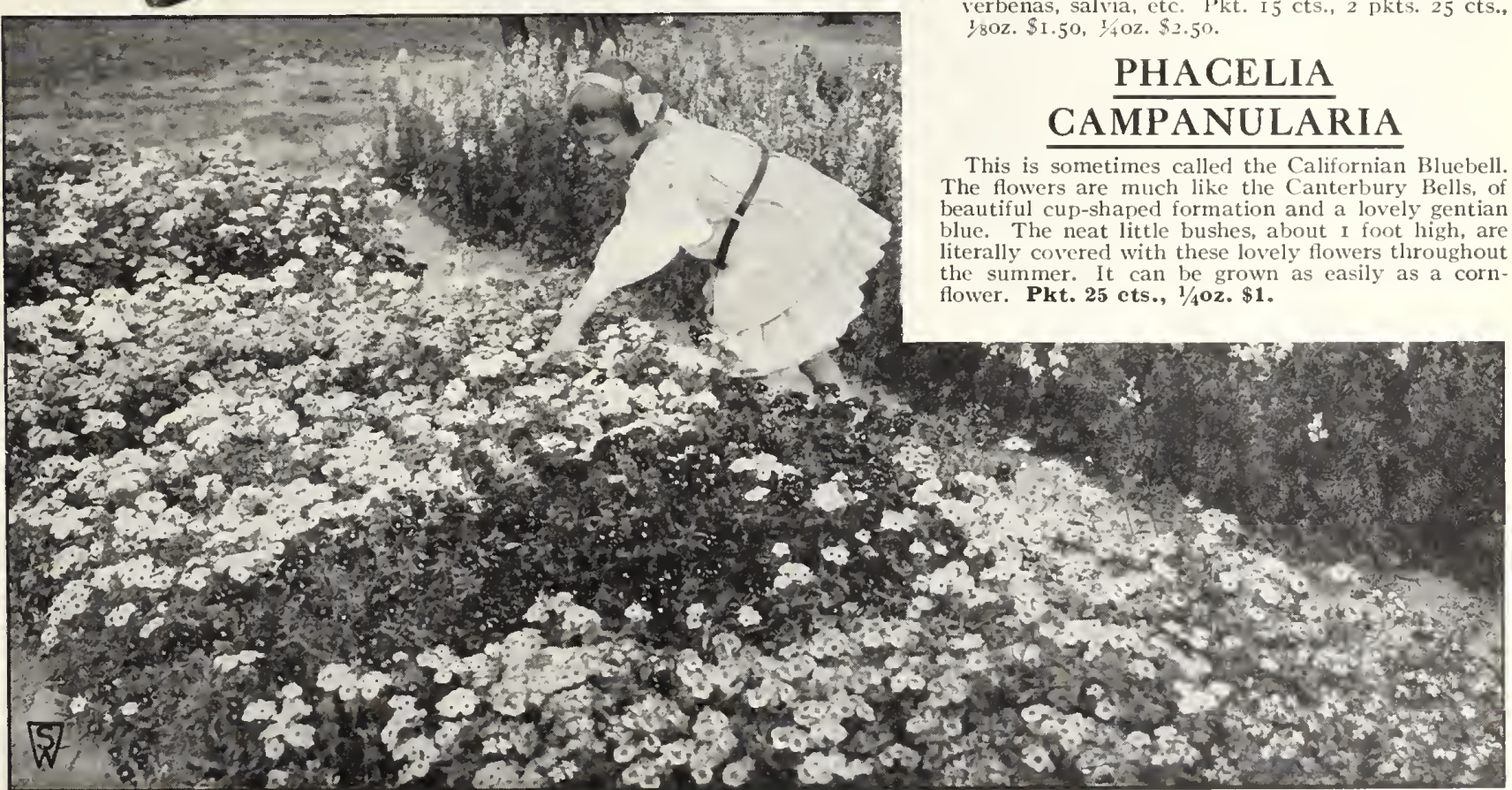

\section{Large-flowering Dwarf Varieties}

This type resembles the tall sorts offered in size of blooms but the plants are dwarfer in habit. Pkt. 1/4oz. Chamois-Rose. Shell-pink

Defiance. Brilliant crimson.

Fireball. Scarlet.

Purple.

Snowball. Pure white.

Surprise. Vermilion.

IMPORTED COLLECTION. One pkt, each of above 6 varieties, 50 cts.

Star of Quedlinburg. Dwarf; star-shaped

ety. Mixed colors, pkt. $10 \mathrm{ets} ., 1 / 40 z$. 75 ets.

\section{HARDY PHLOX}

Large-flowering Hybrids, Tall Mixed $\$ 0 \quad 25 \quad \begin{array}{llll}\$ 2 & 50\end{array}$ Larre-flowering Hybrids, Dwarf Mixed.

\section{PENTSTEMON (Beard Tongue)}

Highly useful and attractive hardy perennial, and S. \& W. Co.'s Giant-flowered Hybrids, Mixed. This is a mixture of the finest giant-flowment of colors. Pkt. 25 ets., 1/80z. $\$ 1,1 / 40 z$. $\$ 1.50$. S. \& W. Co.'s Pink Strain. A very pleasing strain of pink and pale rose shades. Pkt. 25 cts., 1/80z. 75 cts. 1 OZ. \$I.25.

Sensation. As a bedding plant this takes rank with the petunia, phlox, etc. It grows about 2 feet high, every branch being a spike of large, gloxinia-like flowers in a very wide range of bright colors, including rose, red, carmine, cherry, pink, lilac, purple,
etc. Not quite liardy, and best treated like petunias, verbenas, salvia, etc. Pkt. I 5 cts., 2 pkts. 25 cts." PHACELIA CAMPANULARIA

This is sometimes called the Californian Bluebell. The flowers are much like the Canterbury Bells, of blue. The neat little bushes, about I foot high are literally covered with these lovely flowers throughout easily as a cornflower. Pkt. 25 ets., 1/4oz. $\$ 1$. 


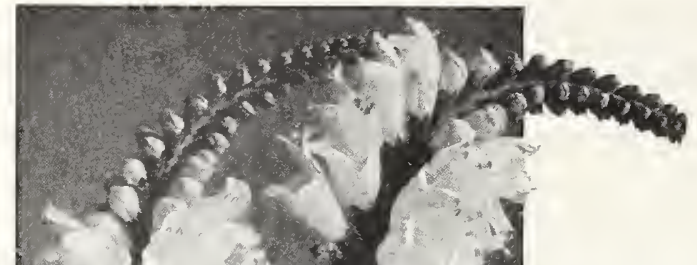

\section{PHYSOSTEGIA (False Dragonhead)}

Virginica. One of the prettiest hardy perennials, forming dense bushes, 3 to 4 feet high, and bearing freely during the summer months spikes of delicate lilac tubular flowers not unlike a gigantic heather. Pkt. Io cts., $1 / 4 \mathrm{Oz}$. \$I.

Virginica alba. White. Height 4 feet. Pkt. $25 \mathrm{cts} ., 1 / 4 \mathrm{Oz}$. $\$ \mathrm{I} .50$.

\section{PLATYCODON}

\section{Balloon Flower; Japanese Bellflower}

One of the best hardy perennials, producing very showy flowers during the whole season. They form large clumps and are excellent for planting in permanent borders or among shrubbery. Easily raised from seed; begin blooming in August if sown outdoors in April. Pkt. $1 / 4 \mathrm{oz}$.

Grandiflor um. Large steel-blue flowers..................... Io \$o 75

Grandiflorum album. Pure white variety.......................

Grandiflorum Mariesii. Large, open, bell-shaped flowers of a rich

violet-blue; plant dwarf and compact.................... To

Grandiflorum japonicum fl.-pl. (Double Japanese Beliflower). Large, glossy, deep blue flowers. The inner petals alternate with the outer ones, giving the flower the appearance of a ten-pointed blue star ..2 pkts. $25 \mathrm{c}$. .

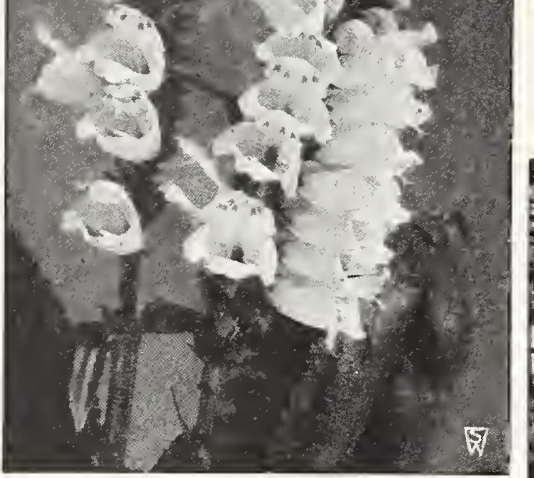

Physostegia

\section{POTENTILLA (Cinquefoil)}

Charming plants for the mixed border, producing brilliant flowers. Will thrive in almost any soil provided the situation is sunny.

Argentea calabra. Hardy peren- Pkt. nial, producing yellow flowers

during summer. Height I 8 in.. . \$o 25

Nepalensis (formosa). Hardy perennial. Red. Height I 8 in... nial. Rose. Height 6 inches....

\section{PORTULACA}

\section{Sun Plant}

One of our finest annual plants, of easy culturc, thriving best in a rather rich, light loam or sandy soil, and luxuriating in an exposed sunny situation. The flowers are of the richest colors and

are produced throughout the summer in great profusion. Fine for massing in beds, edgings on rockwork, and frequently used to sow broadcast over sunny banks, etc. In any case, it is well to mix the seed with three or four times its bulk of dry sand or soil, which permits of even and easy distribution. Height 6 inches.
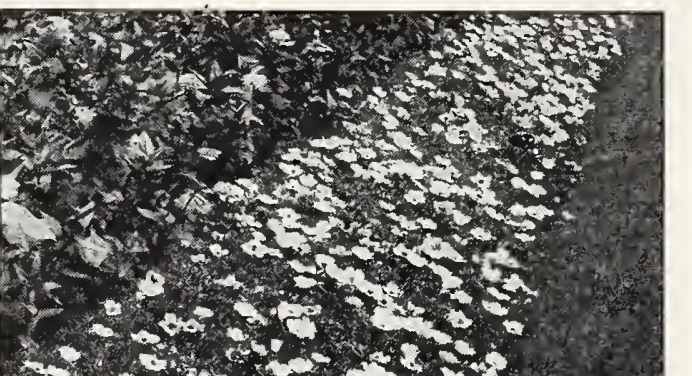

\section{POLEMONIUM \\ Jacob's Ladder}

Popular hardy perennial border plant, with bell-shaped flowers nearly I inch across. 2 feet. Flowers from May to July. Caruleum grandiflorum. Deep

blue. Pkt. Io cts., $1 / 40 z$. $50 \mathrm{cts}$.

Cæruleum album. Pure white. Pkt. Io cts., $1 / 40 z$. $50 \mathrm{cts}$.

Richardsonii. Sky-blue. Pkt. ro cts., $1 / 40 z$. 50 cts.

\section{GIANT POLYANTHUS \\ Primula elatior}

The visitor to any of the famous gardens of England in May-time is greatly impressed with the manner in which this beautiful Primrose is used and the gorgeous display the better varieties present. Many of the larger gardens use them to intersperse between Mayflowering tulips in their bulb-gardens, but they are best seen to advantage in borders or in beds. The strain we are offering is of strong, sturdy habit, and bears immense trusses of large flowers on strong stems ro inches in length. The colors vary from pure white to rich wallflower-red. Seed is usually sown in early summer, in a frame, and the plants transplanted to the garden in the autumn. They require slight protection over winter. Pkt. 25 cts., 5 pkts. $\$ \mathrm{I}$,

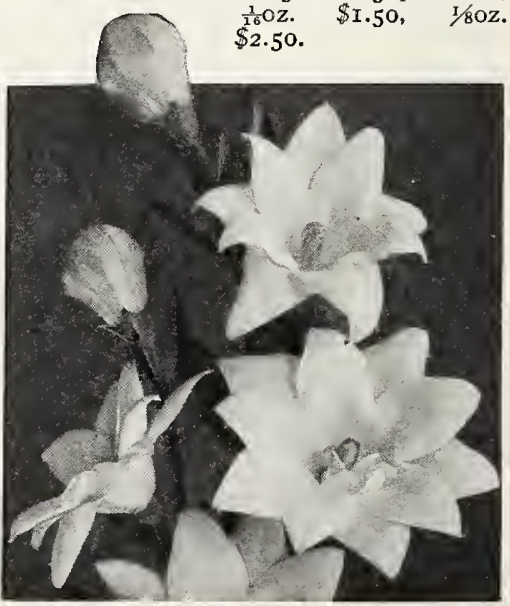

Platycodon grandiflorum japonicum fl.-pl. 


\section{POPPIES}

Annual Poppies should be sown as early as possible in the spring where they are to remain, as they do not transplant readily. It is advis. able to mix the seed with builders' sand, using about twenty-five times as much sand as seed, and then carefully broadcast seed on the surface of the ground and firm well. Plants should be thinned out to stand about 6 inches apart for best results. Seed may be sown in rows also and in succession up to the middle of May. It is advisable to pick flowers just as they are expanding as they last longer; removing the old blooms from plants will help lengthen the flowering season.

\section{Single Annual Varieties

SINGLE SHIRLEY, AMERICAN LEGION

This new single Shirley is a dazzling orange-scarlet of enormous size borne on long, stout stems. The plants are of very erect, robust growth. Highly commended by the Royal Horticultural Society of Great Britain. Pkt. 15 cts., 1/40z. 75 cts., oz. \$2.50.

Shirley, Salmon-Pink.

Shirley, Pure White.

Shirley, Wild-Rose-Pink.

Shirley, Deep Apricot.

Shirley, Picotee. White cup, scarlet edging.

Shirley, Blue Shades. Gray-blue.

Each, pkt. 10 cts., $1 / 4$ oz. 50 cts., oz. $\$ 1.50$ COLLECTION: One pkt. each of above 6 shades, 50 cts. Shirley, Finest Mixed. Pkt. ro cts., 1/40z. $50 \mathrm{cts}$, oz. $\$ 1.50$.

Admiral. A peony-flowered variety of surpassing Pkt. $3 / 40 z$. beauty, having large flowers of glistening white, with a broad band of brilliant scarlet around the top....... \$o ro \$o 40

Dainty Lady. Immense flowers 4 to 5 inches across, of a charming shade of rosy mauve, with a large dark metallic blotch at the base of each petal........

Danebrog (Danish Cross). Very showy variety, producing large flowers of brilliant scarlet, with a silvery white spot on each petal, forming a whi e cross.......

King Edward. New. Gorgeous. Deep scarlet, shaded crimson-red, each petal marked with a black blotch against which the yellow anthers stand out in bold relief. The plant grows $2 \frac{1}{2}$ feet high.............

English Scarlet (Flanders). The common scarlet Field Poppy of Europe....................

Tulip Poppy (Papaver glaucum). One of the most brilliant; the flowers are 3 inches across and closely resemble the brilliant scarlet Gesneriana tulip........

\section{Double Annual Varieties}

The Double Annual Poppies require the same cultural treatment as the Shirley. They are excellent to grow for cutting. For best results plants should be thinned out to stand 8 inches apart.

\section{GARNATION-FLOWERED}

\section{Bright Rose}

Heliotrope

Shell-Pink White Swan

Mikado. Red, white striped.

American Flag. White, bordered scarlet.

Each, pkt. 10 cts., 1/40z. 30 cts., oz. $\$ 1$

COLLECTION: One pkt. each of above 6 colors, 50 cts.

Mixed. Includes all colors. Pkt. Io cts., $1 / 40 z .25 \mathrm{cts} ., 0 z .75 \mathrm{cts}$.

\begin{tabular}{ll} 
& PEONY-FLOWERED \\
\cline { 2 - 2 } $\begin{array}{ll}\text { Bright Rose } \\
\text { Creamy Yellow }\end{array}$ & $\begin{array}{l}\text { Cardinal-Red } \\
\text { White }\end{array}$ \\
Shrimp-Pink \\
Black Prince
\end{tabular}

Each, pkt. 10 cts., 1/40z. 30 cts., oz. $\$ 1$

COLLECTION: One pkt. each of above 6 colors, 50 cts.

Mixed. Includes all shades. Pkt. Io cts., 1/40z. $25 \mathrm{cts}$., oz. $75 \mathrm{cts}$.

Double Queen. This beautiful new strain of Poppies Pkt. $1 / 40 z$. is of the Shirley type, but the flowers are double and semi-double, of the most delicate and brilliant colors,

including salmon, pink, crimson, orange-salmon shaded whitc, brilliant scarlet with white center.....\$o I5 $\$ 1$ oo

\section{Hardy Perennial Varieties}

\section{ORIENTAL POPPIES (Papaver orientale)}

Sow early in spring. Plants disappear in July and August, appearing again in cool weather. When this fall growth starts transplant to their permanent flowering quarters. It is well to mark the places they are planted, to insure the roots against disturbance during their annual resting period.

Orientale, Scarlet.

Pkt. $1 / 80 z$.

Orientale, Oriflamme. Gorgeous orange-scarlet...................... \$I oo

Orientale, Princess Victoria. Inmensesalmontiowers.

Orientale, Finest Mixed... .

\section{ICELAND POPPIES (Papaver nudicaule)}

Iceland Poppies, while considered perennials, will flower the first year from seed. They are of graceful habit, with bright green, fernlike foliage, formed in tufts, from which issue slender stalks about i2 inches high, bearing brilliant flowers in endless profusion. Pkt. $1 / 20 z$.

Iceland (Nudicaule) Scarlet............... I5 \$I oo Iceland (Nudicaule) White........................... I celand (Nudicaule) Yellow............... I5 I oo Iceland (Nudicaule) Mixed...

Iceland (Nudicaule) Double Mixed............ I5 75

ALPINE POPPIES (Papaver alpinum). This miniature, hardy perennial Poppy is one of the most beautiful rock and alpine plants and produces blooms in a marvelous range of colors. Mixed, pkt. $25 \mathrm{C}$.

TIBETAN POPPIES (Meconopsis Baileyi). Recently discovered; believed to be the most beautiful Tibetan Poppr. A perennial 4 feet high, and producing sky-blue flowers. Pkt $50 \mathrm{cts}$.

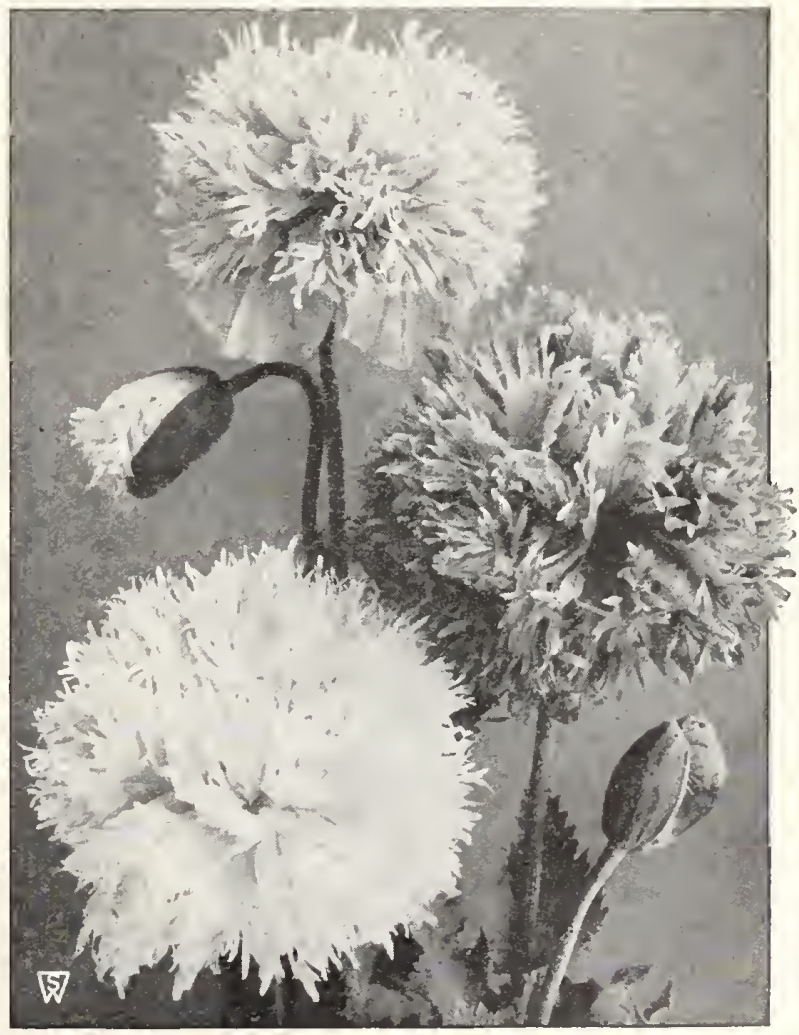

Carnation-flowered Poppies (Annual) 


\section{PRIMULA (Primrose)}

The charming and beautiful Chinese Fringed Primroses and Obconica varieties are among the most important winter-blooming pot-plants. The seed we offer is of the highest merit, and has, as usual, been saved from the best strains of European growth. Seed sown in April will bloom during early winter; August for spring blooming. Sow in shallow pans, in soil consisting of part sand and leaf-mold worked through a fine sieve and allow for good drainage. Cover seeds lightly and water frequently; give a temperature of about 65 degrees.

\section{Primula sinensis (Chinese Primrose)}

This beautiful Chinese Fringed Primrose is indispensable for spring decoration in the home or conservatory, and ranks as one of the finest of all winter-blooming pot-plants grown by the florist or the home-gardener. Giant magnifica, Blue Giant Ruby Queen Giant White, FernGiant Crimson Giant Salmon leaved

Giant Rose Queen Giant Mixed

Pkt. 75 cts.; collection of 6 pkts. for $\$ 4.25$

Giant Double, White

Giant Double, Scarlet

Giant Double, Blue

Giant Double, Rosy Pink

Giant Double, Salmon-Pink

Giant Double, Mixed

Pkt. 75 cts.; collection of 6 pkts. for $\$ 4.25$

\section{Primula stellata}

A very pretty form, with large heads of star-shaped flowers of various colors; a splendid type for decorative purposes.

$\begin{array}{lll}\text { Giant White Star } & \text { Giant Crimson Star } & \text { Giant Rosy Star } \\ \text { Giant Salmon-Pink } & \text { Giant Blue Star } & \text { Giant Mixed }\end{array}$

Giant Salmon-Pink Giant Blue Star Giant Mixed

Pkt. 75 cts.; collection of 6 pkts. for $\$ 4.25$

\section{Giant Primula obconica}

This type of Primula outrivals the old Obconica type, the flowers being considerably larger, often measuring 2 inches across. Pkt.

Atrosanguinea, Mohnstein. Bright crimson............\$o 50 Mueller. Deep crimson................... 50

Rosea, Mueller. Bright rose................. 50

Obconica gigantea alba

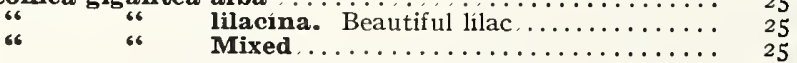

\section{A New Hardy Primula}

Florindæ. A stately variety which often reaches a height of 4 feet. Blooms during July and August, bearing 60 to 80 fragrant, bright yellow, pendent flowers at the top of each stem. Pkt. \$I.

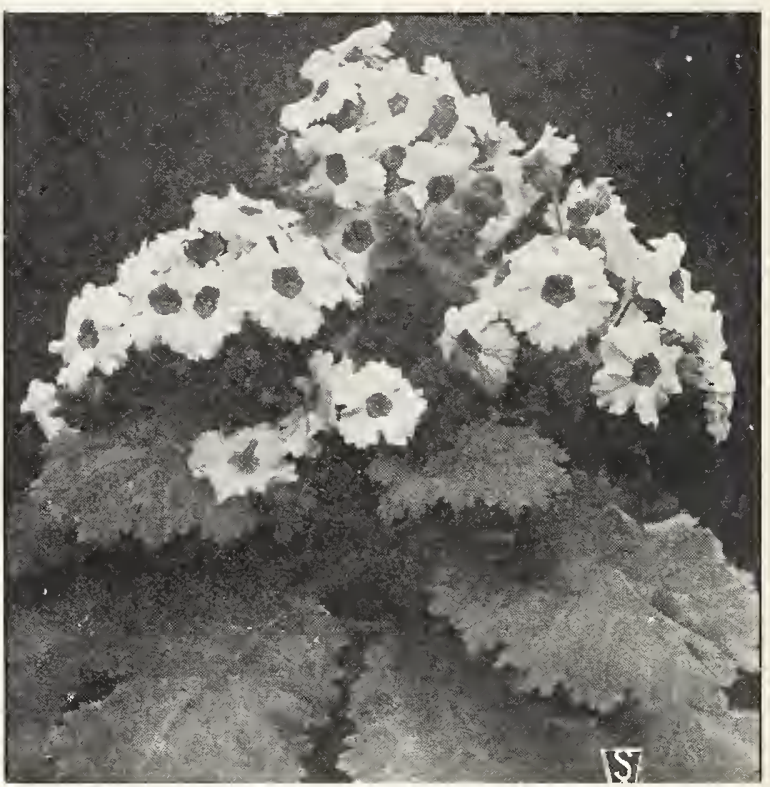

S. \& W. Co.'s Primula sinensis

\section{HARDY PRIMULAS}

Auricula, Mixed Colors. A favorite of great beauty, 6 inches Pkt. Beesiana. Purple with yellow eye. Height 2 feet......... 25 Bulleyana hybrida. Orange, apricot, and carmine shades.

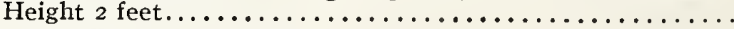

Cashmeriana. Large-flowered hybrids. White, mauve to

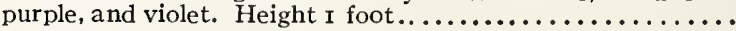
Denticulata. Rosy lilac. Height I foot............... Japonica (Japanese Primrose). Bright and showy flowers, borne in whorls on stems 6 to 9 inches long. Mixed....... Pulverulenta. Rich ruby-crimson. Height $\mathrm{I} / 2$ feet........ Veris. The English Cowslip. Mixed colors................ Vulgaris. Canary-yellow, fragrant. The true English Primrose. Vulgaris, Mixed. Primroses in a variety of colors. Height $\mathrm{I} f \mathrm{ft}$.

\section{SEVEN FINE GREENHOUSE PRIMULAS}

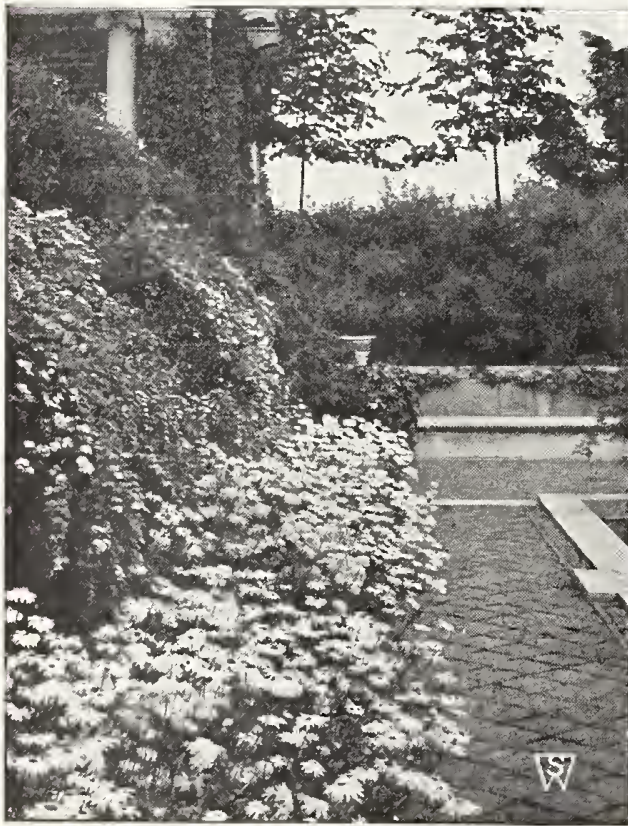

S. \& W. Co.'s Single Pyrethrum
Malacoides (The Giant Baby Primrose). The flowers measure $1 / 2$ to $3 / 4$ inch across, and the plants branch very freely. The flowers, of a pretty light lilac, are borne in whorls on stems which are graceful and strong. Pkt. 25 cts., 5 pkts. \$I.

Malacoides alba. This beautiful new white variety is a welcome addition to this type of Primula. Pkt. 25 cts., 5 pkts. \$I.

Malacoides fimbria ta, pink; Malacoides, Pink Beauty; and Malacoides superba, deep pink - all three of these novelties are decided advances. Each, pkt. 25 cts

Forbesii (The Baby Primrose). The plants throw up tiny flower-stalks when only a few weeks old, but we advise pinching them off and the plants kept growing until October. They may then be allowed to flower. Pkt. $25 \mathrm{cts}$., 5 pkts. \$1.

Kewensis. This new variety is most attractive, with bright yellow flowers. It is delightfully fragrant and stands well as a house plant. Pkt. 25 cts., 5 pkts. $\$$ I.

\section{PYRETHRUM}

The first-named variety is the well-known Golden Feather so much used for edging, carpet-bedding, etc., while the others are most attractive hardy plants, with daisy-like flowers that are perfect gems for cutting.

Aureum (Golden Feather). Half-hardy perennial, grown as an annual. Valuable for edging. Pkt. Io cts., $1 / 4 \mathrm{OZ} .50 \mathrm{cts}$.

S. $\&$ W. Co.'s New Double Hybrids. This beautiful perennial is one ane finest for cutting. The wonderful strain with large, very double flowers in distinct shades of pink, salmon, scarlet, and pure white. Pkt. 25 cts., 5 pkts. $\$ 1,1 / 80 z$. $\$ 1.50,1 / 40 z$. $\$ 2.50$.

S. $\&$ W. Co.'s Single Hybrids. Our single strain of this beautiful hardy per. ennial has been grown specially in England a specialist of this flower. The cosmos-like flowers range in color from the palest pinks to deep red, the bright yellow centers forming a splendid contrast. Pkt. 25 cts., 5 pkts. $\$ 1,1 / 40 z$. $\$ 1.50$. 


\section{RAMONDIA}

Pyrenaica. A rare and beautiful hardy perennial for the alpine garden. Grows 4 inches high and produces violetpurple flowcrs in early spring. Pkt. $50 \mathrm{cts}$.

\section{REHMANNIA}

Angulata. Greenhouse herbaceous perennial from central China, erect habit; 2 to 3 feet in height; flowers 3 inches in diameter, rosy purple with yellow throat, spotted with deep purple; of easy culture; blooms nine month from time of sowing seed. Pkt. $25 \mathrm{cts}$.

\section{RUDBECKIA (Coneflower)}

Well-known hardy perennials, invaluable for the herbaceous border.

Bicolor, Solfatare. Sulphur-y'ellow. Height 3 feet.... \$o I 5

Bicolor superba. Yellow with brown center. Height $3 \mathrm{ft}$. I5

Fulgida. Orange-yellow. Height 5 feet............ I

Newmani. Orange with purple cone. Height 3 feet.... I

Purpurea. Reddish purple. Height 4 feet .......... Is

\section{SALPIGLOSSIS (Painted Tongue)}

Few annual flowers contribute such a wealth of bloom from summer until cut down by frost. It is only of recent years that American gardeners have become better acquainted with this delightful annual. As a cut-flower it has become highly prized. The funnel-shaped flowers, facing upward, revealing their exquisite markings of either gold or silver veins running through the groundwork of the flowers, and their orchid-like appearance, make them instant favorites.

Seeds may be sown in the open ground in spring, or for earlier flowering sow in a hotbed or sunny window, and when all danger of frost is past, place in the garden, allowing 9 inches between the plants.

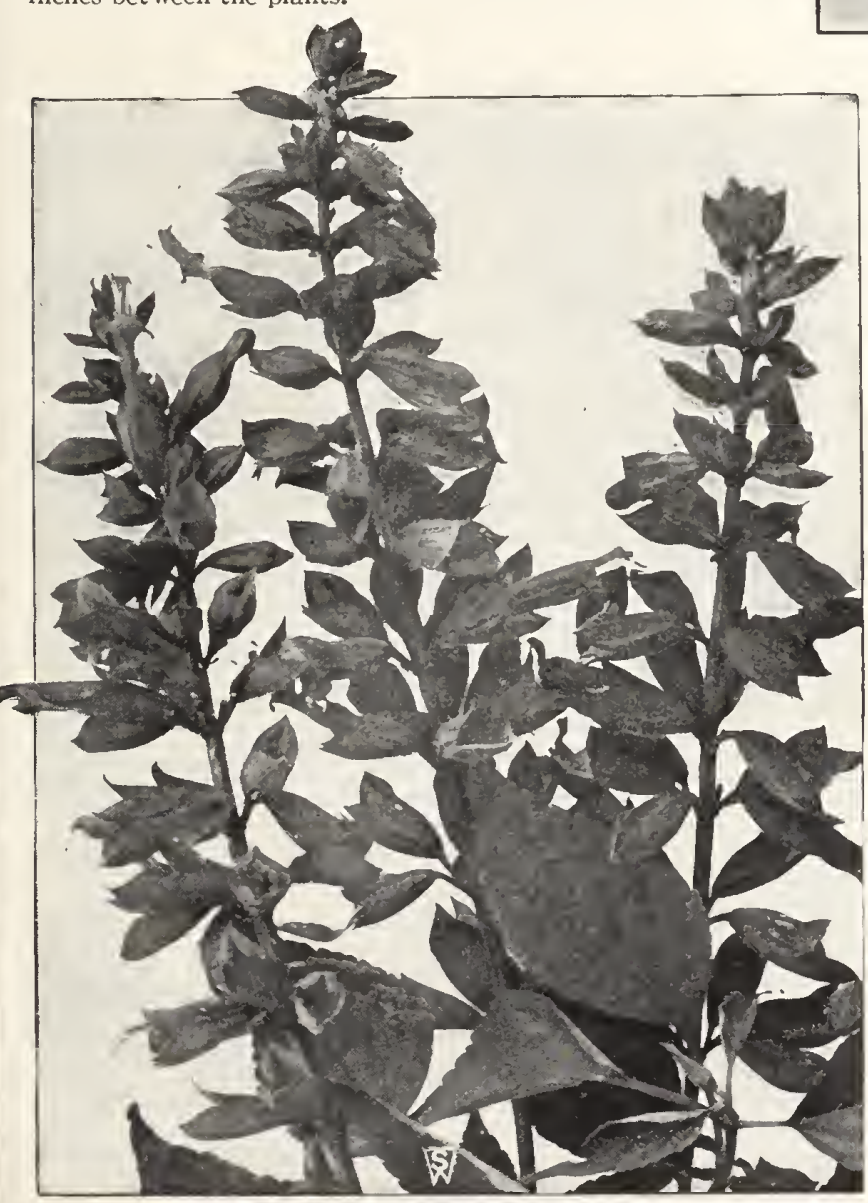

Salvia spleadens (Scarlet Sage)

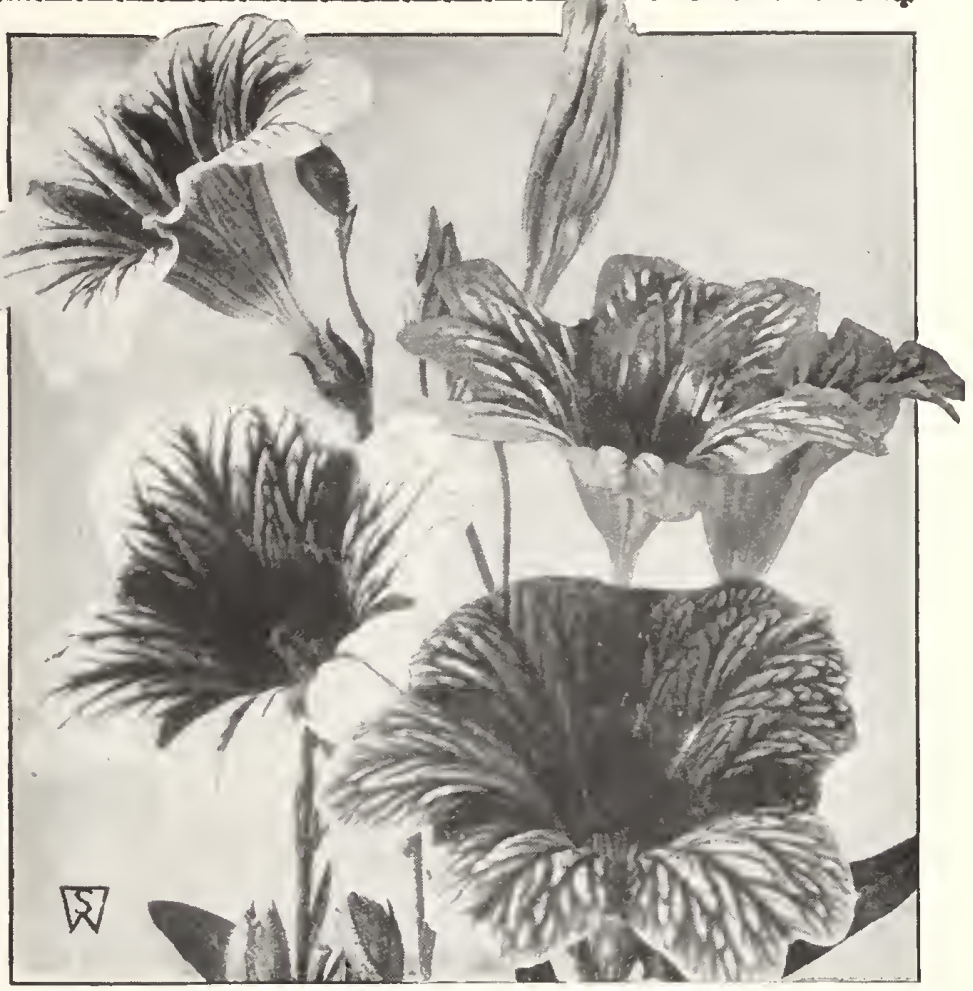

Salpiglossis superbissima (Orchid-flowering)

New Hybrids of Salpiglossis superbissima

Brown and Gold

Crimson

Light Blue and Gold

Primrose

Each, pkt. 15 cts., $1 / 40 z .75$ cts., oz. $\$ 2.50$

COLLECTION: One pkt. each of above 8 colors, $\$ 1$

Finest Mixed. All shades-Scarlet, Pink, Yellow, and Violet. Pkt. Io cts., 1/40z. $50 \mathrm{cts}$., Oz. \$1.75.

\section{SALVIA}

One of our most handsome summer and autumn-flowering plants, growing into compact bushes about 3 feet higl and literally ablaze with brilliant flowers; very effective for massing on the lawn and for garden decoration. Half-hardy perennials, trcated as annuals.

Splendens (Scarlet Sage), Beautiful bright scarlet; 3 fect. Pkt. Io cts., $1 / 4 \mathrm{Oz} .75 \mathrm{cts}$., oz. $\$ 2.50$.

Bonfire. One of the finest Salvias for bedding yet introduced. The plants grow into very compact oval bushes, about $2 \frac{1}{2}$ fcet high, and produce long spikes of brilliant scarlet flowers. They stand out stiff and erect; over 200 spikes to a plant is not unusual, and the spikes bear from twenty to thirty flowers each. Pkt. Io cts., $1 / 8 \mathrm{OZ} .85 \mathrm{cts} ., 1 / 4 \mathrm{OZ}$. $\$ \mathrm{I} .5 \mathrm{O}, \mathrm{I} / 2 \mathrm{OZ} . \$ 2.5 \mathrm{O}, \mathrm{OZ} . \$ 5$.

Scarlet Dragon. This variety is an improvement on the old Splendens type, the flowers being nearly double the size, closely crowding the immensc spikes that of ten measure 6 inches across. Pkt. 10 cts., 1/40z. $\$ 1.25$.

Zurich. A splendid dwarf variety, growing about 2 feet high, and is especially valuable on account of its flowering ten days in advance of any other sort. Pkt. $25 \mathrm{cts}$., $1 / 80 \mathrm{Oz}$. \$I, 1/40z. \$I.75.

Patens (Blue Sage). Deep rich blue. A beautiful plant for the border or greenhouse; tender perennial. 2 feet. Pkt. $25 \mathrm{cts} ., 1 / 80 z$. \$I.50, $1 / 4 \mathrm{Oz} . \$ 2.50$.

Farinacea. A perennial variety, best grown as an annual. Seeds The fine light blue flowers are borne on long spikes. 2 feet. Pkt. 15 cts., $1 / 80 z$. $\$ 1.50,1 / 40 z$. $\$ 2.50$.

\section{SAXIFRAGA}

Cordifolia. Well-known rock-garden plant with pink flowers. Height 9 inches. Pkt. $25 \mathrm{cts}$ 


\section{SAPONARIA (Bouncing Bet)}

Caucasica fl.-pl. (Double-flowering Bouncing Bet). A hardy Pkt. perennial sort with white tinted rose, double flowers, produced all summer and fall. I5 inches.

ocymoides. Hardy perennial rock plant, producing during the summer masses of small, bright rose flowers. 9 inches.

Vaccaria, Rose. Pretty and useful annual variety, growing 2 feet high, and bearing satiny pink flowers somewhat like an enlarged gypsophila. Charming for cutting. Sereral sowings should be inade to keep up a succession of bloom. Oz. 75 cts. .

Vaccaria, White

$\mathrm{Oz} .75 \mathrm{cts}$

\section{SCABIOSA (Mourning Bride; Sweet Scabious;} Pin-Cushion Flower

These beautiful hardy annuals are in great demand. They grow about $21 / 2$ feet high and bloom from early in July without interruption until cut down by the frost. As a flower for cutting they are very popular. The various shades are extremely charming, and are equally well adapted for borders or beds, where they display themselves very effectively. Seeds should be sown any time in the spring after danger of frost is past.

Azure Fairy. Clear lavender-blue.

Crimson. Brilliant and dazzling.

Rose. Strong shade of pink.

Shell-Pink. Delicate light tint

White. Pure white.

COLLECTION: One pkt. each of above 6 varieties, 50 cts

Tall Double Mixed

Dwarf Double Mixed

Io $30 \quad$ I 00

HARDY PERENNIAL VARIE'TIES

Caucasica (Blue Bonnet.) One of the handsomest Pkt. I/8oz. 1/40z. of hardy perennials. It is especially valuable for cutting, the lilac-blue blooms lasting a long time in water. 3 feet. \$o I 5 \$I

Caucasica alba. Pure white. 3 feet.

Japonica. Hardy perennial variety, forming bushy plants $2 \mathrm{I} / 2$ feet in height, and bearing on long stems beautiful, lavender-blue flowers. It produces continuously all summer.

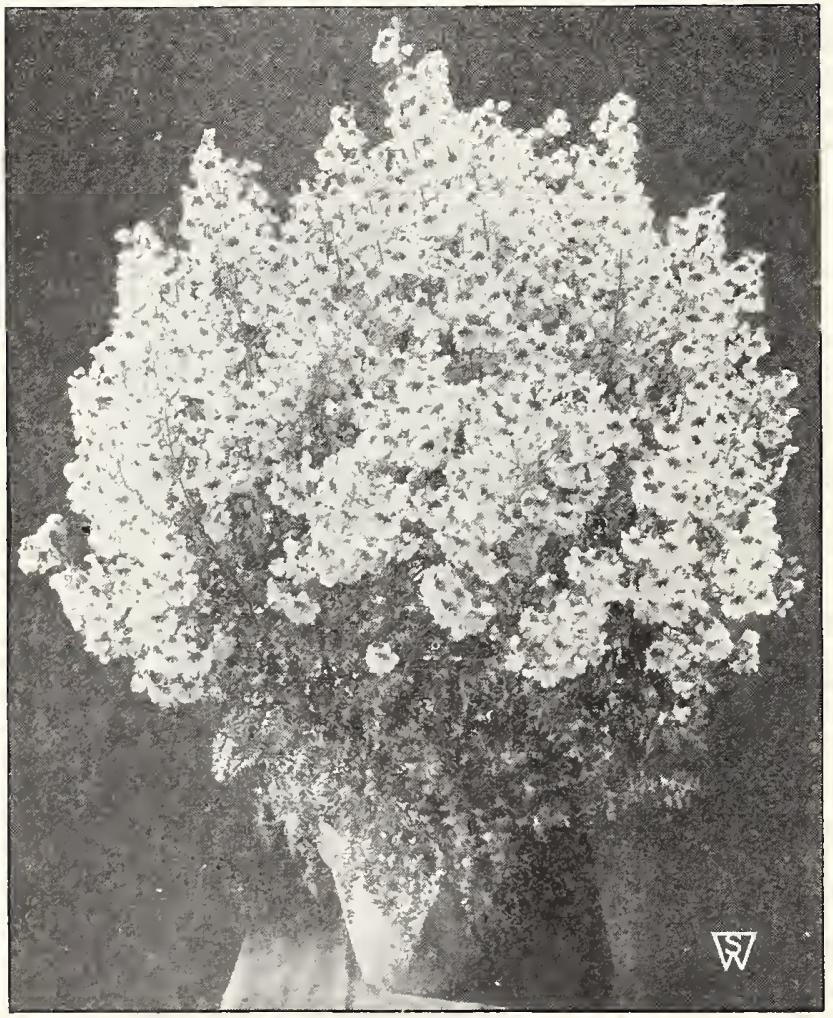

Schizanthus Wisetonensis

\section{SANVITALIA}

Procumbens fl.-pl. An annual of dwarf, compact growth, Pkt. useful in masses in beds, or edges of borders, or in vases.

Showy, bright yellow, double flowers; in bloom all summer... \$o I 5

\section{SCHIZANTHUS (Butterfly or Fringe Flower)}

Although grown largely by the florist as a greenhouse plant, this annual is also of easy culture in any good garden soil.

S. \& W. Co.'s Giant-flowering Hybrids. Considered by many as the finest strain of this splendid pot plant and cut-flower. Rose and Amber Shades Rose and Pink Shades Mauve and Purple Shades Rose and Pink Shades
Mixed. Includes all color Rose and Carmine Shades Each, pkt. 50 cts., 5 pkts. \$2 Wisetonensis. Largely used as a pot plant for the conserva- Pkt. Went It is free-flowering and resents a beautiful appearance, with its myriads of blooms, the ground-color of which is white, dotted with rose...............5 pkts. \$I . So 25 Dwarf Hybridus grandiflorus. Plants grow I2 inches in pyramidal habit, with a great range of colors, bright and handsome. Splendid for border planting............ pkts. $\$ \mathrm{I}$.

\section{SEDUM (Stonecrop)}

Dwarf hardy perennials for the rock-garden and for carpet bedding. Acre. Yellow. Height 6 in.

Album. White. Height 6 in. Middendorffianum. Yellow with dark foliage. Height 6 in.

Spurium. Rose. Height 6 in.

Stoloniferum coccin e u m. Scarlet. Height 6 in.

Each of above, pkt. 25 cts.

\section{SENECIO (Groundsel)}

Forms a neat clump from which develop 2-foot flower-stems Clivorum. Perennial; 5 feet high; yellow flowers. Pkt. 25 cts.

\section{SIDALCEA}

Erect plants with mallow-like flowers.

Rosy Gem. Hardy perennial. Rose-colored flowers. Height 3 feet. Pkt. 25 cts.

\section{SILENE (Catchfly)}

The varieties offered below are very pretty hardy perennials, well adapted for the rockery or the front of the hardy border. Pkt. Alpestris. Glistening white flowers in summer. 4 inches......\$o I 5 Schafta (Autumn Catchfly). Grows from 4 to 6 inches high, with masses of bright pink flowers from July to October.... I5

\section{SOLANUM}

Capsicastrum (Jerusalem Cherry). This is a very useful pot Pkt. plant for winter decoration. It is of dwarf, branching habit, bearing in the greatest profusion bright scarlet globular berries. Leaves oval, small. Height i foot............ \$o Io Capsicastrum, Fra Diavolo. A new variety of the above, of close, compact growth, with foliage somewhat smaller and lighter green. The small, bright scarlet fruits remain on the plant a long time and make it a beautiful decorative plant....

\section{STA TICE (Sea Lavender)}

The c'oud-like masses of flowers of the branching varieties make borders gay for a long time, while their delicate coloring and light, graceful habit are a great help to helichrysums and other everlasting flowers. Sow the Suworowi and Sinuata varieties outdoors early in May or sow in a hotbed in March and transplant in April.

Suworowi. Cloud-like masses of bright rose.

Sinuata, Mauve. Clear mauve.

Sinuata, Rose Superba. New. Beautiful rose.

Sinuata, Blue. Rich deep blue.

Sinuata, Yellow (S. Bonduelli). Bright yellow. Any of the above, pkt. 25 cts., $1 / 4$ oz. 75 cts., oz. $\$ 2$ Pkt.

Latifolia. Purplish blue flowers. Hardy perennial......... \$o I 5 Mixed Perennial Varieties. Containing many sorts........ I5

\section{STEVIA (Piqueria)}

Serrata. Free-blooming tender perennial, bearing a multitude of fragrant, pure white flowers; suitable for summer bedding or winter blooming under glass. Excellent for cutting...... 


\section{STOCKS}

These popular flowers are easily grown, and are so highly fragrant and of such great beauty, and have so many good qualities, that they deserve a place in every garden. They should be given good rich soil to grow in, and will amply reward good treatment with remarkably large pyramids of bloom. The flowers represent a great diversity of color. The Tall Perfection and Dwarf Bouquet Stocks are great improvenents over the Gilliflowers of the olden times, the flowers being much larger and more densely double, and there is also a much larger variety of colors and sliades than there used to be.

As they are half-hardy annuals, seed should be started in the house or hotbed during March or April, planted into small pots, and then set out in the garden during May, allowing 1 foot of space between the plants, in order that they may attain full and perfect development.

\section{S. \& W. Co.'s Early Giant Imperial}

These Stocks are of special merit. They bloom very quickly and continue through the summer. We offer a wide range of color, and in the shades selected the proportion of double flowers is very higll. Plants are of branching habit, 2 to $21 / 2$ feet high.

\section{$\begin{array}{lllll}\text { White } & \text { Lavender } & \text { Dark Blue } & \text { Deep Rose } & \text { Apple Blossoin } \\ \text { Chamois-Rose } & \text { Blood-Red } & \text { Canary-Yellow } & \begin{array}{l}\text { Mixed } \\ \text { Canaryod }\end{array}\end{array}$} Any of the above varieties, pkt. $25 \mathrm{cts} ., 1 / 80 z . \$ 1.50$

\section{S. \& W. Co.'s Improved Giant Perfection}

These are an improvement on the variety offered as Ten-Weeks' Stock. Of splendid, pyramidal growth, freely branching from the main sten, giving an abundance of large spikes of double flowers from early summer until fall, and are used largely for cutting. 2 feet.

White

Fiery Crimson Canary - Yellow

Light Blue

Dark Blue

Mixed

Any of the above varieties, pkt. $25 \mathrm{cts} ., 1 / 80 z$. $\$ 1$

\section{Giant-Flowering Beauty Stocks}

A magnificent, recently developed strain of early-flowering winter or Brompton Stocks, forıning much-branched plants about 2 feet high, and having numerous spikes of very large, double, delightfully fragrant flowers; they are of special value as potplants for greenhouse decoration and for cutting during the dull winter months; for this purpose seed should be sown from July to September; if sown in February or March, will produce plants that will bloom from midsummer to frost.

Almond Blossom. White, shaded car- Monte Carlo. Canary-yellow. mine.

Beauty of Nice. Delicate pink.

Crimson King. Rich blood-crimson.

Mont Blanc. Purest white.

Old Rose. Beautiful shade of old rose.

Queen Alexandra. Beautiful lilac.

Summer Night. Rich deep blue.

Mixed.

Packet, any of the above varieties, $25 \mathrm{cts}$. each, 1/80z. $\$ 1$

\section{STREPTOCARPUS}

S. $\&$ W. Co.'s New Hybrids. A new race of the Cape Primrose, the flowers somewliat resembling those of the gloxinia, but smaller. The plants are compact in habit, the flowers about 2 inches in diameter, with long, tube-like corollas, and are borne in clusters of six to eight on a stem, with several stems to the plants. The colors are varied from white through shades of pink, rose, wine-red, light blue, mauve, etc., many having white throats or marked in various ways. Used for greenhouse decoration. Pkt. 50 cts.

\section{SWEET WILLIAM (Dianthus barbatus)}

A well-known, attractive biennial which flowers the second season from seed. Sow outdoors in May, and transplant in August.

\section{Single White \\ Single Copper-Red \\ Single Black-Red \\ Single Finest Mixed \\ Single Dark Crimson Single Red, Margined White}

Each, pkt. $10 \mathrm{cts.,} 1 / 40 z .50$ cts.

COLLECTION: One pkt. each of 5 colors, 40 cts.

$\begin{array}{lll}\begin{array}{l}\text { Double White } \\ \text { Double Crimson }\end{array} & \begin{array}{l}\text { Double Black-Red } \\ \text { Double Pink } \\ \text { Each, pkt. } 15 \mathrm{cts} ., 1 / 40 \mathrm{oz} . \$ 1\end{array} & \text { Double Finest Mixed }\end{array}$

Newport Pink. A distinct new color which originated in one of the far-famed melon-pink or salmon-rose: strikingly brt, R. I. In color it is what florists call watermassive heads, on stems I 8 inches high. For midseason mass bedding it has no equal. It is also very effective for cutting. Plt. 15 cts., 2 pkts. 25 cts., $1 / 40 z .75$ cts.

Scarlet Beauty. An intensely rich, deep scarlet, very vivid, and quite an improvement over other listed varieties of its color. Pkt. I 5 cts., 2 pkts. $25 \mathrm{cts} ., 1 / 40 \mathrm{oz} .75 \mathrm{cts}$. Holborn Glory. This strain is a large-flowered selection of the auricula-eyed section, the most beautiful and admired of all Sweet Williams. Individual fowers and trusses are of extraordinary size, while the range of color, all showing a clear, white ey'e, is truly superb. Pkt. Io cts., 1/4oz. 5o cts.

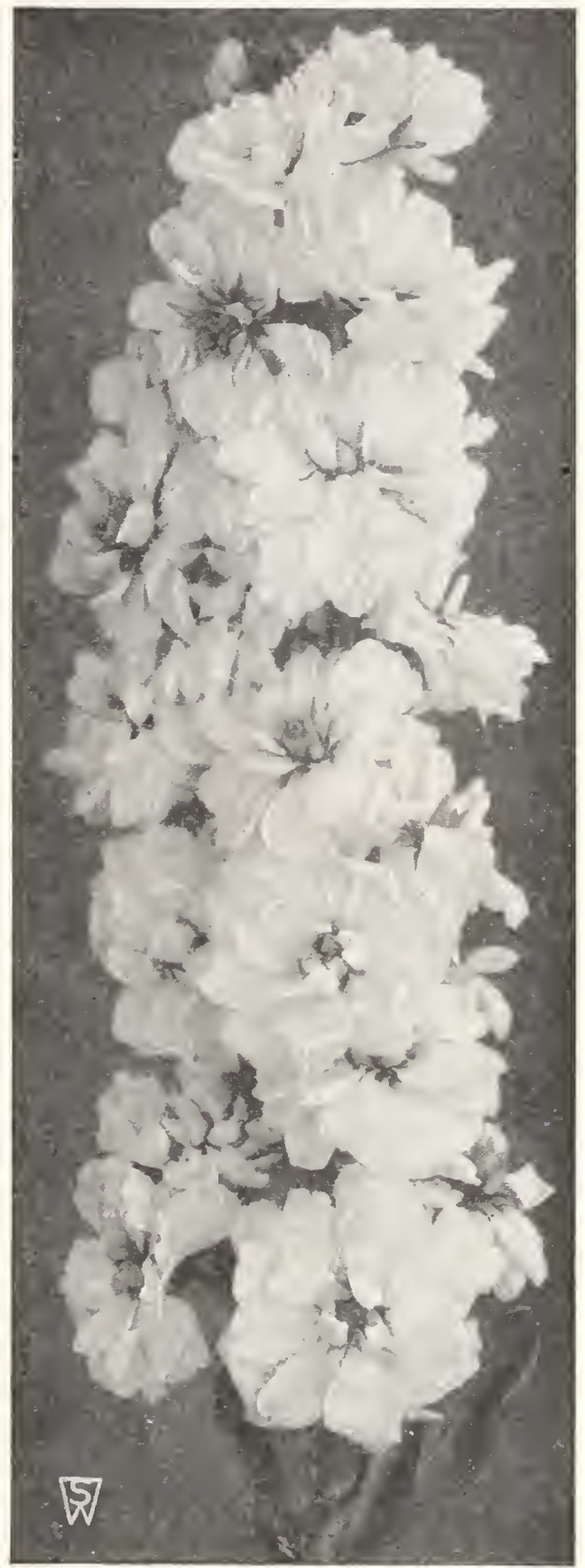

S. \& W. Co.'s Giant Imperial Stocks

\section{STOKESIA \\ Cornflower Aster}

Cyanea. This is not new, but is a rare and beautiful hardy perennial. The plant grows about 2 feet high, bearing from twenty to thirty handsome lavender-blue cornflower-like blossoms which often measure 3 to 4 inches in diameter; in bloom from July till frost. One of the choicest subjects for the perennial border and indispensable for cutting. Perfectly hardy in the latitude of New York. Pkt. I 5 cts., $1 / 4 \mathrm{Oz}$. $\$ \mathrm{I}$. 


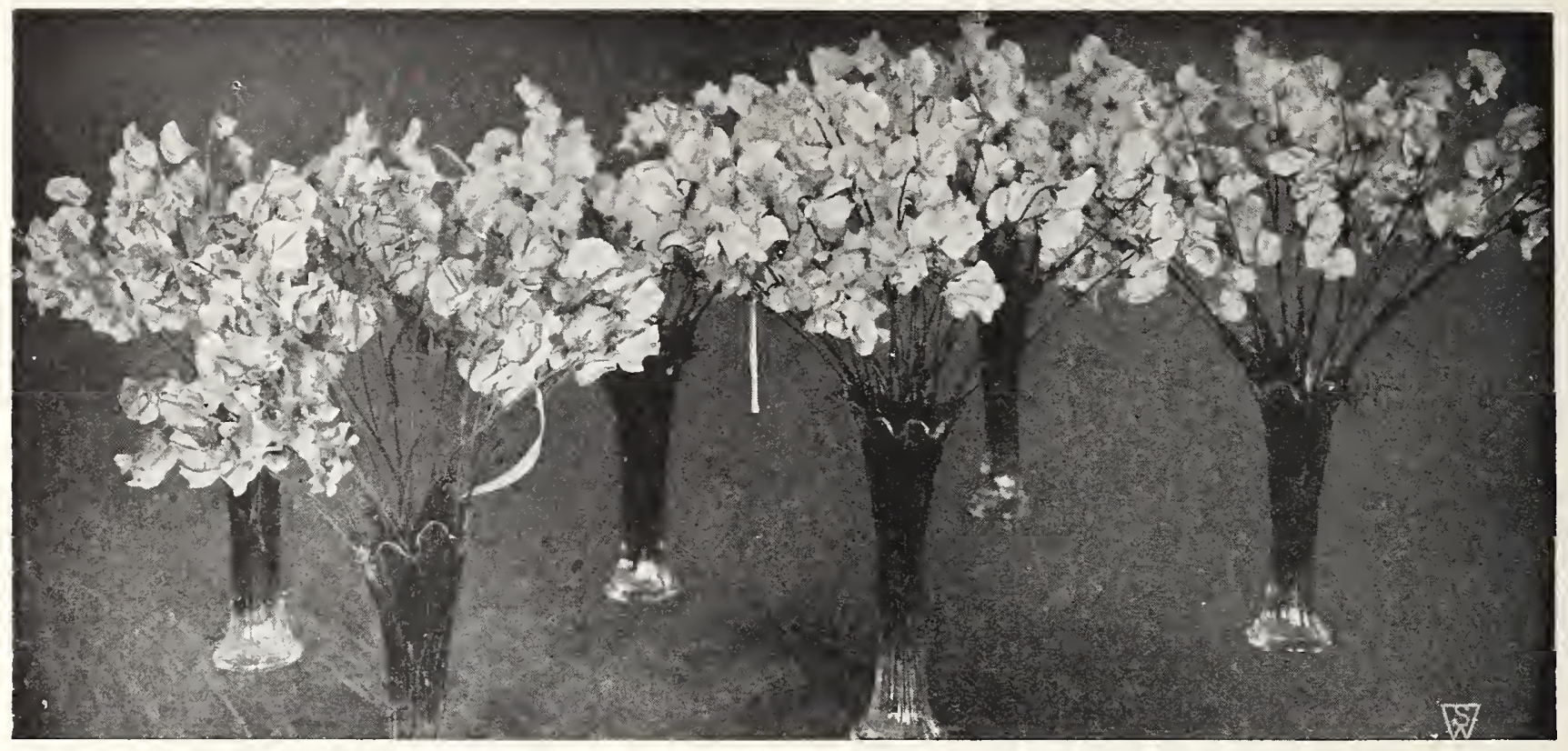

\section{NEW EARLY or WINTER-FLOWERING SPENCER SWEET PEAS}

We have great pleasure in offering to our patrons a very complete list of Early or Winter-flowering Spencer Sweet Peas. Many of our patrons grew them under glass last fall and produced wonderful results. This, however, is not the only reason Sweet Pea growers have worked to produce the large-flowering strain of Sweet Peas to flower early. This new ace of Early-flowering Spencer Sweet Peas is particularly adapted to sections where the Summer-flowering Spencer varieties have not proved satisfactory. In our southern states, Japan, Australia,

\begin{tabular}{|c|}
\hline 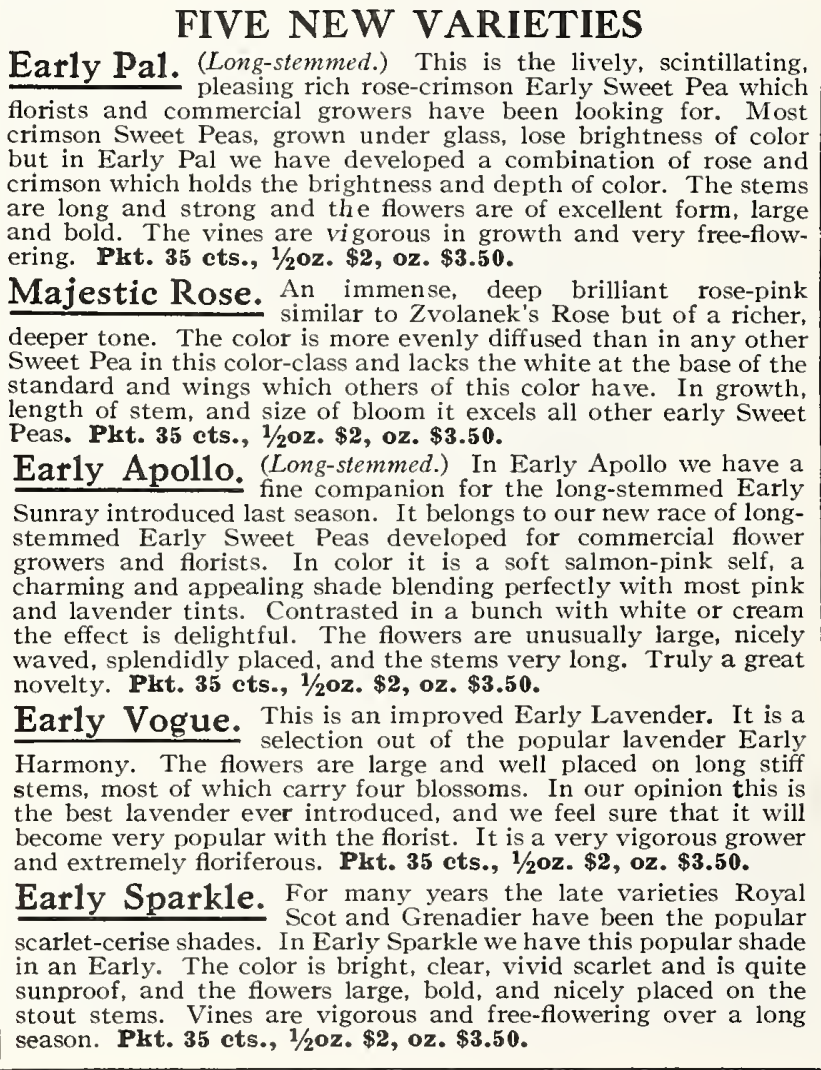 \\
\hline
\end{tabular}
as well as all tropical or subtropical countries, this strain of Early-flowering Spencers, if sown during the early fall months, will produce flowers during the winter and continue luntil killed by the extreme heat. This is a distinct advantage over the regular Spencer Sweet Peas which, if sown at the same time, will not begin flowering until April.

Early Alameda. Deep rose-pink overlaid with Pkt. 1/2oz. Oz. glowing salmon-cerise-pink.............. \$o $35 \quad \$ 2$ oo $\$ 350$

Early Belle. Clear rose-pink on deep cream ground.

Early Blue Bonnet. Beautiful deep blue shade.

Early Blue Bird. The finest Wedgwood blue; throws a small percentage of dark blue rogues, but grows more vigorously than any other blue, fully a foot higher.............

Early Cream. Best pale yellow.

Early Eldorado. Beautiful new orange..

Early Giant Rose. The finest rose-pink, bright and long lasting. Many of the 20 -inch stems bear five blossoms. .

Early Glitters. One of the finest of its color-

Early Imperial Pink. New and good. Large clear pink blooms, with long stems. .

Early Lavender King. Rich lavender

Early Marine. Wonderful clear blue.

Morse's Superior Pink. The color is a beautiful rose-pink, slightly shaded with salmon. Awarded silver medal at the New York Spring Show, and the highest award of the Chicago Florist Club-Certificate of Merit...

Early Mrs. Kerr. Best salmon-pink.......

Early Oriental. Best deep cream.

Early Snowstorm. Good white; vigorous.

Early Sunray. Brilliant cerise on a cream ground.......

Early Valencia. Best orange in cultivation...

Early White Harmony. The flowers are large and pure paper-white, of great substance. Black seed.

Zrolanek's Rose. A fine novelty of recent introduction; rose-pink. .....................

Early-flowering Mixed. A mixture of Early-
flowering Sweet Peas covering all the colors..

$\begin{array}{lllll}35 & 2 & 00 & 3 & 50\end{array}$

$\begin{array}{lllll}35 & 2 & 00 & 3 & 50\end{array}$

25

25

35

35

25

35

25

35

200

85

I 50

60 I 00

$\begin{array}{lll}75 & 300\end{array}$

200

350

85

I 50

oo 350

$60 \quad$ I 00

oo 350

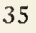




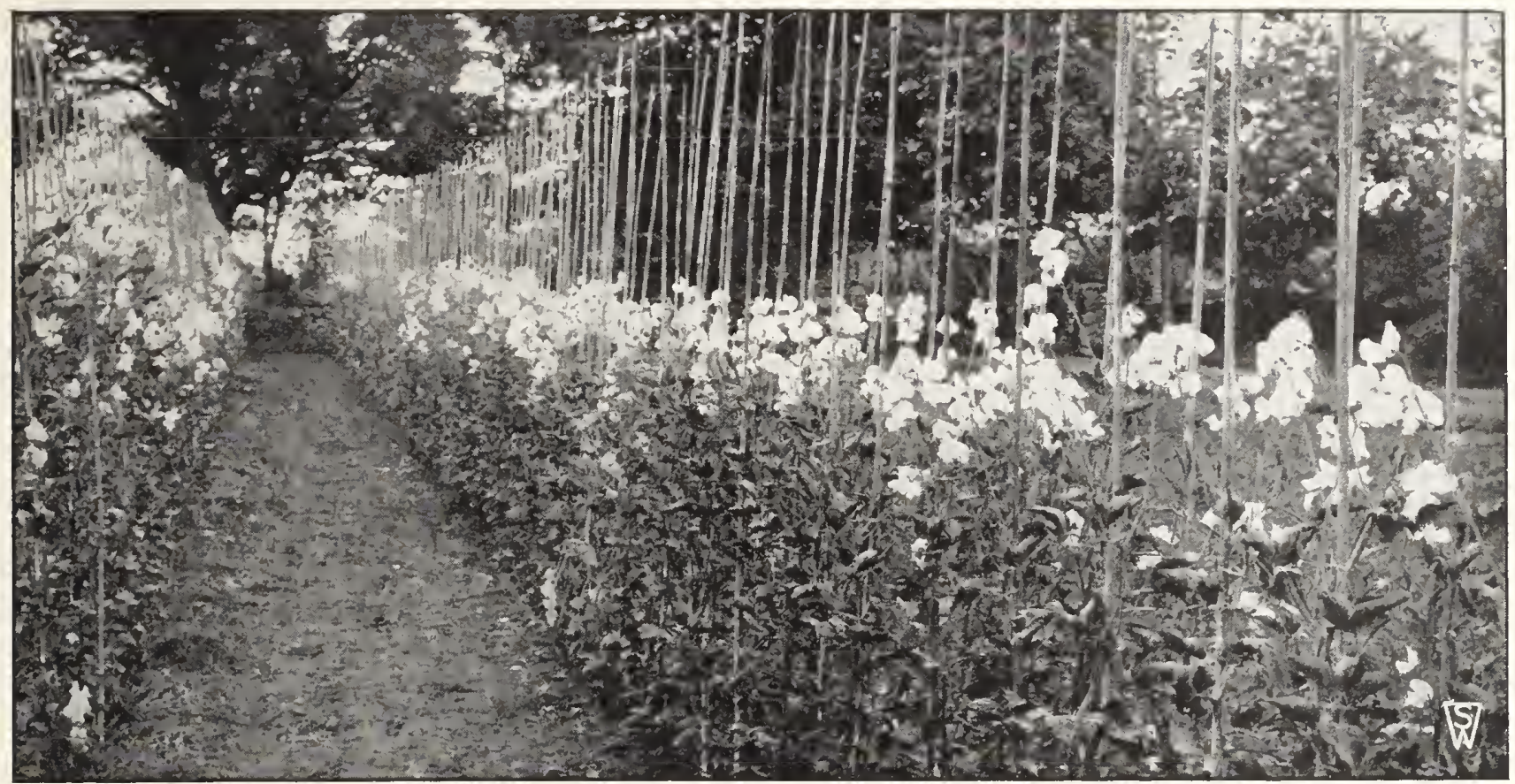

Summer-flowering Sweet Peas when grown for exhibition purposes are best grown in the manner illustrated above. The vines are trained to bamboo stakes. This insures unusually long, strong stems, frequently bearing four flowers of the very largest size. The illustration was taken from a photograph in a famous New England garden.

\section{Stumpp \& Walter Co.'s Sweet Peas}

\section{SUMMER-FLOWERING SPENCER VARIETIES}

Culture of Sweet Peas. It is a well-known fact that, in order to have largest blooms of Sweet Peas, seed must be planted sow in pots and transplant in April, or sow the previous fall.

Sow seed as soon as the ground can be worked in the spring. Dig a trench about a foot wide and deep, and fill in with 6 inches of well-rotted stable manure; tread down firmly and replace the good garden soil. Draw a single straight line in the middle of the prepared surface, about 3/4 inch deep; sow seed at even distances of about 3 inches and cover. When the plants grow about 3 or 4 inches high, thin out, leaving the plants 6 inches from each other. (Experts who raise for exhibition thin out to one foot.)

The cutworm is one of the greatest enemies of Sweet Peas, at tacking the young shoots just as they come up. At the first appearance of this pest, a good sprinkling of lime over the row sometimes helps to exterminate it. As soon as the vines reach a height of about 8 inches, proper trellis or other supports should be provided.

The Sweet Pea is a moisture-loving plant, and by the month of May the plants will require water. In order that the water may be retained by the soil and get to the roots, as well as keep them cool, it is advisable to use a mulch of old stable manure and soak well with hose each or every other day, as needed.

We believe, in submitting the following list of 41 varieties of Summer-flowering Spencer Sweet Peas, we have covered the best distinct varieties in commerce.

Austin Frederick Improved. Fine, large, bright Pkt.

lavender flowers, produced freely on long stems.. \$o I5

Avalanche. A very large flower, strong and heavy, and of the purest white.

Blue Flame. The largest dark blue Sweet Pea in existence. See Novelties, page 7o...

Bonfire. The standard is a soft, clear pink, and the wings are white. A large flower of good substance.

Carmelita. Fine, large flowers, well placed on long stems, beautiful shade of rose-pink on white ground.

Celebrity. Best orange-colored Sweet Pea. See Novelties, page 70 .

Charity. This is, without a doubt, the finest rich brilliant crimson which does not burn in the sun. A vigorous grower, the exquisitely waved flowers are usually produced in fours on long graceful stems.

Charming. Lovely shade of rosy cerise; flowers large and stems long...
$\mathrm{O} z$ \$o 75 $15 \quad 75$

25 I 00
Chieftain. Decided mauve, silky and beautiful. Pkt. This large-flowered type has been awarded a Gold Medal by the Scottish Sweet Pea Society and a Certificate of Mcrit by the National Sweet Pea Society.

Conqueror. Large, glowing cherry-cerise. See Novelties, page 70 .

Constance Hinton. Still considered the finest 75 black-seeded white.

Doreen. Very pretty shade of carmine, with long stems and good-sized flowers

5o Eosine. Beautiful tone of eosine-pink. See Novelties, page $70 . .$.

Flamingo. This is a fine exhibition variety. Sometimes as many as five flowers are produced on a single stout stem. The color is a heavy shading of cerise on a ground of orange-scarlet. .

Fortune. The standard is violet and the wings are dark blue-a lovely combination.

Gleneagles. One of the best lavenders in com50 merce. Extra-long stems and very large flowers...
$\mathrm{Oz}$.

$\$ 025 \$ 100$

25

I 50

Iо 50

25

25 I 00

25100

IO 50 


\section{STUMPP \& WALTER CO.'S SWEET PEAS, SUMMER-FLOWERING, continued}

Gold Crest. The flower is orange, and over all is a Pkt. Oz. beautiful salmon sheen-truly an art color in a fine flower of great substance............\$

Good Cheer. Lovely shade of deep begonia-rose. See Novelties, page $70 . \ldots \ldots \ldots \ldots \ldots \ldots \ldots$

Hawlmark Cerise. This variety differs from the dcep cerise form and the rose-cerise in that the blending tone is a pure salmon. Is esteemed the finest salmon-cerise.................

Hero. Cerise-salmon. See Novelties, page $70 \ldots . .$.

Huntsman. Entrancing shade of bright scarlet; sunproof. Good-sized flowers and long, stiff stems

Idyl. A beautiful salmon-pink on cream.

Kitty Pierce. (Duplex.) Lilac, suffused pink. See Novelties, page $70 . . \ldots \ldots \ldots \ldots \ldots \ldots$

Mammoth. Very pretty shade of orange-scarlet, with long stems and large flowers...........

Mary Pickford. A dainty, waved flower, the general color of which is cream-pink; a delicate over-tone of salmon, however, gives us an effect that is beautiful indeed. Long and strong stems often bear four blossoms.

Pinkie. Large; rose-pink. See Novelties, page 70.

Powerscourt. A large, fine, pure lavender variety, outstanding in its loveliness...............

Prince of Orange. This is well named, for the enormous flowers are deep orange-red in color, flame-like, rich and brilliant. A fine variety that should be included in every planting of Sweet Peas.

Reflection. A trace of mauve in the young bud disappears as the flower opens to a true, clear blue, winsome in its delicate beauty. A strong plant, producing three and four flowers on its long, sturdy stems.
I5 75

I 00

IO $\quad 5^{\circ}$

Royal Pink. This is one of the largest Sweet Pkt. Peas grown. Long stems carry enormous flowers, the ground color of which is light pink, suffused with deeper pink and shrimp-pink......\$o I5 \$0 75

Royal Purple. Without a doubt this is the finest rich royal purple. A large-flowering variety, with many four-flowered sprays. .

Splendour. Fine deep reddish maroon. One of the best in its color class, having large flowers and

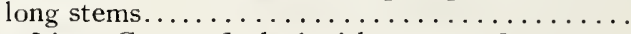

Sunkist. Cream, flecked with orange. See Novelties, page $70 . \ldots \ldots \ldots \ldots \ldots \ldots \ldots \ldots \ldots$

Supreme. A fine clear, light pink. Quite one of

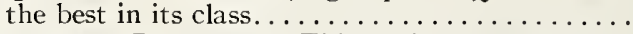

Tangerine Improved. This variety has been appropriately named-a deep orange, almost approaching the colors of the tangerine orange. Flowers of great size and well waved.........

The Sultan. Almost black-deep silky maroon. Large flowers on long, strong stems.........

Valentine. Very pretty shade of blush-pink. Flowers are large and well placed on long, stiff stems.... .

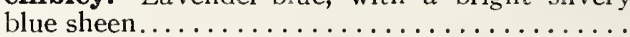

What Joy. This new variety is a beautiful primrose shade, deep and rich, and the flowers are large.

Youth. A large white flower, but on the edges of wings and standard is a blushing of delicate rose. .

\section{What Are Duplex Type Sweet Peas?}

There are as yet no true Double Sweet Peas, but careful breeding has produced types with two, three, or four standards and also several wings. These are Duplex types, and we offer several of these in the above list.

\section{Grand Prize Mixture Giant Summer-flowering Sweet Peas}

We have made a carefully balanced selection of all colors and varieties of the Spencer Sweet Peas in this mixture, using only the finest ruffled and long-stemmed sorts. For general use and garden display, Sweet Pea mixtures of this high type are most satisfactory and much less expensive than named varieties sold separately.

Packet ....................\$ $10 \quad$ Quarter-pound ...............\$0 85

Ounce..................... Half-pound $\ldots \ldots \ldots \ldots \ldots \ldots \ldots \ldots$

Pound $\ldots \ldots \ldots \ldots \ldots \ldots \ldots \ldots \ldots+\ldots$

\section{Classification of Spencer Sweet Peas}

\section{For the Gardener who desires the best variety under each color we submit the following:}

Bicolor, Bonfire.

Blue, Reflection.

Blue (Light), Gleneagles.

Blue (Dark), Fortune.

Blush (Pink), Valentine.

Blush (Lilac), Kitty Pierce (Duplex).

Carmine, Doreen.

Cerise, Charming.

Cerise (Pale), Hawlmark Cerise.

Cerise (Deep), Hero.

Cerise (Scarlet), Flaningo.

Cream, What Joy.
Cream-Pink, Mary Pickford.

Cream-Pink (Pale), Idyl.

Crimson, Charity.

Flushed (White Ground), Carmelita.

Lavender (Rosy), Austin Frederick Improved.

Lavender (Pale), Wembley.

Lavender (Lilac), Powerscourt.

Maroon (Red), Splendour.

Maroon (Dark), The Sultan.

Mauve, Chieftain.

Orange, Tangerine Improved.
Orange (Deep), Prince of Orange.

Orange (Pink), Royal Pink.

Orange (Scarlet), Mammoth.

Picotee-edged (White Ground), Youth. Picotee-edged (Cream), Sunkist.

Pink (Pale), Supreme.

Pink (Deep), Pinkie.

Purple, Royal Purple.

Salmon (Orange), Gold Crest.

Scarlet, Huntsman.

White, Avalanche.

White (Tinted), Constance Hinton. 


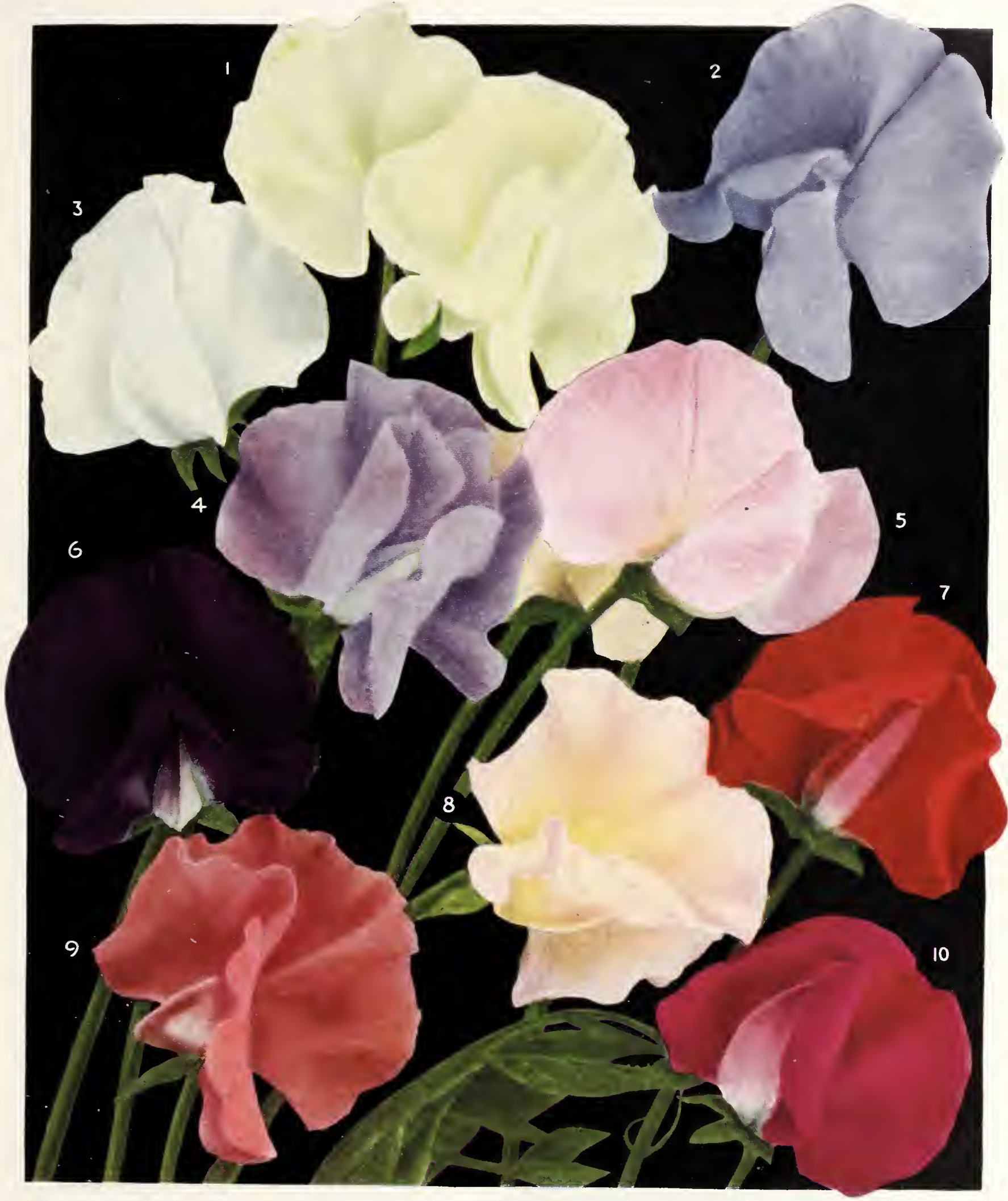

10 DISTINCT GIANT SUMMER-FLOWERING SWEET PEAS

1. CREAM

2. BLUE

3. WHITE

4. LAVENDER

5. LIGHT PINK
6. PURPLE

7. SCARLET

8. CREAM-PINK

9. SALMON-PINK

10. CARMINE

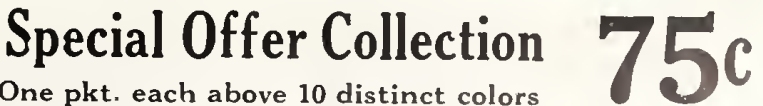




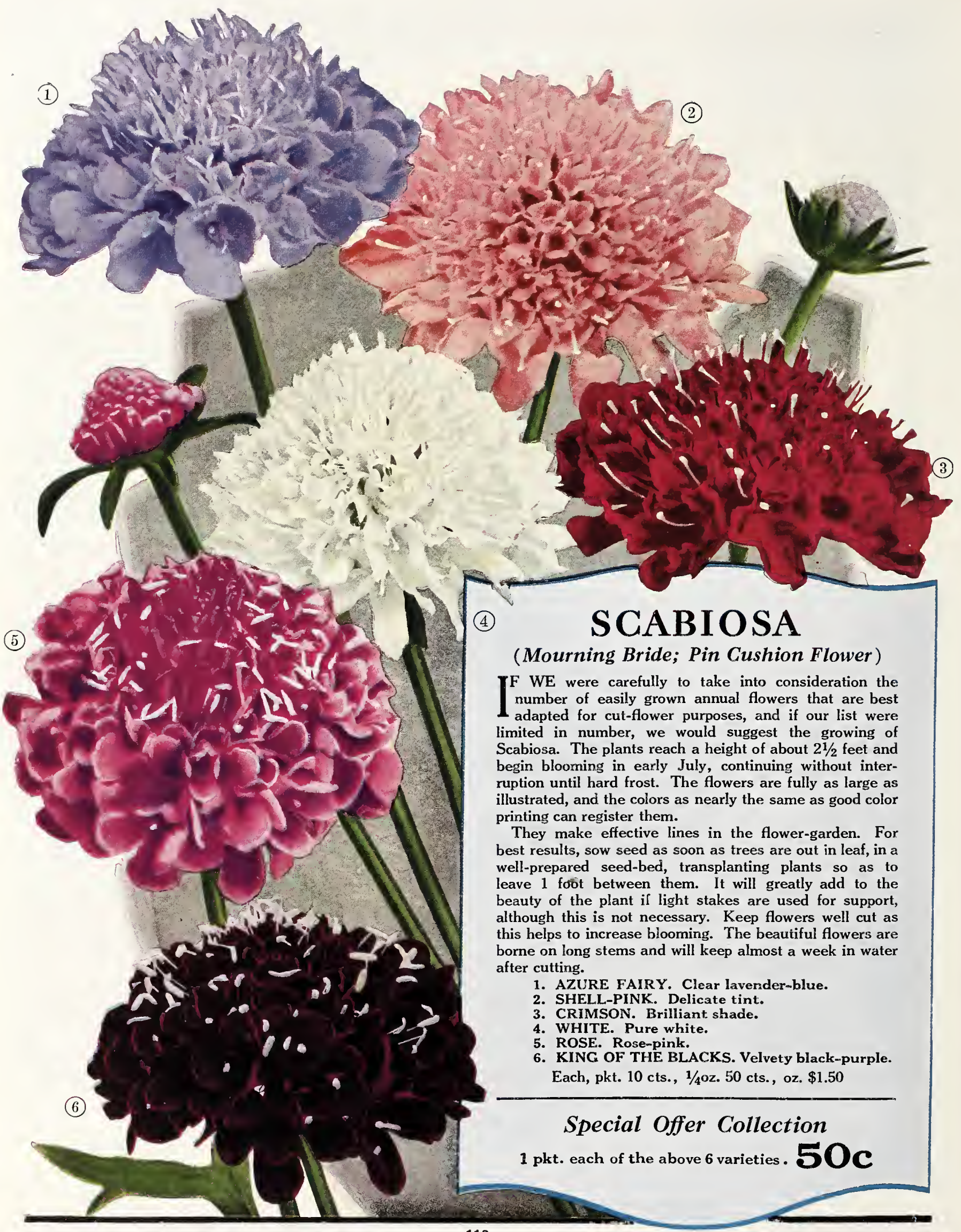




\section{TAGETES}

Signata pumila. A dwarf, compact, buslyy annual Marigold, with beautiful, delicate, fern-like leaves, densely covered with flowers of bright yellow, striped brown; a first-class border plant. Pkt. Io cts., $1 / 4 \mathrm{Oz}$. $50 \mathrm{cts}$.

\section{THALICTRUM (Meadow Rue)}

Adiantifolium. A beautiful hardy perennial, with foliage like the Maidenhair Fern and miniature white flowers in June and July. Pkt. Io cts., $1 / 40 Z$. $50 \mathrm{cts}$, oz. \$I.50.

Aquilegifolium. The foliage is similar to that of the Columbine. Rosy purple flowers in June and July. 2 to 3 feet. Pkt. $25 \mathrm{cts}$.

Dipterocarpum. Among the genus of hardy plants this is a real gem, not only for the garden, but its dainty graceful sprays of flowers elegantly arranged on stems 4 feet high, are invaluable for cutting. The flowers are a charming shade of violet-mauve, which is brightened by a cluster of lemon-yellow stamens and anthers. Pkt. 25 cts., 1/80z. \$I, 1/40Z. \$1.50.

\section{THERMOPSIS}

A very striking plant, 4 feet tall, producing long spikes of yellow blossoms during June and July. Hardy perennial. Pkt. $25 \mathrm{cts}$.

\section{THUNBERGIA (Black-eyed Susan)}

Beautiful, rapid-growing annual climber, preferring a warm, sunny situation; used extensively for hanging-baskets, vases, low fences, etc. Very pretty flowers in buff, white, orange, etc., with dark eyes. 4 feet. Mixed Colors, pkt. Io cts., 1/40z, $50 \mathrm{cts}$.

\section{THYMUS (Thyme)}

Serpyllum. A valuable hardy perennial for the alpine garden. But 4 inches high, it is of trailing habit with bright lilac-purple flowers. Pkt. 25 cts.

\section{TORENIA}

Fournieri. A very fine annual; splendid for vases, hanging-baskets, borders, etc. Sky-blue flowers, with bright yellow center. Pkt. Io cts.

\section{TRITOMA}

(Red Hot Poker; Flame Flower; Torch Lily)

A perennial, not strictly hardy, but will live through the winter with a protective covering of leaves or short manure; or the roots may be lifted and carried over winter in sand in a cellar.

Express. Orange-yellow. Height 4 feet. Pkt. $20 \mathrm{cts}$. I/40z. $75 \mathrm{cts}$. May Queen. Yellow. Height 2 feet. Pkt. $20 \mathrm{cts}, 3 / 40 z .75 \mathrm{cts}$.

\section{TROLLIUS (Globe Flower)}

Like immense buttercups, these striking plants are very effective in the mixed border. Light soil, well drained, and a partly shaded position, suit them admirably. They bloom from May to August. Hardy perennials.

Asiaticus. Orange. Height 2 feet.

Europæus. Yellow. Height 2 feet

Po 25

Ledebouri. Orange. Height 2 feet.

\section{VALERIAN (Garden Heliotrope)}

Hardy perennial. Pinnate foliage and panicles of flowers, with odor of heliotrope. 5 feet. June and July. Pkt. Oz. Red, White, Mixed, Each................. so Io so 50

\section{VERBASCUM}

Olympicum. A stately biennial, often reaching a height of 5 feet. The large leaves are covered with a silvery down, and above them rises a pyramid of bright yellow flowers. Pkt. $25 \mathrm{cts} ., 1 / 40 \mathrm{O}$. \$1.50.

\section{VERONICA}

Spicata. An elegant hardy border plant, growing about I $1 / 2$ Pkt. feet high, bearing all summer spikes of bright blue flowers.. \$o I5 Spicata Mixed

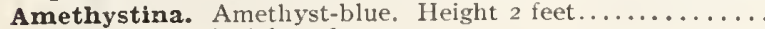

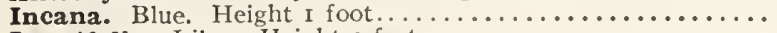

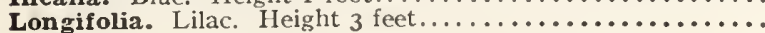

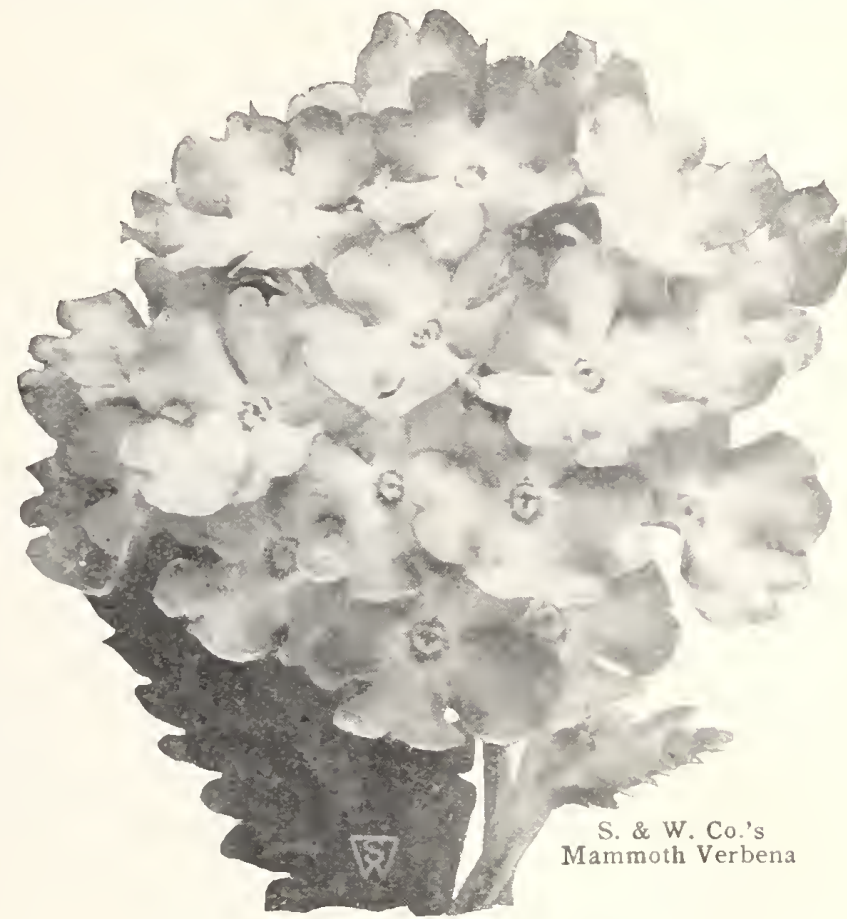

\section{MAMMOTH VERBENAS}

The trusses and individual flowers are of the largest size, of brilliant colors, free-blooming and of vigorous habit. For best and quickest results seed should be sown early in the house or hotbed, and transplanted to Howering quarters in May. If sown outdoors in May, it blooms from the end of July on.

S. \& W. Co.'s Mammoth Defiance (Scarlet), Blue, Pink, White, Striped, Yellow, and Mixed.

Each, pkt. 10 ets., 1/40z. 60 cts., oz. $\$ 2$

\section{VARIOUS VERBENAS}

Lemon Verbena (Aloysia citriodora). Every garden should Pkt. have a few plants of this fragrant favorite. Its pale green, delightfully scented foliage goes well with any flower...... \$o ro

Erinoides (Moss Verbena). This lovely variety produces a mass of moss-like foliage, spreading over the ground like a carpet, above which are borne heads of purplish blue and white blossoms in lavish profusion; comes into flower in June, and continues until frost. For beds, baskets or rockeries....

Venosa (Hardy Garden Verbena). Strong plants, I foot ligh, bear purple flowers continuously through the summer

\section{VINCA (Madagascar Periwinkle; Old Maid)}

Ornamental, free-blooming plants and one of the most satisfactory flowering bedding plants we have. It is best to start the seed early indoors or in a hotbed, but they begin blooming in August from seed sown out-of-doors in May.

Alba. Pure white.

Rosea. Rose

Rosea alba. White, with rosy eye

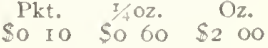

Mixed.

\section{VISCARIA, TOM THUMB}

This beautiful new race of Viscarias is quite unlike others, in that the plants are compact and bushy in form and bloom so freely as to be entirely covered. The plants grow evenly in height and require about the same time from sowing to blooming as sweet alyssum. Individual flowers resemble single wild roses in miniature form. We offer three distinct colors.

White Queen. Pure white

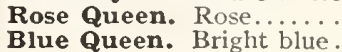
$\begin{array}{rrrr}\text { Pkt. } & 5 \text { pkts. } \\ \text { So } 25 & \text { \$I } 00 \\ 25 & \text { I } 00 \\ 25 & \text { I } 00\end{array}$ 


\section{VIOLA (Tufted Pansies)}

Violas bloom so freely that they are superior to Pansies where effect is wanted, the colors being particularly clear and distinct. They also bloom for a longer time.

Cornuta, Blue Gem (Jersey Gem). The flowers are a very Pkt. pleasing shade of deep violet-blue, with an occasional very slight variation in tint, and may be relied on to come about 70 per cent true from seed. A great feature of this fine new variety is its wonderful power of resisting drought, the plants continuing to throw up flowers long after other varieties are

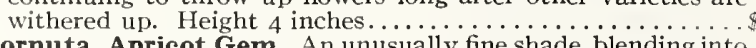

Cornuta, Apricot Gem. An unusually fine shade, blending into a deep orange center. It is of recent introduction and proved merit, and should become as popular as Jersey Gem, with which it should be grown, thus producing in our opinion, an effect impossible to surpass with any other combination of Violas. Cornuta, Mixed. A mixture including all shades ..........

\section{New Large-flowering Violas}

Aurora. Bluish purple; immense flower .....

Avalanche. (New.) Immense, pure white flowers.

John Quarton. Light mauve.

Kitty Belle. Light lavender.

Royal Sovereign. Fine yellow

William Robb. Lavender......

White Queen. Pure white.

Finest Mixed...........

VIOLET (Viola odorata). Single Sweet Violet.

\section{VIRGINIAN STOCKS}

Sown early, these pretty annuals are gay in the period between the spring and summer flowers, their fresh, bright colors in lines and beds producing a charming effect. May be sown like sweet alyssum; excellent for the border. White, Rose, or Mixed, pkt. 10 cts., oz. 60 ets.

\section{WALLFLOWER}

These half-hardy perennial and annual Wallflowers are grown for early spring bedding and for their delightful fragrance. Perennial sorts should be sown in autumn and carried over in coldframe; annual sorts may be sown indoors in March and will flower the first year from seed.

\section{SINGLE ANNUAL VARIETIES}

Pkt.

Early Parisian. Golden, shaded orange-red ............. \$o ro

“ Blood-Red. Red, orange shaded................ no “Golden Gem. Yellow Single Annual Wallflower, Mixed Colors.............. Io

The following varieties are not hardy but should be sown in early fall, and carried over winter in a frame and planted out in the spring.

SINGLE-Cloth of Gold (yellow), Eastern Queen (salmon), Ellen Willmott (ruby-red), Feltham Early (brown-red), Golden Glory (old-gold), Vulcan (deep red).

DOUBLE-Black-Brown, Canary-Yellow, Lilac, OrangeBrown, Yellow, Rosy Purple.

Any of the above varieties, pkt. 25 cts., 5 pkts. $\$ 1$

\section{ZINNIA (Youth and Old Age)}

The seed may be sown in a hotbed or sunny window and transplanted, or sown later in the open ground. The plants come into flower early in the summer and keep on blooming until hard frost. No annual excels the Zinnia in freedom of bloom. Splendid for garden decoration and for cutting.

\section{Giant Mammoth or California Giants}

This is a mutation from the Dahlia-flowered type. When in full bloom, they reach enormous size, but their flatness gives them a more graceful appearance in contrast with the Giant Doubles. They grow to the same height as the Dahlia-flowered and the blooms are larger. Cerise Queen. Beautiful cerise-rose.

Enchantress. Light rose, with deep rose center.

Lemon Queen. Lemon-orange.

Miss Willmott. Soft pink.

Orange King. Cadmium or burnt orange.

Orange Queen. Golden yellow.

Pink Profusion. Delicate shrimp-pink.

Purity. Pure white.

Rose Queen. Striking bright rose.

Scarlet Gem. Glowing scarlet.

violet Queen. Beautiful shade of violet.

Mixed. All shades.

Each, pkt. 25 cts., $1 / 40 z$. 75 cts., oz. $\$ 2.50$

\section{Giant Double-flowering}

Trials of this Zinnia sown in the open ground in April produced flowers 6 inches in diameter on plants 3 feet high. If sown in the open ground in April, thin out as soon as the plants are well up. leaving at least $\mathrm{I} 1 / 2$ feet each way, as they are robust growers, and require a large amount of space to at tain maximum size.

$\begin{array}{ccc}\text { Flesh-Pink } & \text { *Salmon } & \text { Purple } \\ \text { Buttercup } & \text { *Yellow } & \text { *Rose } \\ \text { *Scarlet } & \text { Burnt Orange } & \text { Mixed }\end{array}$

*Crimson

Each, pkt. 25 cts., $1 / 40 z .60$ cts., oz. $\$ 2$

COLLECTION: One pkt. each of the above 6 colors marked $(*) \$ 1 ; 1 / 40 z$. each of these, $\$ 3$

Tall Double-flowering Mixed. This Zinnia is similar in to our Giant Double-flowering except the flowers which are about two-thirds the size. Pkt. 10 cts., 1/40z. 30 cts., oz. \$1.

\section{Dwarf Double-flowering}

This type of Zinnia, while not so tall as our Giant Double-flowering varieties, offered above, is a very satisfactory type for borders or cutting. Grows about I $1 / 2$ feet high; flowers perfect.

Crimson

Scarlet Salmon-Rose

$$
\begin{array}{ll}
\text { White } & \text { Salmo } \\
\text { Golden } & \text { Mixed }
\end{array}
$$

Each, pkt. 15 ets., 1/40z. 50 cts., oz. $\$ 1.50$

\section{Giant Double Dahlia-flowered}

The plants attain a height of 3 feet, producing mammoth flowers averaging 6 inches across by 3 to 4 inches in depth, similar in. shape to the Decorative dahlia, with the same fullness of the petals.

\section{Two Fine New Varieties}

Golden Dawn. Pure golden yellow.

Youth. Beautiful light rose.

Plt. 25 cts., $1 / 4$ oz. $\$ 1$, oz. $\$ 3.50$

\section{Six Popular Varieties}

Buttercup. Very large flowers of deep creamy yellow.

Crimson Monarch. Immense flowers of flaming crimson.

Dream. Deep lavender-blue - a remarkable shade.

Exquisite. Light rose, with deep rose center.

Oriole. A striking two-color flower-orange and gold.

Scarlet Flame. Bright scarlet, blended with orange.

Each, pkt. 25 cts., $1 / 4$ oz. $\$ 1$, oz. $\$ 3.50$

COLLECTION: One pkt. each of above 6 colors, $\$ 1$

Mixed Dahlia-flowered Zinnias. Pkt. $25 \mathrm{cts}$., $1 / 4 \mathrm{Oz} . \$ \mathrm{I}, \mathrm{oz} . \$ 3.5 \mathrm{O}$.

\section{Zinnia, Lilliput}

This variety forms a bush about I foot high, and is covered with small, very double flowers in profusion.

Canary-Yellow

Scarlet Gem (Red Riding Hood) Salmon-Rose

Delicate Flesh-Pink crimson) Finest Mixed

Each, pkt. 10 ets., 1/40z. 50 cts., oz. $\$ 1.50$

\section{Various Zinnias}

Various types of Zinnias, all of which, on account of the odd formation of the flowers, should be more generally cultivated.

CURLED AND CRESTED. The petals of this strain are curled and crested into the most fantastic and graceful forms. Our mixture includes all the brilliant shades. Pkt. $10 \mathrm{cts} ., 1 / 40 z$. 50 c.

HAAGEANA. A dwarf, compact variety growing 9 to Io inches high, and bearing masses of double flowers $I \frac{1}{2}$ inches through in a most unusual range of color-rose grounds tipped yellow, maroon ground tipped cream, yellow tipped wallflower-red. Pkt. 15 cts., 1/40x. \$1. 


\section{Ornamental Grasses}

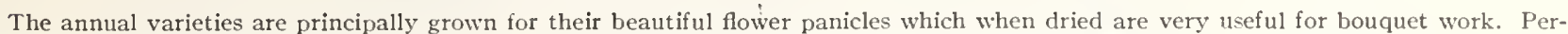

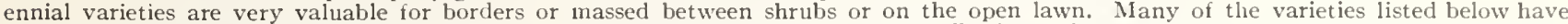
beautifully variegated foliage and, when planted as indicated above, they are most effective and pleasing.

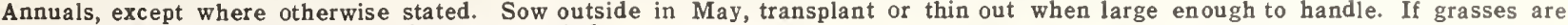
cut before they are ripe, they will keep for a long period.

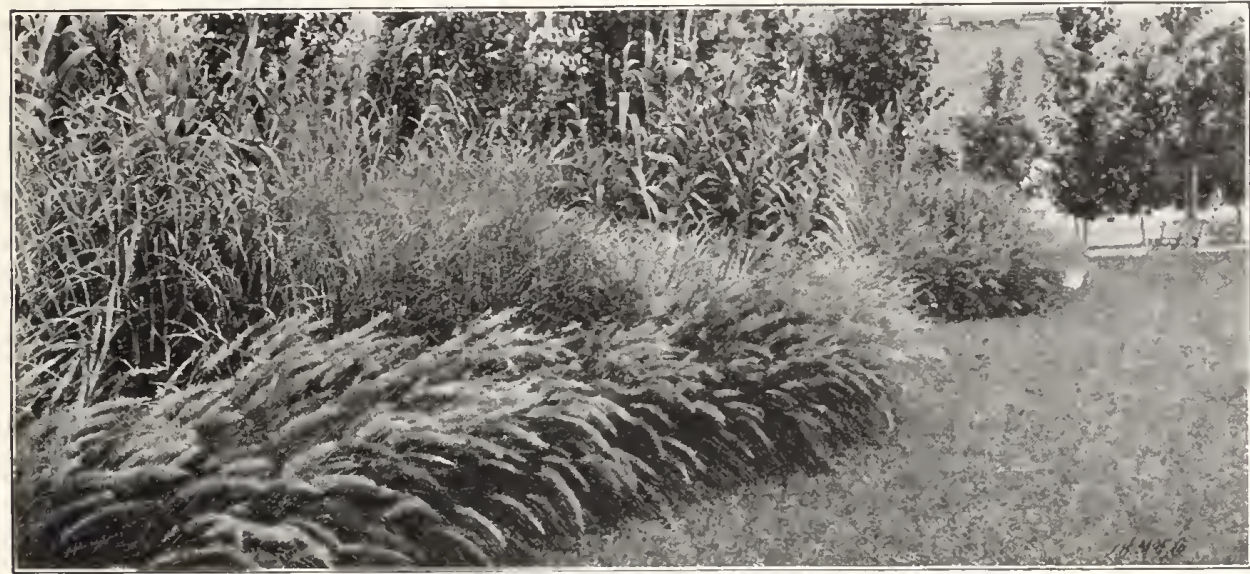

A Bed of Ornamental Grasses

AGROSTIS nebulosa. Annual. A very beautiful variety. Pkt. Io cts.

Pulchella. A very striking sort. Pkt. Io cts.

ANTHOXANTHUM gracile. Annual. Useful for edging. Pkt. Io cts.

BRIZA compacta. Very pretty annual. I 8 inches. Pkt. Io cts. Geniculata. Very pretty annual. I8 inches. Pkt. Io cts.

Gracilis. Very pretty annual for bouquets. I 2 inches. Pkt. Io cts. Maxima. Considered by many to be one of the best varieties for bouquet and dried flowers. Annual. I 2 inches, Pkt. Io cts.

BROMUS brizaeformis. Large drooping panicles, useful for bouquets. Annual. 2 feet. Pkt. Io cts.

CoIX lacryma (Job's Tears). A strong broad-leaved grass with large shining pearly seeds. Annual. 3 feet. Pkt. Io cts.

ERIANTHUS Ravennæ. A hardy perennial grass resembling the Pampas, with beautiful foliage and fine silvery plumes; excellent for lawn specimens. Blooms first year from seed if sown early. Pkt. Io cts.

Special Collections: 1 pkt. each, 6 varieties.

1 pkt. each, 12 varieties.

ERAGROSTIS elegans (Love Grass). Annual. I foot. Pkt. ro cts.

EULALIA japonica foliis vittatis. A very beautiful perennial variety used for forming large clumps. Leaves dark green, striped white. 4 feet. Pkt. ro cts.

Zebrina (Zebra Grass). A very striking variety, very extensively used where an attractive variegated variety is wanted. 4 feet. Pkt. Io cts.

G YNERIUM argenteum (Pampas Grass). Perennial, with magnificent silvery plumes. 6 feet. Pkt. Io cts.

Jubatum. Panicles silvery rose. Pkt. ro cts.

HORDEUM jubatum (Squirrel Tail Grass). Annual. Used for bouquets. 2 feet. Pkt. Io cts.

ISOLEPIS gracilis. Graceful dwarf grass for pots. Pkt. $25 \mathrm{c}$.

LAGURUS ovatus. Hardy annual, with silvery gray tufts. I foot. Pkt. Io cts.

PENNISETUM longistylum. An annual grass with gracefully drooping heads. 2 feet. Pkt. Io cts.

Ruppellianum. The foliage is long and slender, gracefully recurved and glossy deep green in color. If sown in March in heat, the plants should bloom by the middle of July; sown outdoors, will bloom in August. The silvery plumes, tinted with violet-purple, waving in the sunlight, are exquisitely beautiful hardy perennial. 3 feet. Pkt. Io cts.

STIPA pennata (Feather Grass). With silvery white feathery plumes. Pkt. $25 \mathrm{cts}$.

SETARIA macrochaeta. Drooping plumes of graceful appearance. Annual. Pkt, Io cts.

UNIOLA latifolia. Perennial; very pretty. Pkt. Io cts.

ZEA japonica. Striped maize. Pkt. Io cts.

TALL. Annual Varieties, Mixed. Pkt. ro cts.

DWARF. Annual Varieties, Mixed. Pkt. Io cts.

\section{Everlasting Flowers sow outside in May and thin 0 out to incest}

ACROCLINIUM. Hardy annual. Good for cutting. Double White, Double Pink, Single Rose, and Double Mixed. Each, pkt. ro cts.

GLOBE AMARANTH (Gomphrena). Sometimes called "Bachelor's Buttons." Popular bedding annuals; flowers resemble clover heads and can be dried and used in winter bouquets. Rose, White, Purple, and Mixed. Each, pkt. Io cts., oz. 75 cts.

HELICHR YSUM (Straw Flower). One of the best and most popular of the "Everlastings." Annual. Very effective double flowers, making a fine display in beds or borders. To produce excellent plants thin out to 2 feet. Rose Queen, Snowball, Salmon Queen, Golden Ball, Fireball, Violet Queen, and Mixed. Each, pkt. I5 cts., $1 / 4 \mathrm{Oz}$. $50 \mathrm{cts}$., oz. \$I.50.
RHODANTHE. Very beautiful, delicate looking "Everlastings," much prized for winter bouquets. Annual.

Maculata. Single White, Rose, and Mixed. Each, pkt, Io cts STATICE (Sea Lavender). Splendid hardy perennials, either for the border or rockery, producing all summer panicles of minute flowers, which can be dried and used for winter bouquets. Mixed varieties. Pkt. Io cts.

XERANTHEMUM annum (Immortelle). Grows about 3 feet high, and can be sown in the open ground early in May, growing readily in any open, sunny position, remaining in bloom from early summer until frost, bearing in abundance. Annual. Rose, Purple, White, and Mixed. Each, pkt. Io cts.

SPECIAL COLLECTION: One pkt. each, 6 varieties, 50 cts.

\section{Ornamental Beets}

BRAZILIAN. Golden-leaved, scarlet-veined and crimson-veined. DELL'S CRIMSON. A small, compact-growing variety, with Pkt. Io cts., oz. 50 cts. 


\section{NEW AND CHOICE CANNAS}

\section{DORMANT ROOTS}

The wonderful size of flowers, depth of coloring, and graceful habit of plants in the modern Canna have greatly increased its usefulness to the garden-lover. It is much to be regretted that we occasionally observe mass plantings at railroad terminals and at some of our public institutions of the old Indian Shot. The modern Cannas we offer on this page are so far superior in every way that we feel certain that in a few years hence they will not only be used extensively for mass planting in beds, but will also be used in hardy borders, particularly for their foliage and color effect.

Dormant roots of Cannas should be potted in 4- or 5-inch pots or planted in shallow boxes in March or April, and kept in a warm place to start them into growth. The started plants may be planted out about May 20 to June 10 in the vicinity of New York; earlier in the South and later in the North. They should be set about 2 feet apart.

\section{City of Portland}

This variety and Hungaria might easily be called the best two pink Cannas. It is a trifle taller in growth than Hungaria and of a deeper tone of salmon-pink, with beautiful green foliage. Height $4 \frac{1}{2}$ feet.

\section{Eureka}

Canna hybridizers have worked patiently ever since the time of the introduction of the modern Canna, to produce a pure white one. In offering Eureka we feel that our patrons are using the best all-round white variety for general mass planting or bedding. Height + feet.

\section{Hungaria}

The ideal pink bedder. Flowers large, in good trusses; color not unlike that of Paul Neyron rose. One of the best of the newer introductions, the finest pink bedding Canna as yet introduced. Height $31 / 2$ feet.

\section{King Humbert}

Of superlative beauty and by far the finest of all bronze-leaved Cannas. The enormous trusses are made up of flowers that measure 6 inches across, and are a rich salmon-scarlet, distinctly and numerously flecked with deep crimson markings. It is a free bloomer, and with its rich, coppery bronze, massive foliage, it produces an effect both bold and striking. Height 5 feet.

\section{Louisiana}

An orchid-flowering variety of vivid scarlet. The long silky flowers are borne well above the foliage. The beautiful bronze foliage contrasts well with the vivid color of the flower. Height 6 feet.

\section{Mrs. Pierre S. du Pont}

Without a doubt this variety is the leader of all Cannas in the pink section or, for that matter, of any other color introduced 111 to the present time. The foliage is of truly tropical effect, being very broad and long, dark green, and offers a beautiful foil for the gigantic trusses of bloom. Color best described as watermelon-pink. Height 4 feet. 50 cts. each, $\$ 5$ per doz., $\$ 40$ per 100 .

\section{Richard Wallace}

While this variety is not new, it still remains among the best of the canary-yellow sorts. The habit of the plant is excellent. The flowers are very large and are borne gracefully above the foliage. Height $4^{T / 2}$ feet.

We offer Choice Roots of any of the above varieties, $20 \mathrm{cts}$. each, $\$ 2$ per doz., $\$ 15$ per 100, except where noted 


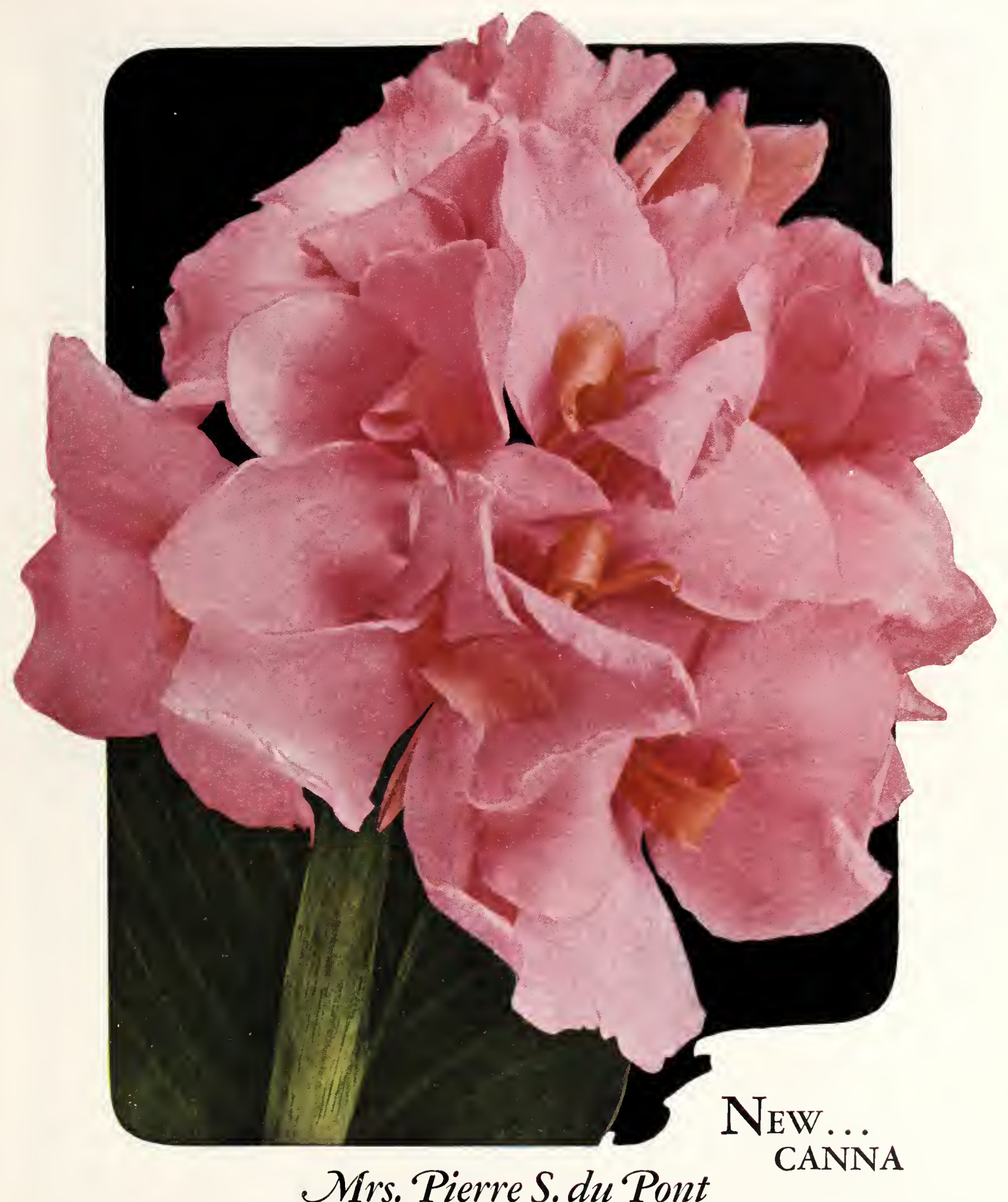

WiThour doubt, this variety is the leader of all any other color introduced up to the present time. The dark green foliage is of truly tropical effect, being very broad and long, and offering a beautiful foil for the gigantic
$\$$ trusses of bloom. Poised on large, heavy stems, it is nothing unusual for these trusses to attain a diameter of a foot or more. The color, as described by the raisers, is watermelonpink, a new shade in Cannas, and as beautiful as it is new. We cannot too highly recommend this glorious variety. 


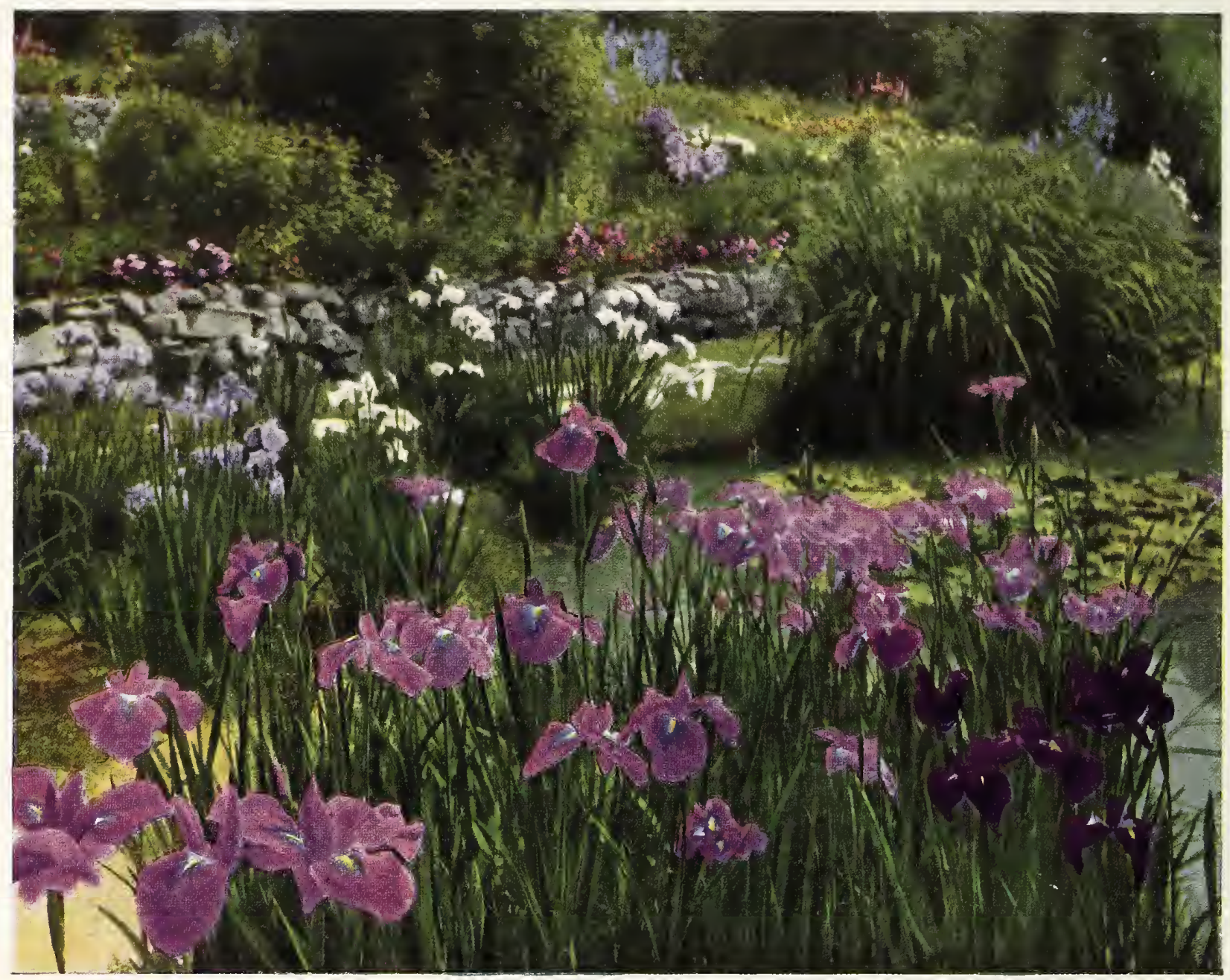

The illustration above features four new Japanese Irises - White Giant, Blue Giant, Violet Giant, and Mahogany Giant

\section{Four Fine New}

VIOLET GIANT. Rich violet, shading to rose. Flower of gigantic size, semi-double. A wonderful grower, distinct in color from any existing varieties. The flowers frequently measure 27 inches in circumference.

BLUE GIANT. We consider this the finest Japanese Iris of its colora beautiful bright blue. The flowers measure 25 inches in circumference.

Any of the above Giant Varieties, $\$ 3.50$ each, $\$ 35$ per dozen

\section{Special Offer Collection: One Each of the 4 Varieties, $\$ 10$}

\section{STANDARD VARIETIES OF JAPANESE IRIS}

CHOSEIDAN. Double-flowered type of ruby-crimson. There are small yellow blotches surrounded by white halos which radiate in broad lines. 50 cts. each, $\$ 5$ per doz.

GOLD BOUND. For all general purposes the best white variety. Not as large as White Giant but a strong-growing kind and one of the best. 50 cts. each, $\$ 5$ per doz.

GRACE SPERLING. Single. Hortense-violet; petaloid stigmas light Hortense-violet. Very early. $50 \mathrm{cts}$. each, $\$ 5$ per doz.

KAMATA. Deep bue, veined with white. A single-flowered variety and quite distinct. $50 \mathrm{cts}$. each, $\$ 5$ per doz.

LA FAVORITE. Large, double, wavy flowers, white veined blue, purple center. $50 \mathrm{cts}$. each, $\$ 5$ per doz.

LAVENDER QUEEN. Very large, single variety of soft even Iavender color. 75 cts. each, $\$ 7.50$ per doz.

MAHOGANY. An attractive red, shaded maroon. Flowers are not as large as some other varieties, but the color of this double-flowered form makes it a favorite. $60 \mathrm{cts}$. each, $\$ 6$ per doz.
MRS. GEORGE STUMPP. Pure white, except for a cast of blue. A single-flowered type. 50 cts. each, $\$ 5$ per doz.

PAINTED LADY. Single. White, center blotched light phloxpurple. The tufts are also white, edged with the same phloxpurple shade. $50 \mathrm{cts}$. each, $\$ 5$ per doz.

PYRAMID. A tall-growing variety. Dark violet-purple in color, with a bright yellow blotch. A double-flowered form of large size. 75 cts. each, $\$ 7.50$ per doz.

RED RIDING HOOD. Single. Fine amaranth, veined and suffused white. 60 cts. each, $\$ 6$ per doz.

ROSE-ANNA. Ivory-white, with heavy ruby-red veins, and conspicuous yellow blotch; stigmas dark plum. A double-flowered type. $60 \mathrm{cts}$. each, $\$ 6$ per doz.

VIOLET BEAUTY. Deep violet. An outstanding variety. The flowers are single in form but very large and very attractive. $75 \mathrm{cts}$. each, $\$ 7.50$ per doz. 


\section{GERMAN IRIS (Iris germanica)}

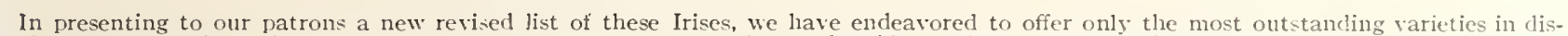

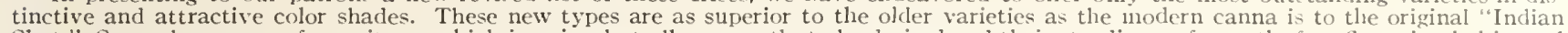

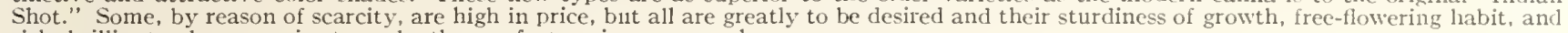
rich, brilliant colors promise to make them a feature in every garden.

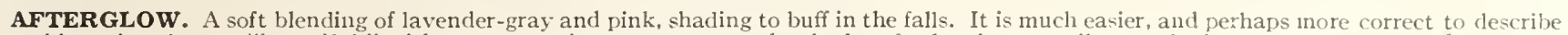

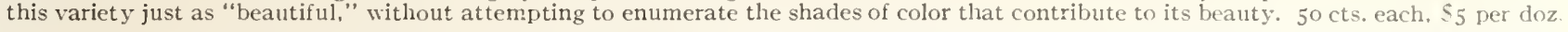

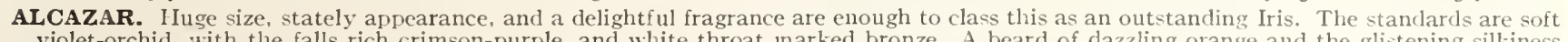

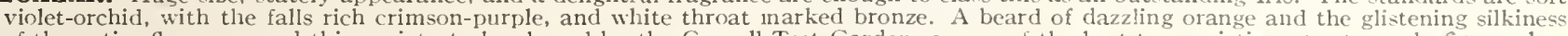

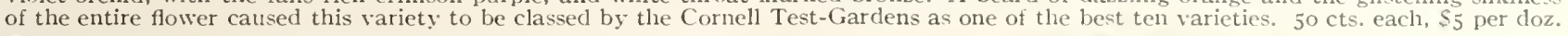

AMBASSADEUR. Judged the most popular Iris in the world by vote of tha American Iris Society. Its coloring is rich throughout, with a charming variety of tints and shades that makes description difficult. The falls are rosy lilac and the standards rich reddish purple. Placed where the rays of the sun shine through it, it appears to be rich ruby-red. SI each, SIo per doz.

ASIA. An aristocrat among Irises. Tall and stately, often growing well over 4 feet in height. The standards are pale silvery lavender, with golden base, with the falls rosy lavender, margined lighter; bright golden yellow beard. A flower of great elegance, both dainty and rich. \$r.75 each, \$I 7.50 per doz.

BALLERINE. This is a favorite among the light blue varieties. The large flowers are produced freely, and are of dainty coloring. They appear quite late, are very fragrant, and are borne on strong, 4-foot stems. \$I eacl, \$IO per doz.

BRUNO. Among the finest of Irises, this variety is a leader. Its qualities are such that it is regarded as the parent of varieties of the future. The flowers, which are large and of fine form, are remarkable for their heavy; plush-like text ure which brings out the beauty of the exquisite coloring to the highest degree. The standards are of heliotrope, flushed bronze, with falls of rich purple, sliaded violet, veined with white in the throat. \$5 each, \$5o per doz.

CLUNY. A tall-growing variety with standards of light lavender; falls darker lavender, shading to blue, with purplebrown markings at the base. \$I each, \$Io per doz.

DOMINION. A forerunner of a new race of Irises. It is the original variety of the class now known as "Dominion Iris," which is characterized by the heavy. plush-like texture of its blooms and their rich, deep coloring. Dominion is the first and, by inany, is considered the best of this race. The standards are of steel-blue and the falls deep rich indigo-purple. \$7.50 each, \$75 per doz

DREAM. Soft, clear, uniform pink. Daintiness and charm find a home with this exquisitely pletty Iris. Truly one of our most attractive varieties, and loved by all Iris enthusiasts. 50 cts. each, $\$ 5$ per doz.

FAIRY. One of the few older varieties that has stood the test of time and the competition of the novelties offered today. With some, its delicious orangeblossom fragrance cannot be duplicated by any other variety. The falls and standards are milk-white delicately penciled and margined light blue, with a bright golden beard. $30 \mathrm{cts}$. eacl, $\$ 3$ per doz.

FRIEDA MOHR. A giant-flowered pink variety that measures up to 7 inches across. The flower, in spite of its huge size, is perfectly formed, of good texture and brilliantly colnred. In addition to being one of the largest-flowered varieties in commerce, it is very frce flowering and blooms over a long period of time. Certainly an outstanding variety. \$5 each, $\$ 50$ per doz.

GOLD IMPERIAL. Deep chrome-yellow throughout, enlianced by a bright orange beard. A greatly admired variety and considered one of the finest of the yellow Irises. \$I.50 each, \$I 5 per doz.

GREVIN. Height and rich coloring make this an outstanding variety in the garden. It is a rich redpurple throughout and a favorite variety. $75 \mathrm{cts}$. each, $\$ 7.50$ per doz.

JACQUELINE GUILLOT. Among the largerflowered varieties, this is unique in color. The blooms are finely formed, silky in texture, and of a beautiful bluish violet throughout. A French variety that has found an enviable place with American Iris fanciers. \$I.75 each, \$I 7.50 per doz.

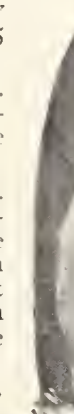




\section{GERMAN IRIS, continued}

KHEDIVE. Another of the older varieties that it has not been easy to replace. Standards beautiful soft lavender; falls white, veined brown. $30 \mathrm{cts}$. each, $\$ 3$ per doz.

LENT A. WILLIAMSON. One of the best garden Irises, and ranked in 1922 as the best Iris in the world. The standards are of lavenderviolet and the falls royal purple. The fine form and great substance of the flowers make this variety a prize-winner. $60 \mathrm{cts}$. each, $\$ 6$ per doz.

LOHENGRIN. Foliage and flowers of gigantic size, with petals 2 inches wide. Standards and falls are of a uniform shade of violet-mauve. $50 \mathrm{cts}$. each, $\$ 5$ per doz.

LORD OF JUNE. The older sorts cannot compare with this peer of blue varieties. The blooms are huge in size, dwarfing other varieties in the garden, and possess an enchanting fragrance. The standards are soft lavender-blue and the falls rich violet-blue. $50 \mathrm{cts}$. each, $\$ 5$ per doz.

MAGNIFICA. Many things contribute to the beauty of this stronggrowing variety. The blooms are delightfully fragrant, of heavy texture and large size. The general color is violet, in the standards shaded blue, and in the falls shaded red. \$I each, \$IO per doz.

MARSH MARIGOLD. A unique and variegated color-scheme places this in a limited and very desirable class. Rich buttercupyellow is the sole color of the standards; the falls are hrownish red, with a heavy margin of the same buttercup-yellow. The heard, too, is yellow. The contrast of colors is delightful. \$I each, \$IO per doz. MEDRANO. Especially valuable becalse of its low growth, being but 2 feet in height. The standards are red-copper, with a suggestion of violet; falls dark crimson-purple, flaked buff and lavender. $75 \mathrm{cts}$. each, $\$ 7.50$ per doz.

MME. CHOBAUT. A late-flowering variety of most unusual color. As a whole it is a pretty shade of yellow. The standards are ruffled, and overlaying the yellow is a flush of rosy bronze; falls are stippled and marked red, with the throat veined the same color. A rich orange beard adds to its attractiveness. 75 cts. each, $\$ 7.50$ per doz.

MOLIERE. Standards of light blue, overlaid brown; falls purplish maroon, lighter at the edges. Flowers of large size, fine form and substance. $75 \mathrm{cts}$. each, $\$ 7.50$ per doz.

MORNING SPLENDOUR. An American introduction of great merit. The blooms, which are sweetly scented, are of deep rich purple. Very fine habit, form, and substance make it an excellent garden variety. \$I.75 each, \$17.50 per doz.

MOTHER OF PEARL. This variety is well named. Introduced several years ago, it has become a favorite. Iridescent shades of motherof-pearl suffuse the entire bloom, which is of large size and perfect shape. The white throat is overlaid with gold. \$I each, \$I per doz.

OPERA. The limited class of violet-red Irises was greatly enriched with the introduction of Opera. Silky blooms of rich violet-red

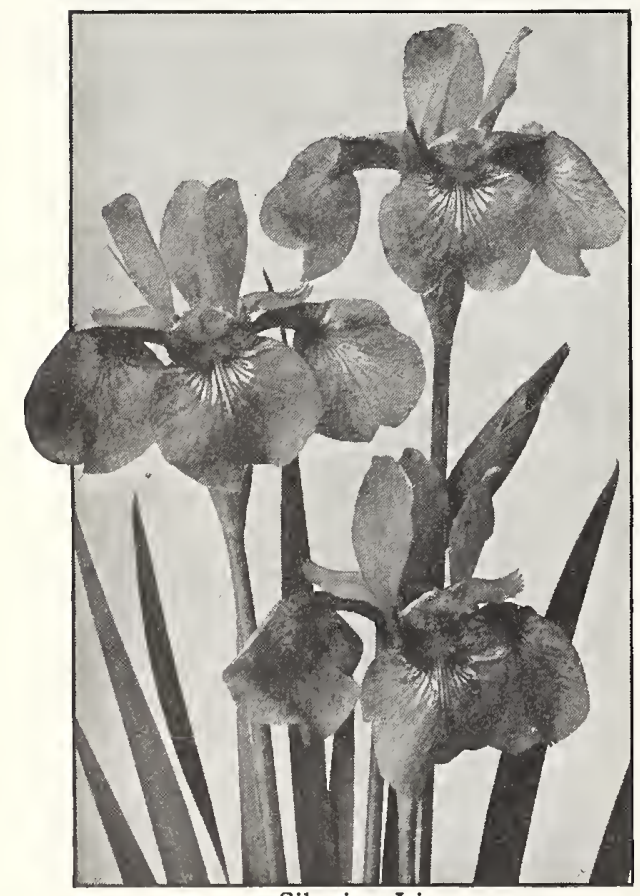
are produced in 2-foot stems. The beard, too, is of a decidedly reddish tone. 75 cts. each, $\$ 7.50$ per doz.

PALLIDA,ALBERT VICTOR. Another of the older varieties that it has been hard to duplicate. Standards soft blue; falls lavender. $30 \mathrm{cts}$ each, $\$ 3$ per doz.

PERFECTION. Standards light blue; falls dark violet. A very free-flowering variety and an excellent one for the garden. $40 \mathrm{cts}$. each, $\$ 4$ per doz.

PRINCESS BEATRICE. Pure, soft, lustrous lavender. Blooms of large size and fine shape. An outstanding variety in its color, and rated as one of the most perfect of Irises. \$I each, \$10 per doz.

PRINCESS VICTORIA LOUISE. The combination of colors found in this variety has kept it in the front rank. The standards are sulphur-yellow and the falls rich plum, bordered cream. $30 \mathrm{cts}$. each, $\$ 3$ per doz.

PROSPER LAUGIER. One of the finest varieties in which bronze predominates, and rated by many as the best in existence. The standards are a glistening fiery bronze, and the falls rich ruby-red with a velvety sheen. The throat is white, netted with old-gold. A glistening orange beard still further adds to its attractiveness. 50 cts. each, $\$ 5$ per doz.

QUAKER LADY. One more of the older varieties that we have retained because of its unquestioned merit. Vigorous in growth and beautiful in color. The standards are smoky lavender and the falls of the same shade overlaid with gold. $35 \mathrm{cts}$. each, $\$ 3.50$ per doz.

QUEEN ALEXANDRA. Standards fawn, shot with lilac; falls bronze with yellow beard. $30 \mathrm{cts}$. each, $\$ 3$ per doz.

QUEEN CATERINA. The most striking point about this variety is the contrast between the pale lavender-violet of the standards and falls and the brilliant orange beard. Under certain conditions of light it appears toned with pink. A delightful fragrance is another point in its favor. $50 \mathrm{cts}$. each, $\$ 5$ per doz.

RAFFET. A variety combining several shades of violet in a most attractive fashion. The standards are intense violet-blue and the falls darker violet, marked white. $50 \mathrm{cts}$. each, $\$ 5$ per doz.

RHEIN NIXE. A very old variety that more than holds its own with recent novelties. The standards are snow-white and the falls rich pansy-violet, with a margin of white. It is of high rating and almost perfect in form and substance. $35 \mathrm{cts}$. each, $\$ 3.50$ per doz.

SEMINOLE. In the limited class of crimson Irises, this is king. No other Iris has yet been introduced to equal it in brilliancy of color. It is a bright velvety zed-purple throughout, with a striking orange beard. 50 cts. each, $\$ 5$ per doz.

SHEKINAH. Considered to be the best all-round yellow obtainable. The standards are slightly ruffled and of clear soft yellow; falls are of the same color, with a fine golden beard. Perhaps not as large as some others, but by far the most attractive for the garden. $50 \mathrm{cts}$. each, $\$ 5$ per doz.

SHERWIN WRIGHT. Fine deep yellow throughout. Perfectly hardy and excellent for landscape work. $35 \mathrm{cts}$. each, $\$ 3.50$ per doz.

SOUV. DE MME. GAUDICHAU. To France we owe this peer of all purple Irises. It is superior to any other variety in this color class, being larger, darker and of higher rating. The standards are dark purple and the falls are even a shade darker, with blackish sheen. Even the beard is of the same color. In addition, it possesses a delightful fragrance. \$I each, \$IO per doz.

SUSAN BLISS. Here, almost at the end of our list, we place the finest pink Iris. Welcomed with enthusiasm by Iris-lovers, it has well deserved their praise. Orchid-pink blooms of perfect form proudly surmount tall, strong stems. \$I.50 each, \$I 5 per doz.

WHITE KNIGHT. Though the stems are but 2 feet tall, the blooms they bear place it among the leaders. Flowering late, it produces waxy white flowers of heavy texture and fine form. lt resist unfavorable weather far better than most Irises. 5o cts. each, $\$ 5$ per doz.

\section{SIBERIAN IRIS}

The Siberian Irises are much like the Dutch Bulbous Irises in form of flower and time of bloom. Their foliage, however, is long and grass-like. They are splendid for cut-flowers.

EMPEROR. A fine dark-flowering variety. The blooms are large and the texture fine. A uniform deep violet-blue throughout. $50 \mathrm{cts}$. each, $\$ 5$ per doz.

PERRY'S BLUE. Decidedly the most popular of the Siberian Irises, and probably the best. In color it is a beautiful shade of sky-blue, with the falls s'ightly marked white. $50 \mathrm{cts}$. each, $\$ 5$ per doz.

SIBERIAN BLUE. Rich blue. $30 \mathrm{cts}$. each, \$3 per doz., \$25 per Ioo.

\section{IRIS PUMILA}

These lovely little Irises do not grow over 4 inches high, and bloom during April and May. They are useful plants for the rock-garden and can also be used for bordering flower-beds or planting in front of the tall Irises. Even if the soil be dry and poor, they will thrive, provided they have sunshine for only part of the day.

Excelsa. Splendid pale lemon-yellow.

Sambo. Dark violet-blue

Siberian Iris
Each Doz.

$\begin{array}{llll}\$ 0 & 35 & \$ 3 & 50\end{array}$

$35 \quad 350$

35300 


\section{General List OF BULBS AND ROOTS}

\section{APIOS TUBEROSA $\begin{gathered}\text { (Tuberous-rooted } \\ \text { Wistaria) }\end{gathered}$}

Clusters of rich, deep purple flowers, which have a strong, delicious violet fragrance. Tubers, I5 cts. each, \$I per doz., \$8 per Ioo.

\section{BEGONIAS TUBEROUS-ROOTED}

Curture. - A popular method of culture adopted by most amateurs is to provide a pan or box, and cover bottom surface to the depth of say one inch or two with sphagnum moss, placing the bulb immediately on top and then covering with still another layer of sphagnum moss. They should be kept moist and moderately warm. Plant in pots in a light but finely sifted soil, about one inch below the surface, and water cautiously until plant has shown considerable growth, then increase the amount. Good drainage is essential. A finely developed plant might consist of three bulbs planted in a 7 -inch pot. Splendid for shady borders or beds. Plant bulbs outdoors 8 inches apart, as soon as weather is warm, in latitude of New York about the middle of May.

\section{ERECT TYPE (Large Bulbs, 11/2 inches}

\section{Single-Flowering Varieties}

This class of the Tuberous-rooted Begonias is largely used for beds or border-planting.

White Yellow

Pink

Scarlet

30 cts. each, $\$ 3$ per doz., $\$ 20$ per 100

Select misture of all sorts, equal proportions, $25 \mathrm{cts}$. each, $\$ 2.50$ per doz., $\$ 17.50$ per 100

\section{Double-Flowering Varieties}

White

Yellow $\$ 3$ per doz., $\$ 20$ per 100

30 cts. each, $\$ 3$ per doz., $\$ 20$ per 100

Select mixture of all sorts, equal proportions, $25 \mathrm{cts}$. each, $\$ 2.50$ per doz., $\$ 17.50$ per 100

\section{CALLAS (Richardia)}

The variety offered below succeeds best when treated in the same manner as gladioli, tuberoses and other summer-flowering bulbs. They should be planted in the open border in a dormant condition when danger from frost is over in spring, and will then flower during the summer months. When the tops are killed by frost in the autumn, $\mathrm{dig}$ and store through the winter as you would potatoes.

Golden Yellow (Richardia Elliottiana). This is the best of the Yellow Callas, its flowers being as large as the popular white winter-flowering variety, and of a rich, lustrous golden yellow of velvety texture; the foliage is dark green, with a number of translucent creamy white spots, which add much to its beauty. Strong bulbs $50 \mathrm{cts}$. each, \$5 per doz., \$40 per Ioo.

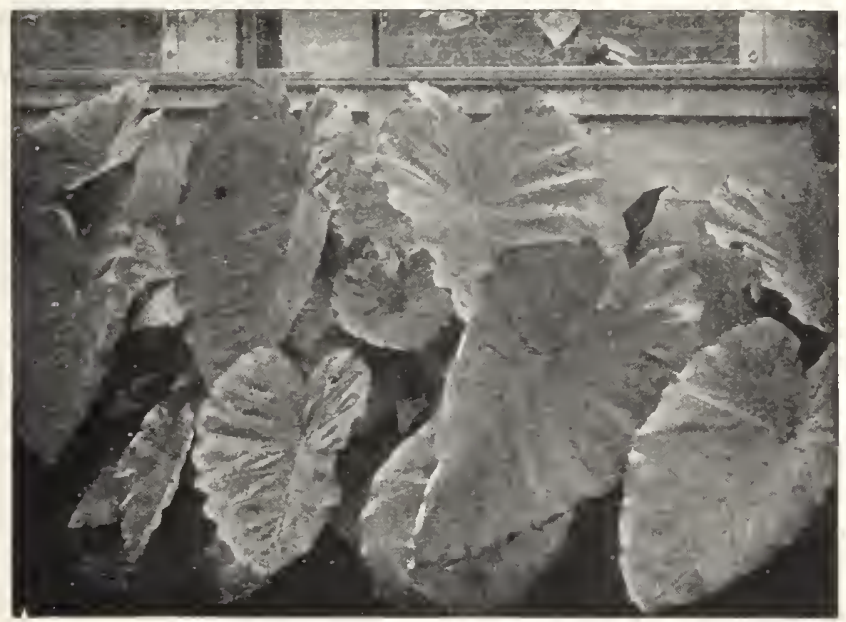

Caladium esculentum (Elephant's Ear)

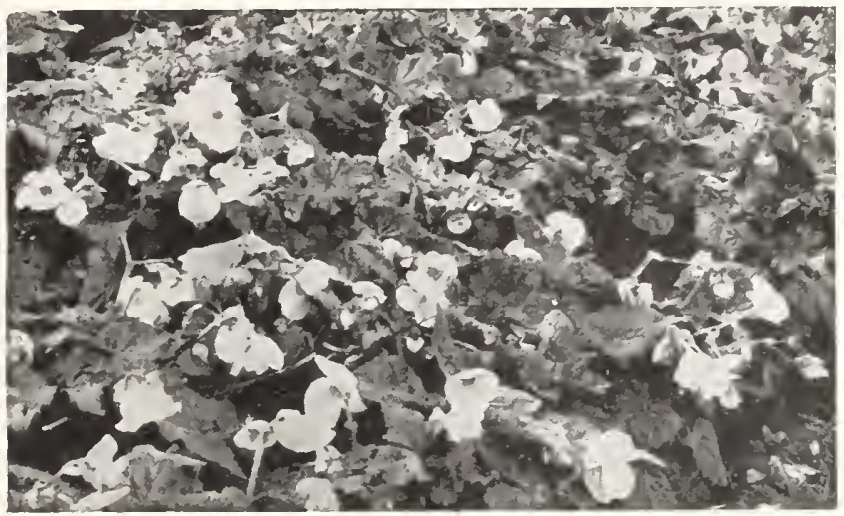

Tuberous-rooted Begonias

\section{CINNAMON VINE (Dioscorea Batatas)}

A beautiful, rapid-growing summer climber, with bright green, glossy foliage, and spikes of deliciously cinnamon-scented, white flowers. It is perfectly hardy, the stem dying down in winter, but growing with great rapidity in the spring, so as to cover any trellis or arbor very early in the season. Large, select roots, I5c. ea., \$I.25 per doz., $\$ 9$ per Ioo; mammoth roots, $25 \mathrm{c}$. each, $\$ 2.50$ per doz., $\$$ I 5 per IOO.

\section{FANCY-LEAVED CALADIUMS}

Few, if any, of the summer foliage plants equal the Fancy-leaved Caladiums in their rich and gorgeous, yet soft, coloring. All the varieties are of marvelous beauty for the furnishing of the conservatory during the summer months, or even for outdoor bedding in shady or semi-shady positions. Bulbs do best if started in pots, planting one bulb to a 6 -inch pot. Bulbs should be planted and handled similar to suggested indoor culture of tuberous-rooted begonias.

Twelve Extra.Choice Named Varieties, 50 cts. each, \$5 per doz., $\$ 35$ per 100 .

Extra-Choice Mixture of Named Varieties, $40 \mathrm{cts}$. each, $\$ 4$ per doz., \$25 per 100.

\section{CALADIUM ESCULENTUM}

Elephant's Ear

One of the most effective plants in cultivation for beds, borders or for planting out upon the lawn. Very frequently used as border plants about suburban residences, where their large, rich green leaves afford an excellent embellishment when contrasted with the colors of the dwellings. Leaves often measure 3 to 4 feet long and $21 / 2$ feet wide. Bulbs do best if planted outdoors in this latitude about June $I$.

Mammoth-size Bulbs.

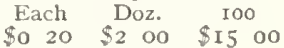

Jumbo-size Bulbs...

\section{DIELYTRA (Dicentra spectabilis)}

Bleeding Heart or Seal Flower

An old-fashioned favorite; its long racemes of graceful heartshaped pink flowers are always attractive. It is used largely for lorcing, but is also excellent for the garden border and especially valuable for planting in the shade. Strong clumps, $75 \mathrm{cts}$. each, $\$ 7.50$ per doz., $\$ 60$ per Ioo.

\section{GLOXINIAS}

This is, perhaps, one of the handsomest of summer-blooming, tuberous-rooted plants and should be grown more by the amateur than it has been. As a pot-plant for the window-garden it is grand. The main points to observe are, proper care in watering, good drainage and properly mixed soil. The cultural directions given for Begonias might also be followed for starting and growing Gloxinias. One bulb is usually used for a 4 -inch pot.

S. \& W. Co.'s Mixture. A mixture of crimson, scarlet, pink, violet, and white. $40 \mathrm{cts}$. each, $\$ 4$ per doz.. \$30 per Ioo. 


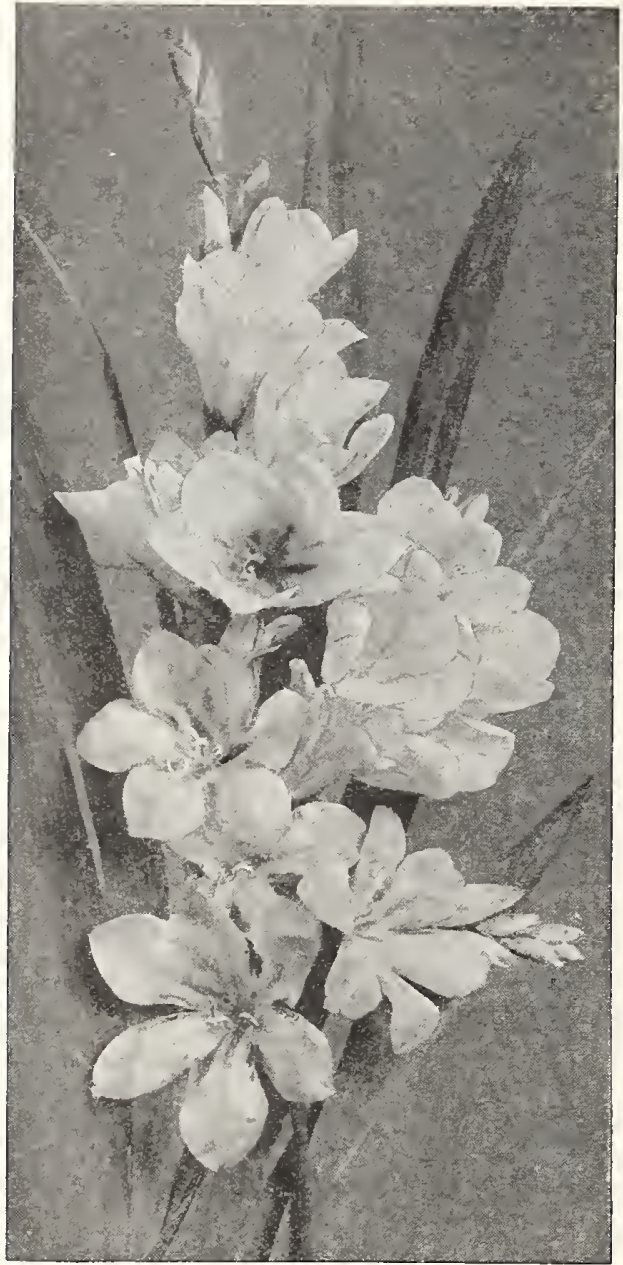

Montbretia, Germania

\section{MONTBRETIAS}

The Montbretias are one of the brightest of our summer-flowering bulbs, and deserve to be planted extensively. The bulbs should be set out during April or May, 3 to 6 inches apart, in clumps of a dozen or more. They should be protected during the winter with a heavy covering of leaves or litter.

\section{NEW GIANT-FLOWERING VARIETIES}

The following seven varieties of new, giant-flowering Montbretias should be grown by everyone desiring the best. The type is so distinct from existing kinds as to justify recognition as an entirely new race. The flowers are held erect, sometimes as much as 4 inches across, and are borne on stems 3 or 4 feet high.

His Majesty. The largest and finest of all the Montbretias. Tall grower, with of brilliant scarlet, with yellow center, 50 cts. each $\$ \mathbf{4 5 0} 3$ inches across, an even tone Queen Alexandra. A choice variety of erect habit of growth, chrome-yellow, Queen with carmine blotch at the base of petals. The flowers, like all the new Earlham hybrids, are large, and the plant frequently attains the height of 4 feet. 50 ets. each, $\$ 4.50$ per doz., $\$ 30$ per 100 .

Una. Another of the new Earlham hybrids. The large, well-shaped flowers are a rich - apricot, with carmine blotch. Plants frequently attain the height of $3 \frac{1}{2}$ feet. 50 cts. each, $\$ 4.50$ per doz., $\$ 30$ per 100 .

Fire King. Splendid glowing scarlet-red, decidedly one of the most beautiful and compares favorably with any of the new and more expensive sorts. I 5 cts. each, $\$ 1.25$ per doz., $\$ 7.50$ per Ioo, $\$ 70$ per 1,000.

George Davidson. A splendid Montbretia. The stems are 3 to 4 feet high, eight to ten-branched, bearing lovely, pale orange-yellow flowers 3 inches across; among the first to flower, and makes a glorious show in the garden. $20 \mathrm{cts}$. each, $\$ 2$ per doz., $\$$ ro per roo, \$9o per 1,000 .

Germania. Grows from 3 to 4 feet high, producing graceful, free-branching flowerspikes, bearing very large, widely expanded flowers 2 to 3 inches across. The color is a rich, glowing orange-scarlet, with red throat. I5 $\mathrm{cts}$. each, $\$ 1.25$ per doz., $\$ 7.50$ per IOO, $\$ 70$ per 1,000 .

King Edmund. A very strong grower. The flowers are of large size, and of a rich golden yellow, with brown markings in the throat. I5 cts. each, $\$ 1.25$ per doz., $\$ 7.50$ per roo, $\$ 70$ per I,000.

\section{LILY-OF-THE-VALLEY PIPS For Outdoor}

In the past, many garden enthusiasts have planted clumps of Lily-of-the-Valley in sheltered locations in their gardens. On account of the ruling of the Federal Horticultural Board, these clumps, before leaving Europe, must have all soil removed from their roots. Our experience for the past two years is that clumps received with the soil removed are not satisfactory for outdoor planting. The best way to get a good Lily-of-thepips 4 inches apart. This method will produce a better bed than by using clumps. We offer pips of smaller size than those used for growing Lily-of-the-Valley indoors for this purpose and at attractive prices. Bundles of 10 pips 60 cts., 25 pips $\$ 1.25,100$ pips $\$ 4,1,000$ pips \$35.

\section{HYACINTHUS CANDICANS (Summer Hyacinth)}

Luxuriant, free-growing summer-flowering plant; spreads 2 to 3 feet, throwing up great, tall spikes, 4 to 5 feet in height, each bearing twenty to thirty large, white, bell-shaped flowers. From our own personal trials we desire to advise our patrons against so-called "Jumbo" bulbs of this delightful plant, as this size frequently decays in the center after being planted. Choice bulbs, I5 cts. each, $\$$ r.50 per doz., \$1o per roo.

\section{MADEIRA VINE (Climbing Mignonette)}

A beautiful and popular vine, covering a large space in a short time. Fleshy heart-shaped leaves of a light green, and numerous racemes of feathery flowers of delightful fragrance. Protect with litter in this latitude. I5 cts. each, \$1.50 per doz., \$Io per Ioo; by mail, I5 cts. per doz. extra.

\section{TUBEROSES}

One of the most delightfully fragrant and beautiful of the summer-flowering bulbs. By skillful management a succession of flowers may be obtained all the year round. For early flowers they can be started in February or March in the greenhouse or hotbed; and for a succession they can be planted at intervals as late as July. For flowering in the open border. plant about the middle of May, or as soon as the ground becomes warm.

Excelsior Double Pearl. Pure white, double-flowering Tuberose.

Jumbo Exhibition Bulbs, ro cts. each, \$r per doz., \$7.50 per Ioo.

Albino. A single white variety blooming in July or August. Not so well known as the

Double Pearl, and the odor is not so pronounced. I $5 \mathrm{cts}$. each, \$1.50 per doz., \$ro per roo.

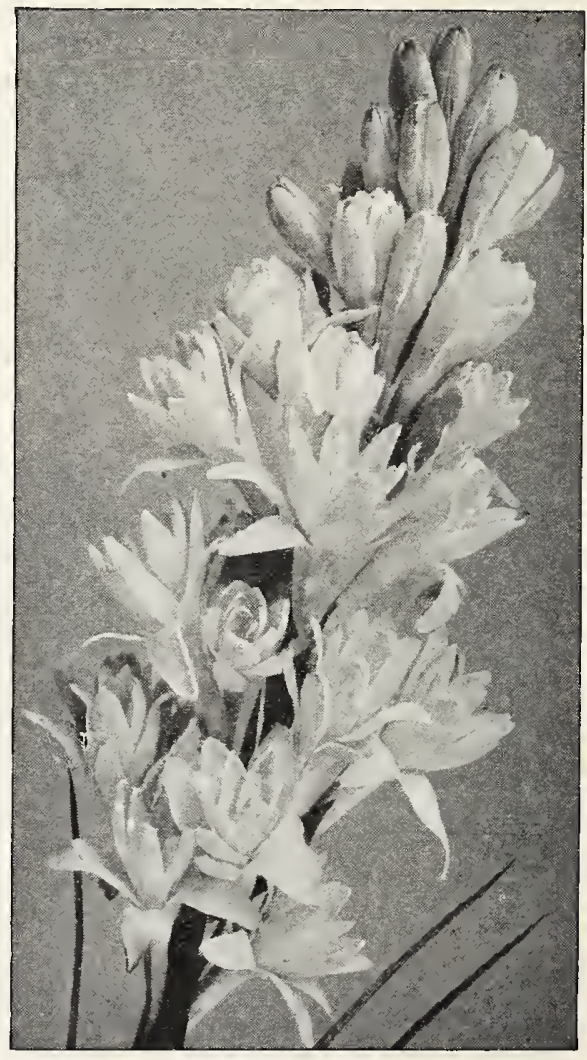

Tuberose 


\section{HARDY LILIES}

The Lilies offered below are among the best for spring planting. For a more extensive list we refer to our Fall Bulb Catalogue, issued in August. Our list is confined to those varieties we know from actual trials do best, and do best, and the following varieties actory if planted by June

Lilies do best in the hardy border or among shrub. bery, for the reason that the flowering stems bear masses of roots immediately below the ground surface. and the shady situation helps these roots to better feed the plant; when through flowering, these roots help in the rehabilitation of the bulbs for another season. Any good garden soil with good drainage will do. In planting cover bulbs at least twice their height, an if possible, cover bulbs at least inice their height and if pos bale, spread i inch of sharp bulders' sand rots the sand will provide drainage if wacer-logged in roots the sand will provide drainage if water-logged in winter. When hard rrost sets in, cover with 4 to 0 inches of leaves or litter which should be removed when spring sets in.

\section{Lilium auratum}

Golden-rayed Lily of Japan

The flowers are pure white, thickly studded with crimson spots, while through the center of each petal runs a clear golden band. Fully expanded. the flowers measure nearly a foot across, are produced abundantly from July to September, and possess a most delicious fragrance. 3 to 5 feet.

g-in. to I I-in. bulbs Each Doz.

$I-i n$. to 13 -in. bulbs

$$
\text { \$o } 45 \$ 450
$$

$\$ 3500$

\section{Lilium speciosum magnificum \\ Oriental Orchids}

Words cannot describe the beauty of this variety. Frosted white, spotted, clouded and bordered with deep pinkish crimson. A much superior variety to the Roseum, Rubrum or Melpomene of the Speciosum type. For the border, among hardy plants or naturalized among rhododendrons, this is an equal favorite with the handsome Lilium auratum offered above. Splendid for pot culture as well. Blooms outside during August.

9-in. to I I-in. bulbs....... \$o 50 Dach $\$ 5$ oo $\$ 40$ oo II-in. to I3-in. bulbs...... $75 \quad 750 \quad 60$ oo

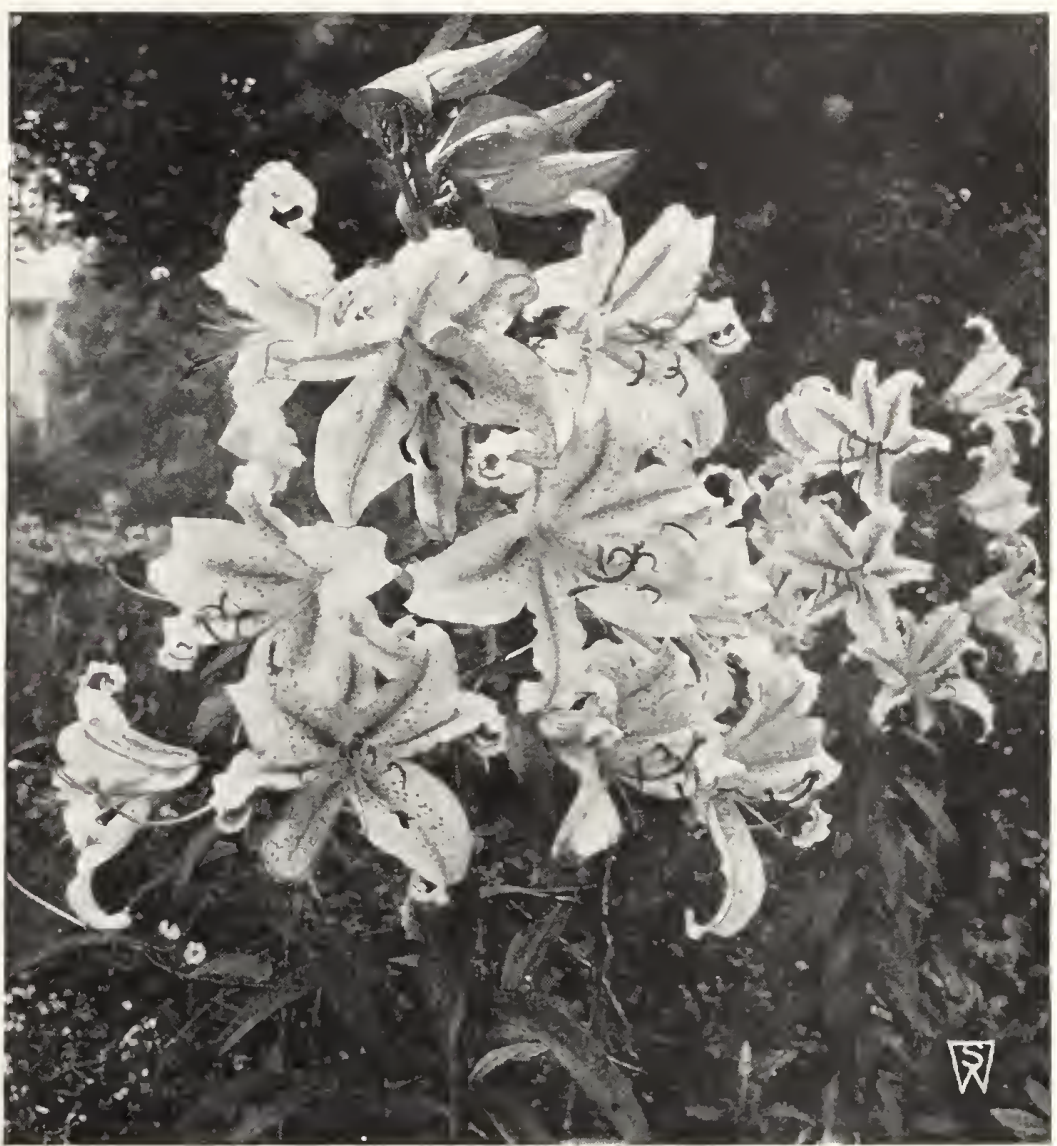

Lilium auratum (Golden-rayed Lily of Japan)

\section{Lilium speciosum album}

The White Speciosum, which is usually grown with Magnificum and Auratum, is a very dainty Lily. It flowers outside in the border or among rhododendrons at the same time as Auratum and Magnificum, and is one of the most extensively cultivated varieties.

8-in. to 9-in. bulbs

9 -in. to I I-in. bulbs.

$$
\begin{array}{ccc}
\text { Each } & \text { Doz. } & \text { I0o } \\
\text { \$o } 50 & \$ 5 \text { oo } & \$ 40 \text { oo }
\end{array}
$$

\section{Lilium Henryi (The Yellow Speciosum)}

A new and very beautiful hardy Lily from northern China. The plants are of vigorous growth, frequently attaining the height of 6 feet. This Lily is noted for its graceful habit and is an unusually excellent bloomer. It is thoroughly hardy, and, when well established, will increase rapidly. Color rich golden yellow, lightly spotted with brown. Flowers during August. 9 to 11 -in. bulbs, 75 cts. each, $\$ 7.50$ per doz., $\$ 60$ per 100 .

\section{Lilium regale}

A regal beauty. The flowers are white, slightly suffused with pink with a beautiful shade of canary-yellow at the center, blending out part way up the trumpet. The fragrance is delightful, similar to the jasmine. A splendid hardy Lily for the garden, flowering about July I. The easiest Lily to grow.

First-size bulbs, 6 to 7 in. circum.......... Sach 40 Doz. $\$ 100$ Mammoth bulbs, 7 to 8 in. circum......... $65 \quad 650 \quad 5000$ Jumbo bulbs, 8 to 9 in. circum............. $75 \quad 750 \quad 60$ oo

\section{OTHER HARDY LILIES}

\section{Suitable for Garden Culture}

Canadense (Canadian Bellflower Lily). One of the most beautiful native Lilies; flowers bright vellow, with spots of red. Blooms in July and August. 35 cts. each, $\$ 3.50$ per doz., $\$ 25$ per 100.

Colchicum Scovitzianum ( $L$. monadelphum Scovitzianum). The stately Caucasian Lily. Great clusters of bell-shaped flowers with strongly recurved petals at the top of 6 -foot stem. Flowers lemonyellow, dotted and suffused with purple and greenish brown, very curious and beautiful, and are produced in late July and August. This is a base-rooting Lily and should not be planted too deep. It likes well-drained, sandy soil and a ground-cover or partial shade. $\$ 1$ each, $\$ 10$ per doz., $\$ 80$ per 100 .

Pardalinum. A California variety bearing twelve to thirty flowers on stems 4 to 6 feet high; bright orange, spotted dark crimson. Flowers in July. 40 cts. each, $\$ 4$ per doz., \$30 per 100 .

Superbum. In a collection of best plants of all countries, our native Superbum Lily would deserve a first place. In deep, rich soil it often grows 8 feet high, with twenty to thirty flowers. It is of the easiest culture, and may be grown as a wild flower in any swampy or rough part of a place where the grass is not mown. Extra-selected bulbs, 30 cts. each, $\$ 3$ per doz., $\$ 20$ per 100 .

Tenuifolium (Coral Lily). A dwarf, very graceful Lily, with threadlike leaves and clusters of nodding, tiny, bell-like, recurved flower of brilliant coral-red in June. Likes damp soil among rocks, with access to sunlight above. Plant 6 inches deep. 35 cts. each, $\$ 3.50$ per doz., \$25 per 100.

Tigrinum splendens. The finest type of the quaint and muchloved Tiger Lily. Large, selected bulbs, 30 cts. each, $\$ 3$ per doz., $\$ 20$ per 100 .

Tigrinum splendens, Double. The double form of the above. 30 cts. each, $\$ 3$ per doz., $\$ 20$ per 100 . 


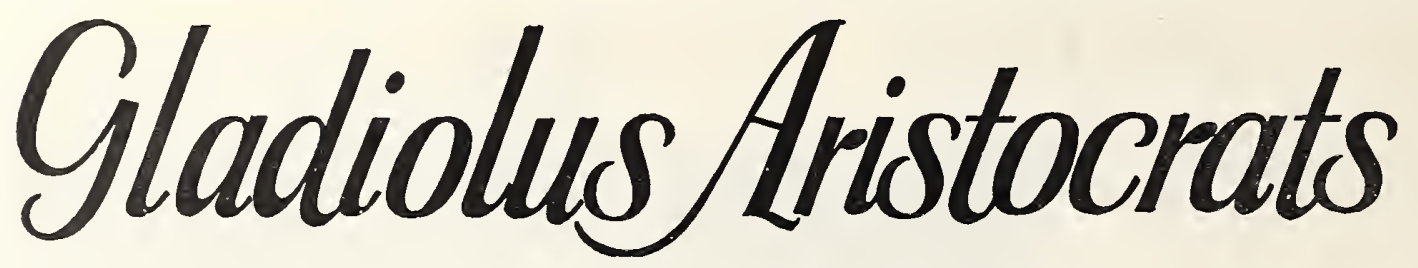

The following Gladiolus are the cream of the varieties originated by the world's best hybridizers. The bulbs have been grown from bulblets at our Farmingdale Farm. Because it takes a number of years to build up stocks of these varieties, the prices on these sterling Novelties have been high. We now have larger stocks and are able to reduce the prices considerably on many varieties. We offer this select list.

AIDA. Large, striking, dark blue flowers Each Doz. 100 with two small red-lilac blotches, like the yellow markings of Baron Joseph Hulot, and earlier than the well-known Halley. It is one of the best propagators and in our gardens 75 per cent of the bulblets flower every year.......\$2 oo $\$ 20$ oo $\$_{150} 00$

AVE MARIA. Has seven or eight large, light blue flowers with small purple blotches, open at one time, all well placed on the strong spike. Noble in form and size. .............. 3 oo 30 oo

BELINDE. Long, straight spikes, well filled with delicate, creamy yellow flowers. An excellent variety for cutting and promises to be profitable commercially for that purpose..........

CHARLES DICKENS. This purpleviolet variety grows 5 feet high and has extra-strong, graceful spikes with ten to twelve wide-open flowers at a time. It is in great demand and is a splendid

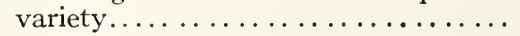

COR YPHEE. Invariably produces eight to ten large, well-formed flowers of the purest pink imaginable. A splendid variety and a favorite at many shows.. 2 o0 2000

FORTUNA. Fourteen or fifteen large, perfectly placed flowers of pure, soft yellow on each spike. The earliest yellow variety.......................

HEAVENLY BLUE. The flowers are
aniline-blue, as its name indicates. A real, first-class variety with very long spikes, having more than ten blooms open at a time. ..............

HERBSTZAUBER (Autumn Fascination). Petals of wonderful orangesalmon. It grows very tall, with beautiful, open flowers, well placed on a
long, strong spike. Resembles Europe somewhat in form, having the same spike and typical round petals .......

JONKHEER VAN TETS. Strong fivefoot spikes with eight or more immense pure white flowers open at once. No marking or throat blotches.........

MRS. ANNA PFITZER. Stunning creamy white flowers, 5 inches across, shaded with soft yellow and pale green, but without throat-markings. Upwards of twelve blooms open at once on handsome, symmetrical spikes.

All the above varieties have
I $00 \quad$ IO $00 \quad 7500$

$75 \quad 7 \quad 5^{\circ} \quad 5000$

200

2000
MRS. GERTRUDE PFITZER. Light Each China-blue, with violet center. This Gladiolus has many well-formed flowers open at one time on a beautiful spike and deserves the consideration

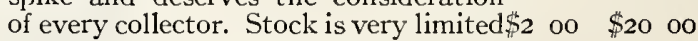

MRS. VAN KONYNENBURG. The leader in its color-light blue. It has an excellent spike, beautifully formed flowers, is free-flowering and a very good propagator. Surpasses all others of its color..................

OTHELLO. Very peculiar color-bright violet-purple, with very small, deepercolored blotches. Blooms are well spaced on the spike............

PAUL PFITZER. Brilliant velvety purple-an attractive new color. The placement of the blooms on the spike is almost perfect. Strong, healthy growers ...................

PFITZER'S TRIUMPH. Unquestionably one of the largest and finest Gladiolus ever introduced and will be a leader for years. The blooms are at least 6 inches across, bright salmonorange, with small velvety red blotches. It has been a sensation all over the world, and we found it to be a real triumph where it was shown........

PHÄNOMEN. A very pleasing combination of the softest pink and finest yellow-both the loveliest shades conceivable. We urge everyone to try this

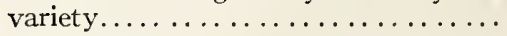

STUTTGARDIA. Five or six brilliant orange-scarlet flowers, 5 inches across, open at once on long, strong spikes. One of the best scarlet varieties. ..... 4

TROUBADOUR. Large, impressive, dark violet flowers, beautifully arranged on the stem. Ten to twelve are open at one time, and even with this niass of flowers the stalk is strong enough to hold it erect.............

VEILCHENBLAU. Fine violet-b $1 \mathrm{u}$ e flowers with pansy-purple blotches. Stock scarce and in great demand .....

WILHELM PFITZER'S MEMORY. Handsome, 6-foot spikes of pure, snowwhite flowers. So good that it was chosen to perpetuate the name of the great horticulturist .............

Doz. I00 


\section{Gladiolus Aristocrats}

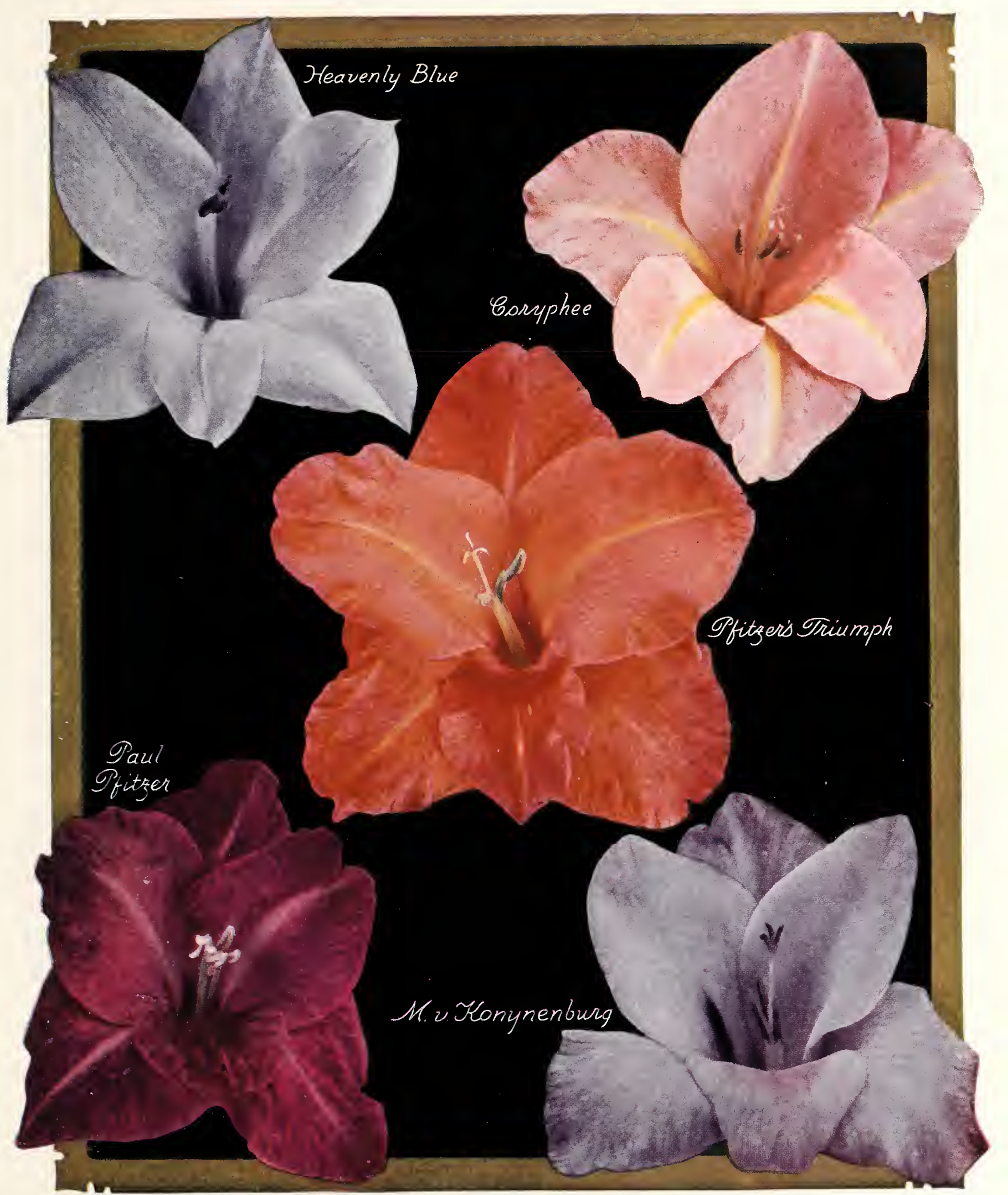




\section{Gladiolus Aristocrats}

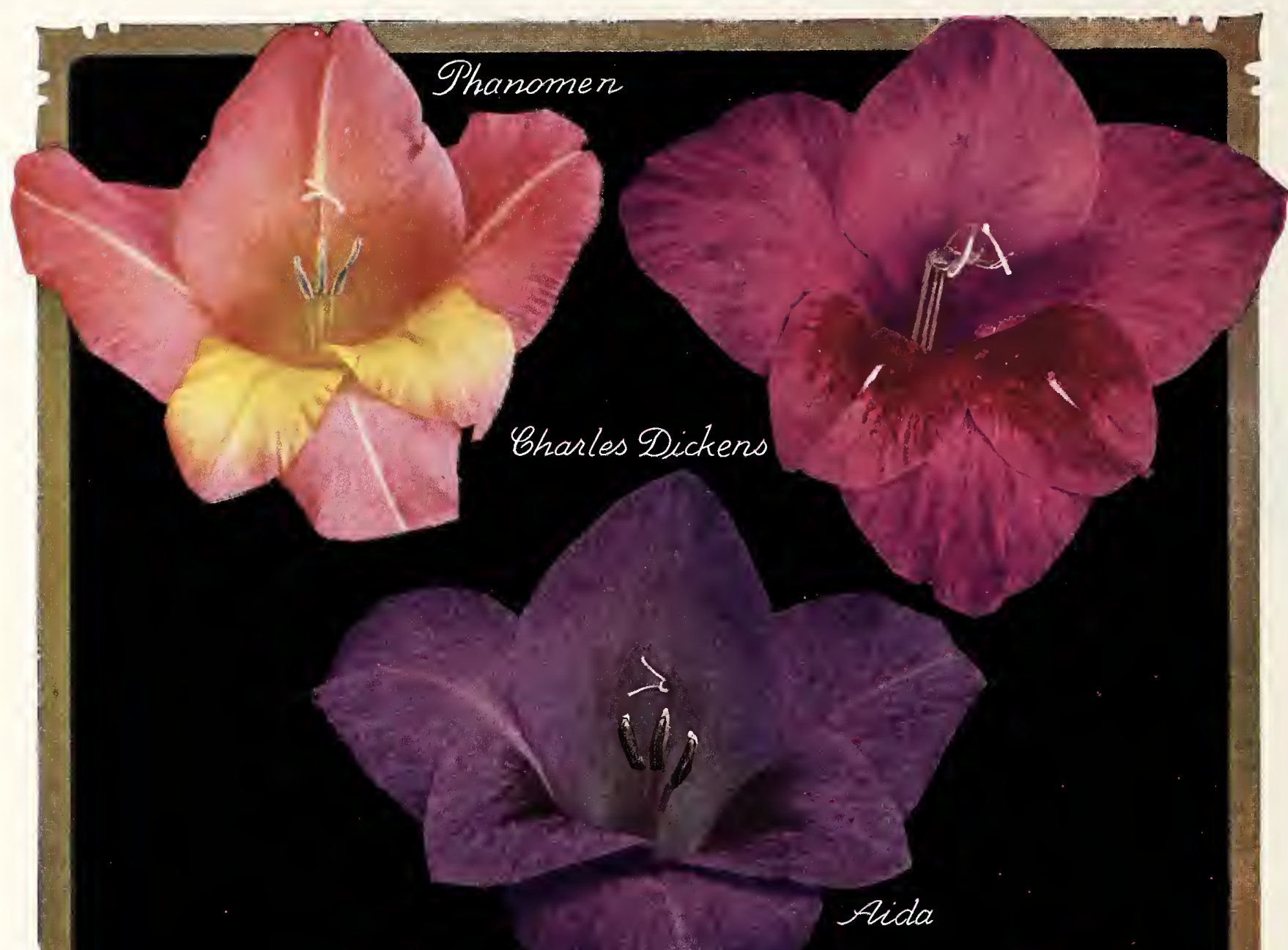

Troubadoner

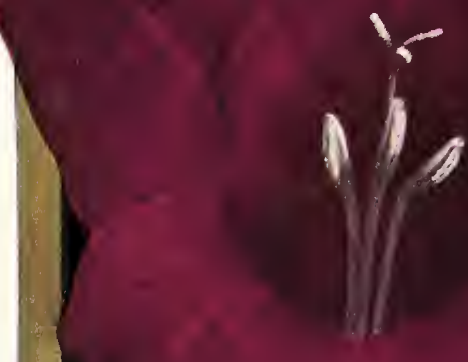

Merbstzauber 


\section{GLADIOLUS}

Few of the Summer-flowering Bulbous Plants have met with the same increased interest that Gladiolus have in the past ten years. Their adaptability for the garden or cut-flower use during summer and autumn months is not surpassed by any other bulbous plant. Care of Dormant Bulbs. On Gladiolus corms which our clients desire to hold for successive planting from May I until July, it is suggested that those required for early summer planting be kept in air-tight containers in a cool place. Some of our patrons who plant Gladiolus July. I 5
for September flowers, order these bulbs in the springtime. These are stored in our cold-storage warehouse in April and are kept in first-class for September flowers, order these bulbs in the springtime. These are stored in our cold-storage warehouse in April
condition for planting in the summer. In the latitude of New York, July I 5 is the latest advisable time to plant.

America. Delicate lavender-pink flowers of large size, borne on America. strong stems, and well placed; splendid habit. Very Anna Eberius. Dark velvety purple, throat deeper shade; very Anna Eberius. large flowers on tall, fine spikes. A very fine variety in an unusual color. 10c. each, 85c. per doz., \$6 per 100. Baron Hulot. Rich, roval violet-blue. One of the finest of its Baron Hulot. color. Flowers are med um in size, well placed. and borne on strong spikes. A variety used for contrasting with the pale and deep yellow sorts. 15 ets. each, $\$ 1.50$ per doz., $\$ 10$ per 100 . Betty Nuthall. A warm, light coral with pale orange throat and Betty Nuthall. a light feathering of carmine. The flowers are often 6 inches across, of splendid substance, and are well placed on tall, strong spikes. One of the best Gladiolus of the later introductions. 75 ets. each, $\$ 7.50$ per doz., \$50 per 100 .

Captain Boynton. A fine shade of lavender with small blotch well placed on tall, erect spikes. 20 cts. each, $\$ 2$ per doz., $\$ 15$ per 100. Carmen Sylva, Large, beautiful snow-white flowers, well Carmen Sylva. placed on tall, straight stems. An excellent cut-flower variety. 15 cts. each, $\$ 1.25$ per doz., \$8 per 100 .

Chateau Thierry, Orange-cerise, bordered yellow, with a spike with wide-open, well-formed flowers. 10 cts. each, \$1 per doz., \$7 per 100.

Chicago White. One of the best of the standard varieties. lavender stripes. Early flowering. 10 cts. each, 75 ets. per doz., $\$ 5$ per 100 .

Crimson Glow. Deep, brilliant crimson, overlaid with darker Crimson Glow. shades; lower petals blotched with deep velvety crimson. The flowers are immense and plentif ully spread on the tall graceful stem. A very striking variety with a very vigorous constitution. 10 ets. each, 85 ets. per doz., $\$ 6$ per 100 .

Dr. F. E. Bennett. Deep peach-red, with flame-scarlet suffusion, lip speckled ruby and white flower is red and it is considered the finest of its color. 20 cts. each, $\$ 1.75$ per doz., $\$ 12$ per 100 .

E. J. Shaylor. Tall, very strong plants and large blooms of a recently been awarded a certificate of merit in London. 10 ets. each, 85 ets. per doz., $\$ 6$ per 100 .

Evelyn Kirtland. The flowers, of strong substance, are a Eeautiful shade of rosy pink, darker at the edges, fading to shell-pink at the center with brilliant scarlet blotches on the lower petals, the entire flower showing a glistening, sparkling I uster. Very tall spike. Extra-fine form and color. 10 cts. each, $\$ 1$ per doz., \$7 per 100.

Giant Nymph. Light rose-pink, with creamy yellow throat; long stems. Grows 6 feet tall. 15 cts. each, $\$ 1.50$ per doz., $\$ 10$ per 100.

Golden Measure. A deeper shade of yellow, heretofore Solden unknown in the large-flowering Gladiolus. most magnificent effect. 15 cts. each, $\$ 1.50$ per doz., $\$ 10$ per 100 . Gretchen Zang. A beautiful rose tone of pink, blending variety of great merit on account of its splendid substance and size. 10 cts. each, \$1 per doz., \$7 per 100 .

Halley. A variety that is largely grown on account of its earliness. Halley. The flowers are large in size, of beautiful salmon-pink, with creamy white blotch in throat. One of the earliest-blooming varieties in our list. 10 ets. each, 75 cts. per doz., $\$ 5$ per 100.

Herada. Blooms of immense size on tall, straight spikes. The deeper markings in the throat. 10 cts. each, $\$ 1$ per doz., $\$ 7$ per 100 . Ida Van. A most beautiful deep salmon-red or flaming orange85 cts. pink-very rich and brilliant color. 10 ets. each,
Jack London. Light salmon-pink with vermilion stripes and placed on strong stems. A robust-growing variety. 15 ets. each, $\$ 1.50$ per doz., $\$ 10$ per 100 .

Joe Coleman. Bright red with carmine blotch. A very atat one time. Strong grower and good propagator. 10 ets. each, 85 ets. per doz., \$6 per 100 .

Lily White. A comparatively recent, reliable, first-class, early, blooms, and many open at a time. Excellent for forcing or as a cutflower for the garden. $10 \mathrm{cts}$. each, $85 \mathrm{ets}$. per doz., $\$ 6$ per 100 . Los Angeles. Beautiful shrimp-pink, with glowing orangeblooms for a long time. A very excellent variety for cutting, being in constant demand by florists. $15 \mathrm{c}$. each, $\$ 1.25$ per doz., $\$ 8$ per 100 . Louise. Well-opened orchid-like flowers of attractive bluish tall and stately new variety is a decided acquisition. 15 cts. each, $\$ 1.25$ per doz., \$8 per 100 .

Lustre. This variety makes a very striking note in the garden. placed on good, strongspikes. 20c. each, $\$ 1.75$ per doz., $\$ 12$ per 100. Marmora. Lavender to lavender-gray with petunia-colored mlotch. Flowers very tall, large, well arranged on tall, strong stems, with from eight to twelve open at once. One of the best Gladiolus ever introduced, 75 cts. each, $\$ 7.50$ per doz., $\$ 50$ per 100 . Mary Fennel. A beautiful shade of deep lavender, with petals medium in height. An excellent variety for contrasting with pale pink and primrose sorts. $15 \mathrm{ets}$. each, $\$ 1.50$ per doz., $\$ 10$ per 100.
Mary Pickford. An extraordinary flower and spike of delicate Mary Pickford. creamy white. Throat sulphur-yellow; stem and calyx also white, 10 cts. each, $\$ 1$ per doz., $\$ 7$ per 100 .

Minuet. Beautiful clear, light lavender. Four to six large, stem. This is the lavender by which all other lavenders are judged. Considered by most growers as the last word in a light lavender Gladiolus. 40 ets. each, $\$ 4$ per doz., $\$ 35$ per 100 .

Mme.Mounet-Sully. Milky white, with a large orange strong stems, with many open at one time. Very attractive. 40 ets. each, \$4 per doz., $\$ 35$ per 100 .

Mona Lisa. Palest soft rose-pink or blush-white. One of the placed on strong stems and many are open at the same time. 10 cts. each, \$1 per doz., \$7 per 100 .

Mr. Mark. A new light blue. There are few varieties of this or $\$ 1.50$ per doz., \$10 per 100 .

Mrs. Frederick C. Peters. This beautiful new variety, chid in coloring. is very desirable for fine gardens. It is a rose-lilac, with crimson blotch bordered white on lower segments. Flowers large and many open at one time. 10 cts. each, $\$ 1$ per doz., $\$ 7$ per 100 Mrs. Francis King. Brilliant flamingo-pink, blazed with account of its attractive color. Splendid for mass effects. Flowers are large in size, well placed on strong, tall spikes, 10 cts. each, 75 cts. per doz., \$5 per 100 .

Mrs. Frank Pendleton. Salmon-pink which extends to as in the center, with a rich, deep maroon blotch on the three lower petals. $10 \mathrm{cts}$. each, 75 ets. per doz., \$5 per 100 .

Mrs. Dr. Norton. Delicate cream and pink, deepening toFlowers widely expanded. A beautiful variety much admired at Gladiolus exhibitions. 10 ets. each, $\$ 1$ per doz., $\$ 7$ per 100 .

Mrs. H. E. Bothin. Light geranium-pink with flame-scarlet and one of the newer varieties which will become more popular when better known. 15 cts. each, $\$ 1.25$ per doz., $\$ 8$ per 100 . 


\section{A DIOTJUS Everybody's Flower Because Everybody Can Grow Them}

CultuRE.-Any good garden soil will grow Gladiolus well, provided they are planted in a sunny location. Bulbs should be planted 4 inches deep and at least 6 inches apart; frequent cultivation with a hoe or weeder, around the base of the plant, to prevent the soil from becoming hard and dry, is advisable. Where desired for garden decoration or exhibition, we advise plants being staked after attaining the height of I foot. (We offer light green dyed bamboo canes, which are excellent for this purpose.) Water copiously, and as the flower-buds begin to form, apply liquid manure for the best results.

Mrs. Leon Douglas. Enormously large flowers of beautiful scarlet, the lower petals pale lemon, speckled ruby. The tall, strong stems produce several side shoots, the whole forming a wonderful bouquet. Considered one of the largest Gladiolus in existence. 15 cts. each, $\$ 1.50$ per doz., $\$ 10$ per 100 .

Muriel. Beautiful pure lilac-blue, with deeper blotch in throat on time on tall, erect stems. A rare beauty, $\mathbf{1 5}$ cts. each, $\$ 1.50$ per doz., $\$ 10$ per 100.

Niagara. Soft primrose, faint lines of lilac in the throat, with Nigara. purple stamens and pale carmine stigmas which add to the attractiveness of the variety. Flowers are large in size, borne on tall spikes. 10 cts. each, 85 ets. per doz., \$6 per 100.

Odin. An early variety of a deeper salmon color than Prince of Odin. Wales, heavily blotched carmine on lower petals. 15 ets. each, \$1.25 per doz., \$8 per 100 .

Panama. Similar in type to America, but of a deeper shade of Panama. pure rose-pink. The flowers are large in size and well (10ced on tall, strong spikes. $10 \mathrm{cch}, 85 \mathrm{c}$. per doz., \$6 per 100 .

Peace. Few varieties have become as popular as Peace. The general effect of the flower is white, with a pale lilac feathering on the interior petals. They are large in size, well placed, and are borne on tall, strong spikes. 10 ets. each, 75 cts. per doz., $\$ 5$ per 100.

Pride of Lancaster. Brilliant orange-salmon, with shading - of deep orange in the throat. A beautiriety named in honor of the birthplace of Luther Bur15 cts. each, $\$ 1.50$ per doz., $\$ 10$ per 100 .

Purple Glory. Deepest velvety maroon with almost black sturdy stems. A real giant in all respects. 15 cts. each, $\mathbf{\$ 1 . 5 0}$ per doz., \$10 per 100.

Rev. Ewbank. A beautiful light porcelain-blue, giving the effect of an almost solid color; deep blue blotch on lower petals; early and good-sized flowers. 20 cts. each, \$2 per doz., \$15 per 100.

Richard Diener. Immense, ruffled blossoms of geranium-pink 15 cts. each, $\$ 1.50$ per doz., $\$ 10$ per 100 .

Rose Ash. Peculiar soft, old-rose tones, fading to ashes of roses on Re outer edges of petals. Very unique in coloring and greatly admired. If you have a room with mahogany furniture and mulberry hangings, this is an ideal indoor setting for Rose Ash. This is a decidedly new color in Gladiolus and one that will appeal to the lover of this splendid summer-blooming bulbous plant. 15 cts. each, $\$ 1.25$ per doz., $\$ 8$ per 100 .
Saraband. Very large, wide-open, rich velvety wine-color flowers, with deep yellow blotch, well placed on tall spike. A very unusual flower. 35 ets. each, $\$ 3.50$ per doz., $\$ 25$ per 100.

Scarlet Wonder. Few Gladiolus are as strong growers as this splendid new variety. The foliage is a rich deep green and the plant attains a height of 4 to 5 feet. The flowers are large, many open at one time, and of a rich, velvety scarlet. 15 cts. each, $\$ 1.50$ per doz., $\$ 10$ per 100 .

Schwaben. Pure canary-yellow, with a carmine blotch deep in the throat which aids in detracting from its uni formity in color. Flowers are wide open, large in sizeand well placed on strong spikes of medium height, 10c. each, 85c. per doz.,\$6 per 100. Trudel Grotz. A very vigorous variety producing enormous flowers of glowing salmon-pink with a small red blotch in the throat. Very striking in appearance. 35 cts. each, $\$ 3.50$ per doz., \$25 per 100 .

Virginia. Large, massive flowers of flaming scarlet, many opening at one time. A planting of this variety makes a gorgeous display of dazzling red. 10 cts. each, $\$ 1$ per doz., $\$ 7$ per 100.

Violet Glory. Large flower, rich self-color of deep violet, deeper throat; with ruffled petals. Its attractive color has made it a very popular variety. 20 cts. each, $\$ 2$ per doz., $\$ 15$ per 100 .

Wilbrinck. Flesh-pink, with yellowish blotch on lower petals. Large, well-placed flowers on tall, strong stems. The first to bloom, together with Halley, of which it is a sport. 10 ets. each, 85 cts. per doz., $\$ 6$ per 100 .

White Glory. A gorgeous pure white variety of the same type splendidly ruffled of pure white color with a lovely iris-blue shaped, 15 cts. each, $\$ 1.50$ per doz., $\$ 10$ per 100 .

\section{AMERICAN HYBRIDS MIXED}

In preparing this mixture of Gladiolus, we have included some surplus named sorts, and have endeavored to cover all the conceivable colors that obtain in this beautiful family of flowers. The mixture is prepared from the finest varieties, and has with it a popular price so as to encourage the liberal planting of them. The sorts used in the mixture are well matured and good growers; they are excellent for cut-flower purposes or for planting in mixed borders, and we offer them at 60 ets. per doz., $\$ 4$ per $100, \$ 38$ per 1,000 .

Semesan is a good disinfectant for all Bulbs and Tubers. Demst your Gladiolus with it at planting time. It
protects against fungus and disease. 2 ozs. $50 \mathrm{cts}$., lb. $\$ 2.75$, 5 lbs. $\$ 13$.

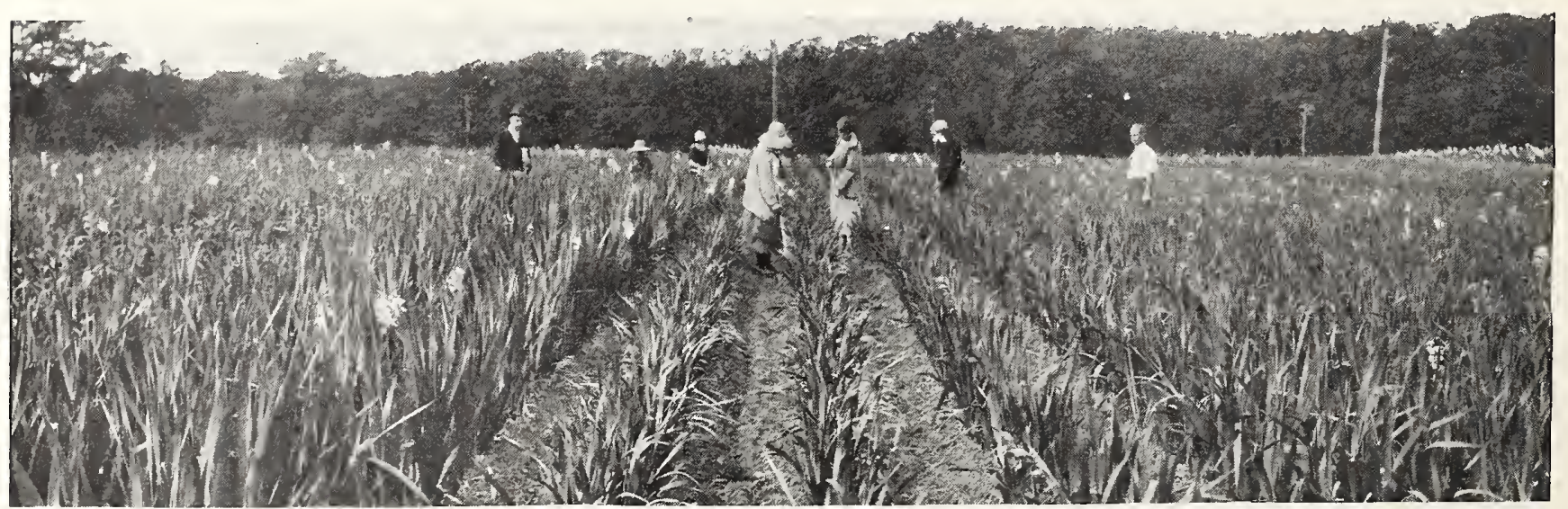

Field of Gladiolus growing on our Long Island Farms. Few soils produce Gladiolus bulbs of stronger vitality than Long Island soil does 


\section{New and Rare Primulinus Hybrids}

To the flower-lover who has become interested in the Primulinus Hybrids and knows them, the following varieties will have a strong appeal.

Primulinus Hybrids are distinguished mainly for their fine and various shades of yellow, orange, and saffron tones. The flowers are borne on graceful stems and when cut are of splendid decorative value.

The commercial florists have come to recognize this wonderful new type of Gladiolus. The pure self-tones of the flowers suggest refinement. They are splendid growers and are excellent for mass effect.

\section{Altair}

Saffron-salmon. A very tall grower and one of the earliest to bloom, frequently producing two flower-spikes, 10 cts. each, 85 cts. per doz., $\$ 6$ per 100 .

\section{Alice Tiplady}

Tall, straight spike with ten to twelve blooms. Immense flowers of brilliant orange-salmon, with golden throat. A very showy, magnificent Hower. A few spikes of this placed in a tall vase makes a very attractive and imposing exhibit. The general color of the flower is magnificent under artificial light. 10 cts. each, 75 cts. per doz., $\$ 5$ per 100 .

\section{Dorothy Wheeler}

Awarded Silver Medal by Massachusetts Horticultural Society in I92I. It is a most beautiful rose-pink. Slightly ruffled with lighter throat. Plant tall and many flowers open at once. 15c. each, $\$ 1.25$ per doz., $\$ 8$ per 100 .

\section{Ethelyn}

Beautiful orange-yellow, similar to Orange Queen, but with a clear lip instead of orange lines. One of the best Primulinus. 20 cts. each, $\$ 2$ per doz., $\$ 15$ per 100 .

\section{Maiden's Blush}

A very popular variety on account of its beautiful shell-pink color and earliness. Splendid for forcing. $10 \mathrm{cts}$. each, $75 \mathrm{cts}$. per doz., \$5 per 100.

\section{Ming Toy}

Deep showy buff with yellow throat. Large flowers on tall, strong stems. A very pleasing variety. 15 cts. each, $\$ 1.25$ per doz., $\$ 8$ per 100 .

\section{Orange Queen}

Purest apricot of a very warm tint; large, open flowers on good stem. Justly considered one of the very choicest novelties in Primulinus Hytrids. 15 cts. each, $\$ 1.50$ per doz., $\$ 10$ per 100 .

\section{Salmon Beauty}

A very large and showy flower; in fact the last two or three seasons it has been pronounced the best Primulinus by the Massachusetts Horticultural Society. The color is deep orange-salmon with a rich salmon-yellow throat. 10 cts. each, $\$ 1$ per doz., $\$ 7$ per 100 .

\section{Souvenir}

Of the many shades and tints in this beautiful type of Gladiolus, we consider Souvenir as being the best pure yellow variety. 15 cts. each, $\$ 1.25$ per doz., $\$ 8$ per 100 .

\section{Primulinus Hybrids Mixture}

When the original Primulinus was first grown in this country, many Gladiolus-growers were impressed with the graceful habit of the plant and flowers. They were small and somewhat hooded. The original species, as they were first introduced from South Africa, created interest among these growers mainly for their habit and the beautiful colorings of the flowers. They proceeded to cross them with the finest of the large-flowering Gladiolus and the resultant crosses brought forth a really beautiful acquisition. The flowers were larger, more open, retaining their graceful placement on the spikes and also their beautiful range of artistic colors. Our hybrids range in color from pale sulphur-yellow-apricot to the deepest chrome-yellow and excellent shades of pink, orange, and scarlet. We are pleased to offer this splendid mixture and suggest that our patrons try some, as for artistic decorations these flowers borne on long slender spikes are wonderful. 60 cts. per doz., $\$ 4.50$ per $100, \$ 40$ per 1,000 .

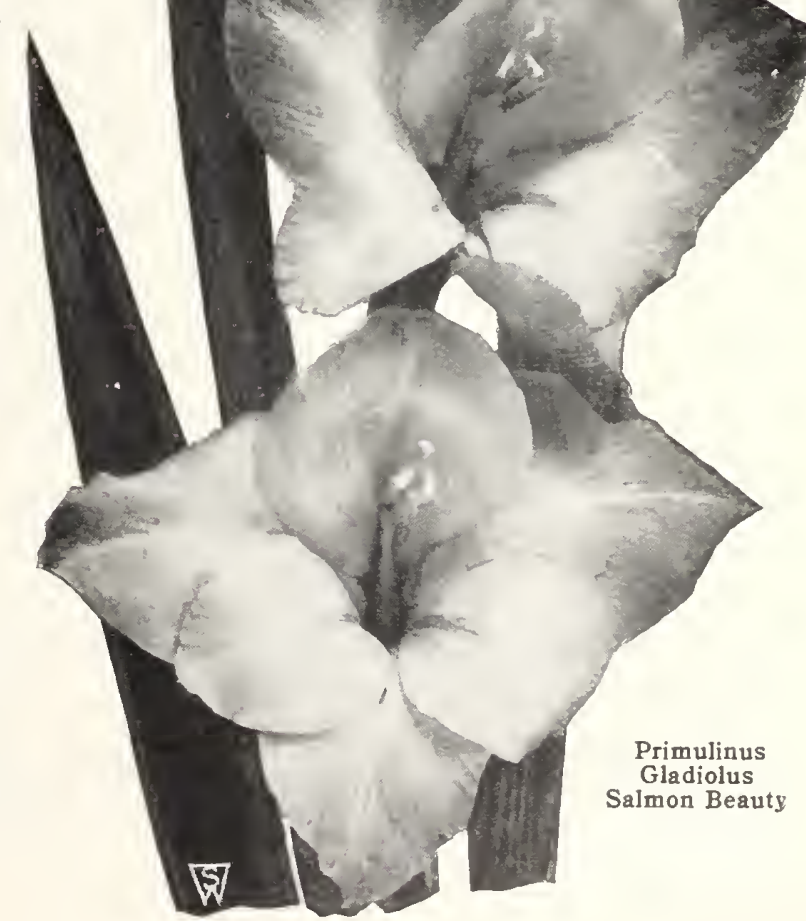




\section{Twenty New Exhibition Dahlias}

The following list of Dahlias has been exhibited extensively at the past season's flower shows. They are the cream of the latest introductions and represent the best advances that have been made recently in the improvement of the Dahlia. We are offering these as our selection of twenty that are among the finest of those exhibited last year. In order to offer them at popular prices, we are selling green plants only, except in the case of Countess of Claverly and Salmon Supreme, as substantial stocks of roots of these varieties are not yet obtainable. We offer green plants out of $21 / 2$-inch pots for May I5 delivery.

Big Chief. Hybrid Decorative. (Success.) Its rich autumn $\underline{\text { Big Chief. }}$ shades give a general effect of salmon-buff. The flowers are immense, carried erect on long, fine, stiff stems. Very free bloomer. Fine exhibition Dahlia. Plants, \$3 each, \$30 per doz. Cora Butterworth. Decorative. (Chapman.) This great come very popular. The form is very attractive with its long, waved petals. Splendid exhibition variety. Plants, $\$ 3$ each, $\$ 30$ per doz.

Countess of Claverly. Hybrid Cactus. (Stumpp \& Walbeing able to offer to our customers this very fine Dahlia which is illustrated on the opposite page. It is, without doubt, the finest, irresistible, real pink Hybrid Cactus Dahlia, bearing full flowers, 8 to Io inches across, from early in the season until killed by frost. A very vigorous grower, with fine stems and a prolific bloomer. The flowers are excellent keepers, and are even more beautiful under artificial light. A sensation wherever shown. Plants, \$2 each, $\$ 20$ per doz. Tubers, $\$ 3.50$ each, $\$ 35$ per doz.

Dorothy Stone. Decorative. (Fisher \& Masson.) A huge Dorothy Stone. flower of true deep pink, brighter than Kathleen Norris, with very full center; petals thick and evenly placed. Profuse bloomer on the best of stems. Plants, \$3.50 each, $\$ 35$ per doz.

Dr. John H. Carman. Decorative. (Derring-Do.) A rose flower, tipped petunia and silver, on stiff, heavy stem. Free flowering. A sensation. Plants, $\$ 2.50$ each, $\$ 25$ per doz.

Edward Thomas Bedford. Decorative. (Brock.) Giant, Edward Thomas Bedford. clear deep purple flower, held perfectly erect on very long stem. A prodigous producer of mammoth flowers throughout the season. A sensation. Plants, $\$ 3.50$ each, $\$ 35$ per doz.

Elizabeth Harding. Hybrid Cactus. (Harding.) A more suffused with pale yellow at base of each petal, would be hard to find. Very large flowers of the most perfect form. Vigorous, free-blooming variety. Plants, $\$ 3.50$ each, $\$ 35$ per doz.

Goodnight. Decorative. (Reed.) Monster flowers of oxGoodnight. blood-red, shaded dark maroon. A sensational $\$ 35$ per doz.

Gov. Morgan F. Larson. Decorative. (Hall.) Blooms center; clear golden yellow with slight apricot shading. Free bloomer on the best of stems. Winner at Camden and Trenton Shows. Plants, $\$ 3$ each, $\$ 30$ per doz.

Jean Trimbee. Hybrid Cactus. (Trimbee.) Flowers very our grower and free bloomer. Splendid for exhibitions. Plants, $\$ 3$ each, \$30 per doz.

Kathleen Norris. $\begin{aligned} & \text { Decorative. (Fisher \& Masson.) A } \\ & \text { bloom of massive proportions. Color a }\end{aligned}$ true rose-pink, deepening to mallow-pink. Broad, overlapping petals with twisted ends. Great bloomer on perfect stems. Plants, $\$ 3$ each, $\$ 30$ per doz.
Monmouth Champion Decorative. (Kemp.) FlameMonmouth Champion. scarlet flowers I2 inches and more across, full centered, and borne high above the foliage on stiff stems holding them forward. Strong grower and free flowering. Plants, $\$ 3$ each, $\$ 30$ per doz.

Salmon Supreme. Decorative. (Stumpp \& Walter Co.) Salmon Supreme. At our Trial-Grounds this splendid seedling of Jersey's Beauty proved a sensation. As the introducers of this variety, we feel justified in predicting that it will become a very popular Dahlia. The form and color are really wonderful. Its very large, glistening salmon-orange flowers are held proudly erect on the strongest of stems. Free flowering and a vigorous grower. This fine new Dahlia should be in every garden. Plants, $\$ 2$ each, $\$ 20$ per doz. Tubers, $\$ 3.50$ each, $\$ 35$ per doz.

The World. Decorative. (Maytrott.) Rich deep rosy The World. magenta overlaid violet, with silver shadings on edges of petals. A strong, thrifty grower and very free bloomer. Plants, $\$ 2.50$ each, $\$ 25$ per doz.

Thomas A. Edison. Decorative. (Maytrott.) Immense did form held upright on the best of stems. Free bloomer and vigorous grower. Plants, $\$ 3.50$ each, $\$ 35$ per doz.

Valentino. Decorative. (Bessie Boston.) A beautiful Valentino. Dahlia with a famous name. Derrill W. Hart describes it thus in the Dahlia Roll of Honor. "A luscious colored Dahlia of a creamy salmon shading to rose-pink. A large flower on good stems and one of the most attractive color-combinations a mong the newcomers. Stem long and upright; bushes of medium height." Plants, $\$ 2.50$ each, $\$ 25$ per doz.

Waldheim Sunshine. Hybrid Cactus. (Peacock.) One new Dahlias. It is the true deep yellow that shows up yellow under artificial light. The reflex is darker, with a rich golden suffusion around the high center. Its form is beautiful, with long, wavy, twisted petals. Stem is long and stiff, holding the flower from facing to upright. Profuse bloomer. Plants, \$2.50 each, $\$ 25$ per doz.

Watchung Prince. Decorative. (Smith.) One of the flowers can be grown to measure 12 inches across and have wonderful keeping qualities. It is a free bloomer and strong grower. Without doubt, one of the finest Dahlias for exhibition and garden. Plants, $\$ 3$ each, $\$ 30$ per doz.

Watchung Wonder. Decorative. (Smith.) Royal red monster flower on the best of stems. Everyone should have this great Dahlia. Plants, $\$ 3$ each, $\$ 30$ per doz.

Western Giant. Decorative. (Lee.) This is the largest I2-inch blooms without disbudding, from plants grown on very ordinary garden soil without forcing. Will be a prize-winner in the sweepstake class. Stems long and strong, holding the big blooms up to look you in the face. Plants are of medium height. Color, a very bright orange with tints of gold; reverse of petals salmon-rose. Plants, \$3 each, $\$ 30$ per doz. 


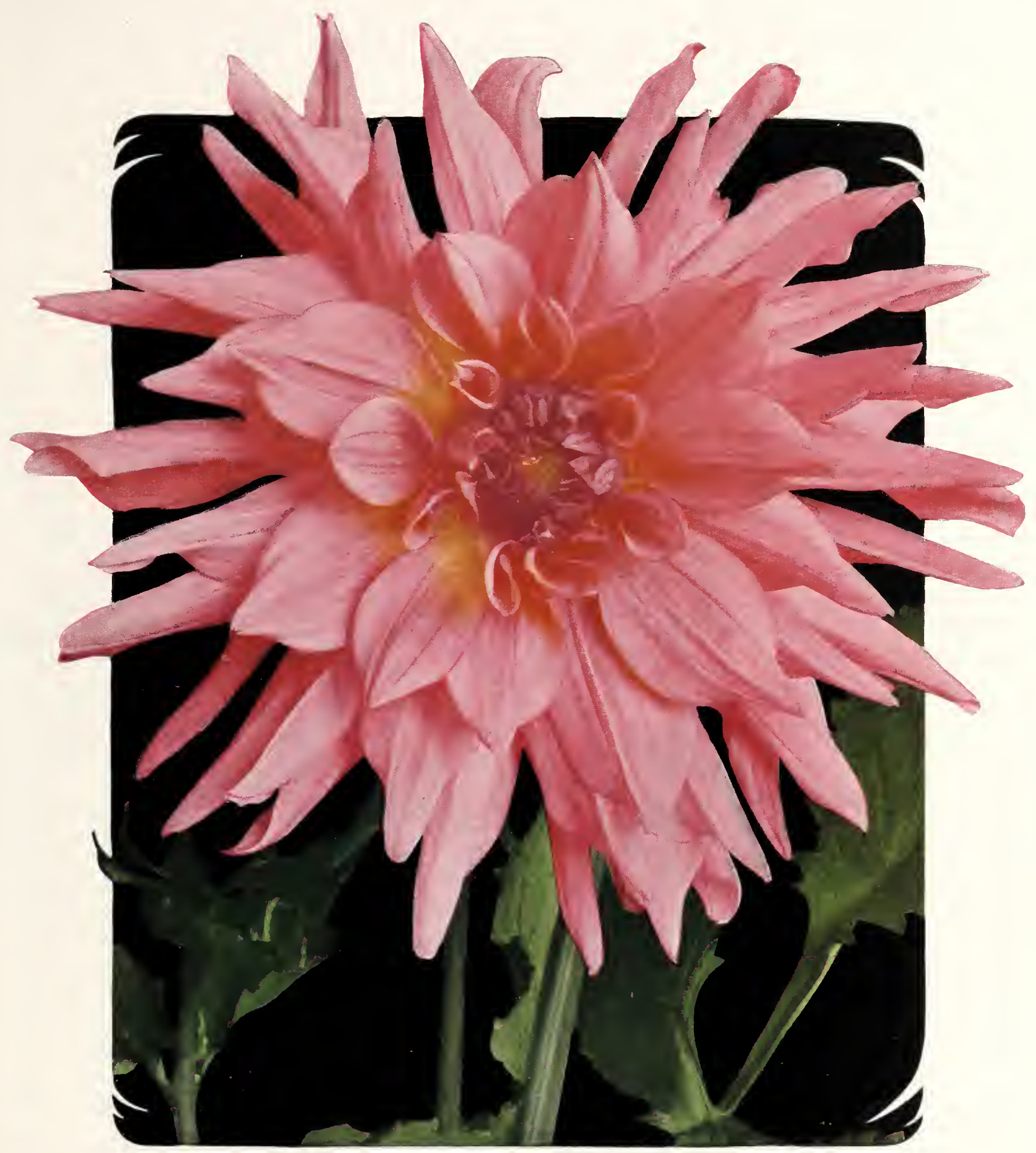

\section{Countess of Claverly (HYвRID састUS)}

WE ARE extremely fortunate in being able to offer to our customers this very finc Dahlia which is, without doubt, the finest, irresistiblc, real pink Hybrid Cactus Dahlia, bearing full flowers, 8 to 10 inches across, from early in the season until killed by frost. It is a vcry vigorous grower, with fine stems, and a prolific bloomer. The flowers are excellent kcepers and are cven morc beautiful under artificial light than outdoors. A sensation wherever shown. We have nothing to add to our description of last year. Owing to our having increased our stock, we are offering at lower prices this year.

Tubers, $\$ 3.50$ each, $\$ 35$ per doz. Green Plants (for delivery after May 15), \$2 each, \$20 per doz. 


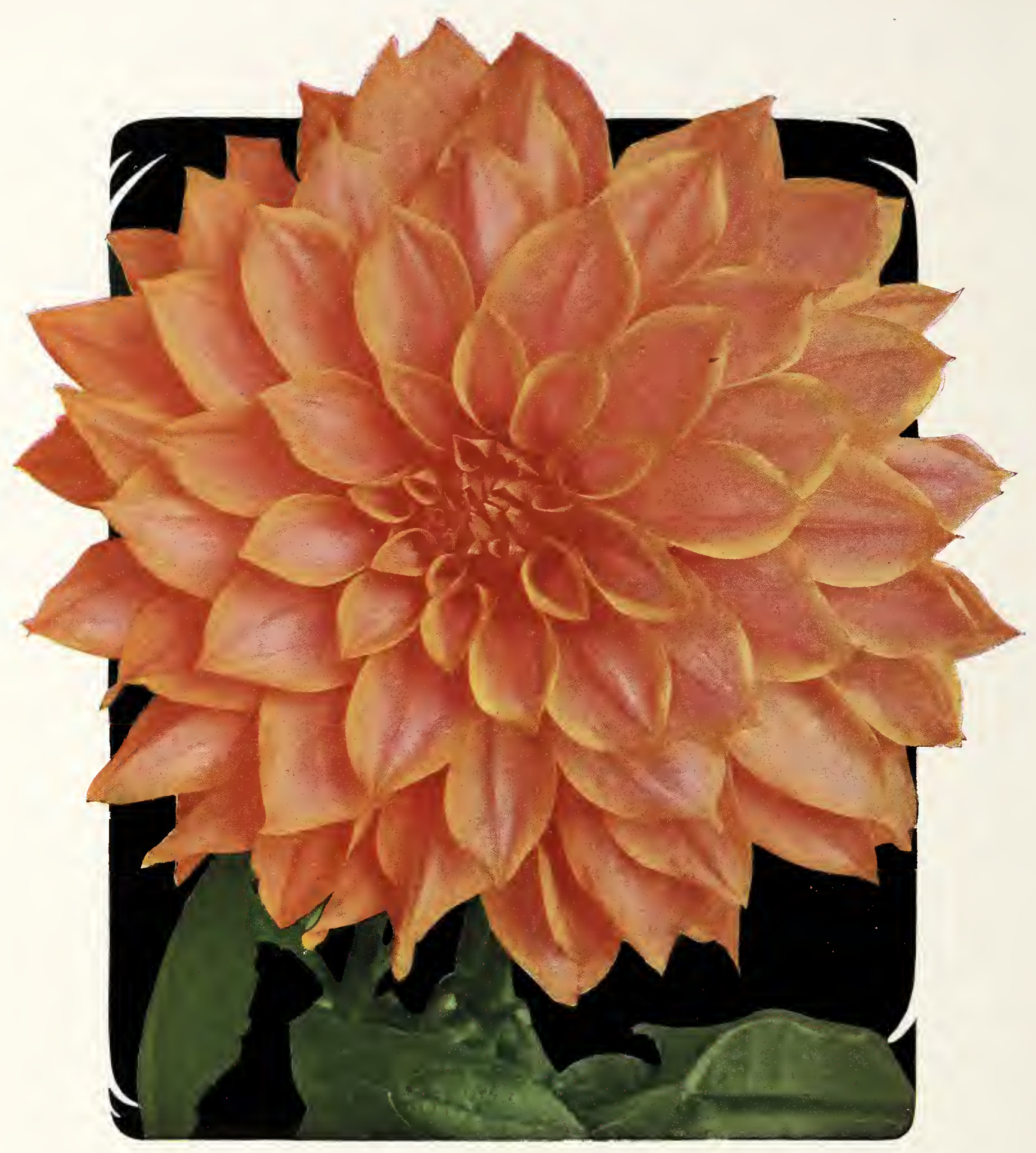

\section{Salmon Supreme (DECORATIVE)}

AT OUR Trial-Grounds this splendid seedling of Jersey's A Beauty proved a sensation. As the introducers of this variety, we feel justified in predicting that it will become a very popular Dahlia.

The form and color are really wonderful-very large, glistening salmon-orange flowers held proudly erect on the strongest of stems; free-flowering and a vigorous grower. This fine new Dahlia should be in every garden.

Tubers, \$3.50 each, \$35 per doz. Green Plants (for delivery after May 15), \$2 each, \$20 per doz. 


\section{NEW AND RARE EXHIBITION DAHLIAS}

The garden-lover who has become interested in Dahlias and vies with his neighbor in excelling him at his local Dahlia show, will be interested to know that some of the very high-priced varieties of last year are now available at more attractive prices. Our list of New
and Rare Exhibition Dahlias has been reduced to those that we consider worthy of a place in every garden, and represents the cream of the finest varieties that are available in reasonable quantities. We offer strong tubers for spring delivery, except a few varieties of which we have green plants out of $21 / 2$-inch pots for delivery after May 15 .

Aida. (Decorative.) Large, very attractive flower of royal vel $\$ 5$ per doz.

Amun Ra. (Decorative.) An immense flower of gorgeous Amun Ra. shades of copper and orange. A strong, vigorousgrowing variety. 50 ets. each, $\$ 5$ per doz.

Barbara Redfern. (Decorative.) Very large, deep flowers of

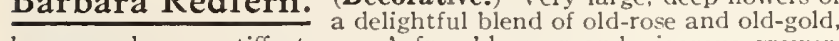
horne on heavy, stiff stems. A free bloomer and vigorous grower. $\$ 2$ each, \$20 per doz.

Bob White. (Decorative.) Pure white, giant flowers, full and Bob White. deep, borne on long cane stems that hold them creation will be a sensation. We have never seen a white bloom so freely. Strong root-divisions, $\$ 10$ each, $\$ 100$ per doz. Green Plants (for delivery after May I5), \$5 each, $\$ 50$ per doz.

Calumet. (Decorative.) Large, attractive flower of deep Calumet. cinnamon-brown. A splendid bloomer and an excellent variety in every way. $\$ 1$ each, $\$ 10$ per doz.

Calvin Coolidge, Jr. (Decorative.) Beautiful and stately pink, suffused salmon and tipped with gold. A vigorous grower and free bloomer. $\$ 1.50$ each, $\$ 15$ per doz.

Carmello. (Decorative.) Very large, rich deep amaranth-pink Carmello. flowers with curly petals, held upright on fine strong stems. \$1 each, \$10 per doz.

Chemar's Masterpiece. (Cactus.) Huge, Io-inch, orchidall conditions. A great prize-winner and very popular. $\mathbf{\$ 1 . 5 0}$ each, $\$ 15$ per doz.

Chevacano. (Decorative.) A beautiful, fine exhibition DecoraChe Dahlia of true form. Flower full and deep. rich apricot. Good bloomer; fine stems. Won many prizes on the Coast. $\$ 2.50$ each, $\$ 25$ per doz.

City of Lawrence. (Decorative.) Strong-growing and freebright canary-yellow. 75 cts. each, $\$ 7.50$ per doz.

Dakota. (Decorative.) This variety occupies a prominent place Dakota. at Dahlia shows. It is of splendid habit, and the blooms are held erect on strong stems. The color is, perhaps, best described as flame. 50 ets. each, $\$ 5$ per doz.

Eagle Rock Sunshine. (Cactus.) In a class by itself. The yellow, are very large and are helders, of a very fine shade of deep stems. It shows no tendency to become pendent, even under the most unfavorable conditions, and produces blooms full to the center until frost. It is unquestionably the finest yellow Cactus Dahlia. $\$ 1.50$ each, \$15 per doz.

Earl Williams. (Decorative.) This giant-flowering Dahlia shows in recent years. The color is a combination of brilliant crimson and white. One of the finest and most attractive of the newer varieties. 75 cts. each, $\$ 7.50$ per doz.

Elkridge. (Hybrid Cactus.) This large, pure white variety is of long, strong steins. Has won many prizes. \$1 each, $\$ 10$ per doz.

Ellinor Vanderveer. $\begin{aligned} & \text { (Decorative.) Very large blooms of } \\ & \text { satiny rose-pink, with great depth and }\end{aligned}$ substance, on fine, long, strong stems. A splendid exhibition variety. 75 cts. each, $\$ 7.50$ per doz.

Francis Larocco. (Decorative.) One of the finest large, ence, and perfect in form. Vigorous grower with fine stems and of profuse-blooming qualities. A Dahlia that should be in everybody's garden. $\$ 2$ each, $\$ 20$ per doz.

F. T. D. (Decorative.) Sport of the well-known Trentonian. $\$ 1$ each, \$10 per doz.
Glen Cove Beauty. (Hybrid Cactus.) A cross between pers, retaining the good points of each. Same color as Mrs. Joln T Scheepers-cliamois, edged pink. Fine, large flowers; ca
vigorous grower and free bloomer. $\$ 2$ each, $\$ \mathbf{2 0}$ per doz. Glory of Sunrise Trail. (Decorative.)

late, and is fairly covered with flowers of unusual formation, due to their depth. A lovely shade of maize-yellow edged violet. Giant flowers on fine stems and a vigorous grower. $\$ 2$ each, $\$ 20$ per doz.

Golden Jubilee. (Decorative.) Large, bronzy orange blooms grower and free flowering. \$1.50 each, $\$ 15$ per doz.

Grace Sperling. (Decorative.) Its splendid color, beautiful able Dahlia. The color is perlaps best described as a two-tone face of golden iridescent buff with reverse of petals amaranth-p!Irple. $\$ 7.50$ per doz.

Harry Mayer. (Decorative.) Beautiful silvery pink with placed, making a heavy, thick bloom. One of the finest exhibition Dahlias to date. $\$ 2.50$ each, $\$ 25$ per doz.

Ida Perkins. (Decorative.) A fine clear white of great subwinner. $\$ 2.50$ each, $\$ 25$ per doz.

Jacqueline Darnell. (Hybrid Decorative.) Very large flowbuttercup-yellow, all petals shaded and tipped rose. Fine stems and good keeper when cut. $\$ 1.25$ each, $\$ 12.50$ per doz.

Jane Cowl. One of the few outstanding exhibition Dahlias in buff and I928 and I929. Deep, massive blooms of a bronzy of unusual strength holds this giant Decorative over a plant of ideal growth, while the foliage is the thick, leathery. kind that insects seldom injure. $\$ 2$ each, $\$ 20$ per doz.

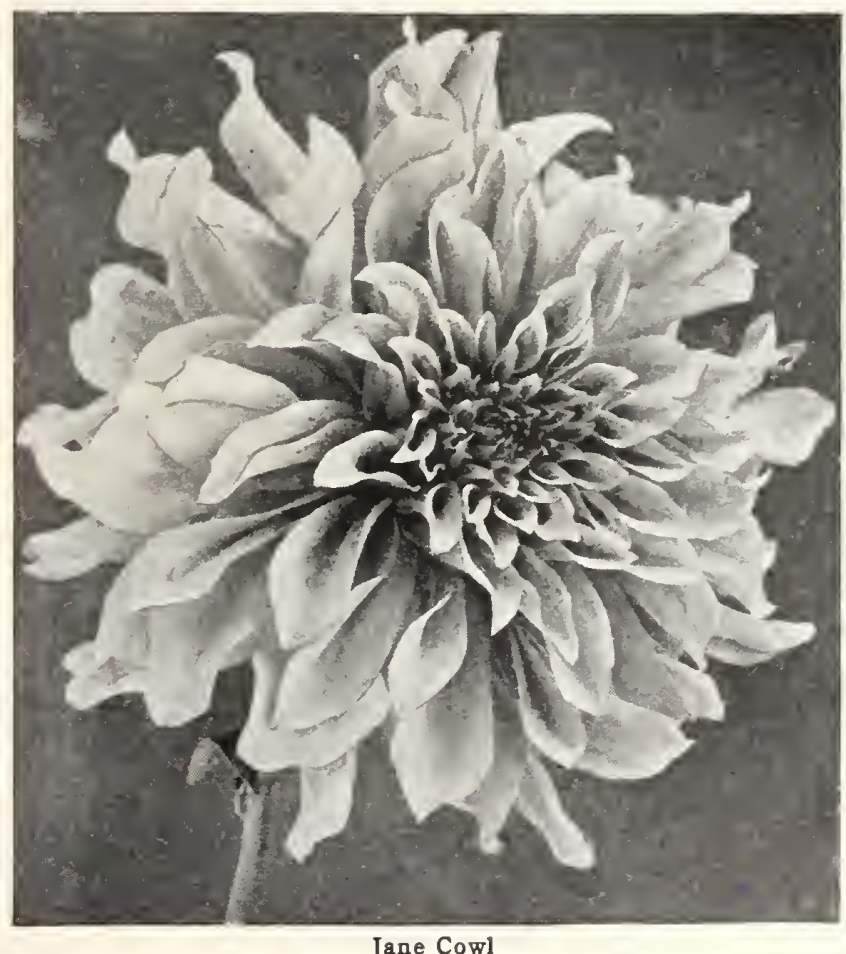




\section{NEW AND RARE EXHIBITION DAHLIAS}

Jersey's Beacon. (Decorative.) This fine novelty is Chinesetoned effect. It is a grcat favorite and a real "beacon of the garden." Large; free bloomer; vigorous growcr, 50 cts. each, $\$ 5$ per doz.

Jersey's Beauty. This is, without a doubt, the finest true pink Lecorative Dahlia yet introduced. The beautiful large, pink flowers are of perfect form and are supported on long, straight, stiff stems, held well above the foliage. As a cutflower, it is a wonderful keepcr and is instantly admired. A splendid exhibition Dahlia, and equally valuable for garden decoration. Owing to a good supply of tubers, we are able to offer this fine Dahlia at a reasonable price this year. 50 cts. each, $\$ 5$ per doz.

Jersey's Glory. (Decorative.) Very large, clear sparkling orange flowers, borne frecly on the best of Clean, vigorous grower. $\$ 5$ each, $\$ 50$ per doz.

Jersey's King. Very large, perfect flowers of a brilliant Oriental stiff stems, well above the foliage. 50 cts. each, $\$ 5$ per doz.

Jersey's Masterpiece. (Decorative.) A bold, upstanding strawberry. Form resembles the old favorite Insulinde, but much more beautiful. Very free bloomer. $\$ 3.50$ each, $\$ 35$ per doz.

Julian H. Walter. (Decorative.) Flowers of great size, Julian H. Warried on perfect stems, and in color a beautiful shade of buff-orange every way. $\$ 1.25$ each, $\$ 12.50$ per doz.

Kemp's Fort Monmouth. (Hybrid Cactus.). One of the color it is a rich crimson-maroon, with a faint tint of bluish violet at tips of petals. An immense flower, frequently 13 inches in diameter, and borne on long, strong stems, well above the foliage. Does not burn; a fine keeper and an excellent Dahlia for exhibition. Tubers, $\$ 3.50$ each, $\$ 35$ per doz. Green Plants (for delivery after May 15), $\$ 1.50$ each, $\$ 15$ per doz.

Kemp's Violet Wonder. $\begin{gathered}\text { (Decorative.) Judges generally } \\ \text { agree that this is the best violet- }\end{gathered}$ colored Decorative Dahlia introduced to date. Flowers frequently ro inches across and of true Decorative form, frequently 5 inches in depth. Blooms are borne on strong, stiff stems Io to $\mathbf{I} 2$ inches above the foliage. Splendid for exhibition. Tubers, $\$ 4$ each, $\$ 40$ per doz. Green Plants ( for delivery after May I5), \$2 each, \$20 per doz.

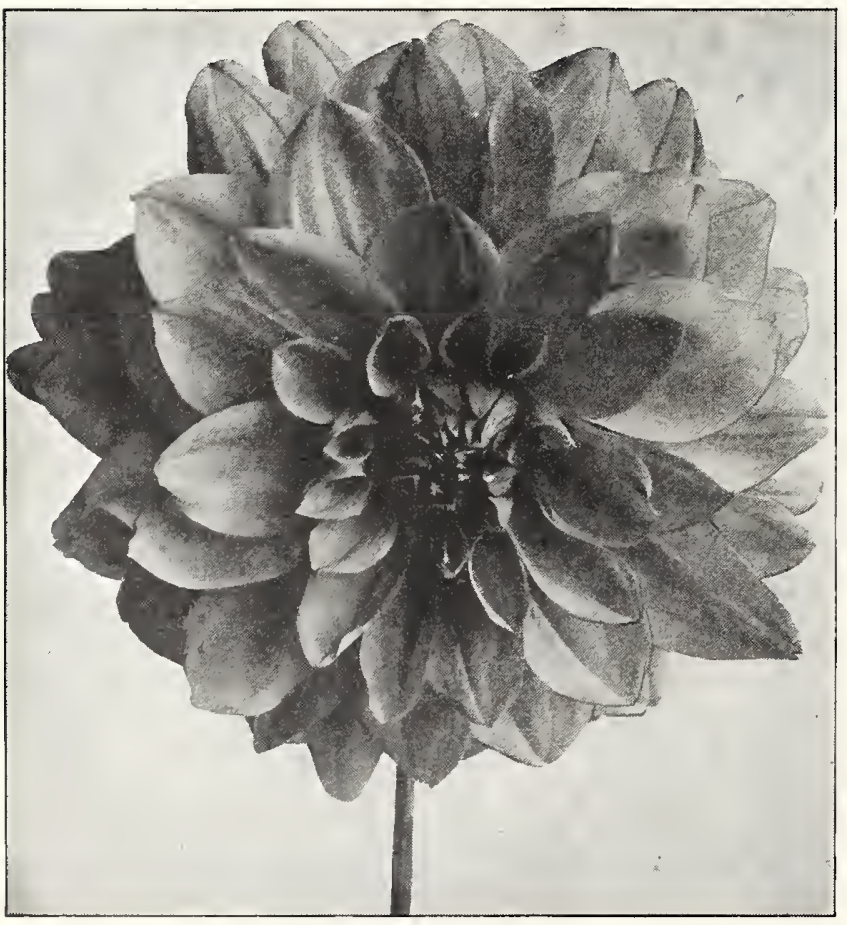

Decorative Dahlia, Sagamore
Margaret Masson. (Decorative.) Beautiful silvery roseprize-winner and very popular. 75 cts. each, $\$ \mathbf{5 0}$ per doz.

Margaret Woodrow Wilson. (Decorative.) An exhibicent pink and tion type of rare opalesfreely on the best of stems. $\$ 1$ each, $\$ 10$ per doz.

Marmion. (Decorative.) This huge, beautiful flower of golden tion. The florets are wavy and curl gracefully. A very free bloomer and vigorous grower. Should be in every collection. $\$ 1.50$ each, $\$ 15$ per doz.

Mr. Edwards. (Decorative.) The color of this lovely Dahlia Mr. Edwards. is a maranth-pink, with reverse of petals shaded plum. Flowers very large and deep. A Dahlia admired by many in our gardens. $\$ 1.50$ each, $\$ 15$ per doz.

Mrs. Carl Salbach. (Decorative.) A large, long-stemmed bluish lavender. Fine tor exhibition and cut-flowers. 50 cts. each, $\$ 5$ per doz.

Mrs. George Stumpp. (Decorative.) One of our own introductions and considered one of the finest new Decoratives. The flowers are of great depth, of true Decorative form, and vary from 5 to 8 inches in díameter. In color they are of a delightful autumn shade - an exquisite biending of yellow and fawn. The plants are strong, sturdy growcrs, with rigid stems, and produce blooms continuously. \$1 each, \$10 per doz.

Mrs. I. de Ver Warner. A refined, deep mauve-pink Dahlia count of its size and beautitul orchid color. It is an abundant bloomer, splendid tor exhibition and fine for the garden. 50 cts. each, \$5 per doz.

Mrs. John T. Scheepers. Very large flower, standing well above the foliage on long, upright stems. The color is, perhaps, best described as a canary-yellow, shading to delicate pink on outer petals. Strong, vigorous, freeblooming variety. 50 cts. each, $\$ 5$ per doz.

Perella. (Decorative.) A large Dahlia of bright rose-pink, shadand a good keeper. \$1 each, \$10 per doz.

Pride of California. Considered by many Dahlia enthusiasts The most brilliant of the new Dahlias. The flowers are of large size, perfect in form, and of a glowing cardinalred. The finest of the dark rich crimson Decorative Dahlias for all purposes. 50 ets. each, $\$ 5$ per doz.

Pride of Stratford. (Decorative.) Giant Decorative of a beautiful two-toned autumn shade; petals are deep cadmium-orange, shading to lighter orange-yellow at base of petals; reverse, reddish bronze; petals slightly quilled. Very fine long stems. $\$ 1.50$ each, $\$ 15$ per doz.

Robert Treat. (Decorative.) Flowers 9 to II inches across Treat 4 inches deep, of a pleasing American Beauty rose color, unlike any existing variety. Strong, healthy grower and free bloomer. A sensational Dahlia. 75 cts. each, $\$ 7.50$ per doz. Roman Eagle. (Decorative.) An immense Dahlia of brilliant, Rurnished copper color. Excellent stems with fine dark green foliage. $\$ 1$ each, $\$ 10$ per doz.

Rose Fallon. (Decorative.) One of the largest of the new Eastern introductions. A beautiful Decorative of pleasing shades of amber, russet, and salmon. The formation of the flower is perfect and the stems are excellent. Its foliage is very dark and fine. A good cut-flower variety. \$1 each, $\$ 10$ per doz.

Rose Glory. (Decorative.) Color begonia-rose. A strong, free-blooming variety of excellent substance, popular. \$4 each, \$40 per doz.

Roycroft. (Hybrid Cactus.) Large, excellent-formed Hybrid - Cactus of cinnamon-buff, deepening to russet. Very prolific bloomer; fine stems; vigorous grower. $\$ 1$ each, $\$ 10$ per doz. Sagamore. (Decorative.) An exceptionally fine cut-flower of a center. It has fine strong stems with splendid keeping qualities. 75 cts. each, $\$ 7.50$ per doz. Sanhichan's Gem. (Decorative.) A shade of old-rose at the points, giving it the appearance of a Hybrid Cactus. A mediumsized flower with good stems. 75 cts. each, $\$ 7.50$ per doz. 


\section{NEW AND RARE EXHIBITION DAHLIAS}

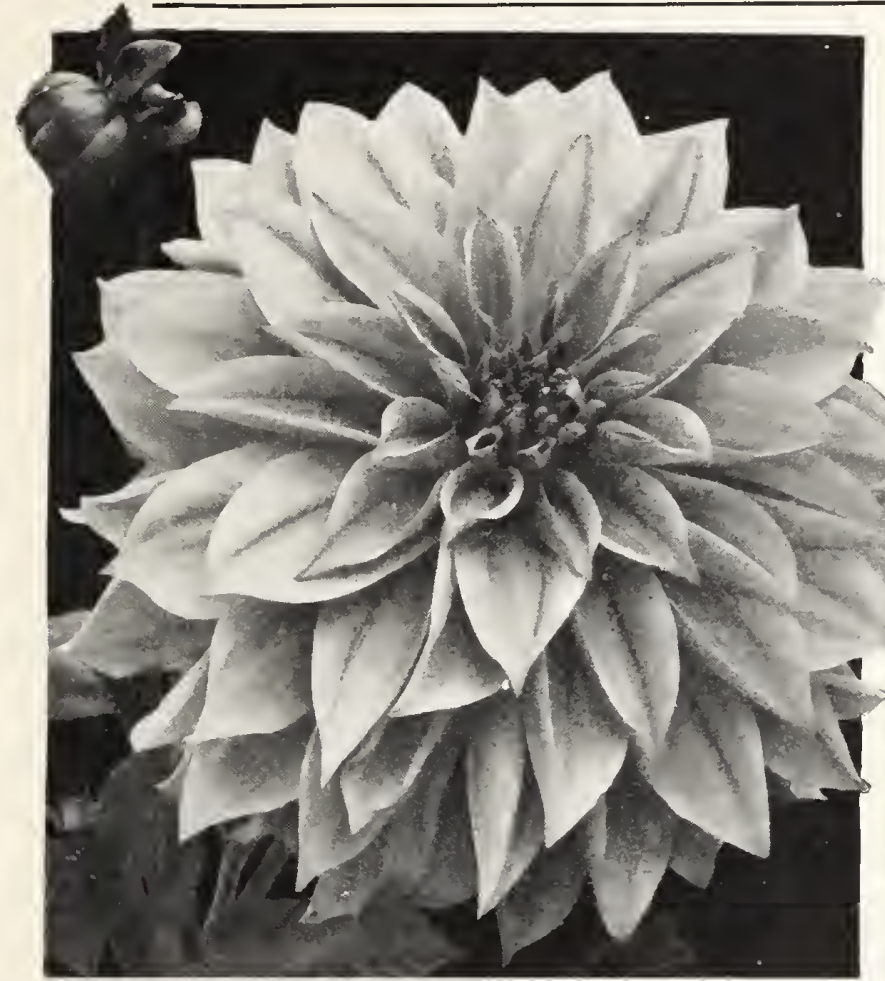

Jersey's Beauty. See page 140
Santa Anna. (Decorative.) One of the largest and most beauSanta Anna. tiful Dahlias. Flowers salmon-rose, suffused olclfree bloomer. $\$ 2.50$ each, $\$ 25$ per doz.

Shackamaxon. (Decorative.) An orange-cinnamon Dahlia of long, narrow petals resembling a chrysant hemum. Good stems. \$2 each, \$20 per doz.

Silverado. (Cactus.) The immense blooms of this lovely. Silvertus are white, gradually shading to a delicate silvery lavender towards the center. Stems extra long and strong. $\$ 1.50$ each, \$15 per doz.

A Snowdrift. (Decorative.) One of the finest white Decorative A Dahlias, either for garden decoration or exhibition. A gigantic flower of perfect form, with broad, waxy white petal borne on long, stiff stems, held erect. $50 \mathrm{cts}$. each, $\$ 5$ per doz. Treasure Island. (Decorative.) One of the finest autumilwith rose suffusion, held erect, with full centers througliout the season. Io-inch flowers are freely produced. A splendid acquisition. Tubers, $\$ 4$ each, $\$ 40$ per doz. Green Plants (for delizery afler May I5), \$1.50 each, \$15 per doz.

Trentonian. (Decorative). A very large Dahlia of a shadle Tomer and coppery bronze, the whole fine blending of oldbeautiful brilliancy, with a reddish bronze center. The stems are long and strong. 75 cts. each, $\$ 7.50$ per doz.

Semesan is a good disinfectant for all Bulbs Semesan and Tubers. Dust your Dahlia roots with it at planting-time. It protects against fungus and disease. 2 ozs. 50 cts., $1 \mathrm{~b} . \$ 2.75$, 5 lbs. $\$ 13,25$ lbs. $\$ 56.25,100$ lbs. $\$ 220$.

\section{SINGLE BORDER DAHLIA}

Just the Dahlia for border planting. Excellent effects may be secured by using this Dahlia as a border plant or for a border on the outside of such tall-growing bedding plants as cannas. Try it as a border plant around green-foliaged cannas, such as Richard Wallace. Ami Barrilet. Coppery foliage and crimson-scarlet, single flowers, with yellow stamens. Grows about 2 feet high. 50 cts. each, $\$ 5$ per doz.

\section{NEW CENTURY SINGLE DAHLIAS}

We offer below a list of the best varieties of these Dablias. They are very popular for garden decoration or for cutting.

Aubright Beauty. A large, pure white variety with golden sellow Aenter; free-flowering.

Cimson Giant. Very large, deep crimson flowers of fine form.

G. E. Varnum. Showy brilliant red, with yellow center; very attracLavender Gem. Pure mauve-color, slightly veined silvery white Wonderfully attractive, and a splendid keeper.

Rose-Pink Century. Flowers 6 inches and over in diameter, of a clear rose-pink color. A strong grower, with , fine for cutting.

Yellow Gem. An even shade of pure golden yellow; very free-flowering.

Price, any of the above, $35 \mathrm{cts}$. each, $\$ 3.50$ per doz.

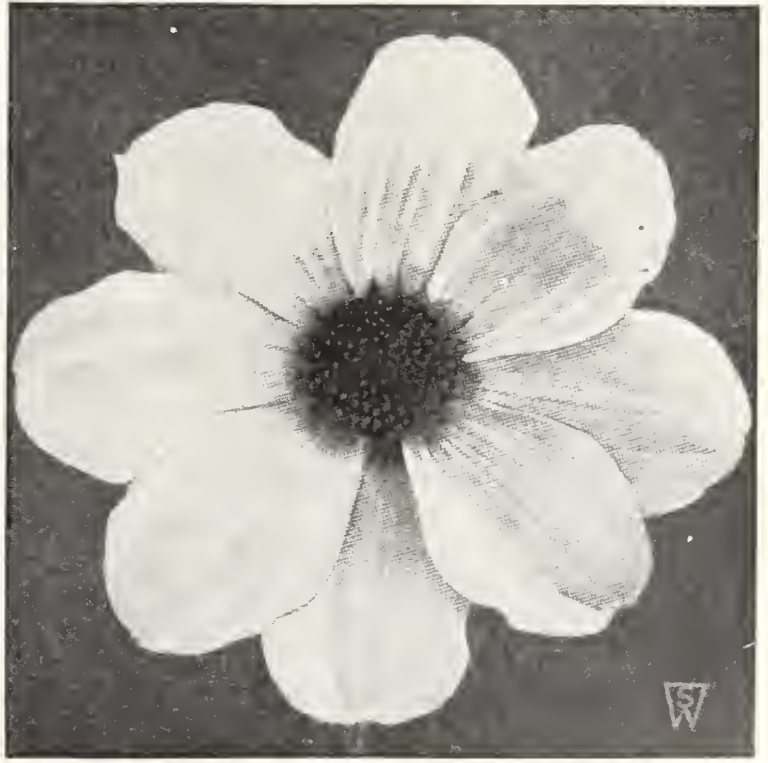

Single Dahlia, Rose-Pink Century 


\section{CHOICE CACTUS DAHLIAS}

We offer below a choice list of Cactus Dahlias which have proved to bloom well under varying conditions. They are all excellent cutflower varieties, as well as splendid varieties for garden decoration. While numerous Dahlia enthusiasts are growing the Decorative type of Dahlias on account of their massiveness, the Cactus Dahlia is still preferred by many flower-lovers on account of its artistic appearance.

Ambassador. An outstanding Dahlia at many of the Amahlia exhibitions, and considered by many as being one of the best and most artistic of recent Dahlia introductions. Its color is, perhaps, best described as a soft yellow at the center, with salmon, amber, and pink shadings, gradually deepening towards the tips. The flowers are of largest size and are set just right on perfect stems. A strong grower and free bloomer. \$1 each, $\$ 10$ per doz.

Attraction. Large, delicate orchid-pink flowers. Attraction. Sturdy, upright grower with the best of stems. 50 cts. each, $\$ 5$ per doz.

Bride's Bouquet. Pure, glistening white flowers of long stems. Fine garden variety. 35 cts. each, $\$ \mathbf{3 . 5 0}$ per doz.

Cigarette. Very fine scarlet, tipped white. A freeon long, stiff stems. 75 cts. each, $\$ \mathbf{\$ 7 . 5 0}$ per doz.

Countess of Lonsdale. The best-known and the Cactunt desired of all the Cactus Dahlias. It is of the older Hybrid Cactus type, with broad, straight, pointed petals of a deep salmon-red color, and is a very abundant and continuous bloomer. If only one Cactus Dahlia could be had, ninety-nine people out of a hundred would select this one. 35 ets. each, $\$ 3.50$ per doz.

Daddy Butler. Color, attractive combination of An early and free bloomer on perfect stems. 75 cts. each, $\$ 7.50$ per doz.

Ethel T.Smith. Enormous flowers held erect on ing to white. Very popular. 50 cts. each, $\$ 5$ per doz.

F. W. Fellowes. We consider this one of the best F. W. Fellowes. Cactus varieties ever raised. The flowers are of unusual size for the long, narrow-petaled type, and of intense coral-red color with deeper suffusion toward the center. A leader in this type at all Dahlia exhibitions or for the garden. Excellent as a cut-flower. 75 cts. each, $\$ 7.50$ per doz.

Gladys Sherwood. Immense, pure white blooms, deep and A most popular white. 50 cts. each, $\$ \mathbf{5}$ per doz.

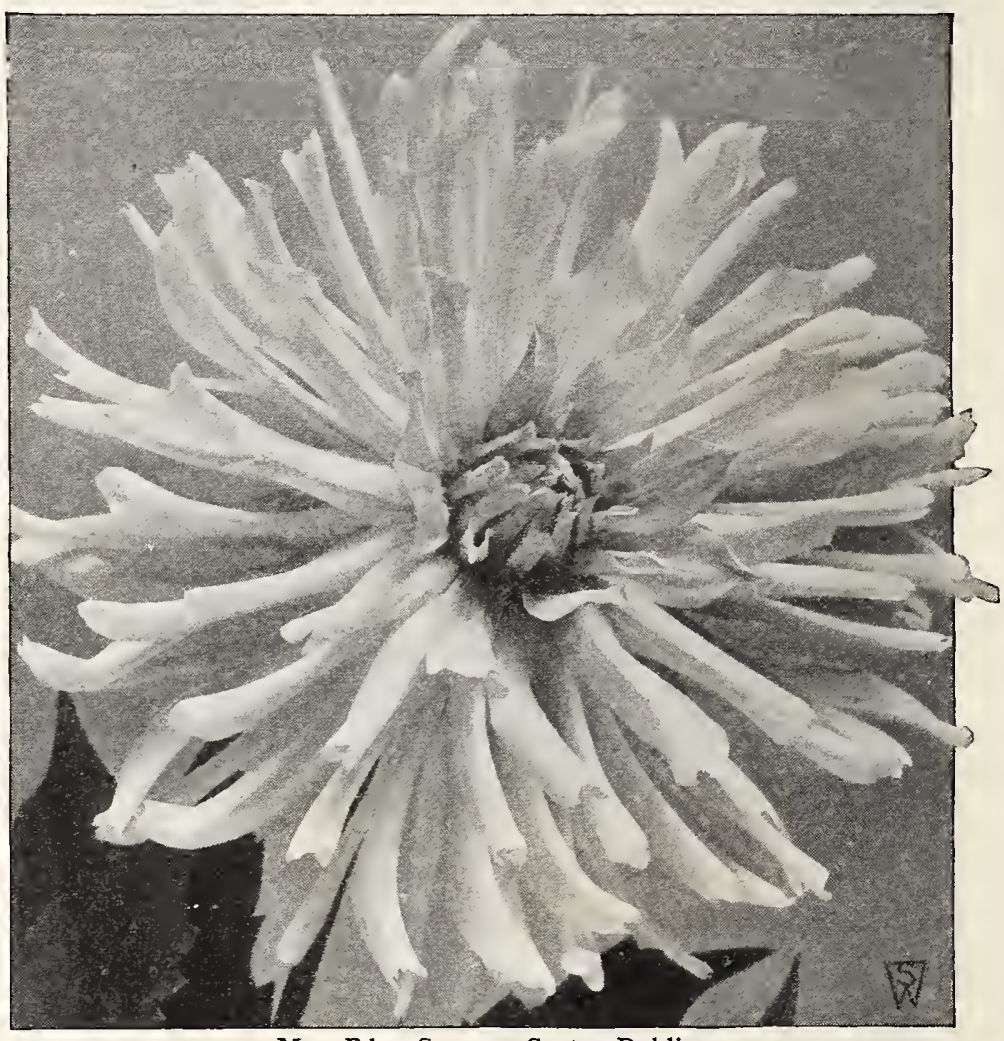

Mrs. Edna Spencer Cactus Dahlia

J. H. Alexander. A beautiful blending of golden yellow shad.H. Alexander. ing to salmon-pink. Large flower and very free bloomer. 75 ets. each, $\$ 7.50$ per doz.

Lorna Doone. Splendid incurved Cactus, yellow at the base, Lorna Doone. changing to pink tinted rose; fine upright growth and stiff stems. 75 cts. each, $\$ 7.50$ per doz.

Mariposa. A delightful shade of orchid-pink which is intensified a by a deeper center, with a violet suff usion. One of the gigantic Californian introductions which has depth as well as diameter of bloom. The flowers are borne on long, straight, stiff stems, well above the foliage. Blooms early and continues in good shape until the end of the season. 75 cts. each, $\$ 7.50$ per doz.

\section{POMPON DAHLIAS}

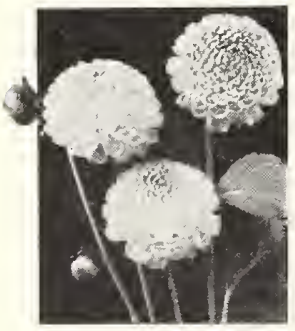

Pompon Dahlias

We offer below a select list of these beautiful Pompon Dahlias, a miniature form of the Show Dahlias, having the same ball-like form, but much smaller in size. The plants are also smaller, of branching habit, and produce an endless profusion of flowers, which are invaluable for table decoration and boutonnières.

Flame. Bright red.

Ganymede. Beautiful fawn, edged pink.

Golden Beauty. Yellow.
Gloria. Crushed strawberry crimson.

Joe Fete. Pure white; very small.

Klein Domitea. Bronze.
Little Jennie. Fine primrose-yellow. Madeline. Primrose, suffused rose. Prince Charming. Pink.

Rosea. Cerise. 


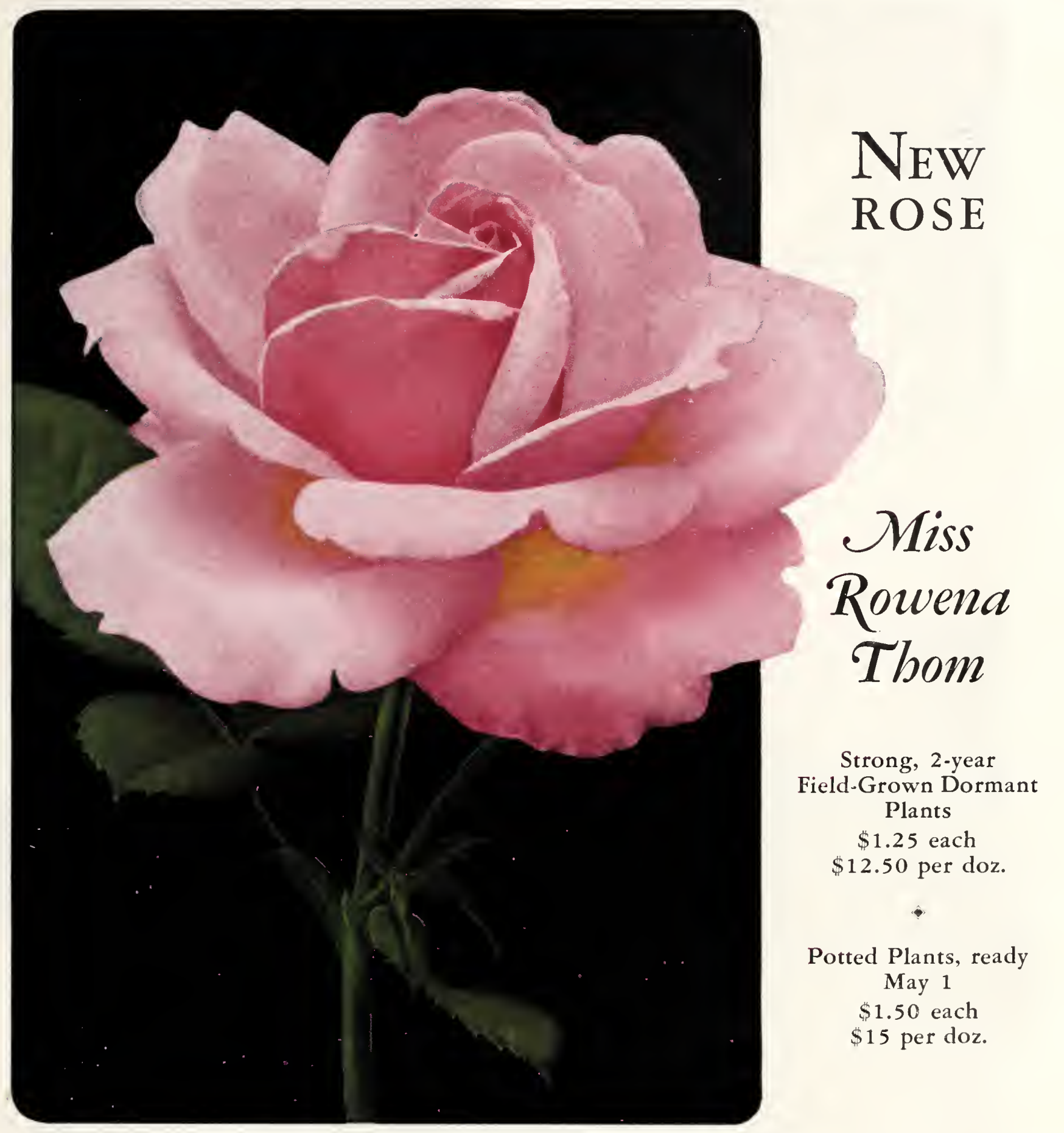

Another california beauty. The giant flowers equal the magnificent Souvenir de Georges Pernet in size, but the plant surpasses it in vigor of growth, length of stem, and continuity of bloom. The color is glowing satiny pink, with a heart of dusky gold, wholly distinct from other pink shades, and unequaled

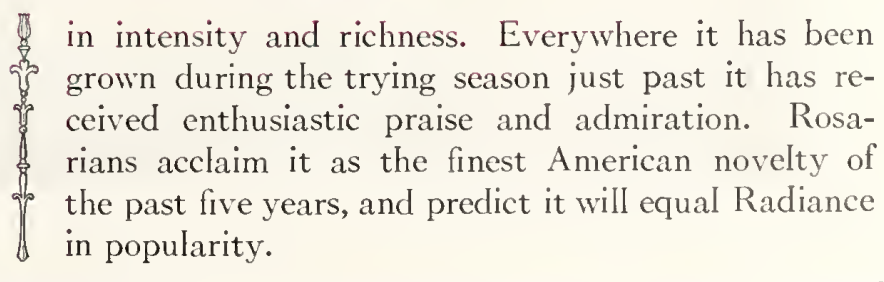




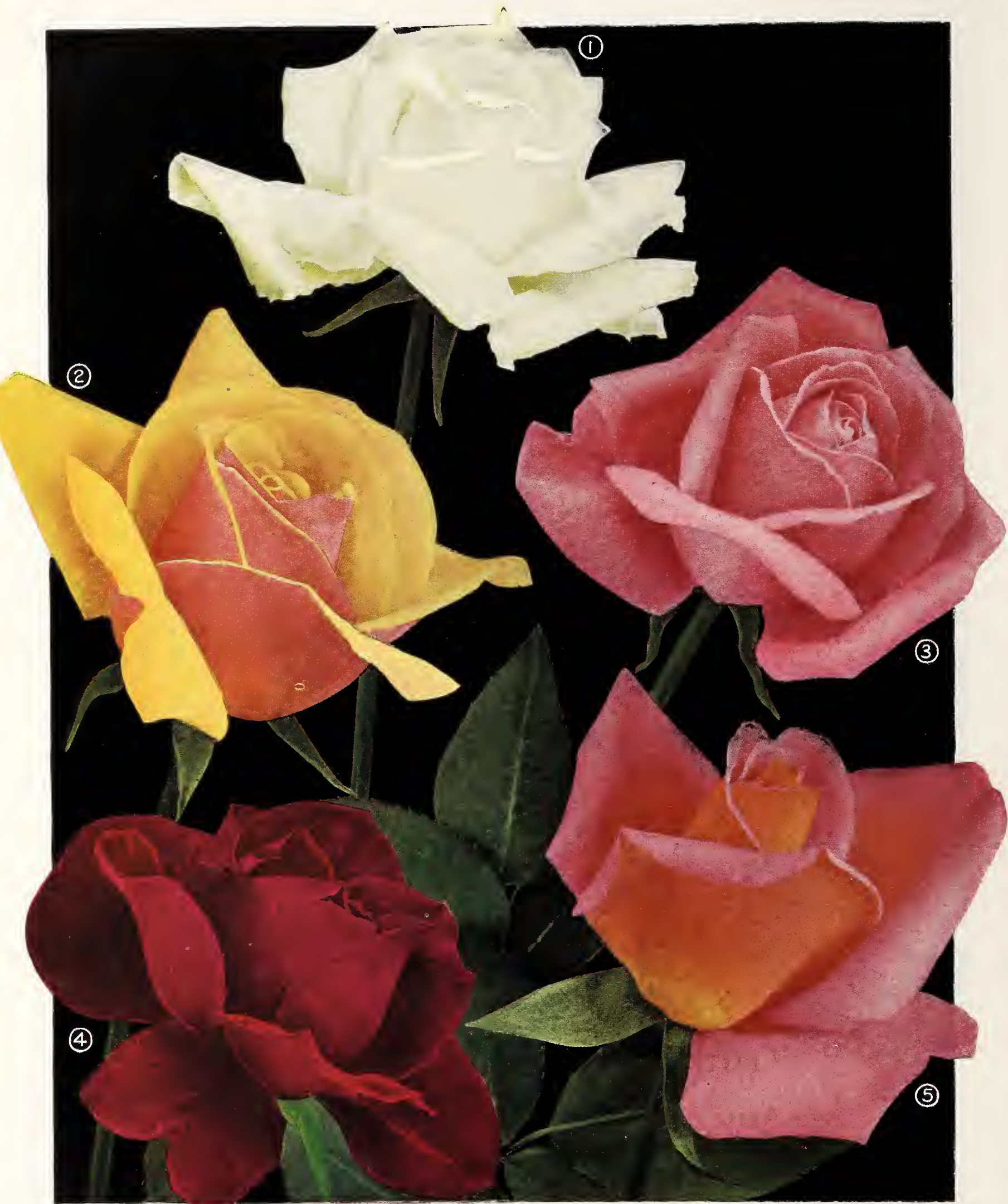

\section{Five New Everblooming Roses}

We are again making a special offer of the above frve Roses. The varieties offered are distinct in their colors and are noted for their free-flowering qualities. Owing to our having had a large quantity especially grown, we are able to offer them at a slightly reduced price in collections only. If our patrons desire to purehase any of these. varieties separately, we suggest their referring to the text pages 148 and $\mathrm{I} 49$. where they will be found listed and more fully described.

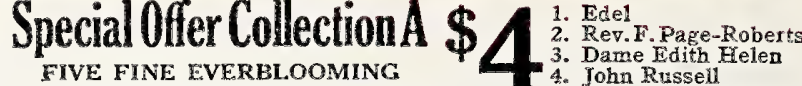 ROSE BUSHES 4. John Russell 5. Willelm Kordes \\ American-grown 2myear-old Dormant Plants. The Rose bushes we are} offering are 2-year $\rightarrow$ ld, budded plants, which make stronger plants and give better results than those grown on their own roots. 


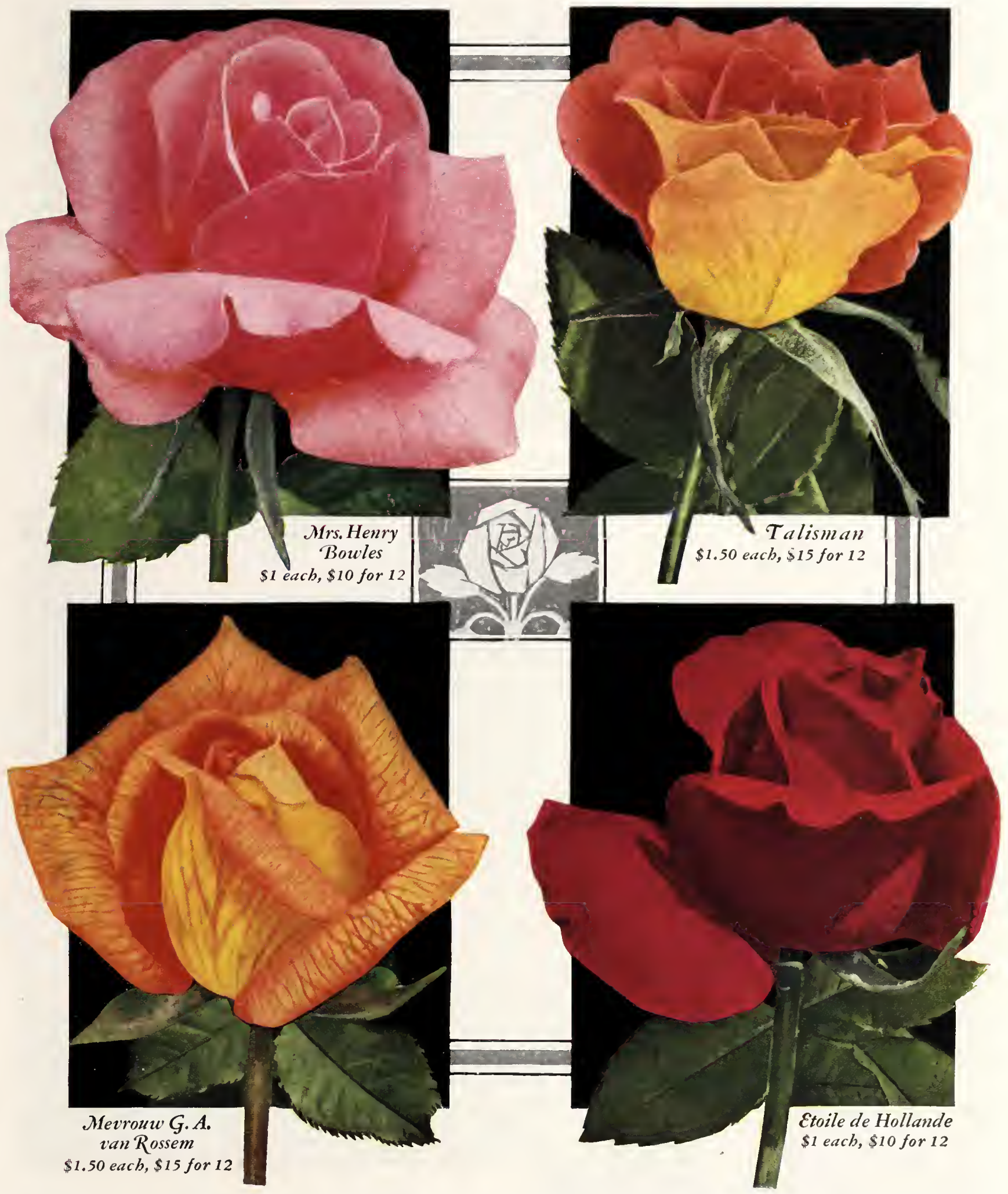

FOUR new and unusually attractive Roses which bloom all summer. F We have gathered into the group on this page the handsome deep pink and warm flesh-colored Mrs. Henry Bowles, the exquisite and sensational Talisman which has been given highest honors everywhere, Mevrouw G. A. van Rossem, a variety of unbelievable variability and brilliance, and the superb, unsurpassable dark red Etoile de Hollande.

SPECIAL OFFER COLLECTION B FOUR FINE EVERBLOOMING ROSE BUSHES

One each of the beautiful $\$$ varieties pictured above for 4.50 


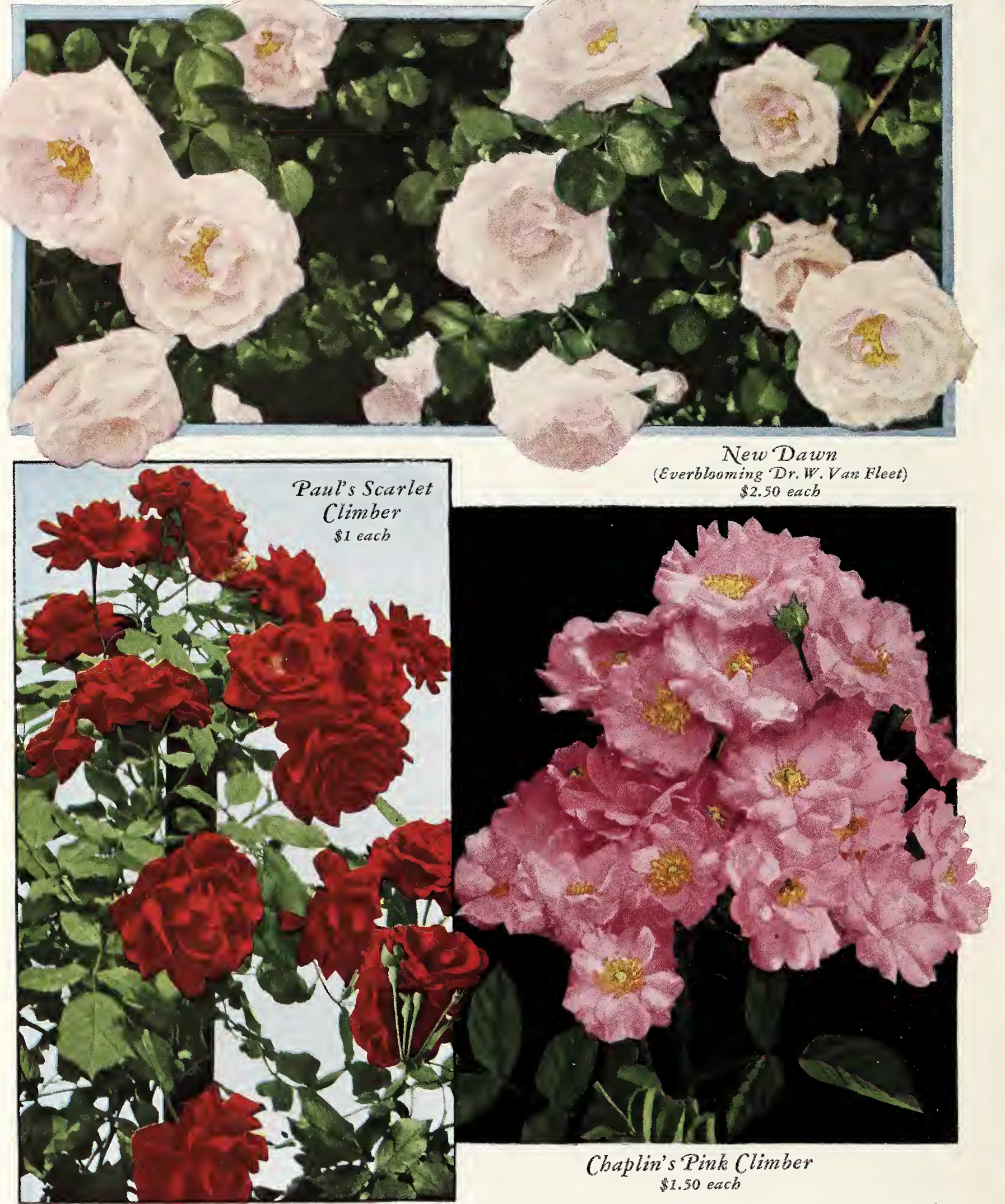

SPECIAL OFFER COLLECTION C One plant each of all 3 varieties for $\$ 4.50$
THREE of the finest modern Climbing Roses pictured above. Chosen for their dependable merit and novelty. Paul's Scarlet is the most popular and widely grown red Rose; Chaplin's Pink Climber, a gorgeous new shade of pink, and New Dawn, an everblooming form of the extremely popular Dr. W. Van Fleet continuing in flower all summer. 


\section{New Hybrid TeaRoses}

We selected the following varieties from the hundred or more I926-I930 introductions as representing the finest types of modern Roses, showing strong tendencies in the way of perfection of form combined with strength and brilliancy of color. They are new, and where we have seen them growing they were lovely and unique. These novelties are really the finest in new varieties, covering every range of colors. A few or all should be in everyone's garden.

Betty Sutor. (I929.) Exquisite both in bud and fully delicate rosy pink, the outside, bright rosy pink. $\$ \mathbf{1 . 5 0}$ each, $\$ 15$ per doz.

Caledonia. (I928.) Large, very long-pointed, conical buds, Caledonia. slightly lemon tinted when first expanding, changing to pure white as the flowers develop. \$1.50 each, \$15 per doz.

Charles P. Kilham. (I926.) A brilliant novelty. The rich, brilliant Oriental red bloom flushed with orange. $\$ \mathbf{1 . 5 0}$ each, $\$ 15$ per doz.

Dr. Edward Deacon. (1926.) Its color is fascinating, the Dr. Edward Deacon. margin of the petals being a delicate tint of shrimp-pink, gradually merging to a deep salmon-orange, forming a fine, full flower. $\$ 1.50$ each, $\$ 15$ per doz.

Gladys Benskin. (I929.) Large, long-pointed buds of very distinct color-the reverse of the petals orange. $\$ 1.50$ each, $\$ 15$ per doz.

Impress. (1929.) A novelty: The ovoid buds when unfolding Impress. are cardinal-red with orange suffusion, and develop into extremely large, full, double, very perfect blooms. \$1.50 each, \$15 per doz.

James Gibson. (I928.) Glorious, glowing crimson-scarlet radiance to the large, full, beautifully formed flowers. $\mathbf{\$ 1 . 5 0}$ each, $\$ 15$ per doz.

J. C. Thornton. (I926.) A most brilliant, glowing J.C. Thornton. scarlet-crimson, with buds of exquisite form, and fine, full, well-shaped, high-centered flowers. $\$ 1.50$ each, $\$ 15$ per doz.

Jules Gaujard. (I928.) Distinct flowers which, as shade of orange-rose. $\$ 1.50$ each, $\$ 15$ per doz.

Lady Barnby. (I930.) Beautifully formed flowers inely shade of clear rosepink. $\$ 1.50$ each, $\$ 15$ per doz.

Lady Forteviot. (1928.) Large, ovoid buds yellow bloom flushed with cardinal-red. $\$ 1.50$ each, $\$ 15$ per doz.

Lucie Marie. (1930.) Long-pointed buds of deep Lellow, splashed with red; as the outer petals unfold, the inner face is yellow. $\$ 1.50 \mathbf{e a c h}$, $\$ 15$ per doz.

Monarch. (I926.) Very large, long-pointed buds, Monarch. developing into large, double, high-centered, very lasting flowers of a rich silvery pink color. $\$ \mathbf{1 . 5 0}$ each, $\$ 15$ per doz.

Mrs. John Bell. (I928.) A Rose of exceptional merit, and very large, full, with large, long-pointed, shapely buds tive, vivid shade of cochineal-carmine. \$1.50 each, \$15 per doz.
Mrs. Sam McGredy. (1929.) The color is quite distinctshades-beautiful scarlet coppery orange heavily flushed with Lincoln red on the outside of the petals. \$2.50 each, \$25 per doz.

Polly. (1927.) A splendid Rose of perfect shape, the center Polly. golden yellow passing to a tender flushed pink toward the edges. $\$ 1.50$ each, $\$ 15$ per doz.

Rosella. (I930.) Large, ovoid bud, developing to a splendid, - large, well-formed, attractive flower of luninous capucine-yellow, with delicate salmon-pink suffusion. $\$ \mathbf{\$ 1 . 5 0}$ each, \$15 per doz. Rudolph Valentino. (I929.) The very large, full flower, arranged, is of a lively shade of shrimp-pink or coral-red, with a golden coppery suffusion. $\$ 1.50$ each, $\$ 15$ per doz.

Schwabenland. (1928.) A Rose of great merit. There are many pink Roses but none just like this. In color it is a luminous, rich rose-pink, retaining its brightness until the petals drop. $\$ 2.50$ each, $\$ 25$ per doz.

Vaterland. (I928.) The most distinct dark-colored variety aterland. yet introduced-a rich, deep, velvety scarletmaroon. The splendidly formed, high-centered flower has remarkable keeping qualities. $\$ 3$ each, $\$ 30$ per doz. 


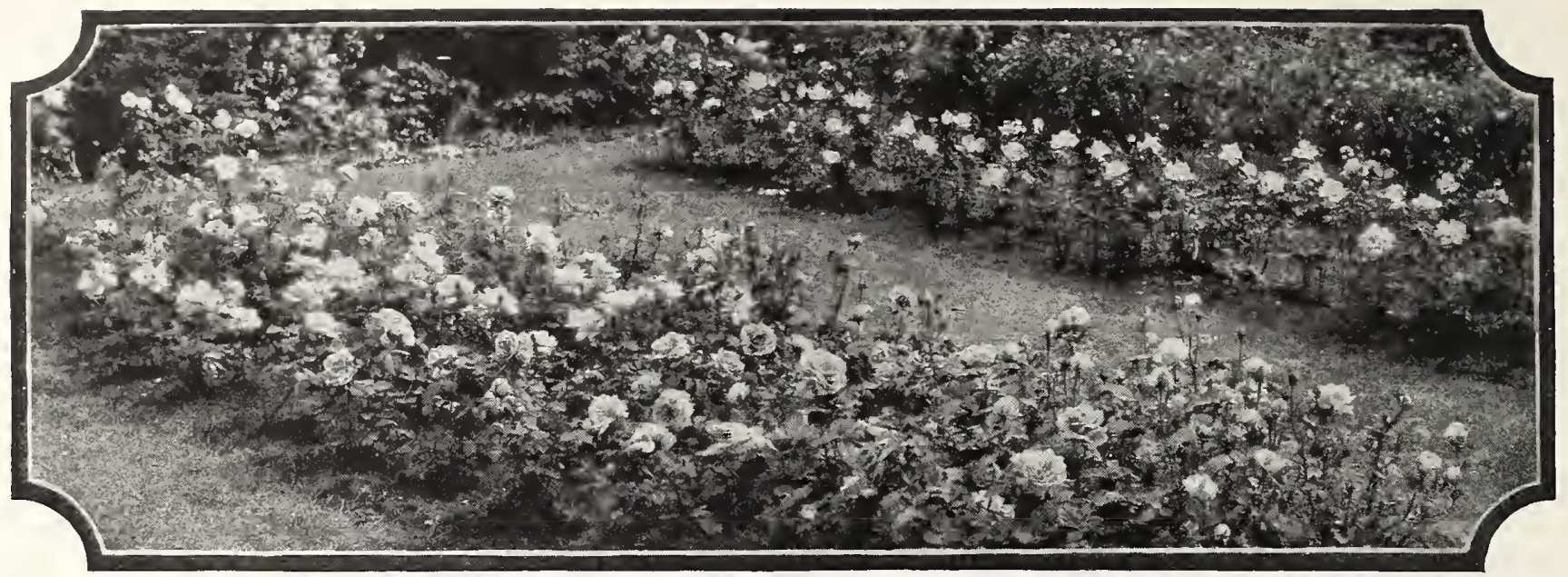

\section{HYBRID TEA ROSES}

Our Roses are all American-grown, two-year-old stock. They are budded or grafted, and while some planters prefer stock grown on their own roots on account of the liability of budded plants to throw up suckers, this will rarely occur if deep plantings are made, and if a wild shoot should appear, it is readily distinguished by the most casual observer, and should be removed close to the root. Budded plants are more vigorous, produce finer blooms, come to bearing sooner, and are equally as permanent and hardy as those on their own roots, and many of the choicest varieties do not succeed unless budded or grafted.

Culture and Hints on Growing. The best soil in which to grow Roses is good topsoil to which rotted cow manure has been added. Dig out the bed to a depth of 2 feet or more, and, if drainage is imperfect, it must be provided for. Fill in with a mixture of soil and manure as above. It is best to make beds, if possible, in advance of planting, so as to allow time for settling. Beds may be made any size, but it is best to have them about $31 / 2$ by 5 feet, which enables you to pick the blooms without stepping on the beds. The ideal time to plant is just after severe frost has passed. Hybrid Teas should be set I $1 / 2$ feet apart; Hybrid Perpetuals 2 feet apart, and both 8 inches from the edge of the beds. They should be planted with the roots well spread out and placed about 9 inches below the surface of the ground, the soil made firm about them, and liberally watered. Throughout the summer the surface soil should be cultivated weekly. If good cultivation, like the above, is given, watering will rarely be necessary.

Winter Protection. In this latitude the most satisfactory form of protection is to draw up a mound of soil from 8 to Io inches high around the base of the plant, then cover the entire bed after the ground begins to freeze with any loose material, such as strawy manure, evergreen boughs, or corn-stalks.
BETTY. When established it produces blooms of marvelous beauty, particularly in the autumn. Large flowers of a glowing coppery rose color, suffused with gold.

BETTY UPRICHARD. This is one of the most popular garden Roses at this time. The flowers are large, semi-double, brilliant in two tones of light salmon-pink, heavily shaded with copper on the backs of the petals. The bush is very vigorous, with good foliage, and is exceptionally free-flowering.

COLUMBIA. This beautiful Rose has not only become one of the most popular greenhouse blooming varieties, but has proved itself one of the best bedding and garden sorts. It is of strong, vigorous habit and exceptionally free-blooming. In color it is a most pleasing shade of rose-pink.

CONSTANCE. A free-flowering variety, producing beautiful, long, orange-yellow buds of perfect form, which, as they develop, open to a full, globular flower of golden yellow. Rosarians consider this among the best of the yellow garden Roses.

DAME EDITH HELEN. A sensational new Rose which has won almost every award at home and abroad. The flowers are produced singly on strong canes throughout the season. They are immensely long, composed of very substantial broad petals which curl back prettily, forming a wonderful, imbricated, full, double flower absolutely perfect in every state of development. The color is a brilliant, yet soft Rose du Barri pink, and is delightfully and strongly sweet-scented. \$1 each, \$10 per doz., \$80 per 100 .

DOUBLE WHITE KILLARNEY. Very long-pointed buds of the typical Killarney form, but snowy white; open blooms beautifully formed with more petals than the original variety.

DUCHESS OF WELLINGTON. As the flower develops it changes in color from a saffron-yellow to a deep coppery saffron-yellow. The flowers are fairly full, with petals of great substance. A very free-flowering and fragrant variety.

EDEL. Massive, double flowers of pure white, with lovely curled petals symmetrically arranged, which makes them excellent for cutting, although the stems are sometimes a little weak. The plants are tall, healthy, and free-blooming. $\$ 1$ each, $\$ 10$ per doz. $\$ 80$ per 100.

Price of any of the above varieties, except where
ETOILE DE HOLLANDE. Acclaimed by all Rose-growers as the best red garden Rose in America. The flowers are sufficiently double to hold the bud shape well, and a rich, lovely shade of glowing scarlet-crimson. They are large, fragrant, and fine for all purposes. $\$ 1$ each, $\$ 10$ per doz., $\$ 80$ per 100 .

FEU JOSEPH LOO YMANS. A large, full flower of buttercupyellow, tinted with vivid apricot. The buds are long and pointed, resembling those of Sunburst. In growth the plant is strong, bushy, and erect. \$1 each, \$10 per doz., \$80 per 100.

FRANK READER. A large flower, with high-pointed center, light lemon-yellow at first, but in its half-expanded form it reveals a heart of golden apricot; delicious rose and apple scent. A vigorous grower and free bloomer. \$1 each, \$10 per doz., \$80 per 100.

GOLDEN DAWN. Massive buds, stained with dark crimson streaks, open to large, double, creamy yellow flowers like the old Maréchal Niel. The plant is remarkably vigorous and free-flowering and seems to be a splendid addition to the groups of dependable pure yellow garden Roses. $\$ 1.25$ each, $\$ 12.50$ per doz., $\$ 90$ per 100 .

GRUSS AN TEPLITZ. Of a rich scarlet, shading to a velvety crimson. A very free grower and in bloom all the time; succeeds well under the most ordinary conditions.

HADLEY. Considered by many as being one of the best garden varieties of its color-a rich crimson, varying to deep velvety crimson. The flowers are well formed and very fragrant.

JOHN RUSSELL. Exquisitely shaped, dark velvety crimson flowers on splendid plants of almost Hybrid Perpetual vigor. Notable for its splendid color and beautiful shape. $\$ 1$ each, $\$ 10$ per doz., $\$ 80$ per 100.

KAISERIN AUGUSTE VIKTORIA. A sof pearly white, faintly tinted lemon in the center. Very fragrant, beautifully formed flowers on long, graceful stems.

LADY MARGARET STEWART. A Rose of unique and distinct color-deep sunflower-yellow, heavily veined and deeply suffused with carmine. As the flowers develop, these colors intermingle, forming a most beautiful cadmium-orange effect. Delightfully sweet-scented. \$1 each, \$10 per doz., $\$ 80$ per 100 . 
LOS ANGELES. The following is the originator's description, all of which we fully endorse: "Los Angeles is, by all odds, one of the finest Roses ever introduced. The growth is very vigorous, and produces a continuous succession of long-stemmed flowers of Iuminous flame-pink, toned with coral and shaded with translucent gold at the base of the petals. In richness of fragrance it equals in intensity the finest Maréchal Niel. The buds are long and pointed, and expand into a large flower; the color is maintained from the bud until the last petal drops."

MARGARET MCGRED Y. Fine, cup-shaped, double flowers of brilliant brick-red with a fiery sheen, very difficult to describe. The plants are large, bushy, covered with healthy bright gieen foliage, and are continuously in bloom. $\$ 1$ each, $\$ 10$ per doz., $\$ 80$ per 100 .

MEVROUW G. A. VAN ROSSEM. This gorgeously colored Rose is a vigorous grower, with large, dark bronzy green, disease-resistant foliage. It produces an abundance of large, double, very fragrant flowers of golden yellow, heavily flamed and shaded orange and apricot, with the reverse of the petals often dark bronze and nearly brown when first open. The buds open well in all weathers and the stems are long and strong. $\$ 1.50$ each, $\$ 15$ per doz., $\$ 115$ per 100.

MISS LOLITA ARMOUR. A beautiful new variety. The flowers are of large size, and as they expand they develop to a deep coral-red with a golden, coppery red suffusion, the base of the petals a rich golden yellow with coppery red sheen.

MISS ROWENA THOM. It is almost impossible to give a true color description of this Rose. It seems as if the tints of a desert sunset have been caught in all their splendor and held by this beautiful Rose. The deep center glows with vivid oriental red, shading to rose as the bud expands and gradually passing to delicate mauve in the full-blown flower. The habit of growth is even stronger than that of Radiance which has for years been held as the peer of garden Roses. The flowers are large and borne on stems 30 inches long, which are practically thornless. It is virtually disease-resistant and produces many blooms which last well when cut. $\$ 1.25$ each, $\$ 12.50$ per doz., $\$ 90$ per 100 .

MME. BUTTERFL Y. A sport of Ophelia, it shows even better growth than this sterling variety, with more and larger flowers of a brilliant pink, suffused apricot and gold. The flowers are of splendid form, good texture, and fragrance.

MME. CAROLINE TESTOUT. Large, globular flowers of bright satiny rose, with deeper center. Very free and fragrant, and one of the most popular and valuable bedding varieties.

MME. EDOUARD HERRIOT. The buds are coral-red in color, shaded with yellow at the base; the medium-sized open flowers, medium double, are coral-red, shaded yellow and bright rosy scarlet, passing to shrimp-red.

MRS. A. R. BARRACLOUGH. A most distinct and valuable Rose of bright but soft, sparkling carmine-pink, passing to yellow at the base of the petals. The color does not fade as the flower ages, but appears to become brighter. The bud is long and perfect and develops into a full, double flower of great size, model form, and substance, and very fragrant. \$1 each, $\$ 10$ per doz., \$80 per 100.

MRS. AARON WARD. Splendidly formed, full, double flowers, equally attractive when full blown or in the bud state, of distinct Indian yellow, shading lighter toward the edges. Under certain weather conditions the entire flower will sometimes come a yellow tinted white, but it is a beautiful variety under all color variations.

MRS. ERSKINE PEMBROKE THOM. Slender yellow buds and large, well-shaped flowers of bright canary-yellow, somewhat deeper in the center. A free bloomer and a strong grower. \$1 each, \$10 per doz., $\$ 80$ per 100 .

MRS. HENRY BOWLES. Warm rosy pink blooms of unusual substance shaded with salmon-orange. It is a vigorous grower upright, bushy, with glossy, dark green, disease-resistant foliage and produces a profusion of large, double, intensely fragrant, very lasting flowers on long, strong stems. \$1 each, $\$ 10$ per doz., $\$ 80$ per 100 .

MRS. HENR Y MORSE. Low, bushy, spreading plants continually producing large, beautifully formed flowers of two lovely shades of pink. One of the finest modern bedding Roses which is becoming more popular every season. $\$ 1$ each, $\$ 10$ per doz., \$80 per 100 .

MRS. LOVELL SWISHER. A remarkably vigorous grower, freely producing perfectly formed, long, shapely buds and double flowers. The buds are a deep coppery salmon at the base, merging to salmon-pink at the tips. Flowers are salmon-pink, deepening toward the center. Delightfully Tea-scented.

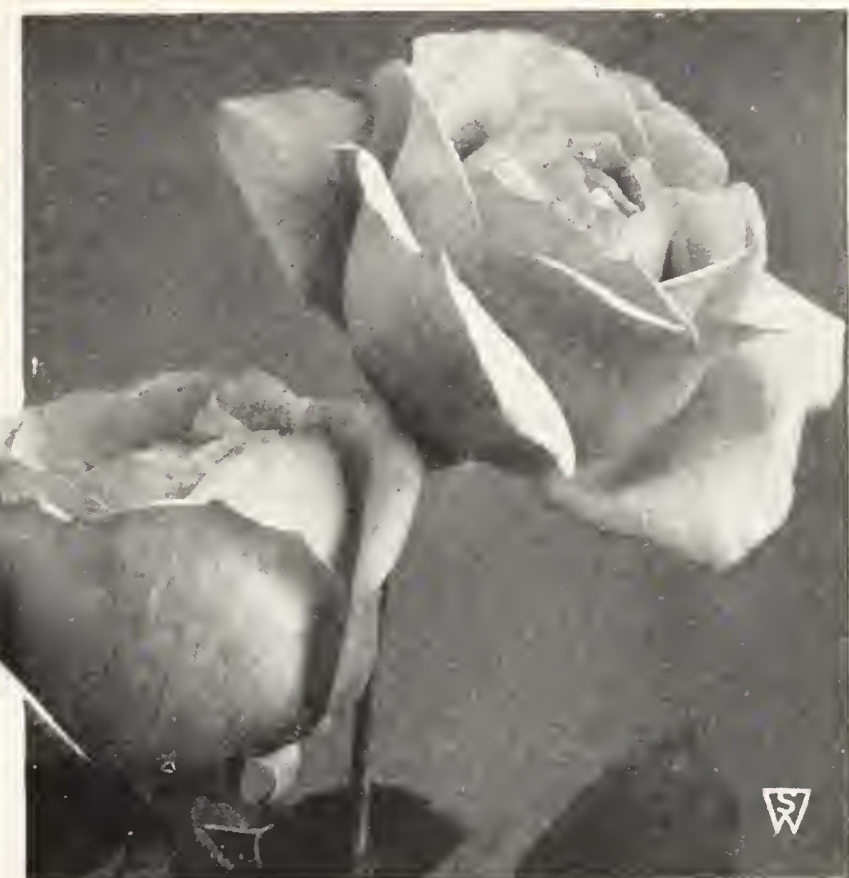

Radiance Roses

NORMAN LAMBERT. Gorgeous yellow buds flamed with red and light yellow, semi-double flowers, narrowly edged with various $\$ 10$ per doz., \$80 per 100.

OPHELIA. Flowers of perfect form, large size, and a most pleasing delicate tint of salmon-flesh, shaded rose, are borne erect on long. stiff stems. A variety that is exhibited in all Rose collections and flower shows on account of its sterling merit.

PRESIDENT HERBERT HOOVER. Large, long-pointed buds and semi-double, very lasting, spicily fragrant flowers of good size are borne in abundance on long, strong stems. In color they are a ver lovely combination of cerise-pink, flame, scarlet, and yellow, witl deeper cerise tints on two of the outer petals. A vigorous grower

RADIANCE. A brilliant carmine-pink, with salmon-pink and yellow shadings at the base of the petals. A Rose that will withstand the most unfavorable hot summer weather.

RED RADIANCE. A counterpart of Radiance, except in color, which is a clear cerise-red. A most valuable addition to our list of Roses.

REV. F. PAGE-ROBERTS. A Rose that is rapidly attaining great popularity. The copper-red buds are of great length, and open t golden yellow blooms stained with red. The flowers are large, full double, and delightfully fragrant. The plant is of strong habit with healthy foliage. $\$ 1$ each, $\$ 10$ per doz., $\$ 80$ per 100 .

SOUVENIR DE CLAUDIUS PERNET. The new yellow Rose that promises to become what has long been wanted, a hardy everblooming real yellow.

SOUVENIR DE GEORGES PERNET. Gigantic, loosely formed flowers of glittering orange-pink, most amazing in size and brilliance. One of the showiest and handsomest Roses grown.

TALISMAN. Brilliant gold, cerise, scarlet, and pure yellow in indescribable richness and combinations make Talisman the most spectacular Rose ever produced. It is a fine grower and bloom like the most seasoned garden veteran. Everybody likes it. $\$ 1.50$ each, $\$ 15$ per doz., \$115 per 100 .

VILLE DE PARIS. Distinct, rich buttercup-yellow, witlout a trace of any other color, retaining its richness under all weather conditions. In form somewhat similar to Radiance, fairly double and splendid for cutting. Plant upright and tall; a profuse bloomer. $\$ 2$ each, \$20 per doz.

WILHELM KORDES. A very fragrant and free-blooming Rose witl long-pointed buds that yield double, high-centered flowers of deep golden salmon, veined with red and overlaid with a tint of copper. It is of strong, compact growth with leathery foliage that is resistan to mildew and black-spot. $\$ 1$ each, $\$ 10$ per doz., $\$ 80$ per 100 . 


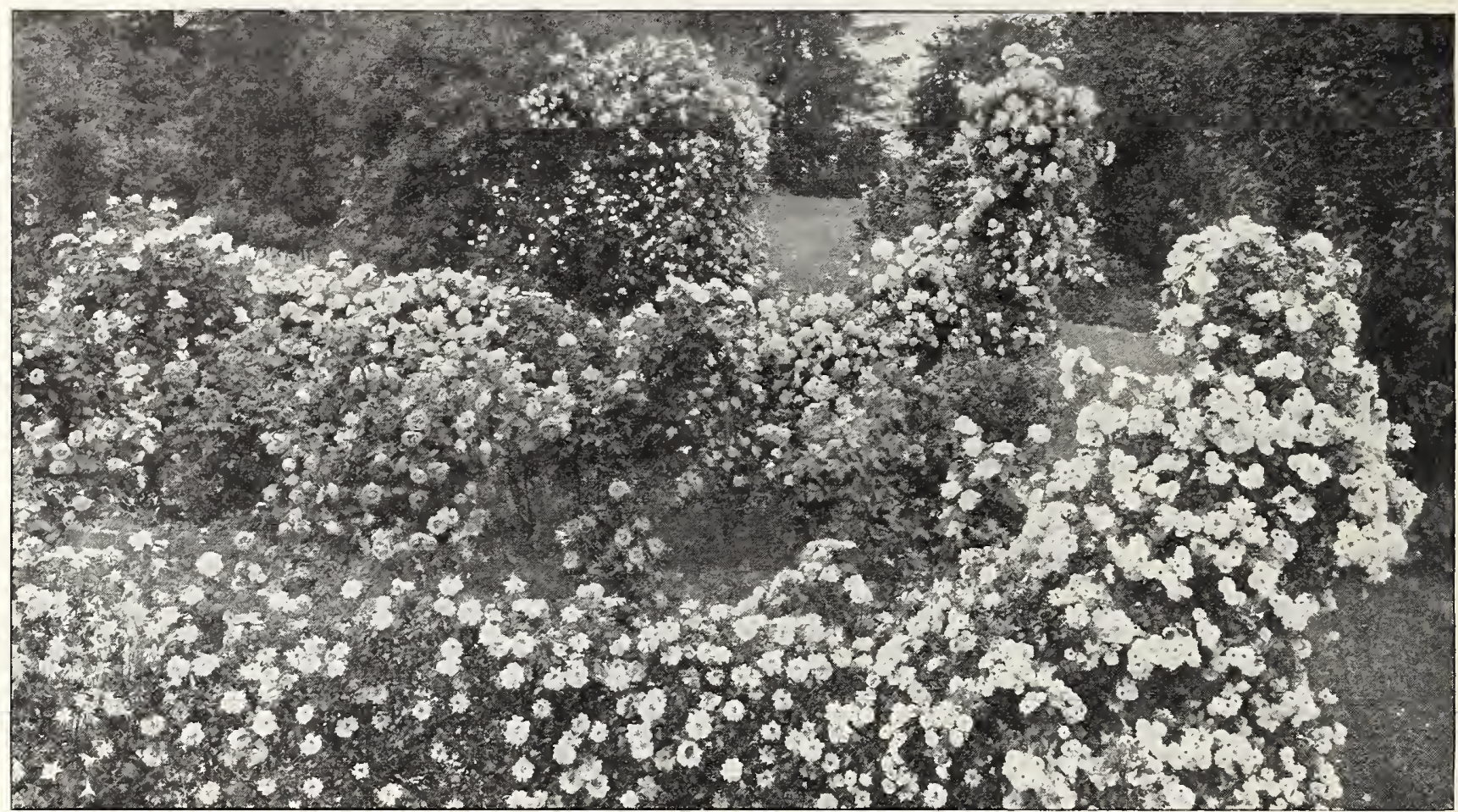

Climbing Rose, New Dawn

\section{GLIMBING AND RAMBLER ROSES}

We offer on this page a selection of the best modern hardy Climbing and Rambler Roses. Climbing Roses require no pruning in the spring, except the cutting out of very old or dead wood, and the shortening of the laterals and long canes to make the growth conform to the space to be covered; but a severe pruning in July, directly after they have finished flowering, is beneficial. Cutting away at that time all old flowering wood will encourage a vigorous growth, which will give an abundance of flowers the following season.

ALBERTINE. Vermilion buds, expanding to moderately double, perfect-shaped flowers of a pleasing cameo-pink, with silvery suffusion. Foliage rich, deep, glossy green.

AMERICAN PILLAR. A single-flowering variety of great beauty. The flowers are of large size- 3 to 4 inches across-of a lovely shade of pink, with a clear white eye and cluster of yellow stamens, and are borne in immense bunches.

BONFIRE. As its name implies, this is a brilliant red, really a rich cherry-crimson. There is a place for a good red Rose for early forcing that will take the place of Excelsa, which is not satisfactory for early work, and this is supplied in this new red. \$1 each, \$10 per doz., \$75 per 100 .

CHAPLIN'S PINK CLIMBER. Unquestionably the most important acquisition in Climbing Roses since the introduction of Dr. W. Van Fleet and Paul's Scarlet Climber, which are universally recognized as the two most popular Climbing Roses, and to which Chaplin's Pink Climber will prove an equally valuable companion. This striking novelty originated at Waltham Cross, England, in the same nursery in which Paul's Scarlet Climber was raised. It is a cross between Paul's Scarlet Climber and American Pillar, of strong, vigorous growth, perfectly hardy, with large, glossy, dark green foliage, producing its large flowers, similar in size and form to Paul's Scarlet Climber, very profusely in strong trusses of from eight to twelve flowers each, but in color it is a rich, lively pink. \$1.50 each, \$15 per doz., \$115 per 100.

CLIMBING AMERICAN BEAUTY. A strong, healthy, vigorous grower, frequently making shoots from Io to I 2 feet long, with good-sized flowers for a Climbing Rose that blooms so freely. A pleasing rose-pink of splendid form.

DOROTHY PERKINS. Soft shell-pink, flowering profusely in large clusters; very fragrant and lasting.

DR. W. VAN FLEET. The long, pointed buds are of a rich flesh-pink on stems I 2 to I 8 inches long. One of the very best of the Climbing Roses.

EMIL Y GRA Y. Considered the best yellow Rambler. The color is a beautiful shade of golden yellow. Flowers nearly double and carried on strong stems. Strong, field-grown plants, \$1 each, $\$ 10$ per doz., $\$ 75$ per 100 .

Price, any of the above varieties, except where noted, extra-
GARDENIA. Pleasing yellow buds, turning white on opening. Has been, until the introduction of Emily Gray, the best yellow of the Climbing Roses.

JACOTTE. Color shrimp-pink, shaded golden yellow at base; flowers fully $2 \frac{1}{2}$ inches in diameter, distinct from all others, and a color which will make it a favorite.

The Everblooming Dr. W. Van Fleet
The DAWN
A sport from what is universally acknowledged as the best and
most popular American Climbing Rose, identical in every way
with its parent in size and formation of its flowers, color, etc.,
but which blooms continuously throughout the summer and fall
months. Really the first worth-while Everblooming Climber
introduced and a variety that every Rose-lover will be anxious
to possess. \$2.50 each, $\mathbf{\$ 2 5}$ per doz., $\mathbf{\$ 1 7 5}$ per $\mathbf{1 0 0 .}$

PAUL'S SCARLET CLIMBER. No Rose can compare with it for brilliancy of color-a vivid scarlet which does not bleach or fade throughout the life of the flower. \$1 each, \$10 per doz., \$75 per 100 .

PRIMROSE. In this Rose we have what has long been sought aftera real hardy yellow Rambler. It is a strong, vigorous climber and hardy under the same conditions in which Dr. W. Van Fleet and similar varieties will thrive. Its light primrose-yellow color lasts until the petals drop, and the flowers, $21 / 2$ inches in diameter, are borne in trusses of 2 to 5 on long stems, and stay in good condition a long time. Blooms freely in midseason and has healthy, dark green foliage. $\$ 1.25$ each, $\$ 12.50$ per doz., $\$ 90$ per 100 .

SILVER MOON. Pure white in color, with petals of great substance. The large bunch of yellow stamens in the center adds to its attractiveness.

TAUSENDSCHON. Large flowers, varying from bud to the open flower through many shades of faint yellow, creamy white and bright rose-pink.

ong, field-grown plants, 90 cts. each, $\$ 9$ per doz., $\$ 70$ per 100 


\section{HARDY HYBRID PERPETUALS}

Before the wonderful development of the Hybrid Tea Roses, the Hardy Hybrid Perpetual Rose was the most popular type for garden planting, and even now most of the varieties offered are grown by Rose-lovers in conjunction with the other sorts. The collection offered below will be found excellent.

In pruning Hybrid Perpet uals it is advisable to cut away all weak growth, and if quality of bloom is desired, cut back the strong canes to within 8 or 9 inclies of the ground, but if quantity of bloom for garden effect is desired, leave these canes from 2 to 3 feet high, according to their strength.

FRAU KARL DRUSCHKI. Pure white in color, perfect in form, strong grower and remarkably free flowering.

GENERAL JACQUEMINOT. One of the old favorites and probably the best known Rose in cultivation. Brilliant scarlet-crimson.

GEORG ARENDS. Long, delicately shaped buds and deep-petaled, pointed blooms of soft pink in its most exquisite shade, delicately scented. Plant is very vigorous, growing to the height of 5 to 6 feet.

JULIET. A splendid, large-flowering variety. Outside of petals deep yellow; inside shaded red.

MAGNA CHARTA. Bright pink, very large, very double flowers, suffused with carmine; heavily perfumed.

MME. ALBERT BARBIER. Large, well-shaped, creamy pink flowers, beautifully stained with yellow at the center. The dwarf plants are almost continuously in bloom. \$1 each, \$10 per doz., \$80 per 100 .

PAUL NEYRON. Perhaps the largest of all; dark rose in color.

ULRICH BRUNNER. A good strong grower with large, full flowers, of a bright cherry-red.

Any of the above, field-grown plants, except where noted, $90 \mathrm{cts}$. each, $\$ 9$ per doz., $\$ 70$ per 100

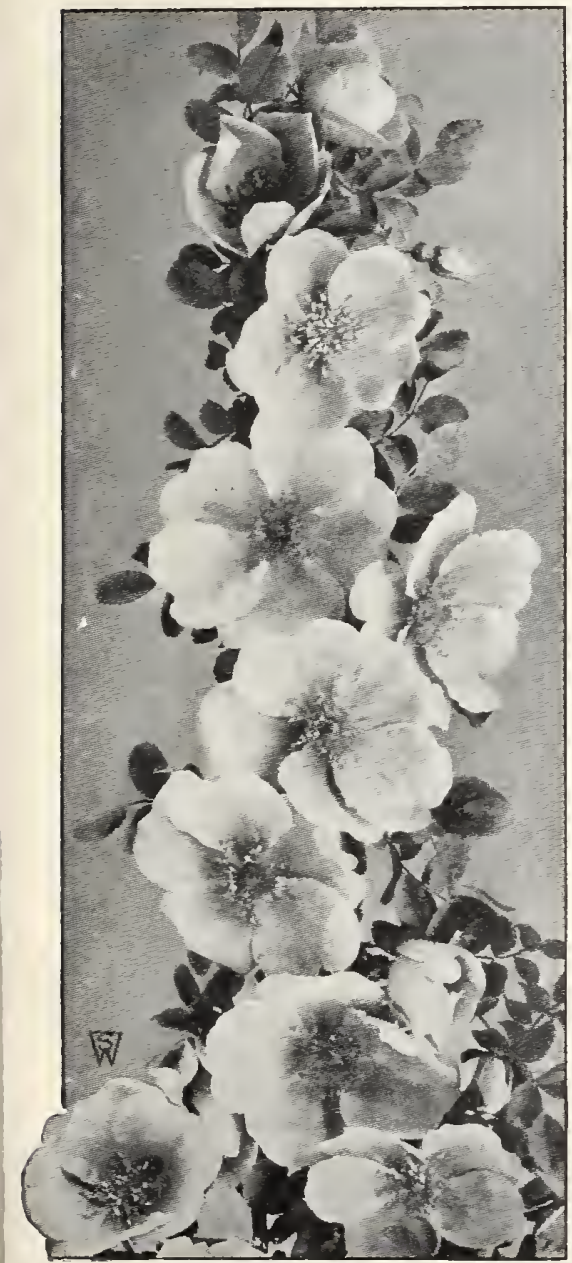

Hugonis Roses

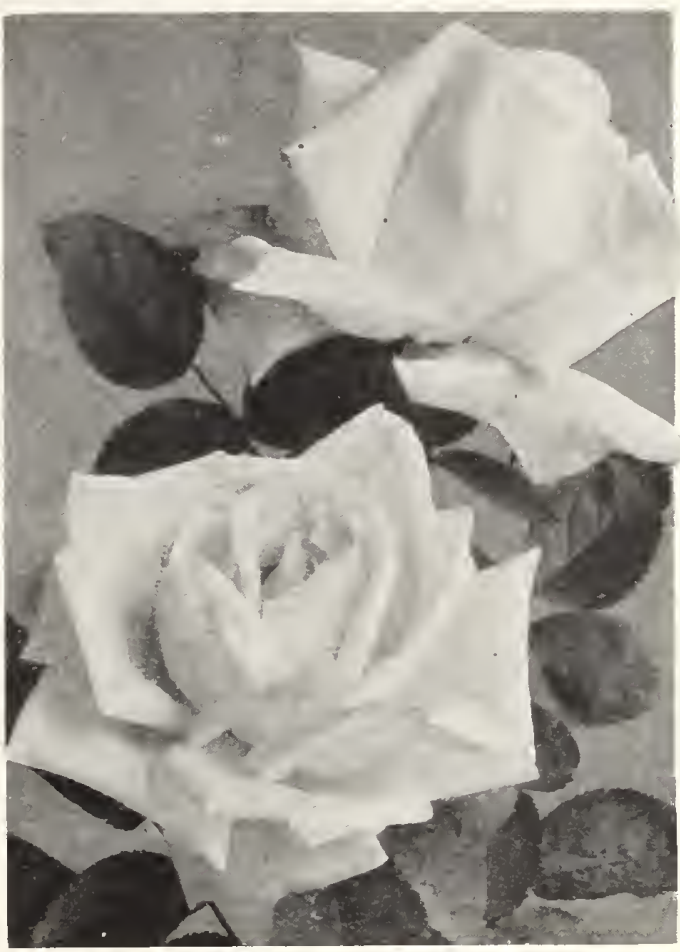

Frau Karl Druschki Roses

\section{F. J. Grootendorst, New Hybrid Rugosa Rose}

This is a new type of Rose - a cross between Rugosa and the Crimson Baby Rambler. It is not a Rose that you would want to plant in with your bed of Hybrid Teas or Hybrid Perpetuals. but is valuable as an isolated specimen, in masses in a bed, in an exposed position, among shrubs in the shrubbery border, or for an everblooming hedge. It is absolutely hardy and continues in bloom until late in the fall. $\$ 1$ each, $\$ 10$ per doz., $\$ 80$ per 100 .

PINK GROOTENDORST. Same as above, except color, which is pink. \$1 each, \$10 per doz., $\$ 80$ per 100 .

\section{Hugonis Rose}

This species, recently introduced from China, is unlike any other Rose. It is of a shrub-like habit of growth and naturally forms symmetrical bushes about 6 feet high, and the same in diameter. Valuable for planting in connection with other shrubs or as a single specimen in the garden. Its single, delicate yellow flowers are produced on long, arching sprays early in May, every branch of the previous season's growth becoming lined on both sides to the very tips with the attractive flowers. $\$ 1$ each, $\$ 10$ per doz., $\$ 80$ per 100 .

\section{Baby Rambler or Polyantha Roses}

This type of Roses forms shapely, compact, bushy specimens, most of the rarieties growing about $I \frac{1}{2}$ feet high. They begin blooming early in June and bear their immense trusses of small flowers until cut down by frost. They are fine for garden decoration, and their miniature flowers are excellent for cutting as well. This type of Roses requires no spring pruning; the flower-stems of the previous season need only be removed.

Cecile Brunner (Sweetheart Rose). This Ideal. The darkest colored of all the Baby Polyantha has dainty flowers of soft rosy Roses-an intense rich lustrous garnet.

pink on a rich creamy white ground.

Orleans. A very striking variety, with large, brilliant geranium-red flowers, becoming suffused with rose as they mature.

Magnifique. Dorothy-Perkins-pink. P r o duces many flowers on long trusses. A splendid variety.

Price, any of the above varieties, $90 \mathrm{cts}$. each, $\$ 9$ per doz., $\$ 70$ per 100

\section{Moss Roses}

Moss Roses derive their name and beauty from the delicate mossy covering which surrounds the buds and gives the opening flowers a rather unique appearance. These Roses should be pruned sparingly; cut out the old wood and cut back the growth of the previous year.

Blanche Moreau. Large; pure white. Henri Martin. Fine crimson; vigorous.

Crested Moss. Rose; beautifully crested. Salet. Large, double, light rose-pink.

Price, any of the above varieties, $90 \mathrm{cts}$. each, $\$ 9$ per doz., $\$ 70$ per 100 


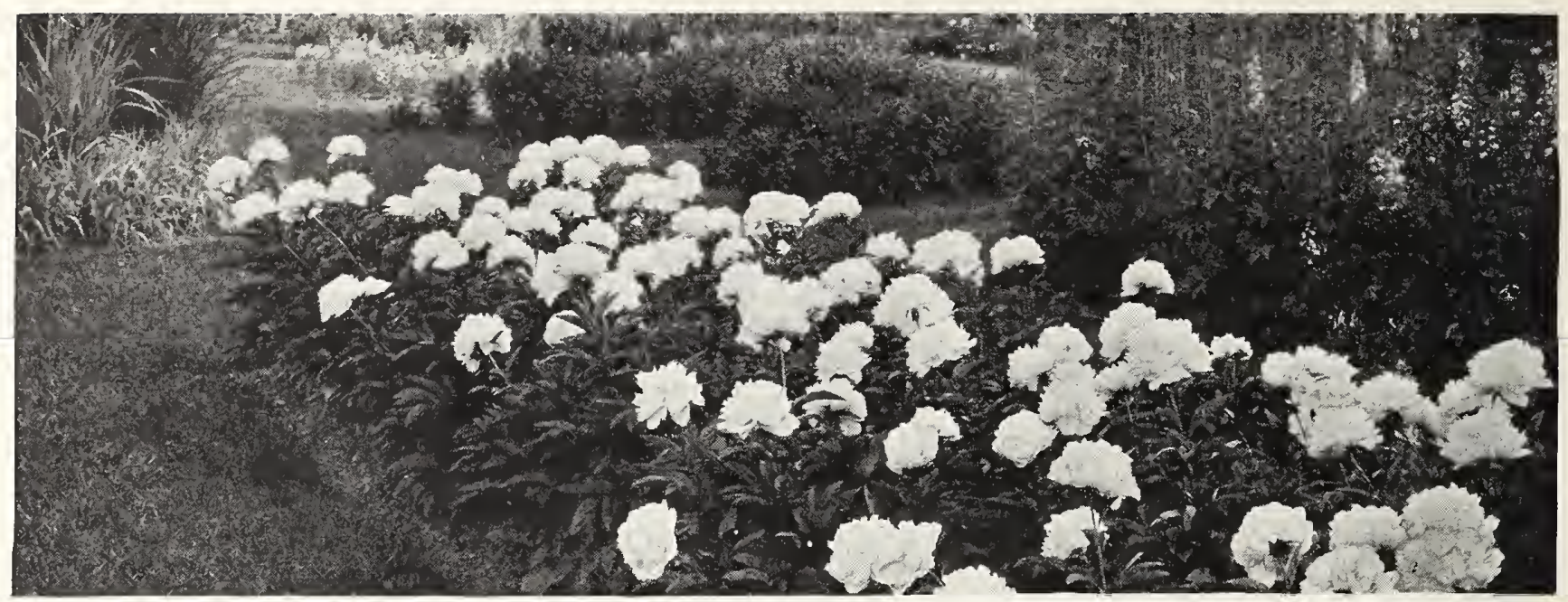

\section{HERBACEOUS PEONIES}

CUlTURE.-The culture of Peonies is quite simple. They require a good, deep, rich soil and an abundant supply of water during the growing season. When enriching the ground, the use of too much fresh manure rear the roots should be avoided. The main point to observe is, while the ground should be well spaded and cultivated, not to plant the roots too deep. The roots should be planted so that the eyes are barely covered (about I to 2 inches). Too deep planting is the cause of shy flowering.

Size of Roots. - The roots we offer have been grown two years from root divisions. If planted during September and October these roots should become well established and give some flowers the following year.

Many of the following varieties of Peonies have received a very high rating. They are grown at our own Farmingdale Farm, on Long Island. Each variety offered has been selected by us on account of its merit.

\section{White Shades}

Alsace-Lorraine. 8.8. (Lemoine, I906.) A late-blooming variety with pointed white petals suffused with a golden light from the stamens. Tall and vigorous. \$2 each, \$20 per doz.

Baroness Schroeder. 9.0. (Kelway, I 889.) Immense, globular flowers with white guard petals and a soft baby-pink center, becoming pure white. Stems very strong and vigorous. Foliage medium green. Late midseason. \$I.50 each, \$I 5 per doz.

Duchesse de Nemours. 8. I. (Calot, I 856.) Cup-shaped blooms; broad guard petals of white and narrower central petals of sulphur-yellow, with oftentimes a marking of green. Early midseason. $75 \mathrm{cts}$. each, $\$ 7.50$ per doz.

Duc de Wellington. (Calot, I859.) Large, bomb shape, with white guards and sulphur center. Medium tall; vigorous grower; free bloomer. Late. $75 \mathrm{cts}$. each, $\$ 7.50$ per doz.

Festiva Maxima. 9.3. (Miellez, I $85 \mathrm{I}$.) This is probably the most widely known of all Peonies. Exceptionally large ivory-white flowers of rather feathery appearance, flecked with crimson in the center. $60 \mathrm{cts}$. each, \$6 per doz.

La Lorraine. 8.I. (Lemoine, Igor.) Large, double, midseason Peony of cream-white, tinted pink, darker in center, with a yellow glow from a few buried stamens. Tall; vigorous; free-flowering. \$I.50 each, \$I 5 per doz.

Mignon. 8.7. (Lemoine, I908.) Lovely light flesh-pink blooms passing to white when fully open and showing a rose-like center with golden yellow stamens; rich rose-like fragrance. Midseason. $\$$ I.5o each, \$I 5 per doz.

Primevere. 8.6. (Lemoine, 1907.) Guard petals deep creamy yellow and center petals sulphur-yellow. If not exposed to the full sun the flowers will hold a most attractive canary-yellow. Very fine. Midseason. \$2 each, \$2o per doz.

Queen Victoria. 6.8. (Hort, I 830.) A good every-day white, and, when cut, a first-rate keeper, having good substance and color. Bomb type; early midseason, being very attractive in the bud, when it has a faint blush tint. 50 cts. each, $\$ 5$ per doz.

Solange. 9.7. (Lemoine, I907.) One of the very finest Peonies. Extra-large flowers with broad, rounded petals of such fine form that the flower does not look coarse. Petals waxy white but suff used with a reddish golden light, so that the total effect is such as may be seen on a cloud at sunset. Late midseason. $\$ 3$ each, \$3o per doz.

\section{Pink Shades}

Alice Balfour. (Kelway, I9I5.) Lovely, large, double rose flower. \$I.50 each, \$I 5 per doz.

Edulis Superba. 7.6. (Lemon, I824.) Deep rose-pink. Guard petals wider than those in the center. \$I each, \$1o per doz.

General Joffre. Large bomb-shaped flowers of a clear rose-pink. Guard petals wider than those in the center. $\$ 2$ each, $\$ 20$ per doz. Gloire de Lorraine. Double dark rose-pink flower. Late. \$1.50 each, \$I 5 per doz.

Mme. Manchet. 8.5. (Dessert, Ior3.) Full, cup-shaped flowers of rose-pink, tinted silver. Tall, stiff stems. $\$ 2$ each, $\$ 20$ per doz.
Henry Woodward. 8.8. (Richardson, I883.) Very large, flat flowers of silvery shell-pink. Petals are pointed, giving a very pretty effect. Very late. \$2 each, \$20 per doz.

La France. Enormous, double, perfectly formed flowers of clear light pink, deeper in center, flecked darker toward tips, crimson splashes on outer petals; fragrant. Free bloomer; vigorous. \$1.50 each, \$I 5 per doz.

Mme. Francois Toscanelli. (Rivière, IgIr.) Anemone type. Very large flower of beautiful flesh-pink, shaded soft rose; center dark salmon-rose-a lively color. Upright grower. \$2 each, \$2o per doz.

Mons. Jules Elie. Giant flowers with flaring, wide petals and a tall, incurved, compact center. Gay silvery pink throughout. Early, and one of the finest Peonies known. \$I each, \$IO per doz.

Princess Olga. (Kelway, I9I 5.) Double, blush-white blooms. \$I.50 each, \$I 5 per doz.

Rachel. 8.3. (Lemoine, I904.) Large, globular flowers of excellent form, soft rose color, borne on strong stems. \$I.50 each, \$I 5 per doz. Susanne Dessert. 7.7. (Dessert \& Méchin, I8go.) Semi-rose type; midseason. Large, very full blooms in clusters; broad petals. Fine clear china-pink, silvery on the tips. Stands very well in full sul. and is very showy. \$I each, \$Io per doz.

\section{Red Shades}

Dr. H. Barnsby. 8. I. (Lemoine, Igo6.) Large, very full blooms of crimson with darker shades. Free bloomer in clusters, making a good variety for garden effect. Late. \$I.50 each, \$I 5 per doz.

Felix Crousse. Compact, globular bloom of large size and fine form. Deep ruby-red, center shading deeper. Very choice. Midseason to late. \$I each, \$ Io per doz.

Karl Rosenfield. 8.8. (Rosenfield, I908.) Brilliant, dark crimson; of good form and substance. Stems stiff. Medium height. Onc of the best in this color. \$I each, \$Io per doz.

Marquis C. Lagergren. 7.8. (Dessert, I9II.) Brilliant cherry-red, with dark shadings. Flowers borne in clusters on stiff, upright stems, which make it an excellent variety for mass planting. Midseason. \$I.5O each, \$I5 per doz.

Rudyard Kipling. (Kelway, I9I7.) Double cerise blooms. \$1.50 each, \$I per doz.

War. (Kelway, I9I6.) Red, double flowers. \$I.50 each, \$I5 per doz.

\section{Single Peonies}

L'Etincelante. 8.4. (Dessert, I005.) Large flowers and broad petals of brilliant carmine with a silvery border. Stems erect and vigorous. \$I each, \$IO per doz.

Nymphe. (Dessert, I9I3.) Large, flesh-colored petals, with a central tuft of golden stamens. \$I each, \$Io per doz.

Othello. Deep rose with good stems, good laterals, and excellent for the Peony border. \$I each, \$Io per doz.

Yeso. 7.7. (Japanese.) Guard or outside petals pure white, narrow center petals white, shaded slightly yellow, of ten with a carmine tip. \$I each, \$1o per doz. 


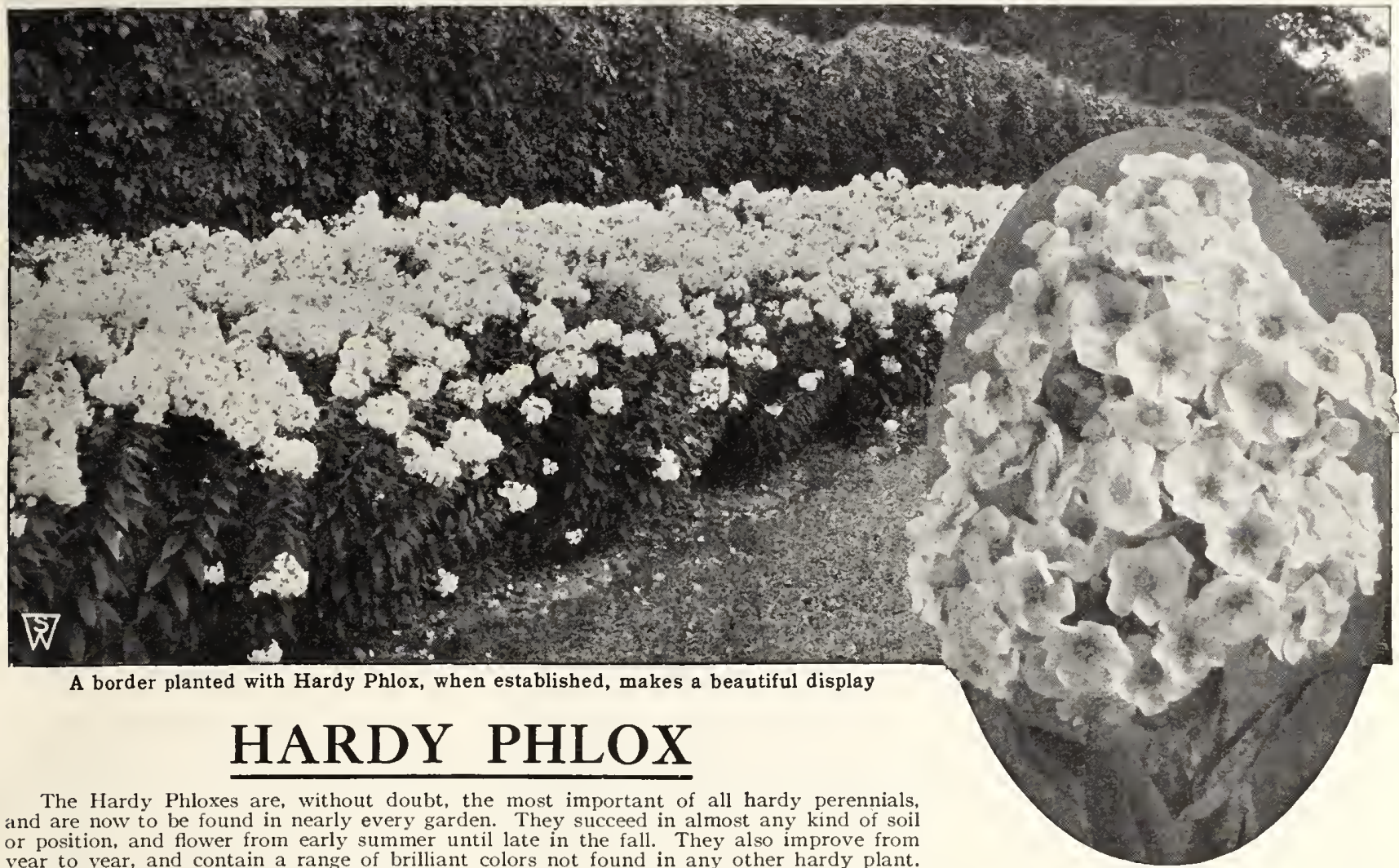
(o year, and contain a range of brilliant colors not found in any other hardy plant.

Cut Phlox should be set out I 8 inches apart, and if kept well watered will produce both individual blossoms and heads of bloom far larger than otherwise, and amply repay the extra trouble. To procure best effects, plants should be massed in from six to twelve clumps of each variety.

\section{Superb Hardy Phlox}

Our plants are choice divisions from field-grown plants which we have found to give excellent sa:isfaction.

Albion. A vigorous-growing variety; pure Maid Marion. One of the best lilac variewhite, with pale pink eye.

Bridesmaid. Pure white with large crimson center.

Commander. Crimson-red with darker eye.

Elizabeth Campbell. Large; soft pink. 35 cts. each, \$3.50 per doz., \$25 per Ioo.

Ethel Pritchard. Beautiful mauve color. Strong grower and free bloomer.

Price of the above varieties, except Elizabeth Campbell and Mrs. Milly Van Hoboken, 30 cts. each, $\$ 3$ per doz., $\$ 20$ per 100

\section{Early-flowering Hardy Phlox (Phlox suffuticosa)}

Miss Lingard. A grand variety which begins flowering after the middle of June and continues throughout the season. Large white flowers, with pale pink eye. Extensively used for cut-flowers. $30 \mathrm{cts}$. each, \$3 per doz., \$20 per Ioo.

\section{TRITOMA}

Pfitzeri. The greatest bedding plant ever introduced, surpassing the finest cannas for attractiveness and brilliancy, equal to gladiolus as a cut-flower, and blooms incessantly from June until December, regardless of frost. Plants are perfectly hardy in the open ground all winter south of Philadelphia; farther north they must be protected or wintered in a cellar like the ordinary Tritoma. Just bury the roots in sand. Should be planted out early in spring, and will commence growth at once and bloom early, growing larger and finer every day. \$4 per doz., \$30 per 100 .

S. \& W. Co.'s Hybrids. This strain of Tritoma is by far the most effective for planting in perennial borders. The plants offered are grown from seed of selected plants and carry a full range of color-from white to burnt orange -in the flowers, some being two-toned pink, rose, orange, red with white and yellow. At the price we offer these they should be bought by the dozen, so as to get the full range of charming colors. $\$ 3$ per doz., \$22 per 100 .

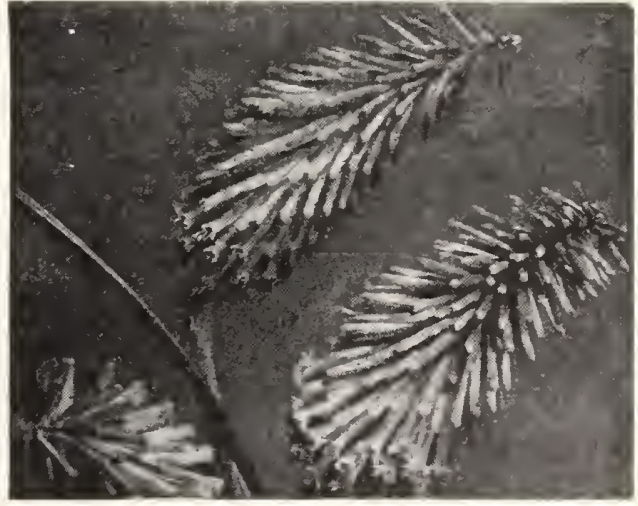

Tritoma Pfitzeri
Rose Queen. An exceptionally fine variety.

Rynstroom. Dark salmon-rose. Easily one of the finest Phlox of its color

Wanadis. Immense trusses with large in dividual florets. Delicate lilac shade with bluish purple eye. Wida. Exquisite two-tone lavender rayed ties; of medium height and a free bloomer.
La Vague. Florets of moderate size, borne Mrs. Milly Van Hoboken. A splendid new $\$ 3.50$ per doz ers of bright rose. Strong, compact grower extra-heavy foliage. 


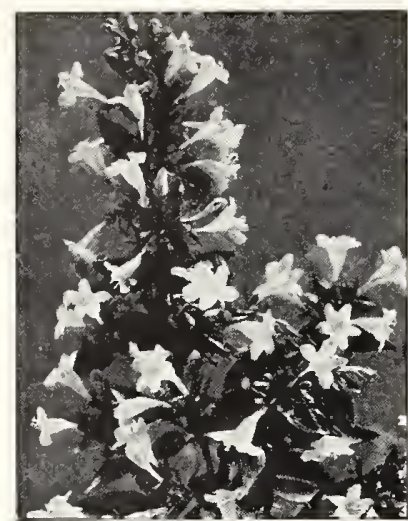

Abelia grandiflora

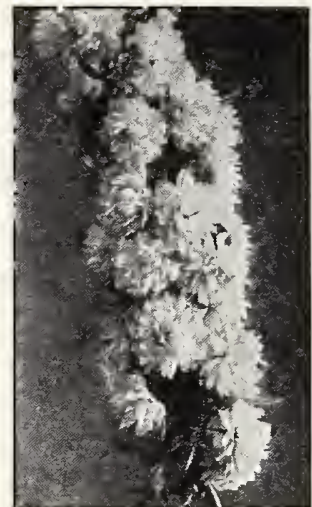

Flowering Almond

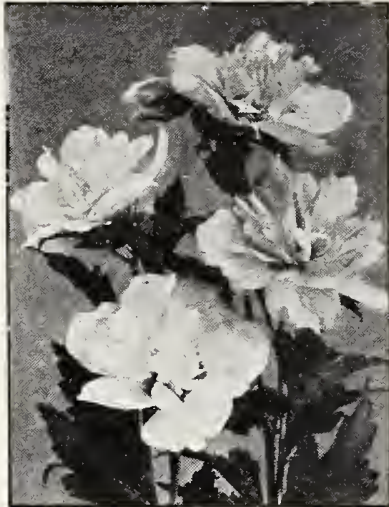

Althea

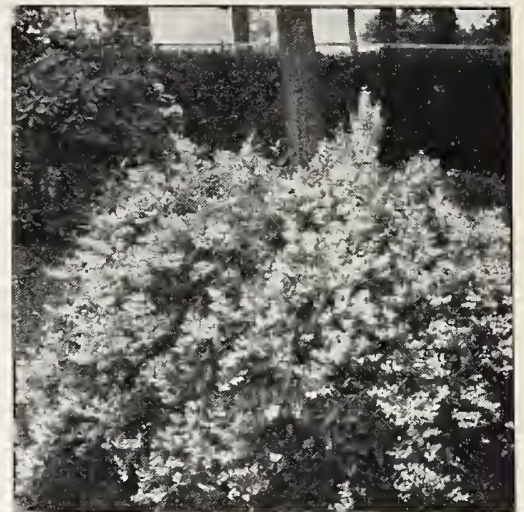

Deutzia gracilis

\section{Hardy Flowering Shrubs}

Shrubs are of great importance for the ornamentation of home-grounds. They have maliy uses; some are valuable as cut-flowers, while others are as decorative as any ornamental foliage plant. They may be used as a dividing-line between the flower and vegetable-garden, or between the lawn and the uncultivated land beyond, as a background for the flower border, and for hiding an unsightly building, fence or foundation. Soil where they are to be planted should be well spaded and enriched with bone-meal. Unless a very immediate effect is required, sufficient space should be allowed between them to permit of full development-3 feet for dwarf varieties and 5 feet for the taller ones. As a general rule, shrubs should be thinned or pruned just after they have finished flowering, and then only slightly, just enough to keep them in nice, symmetrical shape.

NOTICE.-The best time to plant is from early spring, when ground can be worked, until about May 15 , the earlier the better.

\section{Abelia grandiflora}

This, to our minds, is one of the finest of all the shrubs, and should be in every foundation planting. The habit and foliage are distinctly ornamental, and it blooms almost continuously from early summer until frost. The flowers are white, tinted lilac. Strong plants, $\$ 1$ each, $\$ 10$ per doz., $\$ 75$ per 100 .

\section{Almond, Flowering (Amygdalus)}

This beautiful shrub is one of the loveliest. The flowers are borne on its slender branches during May, and are very fragrant.

Pink. Double-flowering; pink.

White. Double-flowering; white.

Strong plants, 2 to 3 feet, $\$ 1$ each, $\$ 10$ per doz.

\section{Althea (Rose of Sharon)}

The Altheas are among the most valuable of our tall, hardy shrubs on account of their late blooming, which is from August to October, a period when few shrubs are in flower. We offer in four distinct colors. Red, Pink, White, and Purple. Strong plants, 2 to 3 feet, 50 ets. each, $\$ 5$ per doz.

\section{New Red-Leaved Japanese Barberry}

The finest shrub novelty of recent years. Identical with the Green-leaved Barberry, except that the foliage is a rich, Iustrous, bronze-red which becomes more vivid as the season advances, changing to brilliant orange. scarlet and red shades in the fail. However, it should be planted in full exposure to the sun. Strong, 2-year-old plants, 75 cts. each, $\$ 7.50$ per doz.

\section{Buddleia variabilis Veitchiana}

Butterfly Shrub; Summer Lilac

One of the most desirable of summerflowering shrubs, beginning to bloom in July and continuing until cut down by severe frost. The flowers are of a pleasing shade of violetmauve, and are borne in dense, cylindrical spikes from I 2 to 15 inches in length by 3 inches in diameter. The plant dies down in winter, coming up the following spring. Strong plants, 50 cts. each, $\$ 5$ per doz.

\section{Calycanthus}

Floridus (Sweet or Strawberry Shrub). A very pretty shrub flowering during May. The flowers are double, chocolate-colored, and strawberry scented. Strong plants, 2 to 3 feet, $\$ 1$ each, $\$ 10$ per doz.

\section{Cerasus (Japanese Flowering Cherry)}

The blossoms of these trees appear in April. The sudden transition from bleak winter to spring, with a most gorgeous display of blossoms, is startling, and the beauty of the trees a sight to behold.

Pink. Double-flowering; pink.

White. Double-flowering; white

Strong plants, 2 to 3 feet, $\$ 2.50$ each, $\$ 25$ per doz.

\section{Cratægus oxyacantha}

\section{Paul's Scarlet Thorn}

The most popular of the Thorns, producing rich, brilliant, double, scarlet flowers in the spring, followed by handsome fruit which remains on the bushes throughout the winter. Strong plants, 3 to 4 feet, $\$ 2$ each, $\$ 20$ per doz.

\section{Deutzias}

Well-known, profuse-flowering

blooming in early summer.

Gracilis. A great favorite, dwarf, covered with spikes of pure white flowers in early summer. Strong plants, $1 \frac{1 / 2}{2}$ to 2 feet 50 cts. each, \$5 per doz.

Pride of Rochester. A fine, tall-growing, double, white-flowering variety. Strong plants, 2 to 3 feet, 50 cts. each, \$5 per doz.

\section{Dogwood (Cornus)}

Florida. Handsome, small trees covered with myriads of large, four-petaled white flower in spring; beautiful, glossy foliage. 3 to 4 feet, \$3 each, \$30 per doz.

Florida rubra. Like the preceding, except that the flowers are bright, shiny pink. Very rare and valuable and a decided acquisition. 3 to 4 feet, $\$ 6$ each, $\$ 60$ per doz.

Sibirica (Siberian Dogwood). This type of Dogwood differs from the above in that it is distinctly shrubby in growth. It is a strong-growing variety with small white flowers. The branches are crimson colored in winter. Strong plants, 2 to 3 feet, 50 cts. each, $\$ 5$ per doz.

\section{Forsy thia}

A very decorative shrub with bright golden Allow, star-shaped flowers which burst into bloom at the beginning of spring while the bush is otherwise bare.

Suspensa (Weeping Golden Bells). A tall shrub of willowy growth, the branches gracefully arching and covered with golden yellow bells in early spring.

Viridissima (Golden Bells). Similar to the above but of more erect habit.

Strong plants of either of the above, 2 to 3 feet, $75 \mathrm{cts}$. each, $\$ 7.50$ per doz.

\section{Honeysuckle}

Bush Honeysuckle (Lonicera)

We offer two varieties of the Bush Honeysuckle. They are splendid for lawns or borders.

Tatarica. Pink flowers, contrasting with the foliage. Blooms in June.

Tatarica alba. White form of the above. Either of the above, strong plants, 2 to 3 feet, $75 \mathrm{cts}$. each, $\$ 7.50$ per doz.

\section{Hydrangea}

We offer two varieties of this, perhaps the most popular of flowering shrubs.

Arborescens grandiflora (Snowball Hydrangea). This magnificent, perfectly hardy American shrub has snow-white blossoms of largest size. One of its most valuable characteristics is its coming into bloom just after the passing of all the early spring-blooming shrubs. Strong plants, 75 cts. each, $\$ 7.50$ per doz.

Paniculata grandiflora. The flowers, which are borne in dense, pyramidal panicles a foot long in greatest profusion, are white when they first open but gradually change to rose color. Strong plants, 75 cts. each, $\$ 7.50$ per doz.

\section{Kerria (Corchorus)}

One of the most graceful of the lower-growing shrubs for the front of a shrubbery border, or in a mixed planting of low shrubs around porches. Japonica flore-plena. Attractive golden yellow flowers are borne continuously from June to October. Strong plants, $\$ 1$ each, $\$ 10$ per doz. 


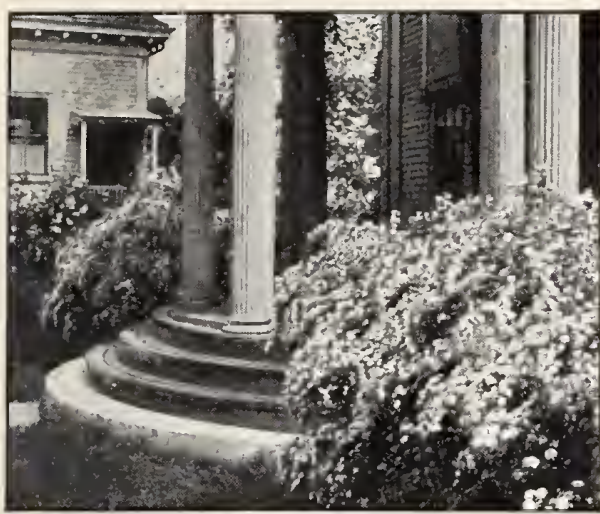

Spiræa Van Houttei

\section{Kolkwitzia amabilis}

\section{Beauty Bush}

Mature plants of this new introduction from China appear like a cloud of beautiful, delicate pink when in flower. Strong plants, 18 to 24 inches, $\$ 1$ each, $\$ 10$ per doz.

\section{Morus alba pendula}

Tea's Weeping Mulberry

A valuable shrub for lawn planting. The long, drooping sprays form a true weeping effect. The fruits are edible and are eagerly sought by birds. Strong plants, \$3 each.

\section{Philadelphus (Mock Orange)}

This old-fashioned sweet-scented shrub has long been a close rival of the lilac in popularity:

Coronarius. This is a popular tall variety: large white flowers. Strong plants, 75 cts. each, \$7.50 per doz.

Avalanche. Very fragrant white flowers. $\$ 1$ each, \$10 per doz.

Brachybotrys. Saucer-shaped flowers of pure white. $\$ 1$ each, $\$ 10$ per doz.

Splendens. Creamy white flowers; branches of drooping habit. \$1 each, \$10 per doz.

Virginal. Semi-double, large, white, showy flowers. $\$ 1$ each, $\$ 10$ per doz.

\section{Malus (Flowering Crab)}

Ioensis plena (Bechtel's Double-Flowering Crab). The Flowering Crabs are valued not only for their beautiful blossoms but for the handsome fruits, which in the fall areattractive to us and to the birds as well, who relish them greatly as a winter food. In the spring a well-grown plant is a mass of bloom, a wonderful sight in any garden. Strong plants, 3 to 4 feet.

Aldenhamensis. Recently introduced. Flowers dark red. Foliage purple.

Eleyi. Large, semi-double, in red shades.

Floribunda. Bright pink flowers of brilliant color. Yellowish fruit.

Floribunda sanguinea. Carmine flowers and very attractive purple foliage.

Kaido. A novelty in Flowering Crabs. Reddish pink flowers and beautiful foliage.

Niedzwetzkyana. Remarkable red flowers, leaves, and fruit.

Parkmani. Large, double, rose-red flowers.

Sargenti. Dwarf Japanese variety with large white flowers.

Scheideckeri. Dwarf tree with beautiful, double rose-colored flowers.

Sieboldi. Large pink and white flowers. Brilliant scarlet fruit.

Spectabilis. Double, large, pink flowers. Very showy yellow fruit.

Prices on above, $\$ 1.50$ each, $\$ 15$ per doz.

We offer a collection, 1 each $\$ 12$
of the above 12 varieties, for

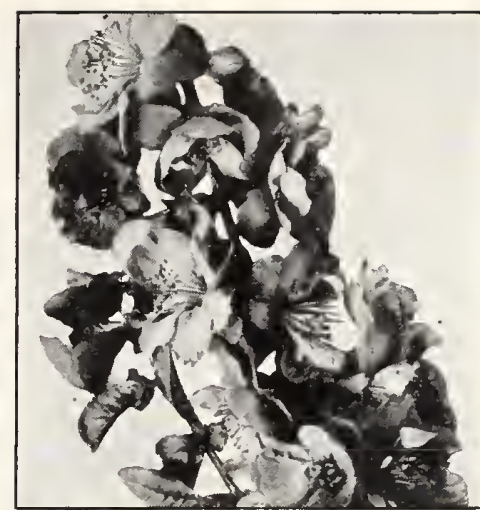

Pyrus japonica

\section{Pyrus (Cydonia) japonica}

\section{Flowering Quince}

A very showy shrub of medium height; blooms profusely in early spring; flower dazzling scarlet. Makes an excellent hedge plant. Strong plants, $\$ 1$ each, $\$ 10$ per doz.

\section{Prunus}

We offer six varieties of the Flowering Plum.

Pissardi (Purple-leaved Plum). A dwarf shrub covered with single white flowers in spring. When thcy first appear the lcaves are crimson, changing to rich purple.

Triloba (Double-flowering Plum). An inter esting shrub, of medium height, bearing in early spring semi-double, delicate pink flowers over an inch in diameter.

Cerasifera. An Early-flowering Plum, suit able for partial shade.

Cerasifera purpurea. Same as above, only dark purple foliage.

Mume. Famous native flower of Japan, pure white, flowers very early.

The Dawn. Same as above, but shiny purple foliage.

Prices on above, $\$ 1$ each, $\$ 10$ per doz.

\section{Spiræa}

Anthony Waterer. Color bright crimson. It is of dwarf, dense growth, never exceeding 30 inches in height and blooms the entire summer and fall, if thc old flower-heads are removed. 75 cts. each, $\$ 7.50$ per doz.

Van Houttei. It is of compact habit and a beautiful ornament for the lawn when in flower; the white blooms almost entirely cover the foliage. $75 \mathrm{c}$. each, $\$ \mathbf{\$ 7 0}$ per $\mathbf{~ d o z}$.

Trichocarpa. Full-grown plants of this variety are 4 to 6 feet tall, and even larger in diameter, and are covered with huge clusters of snow-white flowers with darker eyes. $\$ 1$ each, \$10 per doz.

Thunbergi. Light green lcaves, small white flowers. 75 ets. each, $\$ 7.50$ per doz.

\section{HEDGE PLANTS}

We offer two of the principal shrubs that are extensively used for Hedge Plants

\section{Berberis Thunbergi (Japan Barberry)}

Where a dwarf, deciduous hedge is wanted, nothing equals this beautiful Barberry. It requires but little pruning to keep it in shape. The leaves are small, light green, and towards fall assume rich, brilliant colors, the fruit or berries becoming scarlet. It is used extensively throughout the country and is perfectly hardy. Extra-strong, 1 1 1/2 to 2 ft., 4 to 6 branches, packed in bundles of 10 or 25 at $\$ 4$ for $10, \$ 7.50$ for $25, \$ 25$ per 100 .

\section{California Privet (Ligustrum ovalifolium)}

This is, perhaps, the most popular of all the hedge plants. Being absolutely hardy, it increases in beauty with each successive year. To get best results, plants should be set I foot apart in double rows in zigzag fashion, so that the plants are diagonally opposite each other. This practically places them 6 inches apart, which is desirable to get quick, dense growth. May be planted from March I5 to May I5, or from October to frost. The Privet which we are offering is grown specially on contract for us and is selected and well-graded plants. This is the best size to plant and is in the most vigorous condition. It will immediately establish itself. Extra-strong, 3 ft., $\$ 2$ tor $25, \$ 7$ per 100, $\$ 60$ per 1,000. 


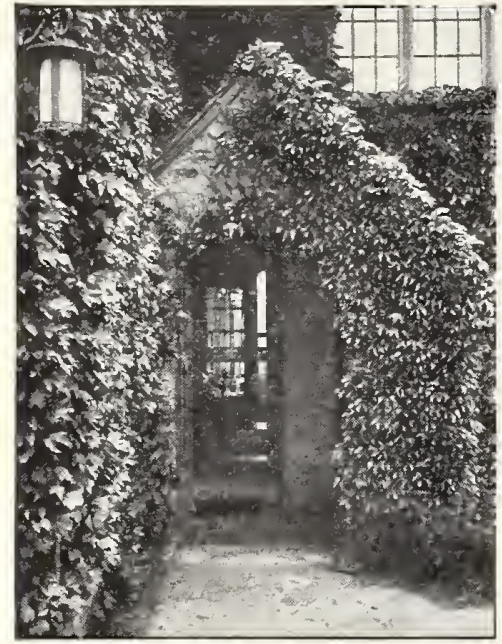

Ampelopsis Veitchii

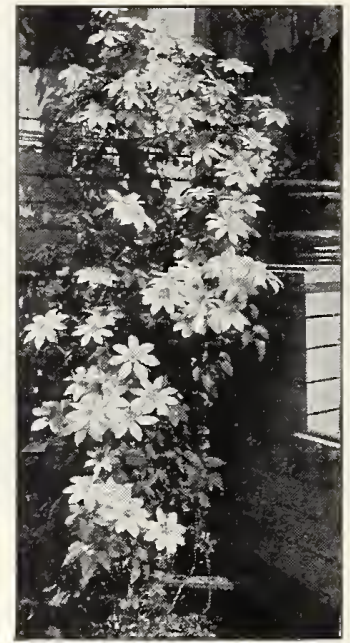

Clematis Jackmanii

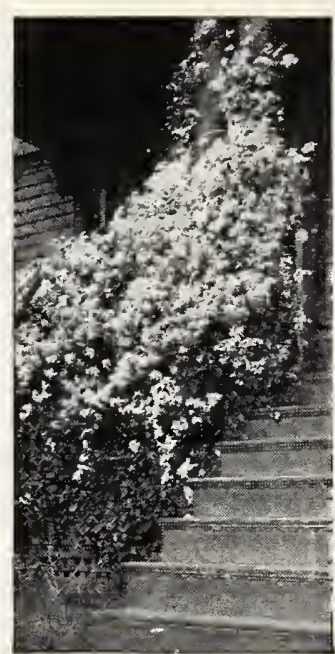

Clematis paniculata

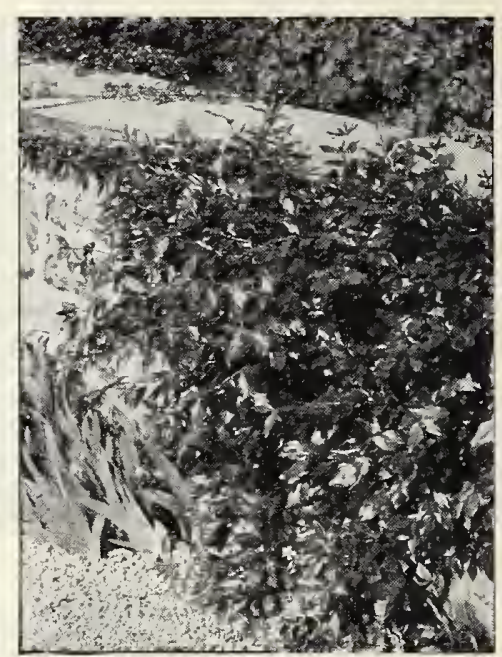

Euonymus radicans vegeta

\section{HARDY GLIMBING PLANTS}

\section{AKEBIA QUINATA (Akebia Vine)}

A very graceful, hardy climber, with small, deep green foliage, producing in early spring bunches of violet-brown flowers which have a pleasant cinnamon odor. Strong plants, $75 \mathrm{cts}$. each, $\$ 7.50$ per doz.

\section{AMPELOPSIS Sometimes called Boston Ivy \\ and Japan Ivy}

Veitchii. This is the most deservedly popular of all climbing plants, being entirely hardy in the most exposed places and attaining a height of 30 feet in two or three years; clings to stones, brick, or woodwork with the greatest tenacity. During the summer the leaves are a rich shade of green, but it is in the fall that it shows its exquisite beauty. The leaves then change to the brightest tints of scarlet, crimson, and orange. Extra-strong, field-grown plants, 50 cts. each, \$5 per doz., \$40 per roo.

Quinquefolia (Virginia Creeper; American Ivy). This well-known climber is one of the best and quickest growing varieties for covering trees, trellises, arbors, and the like. The large, deep green foliage assumes brilliant shades of yellow, crimson, and scarlet in the fall. Strong, field-grown plants, 5o cts. each, $\$ 5$ per doz., $\$ 40$ per Ioo.

\section{ARISTOLOCHIA SIPHO}

\section{Dutchman's Pipe Vine}

A vigorous and rapid-growing climber, bearing brownish colored flowers which resemble a pipe in shape. This plant is, however, more admired for its light green leaves, which retain their color from early spring until the fall. Strong plants, \$I each, \$Io per doz., \$75 per Ioo.

\section{BIGNONIA RADICANS}

\section{Scarlet Trumpet Vine}

For covering unsightly places, stumps, rockwork or planting in crevices in ledges, the Bignonias will be found very useful. The flowers are large, attractive, and showy, and borne profusely when the plant attains a fair size. $50 \mathrm{cts}$. each, $\$ 5$ per doz., $\$ 40$ per Ioo.

\section{CELASTRUS SCANDENS}

\section{Bittersweet or Waxwork}

One of our native climbing plants of rapid growth, succeeding in almost any situation, sun or shade, with attractive light green foliage and yellow flowers during June, followed in the autumn by bright orange fruit which usually remains on the plant throughout the winter. Strong plants, 5o cts. each, $\$ 5$ per doz., $\$ 40$ per Ioo.

\section{POLYGONUM AUBERTI (Silver Lace Vine)}

One of the most desirable flowering climbers. The plant is of strong, vigorous growth, attaining the height of 25 feet or more, and producing through the summer and fall great foamy sprays of white flowers. Strong plants, \$I each, \$Io per doz., \$75 per Ioo.

\section{CLEMATIS}

Paniculata (Japanese Virgin's Bower). This hardy climber is one of the most satisfactory climbing flowering plants. The flowers appear in profusion during August, and continue until late in the fall, are white in color and deliciously fragrant. $50 \mathrm{cts}$. each, $\$ 5$ per doz., \$40 per Ioo.

Jackmanii. A perfect mass of bloom when in full flower. Color, dark, rich, royal purple. Strong, field-grown plants, $\$$ I each, $\$$ Io per doz., \$75 per Ioo.

Henryi. Pure white; large and remarkably handsome. Strong, fieldgrown plants, \$I each, \$IO per doz., $\$ 75$ per Ioo.

Ville de Lyon. Bright red, well-formed flowers; a very fine variety. Strong, field-grown plants, \$I each, \$10 per doz., \$75 per Ioo.

\section{EUONYMUS}

Radicans. Deep green, evergreen foliage. It is extremely hardy and useful for covering low foundation walls or may be clipped the same as boxwood for an edging plant. Strong, field-grown plants, 50 cts. each, $\$ 5$ per doz., \$40 per Ioo.

Radicans vegeta (Evergreen Bittersweet). Produces bright orangered berries which remain on the plant the greater part of the winter. As a hardy evergreen plant for wall-covering, this variety is unequaled. Strong plants, $75 \mathrm{cts}$. each, $\$ 7.50$ per doz., $\$ 50$ per Ioo.

\section{HONEYSUCKLE}

Halliana (Hall's Japan Honeysuckle). A strong, vigorous, almost evergreen sort; white flowers changing to yellow; very fragrant; flowering from July to December; holds its leaves nearly all winter. Extra-selected plants, 5o cts. each, $\$ 5$ per doz., $\$ 40$ per Ioo.

Scarlet Trumpet. This and its varieties are the handsomest in cultivation. It is a strong, rapid grower and produces scarlet, inodorous flowers. 50 cts. each, $\$ 5$ per doz., $\$ 40$ per Ioo.

\section{NEW WISTERIA}

We are glad to offer, this year, six new Wisterias which include the pinks and aiso the double varieties so much in demand. These are all strong, 2-year-old, grafted plants which will be sure to flower in one or two years.

Floribunda Plena. A true double, blue-flowering variety. Exceptionally free bloomer. \$2 each, \$20 per doz.

Multijuga rosea. She! 1 -pink, single flowers in racemes 2 feet long or over. \$2 each, \$20 per doz.

Multijuga alba. Same as above but flowers pure white. \$1.50 each, \$I 5 per doz.

Mrs. McCullough. A single, dark purple variety of tremendous vitality. Flowers are borne on large trusses. \$2 each, \$20 per doz.

Noda Murasaki. A new Japanese variety of real merit. Flowers single, deep blue. $\$ 3$ each, \$30 per doz.

Shira Noda. Same as above, but flower lovely shade of Delft blue. $\$ 3$ each, \$30 per doz.

Sinensis (Chinese Wisteria). A most beautiful climber. When established it grows I 5 to 20 feet in a season. Flowers pale blue. Extra-strong plants, \$I each, \$Io per doz., $\$ 75$ per ioo.

Sinensis, White. A white-flowering form of the above. Strong plants, \$I each, \$Io per doz., $\$ 75$ per Ioo. 


\section{Broad-Leaved Evergreens Azaleas}

Charming shrubs which bloom profusely over a period of several months from early spring to midsummer. Most of them are evergreen or exhibit evergreen characteristics. The flowers are tubular, usually in clusters, brilliant in color, and some are fragrant.

ALTACLARENSE. A variety of the Ghent or garden Azaleas, with clusters of large, soft yellow blooms. One of the most beautiful and hardy for outdoor use. 8 to Io in., $\$ 2$ each, \$20 per doz.

AManA. An evergreen shrub. Shapely, bushy, reaching 3 feet after several years. Covered in spring with a profusion of reddish purple flowers. I 2 to I 5 in., $\$ 2.50$ each, $\$ 25$ per doz.

CALENDULACEA. Not evergreen. A picturesque, branching shrub with a jurofusion of yellow and flaine-colored flowers in early summer. I 2 to I5 in., \$2.50 each, \$25 per doz.

HINODEGIRI. Similar to Amona, except that the flowers are blazing red. The showiest and most useful of this type. I 2 to 15 in., \$3.50 each, \$35 per doz.

KAEMPFERI HYBRIDS. A new race descended from the orange-red Azalea Kaeinpferi. They vary widely in colors, ranging from rich salmon and orange to yellow. I 8 to $24 \mathrm{in.}$ $\$ 5$ each, \$50 per doz.

In separate colors we offer:

Rose-Pink. I 5 to I 8 in., \$4 ea., \$40 per doz. Brick-Red. I 8 to 24 in., \$5 ea., \$50 per doz.

Light Rose. I5 to I8 in., \$4 ea., \$40 per doz. $\quad$ Lavender. I 8 to 24 in., \$5 ea., \$5o per doz.

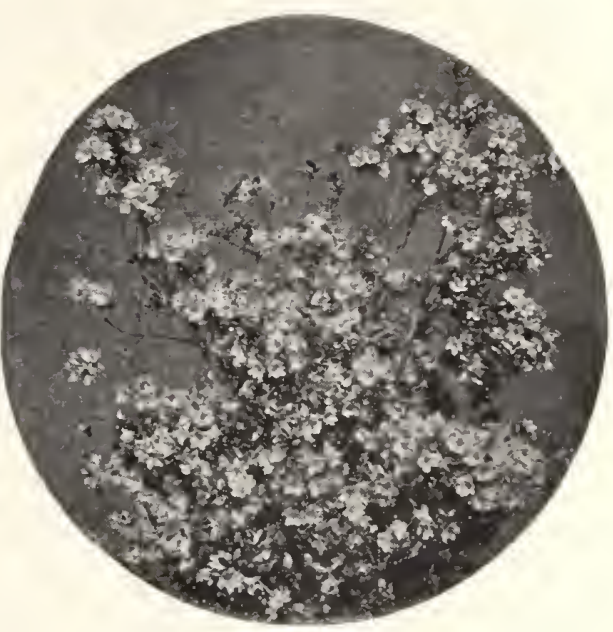

Azalea amœna

I8 to 24 in., $\$ 5$ ea., $\$ 50$ per doz.

KURUME. This race of Azaleas is dwarf and bushy, resembling in many respects the type of Azalea amona, and provides the same superabundance of brilliant-colored flowers in various shades.

Daybreak. Pure light pink blooms in dense clusters. I 2 to 15 in., $\$ 3$ each, \$30 per doz.

Hexe. Large; semi-double; crimson. Very showy. 8 to ro in.. $\$ 2$ each, \$20 per doz.

Snow. A most profuse bloomer with large, pure white flowers in clusters. I 2 to I 5 in., $\$ 3$ each, $\$ 30$ per doz.

Sunstar. Small, rose-pink blooms, striped with carmine, freely produced, 8 to Io in $\$ 2$ each, $\$ 20$ per doz.

MOLLIS. Not evergreen. A dwarf variety producing enormous flowers in clusters, ranging in color from yellow through salmon-pink and orange scarlet; fragrant. Mixed varieties, I 2 to $I_{5}$ in., $\$ 2$ each, $\$ 20$ per doz.

J. C. Van Tol. A delightful brilliant red variety of high quality. Io to I 2 in., $\$ 2$ each, $\$ 20$ per doz.

NUDIFLOKA. The Wild Honeysuckle of the eastern mountains. Not evergreen. Flowers fragrant, varying from light pink to purple-rcd. I 2 to I 5 in., $\$ 2.50$ each, $\$ 25$ per doz.

\section{Rhododendrons}

These are large, handsome shrubs, with long, leathery, evergreen foliage. They produce their flowers in large, showy clusters and are among the handsomest objects for garden decoration.

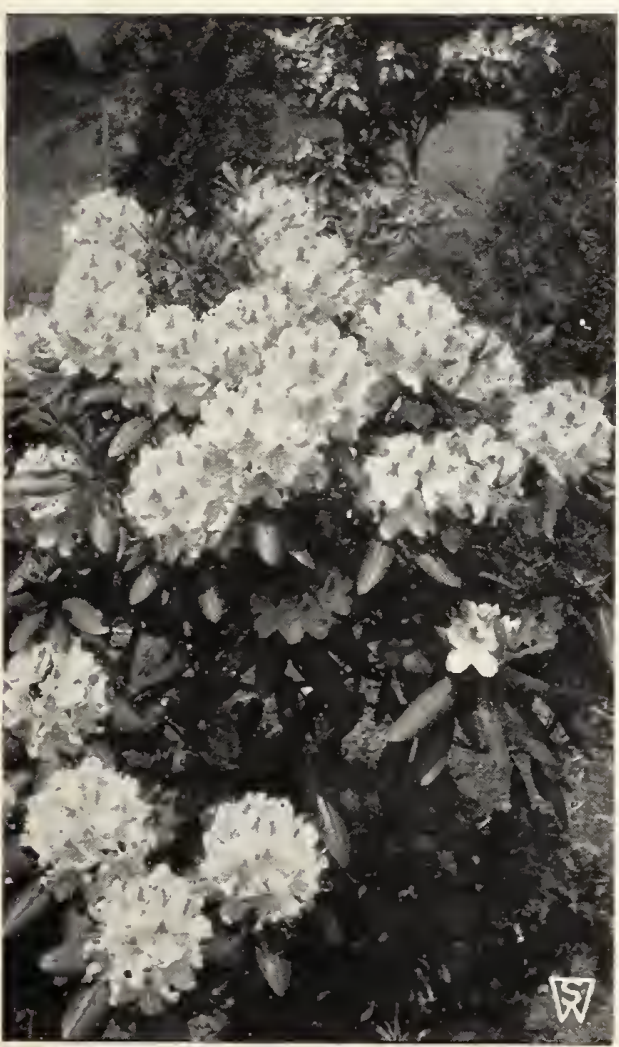

President Lincoln Rhododendron

\section{HARDY HYBRID RHODODENDRONS}

\section{Grafted Plants}

Catawbiense album. A tall rapid grower with pure white flowers. I 5 to 18 in.

Dr. H. C. Dresselhuys. Robust plants with brilliant crimson-red flowers. I 5 to I 8 in.

Mrs. C. S. Sargent. Dark pink blooms changing to rosy red. I5 to I 8 in.

President Lincoln. A most handsome variety of clear rose color. I5 to 18 in.

Roseum Elegans. Giant clusters of brilliant rose-pink fiowers of the purest shade. I 5 to 18 in.

Prices on above, $\$ 5$ each, $\$ 55$ per doz.

\section{Seedlings}

These are strong, weli-rooted seedlings from seed collected from the finest English named varieties, including a wide range of desirable colors, mostly in the darker shades.

We offer in three sizes:

3 to 6 -in. plants.

5 to 8 -in. plants.

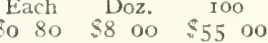

8 to Io-in. plants.

\section{NATIVE RHODODENDRONS}

Rhododendron catawbiense. A shapely, moderate-growing shrub with variously tinted flowers ranging from lilac-purple to paie pink. $\$ 2.50$ each, $\$ 25$ per doz.

carolinianum. In extremely handsome evergreen 4 to 6 feet tall, with trusses of dark pink flowers changing to light pink as they open. \$2.50 each, \$25 per doz.

\section{Other Evergreen Shrubs}

PIERIS floribunda. A low shrub with narrow, dark green, glossy leares. Sprays of pretty white flowers adorn the tips of the branches. I 8 to 24 in., $\$ 2$ each, $\$ 20$ per doz.

KALMIA latifolia. A strong, evergreen shrub covered in early summer with clusters of pink and white flowers of unique form. This is the well-know'n . Iountain Laurel, one of the finest American natives. 24 to 30 in., $\$ 3.25$ each, $\$ 32.50$ per doz.

BUXUS sempervirens. Exceptionally bushy and well-shaped plants. I 5 to I 8 in., $\$ 2$ each, \$20 per doz.

suffruticosa. The true form of the English edging Boxtood. Always dwarf, and invaluable for edging walks and borders.

4 to 6 in., $30 \mathrm{cts}$. each, $\$ 3$ per doz., $\$ 22.50$ per I00, $\$ 200$ per I, 000 .

6 to 8 in., 60 cts. each, $\$ 6$ per doz., $\$ 45$ per Ioo, $\$ 400$ per I, 000 . 


\section{GRAPE-VINES}

Selected vines, except where noted, $50 \mathrm{cts}$. each, $\$ 5$ per doz.

\section{White Grapes}

Diamond. Bunch large, compact, shouldered; berries large, round; skin thin; flesh tender, juicy, with but little pulp. Ripens a little before Concord.

Niagara. Bunch very large, often shouldered; compact; berries large, round; skin thin, does not crack, and carries well. Ripens with Concord.

\section{NEW GRAPES}

Fredonia. Black. Extra-early ripening and by far the best quality. Vine a strong, healthy grower. Berries and cluster large. Productive.

Portland. White. Earliest of all. Large bunch and berry. Resembles Niagara but is superior in quality. Fruit sweet, juicy, and of fine flavor. Vigorous and healthy grower.

Sheridan. Black. Large in bunch and berry; compact. Skin not so tender as Concord and therefore it is a better shipper. Ripens with Concord and it may prove a rival of that old. standard sort for both garden and vineyard planting.

2-yr., first-class Vines, $\$ 1.50$ each, $\$ 15$ per doz.

\section{Black Grapes}

Concord. Early. Deservedly the most popular Grape in America. Bunch large, shouldered, compact; berries large, covered with a rich bloom; skin tender, but sufficiently firm to carry well to distant markets; flesh juicy, sweet, pulpy, tender. Vine a strong grower, very hardy, healthy and productive. For general cultivation the most reliable and profitable variety.

Hubbard. Quality sweet and delicious, having that fine and pleasant flavor approaching the European or Vinifera Grapes. Seeds few and small. Skin thin and firm. Ripens about Io days earlier than Concord.

\section{Red Grapes}

Brighton. Bunch medium to large, long, compact, shouldered; berries medium; skin thin; flesh tender, sweet, with scarcely any pulp; quality best. Ripens with Delaware.

Catawba. Dark red when fully ripe. Bunch large, moderately compact, shouldered; berries medium to large; skin thick, tough; flesh somewhat pulpy, with rich, vinous flavor, of best quality for both table and wine. Ripens too late for high latitudes.

Delaware. Bunch small, compact, sometimes shouldered; berries small; skin thin, but firm; flesh juicy, very sweet and refreshing, of best quality for both table and wine; ripens with Concord or a little before. It should be in every garden and vineyard.
We cannot ship CORRANTS and GOOSEBERRIES outside of New York State due to the Federal Quarantine on account of the white pine blister rust.

We have endeavored to list only the choicest sorts and, while our list is a short one, only the finest sorts are offered. This is preferable to a long list which would necessarily contain varieties of less merit.

\section{SHIPPING SEASON APRIL AND MAY}

\section{BLACKBERRIES}

Blackberries require the same treatment as raspberries and should be planted the same distance apart. We have avoided listing varieties of the prostrate habit, the tips of which constantly root in the ground.

Extra-strong canes, 20 cts. each, $\$ 2$ per doz., $\$ 15$ per 100

Blowers. Large; glossy; fine quality. Ripens early and continues long in season.

Eldorado. Large, coal-black, sweet, melting, without hard core.

Vigorous, hardy and very productive. Fine market variety.

Rathbun. Very large, jet-black; firm; best quality; very productive.

\section{RASPBERRIES}

Raspberries succeed well on any good land suitable for corn or wheat, but amply repay high cultivation. Ground bone is the best fertilizer. Red and yellow varieties should be planted in rows 6 feet apart and 3 feet apart in the rows; black- and purple-cap varieties 7 feet apart and 3 feet in the rows. Cut out all old wood as soon as the canes have done bearing-to give more vigor to the young canes.

Extra-strong canes, except where noted, $20 \mathrm{cts}$. each, $\$ 2$ per doz., $\$ 15$ per 100

Latham. The new mosaic-free, hardy, red Raspberry. The berries are large and round and the color is a richly brilliant red.

Marlboro. Light crimson, large, very firm, and of good quality. A fine early market variety; vigorous and productive.

Early June. A new, early, red Raspberry, originated at the New York Experiment Station. Berries large and firm, bright red color; very productive. A valuable sort for the garden or market.

White Queen. This wonderful new Raspberry bears an abunwell into November. The extra-large, firm berries, which are free from seeds and acid, are of exquisite flavor and aroma. Plants attain a height of 6 feet and bear good crop the first year. $30 \mathrm{cts}$. each, $\$ 3$ per doz., \$20 per Ioo.

St. Regis. A remarkable Raspberry and, all things considered, last quarter of a century. The berries are bright red and of excellent quality. It ripens very early, in advance of all the other red varieties, and in addition to being exceedingly hardy and drought-resistant, is exceedingly prolific. Its rich green foliage
RASPBERRIES, continued

does not scald or rust, hence it succeeds on hot, sandy soil where other varieties fail. Besides yielding an enormous crop in June, it gives also a moderate one in the autumn, and, unlike other red Raspberries, it produces a crop of bcrries the first year, or the season it is planted.

\section{GURRANTS}

Plant in rows 6 feet apart, and 4 feet apart in the rows, or, if to be cultivated both ways, 5 feet apart each way. The soil should be well cultivated to a depth of $\mathrm{I} 2$ inches. Plants should be well set and roots firmed in the soil. After planting cut back the tops one-half of the previous year's growth. For the first 4 or 5 years some of the wood made in the spring should be cut back in the fall, in order to make a more symmetrical plant and a greater number of fruit-buds. Rotted stable manure around base of plant forked in each fall will prove very beneficial.

Selected 3-year-old stock, 35 cts. each, $\$ 3.50$ per doz. $\$ 25$ per 100

Wilder (President Wilder). Bush upright, vigorous; clusters above medium length; berries averaging large; bright red; excellent, with a mild subacid flavor. Ripens early and remains bright and firm until very late. Because of its exceedingly vigorous growth, great productiveness, high quality, and remaining good so long after ripening, we recommend this as one of the best Red Currants, both for table and market.

White Transparent. Bush vigorous and very productive; clusters large; berries very large, sweet and most delicious. This is the best of the White Currants, and fine for the table. Equally desirable as a market Currant.

\section{GOOSEBERRIES}

Plant in the same manner as described for currants, and give the same annual manuring. The American varieties will need close pruning every year.

Selected 3-year-old stock, 60 cts. each, $\$ 6$ per doz. $\$ 45$ per 100

Downing. Pale green, large, prolific and good. Best for home and market use.

Chautauqua. Golden yellow; large variety and of fine quality.

FRUIT TREES. We shall be pleased to send a selected list of Apples, Pears, Peaches, Plums, etc., on request. 


\section{Planet Jr.Wheel Hoes and Seeders}

Wheel Garden Tools do the work of three to six men, make your garden yield more abundantly, and save several times their cost in a single season. Every tool is fully guranteed.

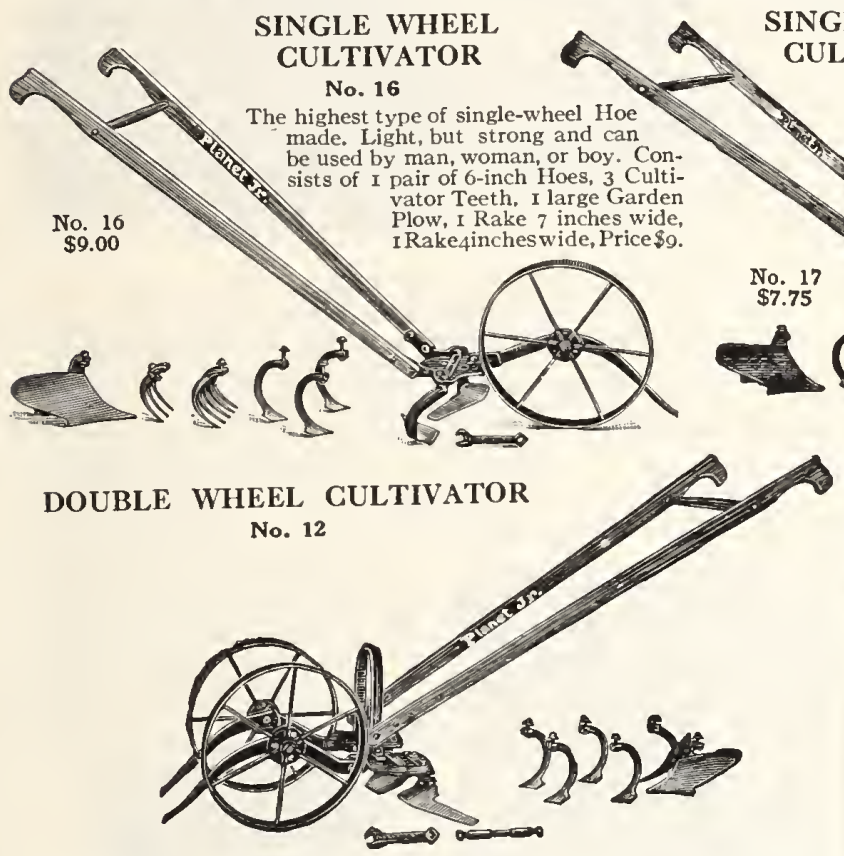

A Single and Double Wheel Cultivator in one. Used as a Double Wheel Hoe, it straddles crops until they are 20 inches high, cultivating both sides at once. Comprises I pair of 6-inch Hoes, 4 steel Cultivator Teeth, I pair of Plows, and 2 Leaf-lifters. Price, $\$ 10.75$.

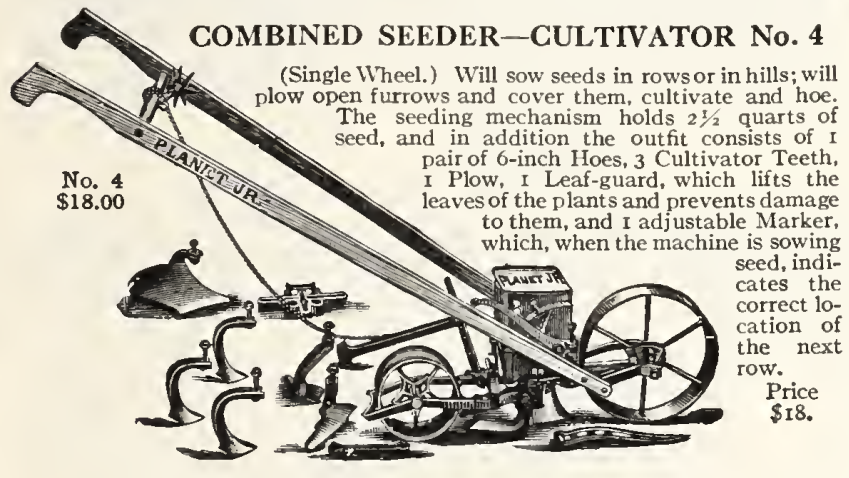

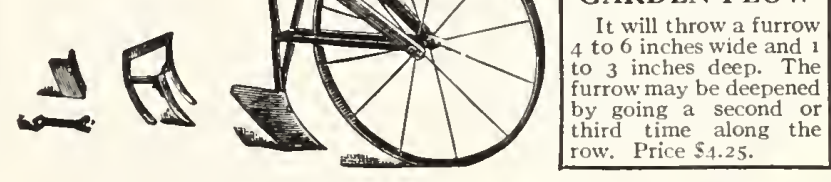

SEEDER No. 4D

Consists of the seeding mechanism only of Outfit No. but does not include the cultivating attachments. Sow 4 efficiently in rows or in hills. Capacity $2 \frac{1}{2}$ quarts. efficiently in
Price $\$ 14.25$

\section{SEEDER No. 3}

This holds 3 quarts of seed. A avorite among onion-growers, market-gardeners, and seed - growers. Sows in a narrow line, making wheel - hoe cultivation

$\$ 17.50$.
No. 119
SINGLE WHEEL CULTIVATOR

No. $171 / 2$

Consists of I pair of 6-inch Hoes and 3 Cultivator Teeth. Price $\$ 6.75$.

No. $171 / 2, \$ 6.75$

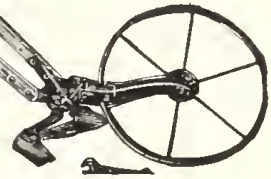

COMBINED SEEDER AND CULTIVATOR

Single wheel.) The seed-box holds $2 \frac{1}{2}$ quarts of seed, and the combination HIGH WHEEL GULTIVATOR No. 119 (Single Wheel.) Has a special 24-inch steel wheel. The outfit consists of one $1 / 2$-inch Cultivating tooth, I 4-inch Cultivating Tooth, I Plow, and I Reversible Scuffle

\section{HOTKAPS. They Keep Plants Warm}

Made of strong, weather-proof paper. Hotkaps are quickly placed in position over newly sown seeds, or newly transplanted seedlings, by means of a "Setter." and they are fixed by drawing a little soil around the edge.

Better than cold frames, they insure against damage by late spring frosts; they protect against wind, rain, and hail; they guard against insects. By the use of Hotkaps, crops may be matured sooner and an early market secured.

Protect tomato plants, pepper and eggplants with Hotkaps. Corn may be sown earlier and will yield sooner with their help. Cucumbers, muskmelons, pumpkins, and squashes grow quickly and are shielded from borers. Tomato pepper and eggplant seeds may be sown directly in the ground, and, protected by Hotkaps, they will yield a full crop. Hotkaps are packed in Ioo and I,ooo lots. Shipping weight 3 and to pounds respectively.

Prices, $\$ 1.50$ per Ioo, $\$ 6.50$ tor 500 , $\$$ II .50 per I,000. Steel setter for placing Hotkaps, \$2.50; Garden Setter (made of papier-mache), 50 cts. Special Home Garden Package containing 5o Hotkaps with Garden Setter, \$1.50.

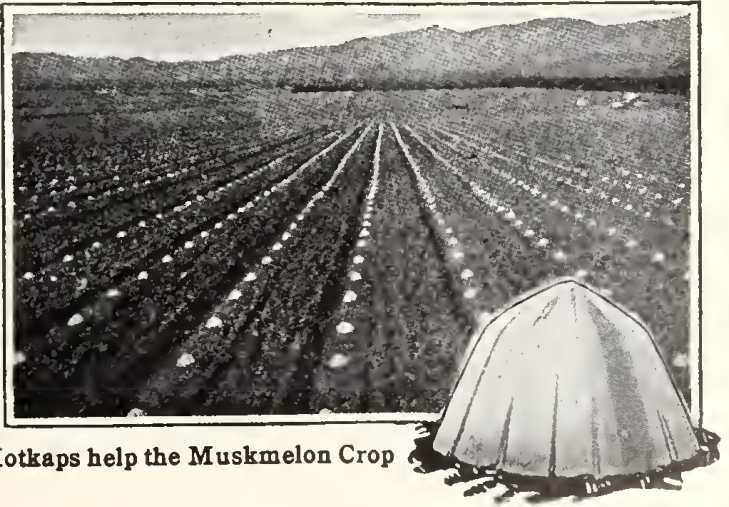




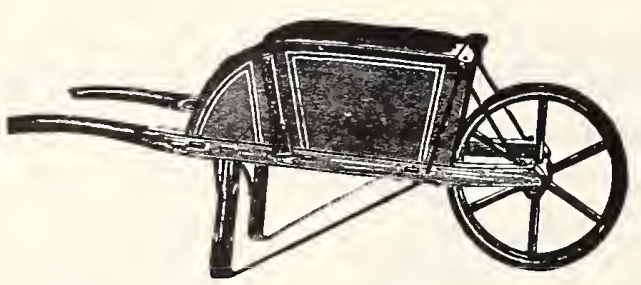

S. \& W. Co.'s Garden Barrow

We guarantee the S. \& W. Co.'s Barrows to be better made and more neatly finished than any other Garden Barrow on the market. Constructed of white oak and finished in the natural wood, varnished, they are made light and substantial for long service.

\begin{tabular}{|c|c|c|c|c|c|c|c|c|}
\hline \multirow{2}{*}{ SIzE } & \multirow{2}{*}{ - } & \multirow{2}{*}{$\begin{array}{l}\text { Front } \\
\text { Width }\end{array}$} & \multicolumn{2}{|c|}{ SIZE OF BOX } & \multirow{2}{*}{$\begin{array}{c}\text { Rear } \\
\text { Width }\end{array}$} & \multicolumn{2}{|c|}{ SIZE OF WHEEL } & \multirow{2}{*}{ Price } \\
\hline & & & Depth & Length & & Diam. & Tread & \\
\hline $\begin{array}{l}\text { Medium.... } \\
\text { Regular... } \\
\text { Boys' ..... }\end{array}$ & $\begin{array}{l}\cdots \\
\cdots \\
\cdots\end{array}$ & $\begin{array}{l}181 / 2 \text { in. } \\
20 \text { in. } \\
151 / 2 \text { in. }\end{array}$ & $\begin{array}{l}\text { I } 2 \text { in. } \\
\text { I } 2 \text { in. } \\
9 \text { in. }\end{array}$ & $\begin{array}{l}261 / 2 \text { in. } \\
28 \text { in. } \\
21 \text { in. }\end{array}$ & $\begin{array}{l}23 \text { in. } \\
24 \text { in. } \\
\text { I } 8 \text { in. }\end{array}$ & $\begin{array}{l}20 \mathrm{in} . \\
22 \mathrm{in.} \\
\text { I } 6 \mathrm{in} .\end{array}$ & $\begin{array}{l}3 \text { in. } \\
3 \text { in. } \\
1 / 2 \text { in. }\end{array}$ & $\begin{array}{r}\$ 8.50 \\
9.50 \\
6.75\end{array}$ \\
\hline
\end{tabular}

\section{Sawco Turf Barrow}

An extra-sturdy, pressed-steel-tray Wheelbarrow designed especially for use on golf courses and in cemeteries and parks. The wheel has a crowned face 4 inches wide, which allows it to be used on lawns or greens without the use of planks or boards. The shoes on the legs are also extra wide. Capacity, $3 \frac{1}{2} 2$ cubic feet. Price, $\$ 9.50$.

\section{S. \& W. Co.'s Platform Cart}

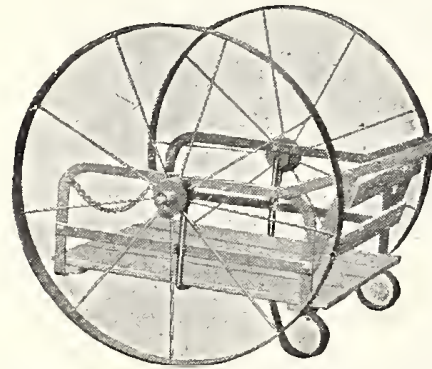

Used for general carrying purposes. Will carry a load of 800 pounds.

This Cart is well built of the best material and nicely finished. The wheels used are of the highest grade steel with 3 -inch oval tires and 9 spokes. The axles and framework are of steel, strong enough to resist six times the load required.

A more useful implement for the farm, the estate, or the golf course would be very difficult to find.

Platform $28 \times 32$ in.; 36-in. wheels; weight I2I lbs. Price, \$I5.

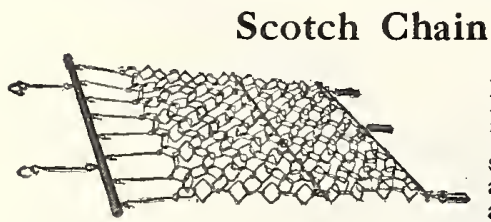

Harrow

Hundreds of wrought-iron links are woven into what is practically a blanket of chain. This arrangement is ideal in smoothing land as a final preparation for grass seeds; it may also be drawn over the soil after seeds are distributed for the purpose of covering them. Made in three sizes, the Small for one horse, the Medium for two horses, and the Large for tractor. Small size, $5 \times 6 \mathrm{ft}$., $\$ 25$; Medium, $6 \times 71 / 2 \mathrm{ft}$., $\$ 35 ;$ Large, $71 / 2 \times 71 / 2 \mathrm{ft}$., $\$ 45$.

\section{Hand Fertilizer Sower for Top-Dressing}

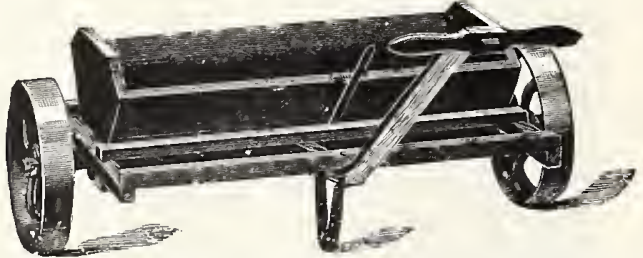

Has the same adjustment as a more expensive machine and will sow all commercial fertilizers. The hopper is 34 inches long and holds one and one-half bushels. When two blades are removed, it will sow damp sand. Also is an excellent machine in the winter for covering icy roads and walks with sawdust, sand, etc. Shipping weight, 83 lbs. Price, $\$ 28$.

\section{S. \& W. Co.'s Lawnette}

Broadcaster for Seeds and Fertilizers

Especially designed for small lawns. Holds up to 25 pounds and will spread, rapidly and uniformly over every inch of ground, at the rate desired, grass seed, plant-foods, and highly concentrated chemical powders (for control of pests, fungous and turf diseases), pulverized sheep-manure, sand, lime, and top-dressing. Spreads I4 inches wide. So simple, so easy, a child can run it, and operates faster than a lawn mower. Price, $\$ 8$.

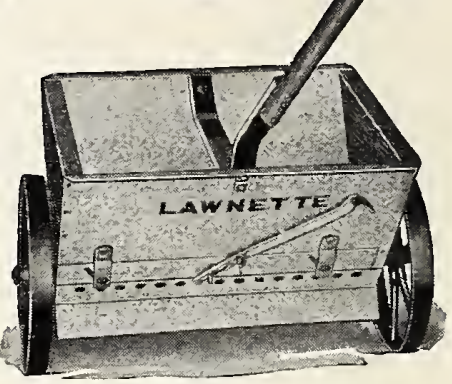

\section{Sawco Wide-Spread Combination Broad caster (Not illustrated)}

Recommended for larger lawns, golf courses, parks, and cemeteries. Hopper capacity, I $3 / 4$ bushels; spreading width, 3 feet. Will spread rapidly and uniformly all the materials mentioned above. Price, \$20.

\section{Burners for Leaves, Paper, and Rubbish}

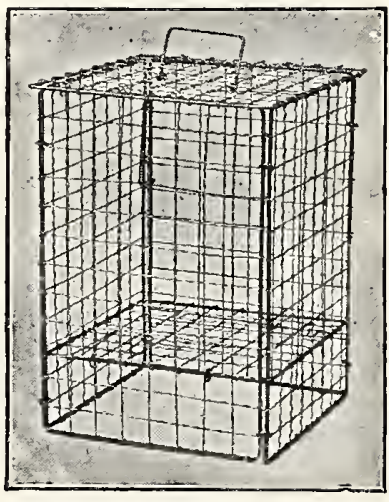

This handy knock-down Burner is a safeguard against many fires that have their origin in the burning of rubbish in the open. Made to give life-long satisfaction. No. Square Height Each I $\quad$ I5 in. 22 in....\$3 oo $2 \quad I 7$ in. 29 in..... 4 oo

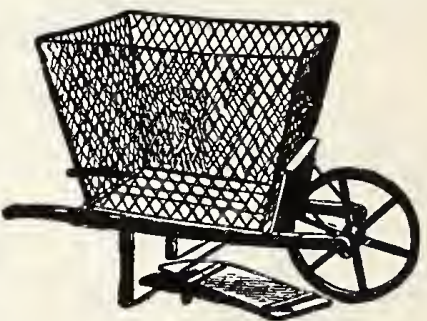

\section{Wire Leaf-Rack}

A practical device for transporting leaves, cut grass, and litter. Can be attached readily to any wheelbarrow having removable sides. It is made of galvanized wire bolted to a wooden base; capacity about Io bushels. Price, Rack only, \$9; Rack and Barrow, \$I7.50.

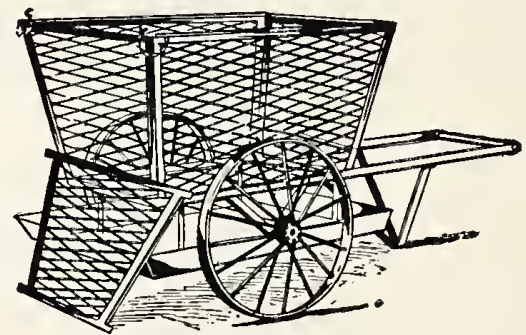

\section{S. \& W. Co.'s All-Steel Refuse and Leaf Burner}

A portable incinerator for the efficient destruction of all waste matter in the garden. Made of angle iron and heavy steel netting, which is guaranteed not to burn out. Is fitted with wide wheels, enabling it to be drawn over lawns or soft ground. A steel pan catches any live ashes that may drop through the fire.

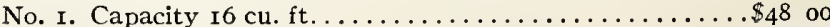

No. 2. Capacity II cu. ft. ............................ 43 oo

No. 3. Capacity 5 cu. ft............................. 38 oo 


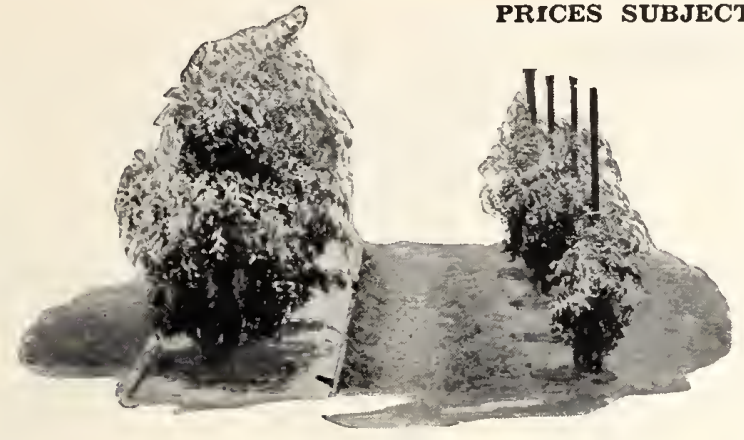

\section{Mulch Paper}

A weather-resistant, heat-absorbing, strong Paper which is placed on the soil between plants.

It stimulates, promotes, hastens growth by the simple expedient of raising the soil-temperature and preventing evaporation of the soil-moisture. Vegetables of all kinds, fruits and flowers growing with Mulch Paper not only mature earlier but experience proves they are bigger, better, have more flavor, and are in general of higher quality. Actual tests show increases in yield from the same soil of 25 to 200 per cent

It saves labor, too. Weeds cannot come up in soil that is covered by it. They're blanketed.

Comes in two types, each in I8-inch and 36-inch rolls:

Type A. Light weight, for annuals:

I 8 in. wide, $900 \mathrm{ft}$. long, I,350 sq. $\mathrm{ft}$

$36 \mathrm{in.}$ wide, $900 \mathrm{ft}$. long, $2,700 \mathrm{sq}$. $\mathrm{ft}$

Type B. Heavy weight, for perennials and all garden work:

I $8 \mathrm{in.}$ wide, $450 \mathrm{ft}$. long. $675 \mathrm{sq}$. $\mathrm{ft}$.

$36 \mathrm{in}$. wide, $450 \mathrm{ft}$. long, $\mathrm{r}, 350 \mathrm{sq} . \mathrm{ft}$.

I 8 in. wide, $45 \mathrm{ft}$. long, $67 \%$ sq. $\mathrm{ft}$

\section{Acme Asparagus Buncher}

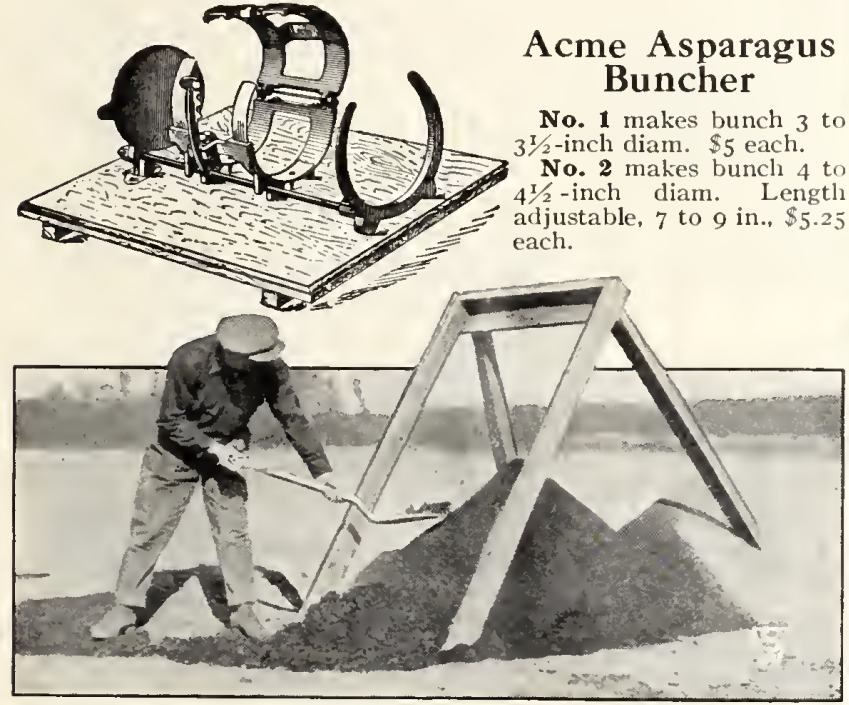

\section{Flat Screen}

Handy for compost, soil, sands, gravel, etc. Extra-heavy galvanized wire; spruce frames. Size, 66 in. $x 28$ in., $1 / 2$-inch mesh. Price, $\$$ I 6 .

\section{Sowrite Seed Sower \\ Sows Seeds at a Touch}

It scatters seeds individually and prevents crowding and choking of the seetlings when coming up. Small size, for fine seeds, \$r; large

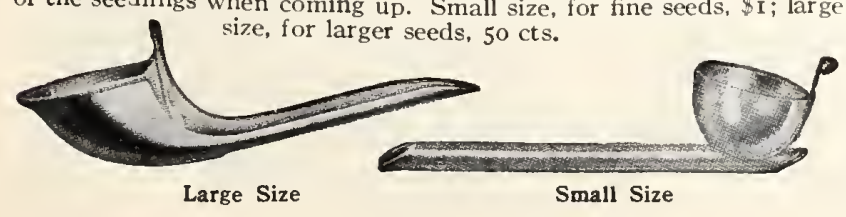

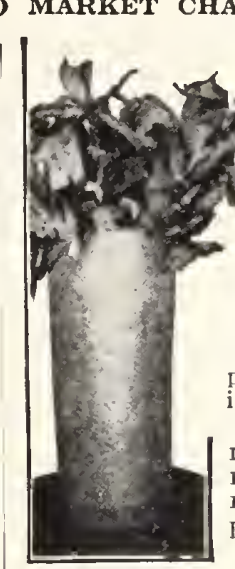

\section{The Cahoon Improved Broadcast Seed Sower}

It is well known as a practical and cheap broadcaster of wheat, rye. oats, barley, hemp, timothy, and millet, but not recommended for lawn or grass seed. The operator can sow from 4 to 8 acres per hour. $\$ 5$ each.

\section{Celery-bleaching Tubes}

Labor and money-savers. The brass Handler is placed around the celery plant, the tube is slipped in place and the Handler removed.

I 2 inches high

13 inches high

I4 inches high

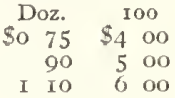

Handlers for use in placing tubes, brass. $\$ 2.50$.

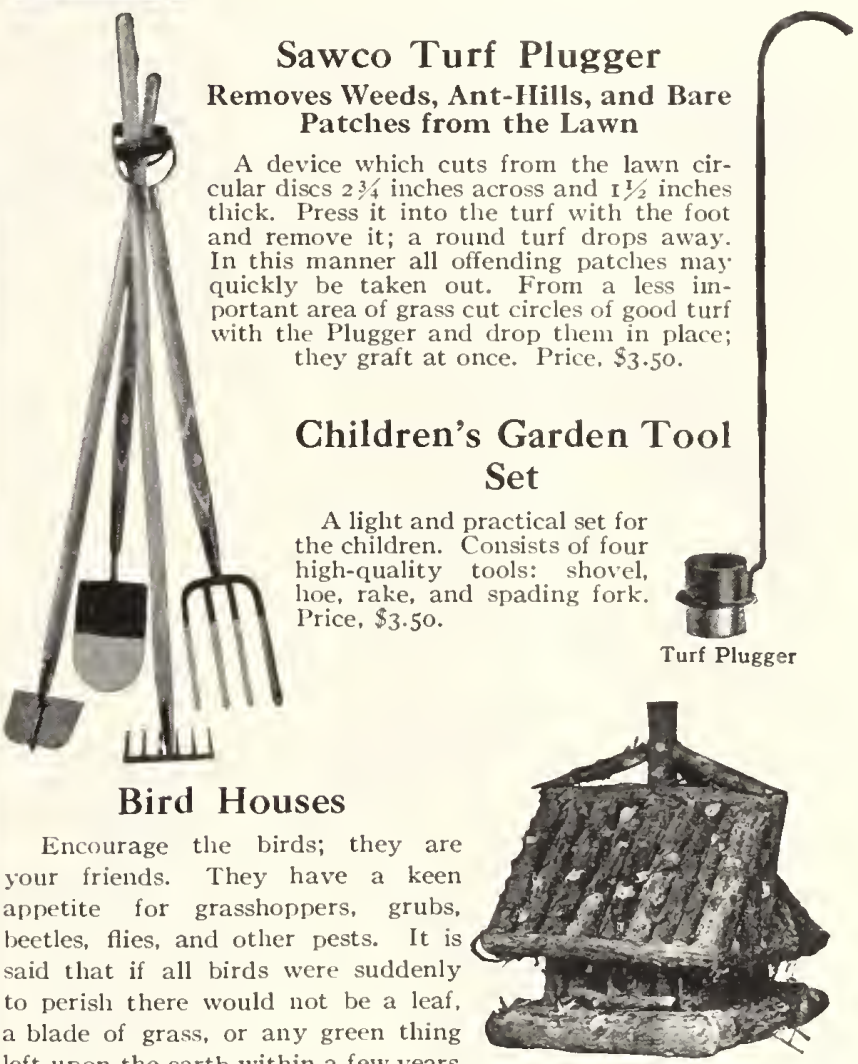
left upon the earth within a few years

-it would be uninhabitable. The presence of birds in the garden should indeed be welcome. You can easily find places for bird louses on your fences and trees and we can offer same as follows:

\begin{tabular}{|c|c|c|c|c|c|}
\hline Type & Families & Width & Height & Depth & Each \\
\hline Log Cabin..... & $\mathbf{I}$ & Io in. & ro in. & Io in. & $\$ 250$ \\
\hline Log Cabin..... & 2 & Io in. & I 2 in. & 14 in. & 400 \\
\hline Log Cabin...... & 2 & I 4 in. & I $2 \mathrm{in.}$ & I 7 in. & 475 \\
\hline Colonial........ & 2 & I 4 in. & I 7 in. & I6 in. & 725 \\
\hline Colonial........ & 4 & I 4 in. & I $8 \mathrm{in.}$ & $19 \mathrm{in.}$ & 875 \\
\hline Hexagonal...... & 2 & I 2 in. & I 4 in. & I 2 in. & 475 \\
\hline Bird Shelters.... & & I 2 in. & Io in. & I 7 in. & 375 \\
\hline
\end{tabular}

Blue Martin House.

Hexagonal..... I $2 \quad 22$ in. 24 in.

2500 


\section{Garden and Lawn Tools}

Tampers

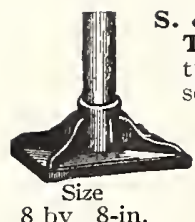

Io by Io-in. handle. I 8 lbs
S. \& W. Co.'s I r o n S o d Tamper. Used when laying urf and for compacting the od after frost. The Tamper is square and is furnished complete with a 4-foot

250

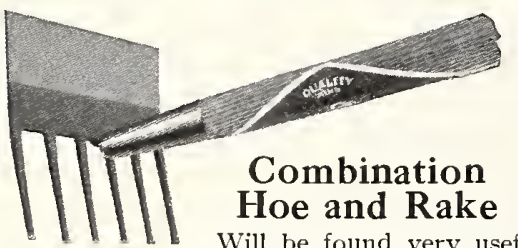

Will be found very useful around the garden. Price, $\$ 1.25$ each.

S. \& W. Sod Perforator

The best low-priced device for renovating bare spots in lawns. Use before sowing $\mathrm{g} \mathrm{r}$ a s seeds, permitting the The spikes are set firmly in an oak block. made in two halves and put together with screws. A 4-foot handle is included. Io by I 2 ins. $\$ 4 \cdot 50$.

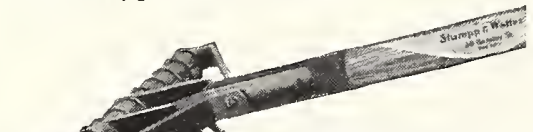

Sawco Lawn Cultivator Rake

This consists of a heavy, solid head, carrying I3 curved, sharp-pointed and sharp-edged teeth. The grass and roughens the turf to prepare it for reseeding. With handle, $\$ 2.50$ each.
Weight Price I4 lbs........\$I 75 Cultivator Rake tears out clover or crab-

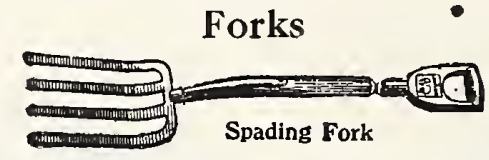

Spading Forks. Best grade; tines spearpointed with diamond-shaped backs handle strapped both sides. Of superior quality and very strong. Each 4-tine, D-Handle........... \$2 25
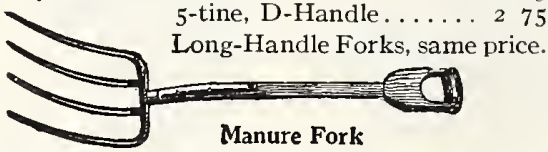

\section{Manure Fork}

Manure Forks. Best grade; strong oval tines.

4-tine, D-Handle.............. \$2

5-tine, D-Handle.............. 225

6-tine, D-Handle.............. 25

Long-Handle Forks, same price.

Hay Forks. With long handles. Each 3-tine, Long Handle........... \$ I 75

Boys' Spading Forks............ I 25

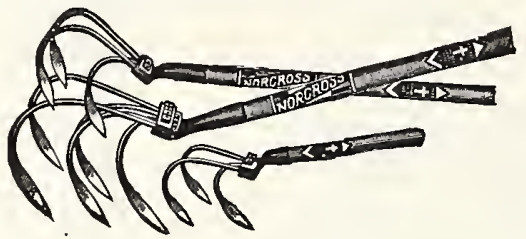

\section{Norcross Cultivator Hoe and Weeder}

Wherever vegetables, plants and flowers are grown, these modern tools are rapidly replacing the ordinary hoe. They are made in three sizes, and can be used in wide or narrow rows. Will also cultivate both sides of a row at one operation, when the middle prongs are removed. The three-prong weeder is the women's size. They destroy weeds. leave the soil level, loose and untrampled. 5-prong, $\$ 1.40$; 3-prong, \$I; Midget, 65 cts.

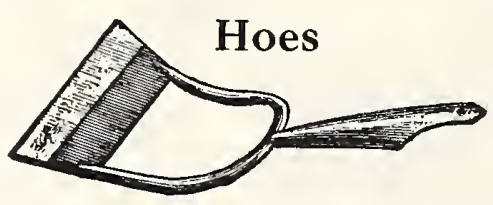

English Scuffle Hoe. Complete with handle. Imported. Positively the best. The quality of material used and finish is superior to all others.

\begin{tabular}{|c|c|}
\hline Each & Size \\
\hline in......\$I 50 & 8 -in.......\$I 9 \\
\hline $\begin{array}{ll}\ldots \ldots & \text { I } 60 \\
\ldots \ldots \ldots & \text { I } \\
\ldots 0\end{array}$ & 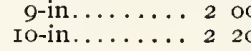 \\
\hline
\end{tabular}

Style A. 3-prong Weeder. $25 \mathrm{cts}$. each.

Style D. 4-prong Weeder and Hoe. $60 \mathrm{cts}$.

\section{Turf Edgers for Lawns}

Solid Welded-Steel Edging Knife. Without handle; made of the very best steel; imported English. 8-inch, $\$ 2.50 ; 9$-inch, $\$ 3$. Half-Moon Edging Knife. Solid steel, with a polished handle. \$I.4O.

\section{Planet Jr. Revolving Disc Edger}

A very dependable implement; easy to handle. \$1.60 each.

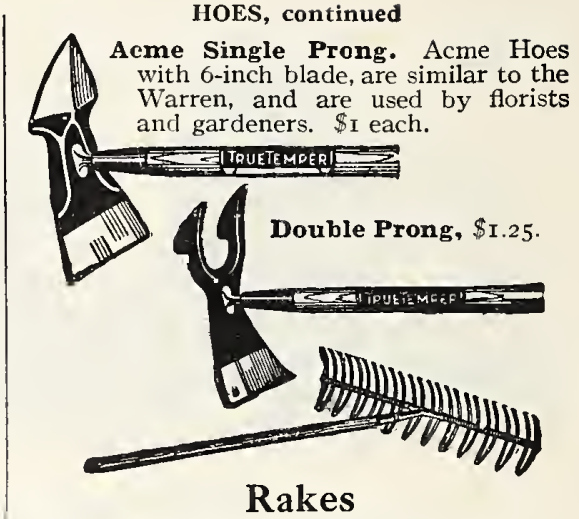

Reversible Steel. Suitable for lawn and garden. Has 24 teeth. $90 \mathrm{cts}$. each.

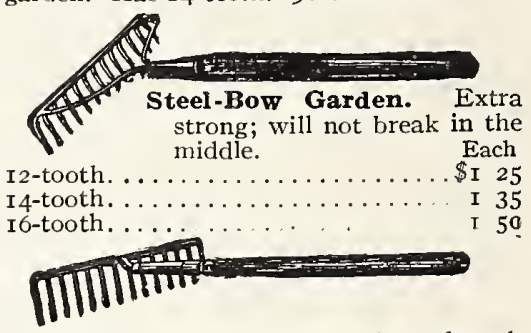

Steel Garden. Cut from one piece of steel; strong and durable. Polished teeth.

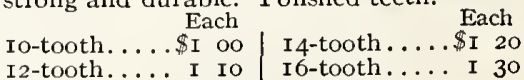

Steel Gravel. Like the Garden Rake. Made substantially, with short teeth.

$\begin{aligned} & \begin{array}{r}\text { Each } \\ \text { I4-tooth.......... }\end{array} \text { I } 25 \\ & \text { I6-tooth........ I } 35\end{aligned}$

I8-tooth.

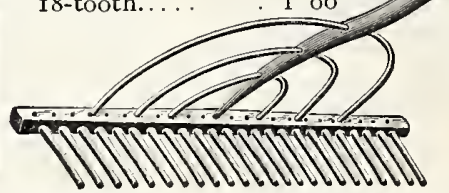

Wood Hay and Lawn. Made especially for us with an extra-heavy head to give double service. Each Doz. I4-tooth Hay............ \$I 20 \$I 200 24 -tooth Lawn........... I 50 I5 00

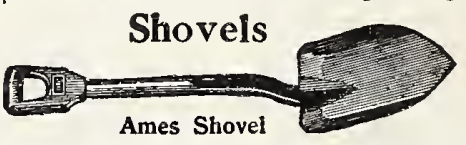

Ames Shovels are the best manufactured; give best service. Each Square Point, D-Handle........ \$2 75 Round Point, D-Handle........ 275 Long-Handle Shovels, same price.

S. \& W. Co.'s Shovels.

Square Point, D-Handle......... I 75

Round Point, D-Handle........... I 75

Long-Handle Shovels, same price.

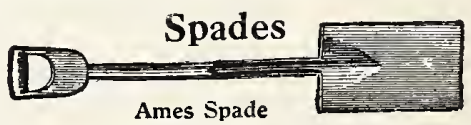

Ames Spades are the same grade as the Ames Shovels. Each

D-Handle and Long Handle...... \$2 75 S. \& W. Co.'s Spades are the same grade as

S. \& W. Co.'s Shovels. Each

D-Handle and Long Handle....... \$I 75

Boys' Spades................. I 75 boys, ladies and men. Each 5 -in.............\$o 90 7 -in........... 


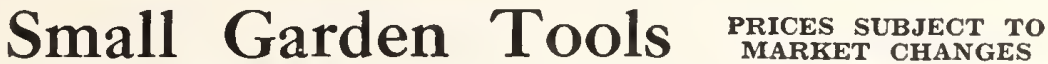

\section{Dibbles or Dibbers}

Just the tool for transplanting tomatoes, $\mathrm{cabb}$ a g e.

celery, etc.

B $\mathbf{r}$ a $s$ s

po i n $t$

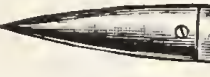

and

Brass Dibber

wood handle. The best Dibber.

Polishes quickly; does not

rust. \$I. 25 each, \$I 2 per doz.

Steel point and wood handle. Regular size, 93/4 in., \$I each, \$I per doz. Small size, 8 in.. 90 cts. each, \$9 per doz.

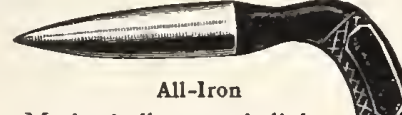

All-Iron. Made hollow and light; japanned handle. Regular size, $9^{3 / 4}$ in., 90 cts. each. $\$ 9$ per doz.

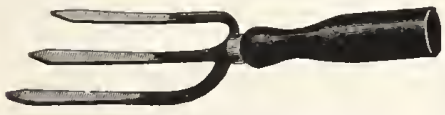

\section{Gem Hand Fork}

Has three steel prongs and finished handle. Is a handy Fork for transplanting strawberries, loosening the soil, etc. 60c. each.

\section{Grass Hooks}

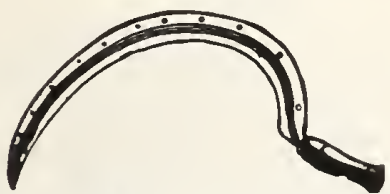

Imported English. With heavy riveted back, thin cutting blade, easy to sharpen; forged from the best-grade steel. Medium, \$I; Large, \$I. I 5

\section{Grass and Lawn Scythes}

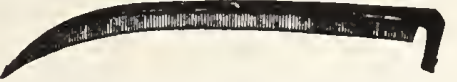

Imported English. Has a riveted back, broad, thin, light blade. Best Scythe for cutting grass, rye, oats, etc.

32 -inch. Medium............\$3 25 34 -inch. Large medium......... 350 36-inch. Large ............. 375

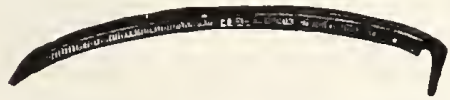

Domestic. Cutlery steel, natural oil finish, cutting edge, web and backs polished.

32 -in. Med. \$2 35 | 36-in. Large. \$2 60

Scythe Snath or Handle. The very best, with patent socket. $\$ 2.50$.

Scythe Stones, Genuine English. Round, tapering. 35 cts. each.

Unbreakable Radiac. $30 \mathrm{cts}$. each, $\$ 3$ per doz.

Scythe Rifles, Emery-coated. 25 cts. each, $\$ 2.50$ per doz.

Scythe, Bush. High-grade steel blade. I 8in., $\$ 2.25$ each; 20-in., $\$ 2.50$ each.

Bush Hook : lbs. Including handle, $\$ 3$ each.

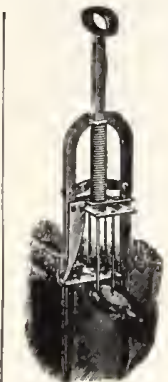

\section{Mole Traps}

Schroeder Improved No. 1. It has a rest on top for a weight, also eight sharp prongs and a strong spiral spring. \$2.50 ea., \$25 per doz.

The Ritten

house. The

simplest

safest, auld

surest Mole

Trap ever

invented.

Self-set-

ting. No

The Ritten-

danger of

house its going

off unless the trigger

is touched. Made

of all steel and

tinned. Six in a

crate. The spears

are spring steel,

therefore not so

long as soft steel.

\$I.IO ea., \$I I per

doz.

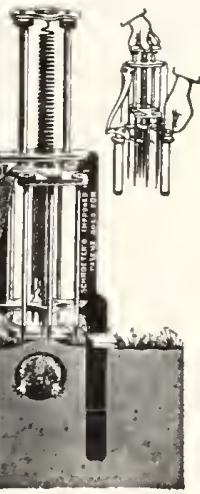

Schroeder Improved

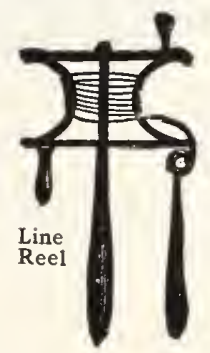

Garden Line Reels

Malleable Iron. Holds Ioo feet. \$1.25.

Eureka. Galvanized steel. Single, 500 feet size, $\$ 3.25$. Double, 1,000 feet size, $\$ 4$.

Garden Line

Best Braided Linen. 100 feet, one length, \$1.75. 200 feet, one length, $\$ 3.50$

\section{Trowels}

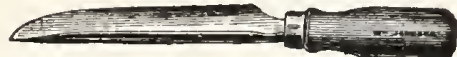

Slim Jim. Excellent for setting bulbs or transplanting. 5-in. size, 20 cts.; 7-in size, 30 cts. each

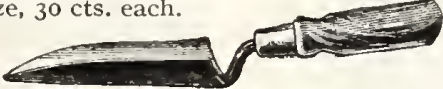

Forged Steel. This Trowel is second to the Stumpwall Trowel in quality and finish. The blade and shank are one piece, forged out of the best of steel. Made in three sizes. 5-in., 65c. each; 6-in., 75c.; 7 -in., 85 c.

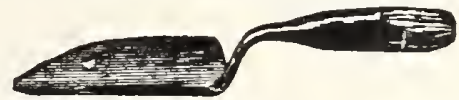

The Stumpwall is the best made Trowel The ferrule and shank, as well as the blade, are forged in one piece. Only the very best material used. 6-in., \$I each.

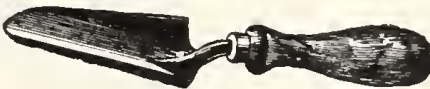

Florists' Steel Trowel

This Trowel is made in one piece of heavy sheet steel One size only, 6-in., 50 cts, each.
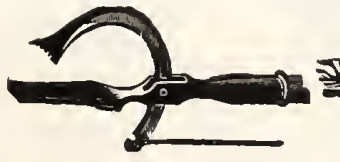

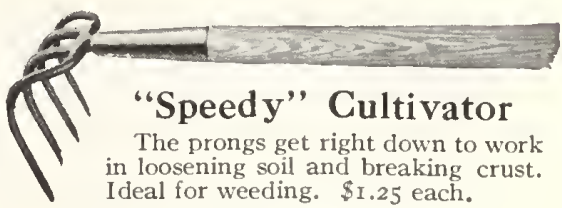

Ideal for weeding. \$1.25 each.

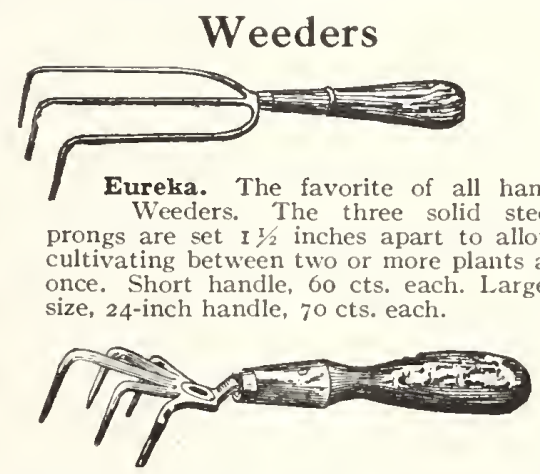

Excelsior Finger. This five-short-pron Weeder is excellent for loosening the soil in small flower-beds, etc. 35 cts. each, $\$ 3.50$ per doz.

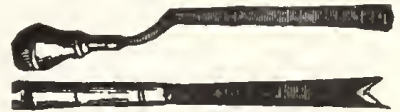

Asparagus Knives

American Asparagus Knives.

Straight Edge. $50 \mathrm{cts}$. each.

V-Shape. $50 \mathrm{cts}$, each.

\section{Dandelion Digger}

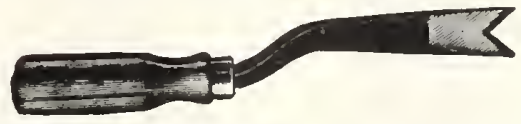

Used for digging out Dandelions from lawns. Blade, 6 inches. $60 \mathrm{cts}$. each, $\$ 6$ per doz.

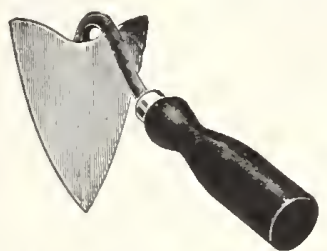

Midget Warren Hoe. Blade and shank forged from the best quality of steel. Handle is turned, polished, and enameled. Excellent for making drills and covering; also for transplanting and weeding. $80 \mathrm{cts}$. each, $\$ 8$ per doz.

Cleveland Lawn Weeder. Is simple to operate; it not only saves the back, but is actually a pleasure to use. The cut is a good illustration, showing how to work it. $\$ 1.50$ each. 


\section{Flower Boxes, Pots and Fibreware}

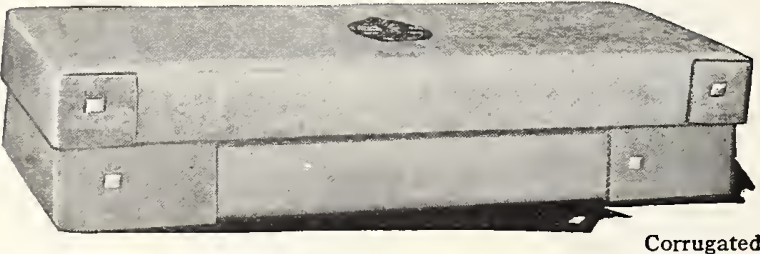

Flower Boxes

Cardboard, Flower. Ivy green; lock corners.

\begin{tabular}{|c|c|c|c|c|c|}
\hline & Depth & Length & Width & Doz. & 100 \\
\hline & 3 in. & I 8 in. & 5 in... & $\$ 100$ & \\
\hline & $3 i$ & $21 \mathrm{in}$. & $5 \mathrm{i}$ & I 20 & 700 \\
\hline & 4 & 24 & & I 75 & IO 50 \\
\hline & $5 \mathrm{in}$. & $28 \mathrm{in.}$ & 8 in........ & 225 & 1300 \\
\hline & $5 \mathrm{in.}$ & 36 in. & & & \\
\hline
\end{tabular}

Corrugated Cardboard. Very heavy and durable; extensively used by florists for shipping cut-flowers.

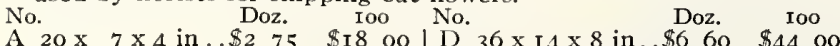

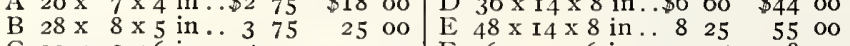

C $30 \times 12 \times 6$ in..5 $500 \quad 3300$ F $36 \times 12 \times 6$ in .. $575 \quad 3800$

\section{Paper}

Wax. I $8 \times 24$ in. Ream...

$24 \times 36$ in. Ream.

Tissue. $24 \times 36$ in. Ream.

Manila. $24 \times 36$ in. Ream.

Wrapping. $40 \times 48$ in. Lb.

Wrapping. In rolls: Widths 24 in., 30 in., 36 in. Weight approximately 50 lbs. Kraft or Manila, lb. I4 cts.

\section{Fibreware Flower Vases WATERPROOF}

Deep shade of mahogany color.

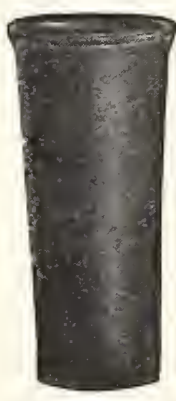

Fibreware Flower Vase

\begin{tabular}{|c|c|c|c|c|}
\hline No. & Depth & Diam. & Each & Doz. \\
\hline & Io in. & 6 in.... & \$1 70 & $\$ 1700$ \\
\hline 44 & $83 / 4$ in. & $3^{1 / 2}$ in. & I 25 & 1260 \\
\hline 22 & I 5 in. & $4 \frac{1}{2} \mathrm{ing}$. & 260 & 2600 \\
\hline & $18 \mathrm{in.}$ & $6 \mathrm{in..}$ & 3 оo & 30 oo \\
\hline
\end{tabular}

\section{Plantnurse Pots}

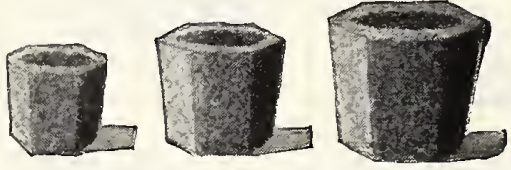

This pot does just what its name implies. It nurses and nourishes the young plants that are entrusted to its care. When put into the soil, it absorbs nine times its own weight of moisture, thus releasing the plant-nourishing substances which the Plantnurse Pot contains, feeding the young plant in a most practical and easy manner. It gives the plant strength and protects the young roots. In a few weeks the roots will have grown through the Plantnurse Pot and a short time later you will find that the roots and the pot are one solid ball, ready to plant out withont any checking of growth.

The Plantnurse Pot is made from peat-moss and manure, and is not only a pot, but a fertilizer for the young plant.

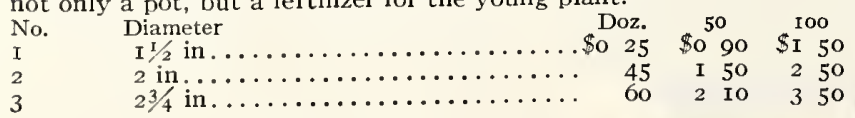

\section{Azalea Pots}

These pots differ from standard flower pots in that they resemble the bulb pans but are deeper. Diam. 6 in. $\begin{array}{ccc}\text { Each } & \text { Doz. } & \text { IOO } \\ \$ 0 \text { I5 } & \$ \text { I } 50 & \$ 10 \text { 0O }\end{array}$ 7 in

8 in 9 in $\begin{array}{lllll}25 & 2 & 50 & \text { I } 5 & 00\end{array}$ $\begin{array}{lllll}25 & 2 & 50 & 15 & 00 \\ 30 & 3 & 00 & 22 & 00\end{array}$ Io in...

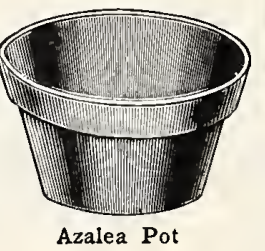

Flower Pots, Standard EARTHENWARE. Best on the market

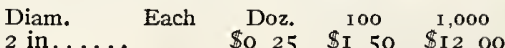
2 in..... \$O 25 \$I 50 \$I 200 $2 \mathrm{~T} / 2$ in.... 30 I 75 I5 00 3 in...... $\quad 40 \quad 250 \quad 2000$ 4 in...... 60 so 4 oo 30 oo $700 \quad 5500$

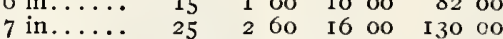
8 in ....... $35 \quad 320 \quad 20$ oo 180 oo On orders of 50 pots or more we make shipment direct from factory to customer.

Saucers of same material, to fit Pots, furnished extra

4 in...

6 in...

7 in...

9 in.

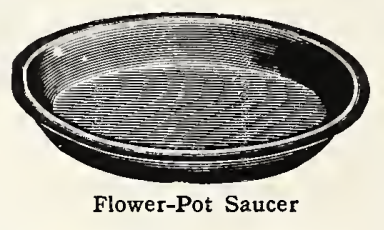

\section{Flower-Pot Saucers}

FIBREWARE. Waterproof

Light and not readily broken; have a surface that will not scratch, like earthenware. Order saucer 2 inches larger than the bottom diameter of pot. Diam. Outside Each Doz. Diam. Outside Each Doz.

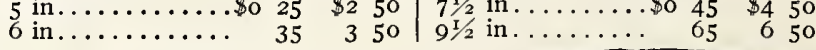
Bulb Pans. Earthenware Diam. at top 6 in

7 in

9 in.

Io in.

$\ldots \ldots \ldots 70 \quad 700$

150

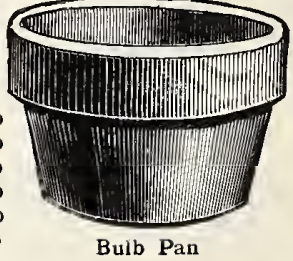

Bulb Pan

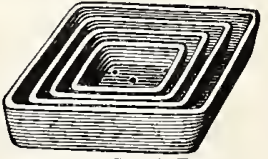

Square Seed Pans

\section{Square Seed Pans} EARTHENWARE

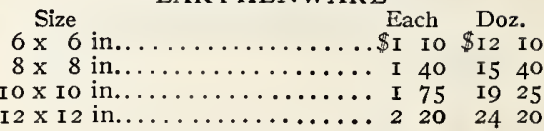

\section{Paper Flower Pots, Neponset}

Very economical; waterproof; can be nested closely for shipping.

Diam.

$21 / 4$ in

$21 / 2$ in $\ldots \ldots \ldots$

3 in $\ldots \ldots \ldots \ldots$

$3 \mathrm{~s} / 2$ in $\ldots \ldots \ldots \ldots$

5 in.................

6 in

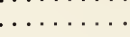

\begin{tabular}{|c|c|c|}
\hline Doz. & 100 & $\mathrm{I}, 000$ \\
\hline & \$o 65 & $\$ 450$ \\
\hline I5 & 70 & 500 \\
\hline 20 & 85 & 725 \\
\hline 25 & I 20 & 900 \\
\hline 30 & I 75 & II 25 \\
\hline 40 & 250 & I7 50 \\
\hline 50 & 300 & 2200 \\
\hline
\end{tabular}

\section{Flower-Pot Brackets}

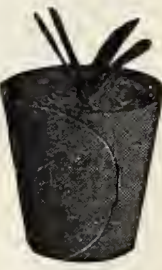

Paper Pot
Made of steel, artistic in design, finished in black. Saucers are absolutely secured by spring clasp.

No. I. Length of arm, 7 in. Clasp will hold 5 -in. pot.....\$o 65

No. 2. Length of arm, $8 \mathrm{in}$. Clasp will hold 6 -in. pot...... 75

No. 3. Length of arm, Io in. Clasp will hold 7-in. pot...... 90

\section{Waterproof Green Flower-Pot Covers}

To fit 4-, 5-, and 6-in. standard clay pots. I2 25 I00 4 in........................\$0 50 \$0 $90 \cdot \$ 300$

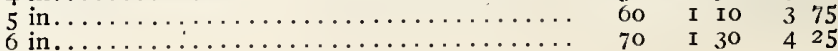




\section{S. \& W. Co.'s Plant and Tree Tubs}

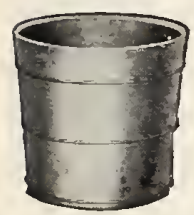

Barclay Tree Tubs. Made of seasoned, selected Virginia white cedar; bound with electric welded wire hoops (galvanized), three hoops to each, except the two smallest tubs which have two.
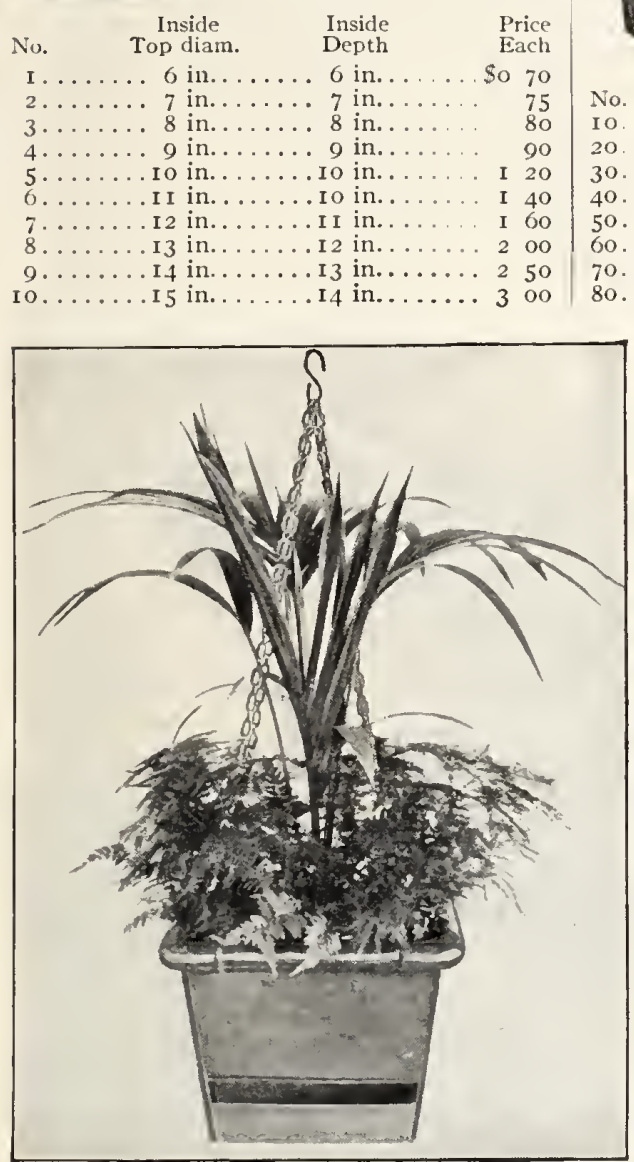

The S. \& W. Co.'s Irrigating Hanging-Basket

The S. \& W. Co.'s Irrigating Flower-Boxes

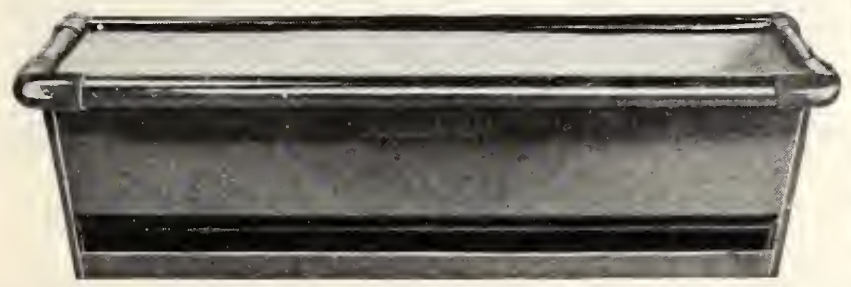

Length Width Depth Each Length Width Depth Each

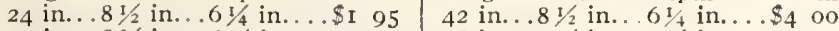

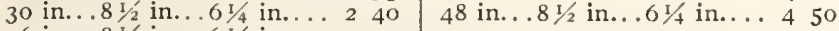
36 in.. $8 \mathrm{~s} / 2$ in. . $61 / 4$ in... 325

Brackets for Attaching the Above to Window Frame, Etc.

No. 1. Sets on window-sill. go cts. per pair.

No. 2. Sets below window-sill. \$I. Io per pair.

No. 3. For porch-rails and wooden sills. $65 \mathrm{cts}$. per pair.

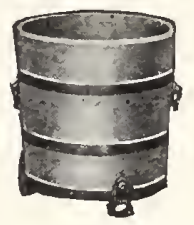

New York Cedar Plant Tubs. Made of the choicest seasoned selected Virginia White Cedar These tubs are painted both inside and out with best oil paints, and the hoops and castings are trimmed in a jet black paint. Will outlast tubs made of any other known wood.

green. (For height
over all, add 3 in.) Top Bottom Depth
8 in... 7 in... 8 in..... $\$ 525$ 10 in... 9 in.... 10 in......6 60 12 in... . I I in... I 2 in...... 725 14 in... I3 in... I 4 in...... 8 o0 I 8 in.... I 7 in.... I 8 in...... I 50 20 in... I 8 in...20 in..... I 375

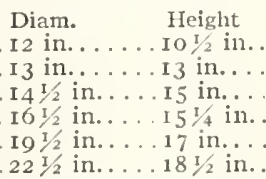

Price

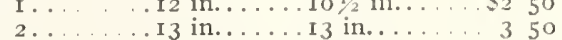
$3 \ldots \ldots$ I $4 \frac{1 / 2}{2}$ in.... I5 in...... 425 $4 / 2 \ldots 1018$ in 5.

\section{S. \& W. Co.'s Irrigating Flower-Boxes and Irrigating Hanging-Baskets}

The S. \& W. Co.'s Flower-Boxes and Hanging-Baskets make it easy to have all the The want. for all plants thrive in the

, are strongly made, water-tight, galvanized sheet-steel Boxes. any surroundings.

Drainage is very easily controlled. There is a specially patented device along the side of the box, full length, for collecting the drainage-water and which indicates when the proper amount of water has been used, thus preventing over-drainage. The aircirculation is perfect and the soil is kept sweet and healthful.

\section{The S. \& W. Co.'s Irrigating Hanging-Baskets}

Io in. square, $71 / 4$ in. deep.....\$2 $35 \mid \mathrm{I} 6 \mathrm{in}$. square, I $21 / 4 \mathrm{in}$. deep.....\$4 oo I 2 in. square, $8 \mathrm{I} / 4 \mathrm{in}$. deep........... 47575 If in. square, Io 1 in deep.
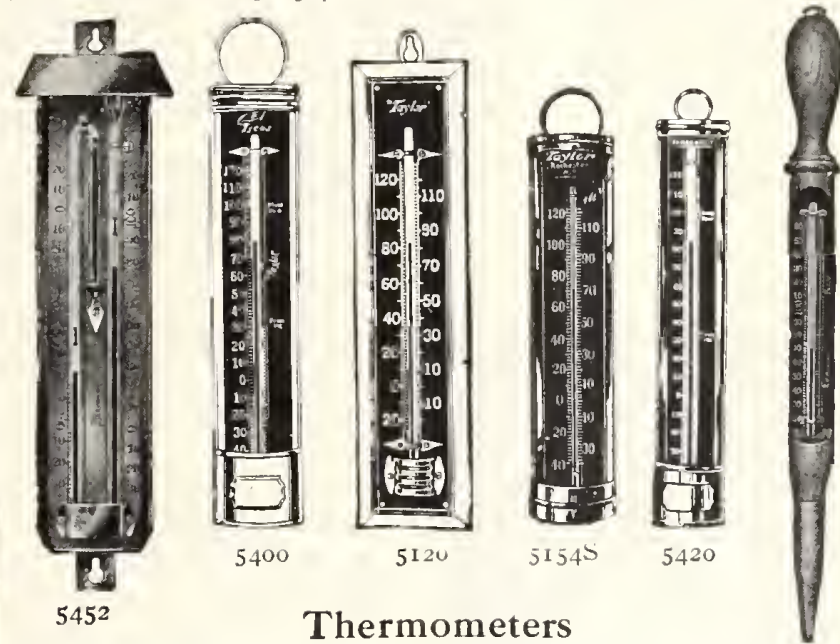

No. 5452, Self-Registering. (Siexe's Pattern.) Lacquered 598I polished brass case, white figures. Maximum and Minimum. Io-inch, \$7. Magnet with each.

No. 5400. Black japanned heavy tin case; brass scale, white figures. (Mercury.) Scale range, Io to 40 degrees below zero to I20 above. Standard Grade. 8-inch, \$1.75; I0-inch, \$2.

No. 5420. Black japanned heavy tin case. For greenhouses. Black oxidized brass scale white figures. (Spirit) 8-in. \$I; IO-in. \$I.25.

No. 5154S. Coppered tin case; distance reading. Black oxidized brass scale, white figures. (Spirit.) Scale range, I 20 degrees above to 40 degrees below zero, 8 -inch, $85 \mathrm{cts}$.

No. 5120. Distance reading. IVood-back Mission finish, brass scale, white figures and graduation. (Spirit.) Easy to read at distance. 8 -inch, \$I.25.

No. 5981. Hotbed. Wood frame, I5 inches, with point. Brass oxidized scale, white figures and graduations. Best grade, mercuryfilled bulb-chamber giving good contact. Price, $\$ 3$. 


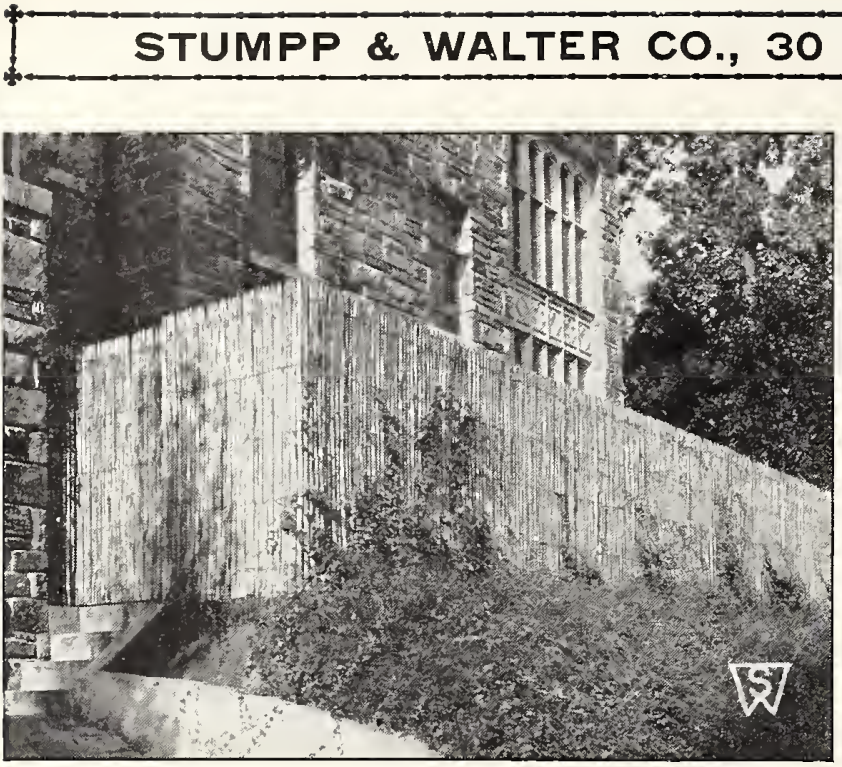

AND 32 BARCLAY ST., NEW YORK

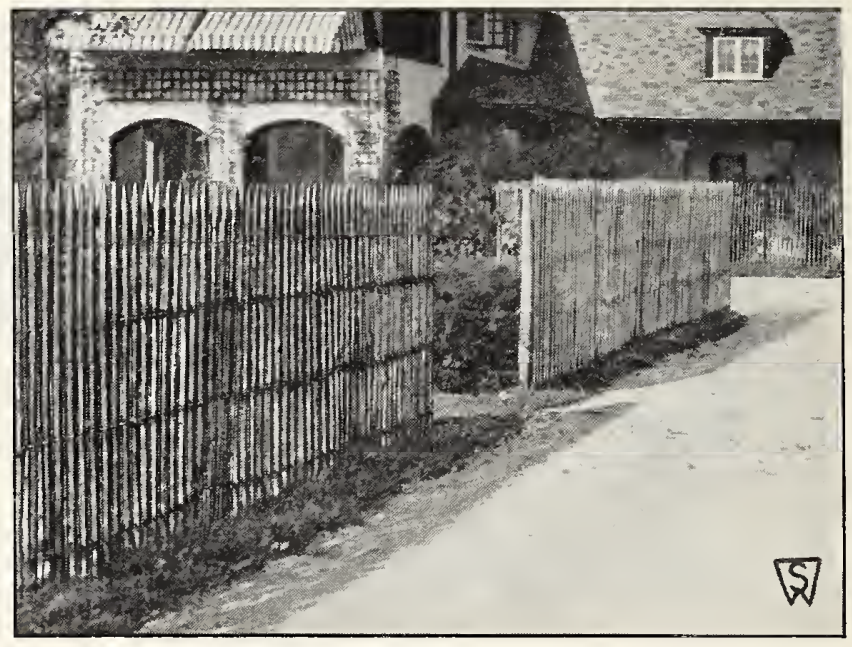

\section{Dubois Woven Wood Fence}

Dubois Woven Wood Fence is made of split, live chestnut saplings which have first been carefully matched and then woven together against horizontal braces with heavy, non-rusting Copperweld wire to form a solid screen. When new the saplings are a natural brown which mellows, as time goes on, to a beautiful, soft, silver-gray tone that only Nature can achieve.

One of the greatest advantages of Dubois is that it blends with any landscape as readily as fine old shade trees. Another is that it never requires painting or other maintenance expenses. With it, the first cost is the last.

The erection of Dubois is a simple matter. No skilled labor is required. You need only a framework of posts and cross-pieces. Against this framework the sections of Dubois are simply nailed. Erection methods may be varied to suit special conditions.

Dubois comes in sections 5 feet long, in three heights. Gates to match can be had at additional cost.

\begin{tabular}{|c|c|c|}
\hline $6 \mathrm{ft} ., 6$ in. high......... & Io ft. high. . & $\begin{array}{r}\text { Per lineal ft. } \\
\ldots \ldots \ldots \$ 285\end{array}$ \\
\hline $4 \mathrm{ft} .$, I I in. high......... I 65 & $8 \mathrm{ft}$. high.... & $\cdots \ldots 245$ \\
\hline $3 \mathrm{ft} .$, Io in. high......... I 45 & $\begin{array}{c}\text { I I/2 ft. high.... } \\
3 \mathrm{ft} \text {. wide } \\
\text { Walk-Gates }\end{array}$ & $\begin{array}{l}\text {....... fid. wide } \\
\text { Io } \\
\text { Double-Driveway }\end{array}$ \\
\hline 61 & $\ldots \$ 2 I 50$ & $\$ 45$ oo \\
\hline I I $\mathrm{i}$ & 1950 & 4250 \\
\hline ft., Io in. & I 850 & 40 oo \\
\hline
\end{tabular}

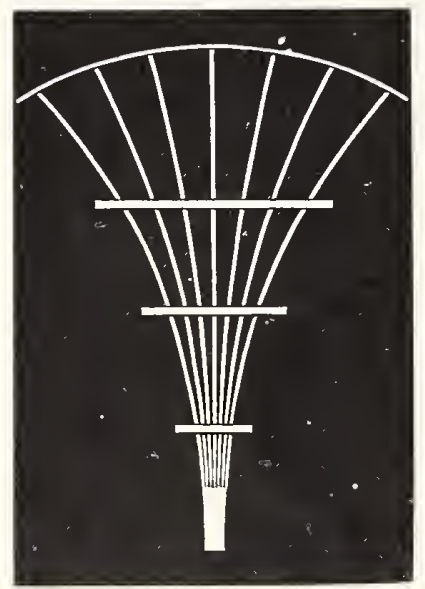

Lawn Fan, Seven Leaf

In two sizes. Wood is painted white. 70 in. high, 45 -in. spread, $\$ 2 ; 94$ in. high, 60-in. spread, $\$ 2.50$.

\section{Rose-Bush Fan,} Five Leaf

Wood is painted white. Height 58 in., spread 30 in., $\$ 1.75$.

\section{Gazing-Globe with Pedestal}

The Globe is I2 inches in diameter, and the Pedestal is 24 inches high. These are sold separately. Globe, \$Io. Pedestal, $\$ 7 \cdot 5^{\circ}$.

\section{Bird-Bath with Pedestal}

The Bowl is 20 inches in diameter and the Pedestal is 24 inches high. \$I5.

\section{Brass Sun-Dial}

$73 / 4$-inch diameter. $\$ 7.50$ Pedestal suitable for above, made of hard burnt clay and very decorative. $\$ 7.50$.

\section{Cleft Chestnut Fencing}

Cleft Chestnut Fencing is made of roughly split saplings, but spaced about $I$ inch apart and bound with galvanized wire. Makes a splendid background for plants and vines.

Furnished in rolls I6 feet long. Comes in three heights. (Gates to match can be furnished at additional cost.)

$6 \mathrm{ft}$, 6 in. high.

Per lineal $\mathrm{ft}$.

$4 \mathrm{ft}$. , I I in. high

$3 \mathrm{ft} .$, Io in. high.

$6 \mathrm{ft.}, 6 \mathrm{in.} \mathrm{high}$

$4 \mathrm{ft.}$. I I in. high.

$3 \mathrm{ft}$., ro in. high..................

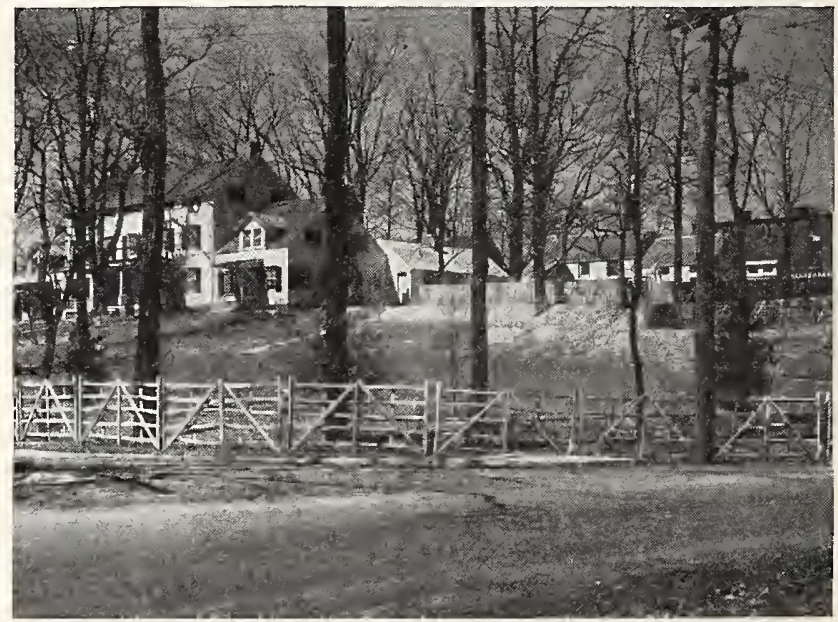

\section{English Type Hurdle Fencing}

Made of split chestnut lumber. It is 8 feet, 3 inches long. The posts are 6 feet high and extend 18 inches into the ground. When set, the fence is 4 feet high.

The posts of one hurdle lock with those of adjoining hurdles by means of wooden pins which are supplied with them. Strong enough tor any purpose, yet readily portable.

The hurdles are made in three styles, 4,5 , and 6 bars, all of which are the same length and height, the difference being in the spacing between the bars. (Gates to match may be had at additional cost.)

Each 4 ft. wide Ioft.wide 4-bar Hurdles.... \$2 $75 \mid$ 4-bar Hurdle Gates.... \$5 oo $\$ 8$ oo

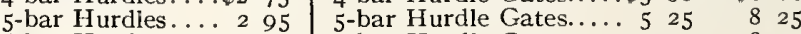
6-bar Hurdles.... 3 I5 6 6-bar Hurdle Gates..... $5550 \quad 850$ 


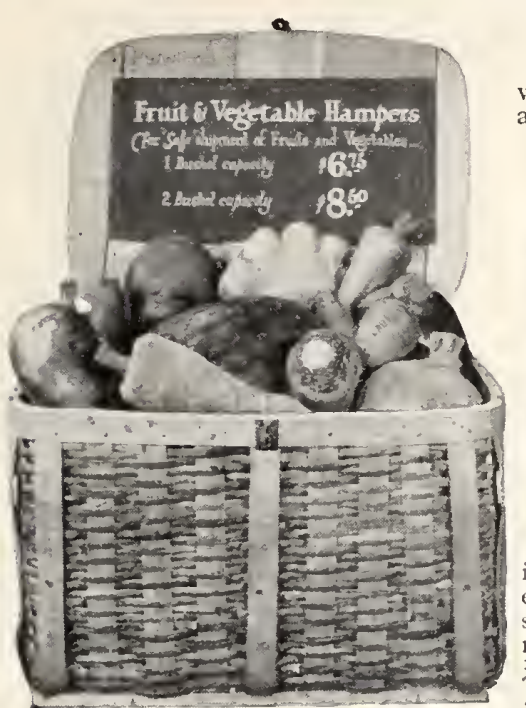

\section{General-Purpose Basket}

Handy for carrying corn, coal, wood, vegetables, leaves and rubbish, etc. Best oak splint. Made strong.

I-bus. size...... \$I 75 I $1 / 2$-bus. size........ 225 2-bus. size....... 275 3-bus. size...... 350
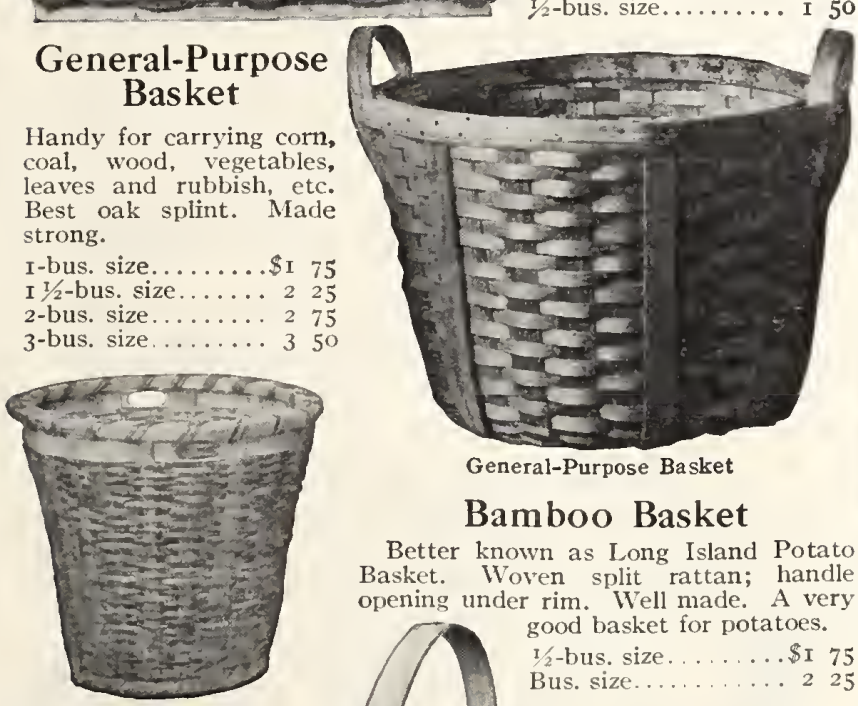

Bamboo Basket

Better known as Long Island Potato Basket. Woven split rattan; handle opening under rim. Well made. A very

Picking Basket

A handy basket for picking fruit and gathering eggs, etc. Best oak splint, stiff bail, light and well made.

I/4-bus. size.......\$I oo $1 / 2$-bus. size......... I 50

good basket for potatoes.

Bamboo Basket

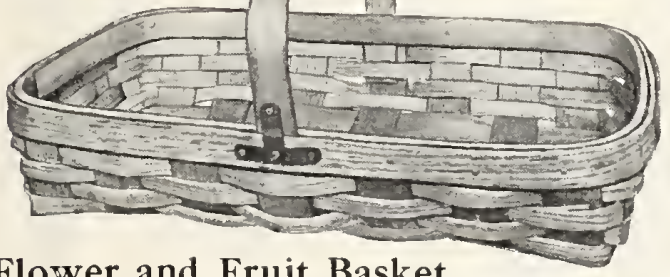

Flower and Fruit Basket

This basket is made light and especially for gathering cut-flowers, berries, grapes, asparagus, and small vegetables.

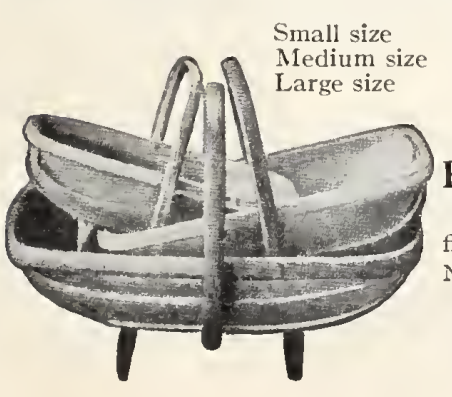

Length Width Depth

I 8 in. Io in. $3 \frac{1}{2}$ in

20 in. 12 in. $3 / 2$ in

22 in. 14 in.

English Garden Baskets

Durable, light and handy for cutflowers or vegetables.

No. Length Width Each Doz.

5. $161 / 2 \times 9$ in ....\$2 oo $\$ 22$ oo

6. $181 / 2 \times 10$ in... 22525 oo

7. 2 I XII in...... 275 30

\section{Fruit and Vegetable Hamper}

.

Extra-strong and durable Baskets for gathering heavy fruits and regetables. Made with bamboo and strapped with galvanized iron. No. 1. $20^{3} / 2 \times 13 \frac{\pi}{2} \times 7$ in. deep $\begin{array}{lll}\text { No. 2. } 23 & \times 141 / 2 \times 8 \text { in. deep. } \\ \text { No. 3. } 24 & \times 151 / 2 \times 9 \text { in. deep. }\end{array}$ $\begin{array}{rr}\$ 2 & 25 \\ 2 & 50\end{array}$

\section{Bird Netting}

To protect strawberries, small fruits, and vegetables from birds. $\mathrm{I}$-in. mesh only, in $20-$ and $30-\mathrm{ft}$. widths. $\$ 2$ per Ioo sq. ft.

\section{Sponge Rubber Kneeling Mats}

Made of high-grade sponge rubber. Protects the knees from becoming sore while kneeling on damp ground. Absolutely sanitary; can be washed without injuring the mat. Makes kneeling a pleasure. \$I each.

\section{Best Quality Gardeners' Gloves}

Good gloves for pruning and farm-xork. Made substantially of horse-hide; heat- and water-proof; with gauntlets. Per pair No. 5990. Ladies'. Sizes $7,7 \frac{1}{2}$, and 8 .

No. 259. Men's. Sizes $81 / 2,9$, and IO..

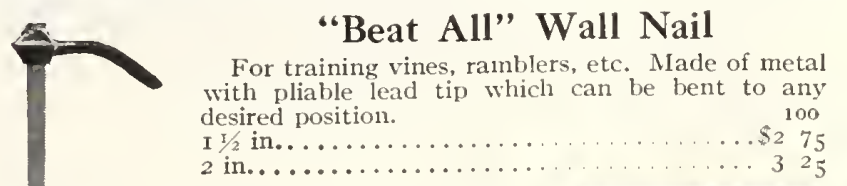

Galvanized Heavy Wire Hanging-Baskets

For decorating the porch, piazza, or sunparlor.

8 -in.

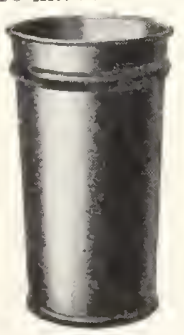

Galvanized Iron Flower Vases

PAINTED GREEN No. Height diam. Each Doz. I. Io in. $43 / 4$ in. . \$o $75 \$ 750$ 2. 12 in. $61 / 2$ in. 909900 Galvanized Iron 4 . I 5 in. $61 / 2$ in. I I 25 I 250 Flower Vase 5. I 7 in. $6 \frac{1}{2}$ in. I 50 I 500

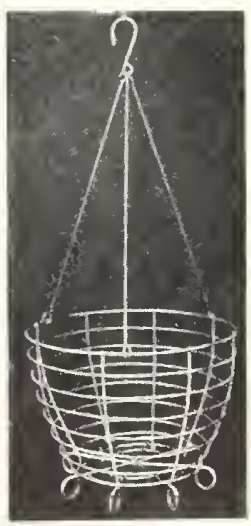

Galvanized Wire Hanging-Basket 


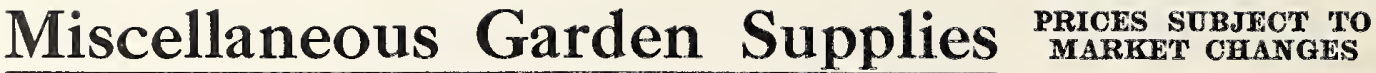

\section{Hotbed Sash and Frames}

PACKING charged extra on crates containing glazed Sash, $\$ 1.25$ per crate. Crates hold up to 4 Sash.

Stumpp \& Walter Co.'s Standard Frames are made of selected Gulf Cypress, free from knots and sap. Frames are dressed and finished with two coats of gray paint. The four corners are securely held with angle irons and bolts. Easily taken apart when necessary

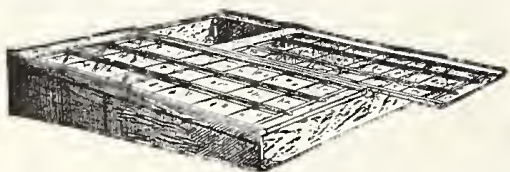
to store or s h i p them. $\mathrm{T} h \mathrm{e}$ rails between $t \mathrm{~h} e$ $\mathrm{s}$ a $\mathrm{sh}$ a $\mathrm{r}$ e rabbeted and grooved for drip, and dovetailed into the sides. The back depth of frame is I6 inches, front depth 8 inches. This provides the necessary pitch to carry away rain and snow. Frames are made for $2,3,4$, and 5 sash.

No. 2 Frame. With two $3 \times 6 \mathrm{ft}$. sash $\$ 32$, without sash $\$ 16$.

No. 3 Frame. With three $3 \times 6 \mathrm{ft}$. sash $\$ 45$, without sash $\$ 2$ I.

No. 4 Frame. With four $3 \times 6$ ft. sash $\$ 58$, without sash $\$ 26$.

No. 5 Frame. With five $3 \times 6 \mathrm{ft}$. sash $\$ 72.50$, without sash $\$ 32.50$. Half-width Frame. Made of the same lumber and painted exactly as our full size frames described above. $3 \times 3 \mathrm{ft}$. Frame, complete with glazed sash, \$I ; without sash, $\$ 8.50$, packing extra.

Single Light Sash. Stumpp \& Walter Co.'s Single Light are standard size, $3 \times 6$ feet. Made of selected cypress, $I \frac{7}{16}$ inch thick, free from knots and sap. Mortised and leaded joints. Three rows of IO $\mathrm{x}$ I2 inch double-thick glass, iron cross-bar across the center. Made extra strong and durable. Finished with two coats best white lead. \$8 each, \$0o per doz.

Double Light Sash. Stumpp \& Walter Co.'s Double Light or Double-Glazed Sash are made with two layers of glass, providing an air-chamber or insulator, which keeps the warmth in and the frost out. With the Double Light Sash it is not necessary to use mats or covering in severe cold weather. In locations where snow is frequent or stays long it does not interfere with the Double Light Sash, providing the snow is cleaned off. The plants receive the benefit of the sunlight and grow uninterruptedly. The sash are standard size, $3 \times 6$ feet, I 7/8 inches thick. Made of clean Guif Cypress, free from knots and sap. Mortised and leaded joints. Three rows of Io $\mathrm{x}$ I 2 inch double-thick glass. Strengthened with a $3 / 4$-inch iron bar across the center and finished with two coats of best white lead. \$I4.50 each, \$I65 per doz.

\section{Hotbed Mats}

For protecting coldframes and hotbeds. Warmly lined with waste wool and cotton, hich are quilted in to hold position. No. I. $40 \times 76$ i $\mathrm{n}$. Burlap on both sides. $\$ 2.75$ each, \$30 per doz. Burlap on both sides. $\$ 3.75$ each, $\$ 42$ per doz $\mathrm{S}$ a w c o Waterproo Burlap Mats. Rain sleet, and snow will not penetrate. Proof against frost; repellent to rats and mice. $40 \times 78$ in. $78 \times 80$ in...

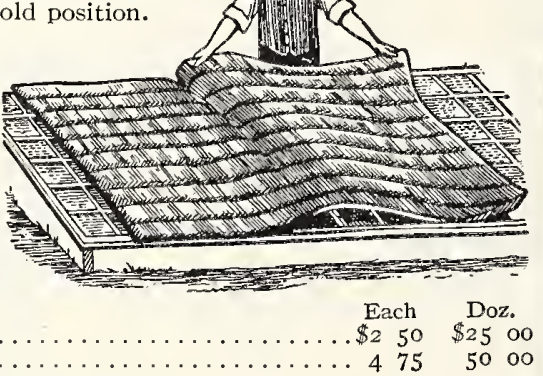

\section{Glazing Materials}

Permanite is a glazing compound composed of asbestos fiber and special long-life, weather-resisting, non-drying oils, which always keep it in an elastic condition and never allow it to harden. Little needs to be said about the addition of asbestos as the advantage of using this material-its indestructibility and ability to resist heat and cold are too well known. I gal. $\$ 2.50,5$ gals. $\$ 2.40$ per gal. I 5 gals. $\$ 2.25$ per gal., 35 gals. $\$ 2$. Io per gal., 60 gals. $\$ 2$ per gal.

Permanite Gun. Makes application of Permanite easy. $\$ 7.50$ each

Mastica. A very excellent material for cementing cracks or seams in roof joints and frames of greenhouses, sash, etc. Easy to apply and not the least bit affected by climatic conditions. Gal. \$2.50, 5 gals. $\$$ I 2 .

Mastica Gun. For applying above. Very practical and easy to operate. \$3 each.

Putty Bulb, Scollay. A useful tool similar to the well-known Scollay Sprinkler, with a tube instead of spray for applying liquid putty in glazing greenhouses. $\$ \mathbf{I} .50$.

Glazing Points, Van Reyper's. No rights or lefts. No. 2, large, for single- and double-thick glass for greenhouses and skylights. Box of I,00o, $75 \mathrm{cts}$; 5,000 for $\$ 3.25$. Pliers for same, $75 \mathrm{cts}$.

Red Devil Glass Cutter. $25 \mathrm{cts}$., and $50 \mathrm{cts}$

Putty Knife. No. Ioo. A very good tool. $50 \mathrm{cts}$. each.

\section{Simplex Waterproof Tie-on Plant Labels}

The writing is protected by the transparent cover and will last indefinitely if done with lead pencil.

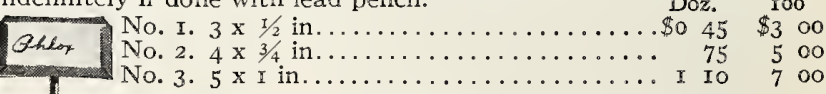

\section{S. \& W. Co.'s Permanent Label Holder}

This Label Holder is furnished with an index card covered with mica, finished in iron, galvanized and japanned green, making it absolutely rustproof. Stake 24 inches high. No. Io card, $23 / 4 \times$ I I $1 / 2$ inches, 25 cts. each; No. II card, $3 \times 2$ inches, 30 cts. each.

\section{Pot or Garden Labels}

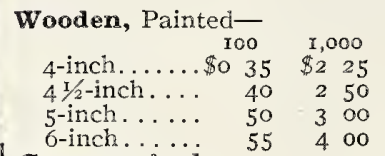

8 -inch....... \$I $25 \$ \$ 9^{10000}$ Io-inch....... I 40 II 00 I 2 -inch....... I 60 I3 25

Holder Copper-wired-

Holder $31 / 2$-inch.................. 50 300

Label Pencils. Insure permanent writing on wooden labels. Io cts. each, \$I per doz.

X-L-All Pencil. 25 cts. each, $\$ 2.50$ per doz.

Zine Garden. These are unsurpassed, being neat and durable. For use with our Indelible Ink which makes a jet-black mark.

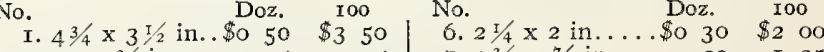
$2.4 \times 23 / 4$ in... $35 \quad 225 \quad 7.23 / 4 \times 7 / 8$ in ... 30 20 I 25

$3.4 \times 3$ in..... $30 \quad 200 \quad$ I $3.23 / 4 \times$ I $1 / 4$ in... $20 \quad$ I 25

$4.5 \times$ I in..... $30 \quad 200 \quad$ I4. II $1 / 2 \times I^{1} / 4$ in... 20 I 25

5. $31 / 2 \times 21 / 2$ in.. $30 \quad 2$ oo $15.41 / 4 \times 3 / 4$ in... 25 I 50 Indelible Ink. For use on these markers. Bottle, $50 \mathrm{cts}$.

\section{S. \& W. Co.'s Peerless Plant Marker}

Made of non-rusting copper-bearing galvanized metal. No acids or special ink are necessary-an ordinary lead pencil may be used for writing. Names and notations on the Peerless cannot be destroyed by rain, snow, ice, frost, birds, or animals. Made in two sizes:

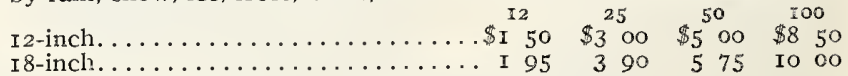

\section{Magno Garden Marker}

The glass top enlarges the lettering on the name-card more than twice its actual size, making it easy to read at a distance. Rustproof, water-proof, sturdy, practical, and durabie, $121 / 2$ inches long. $30 \mathrm{cts}$. each, $\$ 3$ per doz., \$22.50 per Ioo.
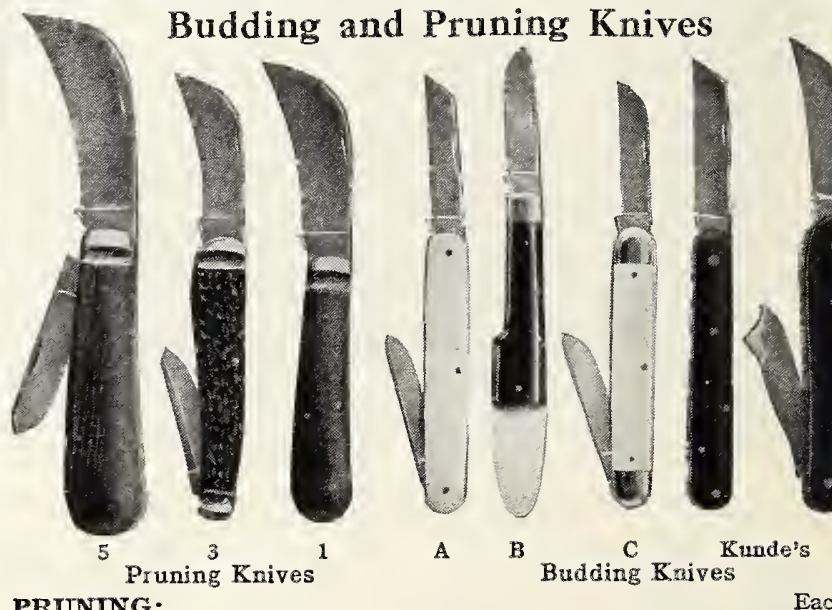

PRUNING:

No. I. Strong pruning blade; cocoa handle............\$I 50

No. 3. Pruning and budding blades; patent stag handle.... 275

No. 5. Two high-quality pruning blades with cocoa handle.. 325 BUDDING:

No. A. Two blades with ivory handle.............. 350

No. B. Budding blade with ivory budder, black rubber handle 200

No. C. Two strong budding blades with bone handle...... 250

Kunde One-blade Budder. Wooden handle..........2 2

Kunde Budder and Prunex, 2 blades, polished wooden

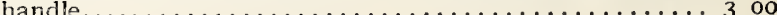




\section{Painted Plant Stakes}

Plant Stakes, Green-

I $1 / 2$ feet.

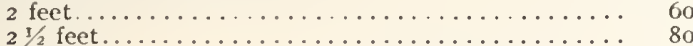

3 feet.....

$31 / 2$ feet.

4 feet.

5 feet. .

Dahlia Poles, Tapering-

3 feet...................... I 80

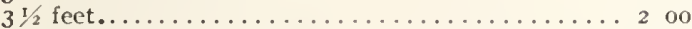

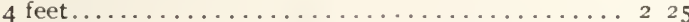

5 feet.............................. 75

6 feet...

Special Dahlia Poles. Solid ash; $3 / 4$ inch thick; non-

tapering; painted greell.

5 feet................................ 200

6 feet................................ 75

\section{Canes for Supporting Plants}

Chinese Tonkin Cane. These are Chinese canes, very strong and heavy. 2,3 and 4 -ft., $1 / 4$ to $1 / 2$-in. diam.; 5 and 6 -ft., $3 / 4$-in. diameter. Doz, I00 I,000 2 feet..................... 3 feet........................ 35 2 2 oo 17 oo

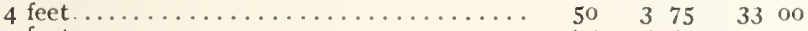
5 feet.................... $75 \quad 5 \quad 50 \quad 45$ oo 6 feet....................... I oo $650 \quad 5500$

Japanese Bamboo Canes. Dyed green.

2 feet....................... $20 \quad 85 \quad 680$

3 feet..............

4 feet...................... 40 I 50 I2 00

5 feet...................... 45 I 80 I4 50

Japanese Cane. Natural. For staking plants and trees.

6 feet....................... $35 \quad 2$ oo I 750

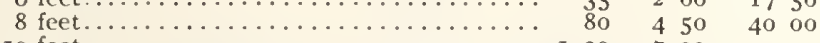

Io feet.................. I $20 \quad 7$ oo

20 feet..................... 5 oo 3500

Extra Heavy Bamboo Poles. Natural. I-in. diameter.

6 fect....................... I 75 I0 00

7 feet................

\section{Bean Poles}

Excellent for staking pole lima beans. $35 \mathrm{cts}$. each, $\$ 3.50$ per doz.

\section{Wire Stakes, Carnation Supports, Etc.}

Galvanized Wire-

feet.................................... 40 \$2 50 \$18 75

5 feet.................. $60 \begin{array}{llll}3 & 30 & 24 & 75 \\ 4 & 00 & 30 & 00\end{array}$

Eureka Stake Fastener. For fastening rose and chrysanthemum wire stakes. \$1.75 for 500, \$3 per I,000.

Carnation Supports. Model Extension, 2-ring, \$1.Io per doz., $\$ 7.50$ per I00; 3 -ring, \$1.35 per doz., \$8.50 per Ioo.

Baur's Carnation Clip. Plier and I,ooo Clips, $\$ 4.50$. Plier alone, $\$ 3.50$. Extra Clips, \$I per 1,ooo.

Carnation Bands, Rubber. Prevent splitting. I $5 \mathrm{cts}$. per oz.

\section{S. \& W. Co.'s Spiral Plant Stake}

A new and practical device for supporting plants and flowers. Made of galvanized wire with a coating of handsome green enamel, it is inconspicuous and practically invisible. A simple twist of the Stake curls the spiral end about the stalk of the plant and forms a circular lock that is non-binding on the plant. No tying required.

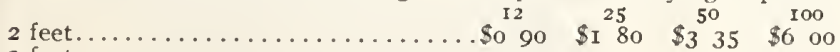
3 feet..................... I oo 2 oo $\begin{array}{r}3 \\ 3\end{array}$ 4 feet.................... I 25 2 $50 \quad 4 \quad 759$ o

\section{S. \& W. Co.'s Sweet Pea and Vine Trellis}

Gives the advantage of a rugged metal frame with a rope center for the clinging vine that will not heat nor injure the more tender plants. It is 5 by 5 feet over all and stands about 4 feet above the ground when placed. Several can be used, end to end, for long rows. $\$ 2.25$ cach.

\section{Twines}

S. \& W. Co.'s Smilax Thread. This Thread is very strong, green in color and warranted not to fade. Best Thread on the market. 35 cts. per spool, $\$ 2.25$ per 8 spools, $\$ 6$ per box of 24 spools.

Silkaline. Very largely used for tying. Three sizes, F, fine; FF, medium; and FFF, coarse. 40c. per spool, $\$ 3$ per box of 8 spools.

Bouquet Twine. White. 3-0z. balls $20 \mathrm{cts}$. each, \$I per 1b., $\$ 4.50$ for 5 lbs.

Sea Island Cotton. Green. Ball $20 \mathrm{cts.}$, box of 8 balls $\$ 1.50$.

Twine, Soft. For tying vines, etc.; very strong, 2 and $3-$ ply. Ball 25 cts., 3 balls 60 cts., 12 balls $\$ 2.25$.

Tarred Yarn. Excellent, low-priced material for raspberries, shrubs, etc. Ball (I lb.) 5o cts., 5 balls $\$ 2.25$.

Raffia, Natural. For tying plants. 1/21b. $30 \mathrm{cts}$., 1b. $50 \mathrm{cts}$., 5 lbs. $\$ 2$. Colored. All standard shades. 1/2lb. 50 cts., lb. 90 cts.

Wire, Bouquet, Florists' Annealed. Nos, 22 and 24. In coils of I2 lbs., \$4 per coil.

Florists' Bright. Cut in lengths. In boxes of 12 lbs. (one stone).

\section{Watering Pots}

$H$ e a v y galvanized i r o $\mathrm{n}$, reinforced; made well and substantially. Each pot has a long spout, with one fine and one coarse rose.

Round Pattern.

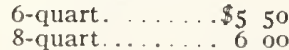

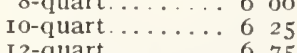

French Oval Pattern

6-quart.......\$6 25

8 -quart.......6 650

ro-quart....... 700

I 2-quart........ 775

Haw's Pattern.

2-quart........\$5 oo 3-quart.......6 600 4-quart.......6 650 6-quart.........7 7 oo

8 -quart....... 8 oo

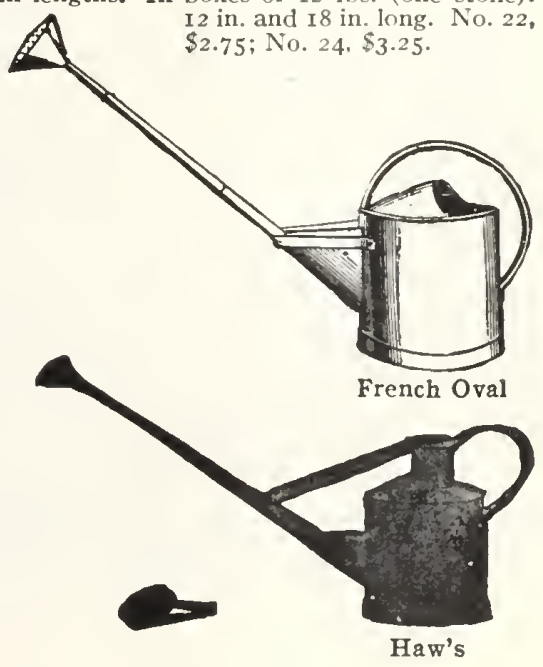

\section{Rubber Plant Sprays}

Sawco. Straight neck, capacity 8 ffuid ozs............ \$o 90

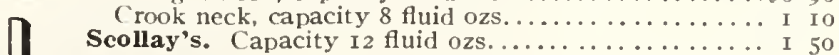

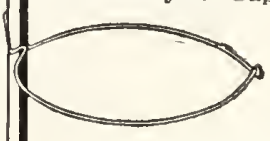

\section{Adjusto Plant Supports}

Sturdy, hardwood stakes, 2/8-inch square, 3. 4, 5. or 6 feet long with a strong wire support instantly adjustable to any height. Holds the plant firnly together, vet lonse enough to adinit air and sunlight in order to promote healthy growth.

$$
\begin{aligned}
& 3 \text { feet } \\
& 4 \text { feet. } \\
& 5 \text { feet. } \\
& 6 \text { feet } \\
& \text { I } I / 2 \text { feet } x \text {; inch square. } \\
& 2 \text { feet } x \frac{3}{16}-\text { inch square }
\end{aligned}
$$

\section{Perfection Tomato Support}

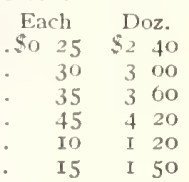

Is 36 inches high, I2 inches wide, made of wood, and will not burn the vines in hot weather or cut them off when wet and swayed by the wind. Can be unfolded without damage and stored away for following season's use. $40 \mathrm{cts}$. each, $\$ 4$ per doz.

Tomato Supports, Wire. 32 inches high. I4 inches in diameter, made of heavy steel wire. 50 cts. each, $\$ 4.75$ per doz., $\$ 32$ per Ioo.

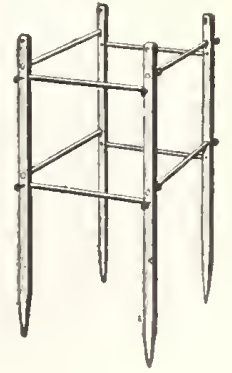




\section{The Stumpp \& Walter Co. Ball-Bearing Lawn Mower}

ALWAYS READY, EASY-RUNNING, NOISELESS, SELF-SHARPENING; PERFECT ADJUSTMENT. WILL CUT GRASS 6 INCHES HIGH

The Stumpp \& Walter Co. Ball-Bearing Lawn Mower is universally a family Mower. Most anybody-man, woman or child-can use it with little exertion. It is a high-grade standard machine, adopting only the best features in its construction. The cutting parts are made of

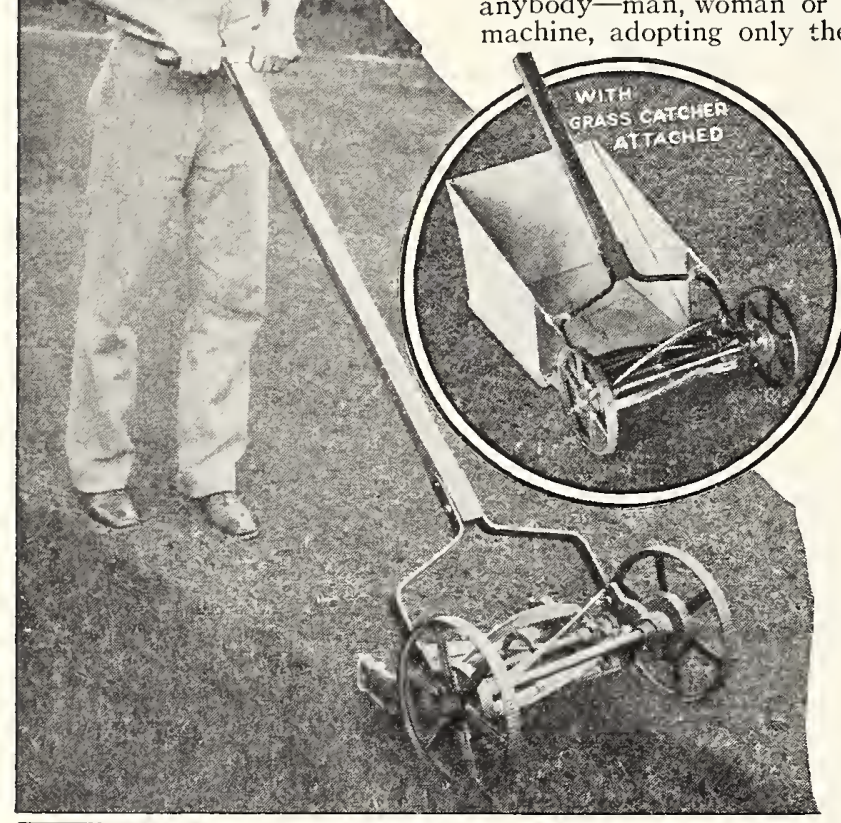
oil-hardened crucible tool-steel. The knives and blade will hold a durable edge and will not dull as the softer cutting parts of other Mowers do. The lawn is shaved smooth and even and without corrugations. The simple adjustment sets the machine to shave the lawn to $1 / 2$ inch or up to $1 / 2$ inches as may be desired. See the illustration which is a photograph of actual results. The expense of mowing a lawn is reduced to a minimum with the S. \& W. Co. Lawn Mower. The durability of this Mower is unquestionable. It does not have to go to the repair shop each season as do frequently the lower-priced Lawn Mowers.

The construction of this Lawn Mower has overcome the bobbing up and down and gouging that is common to some hand Mowers. The axle revolves in extra-large balls placed in hardened tool-steel cones and cups, and is driven with three gears on each side, by two Io-inch traction wheels. These wheels are made durable and are not easily broken.

This Lawn Mower is made to give good and long service, and with ordinary good care will last years. We take the liberty to recommend the S. \& W. Co. Ball-Bearing Lawn Mower to be the best all-round Lawn Mower of its type manufactured. We guarantee it to give entire satisfaction. The S. \& W. Co. Lawn Mower is made in four sizes.

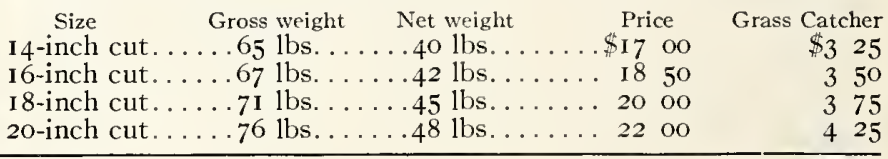

\section{Super Great American Lawn Mower}

The Super Great American, as a machine for the home lawn, is unsurpassed in quality, durability, and the perfection of its working parts. It is a machine of the very highest class in every respect.

The Super Great American is a double-gear machine with five knives made of crucible toolsteel of the very highest quality, oil-tempered, and water-hardened. Its bottom knife is of the same quality and self-sharpening. The case-hardened tool-steel cones and cups in which extralarge balls revolve in conjunction with the very high wheels (Io inches in diameter), make it one of the easiest running Lawn Mowers on the marlet.

\begin{tabular}{|c|c|c|c|}
\hline Gross weight & Net weight & Price & $\begin{array}{c}\text { Grass Catcher } \\
\$ 350\end{array}$ \\
\hline .65 lbs. & 42 lbs. & $\$ 1950$ & $\$ 350$ \\
\hline$\ldots \ldots \ldots \ldots \ldots \ldots \ldots$ 6 lbs. & 44 lbs. & 2250 & \\
\hline$\ldots \ldots \ldots \ldots \ldots \ldots \ldots 7$ I lbs. & 48 lbs. & 2500 & \\
\hline
\end{tabular}

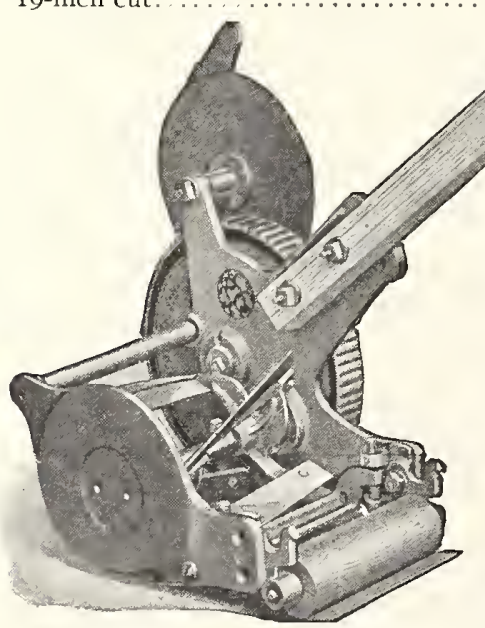

Lawn Trimmer and Edger

\section{Townsend Flyer Mower}

The best low-priced Mower made with ball-bearings. Four revolving blades, flexible bottom knife, self-sharpening. Made of best materials. A very easy-running and light Mower for ladies and children to o perate.

Size

I2-inch cut I 4 -inch cut I6-inch cut I 8 -inch cut.

\section{Lawn Trimmer and Edger}

With this combination machine, equipped with a steel disc and a small plow, you can trim the overhanging grass along the edges of paths and flower-beds and do any similar work that has heretofore required a half-moon hoe, a grass-hook, or hand shears. Price, $\$$ Io.5\%.

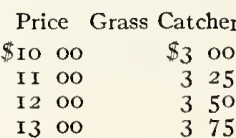

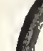




\section{Mowers for Golf Courses and Tennis Courts}
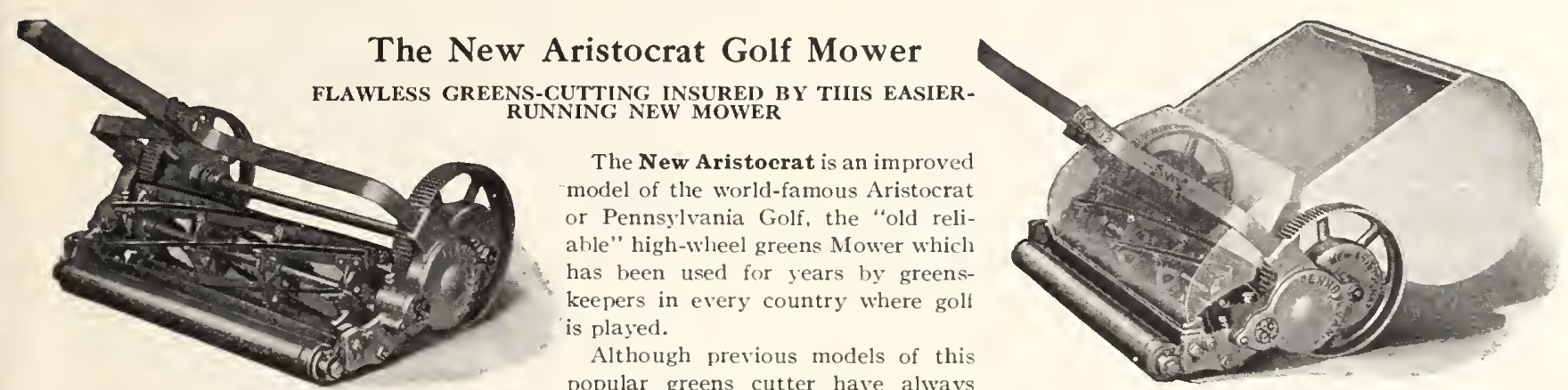

been noted for their easy-pushing, close-cutting qualities, the refinements embodied in the New Aristocrat make it still lighter-running, while its higher gearing absolutely insures a close-cut and ridgeless wake. It has proved particularly efficient in close-cropping the modern creeping bent greens.

The New Aristocrat has a 7 -blade, high-speed cylinder, 5 1/2 inches in diameter, and a train of three cut gears on eacl side, with six pawls to prevent lost motion. The cylinder is equipped with the new Braun Self-aligning Ball Rearings, with positive lock pad and screw, easily adjusted for wear. The wheels and intermediate gears have roller bearings. Alemite lubrication throughout.

Made in one size only (I9-inch). Net weight, only 58 lbs.; slipping weiglut, 85 lbs. Price, without Grass-Box, $\$ 40 ;$ Grass-Box, $\$ 8$ extra.

\section{Pennsylvania High-Speed Super-Mower}

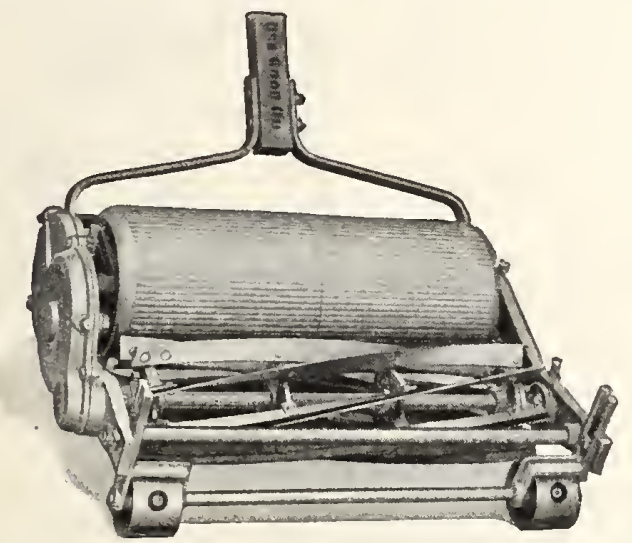

The Pennsylvania High-Speed Super-Mower is a high-geared, 7-blade machine of the roller-drive type, the rollers being made of aluminum. Every moving part runs either on roller-or ball-bearings. The train of cut gears is enclosed in a grease-tight case, protected from rain, dust, and grass-clippings, so that they revolve in a bath of oil. Alemite lubrication throughout. A light wheel carriage facilitates transportation of the Mower from green to green.

The Pennsylvania High-Speed Super-Mower leaves a wonderful "finish" to the turf, without the slightest trace of ridging.

Obtainable in only I8-inch size. \$50 each; Grass-Box, \$8; and light Wheel Carriage, $\$ 5$ additional. Complete outfit $\$ 63$, f.o.b. New York.

\section{Pennsylvania Undercut Ball-Bearing Trimmer}

The unique construction of this Trimmer permits cutting, not only close up to a wall, fence, tree, etc., but, it will get the grass under fences and other places hitherto out of reach of anything but hand shears. \$1 2 each.

\section{Leather Horse Boots (QUALITY KIND)}

Easily attached to the horse's feet; prevent marring the lawns. Frequently after rains, or in the spring, the lawns are soft and easily eut up. Use a good leather boot and save the lawn. Quality Kind are well made. Double-thick soles and uppers reenforced; heary parts put together with copper rivets. Per set of four: Small size, \$20; medium size, \$21; large size, \$22; extra-large size, \$23.

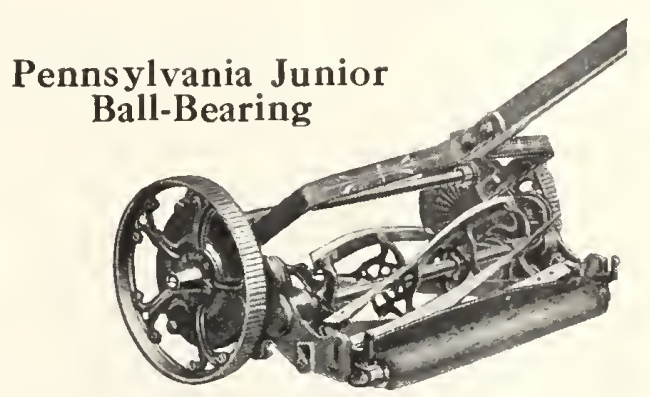

The perfection of Lawn Mowers. The Pennsylvania Junior has all the good features incorporated in a perfect Lawn Mower. The five revolving blades are driven by a triple set of gears and a ro-inch traction wheel from each side. The revolving blades and the bottom knife are the best crucible tool-steel, oil-tempered and water-hardened. The Pennsylvania Junior is particularly adapted for the cutting of tees and approaches.

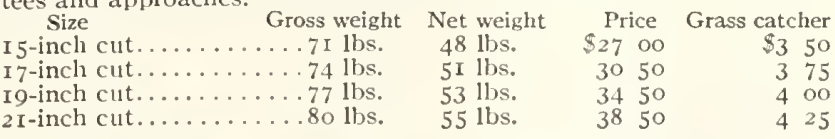

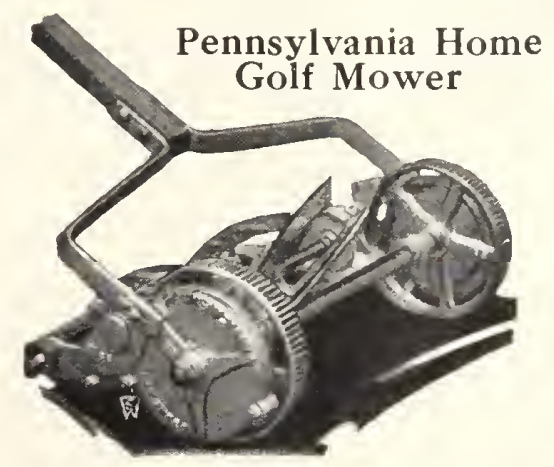

Jow wheel, plain bearings, for home greens

This Mower is especially adapted for small golf links, tennis courts, bowling greens, and ericket creases. Can be adjusted to cut $\frac{3}{16}$ of an inch, practically shaving the lawn. Size, I6-inch; gross weight, 67 pounds; net weight, 37 pounds; price, $\$ 25$; grass box, \$8. 


\section{Four-Acre Heavy Duty Power Lawn Mower}

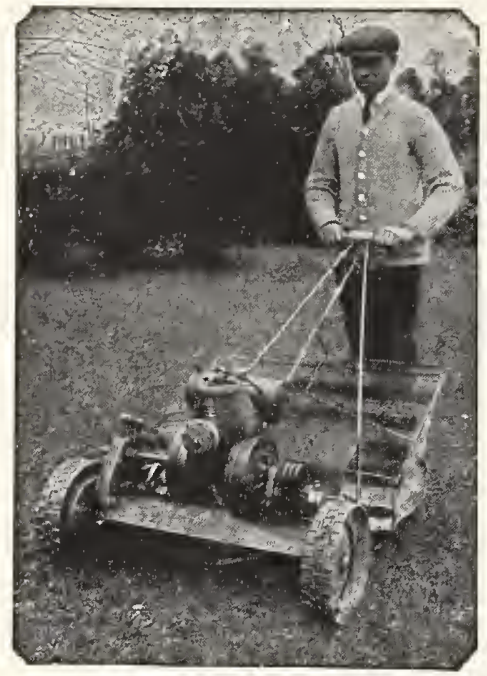

Four-Acre Heavy Duty Lawn Mower, 24-Inch Cut

\section{The Pinnacle of Perfection in Heavy Duty Power Mowers}

THE FOUR-ACRE HEAVY DUTY MOWER is a powerful grass-cutter, sturdy as a tractorthe handiest and most economical Power Mower on the market. Performance is the standard by which Power Mowers are judged, and in this respect the Four-Acre Heavy Duty is in a class of its own.

THE MOTOR is specially designed, air-cooled, has forced-draft and throttle control; starts easily, is powerful and reliable.

INDEPENDENT CONTROL of power on cutting unit and traction allows it to travel over stony roadways, up and down curbings, etc., without revolving cutting unit. In case any sticks or stones become caught in the cutter blades, the reel clutch will slip, leaving knives uninjured.

Price \$295, f.o.b. New York. Grass Box, $\$ 10$ extra

Four-Acre Heavy Duty Power Mower with Sickle-Bar Attachment. This attachment gets all weeds, dandelions, plantain, buckhorn and other well-known destroyers of lawn beauty and enables the revolving cutter of the mower to cut or mow the obnoxious weeds level with the grass. Price $\$ 370$. Grass Box, $\$ 10$ extra.

\section{Estate Roller-Driven Power Mower}

It is equipped with the same motor and controls as the Four-Acre Heavy Duty. Designed for large fine lawns that are mowed close and often. Very easy to handle and can trim close to flower-beds and obstructions. Built in two sizes, 24-in. cut and 30-in. cut. 24-in. cut, $\$ 310$; Grass Box $\$ 10$ extra. 30-in. cut, $\$ 350$; Grass Box $\$ 15$ extra. Riding Cart for use with Four-Acre or Estate Mower \$45.

\section{Two-Acre Junior Power Lawn Mower 19-INCH CUT}

Designed especially for moderate-sized lawns and lawns broken up by numerous obstructions. Cuts 2 acres a day on less than I gallon of gasoline at a speed which may be varied from 2 to $2 \mathrm{I} / 2$ miles per hour. Has a four-cycle $3 / 4 \mathrm{~h}$. p. motor. The cutter has five blades, which may be adjusted to cut the grass from $1 / 2$ to $1 \frac{1}{2}$ inches. This is a durable and efficient machine, fully guaranteed. Mower equipped with independent controls at the handle for power on cutting unit and traction wheêls. \$2 Io, f.o.b. New York. Grass Box, \$7 extra.

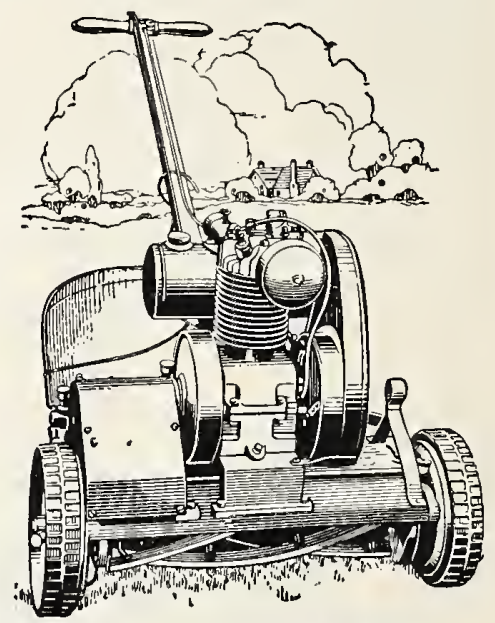

Two-Acre Junior Lawn Mower 19-Inch Cut

\section{Supplies for the Golf Course}

For complete list of Golf Equipment and Lawn Tennis Requisites, see our GOLF TURF publication, a copy of which is free for the asking

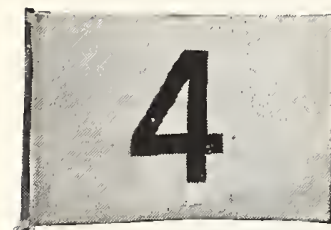

Numbered Flag
Sawco Hole Cutter. With notched teeth. The easiest-working, cleanest Cutter made. 4 $1 / 4$-in. diameter for regulation hole-rim. \$12.50 each.

S. \& W. Co.'s Aluminum Mudless Hole-Rim. Regulation size $-4 \frac{1}{4}$ inches in diameter. Made to accommodate flag-poles fitted with either spike or ferrule. Due to its peculiar construction, the accumulation of mud or water in the rim is prevented. Especially strong, non-corrosive and practically everlasting. \$2 each, \$I 7.50 for set of 9 .

Sawco Flag Poles. Strongly made of straight-grain ash. Length 8 feet, the lower end strongly shod with Sawco Special Brass Ferrule, which insures the pole standing perpendicular in the Sawco Hole Cup. Painted black, white and orange, heavily varnished with marine spar. Very effective. $\$ \mathbf{I} .5^{\circ}$ each.

Numbered Flags for Putting-Greens. Red with White numeral; White with Red numeral; and Orange with Black numeral. These are made of Grade A All-Wool Marine Bunting; dyed with steadfast colors, guaranteed not to fade or run when wet. Flags are oblong in shape, 12 by 18 inches. 75 cts. each, $\$ 6.60$ for set of 9 .
Plain Flags for Direction (Without numbers). Can be had in two shapes, oblong or triangular, size $12 \times 18$ inches, in single color or combination of two colors sewed horizontally or diagonally. Red, White, Blue, Green, Orange, Black, and Gold. 6 cts. each, $\$ 5.25$ for set of 9 .

Sawco Weatherproof Tee Balls. With burned-in arrow, showing direction of play. Two required for every tee. $\$ I .50$ per pair, $\$ 12.5^{\circ}$ for set of 9 pairs.

Teeing Plates. Drop forged metal plates to lie flush with the ground. Two required for every tee. \$I per pair, $\$ 8.50$ for set of 9 pairs.

S. \& W. Co.'s Marker and Ball Lifter. For the miniature putting course and for lawn golf. White enameled wooden ball with black numerals, 1 to 9 only. Length over all, 36 inches. Has metal disc which enables the ball to be taken out of the cup without trouble. $\$ 17.50$ for set of 9 .

Heart-Shaped Metal Marking Discs. For miniature courses. Painted red with numerals in white. I4 inches long. $\$ 1.5^{\circ}$ each, $\$ 12.5^{\circ}$ for set of 9 .

Miniature Golf-Set. For use on the home lawn. The game is interesting and is unsurpassed for practicing approach shots and putting. Set consists of 9 small (not regulation size) Hole-Rims, 9 Miniature Flags and 9 Teeing Plates. Price $\$ 12.50$. 


\section{Lawn Cleaners, Golf Sweepers, and Lawn Rollers}

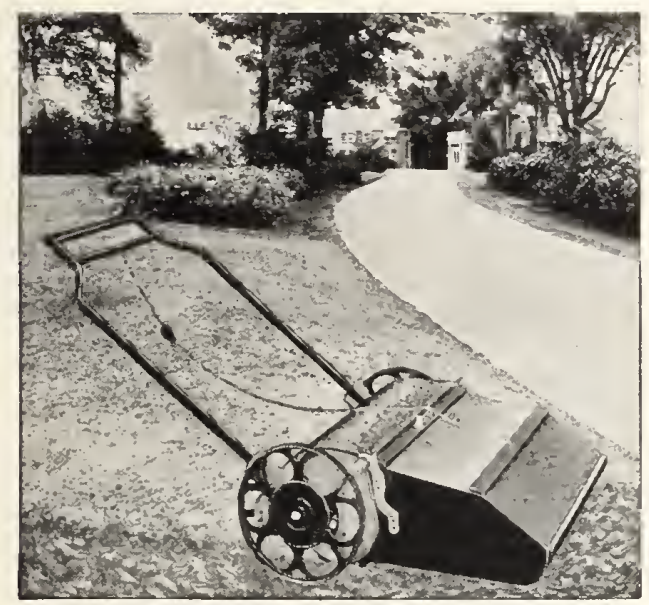

\section{Stumpp \& Walter Co.'s Lawn and Golf Sweeper}

Is equipped with Palmet to Brushes of the toughest fiber and unaffected by water. Sweeps and gathers fresh-cut and dead grass, leaves, stones, and other litter. A real necessity for the quick and economical sweeping of lawns and golf courses. Labor-saving, efficient, and durable machine. Width, 28 inches. Net weight, 84 lbs.; gross weight, I 06 lbs. Price $\$ 42$.

\section{Pennsylvania Lawn Cleaner}

This machine is designed to remove dead leaves, but it may be converted quickly into a mechanical brush for distributing wormcasts, etc., when steel rakes, with which the machine is normally fitted, are removed and replaced with brushes. The brushes are made of high-grade fiber set in a hardwood head, and they give long wear. The brushes are easily removed for cleaning or for interchanging with the raking cylinder. 24-in. Cleaner, fitted with steel rakes, \$30. Brushes, 24 in., $\$ 7$ per set of 3 .

\section{Sod-perforating Attachment}

Made especially for use with our No. 603, No. 605, and No, 606 Water-Ballast Lawn Rollers. Aids in keeping the lawn in perfect condition. Spiking permits the air to get at the roots, resulting in a stronger, healthier, and better grass. The Lawn Roller acts as weight for the attachment. Very easy to attach or detach, simply by tightering or loosening two bolts and two thumb-screws. Sod-perforating

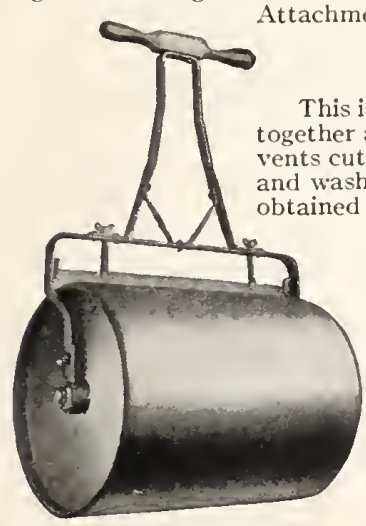

Fill it with Water or Sand when turning.

\section{Stumpp \& Walter Co.'s Water-Ballast Lawn Roller}

This Roller is manufactured to do heavy work. Is used with excellent success on golf courses and private estates, on roads and lawns. Has strong, plain bearings, pulls directly from the axle, and is equipped with a substantial weight box for additional weight. Each section is turned smooth on the surface with outer edges beveled.

Pole and whiffle-trees or shafts will be furnished instead of tractor hitch without extra charge.

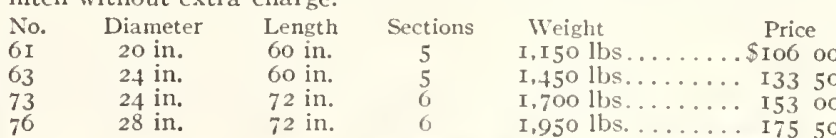

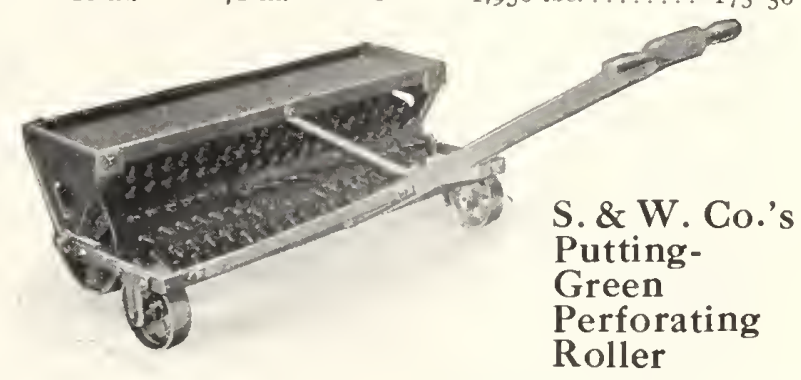

A Spike Tooth Roller for aërating the sod on golf courses, puttinggreens, parks, and large lawns.

Consists of three sections, each I 2 inches in length by Io inches in diameter, made of seasoned oak staves compressed in cast iron heads. Closely covered with steel spikes, which are easily replaced with a socket wrench. Steel top and frame so constructed that sand bags can be used for additional weight. Carrying wheels for turning or moving. Rolls $3 \mathrm{ft}$.; weight I9o lbs. \$5o.

is is a most satisfactory Roller, being light-running and easy to pull. It is constructed of 3 heavy steel plates, pressed rether and electric-welded, forming one solid steel drum with no leaky joints. The drum has rounded edges, which prevents cutting of the sod. Heads are held through the center by a full-length axle firmly fastened by double steel lock nuts and washers. A scraper keeps the Roller clean. Can be filled with water or sand, and by using more or less a weight is obtained suitable for the conditions-light for moist lawns, medium for dry lawns, and heayy for paths.

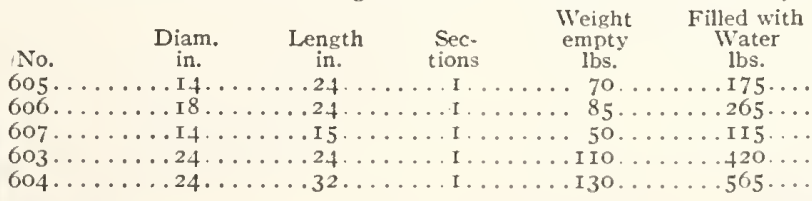

\section{Cast-Iron Hand Lawn Rollers}

The face of each Roller is made smooth, with outer edges rounded to avoid cutting the sod. Will not injure the grass

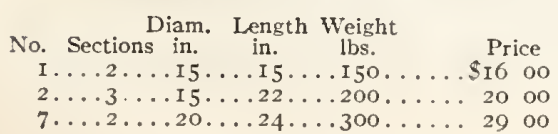

Diam. Length Weight
No. Sections in. in.

$8 \ldots 3 \ldots 20 \ldots 30 \ldots 350 \ldots$

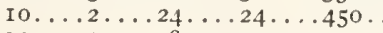

$13 \ldots 2 \ldots .28 \ldots 24 \ldots 500 \ldots .43$ oo
Price

$\$$ I 5 oo

I8 00

I4 00

$\begin{array}{ll}23 & 00 \\ 26 & 00\end{array}$

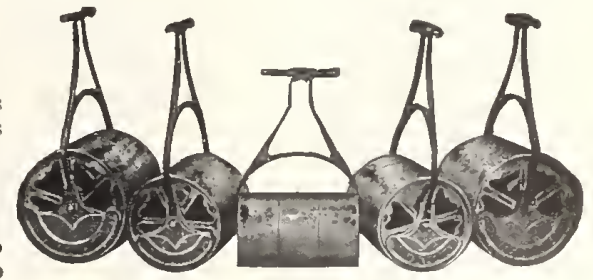

Cast-Iron Hand Lawn Rollers 


\section{HEDGE SHEARS}

\section{Sheffield Hedge Shears, Finest English Steel}

Solid steel blade, crucible tool-steel, tempered to hold an edge. Give good service. Shears with notch are the best for cutting heavy stems of hedge plants.

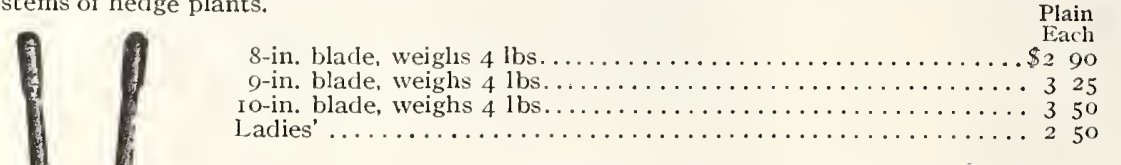

\section{"Professional" Hedge Shears}

Blades made of crucible steel, nickeled; one serrated edge, the other knife edge. Handles riveted-cannot come off.

8 -in. blade, $\$ 3 ; 9$-in. blade, $\$ 3.25 ;$ io-in. blade, $\$ 3.50$.

\section{S. \& W. Co.'s Grass Shears}

A very simple but practical locking device holds the Shears together. Made of the best crucible tool-steel; polish finish. One size only, $61 / 2$-in. blade, $\$ 2.50$.

Western Grass Shears. Made of good-quality tool-steel. A one-piece Shears. Plain finjsh, 6-in. blade, \$1.50.

\section{Grass Edging or Border Shears}

Border Shears

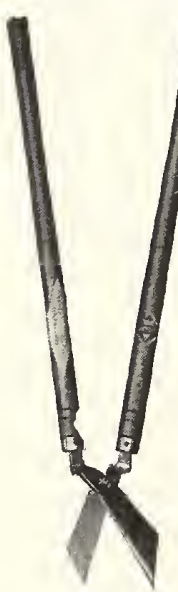

Designed to trim the overhanging grass on borders around flower-beds and walks. 9 -in. blades of high-grade tool-steel; polished handles and blades. Without wheel, $\$ 5.50$; with wheel, $\$ 6$.

\section{Lawn Shears}

Designed to cut grass under hedges, fences, grape arbors, and flower-beds or shrubs. 9-in. blades of high-grade tool-steel, polished handles, and blades. Without wheel $\$ 6$; with wheel, $\$ 6.50$. Notice: When shipping the above Shears, unless stated on orders, we send Shears with wheel.

\section{Pruning Shears}

Kunde. One of the best Shears obtainable. It is very durable and efficient. Solid steel, \$5.

Wiss. Crucible tool-steel; blades are detachable; tempered to hold an edge; will not break. Made in two sizes. 9 -in. $\$ 3.50$; ro-in. $\$ 4$.

S. \& W. Co.'s Solid Steel. Crucible tool-steel. Blade and handle are one piece of polished steel; a ratchet nut keeps the Shears properly tightened; will not break; excellent finish. Made in three sizes. 8-in. \$3.25; 9 -in. $\$ 3.50 ;$ Io-in. $\$ 3.75$.

French. Made of good-quality tool-steel; flat roller spring; works easily and cuts well; detachable blades; plain finish. Made in two sizes. 8-in. \$2.25; 9-in. \$2.75.

Sawco. Made of high-quality steel. A very good Shears for grape-vines and shrubbery. \$I.5O.

Lawn Shears Ladies' Nickel-plated. Light, practical, handy to use on roses and shrubbery. $61 / 2$-in. $\$ 2.50$.

GRAPE-THINNING SCISSORS. Nickel-plated. \$2.

FLOWER-GATHERING SHEARS. Nickel-plated. Made to hold within its grasp the stem of the cut flower. $\$ 3$.

ROLCUT PRUNING SHEAR. The only light-weight Pruning Shear with genuine draw cut-cuts cleaner and quicker. $\$ 2.50$.

\section{Little Wonder Hedge Trimmer}

A well-designed machine which entirely revolutionizes hedge trimming. It actually cuts a hedge as fast as you walk, and in an hour will trim the top and two sides of a hedge 300 feet long; this is from five to ten times as fast as hand-work.

The cutting blades are of tough steel, holding a sharp edge for a long while and trimming every variety of hedge grown. Use it for trimming, and not for "cutting back" a hedge, and it will last for years, 30-inch one-man Trimmer, $\$ 25 ; \quad 40$-inch one and two-man Trimmer, \$27.50; 6o-inch twoman Trimmer, $\$ 35$

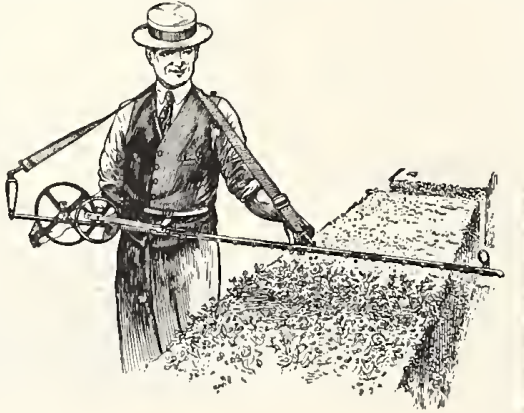

\section{Electric Little Wonder Hedge Cutter}

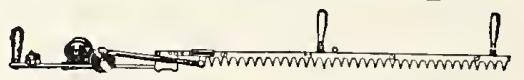

\section{A MARVEL FOR HEDGE TRIMMING}

The most rapid, practical, and easy method yet devised. A proved success. It is guaranteed to trim 300 to 500 feet (top and both sides of ordinary hedge) in one hour, and the only effort required is to guide the machine. 40 -inch machine, including roo feet of weatherproof extension cord and General Electric motor, \$106.50.

\section{The Scissors-Like Grass Shears}

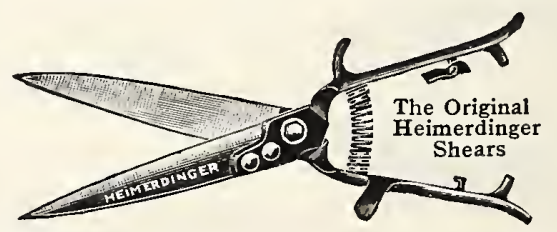

The Original Heimerdinger has the finest quality Shear steel blades. hardened and tempered, and finely polished. The handles, so designed as to fit the hand, are made of refined malleable iron, and finished in a beautiful high-lustre baked enamel.

Very practical for trimming the edges and borders of lawns, flower-beds, etc. Total length of Shears $121 / 2$ inches, blades 6 inches. Price, \$I.35 postpaid. 


\section{Pruning Tools and Orchard Supplies $\begin{gathered}\text { PRICES SUBJECr TO } \\ \text { MARKET CHANGES }\end{gathered}$}

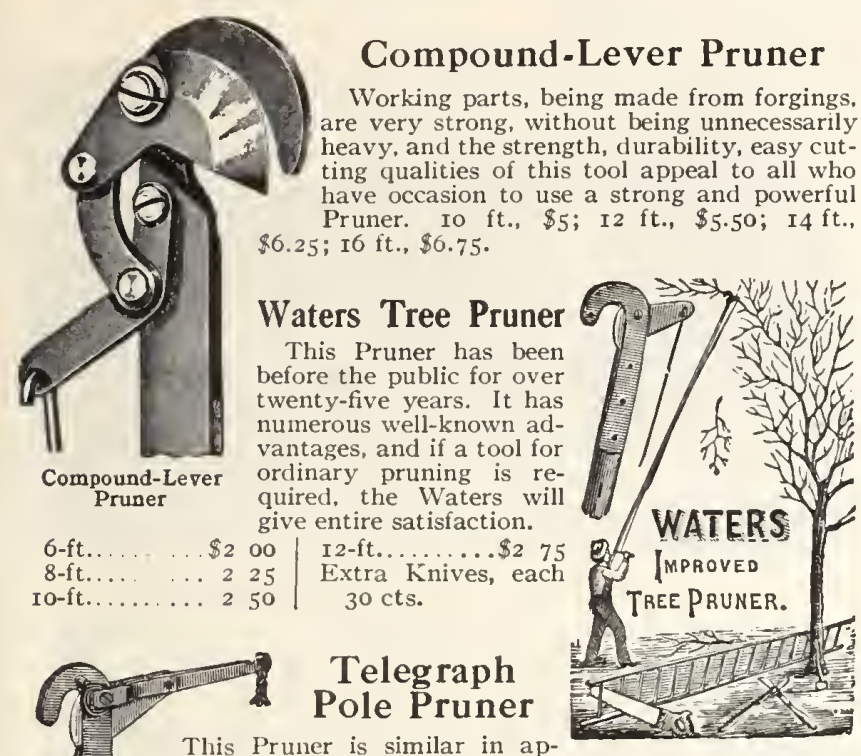

This Pruner is similar in apThis makes it very strong and durable. As illustrated, no handle, \$I.75. Extra knives, $30 \mathrm{cts}$. each.

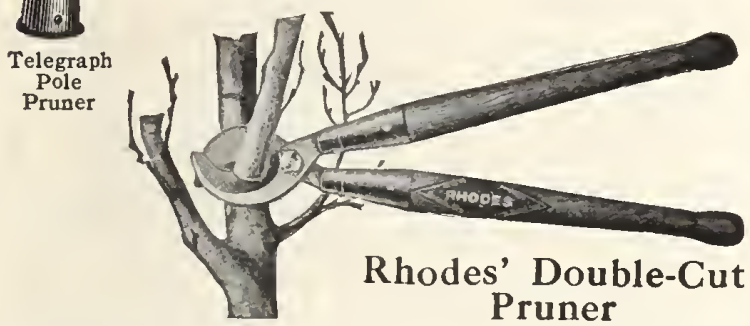

A good and powerful Pruner. Cuts from both sides of the limb, and does not bruise the bark. Long ferrules; handles do not pull out; blades are of the best forged steel. 30 -inch, $\$ 5 ; 36$-inch, $\$ 5.25$.

\section{Grafting Chisel}

Makes clean splits and does not tear the bark. \$I.5o.

Grafting Wax. 1/4b. 20 cts., Ib. 65 cts.

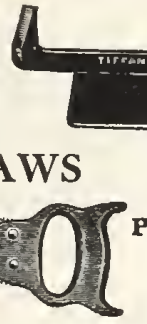

\section{PRUNING SAWS}

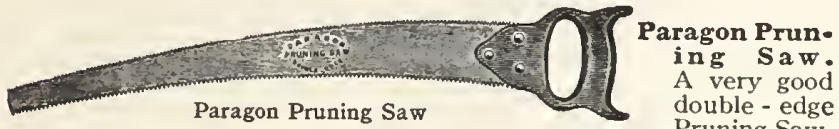

with the draw cutting and thrust cutting edges. Will cut large limbs better than the lighter Saws. I 8 -inch, $\$$ I.90; 20-inch, $\$ 2$.I0.

No. 4 Pruning Saw. Without this Saw

no pruning outfit is complete. The taper-

ing blade permits of its use

in close

places. Used

for other pur-

poses. A

very useful

Saw. 20-in., $\$ 2.25$.

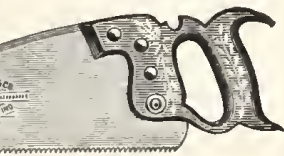

No. 4 Pruning Saw

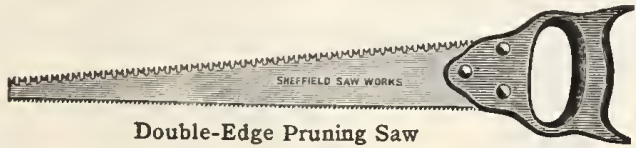

Double-Edge Pruning Saw. Has fine teeth on one edge. and "Lightning" teeth on the other. I6-in., \$1.50; I8-in., \$1.75; 20-in., \$2.

PRUNING SAWS, continued

One-Man Crosseut Saw. Can be used also as a Two-Man Saw.

Has "Lightning" teeth; cuts easily and rapidly.

$31 / 2$-ft........... \$5 oo $41 / 2-\mathrm{ft} \ldots \ldots \ldots \ldots . \$ 6_{50}$ 4 -ft............... 575

Orchard Pruning Hook and Saw. Better adapted for pruning or sawing smaller branches than the Little Giant. Without pole, $\$ 3$

Little Giant Pruner and Saw Combined. The knife operates witl a cord; a spring Saw can be removed Little Giant Pruner and Saw when desired; attaches to pole of any length. Without pole, $\$ 3$.

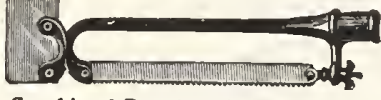

Combined Pruning Saw and Chisel

chisel cuts off small branches.

limbs. Without pole, $\$ 2.50$.

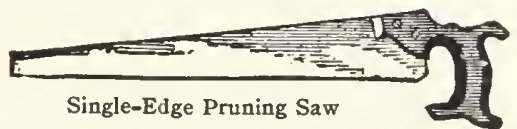

Single-Edge Pruning Saw. Best spring-steel I 8 in., \$1.60; 20 in., \$1.75.

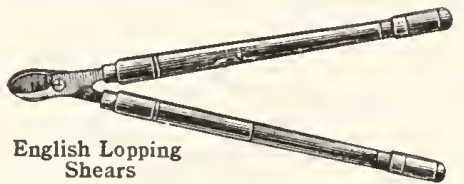

English Lopping Shears. The Shears are well known, and do good service.

No. 2. 24 -in... $\$ 450$

No. 3. 28 -in... 550 No, 4,32 -in... 625

Rhodes' Pole Pruning Saw. Attached to a light, Io-foot pole. Is adjustable to any angle. The Saw is a Paragon blade, made of the best spring-steel; has a draw and thrust cutting edge; saves a lot of climbing and risk of

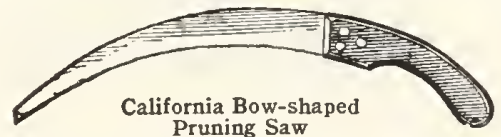
falling. $\$ 4$

California Bow shaped Prun. ing Saw. Excellent to use Rhodes wherever two Pole

limbs are close together. Can be used in the forks without Pruning bruising the bark of other limbs. I 2 -in., \$I.I 5; I4-in., \$I.25. Saw Swivel Pruning Saw. Very handy to use where the limbs are close together. The blade is adjustable to cut from any angle; it saves the trouble so often found when using ordinary

Saws. \$2.50. Extra blades, $50 \mathrm{cts}$. each.

\section{Perfect Fruit-Picker}

Made of steel wire, heavily galvanized; can be attached to anv pole. $60 \mathrm{cts}$. I 2 -it. Pole, $50 \mathrm{cts}$.

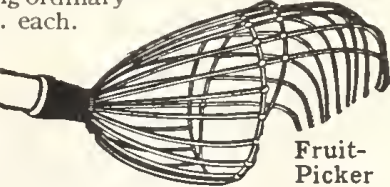

\section{Asbestos Torch}

Attach the Torch to the end of a pole; saturate with kerosene oil, light and hold under the caterpillars' nests. and pass quickly along the branches and around the trunk of the tree. The heat instantly destroys the insects and will in no way injure the trees. Without pole, $60 \mathrm{cts}$.

\section{Berry or Thinning Hook}

For thinning out berry bushes and shrubbery. It cuts off and hooks out in thick places where it is hard to operate any other tool. Fine for sprout and suckers. \$I.5O.

\section{All-Steel Tree Pruners}

Strictly high class Pruner in every detail. Light, powerful, and practical; cuts I $1 / 2$-inch limbs with ease.

No. A. 20 in. long.

No. B. 24 in. long.
No. C. 30 in. long.

$\$ 350$

375

450

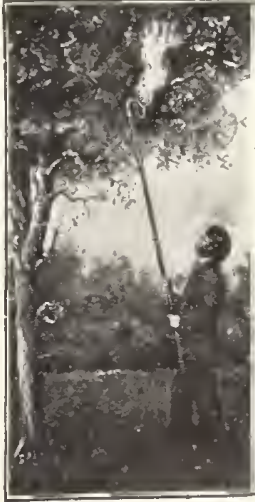

Asbestos Torch 


\section{Rubber Hose, Menders, Nozzles, and Sprinklers}

PRICES SUBJECT TO MARKET CHANGES

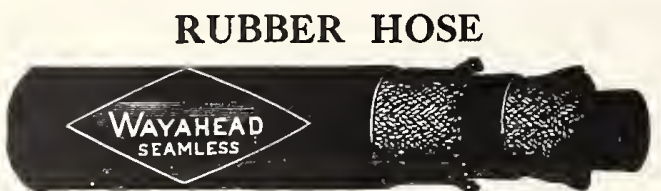

S. \& W. Co.'s Special Brand (Wayahead). Surpasses all the cheaper grades of Hose. Its durability is not excelled by much of the higher-priced Hose. It is three-ply, seamless, and non-kinkable. Standard lengths, $3 / 4$-inch bore, $25 \mathrm{ft}$., $\$ 4.50 ; 50 \mathrm{ft}$., $\$ 8 ;$ I $00 \mathrm{ft}$., $\$ 15$.

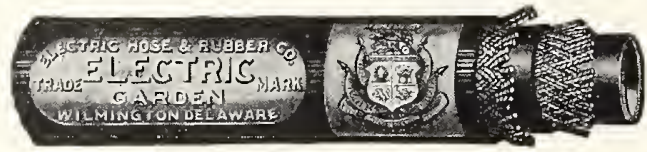

Electric. Three-ply, non-kinkable, molded Hose. The strength and durability of this Hose place it with the very best grade of Hose manufactured.

Standard lengths, $3 / 4$-inch bore, $25 \mathrm{ft}$., $\$ 6.25 ; 50 \mathrm{ft}$., $\$ \mathrm{I} 2$.

Standard lengths, I/2-inch bore, $25 \mathrm{ft}$., $\$ 5.75 ; 50 \mathrm{ft}$., $\$ 10.50$.

5 lengths or more of $50 \mathrm{ft} ., 3 / 4$-in. bore, cut and coupled, ft. $23 \mathrm{cts}$. 5 lengths or more of $50 \mathrm{ft}$., $1 / 2$-inch bore, cut and coupled, $\mathrm{ft} .20 \mathrm{cts}$.

Golf-Course. This Hose is of double braid construction, the braid being incorporated in pure gum rubber and the outside cover is smooth, therefore non-abrasive. Will stand up and give satisfaction under conditions where ordinary garden Hose has failed. Less than I, 000 ft., $20 \mathrm{cts}$. per $\mathrm{ft}$; $\mathrm{I}, 000 \mathrm{it}$. or more, $\mathrm{I} 8 \mathrm{cts}$. per $\mathrm{ft}$.

\section{HOSE NOZZLES}

Stott's. A Nozzle that has become a favorite among rose-growers, etc., for exterminating red spider. Splendid Nozzle for reaching under the foliage; gives a very fine, misty spray. Single, $\$$ I.75; double, $\$ 3$

Justrite Spray. A very popular adjustable Nozzle. It gives a copious spray or a well-defined, full stream. $60 \mathrm{c}$

Bordeaux Spray Nozzle. A good Nozzle for whitewash and all heavy spray materials. \$I.

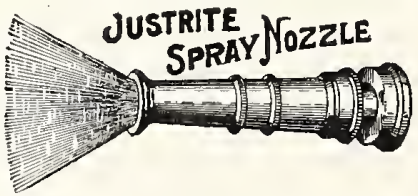

Aquamatic Nozzle. Fits any $3 / 4$-inch garden hose connection Gives a solid stream or spray. Has a positive automatic shut-off. Practical and durable in every way. \$2.50 each.

Water-Gun. The most convenient article of its kind ever offered, and as a nozzle is much more adaptable than the old style. Spray or full stream, as desired. No leakage or drips. $\$ 1.50$ each.

\section{HOSE SUPPLIES}

Siamese Hose Attachment. Permits use of two leads of hose at one time. $3 / 4$-in., $\$$ I.25 each.

Hose Clamps or Bands. $1 / 2$ - and $3 / 4$-in. sizes, Io cts. each, $\$$ I per doz.

Regular Hose Couplings. Easily applied. 1/2-in., I5 cts. each, $\$ 1.50$ per doz.; $3 / 4$-in., $20 \mathrm{cts}$. each, \$2 per doz.

Perfect Clincher Hose Coupler. Self-fastening Coupling that does not require extra bands, bolts, or wire. $25 \mathrm{cts}$. each, $\$ 2.50$ per doz.

Rain King Hose Coupler. Don't bother screwing hose connections together. Just snap them on instantly with this new invention. $3 / 4$-in., 6 o cts. each.

Perfect Clincher Hose Mender. 1/2- and 3/4-in. sizes, 15 cts. each, $\$$ I.50 per doz.

Cooper's Brass Hose Mender. Easily applied-no fasteners required. I/2-in., Io cts. each, $\$$ I per doz.; $3 / 4$-in., I 5 cts. each, $\$$ I.5O per doz.

Hydrant Swivel. Prevents hose from kinking and turns in any direction. $90 \mathrm{cts}$. each.

Hose Washers. For $3 / 4$-in. hose. Io cts. per doz.

\section{Sawco Portable Spray-heads}

For connecting with hose in series, to create a movable and flexible lawn-sprinkling system. Produces a perfect, mist-like spray, covering wide areas. $75 \mathrm{cts}$. each, $\$ 7.50$ per doz.

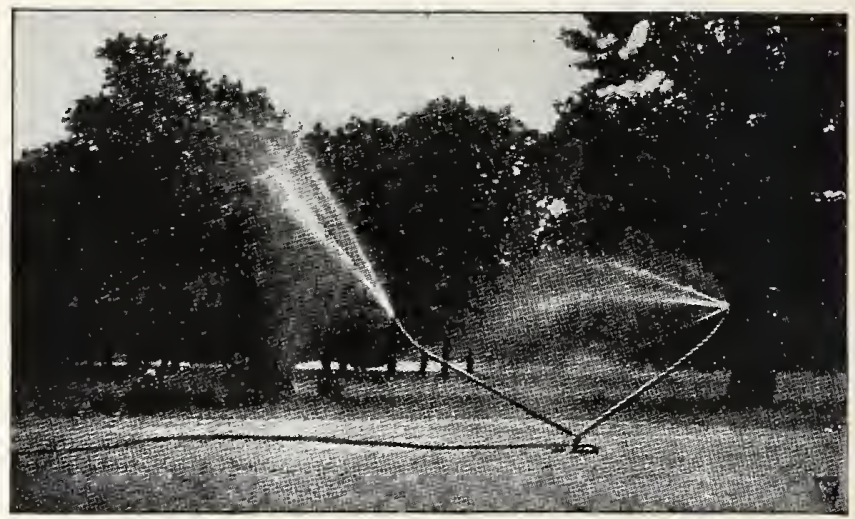

\section{Majestic Revolving Sprinkler}

The long-arm Majestic gives a fine spray. It is a slow-moving machine, and the water is warmed by the air before reaching the ground. Also, there being an appreciable period between each shower, the soil has time to absorb it before the next shower. The Majestic is driven direct from turbine blades at the base, without intermediate gearing; wear is thus reduced to a minimum. Will water an area of from 800 to I,000 square yards. Large size, 5 -ft. arms, $\$$ Io; medium size, $31 / 2$-ft. arms, $\$ 8$.

\section{All-Iron Hose Reel}

The All-Iron Hose Reels are constructed entirely of iron, and are indestructible. They are light in weight, frictionless. and the wheels being high, they are easily manipulated. These Reels cannot tip over when unreeling and there is no weight on the handle.

No. Io, 2 I-in. wheel, holds Ioo feet $3 / 4$-in, hose, $\$ 5$ each.

No. 20, 24 -in. wheel, holds I 50 feet $3 / 4$-in. hose, $\$ 5.50$ each.

No. $30,30-$ in. wheel, holds 500 feet $3 / 4$-in. hose, $\$ 9.25$ each.

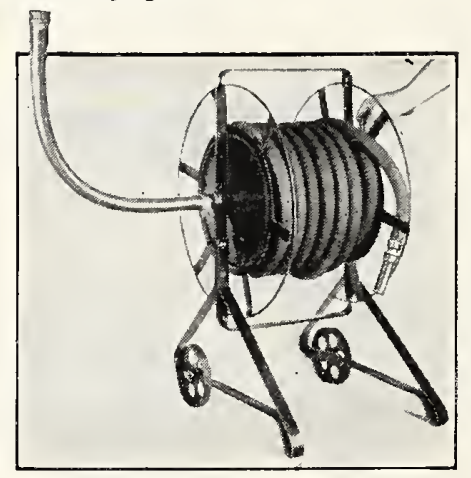

\section{Sawco Hose Reel}

The great advantage of the Sawco Hose Reel is that it is placed alongside of the faucet and the reel is attached to it by a short length of hose (about 3 or $4 \mathrm{ft}$.). All that is necessary then is to uncoil only the length of hose you require to use. Wind it back on the reel with the crank when you have finished using it.

Capacity of reel- $\mathrm{Ioo} \mathrm{ft}$. of $3 / 4$-in. hose. Reel without hose, $\$ 6.25$.

\section{The C. B. G. Sprinkler Cheap But Good}

Nothing to get outt of order. Will last a lifetime. It is easily drawn about the lawn without shutting off the water. $60 \mathrm{cts}$. each, $\$ 6$ per doz.
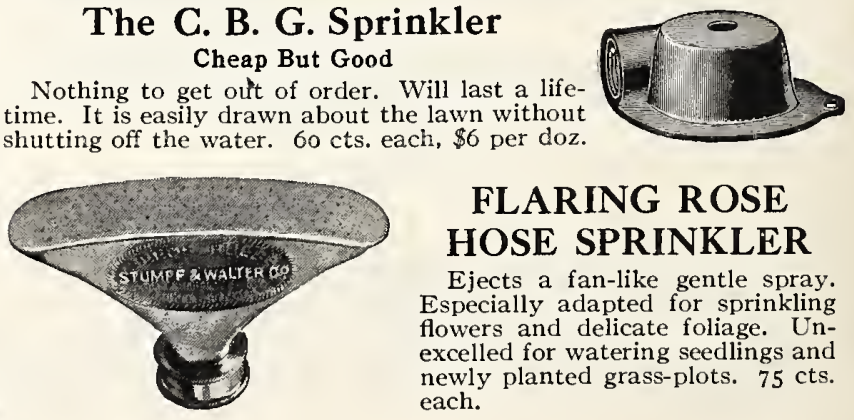

\section{FLARING ROSE HOSE SPRINKLER}

Ejects a fan-like gentle spray. Especially adapted for sprinkling flowers and delicate foliage. Unexcelled for watering seedlings and newly planted grass-plots. $75 \mathrm{cts}$. each. 


\section{LAWN SPRINKLERS}

\section{Double Rotary Sprinkler} Efficient Long-Wearing Reliable

This Sprinkler has always had many friends on account of the efficient manner in which it sprays, eovering an area from I5 to 80 feet in diameter, according to water-pressure-more than 5,000 square feet.

The model which we offer includes many improvements. The gears, of hardened steel and bronze, are enelosed and run in oil. It is so simple in construction that it is rarely necessary

to make adjustments, even after long wear. The nozzle is adjustable for fine or coarse spray and permits covering small or large areas without reducing the volume. The skid base permits moving while in operation. Cannot tip over. $\$ 12.50$ each.

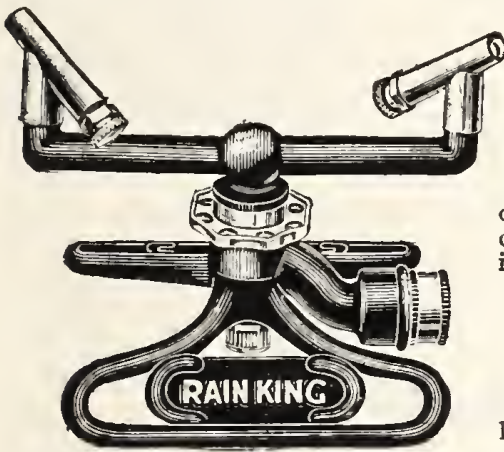

\section{The Rain King}

Quickly adjustable to revolving or stationary sprays. Waters large lawns, strips, or small corners. Sprinkles two directions at once or concentrates wherever water is wanted. $\$ 3.50$ each.

\section{Majestic Rain King}

Stands I5 inches high has double brass watercolumns, is built a trifle heavier than the Rain King, and throws the water farther. Because of extra height, throws spray well out over tops of near-by plants. $\$ 6.50$ each.

\section{Rainstorm Sprinkler}

Has two short center nozzles and $t w o$ longer arms, giving it an even distribution of water clear from the base of the sprinkler to the extreme outer radius. Covers circle from I 5 to 48 feet in diameter. Adjustable for light heavy flow. $\$ 2.50$ each.

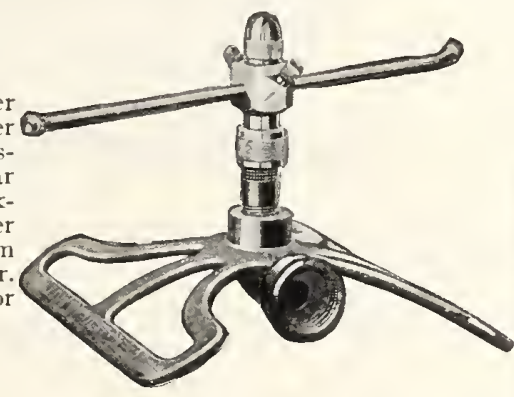

S. \& W. Co.'s Three-Way Sprinkler

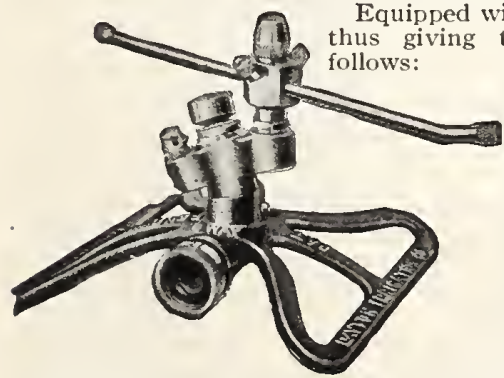

Equipped with three tested spray-heads. thus giving three kinds of sprays, as

I. A whirling spray that operates on low as well as high pressure, covering a circular area up to 48 feet. 2. An intensified spray. to cover a circle from a fey feet up to 28 feet, as desired. 3. A half-spray for oblong or narrow spaces in the garden or lawn or for curb strips.

Changing from one spray A mere turn with the fingers puts into position the proper head for the kind of spray wanted, and the other two heads are automatically shut off. \$4 each.

\section{PRICES SUBJECT TO}

MARKET CHANGES

\section{The Lark Sprinkler}

"It Sprinkles Evenly up to 150 feet"

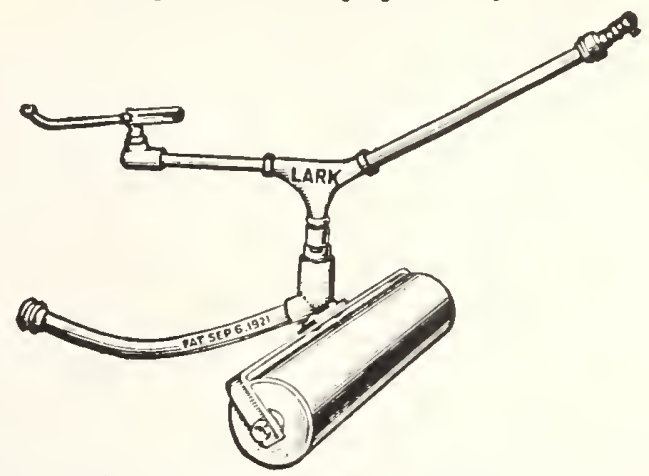

All gears and complicated wearing parts have been eliminated, thereby insuring long life, without constant repair. Can be arljusted. Will cover well a diameter of from 60 feet to I 50 feet, depending upon the pressure at the Sprinkler. Operates on water-pressures of from I 5 to 75 pounds. Gives an even, rain-like distribution of water from the center to the extreme outer circle without puddling. \$ I5 each.

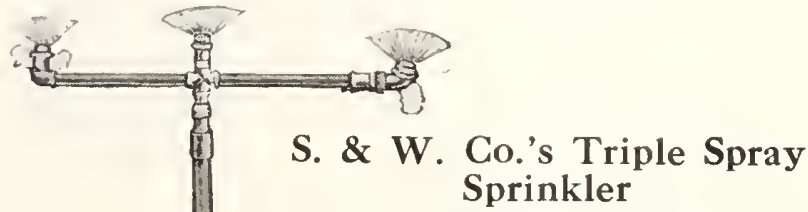

This has three waterheads, one throwing an upward spray and two (one on each end of arm) which can be adjusted to any angle. When revolving, this type of Sprinkler will throw a spray covering a circular area 60 feet in diameter Setting the waterheads in an opposite direction and tightening the set screw eollar so that the arms do not revolve, will cause a spray to be

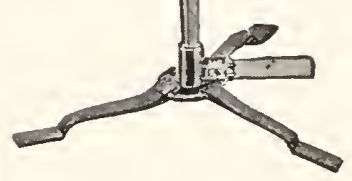
thrown 35 feet on each side of the stand, making in all an even distribution of water, covering 70 feet. Sprays perfectly, throwing the water in a mist-like cloud. $\$$ Io each

\section{Waterfan}

The new Automatic Oscillating Irrigation Sprinkler.

Will soak a rectangle 40 feet by 45 feet with a mist-like spray. The plane of the spray oscillates back and forth. \$i 6.50 each.
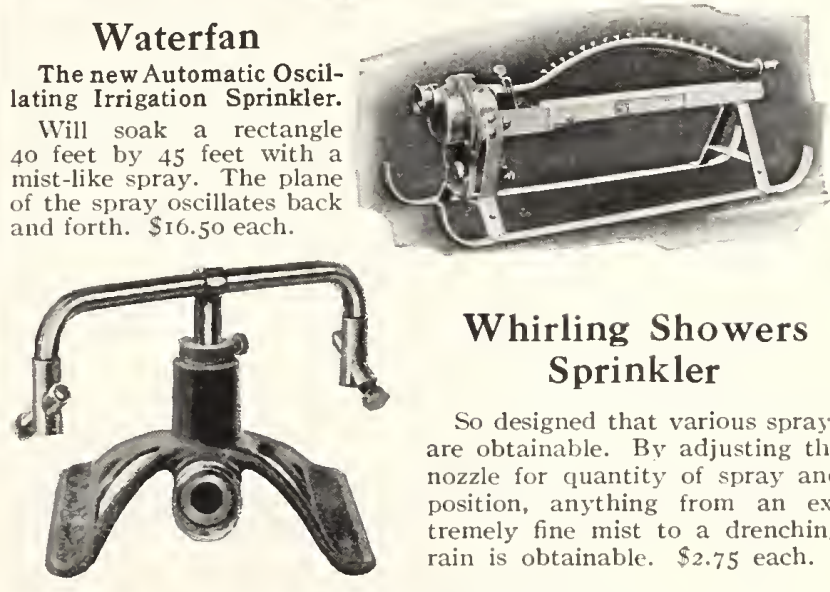

\section{Junior Double Rotary}

A small type of the famous Double Rotary that distributes water economically and evenly. Will operate wherever water-pressure is obtainable, sprinkling areas up to 60 feet in diameter. Readily regulated to cover large or small areas-to sprinkle in a circle or on a straight line. $\$ 7.50$ each. 


\section{Sprayers for Applying Insecticides and Fungicides}

\section{PRICES SUBJECT TO MARKET CHANGES}

\section{S. \& W. Co.'s Super Auto-Spray}

For the effective spraying of vegetable and flower plants, vines, shrubbery and low trees. Can also be used for spraying all-round disinfectants in the stable, poultry house, kennel, etc.

The Super Auto-Spray is made of extraheavy metal to hold up under a pressure of 90 pounds; the pump is of small bore, so that this pressure can be pumped with little exertion. It is double riveted and specially soldered and tested carefully. The large capacity, extra-high pressure, extra strength, and beautiful appearance make it a super auto-spray.

Tank made of corrugated galvanized steel or brass. High-grade hose. Castings for handle, etc., al malleable. No continuous pumping as in the case of the Knapsack Sprayer, nor continuous pumping or slopping as in the case of the Bucket Pump. A few strokes of the plunger compresses enough air to cover a quarter acre of potatoes or similar crop. Extension pipes useful for spraying tall trees. Capacity 4 gallons.

No. 9B. Brass Tank with "Auto-Pop" Nozzle and one 2-foot Extension Rod, $\$$ I0.50.

No. 9D. Galvanized Tank with "Auto-Pop" Nozzle and one 2 -foot Extension Rod .......................... 25 Non-Clog Nozzle with small and large Spray Discs.......... 80 2-foot Brass Extension Pipe..................... 60 20-inch Hose complete with Auto-Pop Shut-off and Nozzle. . . . 225

\section{No. 50 Auto-Spray}

This sturdy little machine is almost identical to Auto-Spray No. 9 in construction and manipulation, but holds only $2 \frac{1}{2}$ gallons. It is particularly recommended for spraying on a small scale, and for use

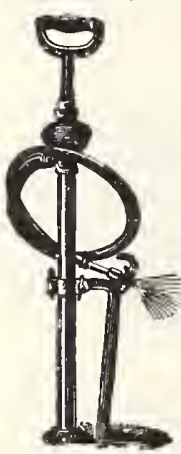
where weight is a factor, as when the women folk or youngsters help out with the spraying.

No. 50B. Brass Tank with Auto-Pop Nozzle and one 18 -inch extension $\operatorname{rod} \ldots \ldots \ldots \ldots \$ 9$ oo No. 50D. Galvanized Tank with Auto-Pop Nozzle and one I8-inch extension rod.....6 600

\section{S. \& W. Co.'s Bucket Spray Pump}

An economical hand Sprayer for applying whitewh cold-water paints and disinfectants. The pump is made of heavy seamless brass tubing with a large brass air-chamber; it has brass ball valves, is double-acting, and will produce a continuous spray or stream, simply by regulating the nozzle. A bordeaux nozzle with 3 feet of $1 / 2$-inch spray hose is furnished. Price $\$ 6.50$.

Extra $1 / 2$-inch hose of good quality at $25 \mathrm{cts}$. per foot.

Extra Couplings, $60 \mathrm{cts}$. per set.
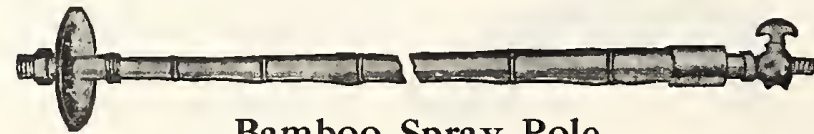

\section{Bamboo Spray Pole \\ FOR TALL-TREE SPRAYING}

Bamboo Spray Poles are brass lined to resist the corroding effect caused by strong solutions. Each Spray Pole is equipped with a drip-shield at the top and brass shut-off at the bottom. Spray Poles over Io feet are not entirely satisfactory, and we do not recommend them. $8 \mathrm{ft}$., $\$ 3.50$; I0 $\mathrm{ft} ., \$ 4$.
S. \& W. Co.'s Compressed Air-Sprayer 


\section{Sprayers for Applying Insecticides and Fungicides}

\section{PRICES SUBJECT TO MARKET CHANGES}

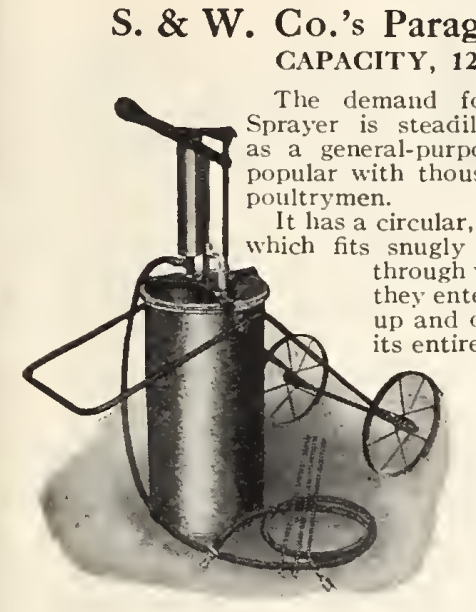
only in our Sprayer, permits of the use of a finer nozzle and enables the operator to do better, neater, and quicker work with less waste of material.

Recommended for spraying whitewash, cold-water paint, insecticides, fungicides, and all solutions in the garden, greenhouse, or poultry plant. Will also spray trees 25 feet high.

Sprayer mounted on truck with two I 2 -inch wheels. Price, $\$ 25$; without truck, \$2I.50.

Equipment: Io-ft. Special Spray Hose, $7 \frac{1}{2}-\mathrm{ft}$. Extension Pipe I Mist Nozzle, I Steel Cap, I Straight Spray. A Single Wheel Truck. with I6-inch wheel, will be furnished with the No. 3 Sprayer, when desired. Price, \$25.

\section{S. \& W. Co.'s Savage Jr. Dust Gun

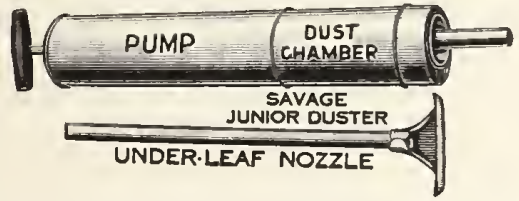

A simple device with an improved nozzle giving a broader distribution of dry powder insecticides and fungicides without waste and with the least possible effort. It blows the powder onto the plants. Insecticides which may be applied economically with this Dust Gun include hortex, tobacco dust, bug death, hellebore, Paris green, arsenate of lead, etc.; fungicides which may be used with it are Semesan, bordeaux powder, grape dust, powdered sulphur, etc. Price, \$I.25.

\section{Bellows, Woodason's}

Powder, small size......\$3 50 Powder, large size........ 5 oo Liquid, small size.........4 425 Liquid, large size......... 5 oo

Double-Cone Powder Bellows. For dusting plant with dry powders for insects and fungus. Price, \$7.50.

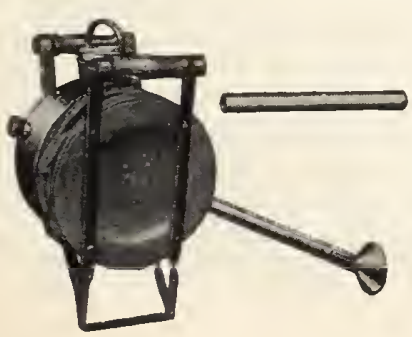

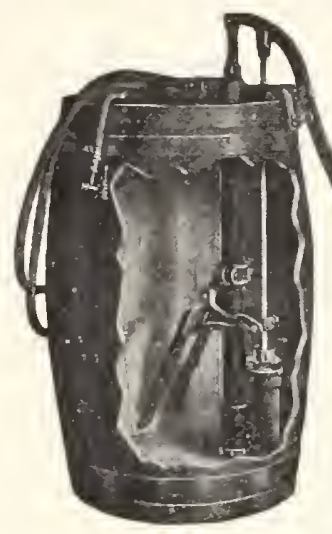

\section{S. \&W.CO.'S “FRUITALL” SPRAY PUMP}

The "Fruitall" illustrated herewith has been designed especially to meet the demand for a lowpriced Sprayer combining the necessary duralsility, efficiency, and strength.

Outfit C. Spraver with agitator and one lead of I5 feet $1 / 2$-inch discharge hose, witl "Mistry Jr." spray nozzle. Price, without barrel, $\$ 21.50$; with truck and barrel, $\$ 43.50$

Outfit D. Sprayer with agitator and two leads, I 5 feet each, $1 / 2$-inch discharge hose, with "Mistry Jr." spray nozzles, Price, without barrel, \$28.50; with truck and barrel, $\$ 4^{8} .5^{\circ}$

\section{POMONA SPRAY PUMP}

The Best Barrel Spray Pump on the Market

It is of large capacity and powerful, with long adjustable leverage, so that it is easily operated by one person, when necessary, but is especially built for spraying from two leads of hose. The unusually large steel air-chamber gives sufficient pressure for a continuous and regular spray. All working parts are of brass, including plunger and valves, which are easily accessible it has a paddle agitator. The bulk of the pump goes. within the barrel, it is not top-heavy, and does not catch low branches.

Pomona Outfit A. Sprayer with agitator and one lead of 15 feet of 3 s-inch spray hose, with "Mistry Jr." spray nozzle. Price, \$33; with truck and barrel, $\$ 53$.

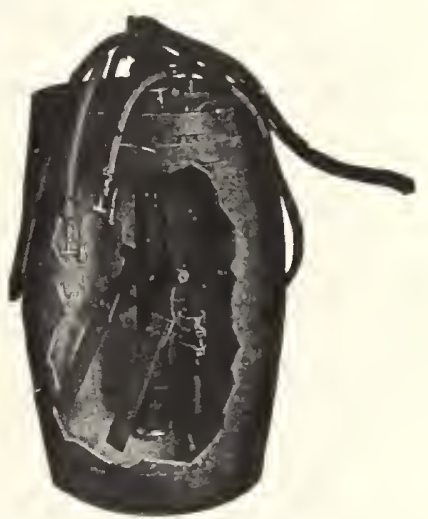

Pomona Outfit B. Same as the above, except with two leads of hose and two nozzles. (See cut.) Price, \$40.25; with truck and barrel, \$60.25

Extra trunnions for barrel, \$I per pair.

S. \& W. Co.'s Truck is recommended to save tine and labor.

\section{Rubber Spray Hose}

High-Pressure, $1 / 2-i n$. bore, to stand $500 \mathrm{lbs}$, pressure, $40 \mathrm{cts}$. per $\mathrm{ft}$. : Low-Pressure, $1 / 2$-in. bore, to stand I $50 \mathrm{lbs}$. pressure, $25 \mathrm{cts}$. per $\mathrm{ft}$. Couplings and Clamps, $60 \mathrm{cts}$. per set, extra.

\section{S. \& W. Co.'s Water Barrel Cart and Accessories}

The Cart is not permanently attached to the Barrel. In using, the Barrel is raised from the ground, carried to the place desired, and instantly detached, all without handling. The weight being balanced over the axle, no lifting or down pressure is needed in transportation. Special attachments can be obtained to convert the Cart into a WaterBarrel Combination, Leaf-Rack, or Handy Cart-Box.

Truck only, fitted with 3 -in. steel wheels............ \$ I 5 oo

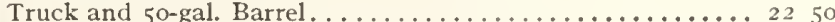

Extra Trunnions for 50-gal. Barrel, per pair............ I oo

Handy Cart-Box fitted with spring catch to permit dumping. 38 in. long $\times 24$ in. wide $\times$ Io in. deep.

Leaf-Rack. Will be found extremely useful for the cartage of leaves and dead grass from the lawn, etc, 42 in. long $\mathrm{x} 28 \mathrm{in}$.

wide $\times 2 \mathrm{I}$ in. deep. 


\section{REMEDIES FOR INSEGTS AND FUNGUS}

NOTE: Most insecticides being of a poisonous nature cannot be sent by parcel post. When cash accompanies your order we prepay charges within fifty miles of New York

\section{Antrol \\ For controlling Argentine and species of house ants commonly known as} Antrol Cottage Extra Jars

Pint Bottles of Syrup.

Gallon Cans of Syrup

190

95

Aphine. Effective against all soft-bodied and plant-sucking insects, such as green, black, and white fly, red spider, thrips, mealy bug, brown and white scale. Used as a spray when diluted with water in the proportions as directed on each can. An insecticide which can be used indoors and in the garden. An excellent cleanser for houseplants. Qt. \$I, gal. \$3.

Arsenate of Lead, Powder. Better than Paris green, does not burn the foliage, goes twice as far, and is easier to handle. Stir in I pound to 50 gallons of water. $r / 21 b .25 \mathrm{cts}$., lb. $50 \mathrm{cts}$., 5 lbs. $\$ 2$, Io lbs. $\$ 3.50,25$ lbs. $\$ 8$, I oo lbs. $\$ 24$.

\section{Black Leaf 40}

A concentrated solution of nicotine sulphate and an excellent spray for aphis and sucking insects of all kinds. Dilute one part to $I, 000$ parts of water, according to treatment. Full directions on package. I-oz. $35 \mathrm{cts}$, 1/2lb. $\$ 1.25,1$ b. $\$ 2.50,2$ lbs. $\$ 3.75,5$ lbs. $\$ 7$, Io lbs. $\$ 11.85$.

Bordeaux Mixture, Dry Powder. The recognized fungicide for the control of most fungous diseases of fruits and ground crops. Stir in 4 to $4 \frac{1}{2}$ pounds to 50 gallons of water. $1 / 21 \mathrm{~b} .25 \mathrm{cts}$., lb. $40 \mathrm{cts}$. 5 lbs. $\$ 1.50$, Io lbs. $\$ 2.75,25$ lbs. $\$ 5.75,50$ lbs. $\$$ IO, IOO lbs. $\$ 18$.

Carbon Bisulphide (Ant Destroyer). Poisonous and explosive. Keep away from all flames and your nose. For ants in walks, pour a little Bisulphide on each nest; in lawns and gardens, insert the Stumpp \& Walter Funnel and Skewer at intervals of Io inches and pour a tablespoonful in each hole. Can $75 \mathrm{cts}$. Funnel and Skewer for using Carbon Bisulphide, \$2.50.

Copper Sulphate (Bluestone). An ingredient in home-made Bordeaux Mixture. Also used alone for spraying. Lb. 20 cts., 5 lbs 85 cts., Io lbs. $\$ 1.50,25$ lbs. $\$ 3.50$, Ioo lbs. $\$ 12$.

Copper Solution, Ammoniated. A fungicide similar to Bordeaux Mixture; the essential ingredient, carbonate of copper, being dissolved in ammonia in this, while in Bordeaux it is counteracted by lime. For late sprayings, when fruits are nearing maturity, or plants in bloom, copper solutions are usually used. Qt. \$I.25, gal. \$4

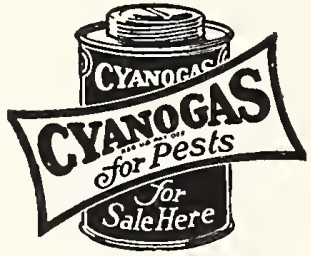

(A) Dust. For outside use in killing rats, moles, woodchucks, gophers, and ground squirrels. Also for white grubs and crayfish in lawns. Lb. 75 cts., 5 lbs. $\$ 3$ 25 lbs. \$IO, Ioo lbs. \$30. Gun for applying same, $\$ 1.25$.

(G) Fumigant. For greenhouse, mushroom, and soil-fumigation. Scatter over the greenhouse walks and close the house for the night. Generates deadly hydrocyanic acid gas which is very effective in controlling aphis, thrips, white fly, and soft scale. Lb. 75 cts., 5 lbs. $\$ 3$, 25 lbs. $\$ 10$, IOO lbs. $\$ 30$.

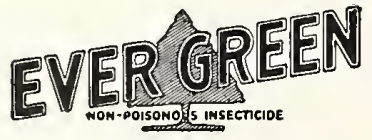

Non-poisonous; highly effective against both chewing and sucking insects; harmless to the tenderest foliage. Easy to prepare and pleasant to use. Oz. $35 \mathrm{cts}$., 6 ozs. \$I 32 ozs. \$3.50, gal. \$I3.

Fish-Oil Soap. For mild forms of scale. An excellent summer spray, when something stronger cannot be used, where the San José scale exists. It is good for washing off lemon trees, oleanders and almost anything that would be infested with a soft-shelled or in fact almost any kind of insect. Lb. 30 cts., 5 lbs. $\$ 1.25,25$ lbs. $\$ 4$, I 00 lbs. \$I3.

Fungine. An infallible remedy for mildew, rust, wilt, bench-rot, and other blights affecting flowers, fruits, and vegetables. Does not stain foliage. Qt. \$I, gal. \$3.

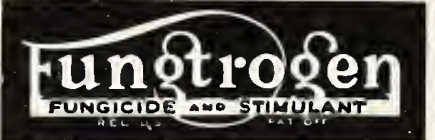

A liquid spray for the control of mildew and black-spot. Highly concentrated fungicide invisible on the foliage or blooms. It is also a plant stimulant. Ready to use when its volume. $1 / 2$ pt. 75 cts., qt. $\$ 2$, gal. $\$ 6$

mixed with water to 60 times

Grape Dust. For mold, mildew, or rust-mites, either in the greenhouse or open air. The application is made by dusting. Apply the Grape Dust thoroughly and frequently as spores of fungi are constantly spreading in season. 5 lbs. 85 cts., Io lbs. $\$$ I.6O, 25 lbs. $\$ 3.75$.

Hellebore, Powdered. Good for exterminating currant worms. I $/ 2$ lb. 30 cts., lb. 55 cts., 5 lbs. $\$ 2.50$.

Hortex. A superior sulphur-arsenate-nicotine dust testing 2 per cent pure nicotine. This all-in-one mixture is used for the control of many fungous diseases, chewing insects, and sucking insects. Used as a dust it cannot be surpassed for general garden use. Lb. can 50 cts., 5-lb. can $\$ 2$, Io-lb. can $\$ 3.50$

Imp Soap Spray. Destructive to insects. Does not spot fruit or foliage or deface paint work. Contains no mineral poison. Very effective against rose bug, white, black and green fly, red spider, thrips and aphis. Gal. $\$ 3.50,5$ gals. $\$ 15$.

Lime-Sulphur, Concentrated. For destroying San José scale. One gallon makes ten gallons of spray; dilute with cold water. Ot. 50 cts., I-gal. can $\$$ I.25, 5-gal. can $\$ 4$, half-barrel (about 25 gals.) $\$ 10.50$, barrel (50 gals.) \$I5.

Lime-Sulphur, Dry. A very effective dormant spray for fruit and shade trees. Lb. 40 cts., 5 lbs. $\$$ I.75, Io lbs. $\$ 3.25,25$ lbs. $\$ 6$.

Mag-o-Tite. Insures a good crop of radishes, kale, cabbage, onions, turnips, cauliflower, etc. You can now sow any of these crops and be certain of protection against the destructive root maggot, earthworm and other pests. Quantity required: A 2-lb. package will cover about 300 feet of drill, mixed with the soil at planting-time, with an occasional top dusting as a preventive during the growing period. For field culture the approximate quantity required is from 300 to $500 \mathrm{lbs}$. per acre. 2 -lb. pkg. $40 \mathrm{cts}$., 4 -lb. pkg. $70 \mathrm{cts}$., 8 -lb. pkg. \$1.25.

Mo Lo. Clears a lawn of moles and field-mice in a few nights. Punch a hole in the top of the run, drop in one pellet and cover lightly; repeat every 8 feet. Mo Lo is poisonous-wear gloves. Pkg. $25 \mathrm{cts}$.

Nico-Fume Liquid. This preparation is a free nicotine preparation, and is used by many of the leading growers. $x / 4-1 b$. can $75 \mathrm{cts}$., I-lb. can $\$ 2,4$-lb. can (I/2gal.) $\$ 6.25,8$ lbs. (I gal.) \$I I.50.

Nieo-Fume Paper. This is a paper treated with nicotine, giving off dense fumes of strong nicotine when ignited. It is also used for tying near blooms of chrysanthemums in early fall to keep down insects. Preferred by many who do not wish to spray or vaporize. Box of 24 sheets $\$$ I.25, box of I44 sheets $\$ 5$, box of 288 sheets $\$ 8.75$.

Nico-Fume Tobacco Powder. For fumigating the greenhouse and conservatory. Lb. $\$$ I, 5 lbs. $\$ 3.75$, Io lbs. $\$ 6.85$.

Very effective for preventing and conNU-GRERT trolling brown-patch in lawns. Kills the property of quickly restoring the diseased grass to its normal healthy condition. $3-0 z$. tin 50 cts., I-lb. tin $\$ 2,5-1 b$. tin $\$ 9$, 25 -lb. tin $\$ 37.50$, I0o-1b. drum $\$ 145$.

Para-Dichlorobenzene. Highly recommended for destroying the peach borers in trees four years and older. During September a ring of the crystals is placed on the soil around the trunk and covered by mounding the earth against the tree. One ounce is sufficient for each tree. Lb. 75 cts., 5 lbs. $\$ 2.75$, Io lbs. $\$ 5$.

Paris Green. $1 / 4$ lb. I 5 c., I/2lb. 30 c., lb. 55 c., 5 lbs. $\$ 2.50$, I 4 lbs. $\$ 5$.

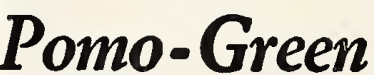
A leaf-green Kolodust containing arsenate of lead and Bentonitesulphur. A complete dust that wil control black-spot, mildew, and external chewing insects on roses, also snapdragon rust, carnation rust, and mildews in general on flowers and shrubs. Lb. $50 \mathrm{cts}$. 5 lbs. $\$ 2,25$ lbs. $\$ 8$. 


\section{REMEDIES FOR INSEGTS AND FUNGUS}

NOTE: Most insecticides being of a poisonous nature cannot be sent by parcel post. When cash accompanies your order we prepay charges within fifty miles of New York

Pyrox The one best and safest all-round spray which kills all $\underline{\text { y r ox }}$ leaf-eating insects and prevents blight and all fungous troubles, without injury, on trees, grape-vines, currant bushes, potatoes, cantaloupes, cucumbers, and other garden vegetables, also on rose bushes, shrubbery, etc. It is a creamy paste which looks like paint and "sticks like paint." It needs only to be mixed with cold water and it is ready to apply. Lb. 50 cts., 5 lbs. $\$ 1.75$, Io lbs. $\$ 3.15,25$ lbs. $\$ 6.50,50$ lbs. $\$$ II.25, I0o lbs. $\$ 18,300$ lbs. $\$ 5$ I.

Reade's Electric Worm Eradicator. (Liquid.) One gallon is diluted with from 200 to 250 parts of water, and the turf thoroughly drenched with the diluted liquid. Four gallons of concentrated material is the average allowance per golf putting-green. Gal. \$5, 5 gals. $\$ 17.50$, Io gals. $\$ 30,50$ gals. \$1 50 .

\section{RED ARROW}

\section{IASECT SPRAY}

Absolutely non-poisonous to children or pets but deadly to insects. IVill positively not burn, blight, or stain the tenderest leaf or flower. It leaves no injurious residue on anything sprayed. Recommended highly for the Mexican bean beetle. A contact spray fatal to both chewing and sucking insects. One ounce makes 4 to 8 gallons of spray. Oz. $35 \mathrm{cts}$., $31 / 2$ ozs. \$I, qt. $\$ 6$, gal. $\$ 20$.

Scalecide. Used for the destruction of the San Jose scale. Dilute at the rate of one gallon to twenty gallons of water. Scalecide does not clog nozzles, hose or pump, and is pleasant to use. Trees may be sprayed in winter and early spring before they start to come to bud. Qt. 75 cts., gal. $\$ 1.75,5$ gals. $\$ 6.25$, Io gals. $\$ 10.60$, I 5 gals. $\$$ I3.50, 30-gal. bbl. \$25, 50-gal. bbl. \$35.

A mercuric disinfectant. A remedy for the malignant grass disease called "brown patch." Also used in the treatment of seeds, bulbs, and plants. Preserves seeds against rotting in soil and generally speeds and increases germination, thereby developing sturdier plants. Promotes early maturity and improves quality and quantity of blooms. Can be used in either liquid or powder form. 2 ozs. $50 \mathrm{cts}$., lb. $\$ 2.75,5 \mathrm{lbs}$. \$13, 25 lbs. $\$ 56.25$, I0o lbs. $\$ 220$.

6

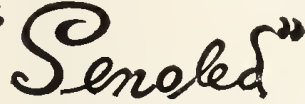

A compound of lead arsenate for grubproofing lawns and gardens. Will destroy Japanese beetles, wireworms, cutworms, maggots, and earthworms. Discourages crab grass and other weeds in lawn. This preparation also contains colloidal phosphate, the properties of which tend to hold lead arsenate in the soil and delay its loss through leaching, and, in addition, feeds the growing plants. 25 lbs. $\$ 3$, I 00 lbs. $\$ 8,500$ lbs. $\$ 35$, ton $\$ 125$.

Slug-Shot. The standard remedy for currant worms, rose slugs, cabbage worms, and almost any soft-shelled insects that infest the garden. Lb. 25 cts., 5 lbs. 75 cts., Io lbs. \$I.20, I 25-lb. keg \$I 2.50 .

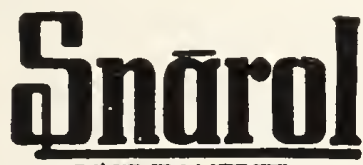

\section{The National Pest Control}

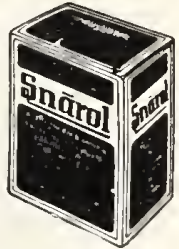

\section{For Cutworms, Slugs, Snails, Sowbugs Earwigs and Grasshoppers}

Snarol is a meal, ready for immediate use. Not injurious to plants or other vegetation when used according to directions and is not soluble in water. Rain, dew, sprinkling, or moisture applied in any manner does not weaken Snarol's efficiency. Snarol is an unusual combination of materials, carefully selected. It is made to kill the pests that ruin lawns and garden produce, flowers and shrubs, in the quickest, most convenient, surest, most effective way, without any damage from itself. Lb. $40 \mathrm{cts}$., 3 lbs. 75 cts., I 5 lbs. $\$ 3,50 \mathrm{lbs}$. $\$ 8$. Styptic. To prevent bleeding of vines after pruning. Bottle $\$ 2$.

Sulphur. Used principally in greenhouses for checking mildew. Lb. 25 cts., 5 lbs. \$I, Io lbs. \$I.60, IOO lbs. \$I 2.

Thrip Juice (Hammond's). Very effective against aphis, red spider, mealy bug, etc, Qt. $\$ 1,50$, gal, $\$ 4.25$.
Tobacco Dust (Kilmdead). The best of the Tobacco Dusts for dusting or fumigating. Lb. 25 cts., 5 lbs. 75 cts., 25 lbs. $\$ 2$, Ioo lbs. $\$ 6$.

Tobacco Stems. Used for fumigating and for placing under benches in greenhouses. Bale of Ioo lbs. $\$ 5$.

Tree Tanglefoot. A paste preparation for painting around the trunks of trees, in the form of a band. Caterpillars and other crawling pests cannot get over it. Lb. $60 \mathrm{cts}, 5^{-1 b}$. can $\$ 2.75$, Io-1b. can $\$ 5.25,25 \mathrm{lbs}$. \$I I.

Tree Wound Paint. Prevents decay. A residuum, penetrating, antiseptic paint that is not affected by heat, cold or moisture. Does not peel, crack or get brittle. Stops tree bleeding. Pt. $75 \mathrm{cts}$., qt. \$I, gal. \$3, 5 gals. \$I .

Vermol. Common earthworms or "angleworms" are a decided nuisance in lawns, turf courts, and putting-greens. The casts are unsightly, impair the playing qualities of greens and add greatly to the upkeep cost, as daily sweeping and rolling become necessary. To rid greens, courts or lawns of worms, apply Vermol evenly at the rate of one-half pound to the square yard, and flood the greens immediately. If possible, the application should be made on a warm, damp day, early in May. The worms will come to the surface and die. Sold in powder form. 5 lbs. $75 \mathrm{c} ., 25 \mathrm{lbs} . \$ 2.25$. IOo lbs. $\$ 6.50,500$ lbs. $\$ 30, \mathrm{I}, 000 \mathrm{lbs}$. $\$ 57.5 \mathrm{O}$, ton $\$$ I IO.

Volck. A spray for scale insects, mealy bugs, white flies, red spiders, rust mites, and similar insects. Qt. $\$ I$, gal. $\$ 3,5$ gals. \$I2, I4 gals $\$ 25,28$ gals. $\$ 40$

Wilson's O. K. Plant Spray. For roses, chrysanthemums, evergreens, and all plants affected with scale or insects, under glass or outside. Recommended for rose bugs. I/2pt. $40 \mathrm{cts}$., qt. \$I, gal. \$3, 5 gals. \$12, 25-gal. bbl, \$50, 50-gal. bbl. \$90.

X-L-ALL Liquid Insecticide. Destroys mealy bug, scale, thrip red spider, green and black fly, caterpillars, blight and all insect pests in the garden; it is perfectly safe to use on tender plants. For the winter dressing of vines, figs, peaches, and other fruit trees, it has been proved to be the safest and most valuable preparation in the market. Leaves the foliage bright and clean and much improved in appearance. Qt. \$3, 1/2gal. \$4.50, gal. \$8.50.

\section{Weed Killers}

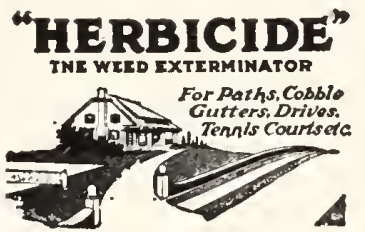

There is nothing more annoying to the well-kept home grounds than weeds constantly coming up in the roadways, paths and gutters. This weed killer may be applied by means of a sprinkling apparatus of any kind from the small sprinkling can to the large street-sprinkling wagon. It is harmless to stone, woodwork or shoes and is perfectly odorless. One thorough application will kill all weeds, as well as their roots. One gallon diluted I part to $4^{0}$ parts of water is sufficient to cover IoO to I50 square yards of space. Qt. can 70 cts., gal. can $\$ 2,5$-gal. can $\$ 7.50$, Io-gal. can $\$$ I 2.50 , 30-gal. drum $\$ 30,50$-gal. bbl. $\$ 45$.

Atlacide (Non-Poisonous, Powder). Exterminates all undesirable vegetation, including poison ivy" Canada thistle, etc. without danger of poisoning humans or animals. Apply as a dust only. Lb. $50 \mathrm{cts}$., 3 I $/ 2$ lbs. \$I.5O, 10o lbs. \$19.

Climax Lawn Sand. A combination of carefully dried and finely ground chemicals. Destroys weeds in lawns. $31 / 2-1 \mathrm{~b}$. can $65 \mathrm{cts}$., 7 -lb. can $\$ 1.25,14-1$ b. can $\$ 2,28-1$ b. pkg. $\$ 3.75,56-1 b$, pkg. $\$ 7.25$.

\section{Vaporizers}

Vaporizing Lamp, Defiance. Practical and indestructible; all metal; burns kerosene; used for dispensing fumes of nicotine preparations. $75 \mathrm{cts}$. each.

X-L-ALL Vaporizing Lamp. A lamp specially designed for vaporizing of X-L-All Compound. Small size, \$I.5O; larger size, \$I.75.

\section{Hydrometers}

For testing the specific gravity of lime-sulphur and other sprays. Price $\$$ I.25 (postpaid $\$ \mathbf{I} .40$ ). 
When cash accompanies your order for fertilizers listed below, in lots of 100 pounds or over, we prepay freight to your station if within 100 miles of New York, except where otherwise noted

There are two secrets of soil fertility: The soil must be correct mechanically and right chemically. Correct mechanically means that it should possess the proper framework-enough clay to form a 'body,' sufficient grit to allow moisture to seep downward during rainy weather and to encourage it to work upward during dry weather by capiliary action, and some remains of dead plants or humus to act as a sponge to hold moisture ready for the plant-roots to absorb it. Right chemically means that the soil contains the proper plant-foods in a condition easy for the plant to feed upon and in sufficient quantity to afford uninterrupted growth. You can make almost any soil mechanically correct and chemically right by the proper use of some of the materials listed on this and the following page.

\section{Sawco Special Colloidal and Bone Base Fertilizers}

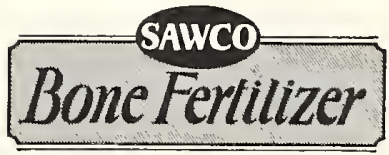

Mixed Fine and Coarse. (For general use.) This grade is recommended for the garden and for lawns. It is quick to give results, yet the benefits are lasting. The standard food for roses; much used on hay and pasture fields. Use I,500 pounds per acre or 5 ounces to the square yard, dug or raked into the soil; use one-half this rate when top-dressing grass. 5 lbs. 50 cts., Io lbs. 90 cts., 25 lbs. $\$ 2$, IOO lbs. $\$ 5.50,500$ lbs. $\$ 22.50$, ton $\$ 65$

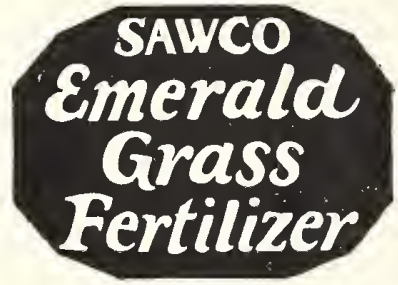

For lawns and golf puttinggreens. A well-balanced formula, designed to feed only the finer grasses and to keep them in a healthy condition. When building a lawn, from $\mathrm{I} / 2$ ton to $\mathrm{I}$ ton per acre $(3$ to 6 ounces to the square yard) should be harrowed or raked into the upper surface. Every spring and early autumn existing lawns may be given a dressing of 500 to $\mathrm{I}, 000$ pounds per acre ( $\mathrm{I} / 2$ to 3 ounces to the square yard); when applied as a top-dressing to turf, it is best to mix the Emerald Grass Fertilizer with four times its bulk of fine soil or sand before broadcasting. 5 lbs. 50 cts., Io lbs. 90 cts., 25 lbs. $\$ 2$, I OO lbs. $\$ 5.50$, 5 oo lbs. $\$ 22.50$, ton $\$ 75$.

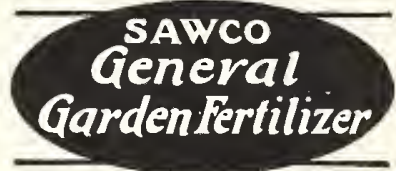

For vegetables, flowers, and fruit. Recommended strongly as the best for all-round work in the garden. Use it at the rate of 1, ooo pounds to the acre, or 3 ounces to the square yard when preparing land for planting in the spring. Good practice, too, is to spread General Garden Fertilizer between the rows of plants when they are growing and then to hoe it into the soil; use about 3 pounds per roo running feet for this, repeating every month. When planting beans, cucumbers, etc., in hills, a handful worked into the soil under the hill will be a great help, and the same thing may be done when planting tomatoes, cabbages, peppers, dahlias, peonies, etc. The soil immediately around roses may be whitened with General Garden Fertilizer and then raked. Before sowing seeds in rows a little General Garden Fertilizer may be placed in the drill and the soil stirred to $\operatorname{mix}$ it thoroughly. 5 lbs. 50 cts., Io lbs. $90 \mathrm{cts}$., 25 lbs. $\$ 2$, IOO lbs. $\$ 5.50$, 5 OO lbs. $\$ 22.50$, ton $\$ 75$.

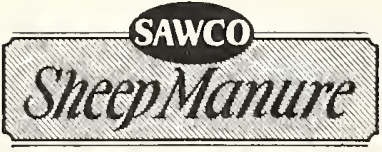

A pure, natural, nutritious, pulverized manure that is immediate and lasting in effect and excellent for mixing with the soil. It makes a rich liquid manure. Sawco Sheep Manure has been heated to a high temperature, expelling moisture and destroying weed seeds. 5 lbs. 50 cts., ro lbs. 90 cts., 25 lbs. $\$$ I.75, I oo lbs. $\$ 5,500$ lbs. $\$ 19$, ton $\$ 65$.

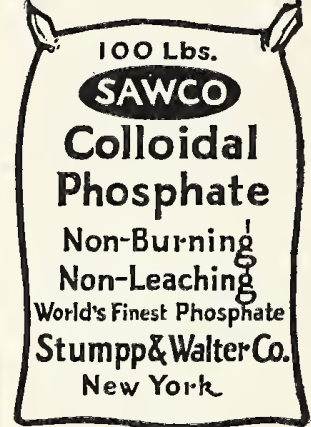

Will not harm vegetation, regardless of the amount used. Use it in addition to other fertilizers. It conserves nitrogen, the most valuable and essential plant-food, holds water, and gives it to the plants with least resistance. It contains many of the colloidal mineral elements most necessary to plant-life and production, and is a non-burning, non-leaching plant-food. Sawco Colloidal Phosphate gets down in the soil where the plant-roots absorb it. It regulates and increases the plant-food supply in the soil, and contains and produces carbon dioxide which the foliage of the plant takes up from the air and which builds 95 per cent of the plant-structure. It increases root-growth and resists drought, stimulates and increases the growth of bacteria in the soily discourages growth of weeds. Can be applied at any time, and is not affected by weather or time. A fine, odorless plant-food, pleasant to use, and free from harmful bacteria and weed seeds. Ioo lbs. $\$ 5,500$ lbs. $\$ 17.50,1,000 \mathrm{lbs}$. $\$ 30$, ton $\$ 50$, car-lots ( 5 to 20 tons) $\$ 40$ per ton.

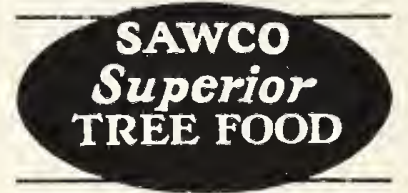

A highly concentrated, balanced fertilizer strongly recommended for shade trees, evergreens, and flowering shrubs. On evergreens and shrubs, broadcast lightly and rake well into the soil. Water immediately. For shade trees, punch holes in ground, about $\mathrm{I} 2$ inches deep and $\mathrm{I}$ inch in diameter, in circular formation, I 8 inches apart, directly under the farthest branch, and fill holes with the fertilizer, covering with soil. Do not apply near the trunk. Lb. $5^{\circ}$ cts., 5 lbs. $\$ 2,25$ lbs. $\$ 5$, Ioo lbs. $\$$ I 7.50 .

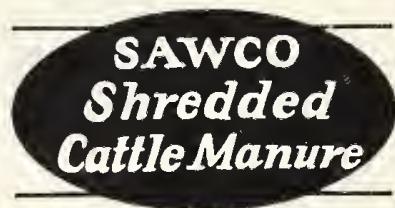

A soil-builder and ideal mulch that is especially recommended for crops in hot, sandy soils. Thoroughly incorporate with the soil. About 400 pounds of the concentrated material may be considered as equal in value to one ton of fresh cow-manure. Use from I to 3 tons to the acre; 6 to 20 ounces per square yard. IOO lbs. $\$ 5.50,500$ lbs. $\$ 22.50$, ton $\$ 70$.

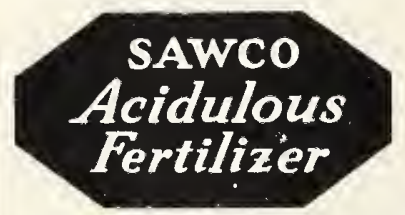

A plant-food and soil-acidifier for rhododendrons, $\mathrm{ka} l \mathrm{~m}$ i as, azaleas, mountain laurel, blueberries, cranberries, and many other acid-loving plants. Apply at the rate of $\pi / 4$ pound per square yard, and rake well into the soil. For best results, apply at least three times during the season. 5 lbs. $\$$ I.25, 25 lbs. $\$ 2.75$, Ioo lbs. $\$ 6.50,500$ lbs. $\$ 30$, ton $\$ 95$. 


\section{GENERAL LIST OF FERTILIZERS}

Adco. A culture of bacteria associated with the breaking down of organic materials. Add it to garden rubbish, leaves and grass clippings to hasten decay and quickly produce manure. 25 lbs. $\$ 2.25$, I50 lbs. \$10.50.

Aluminum Sulphate. Makes soil acid, and for this purpose is much used in the culture of rhododendrons and similar plants. 5 lbs. 75 cts., 25 lbs. $\$ 2.50$, I00 lbs. $\$ 7.50$.

Ashes, Canada Hardwood. These furnish potash. One to two tons per acre may be harrowed into land in winter or early spring. May be broadcast between rows of corn, potatoes, beets, carrots, etc., Io pounds per Ioo feet. Bbl. (about 200 lbs.) $\$ 6$, ton $\$ 45$.

Basic Slag. A slow-acting fertilizer, the effect of which is spread over several seasons; contributes phosphoric acid and lime to the soil. As a winter and early spring dressing is excellent for hay and pasture fields, alfalfa, clovers, grain, etc. Use I, 000 to 2,000 pounds per acre. I00 Ibs. $\$ 5,500$ lbs. $\$ 22.50$, ton $\$ 75$.

Blood, Dried. Adds nitrogen and a small amount of phosphoric acid and lime; much used for greenlouse plants, carnations, roses, and the like. Acts quickly. 5 lbs. 75 cts., 25 lbs. $\$ 2.75$, IOo lbs. $\$ 7$, $500 \mathrm{lbs}$. $\$ 30$, ton $\$ 100$.

Bone, Vineyard. These large particles of bone, averaging from $1 / 4$ to $1 / 2$ inch. make an ideal fertilizer for grape-vines and fruit trees. Apply liberally and thoroughly incorporate with the soil as deeply as possible. 25 lbs. \$1.75, I0o lbs. \$6, 500 lbs. \$27.50, ton $\$ 85$.

Charcoal. Sweetens and lightens sour and heavy soils; helps to dry out wet land. Frequently used for lawns on soils of this character. 50 lbs. $\$ 2.50$, IOo lbs. $\$ 4.50$, 500 lbs. $\$ 20$, ton $\$ 65$.

Clay's Fertilizer. Has a splendid reputation for flowers, vegetatles, and fruit. Two to 4 ounces to the square yard, raked into the soil around the plants. 7 lbs. $\$ 1.50$, I 4 lbs. $\$ 2.25,28$ lbs. $\$ 4,56$ lbs. $\$ 7$, I 2 lbs. \$ I 2 .

Cottonseed Meal. Rich in nitrogen and potash; suitable for grain crops, but most largely used on lawns. Use $3 / 4$ to $\mathrm{I} 1 / 2$ tons per acre. Ioo lbs. \$5, 500 lbs. $\$ 22.50$, ton $\$ 75$.

Floranid (Urea). The most highly concentrated nitrogenous fertilizer in commerce, contains 46 per cent of available nitrogen, and leaves no harmful residue in the soil. A quick-acting stimulant for lawns, vegetables, fruits, and flowers. Allow 2 ounces per square yard in the garden, $1 / 2$ ounce per square yard on the lawn; in the latter case it must be mixed with four times its bulk of fine soil or sand. Lb. 50 cts., 5 lbs. $\$ 2$, Io lbs. $\$ 3,25$ lbs. $\$ 5$.

Gypsum or Land Plaster. Widely used as a dusting for the manure pile to $\mathrm{fx}$ and hold nitrogen. When applied to land it furnishes lime without giving the soil an alkaline reaction. From one to three tons per acre may be given. Ioo lbs. $\$ 2.50$, 500 lbs. $\$$ Io, ton $\$ 35$.

Humus. Furnishes but little plant-food; highly valuable, however, as a soil ingredient, improving its texture and increasing its water-holding properties. May be used freely. Ioo lbs. will cover 80 square feet I inch deep. Shipped in bags, Io lbs. 75 cts., 50 lbs. $\$ 2$, bag (100 lbs.) \$3, 5 bags (500 lbs.) $\$ 12.50,20$ bags (I ton) $\$ 35$. In bulk in carload lots, minimum 20 tons, \$IO per ton, f.o.b. plant.
Lawn Sand, Climax. Imported. A concentrated fertilizer used for killing certain weeds in lawns, especially chickweed and mouse-ear. Applied thickly to weed patches, or generally over the grass at the rate of 6 ounces to the square yard. $3^{2} / 2-$ 1b. can 65 cts., 7 -lb. can $\$$ I. 25 , I4-lb. can $\$ 2,28$-lb. pkg. $\$ 3.75,56$-lb. keg $\$ 7.25$.

Lime, Agricultural Hydrated. Corrects acid conditions of the soil and at the same time is a plant-food. Binds loose soils and, curiously enough, opens heavy land. Quick acting. Use from I to 3 tons per acre; 6 to I8 ounces to the square yard. As a winter dressing to sweeten lawns, broadcast I ton to the acre or 6 ounces per square yard. 5 lbs. 35 cts., 25 lbs. $\$$ I.25, I oo lbs. $\$ 2.75,500$ lbs. $\$ 9.50$, ton $\$ 30$.

Muriate of Potash. Excellent for potatoes, corn, grains, etc. Use from 350 to $75^{\circ}$ pounds per acre. 5 lbs. $\$ 1,25$ lbs. $\$ 2.50$, Ioo lbs. \$7.

Nitrate of Soda. A plant stimulant. Add nitrogen in a form which is immediately available to the plants. Forces a heavy, succulent growth in lettuce and similar leaf vegetables. Use it sparingly and with great care; not more than $I \frac{1}{2}$ ounces per square yard, or 500 pounds to the acre. rakec or harrowed in. As a liquid fertilizer one ounce may be dissolved in one gallon of water. Lb. $25 \mathrm{cts} ., 5 \mathrm{lbs} .75 \mathrm{cts}$., 25 lbs. $\$ 2$, I0o lbs. $\$ 6,500$ lbs. $\$ 25$, ton $\$ 80$.

Pulverized Poultry Manure. An excellent fertilizer, rich in plant-food, for all garden crops. Dig in 3 to 16 ounces per square yard, or $1 / 2$ to $2 \frac{1}{2}$ tons to the acre. IOO lbs. $\$ 4.50,500 \mathrm{lbs}$. $\$ 17$, ton $\$ 60$.

Salt, Agricultural. Occasionally used as a top-dressing for asparagus. Also effective as a weed-killer on roadways, paths, etc. IOo 1 bs. $\$ 2.25,500 \mathrm{lbs}$. $\$$ Io, ton $\$ 35$.

Scotch Soot. A valuable plant-food. On grass, or dusted around vegetables or on the plants themselves, it discourage caterpillars, slugs, grubs, wireworms, cutworms and earthworms. I I 2-lb. bag $\$ 7$, 5 bags $\$ 30$, ton \$100.

Stim-U-planT. Fertilizer in tablets. These may be placed in the soil around plants, in flower pots, or dissolved in water for liquid fertilizer. 30 tablets $25 \mathrm{cts}$., postpaid $30 \mathrm{cts}$.; Ioo tablets $75 \mathrm{cts}$., postpaid 85 cts.; I, ooo tablets $\$ 3.50$, postpaid $\$ 3.65$.

Sulphate of Ammonia. A nitrogenous plant stimulant, very quick in action, tending to make soil acid. Increases leafgrowth. Much used on lawns, which it not only feeds, but weeds are discouraged: when top-dressing lawns apply I ounce per square yard or $35^{\circ}$ pounds to the acre but first mix with several times its bulk of soil or sand. 5 lbs. 75 cts., 25 lbs. $\$ 2.50$, Ioo lbs. $\$ 7$.

Sulphate of Potash. Highly recommended for all acid-loving plants such as rhododendrons, azaleas, kalmias. Sprinkle around plants and water in thoroughly. 5 lbs. \$I, 25 lbs. $\$ 2.50$, Ioo lbs. $\$ 7$.

Super-Phosphate. Adds phosphoric acid and a small quantity of lime. From $75^{\circ}$ to 1,500 pounds may be applied to an acre of plowed land. Ioo lbs. $\$ 2$, ton $\$ 27.50$.

Tankage (Blood and Bone). Similar in general effect to bone-meal, yielding lime and phosphoric acid. Used largely by greenhouse men. Apply 3 ounces per square yard ( 1,000 pounds to the acre) and rake in. Ioo lbs. $\$ 4.50,500$ lbs. $\$ 22.50$, ton $\$ 80$.
Tobacco Fertilizer. For lawns, vegetables, and farm crops. In addition to its value as a fertilizer, it discourages many soil-pests, such as beetles, ants, cutworms and snails. A slow-acting fertilizer, rich in potash. Use from $2^{1 / 2}$ to $3^{1} / 2$ tons per acre, I to $I^{I / 2} \mathrm{lbs}$. to the square yard. Ioo $1 \mathrm{bs}$. $\$ 4,500$ lbs. $\$ 17$, ton $\$ 60$.

Tobacco Stems. Placed around the roots of roses and other plants; occasionally recommended as a dressing for grass over winter. Feeds the plants, protects against cold, retains moisture, deters insects. Use from $2 \frac{1}{2}$ to $3 \frac{1}{2}$ tons per acre; I to $\mathrm{I} / 2$ pounds to the square yard. Ioo lbs. $\$ 5$, 500 lbs. $\$ 20$, ton $\$ 60$.

Thomson's Special Flower, Vegetable and Vine Manure. Imported. An excellent all-round fertilizer that is a great favorite with the private gardener. I4 lbs. $\$ 1.75,28$ lbs. $\$ 3,56$ lbs. $\$ 5.50$, I I 2 lbs. $\$$ Iò.

Nitrogen-Fixing Bacteria for All Leguminous Plants

\section{STIMUGERM}

\section{Small Garden Unit. A composite} culture of the bacteria essential for the growth of Peas, Beans, and Sweet Peas. Unit $25 \mathrm{cts}$., post paid $35 \mathrm{cts}$.

Large Seed Units. Culture of bacteria for Garden Peas. Beans, Sweet Peas, Peanuts, Vetches, and Field Peas. I/2-bus. size $35 \mathrm{cts}$., bus. $60 \mathrm{cts}$., 5-bus. size \$2.25. When ordering, state the crop for which Stimugerm is required.

Clover Units. Culture of bacteria necessary for the growth of Alfalfa and all Clovers. Sufficient to treat $1 / 4$ bus. of seed 35 cts., $1 / 2$-bus. size $60 \mathrm{cts}$., bus. size $\$ I, 21 / 2$-bus. Size $\$ 2.25$. When
ordering state the Clover for which Stimugerm is required.

\section{Leaf-Mold, Moss and Peat}

Sawco Leaf-Mold. Used for preparing rhododendron beds and as an ingredient in potting soil. Box ( bags) $\$ 60$

Moss, Sheet, Natural Green. For covering pots or tubs, for decorating the conservatory, rock-garden, etc. Bag (Io lbs.) \$5.

Moss, Dry Sphagnum. For wrapping around plant roots, orchid-growing, covering conservatory soil, etc. Large bale $\$ 4$.

Peat, Osmundi. For orchid-growing. Bbl. $\$ 5$.

Potting Soil. A fine mixture of loam, leafmold, and sand. Suitable for house plants, ferns, etc.; excellent for growing bulbs. $\mathrm{Pk}$. \$I, bus. \$2.50.

Sawco Peat Fiber. A regetable product which remains in the soil for many years without decaying; in the meanwhile it absorbs moisture and holds it for the plants. Its presence in the top layer of a lawn adds materially to the resilient carpet-like feel of good turf. As a mulch around the roots of plants it is excellent. May be used freely. Large bale, I2 cubic feet (about I 75 bs.), $\$ 5$; in lots of 5 bales, $\$ 4.50$ per bale; in lots of Io bales, $\$ 4$ per bale. (Write for prices on carload lots.) Small sample bale (about 20 lbs.) \$I.75. 


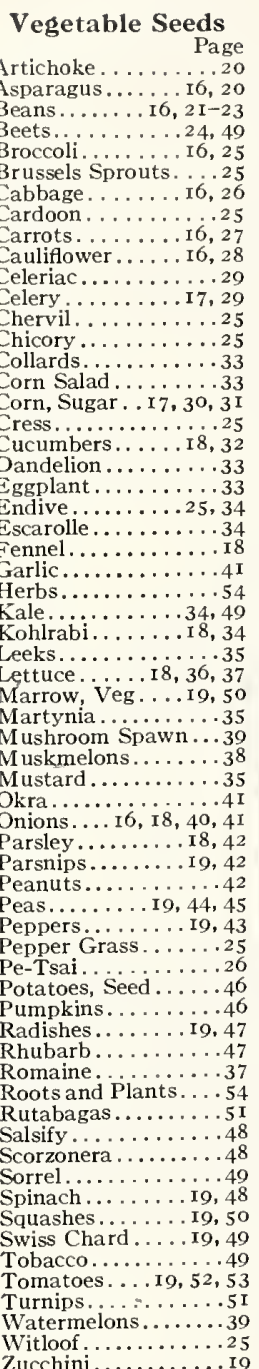

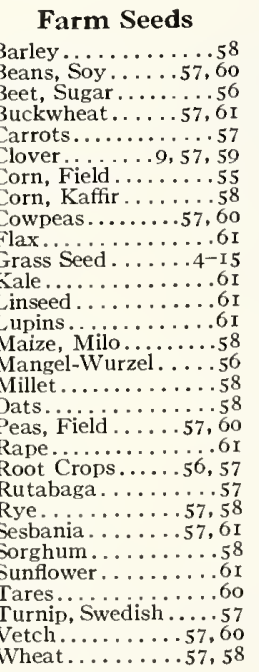

Flower Seeds

Abronia.

Abutilon.

Achillea.

Aconitum
Page

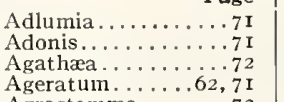

Agrostemma......... 72

Alyssum........

Amaranth, Ġlobe.... . .92

Amaranthus........7\% 72

Anchusa ............ 72

Anthemis. . .

Antirrhinum.......62, 77

Apple, Balsam..... I 00
Aquilegia.........

Arabis.....

Arenaria....

Argemone.

Armeria.

Asclepias.

Asparagus...

Asters. . 62, 74-76, rI 3

Astermums........75

Baby's Breath .

Bachelor's Button ...8 80

Balloon Vine........78

Balsam ...........78

Baptisia .............7. 78

Bartonia . . . . . . . .78
Bean, Hyacinth....90

Beet, Ornamental . . I 2 I

Begonia ..........
Bellflower..... 82, Io8

Bellis............. I . 8

Black-eyed Susan... II

Blanket Flower .....9

Blazing Star......
Bluebells......

Bocconia ......... 8I

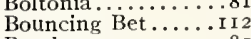

Brachycome......8 8

Browallia .......... 8 I
Butterfly Flower... I 22

Cacalia ............8

Calceolaria ......62, 82
Calendula.....62,81

Calendula $\ldots \ldots \ldots 62,81$
Calliopsis ...62, 79,81
Campanula .....63,82

Campanula ......63.82
Campion, Rose .....72
Canary-bird Flower..82

Canary-bird Flower..82

Canterbury Bells....82

Cardinal Climber ...82
Carnation.......73.82

Carnation .........73.88
Castor-oil Plant .....83
Catananche.......8 85

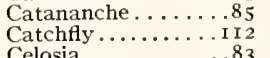

Celosia....

Centaurea.

Chamomile, False...8

Cheiranthus.......63

Cherry, Jerusalem. . II 2

Chrysanthemum . 63, 85
Cigar Plant.........85

Cineraria............85

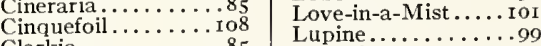

Clarkia............85 $\quad$ Lychnis.............99

Cobæa...........85 Lythrum.........96,999

Cockscomb.......83

Columbine..........72
Coneflower....... I I I

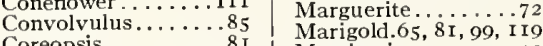

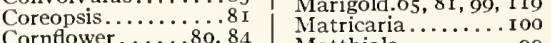

Cosmos..........8.86

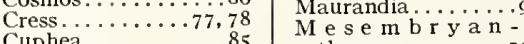

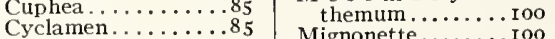

Cynoglossum........85

Cypress, Summer...97
Cypress Vine......89

Cypress Vine. . . . . .89

Dahlia...... $2.63,89$
Daisy ....63, 64, 72,76

77,81, 85, 89,90 Moonflower...........97

Delphinium........63,87

Dianthus...... 88, I I 3

Diascia............ 89
Dictamnus.......89

Didiscus ............ 89
Digitalis..... 69,89

Dimorphotheca .....89
Nemophila

Page
IOI

Nicotiana....

Nolana............. 10

Oak, Silk.........92

Enothera

Painted Tongue I04, I I I

Pansy........ 105, I 20

Papsion Filower.... . 107 109

Pear, Balsam ...... I00
Pentstemon...65, 107

Periwinkle........ I I9
Petunia....65, I03, I06

Petunia....65, I03, I06
Phacelia.......... I07

Phlox ............... I07, I53

Physalis........... I07
Physostegia....... I08

Pink .........72, 77,88

Platycodon ........ I08
Poinsettia, Annual...9I

Poinsettia, Annual...

Polyanthus....... ${ }^{108}$

Poppy .. $3 \ldots . .64,66$
Portulaca $1,90,97$, 109
Pog

Portulaca.........

Primrose.. IoI, I Io, II3

Primula....65, 108, I I0

Pyrethrum......... I Io

Queen Anne's Lace
Flower......... 89

Flower........... 89
Ramondia........ III

Ranunculus..........66 66

Red-HotPokerPlant in 19

Rehmannia........ I I I

Rhodanthe....... I2I

Ricinus $\ldots \ldots \ldots \ldots .83$
Rudbeckia.......... I I I

Rue, Meadow....... I 19

Sage, Scarlet....... I I I

Salpiglossis.... I04, I I

Salvia........66, I I I

Saponaria............ II

Saxifraga............ I I

Scabiosa...66, i i 2 , i 18

Schizanthus......... I I 2

Senecio....

Sensitive Plant...... 1 oo

Sidalcea........... II 2

Silene............ I I

Snapdragon ......62, 77

Sneezewort.......7 7 , 95

Solanum ........... I I 2
Spider Flower...... 85

Spider Flower......85

Stevia ............. II

Stock...66, 99, 1 I3, I 20

Stokesia........... II 3

Streptocarpus........ II

Sunflower.......64, 95

Sweet Peas.70, II I $^{-1}$ I 7

Sweet Peas.70, II $4-117$
Sweet Pea, Everlast-

ing. ..........97

Sweet Scabious.... II 2

Sweet Sultan........84

Sweet Woodruff......78

Tagetes.

Thalictrum.......... II

Thermopsis ........ II

Thistle, Globe .......90

Thoroughwort...... 90
Thunbergia ......... I I9

Thymus............. II

Thyme............ I I9

Torenia............ II9
Tritoma....... I I9, I 53

Trollius........... I I9

Tropæolum.........82
Ursinia............66

Valerian...............

Verbascum........ I I9

Verbena......68, 69, I19
Veronica.......... I I9

Veronica.......... I I9
Vinca ........... I I9

Viola ............ I20

Viscaria............ I 19

Wallflower...63, 69, 120

Windflower.........72

Woolflower, Chinese.83

Xeranthemum...... I2 I
Zinnia......67,69, I20
Bulbs and Plants

Apios............ Page

Begonias ............127

Caladium........... 127

Callas............ 127

Cannas....... 122, 123

Dahlias....... 136-1 42

Dicentra.......... I27

Dielytra $\ldots \ldots \ldots \ldots$ I27

Gladiolus...... I30-135

Gloxinias............ I2

, Summer. 128

Lilies ...... Valle... I 29

Madeira Vine..... . I 28

Mignonette........... I28

Montbretias........ I28

Pæonia............... I 5

Peonies............ I 52

Phlox....

Roses....

Tritoma

Tuberose

i $43-15$

Climbing Plants

Akebia ............ 156

Aristolochia .......... I56

Bignonia...

Bittersweet......... I56

Clematis.

Dutchman's Pipe ... I56

Euonymus......... 156

Honeysuckle.......... I5 6

Polygonum............. 156

Silver Lace Vine .... I I56

Trumpet Vine....... I56

Virginia Creeper.... I 56

Waxwork..........156

\section{Shrubs}

Abelia ............. I 54

Almond, Flowering. I54

Althæa............. I54

Azalea.............. I57

Barberry.......... I54, I55

Beauty Bush...... I55

Berberis............ I5

Buddleia ........... I5

Butterfly Shrub.... I5

Calycanthus......... I5

Cerasus.......... I5

Cherries, Jap. Fl.... I 54

Cornus.....

Crab. Flowering..... I5

Cranberry .......... I5

Cratægus

Cydonia

Deutzia.........

Forsythia

Hedge Plants....... I5

Honeysuckle........ I5

Hydrangea ......... I5

Kerria

Kolkwitzia...........155

Ligustrum......... 55

Malus...............

Mock Orange....... I5

Morus............. I55
Mulberry........ I55

Muiberry ............ I55

Pieris........... I57

Plum, Flowering . . . I55

Prunus............. I55

Quince, Flowering...155

Rose of Sharon.... I 54

Snowball............155

Strawberry Shrub...I54

Symphoricarpos..... I55

Syringa............ I55

Viburnum.......... I 55
Weigela........... I55

Fruits

Blackberries....... Page

Currants........... I58

Grape-vines......... I58

Implements and

Miscellaneous

Barrows .......... I60

Baskets....... I6 5, I67

Bellows......... I79

Bleaching Tubes.... I6I

Books .... 3d Cover, 56

Boots, Horse...... I 7 I

Boxes, Flower...... I64

Cart, Platform....... I60

Crow Repellent..... 58

Cultivators I 59, I62, 163

Dibbles........... I6
Digger........... $6_{3}$

Duster, Powder...... I 79

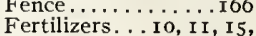

$35,43,182,183$
Flower-Boxes. . . . I 64

Forks........... I62, I63

Garden Supplies.... I6I, I68, I69

Glazing Materials.. I68

Golf Supplies....... I 72

Grass Hooks....... 163

Harrows ........ I4, I60
Hoes......... I62, I63

Hose Supplies...... I76

Hose, Rubber... 7 76, I 79

Hotbed Frames.... I68
Hotkaps........... I59

Hydrometers......... I 8 I

Insecticides, Fungi-

cides... 8, 9, I80, I8I

Knives.... 162, 163, I68

Labels............. I68

Lawn Mowers . I 70-1 72

Lawnette.......... I60

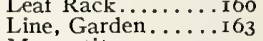

Mag-o-tite ......... 35

Mat, Kneeling...... I67

Mulch Paper....... I6 I

Nozzles, Hose ...... I 76

Pans, Bulb or Seed. . I64

Perforator, Sod I62, I

Garden Toois .... I 59

Plant Stakes....... I69

Plant Supports . . . . I69

Pluws............. I59

Poles, Spray ........ I 78
Pots, Flower, etc.... I6 4

Pruners .......... I75 


\section{SPECIAL ORDER SHEET for Colored Illustrations-Spring Catalogue, 1931}

We, Stumpp \& Walter Co., give no warranty, express or implied, as to description, quality, productiveness, or any other matter of any seeds, bulbs, or plants we send out, and will not be responsible for the crop.

\section{STUMPP \& WALTER CO.} 30 and 32 Barclay St., New York

Date 1931

AMOUNT ENCLOSED

Name

P. O. Box, Street

or Rural Delivery

Post Office.

State

\section{Station or Express Office}

Send by

Only if different from Post Offce

Superintendent or Gardener

Stale if wanted by Mail. Express, or Freight

That we may enter for catalogues

SPECIAL COLLECTION OFFERINGS - Flower Seed, Iris, Cannas, Gladiolus, and Dahlias

We have enumerated below numerous varieties of Flower Seed, Iris, Cannas, Gladiolus, and Dahlias which we have illustrated in color in our catalogue this year. Our idea in doing this on a separate order sheet is to make it easier for you to order them.

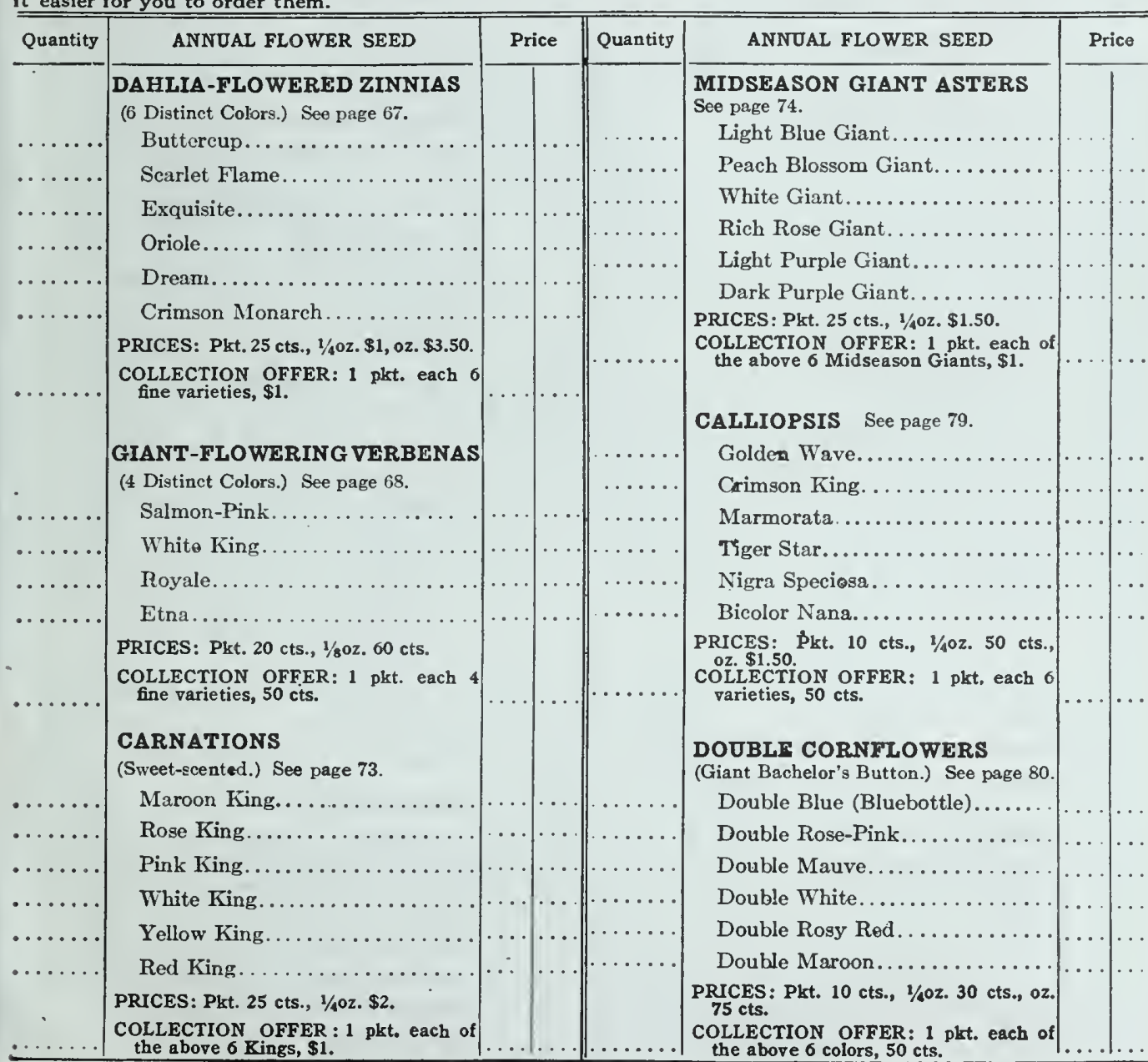




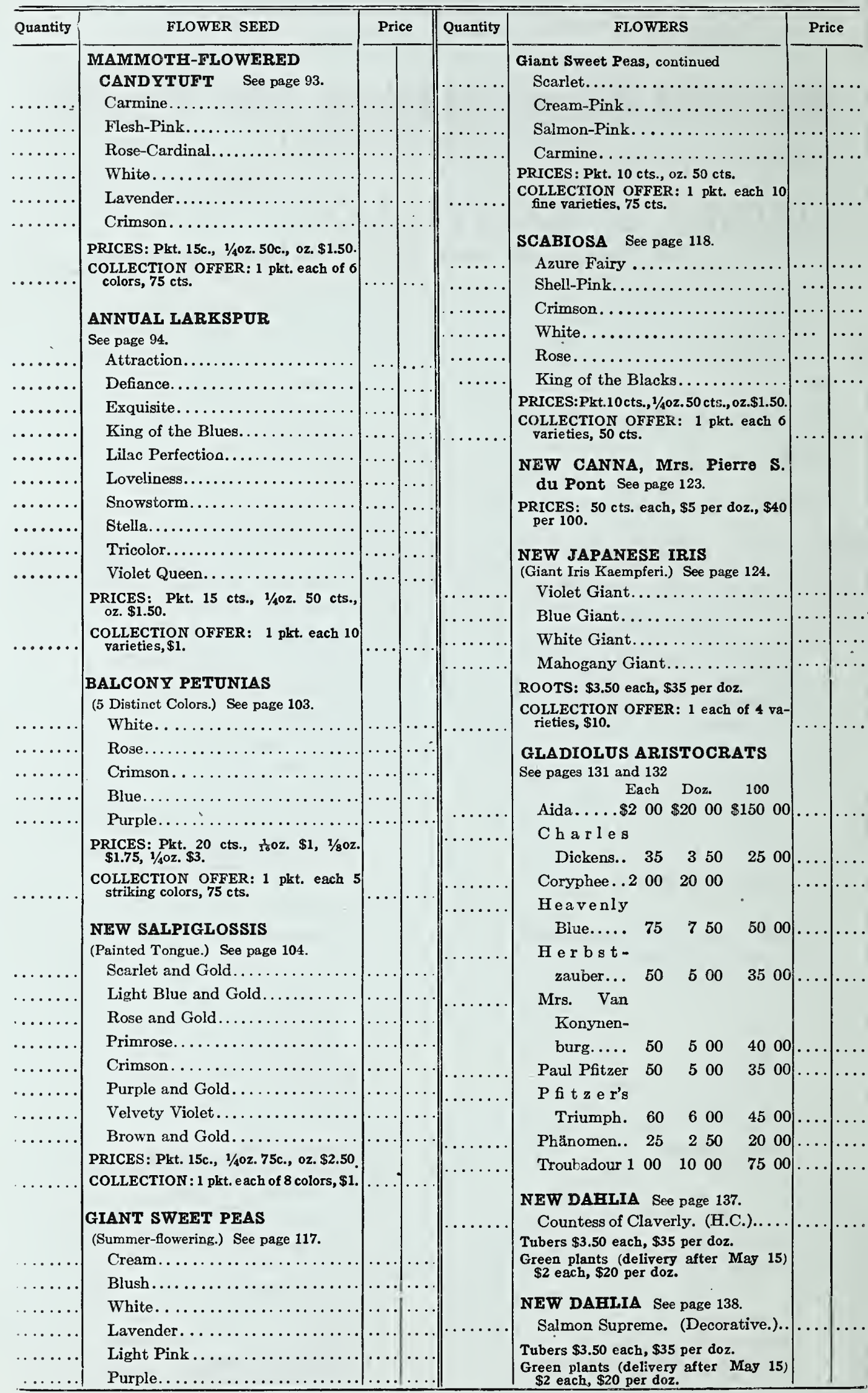




\section{ORDER SHEET-Seeds, Bulbs, Garden Supplies-Spring Catalogue, 1931}

We, Stumpp \& Walter Co.. give no warranty, express or implied, as to description, quality, productiveness, or any other matter of any seeds, bulbs, or plants we send out, and will not be responsible for the crop.

\section{STUMPP \& WALTER CO.} 30 and 32 Barclay St., New York

Dale 1931

AMOUNT ENCLOSED $\$$

Name

P. O. Box, Street

or Rural Delivery

Post Office State

Station or Express Office

Only if different from Post Office

Send by

Superintendent or Gardener

State if wanted by Mail. Express or Freight

That we may enter for Catalogues

Please use Special Order Sheet for Roses and other plants listed on pages 143 to 158 inclusive.

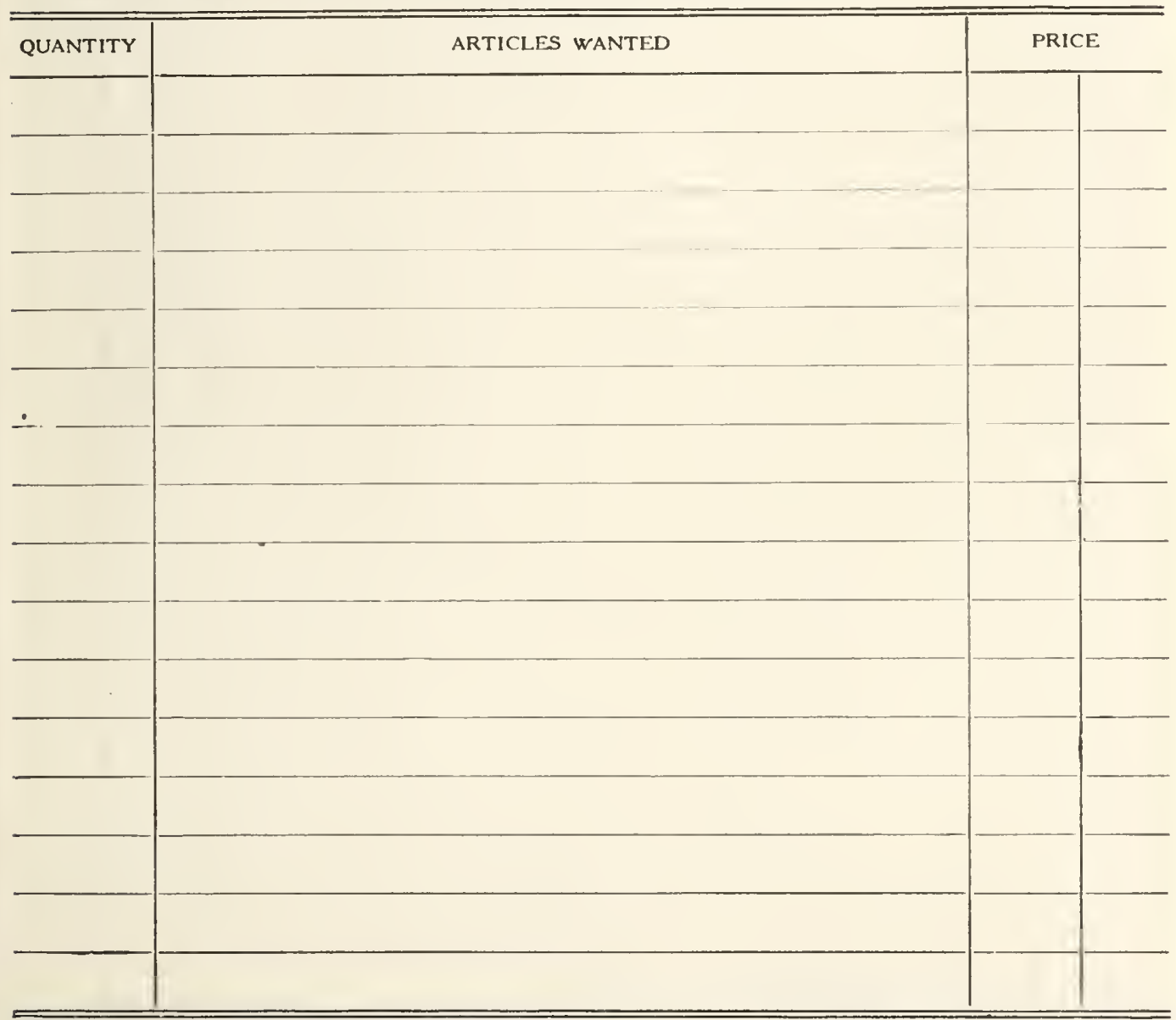




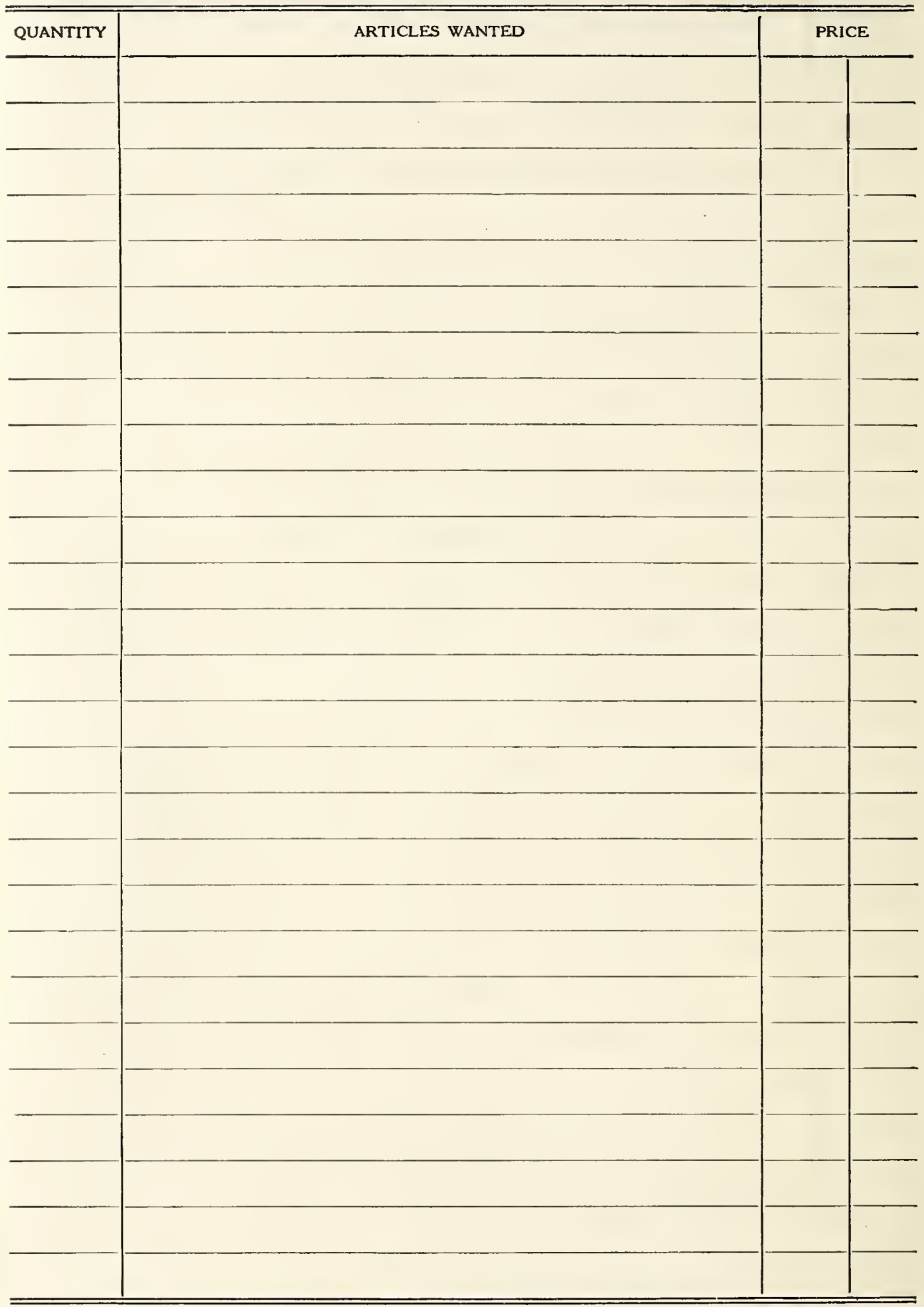

STUMPP \& WALTER CO., 30-32 Barclay St., New York ISES AND OTHER PLANTS LISTED ON PAGES 143 TO 158 INCLUSIVE 


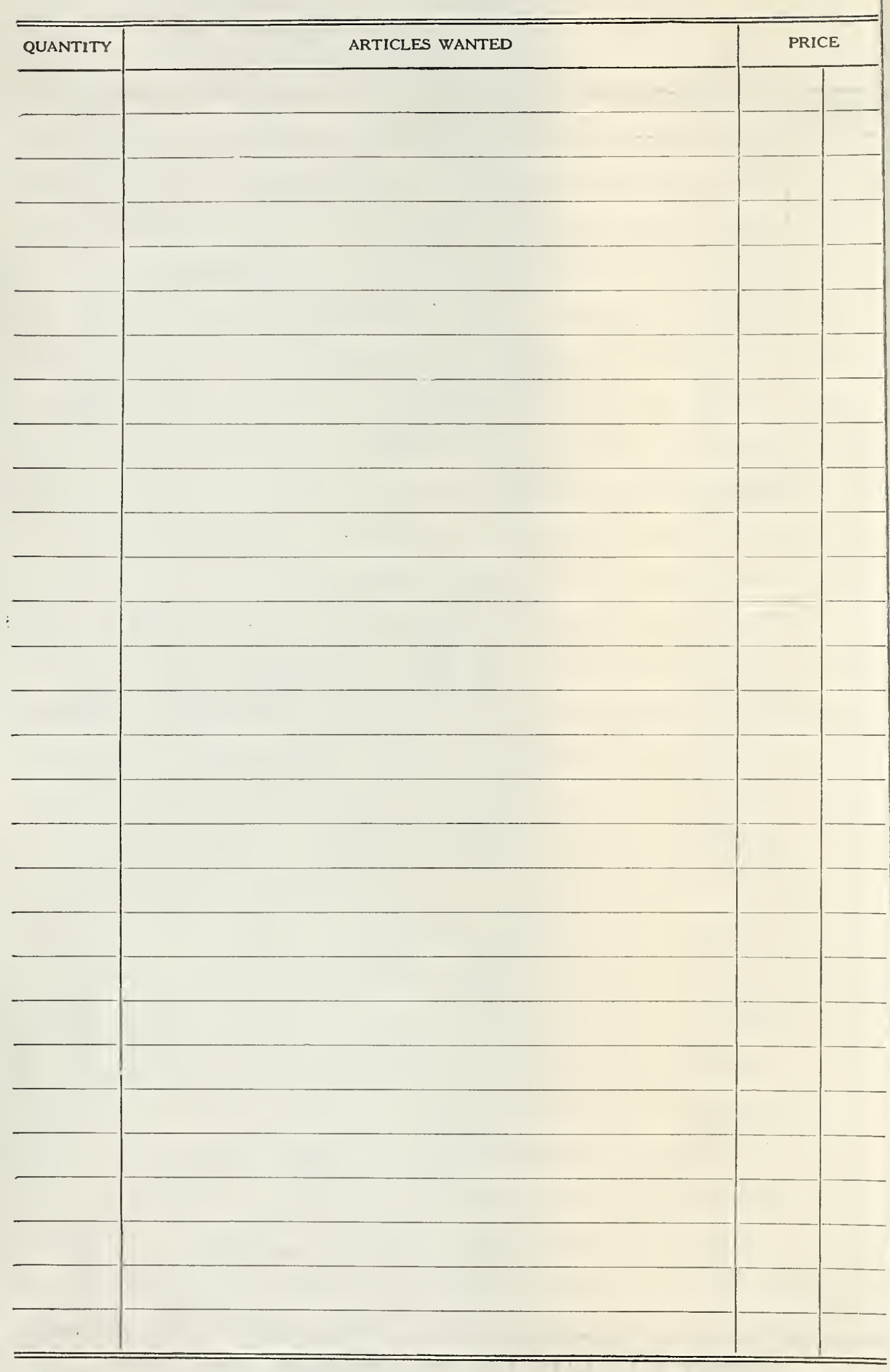




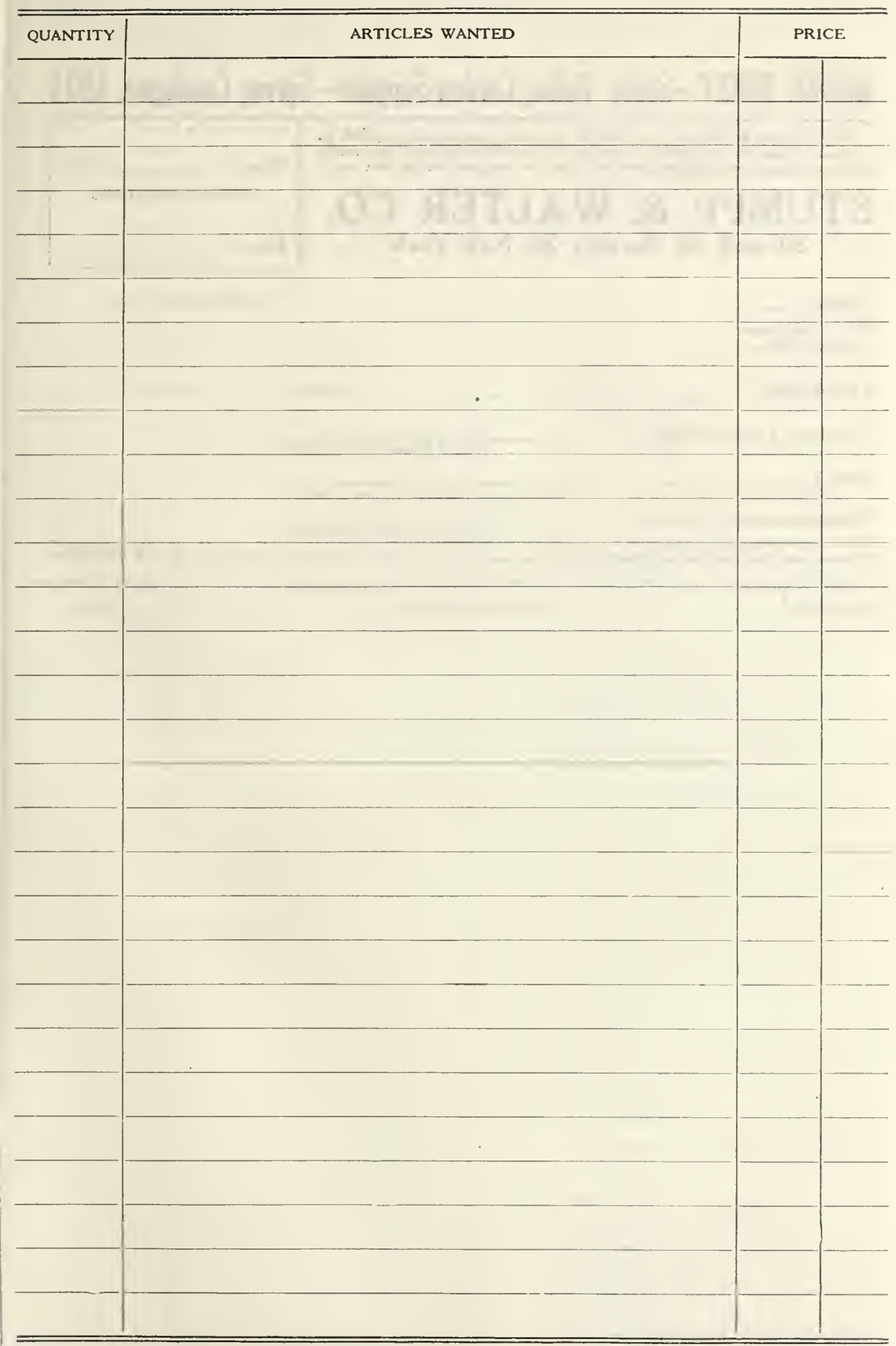

IAME AND ADDRESS ON FRONT PAGE

ficial Order Sheets for Roses and other plants listed on pages 143 to 158 inclusive. 


\begin{tabular}{|c|c|c|c|c|c|}
\hline Quantity & - & Price & Quantity & & Price \\
\hline & $\begin{array}{l}\text { German Iris, continued } \\
\text { Rhein Nixe ...... }\end{array}$ & & & $\begin{array}{l}\text { New Hybrid Tea Roses, continued } \\
\text { Mrs. Sam MeGredy ......... }\end{array}$ & \\
\hline & Seminole............... & & & Polly .................... & \\
\hline & Shekinah................ & & & Rosella............... & \\
\hline & Sherwin Wright........... & & & Rudolph Valentino......... & \\
\hline & Souv. de Mme. Gaudichau. . & & & Schwabenland........... & \\
\hline & Susan Bliss............. & & & Vaterland............... & \\
\hline & White Knight............. & & & HYBRID TEA ROSES $\begin{array}{l}\text { (See pages } \\
148,149 .)\end{array}$ & \\
\hline & $\begin{array}{l}\text { SIBERIAN IRIS. (See page } 126 .) \\
\text { Emperor } \ldots \ldots \ldots \ldots \ldots \ldots \ldots\end{array}$ & & & $\begin{array}{l}\text { Betty } \ldots \ldots \ldots \ldots \ldots \ldots \ldots \\
\text { Betty Uprichard } \ldots \ldots \ldots \ldots \ldots\end{array}$ & \\
\hline & Perry's Blue...$\ldots \ldots \ldots \ldots \ldots$ & & & Columbia ............... & \\
\hline & Siberian Blue............. & & & Constance ........... & \\
\hline & IRIS PUMILA. (See page 126.) & & & Dame Edith Helen . . . . . . . & \\
\hline & Excelsa................ & & & Double White Killarney..... & \\
\hline & Sambo............... & & & Duchess of Wellington...... & \\
\hline & Schneekuppe........... & & & Edel................... & \\
\hline & $\begin{array}{l}\text { EVERBLOOMING ROSES } \\
\text { (See pages 143-149.) }\end{array}$ & & & Etoile de Hollande. ......... & \\
\hline & NEW ROSE. (See page 143.) & & & Looymans & \\
\hline & Miss Rowena Thom ............ & & & Frank Reader............ & \\
\hline & 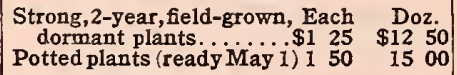 & & & n............. & \\
\hline & 5 NEW EVRR BLOOIMING & & & Hadley................. & \\
\hline & $\begin{array}{r}\text { ROSES: A (See page } 1 \\
\text { Edel ................. }\end{array}$ & & & John Russell. ............ & \\
\hline & Rev. F. Page-Roberts... & & & Kaiserin Auguste Viktoria. . . & \\
\hline & Dame Edith Helen...... & & & Lady Margaret Stewart.... . & \\
\hline & John Russell. . . . . . & & & Los Angeles.............. & \\
\hline & Wilhelm Kord & & & Margaret McGredy......... & \\
\hline & FER: One plant each & & & Mevrouw G. A. van Rossem . & \\
\hline & of 5 varieties, $\$ 4$. & & & Miss Lolita Armour..... & \\
\hline & $\begin{array}{c}4 \text { N EW EVE R B L O O OM I N G } \\
\text { ROSES: B (See page } 145 \text {.) }\end{array}$ & & & Miss Rowena Thom..... & \\
\hline & Mrs. Henry Bowles............. & & & Mme. Butterfly........ & \\
\hline & Talisman................ & & & Mme. Caroline Testout..... & \\
\hline & Mevrouw G. A. van Rossem.... & & & Mme. Edouard Herriot...... & \\
\hline & Etoile de Hollande. ........... & & & Mrs. A. R. Barraclough. ... & \\
\hline & One plant each & & & Mrs. Aaron Ward.......... & \\
\hline & $\begin{array}{l}\text { of } 1 \text { varieties, } \$ 4.50 \text {. } \\
\text { FINEST CLIMBING ROSES: C }\end{array}$ & & & Mrs. Erskine Pembroke Thom. & \\
\hline & $\begin{array}{l}\text { (See page 146.) } \\
\text { (SilliNG RUSHS: C }\end{array}$ & & & Mrs. Henry Bowles......... & \\
\hline & New Dawn................ & & & Mrs. Henry Morse....... & \\
\hline & Paul's Scarlet Climber....... & & & Mrs. Lovell Swisher...... & \\
\hline & Chaplin's Pink Climber. ........ & & & Norman Lambert.... & \\
\hline & COLLECTION OFFER: One plant each & & & Ophelia ................ & \\
\hline & & & & President Herbert Hoover... . & \\
\hline & $\begin{array}{l}20 \text { NEW HYBRID TEA ROSES } \\
\text { (See page 147.) }\end{array}$ & & & Radiance................ & \\
\hline & Betty Sutor . . . . . . . . . . & & & & \\
\hline & Caledonia........... & & & Rev. F. Page-Roberts......... & \\
\hline & Charles P. Kilham. . . . . . . & & & Souvenir de Claudius Pernet... & \\
\hline & Dr. Edward D & & & Souvenir de Georges Pernet... & \\
\hline & Gladys Benskin............ & & & Talisman................ & \\
\hline & Impress................ & & & Ville de Paris... & \\
\hline & $\mathrm{Jar}$ & & & Wilhelm Kordes... & \\
\hline & & & & CLIMBING AND RAM & \\
\hline & & & & ROSES (See page 150.) & \\
\hline & Jules Gaujard. . . . . . . . . & & & & \\
\hline & Lady Barnby............... & & & American Pillar......... & \\
\hline & Lady Forteviot. . & & & Bonfire.............. & \\
\hline & Lucie Marie..... & & & Chaplin's Pink Climber........ & \\
\hline & Monarch............... & & & Climbing American Beauty.... & \\
\hline & Mrs. John Bell ............ & & & Dorothy Perkins........... & \\
\hline
\end{tabular}




\begin{tabular}{|c|c|c|c|c|c|}
\hline Quantity & & Price & Quantity & & Price \\
\hline & $\begin{array}{l}\text { Climbing and Rambler Roses, cont'd } \\
\text { Dr. W. Van Fleet . . . . . . . . . . }\end{array}$ & & & $\begin{array}{l}\text { Herbaceous Peonies, continued } \\
\text { Susanne Dessert........... }\end{array}$ & \\
\hline & Emily Gray.................. & & & Red Shades & \\
\hline & Gardenia................. & & & Dr. H. Barnsby........... & \\
\hline & Jacotte................. & & & Felix Crousse............ & \\
\hline & New Dawn................ & & & Karl Rosenfield........... & \\
\hline & Paul's Scarlet Climber......... & & & Marquis C. Lagergren...... & \\
\hline & Primrose.................. & & & Rudyard Kipling.......... & \\
\hline & Silver Moon................ & & & War.................. & \\
\hline & Tausendschön .............. & & & Single Peonies & \\
\hline & HYBRID PERPETUAL ROSES & & & L'Etincelante... & \\
\hline & $\begin{array}{l}\text { (See page 151.) } \\
\quad \text { Frau Karl Druschki ........... }\end{array}$ & & & Nymphe.............. & \\
\hline & General Jacqueminot........... & & & Othello................ & \\
\hline & Georg Arends.......... & & & Yeso....................... & \\
\hline & Juliet................. & & & HARDY PHLOX (See page 153.) & \\
\hline & Magna Charta ......... & & & 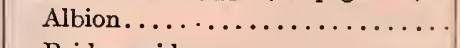 & \\
\hline & Mme. Albert Barbier... & & & Bridesmaid .............. & \\
\hline & Paul Neyron............. & & & Commander............. & \\
\hline & 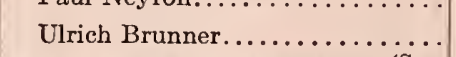 & & & Elizabeth Campbell ....... & \\
\hline & & & & Ethel Pritchard.......... & \\
\hline & $\begin{array}{l}\text { MISCELLANEOUS ROSES p.151.) } \\
\text { F. J. Grootendorst. ............ }\end{array}$ & & & Maid Marion........... & \\
\hline & Pink Grootendorst. .............. & & & La Vague.................. & \\
\hline & 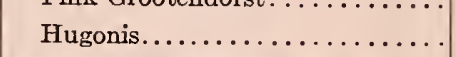 & & & Mrs. Milly Van Hoboken ..... & \\
\hline & BABY RAMBLER or POLY- & & & Obergartner Reichenau ....... & \\
\hline & & & & Rose Queen............ & \\
\hline & $\begin{array}{l}\text { Cecile Brunner } \ldots \ldots \ldots \ldots \ldots \\
\text { Orleans....................... }\end{array}$ & & & Rynstroom .............. & \\
\hline & 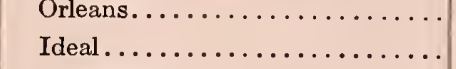 & & & Wanadis .............. & \\
\hline & & & & Wida.................. & \\
\hline & $\begin{array}{l}\text { Magnifique.................. } \\
\text { MOSS ROSES (See page 151.) }\end{array}$ & & & Miss Lingard . . . . . . . . . . . & \\
\hline & Mlanche Moreau.............. & & & $\begin{array}{l}\text { TRITOMA }(\text { See page } 153 .) \\
\text { Pfitzeri } \quad \ldots \ldots \ldots \ldots \ldots \ldots\end{array}$ & \\
\hline & Crested Moss.............. & & & S. \& W. Co.'s Hybrids . . . . . . & \\
\hline & Henri Martin............. & & & FLOWERING SHRUBS $\left.\begin{array}{l}\text { (See pages } \\
154,155 .\end{array}\right)$ & \\
\hline & Salet.................... & & & ABELIA Grandiflora ............ & \\
\hline & HERBACEOUS PEONIES $\begin{array}{c}\text { (See page } \\
152 .)\end{array}$ & & & ALMOND, Pink $\ldots \ldots \ldots \ldots$ & \\
\hline & White Shades & & & White................... & \\
\hline & & & & ALTHEA, Red $\ldots \ldots \ldots \ldots \ldots \ldots$ & \\
\hline & $\begin{array}{l}\text { Baroness Schroeder........ } \\
\text { Duchesse de Nemours..... }\end{array}$ & & & Pink............................... & \\
\hline & & & & White.................... & \\
\hline & $\begin{array}{l}\text { Duc de Wellington......... } \\
\text { Festiva Maxima.......... }\end{array}$ & & & 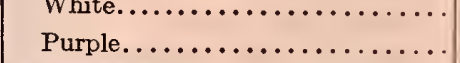 & \\
\hline & & & & 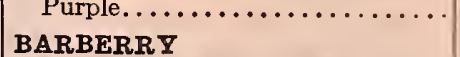 & \\
\hline & $\begin{array}{l}\text { La Lorraine } \ldots \ldots \ldots \ldots \ldots \\
\text { Mignon } . \ldots \ldots \ldots \ldots \ldots \ldots\end{array}$ & & & $\begin{array}{l}\text { BARBERRY } \\
\text { New Red-leaved Japanese .... }\end{array}$ & \\
\hline & $\begin{array}{l}\text { Mignon.................. } \\
\text { Primevere............... }\end{array}$ & & & BUDDLEIA (Butterfly Shrub) & \\
\hline & $\begin{array}{l}\text { Primevere } . . . \ldots \ldots \ldots \ldots \ldots \\
\text { Queen Victoria. . . . . . . . }\end{array}$ & & & Variabilis Veitchiana.......... & \\
\hline & $\begin{array}{l}\text { Queen Victoria............ } \\
\text { Solange. }\end{array}$ & & & CAL YCANTHUS Floridus....... & \\
\hline & Solange............. & & & CERASUS, Pink.............. & \\
\hline & Pink Shades & & & White..................... & \\
\hline & Alice Balfour......... & & & CRAT ZRGUS Oxyacantha...... & \\
\hline & Edulis Superba............. & & & DEUTZIA & \\
\hline & General Joffre............. & & & Gracilis ............ & \\
\hline & Gloire de Lorraine ........... & & & Pride of Rochester............ & \\
\hline & Mme. Manchet............. & & & DOGWOOD (Cornus) & \\
\hline & Henry Woodward........... & & & $\begin{array}{l}\text { Florida................ } \\
\text { Florida rubra. }\end{array}$ & \\
\hline & La France................ & & & $\begin{array}{l}\text { Florida rubra } \ldots \ldots \ldots \ldots \ldots \ldots \ldots \\
\text { Sibirica } \ldots \ldots \ldots \ldots \ldots \ldots \ldots \ldots\end{array}$ & \\
\hline & Mme. Francois Toscanelli..... & & & FORSYTHIA Suspensa.......... & \\
\hline & Mons. Jules Elie............. & & & Viridissima................. & \\
\hline & Princess Olga .............. & & & 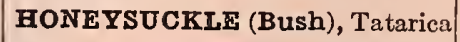 & \\
\hline & Rachel.................. & $\ldots$ & & Tatarica alba.............. & \\
\hline
\end{tabular}




\begin{tabular}{|c|c|c|c|c|c|}
\hline Quantity & & Price & Quantity & & Price \\
\hline & $\begin{array}{l}\text { HYDRANGEA } \\
\text { Arborescens grandiflora .... }\end{array}$ & & & $\begin{array}{l}\text { Syringa (or Lilac), continued } \\
\text { Jacques Calot............ }\end{array}$ & \\
\hline & Paniculata grandiflora...... & & & Marie LeGraye........... & \\
\hline & $\begin{array}{l}\text { KERRIA (Corchorus) } \\
\text { Japonica flore-plena ... }\end{array}$ & & & 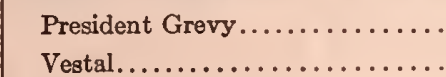 & \\
\hline & KOLK WITZIA Amabilis & & & SYMPHORICARPOS & \\
\hline & $\begin{array}{r}\text { MORUS (Teas' Weeping Mulberry) } \\
\text { Alba pendula } \ldots \ldots \ldots \ldots \ldots \ldots \ldots\end{array}$ & & & Racemosus (Snowberry) ...... & \\
\hline & $\begin{array}{l}\text { Alba pendula } . . . \ldots \ldots \ldots \ldots \\
\text { PHILADELPHOS Coronarius ... }\end{array}$ & & & Vulgaris (Indian Currant).... & \\
\hline & $\begin{array}{l}\text { PHILADELPHOS Coronarius ... } \\
\text { Avalanche.................. }\end{array}$ & & & VIB URNOM & \\
\hline & 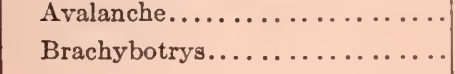 & & & um (Japan Snowball)..... & \\
\hline & $\begin{array}{l}\text { Brachybotrys.............. } \\
\text { Splendens............... }\end{array}$ & & & Opulus (High-Bush Cranberry).. & \\
\hline & $\begin{array}{l}\text { Splendens. } \ldots \ldots \ldots \ldots \ldots \ldots \\
\text { Virginal. } \ldots \ldots \ldots \ldots \ldots \ldots\end{array}$ & & & WEIGELA, Eva Rathke....... & \\
\hline & 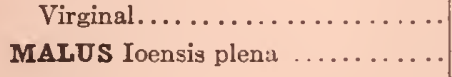 & & & 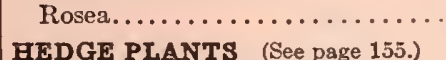 & \\
\hline & 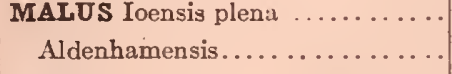 & & & $\begin{array}{l}\text { HEDGE PLANTS (See page 155.) } \\
\text { BERBERIS THUNBERGI }\end{array}$ & \\
\hline & & & & $\begin{array}{l}\text { BERBERIS THUNBERGI } \\
\text { Extra-strong. } 11 / 2 \text { to } 2 \text { feet.... }\end{array}$ & \\
\hline & 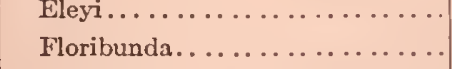 & & & CALIFORNIA PRIVET & \\
\hline & 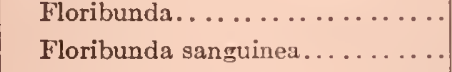 & & & g. 3 feet............ & \\
\hline & $\begin{array}{l}\text { Floribunda sanguinea......... } \\
\text { Kaido................... }\end{array}$ & & & $\begin{array}{l}\text { HARDY CLIMBING PLANTS } \\
\text { (See page 156.) }\end{array}$ & \\
\hline & 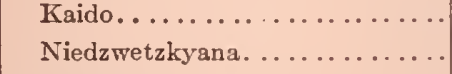 & & & $\begin{array}{l}\text { (See page } 156 .) \\
\text { AKEBIA Quinata ............ }\end{array}$ & \\
\hline & & & & AMPELOPSIS Veitchii ...... & \\
\hline & $\begin{array}{l}\text { Parkmani............ } \\
\text { Sargenti............ }\end{array}$ & & & 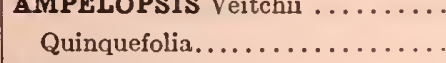 & \\
\hline & & & & $\begin{array}{l}\text { Quinqueiolia................ } \\
\text { ARISTOLOCHIA Sipho .... }\end{array}$ & \\
\hline & & & & $\begin{array}{l}\text { ARISTOLOCHIA Sipho ..... } \\
\text { BIGNONIA Radicans ....... }\end{array}$ & \\
\hline & & & & $\begin{array}{l}\text { BIGNONIA Radicans ........ } \\
\text { CELASTRUS Scandens ...... }\end{array}$ & \\
\hline & $\begin{array}{l}\text { Spectabilis......................... } \\
\text { PYRUS or CYDONIA (Jaincese }\end{array}$ & & & & \\
\hline & 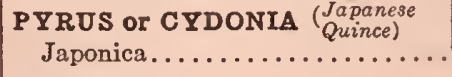 & & & $\begin{array}{l}\text { POLYGONDM Auberti } \ldots \ldots \\
\text { CLEMATIS Paniculata } \ldots \ldots\end{array}$ & \\
\hline & $\begin{array}{r}\text { Japonica.................... } \\
\text { PRUNUS Pissardi } \ldots \ldots \ldots \ldots \ldots\end{array}$ & & & $\begin{array}{r}\text { CLEMATIS Paniculata } \ldots \ldots \\
\text { Jackmanii................. }\end{array}$ & \\
\hline & $\begin{array}{l}\text { PRUNUS Pissardi } \ldots . . \\
\text { Triloba.............. }\end{array}$ & & & 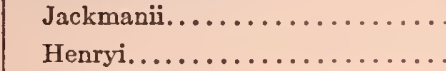 & \\
\hline & $\begin{array}{l}\text { Triloba...................... } \\
\text { Cerasifera............... }\end{array}$ & & & 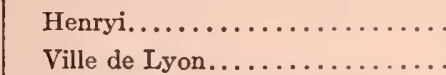 & \\
\hline & $\begin{array}{l}\text { Cerasifera................... } \\
\text { Cerasifera purpurea........ }\end{array}$ & & & 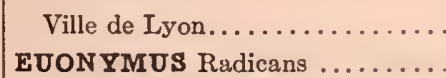 & \\
\hline & $\begin{array}{l}\text { Cerasifera purpurea } . . . \ldots \ldots \ldots \\
\text { Mume................... }\end{array}$ & & & EUONYMUS Radicans ......... & \\
\hline & 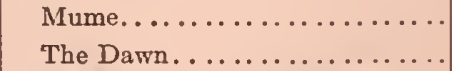 & & & Radicans vegeta............ & \\
\hline & $\begin{array}{l}\text { The Dawn. ................ } \\
\text { SPIREA, Anthony Waterer ... }\end{array}$ & & . & HONEYSUCKLE, Halliana ..... & \\
\hline & $\begin{array}{r}\text { SPIR } \boldsymbol{E A} \mathbf{A} \text {, Anthony Waterer } \ldots \\
\text { Van Houttei.............. }\end{array}$ & & & 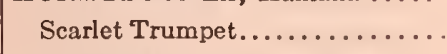 & \\
\hline & $\begin{array}{l}\text { Van Houttei................. } \\
\text { Trichocarpa (Korean Spirea) }\end{array}$ & & - & WISTERIA Floribunda plena ... & \\
\hline & Trichocarpa (Korean Spirea) & & & Multijuga rosea............. & \\
\hline & Thunbergi............... & & & Multijuga alba............. & \\
\hline & SYRINGA (or Lilac) & & & Mrs. McCullough ......... & \\
\hline & Common $\mathrm{P}$ & & & Noda Murasaki........... & \\
\hline & Common White........ & & & Shira Noda.... & \\
\hline & Charles $\mathrm{X} . . . \ldots \ldots \ldots$ & & & Sinensis, Blue........ & \\
\hline & Hugo Koster $\ldots \ldots \ldots \ldots \ldots$ & & ${ }_{n}$ & Sinensis, White........ & \\
\hline
\end{tabular}

Remainder of this order sheet please note for pages 157 and 158 AZALEAS-RHODODENDRONS-EVERGREENS-GRAPE -VINES - CURRANTS GOOSEBERRIES-BLACKBERRIES-RASPBERRIES

\begin{tabular}{l|c|c|c|c|}
\hline \hline QUANTITY & ARTICLES WANTED & \multicolumn{2}{|c|}{ PRICE } \\
\hline & & & \\
\hline
\end{tabular}


Annuals, The Book of. By Prof. Alfred C. Hottes. A reliable guide through the season of annual bloom. Complete instructions for their culture and uses. I82 pages.................

Around the Year in the Garden. By F. F. Rockwell. Written by a practical a mateur grower for the busy man or woman who must use every hour in the garden to the best advantage. 350 pages.......

Bulbs, Book of. By F. F. Rockwell. A complete treatise on growing of bulbs, both for fall and spring planting. .

Bulbs That Bloom in the Spring. By T. A. Weston. All information required in the culture and flowering of newly: purchased bulbs; also the harvesting and ripening of such bulbs as are planted in the fall for spring display. Paper, $\$$ I.50; Cloth...

Cactus Book, The. By A. D. Houghton. With this practical book you can grow the Cactus successfully in either cold or hot climates, indoors or out. I59 pages, I 8 illustrations

Chrysanthemum and its Culture, The. By E. A. White. Contains plain, practical directions for the successful culture of Chrysanthemums. 200 pages.

Climbing Plants, A Little Book of. By A. C. Hottes, The only book obtainable combining all climbing plants, of whatsoever nature, in the one volume. 250 pages.

Dahlia, The Amateur's Book of the. By Mrs. C. H. Stout. Most exlaustive book on the subject. Illustrated...

Dahlia Culture, Modern. By W. H. Waite. Brief, clear complete, based on the actual operations and results of a practical, experienced grower, propagator and exhibitor. I32 pages........................................

Dish Gardening, Adventures in. By Patten Beard. 69 full-
page illustrations with explanations and text showing how to make miniature dish-gardens with growing plants, stones, figures, etc., in colorful pottery bowls.

Evergreens for the Small Place. By F. F. Rockwell. Practical suggestions for using conifers. Illustrated.

Evergreens, Hardy. By Frank A. Schreper, M. S. A practical handbook on the planting and management of all hardy evergreens, exclusive of the broad-leaved species. I 28 pages.

Fertilizers. By Voorhees and Bailey. A most comprehensive work on this subject by two renowned authors...

Floriculture, Commercial. By Fritz Bahr. A practical manual for the trade grower..........................

Garden Guide-The Amateur Gardener's Handbook.
In a class by itself. No other gardening authority approaches it in its completeness. 384 pages. Paper, $\$ \mathrm{r} ;$ Cloth.

Garden, The Complete. By Albert Taylor, M. S. A. An upto-date book on landscape gardening. Profusely illustrated.

Gardener, The. By L. H. Bailey. How to grow fruit, vegetables, and flowers

Gardening, Manual of. By L. H. Bailey. He who would make a garden could not find a better manual............ Gladiolus. By F. F. Rockwell. Compact

Gladiolus. By A. C. Beal, Ph.D. A practical treatise on the propagation and successful culture of gladiolus in home, garden, and under glass. I 28 pages.

Home Flower-growing. By E. C. Volz. A real flower-garden encyclopedia. It tells how, when, and where to grow flowers; also how to plan indoor, outdoor, rock- and water-gardens. 364 pages.... Standard Cyclopedia of. By L. H. Bailey Horticulture, Standard Cyclopedia of. By L. H. Bailey characteristics and methods of cultivation of the plants grown in the United States and Canada, for ornament, for fancy, for fruit, and for vegetables. 3.637 pages, 3 volumes.

House Plants, Milady's. By F. E. Palmer. For those seeking success witli plants in the home.
Iris, The. By John C. Wister. Tells what varieties of iris to plant for certain effects and what varieties to avoid for suc-

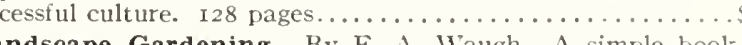

stating the first principles in landscape gardening so clearly that the average amateur can understand them. 1llustrated.

Landscape Gardening, Practical. By R. B. Cridland. Shows in a simple way how to beautify the home-grounds. 276 pages..

Lawn, The. By L. S. Dickinson. Deals with the culture of the turf in park, golfing, and home areas. It gives the latest practical directions that everyone may follow.

Lawns. By F, F. Rockwell. You will find use for this information year after year, for it shows both how to start a lawn right and how to keep it smooth and velvety thereafter.

Lilies, Garden. By Isabella Preston. Written to help amateurs to grow as many species as possible, and particularly to raise varieties from seed. I 28 pages.

Mushroom Growing. By B. M. Duggar. Presents accurately and faithfully the requirements for success in mushroom growing.

Perennials, A Little Book of. By Prof. Alfred C. Hottes Devoted to the general principles of growing, using, selecting, and propagating perennials. 200 pages.

Plant Culture. By George W. Oliver and Alfred C. Hottes. Covers practically all the known plants cultivated in the garden and home-grounds, together with those of the greenlouse and conservatory. 444 pages.

Plant Propagation, Practical. By Prof. A. C. Hottes. An exposition of the art of increasing plants as practised by the nurseryman, florist and gardener.

Rock Gardens. By F. F. Rockwell. How to make a rock garden, the plants to use and where to put them

Rock Gardens, American. By stephan F. Hamblin. Emphasizes only those plants of easy culture suitable for American soils and conditions. I 28 pages.

Rock-Garden Primer. By A. Thornton. Written especially for those wishing information on every minute point in making a rock-garden. 74 illustrations and lists of plants for different types of rock-gardens.

Roses, How to Grow. By Pyle, McFarland, and Stevens. Makes every step in the culture and care of roses so clear that any grower can understand it and succeed with them. I 44 pages of text and 64 full pages of illustrations, 32 of which are in natural colors

Shrubs. By F. F. Rockwell. Designed to give information as to how to select, plant, prune, and take care of shrubs on the home-grounds. 76 pages

Shrubs, The Book of. By Prof. A. C. Hottes. Latest, best, and most complete book on this subject. 384 pages.

Spraying Crops. By C. M. Weed. A treatise explaining the principles and practice of the application of liquids and powders to plants for destroying insects and fungi.

Spraying, Dusting, and Fumigating of Plants. By $\mathrm{A} . \mathrm{F}$ Mason. Tells what pests to expect and how to identify and control them; how to choose the light spray materials; and every other detail for the successful pest-control of fruits, regetables, and doorvard garden plants. 570 pages.

Starting Early Vegetable and Flower Plants under Glass. By C. H. Nissley. Including the details of construction and heating as well as the operation of small greenhouses, sashhouse, hotbeds and coldframes, etc. 320 pages...

Vegetable Garden. By A. Kruhm. How to successfully grow vegetables. 200 pages.

1,001 Garden Questions Answered. By Prof. A. C. Hottes Every problem confronting the home-gardener is satisfactorily answered. Covers flowers, fruits, and vegetables. Paper. $\$$ I.50; Cloth...

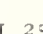

5 


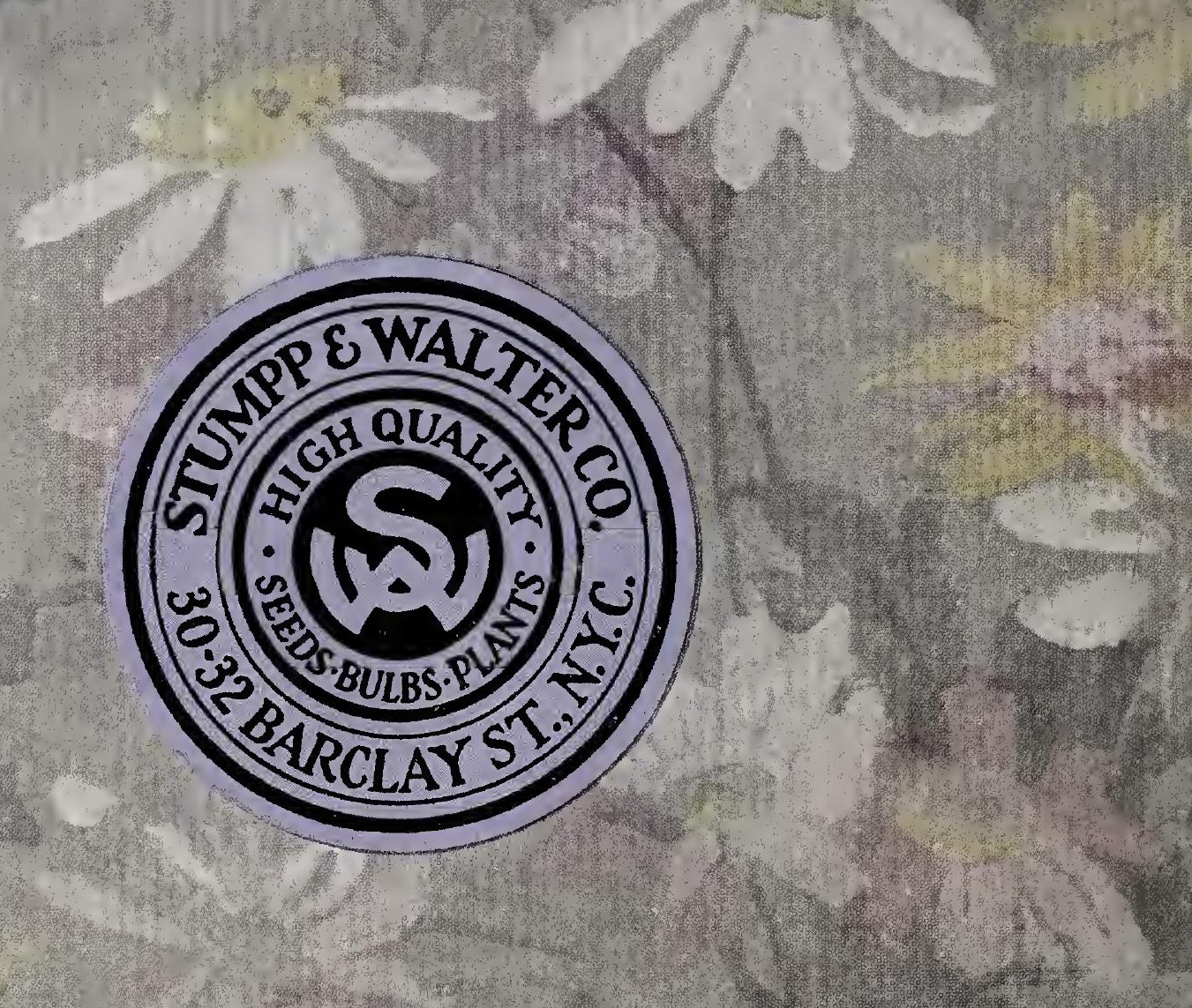

